$$
\begin{gathered}
\text { UNIVERSIDADE DE SÃO PAULO } \\
\text { FACULDADE DE FILOSOFIA, LETRAS E CIÊNCIAS HUMANAS } \\
\text { DEPARTAMENTO DE HISTÓRIA } \\
\text { PROGRAMA DE PÓS-GRADUAÇÃO EM HISTÓRIA SOCIAL }
\end{gathered}
$$

IGOR CARASTAN NOBOA

\title{
O FUTURO E O PASSADO ESTÃO ALÉM DA IMAGINAÇÃO A VIAGEM NO TEMPO E OS EUA NO CONTEXTO DO SEGUNDO PÓS-GUERRA
}

VERSÃO CORRIGIDA 
IGOR CARASTAN NOBOA

\section{O FUTURO E O PASSADO ESTÃO ALÉM DA IMAGINAÇÃO A VIAGEM NO TEMPO E OS EUA NO CONTEXTO DO SEGUNDO PÓS-GUERRA}

Tese apresentada ao Programa de PósGraduação em História Social do Departamento de História da Faculdade de Filosofia, Letras e Ciências Humanas da Universidade de São Paulo, para obtenção do título de Doutor em História Social sob

a orientação do Prof. Dr. Marcos Antonio da Silva

VERSÃO CORRIGIDA 
Autorizo a reprodução e divulgação total ou parcial deste trabalho, por qualquer meio convencional ou eletrônico, para fins de estudo e pesquisa, desde que citada a fonte.

Catalogação na Publicação

Serviço de Biblioteca e Documentação

Faculdade de Filosofia, Letras e Ciências Humanas da Universidade de São Paulo

Noboa, Igor Carastan

O Futuro e o Passado estão Além da Imaginação: a viagem no tempo e os EUA no contexto do Segundo PósGuerra / Igor Carastan Noboa ; orientador Marcos Antonio da Silva. - São Paulo, 2019. $389 \mathrm{f}$.

Tese (Doutorado)- Faculdade de Filosofia, Letras e Ciências Humanas da Universidade de São Paulo. Departamento de História. Área de concentração: História Social.

1. Viagem no tempo. 2. História dos Estados Unidos da América. 3. Televisão. 4. Além da Imaginação. 5. Rod Serlig. I. Silva, Marcos Antonio da, orient. II. Título. 


\title{
ENTREGA DO EXEMPLAR CORRIGIDO DA DISSERTACÃO/TESE
}

Termo de Ciência e Concordância do (a) orientador (a)

\author{
Nome do (a) aluno (a): IGOR CARASTAN NOBOA \\ Data da defesa: 06/11/2019 \\ Nome do Prof. (a) orientador (a): MARCOS ANTONIO DA SILVA
}

Nos termos da legislação vigente, declaro ESTAR CIENTE do conteúdo deste EXEMPLAR CORRIGIDO elaborado em atenção às sugestões dos membros da comissão Julgadora na sessão de defesa do trabalho, manifestando-me plenamente favorável ao seu encaminhamento e publicação no Portal Digital de Teses da USP.

São Paulo, $3 / 1 / 2020$

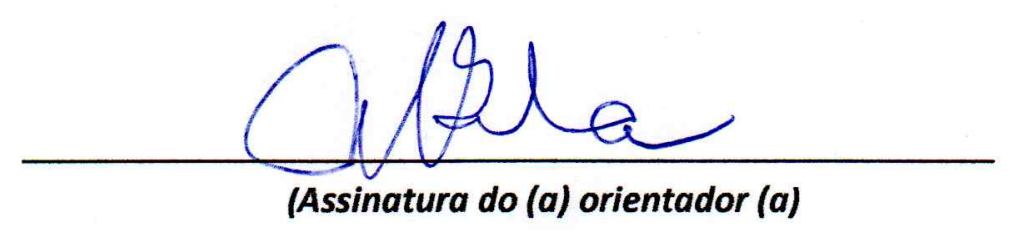


NOBOA, I. C. O Futuro e o Passado estão Além da Imaginação: a viagem no tempo e os EUA no contexto do Segundo Pós-Guerra. Tese apresentada ao Programa de Pós-Graduação em História Social do Departamento de História da Faculdade de Filosofia, Letras e Ciências Humanas da Universidade de São Paulo, para obtenção do título de Doutor em História Social.

Aprovado em:

\section{Banca Examinadora}

Professor Dr. Marcos Antonio da Silva (orientador) Instituiçao: DH/FFLCH/USP Julgamento:

Assinatura:

Professor Dr. Robert Sean Purdy Instituiçao: DH/FFLCH/USP Julgamento: Assinatura:

Professora Dra. Laura Loguercio Cánepa Instituiçao: UAM. Julgamento: Assinatura:

Professor Dr. Alfredo Luiz Paes de Oliveira Suppia Instituiçao: IA/UNICAMP. Julgamento: Assinatura: 


\section{AGRADECIMENTOS}

Gostaria de começar agradecendo profundamente, pelo tempo dispensado, a todos que leram, estão lendo e lerão este trabalho, alguns dos quais estarão citados abaixo e devem se considerar duplamente alvos dos agradecimentos. Aprendi a importância do Tempo e, infelizmente, não tenho como compensá-los, a não ser por apresentar algo realizado com extremo zelo.

Não posso deixar de agradecer inúmeras pessoas que permitiram eu ter contato com os documentos, sem as quais esta pesquisa seria impossível: os arquivistas, bibliotecários, voluntários e estagiários da Merril Collection of Science Fiction, Speculation \& Fantasy (Toronto), da Wisconsin Historical Society (Madison), da Charles E. Young Research Library - UCLA (Los Angeles) e da Rod Serling Memorial Foundation (Binghamton). Espero ter dado um bom fim ao material consultado.

Gostaria de agradecer aos professores anônimos que deram parecer favorável ao recebimento do apoio da Coordenação de Aperfeiçoamento de Pessoal de Nível Superior - Brasil (CAPES), a bolsa foi fundamental para a realização da pesquisa.

Por toda a longa jornada que culminou nessa tese fiz uma série de amigos, conheci colegas, fui a lugares que nunca imaginei que existissem ou que chegaria a ver... Obrigado pela confiança dos professores, amigos, professores amigos, colegas de trabalho e alunos por terem dado opiniões, comentários, sugestões e, principalmente, por terem ouvido incontáveis horas sobre a viagem no tempo, Rod Serling e Além da Imaginação...

Um agradecimento especial deve ser dirigido aos professores Robert Sean Purdy e Laura Loguercio Cánepa. Eles participaram da minha qualificação e eu não poderia ter escolhido melhores nomes para acompanhar todo esse processo. Sou imensamente grato a ambos e ao professor Alfredo Luiz Paes de Oliveira Suppia, que, somando-se a eles, aceitou fazer parte da banca de defesa e sempre incentivou esta pesquisa.

Para não ser injusto, pois realmente são muitas pessoas que eu devo agradecimentos, destacarei apenas mais três para registro: como sempre agradeço a confiança do meu orientador e amigo, professor Marcos Antonio da Silva, minha mãe Jacy Katia Carastan Noboa e minha amiga de longa data Joana D'Arc Portella Alarcon, os quais, cada um a seu modo, participaram da pesquisa, dando incentivo, apoio, comentado e revisando o material.

A todos meus amigos, os mais próximos e os mais distantes, os que falam comigo toda semana e os que encontro raramente, os que estão no passado, no presente ou no futuro, esse trabalho é dedicado a vocês. (vocês sabem quem são ou saberão quem são... essas coisas de passado e futuro podem ser meio confusas...)

O presente trabalho foi realizado com apoio da Coordenação de Aperfeiçoamento de Pessoal de Nível Superior - Brasil (CAPES) - Código de Financiamento 001.

This study was financed in part by the Coordenação de Aperfeiçoamento de Pessoal de Nível Superior - Brasil (CAPES) - Finance Code 001. 


\section{RESUMO}

NOBOA, I. C. O Futuro e o Passado estão Além da Imaginação: a viagem no tempo e os EUA no contexto do Segundo Pós-Guerra. 2019. 389 f. Tese (Doutorado). Faculdade de Filosofia, Letras e Ciências Humanas, Universidade de São Paulo, 2019.

A presente pesquisa parte da reflexão sobre o desenvolvimento das narrativas que apresentam alguma forma de viagem no tempo, analisa a sua origem no século XIX e a sua função social como mediadora entre as sociedades e as mudanças e permanências. Investigou-se como nas décadas de 50 e 60, período marcado por grandes transformações mundiais, os enredos com as mais diversas formas e destinos de viagem no tempo expressaram como as sociedades, grupos e indivíduos interpretavam o presente, contemplavam os mais diversos prognósticos para o futuro e difundiam visões sobre o passado. Em uma época marcada pela Guerra Fria e a ascensão dos Estados Unidos da América como superpotência, as histórias de viagem no tempo produzidas nos EUA são uma fonte indispensável para se compreender como eram encadeados passado, presente e futuro e as mudanças e as possibilidades de transformações sentidas e propagadas. Para se compreender melhor o contexto do segundo pós-guerra, foi escolhido como documento histórico central a série de televisão Além da Imaginação (The Twilight Zone), exibida originalmente entre 1959-1964 e reprisada até hoje. O programa, criado e produzido por Rod Serling, que também assinava a maior parte dos roteiros, é um dos ícones culturais dos EUA e a sua importância na história da televisão mundial, dado sua exportação e influência, é um indicativo da relevância dessa série, observada nesta pesquisa, como um documento crítico de seu contexto histórico. Por exibir de forma reiterada narrativas com as mais diversas formas de viagem no tempo, muitos episódios de Além da Imaginação permitem a percepção de como as mudanças e permanências estavam sendo criticadas, promovidas e vividas, nos EUA no segundo pós-guerra. A viagem no tempo na série exprimiu ímpetos nostálgicos, diagnósticos do presente e perspectivas de futuro, propondo, no modelo criado por Rod Serling de um universo fantástico moralista, a reavalição do presente nos EUA e a correção do que era visto como inadequado para o progresso humano.

PALAVRAS-CHAVE: Viagem no tempo. História dos Estados Unidos da América. Guerra Fria. Televisão. Além da Imaginação. Rod Serling. 


\section{ABSTRACT}

NOBOA, I. C. The Future and the Past are The Twilight Zone: time travel and the USA in the second postwar context. 2019. 389 p. Doctoral Thesis. Faculty of Philosophy, Languages and Human Sciences, University of São Paulo, 2019. Portuguese.

The present research starts with the reflection on the development of narratives that display some form of time travel, analyzes its origin in the 19th century and its social function as a mediator between societies, the changes and the permanences. It was investigated how, in the 50s and 60s, a period of remarkable world transformation, the most diverse plots containing time travel expressed how societies, groups and individuals interpreted the present, disseminated perceptions of the past and contemplated prognoses for the future. In a time marked by the Cold War and the rise of the United States of America as a superpower, the time travel stories produced in the US are an indispensable source for understanding how past, present, and future were linked, and the changes and possibilities for transformation were felt and propagated. In order to better understand the context of the second postwar period, The Twilight Zone television series, originally screened between 1959-1964 and still airing in reruns, was chosen as a main historical document. This television show created and produced by Rod Serling, who also signed most of the screenplays, is one of the cultural icons of the US and its importance in the history of world television given its influence and spread is indicative of the relevance of this series. The Twilight Zone is regarded in this research as a critical document of its historical context. By repeatedly displaying narratives with the most diverse forms of time travel, many episodes of The Twilight Zone allow us to perceive how the changes and the permanences were being criticized, promoted, and lived in the US in the second postwar period. The time travel stories in the series expressed nostalgic impulses, present diagnoses, and future prospects, proposing, in the model created by Rod Serling of a moralistic universe, the re-evaluation of the present time in the US and the rectification of what was seen by Serling against human progress.

KEYWORDS: Time travel. Cold War. American History. Television. The Twilight Zone. Rod Serling 


\section{SUMÁRIO}

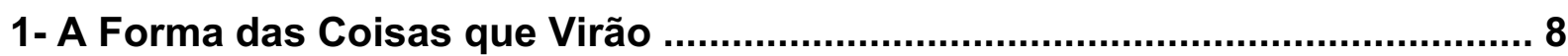

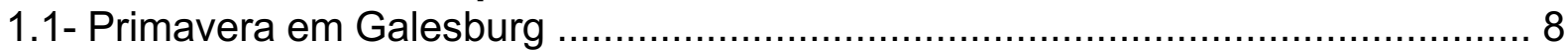

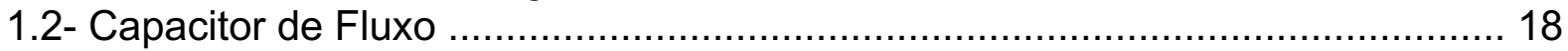

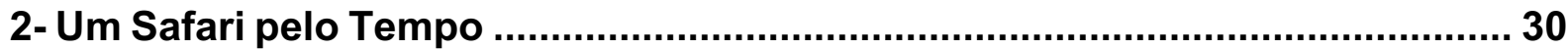

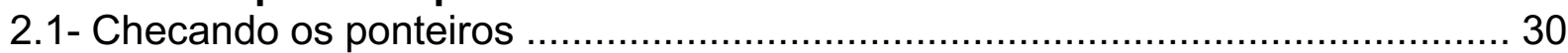

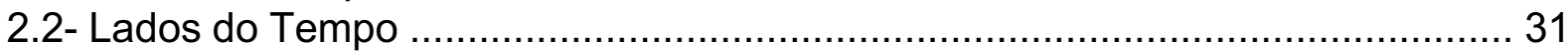

2.3- Seu interior é maior do que seu exterior ................................................... 33

2.4- No jardim onde os conceitos se bifurcam: tempo histórico e viagem no tempo . 35

2.5- Uma dimensão da mente .......................................................................... 41

2.6- Para que tudo não aconteça de uma só vez ................................................. 43



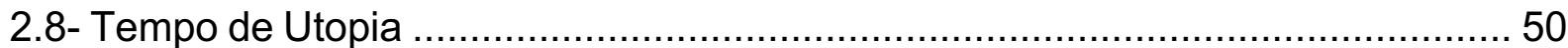

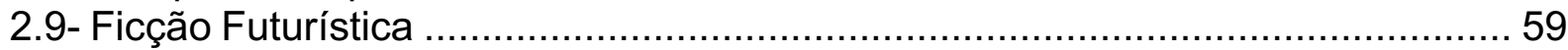

3- Todo o Tempo do Mundo: a viagem no tempo ……....................................62

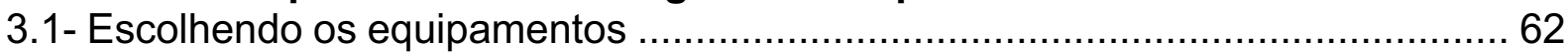

3.2- Deslocamento temporal antes da viagem no tempo ..................................... 67

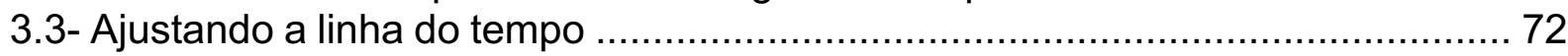

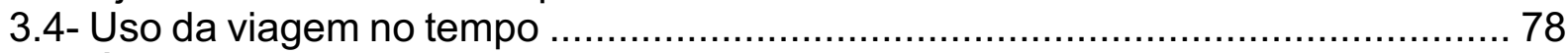

3.5- Água e Metal: a viagem no tempo na Filosofia e na Física .............................. 82

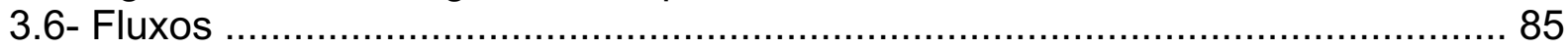

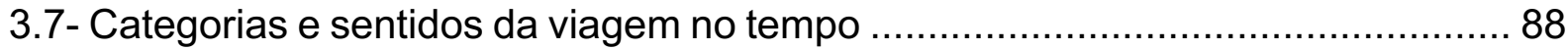

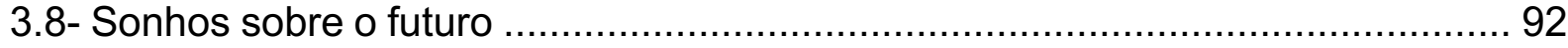

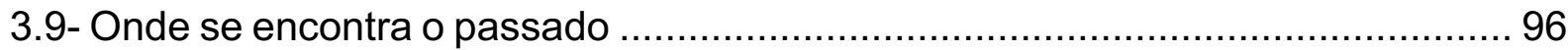

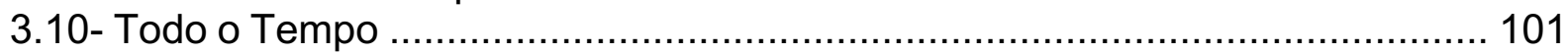

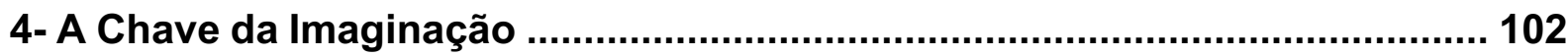

4.1- O Meio Termo entre Luz e Sombras: o contexto do segundo pós-guerra ..........102

4.2- Nova Contribuição para o Entretenimento Familiar: a nascente televisão ........ 107

4.3- Noventa por cento de tudo que se faz é porcaria? ........................................ 122

5- Sua próxima parada, Além da Imaginação ………......................................... 133

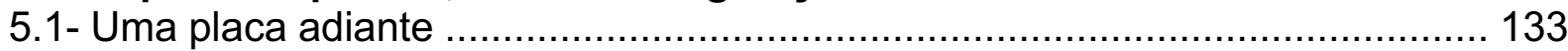

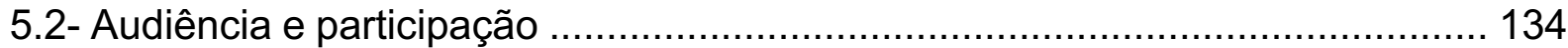

5.3- Aquele homem branco de terno que fuma ............................................. 140

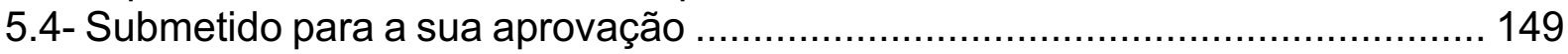

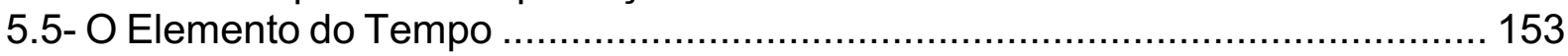

5.6- Diretamente de outra dimensão ……………….................................... 155

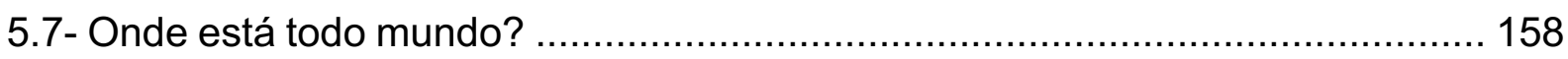

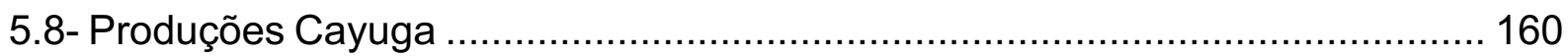

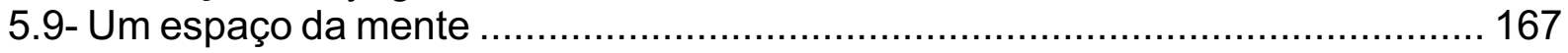

5.10- O que pode ser encontrado além da imaginação ........................................ 177

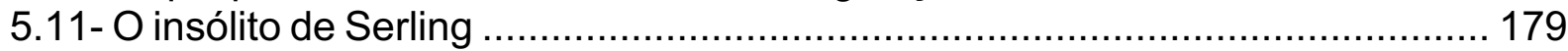

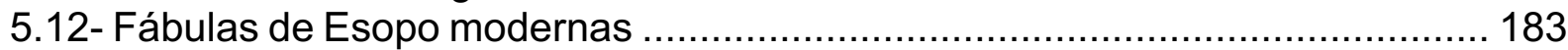

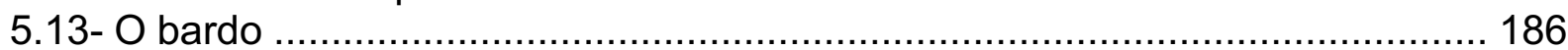

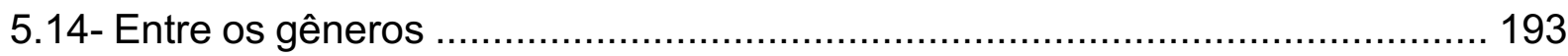




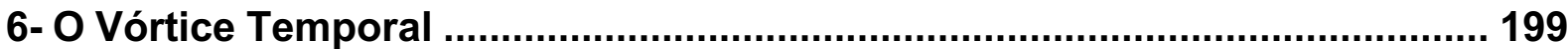

6.1- Introdução à viagem no tempo em Além da Imaginação ................................. 199

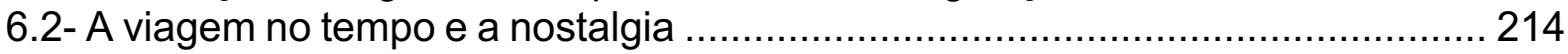

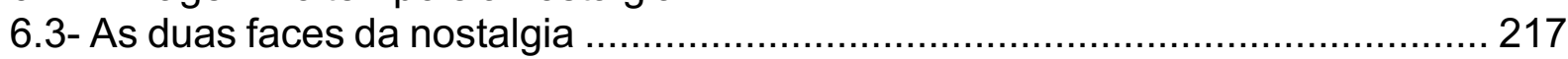

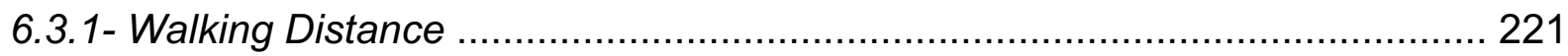

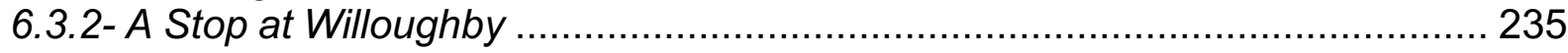

6.3.3- The Trouble With Templeton ......................................................... 244

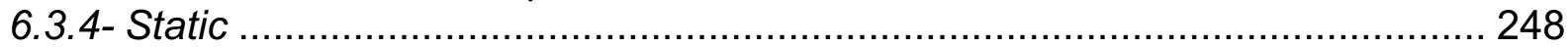

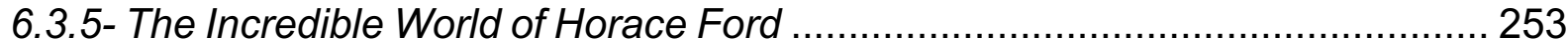

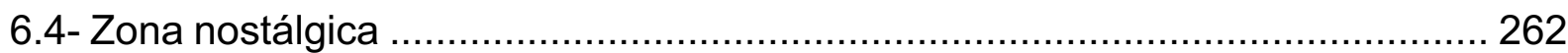

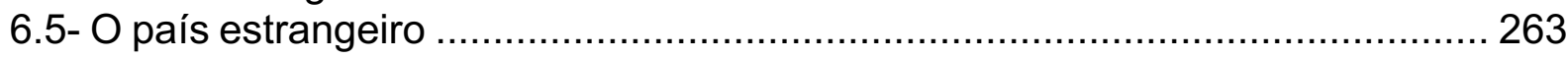

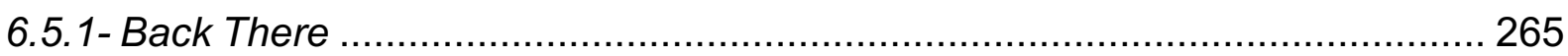

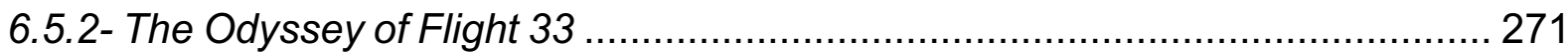



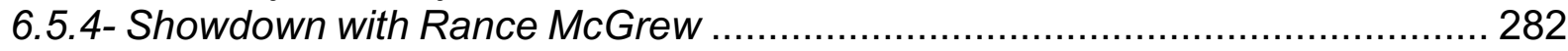

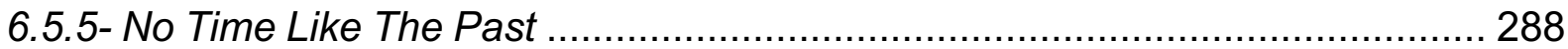

6.5.6- Of Late I Think of Cliffordville ................................................................ 294

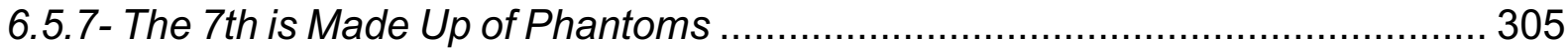

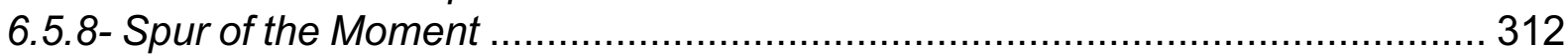

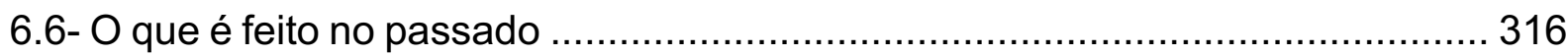

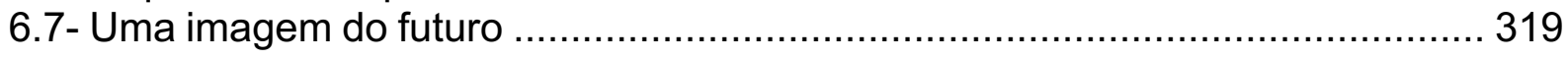

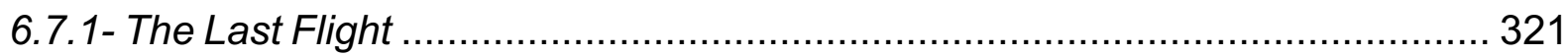

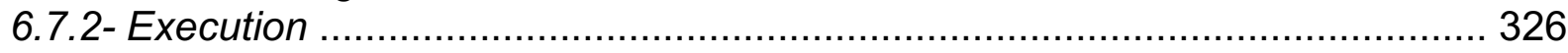

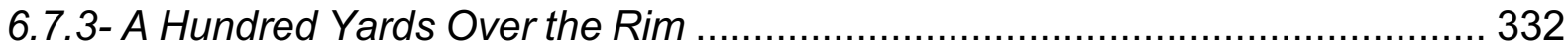

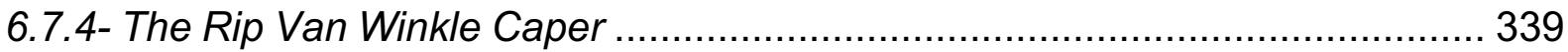

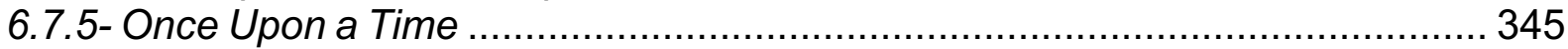

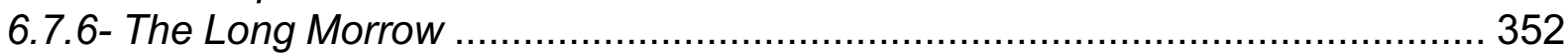

7- O Grande Esquema das Coisas ................................................................. 360

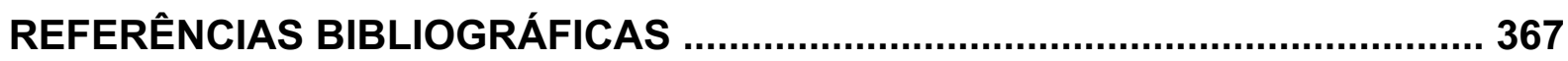

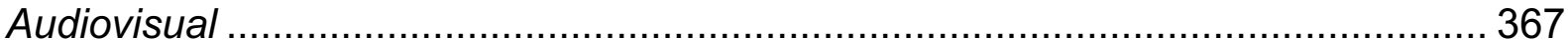

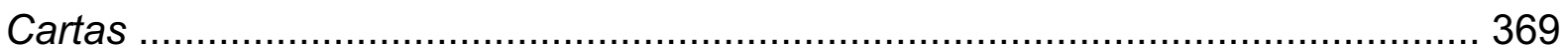

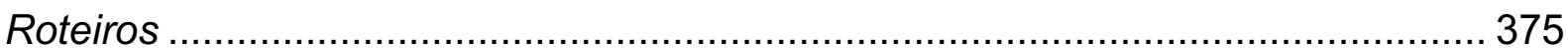

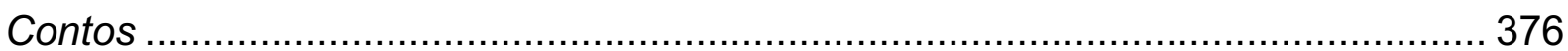

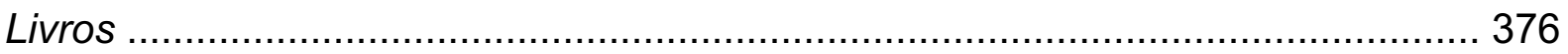

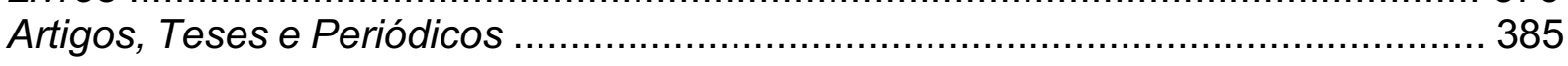


"There are changes

Lyin' ahead in every road And there are new thoughts Ready and waiting to explode

When tomorrow is today The bells may toll for some But nothing can change the shape of things to come

The future's comin' in, now

Sweet and strong Ain't no-one gonna hold it back for long"1 (Max Frost and The Troopers)

\section{1- A Forma das Coisas que Virão}

\section{1- Primavera em Galesburg}

O ano é 1960, cidade de Galesburg, no estado de Illinois, EUA, população de pouco mais de trinta e sete mil habitantes. Nessa pacata cidade, fenômenos sobrenaturais começaram a atormentar os cidadãos, principalmente as pessoas que não só desejavam, mas também, trabalhavam pela modernização do local, com a instalação de novas indústrias, destruição de antigas casas para especulação imobiliária e remodelação de ruas e avenidas.

Bondes e carros do início do século XX foram vistos atacando pessoas, bombeiros trajando uniformes obsoletos teriam apagado um incêndio em uma antiga casa. Era cada vez mais notório que entidades, fantasmas do passado da cidade, estavam se materializando no presente para assustar e até causar dano físico aos homens que tentavam descaracterizar o ambiente idílico daquele lugar, ou levar para Galesburg o progresso da expansão econômica do segundo pós-guerra, tornando-a uma cidade comum sem alma, de prédios de concreto parecidos com caixas de sapatos e discos voadores, enfim, moderna. O passado da cidade estava lutando contra a mudança, estava resistindo ao ímpeto do presente e de parte dos cidadãos

\footnotetext{
${ }^{1}$ Trecho da música da banda fictícia Max Frost and The Troopers, The Shape Of Things To Come, escrita por Barry Mann e Cynthia Weil para o filme Violência nas Ruas (Wild in the Streets, 1968). Há mudanças/ Pela frente em cada caminho/ E há novas ideias/Prontas e esperando para explodir/ Quando o amanhã for hoje/ Os sinos poderão dobrar para alguns/ Mas nada pode mudar o que virá/ O futuro está chegando, agora/Doce e forte/ E ninguém irá contê-lo por muito tempo [tradução nossa].
} 
de abandoná-lo e abraçar o futuro - pelo menos essa é a conclusão explicativa do nostálgico jornalista que acompanhava os estranhos casos, Oscar Mannheim, do jornal galesburguiano Register-Mail.

O passado não permitindo o seu fim, ou seja, o abandono do passado que modelou e permanece vivo no presente e que estava ameaçado por mudanças rápidas é a premissa do conto de Jack Finney, "I Love Galesburg in the Springtime", publicado originalmente na revista feminina americana McCall's de abril de 1960 (a revista não conseguiu vencer o presente e não é mais publicada desde 2002, tendo sobrevivido 129 anos). Finney publicou nas décadas de 50 e 60 uma série de contos envolvendo a questão da nostalgia, com personagens que discutem ou realizam a fuga do presente, geralmente visando o final do século XIX e início do século XX. Uma das principais e mais conhecidas obras do autor é um romance de viagem no tempo, "Time and Again" de 1970, no qual a Nova York do final do século XIX é descrita nostalgicamente. Outra produção de Finney de sucesso, adaptada para o cinema e influente em outras mídias, é o romance de 1955 "The Body Snatchers", a história de um ataque de alienígenas vegetais racionais que substituem os corpos dos habitantes da bucólica cidade suburbana de Mill Valley, Califórnia.

Esse conto, juntamente com outros contos, romances, filmes, séries de televisão, histórias em quadrinhos, etc., de ficção científica ou não, mostram as mais diversas formas pelas quais as sociedades contemporâneas, modernas ou pósmodernas - a depender da periodização e do conceito escolhido- apresentam a complexidade de como o Tempo é interpretado e as mais diversas relações individuais, coletivas e sociais com esse símbolo, perspectiva adotada por esta pesquisa.

Uma das maneiras de se lidar com o Tempo e perceber seu sentido individual e coletivo é por meio das aventuras de viagem no tempo, uma das formas de se pensar o "e se...?" que alimenta a vida contemporânea projetando em outras temporalidades novas possibilidades de alteração da vida cotidiana. Dentre os documentos que permitem ao historiador perceber como determinada sociedade ou seus grupos se relacionavam com as mais diversas temporalidades, temos 0 desenvolvimento desde finais do século XIX (com grande sucesso e ampliação durante o século $X X)$ das narrativas que envolvem alguma forma de viagem no tempo, ou seja, um ou mais personagens se deslocam pelas mais diversas temporalidades de forma não usual, já que somos todos, a nosso modo, viajantes no tempo, como os 
relógios que controlam nossa rotina diária em maior ou menor escala não nos deixam mentir.

O desenvolvimento de tramas que fazem uso do recurso da viagem no tempo somaram-se com as outras obras artísticas, científicas e os sentimentos que lidam exatamente com a problemática e a relação entre as múltiplas temporalidades, e faz parte do movimento de novas relações com o símbolo Tempo, tanto nascentes de uma nova compreensão do ser humano e da natureza, como da organização da produção e do trabalho capitalista, as quais podem ser traçadas até o mundo europeu do século XVIII, dando origem, por exemplo, ao conceito moderno de História e sua escrita, a popularização de obras que se passavam no futuro, a propagação do mito do progresso e as experiências nostálgicas. Dessa maneira, não há uma superioridade documental histórica para entender as relações humanas com o Tempo utilizando as histórias de viagem no tempo de dado contexto histórico e sociedade, mas elas completam e complementam as demais manifestações para a avaliação de como determinados grupos, contextos e sociedades se relacionavam e articulavam passado, presente e futuro, e, como veremos, podem auxiliar a análise, complementando, enfatizando e demonstrando o alcance de determinadas tendências de se vivenciar as temporalidades que podem ser percebidas por se estudar outras fontes históricas.

A escolha por se pensar a viagem no tempo para entender as relações com as mudanças e permanências vem do pouco uso desse tipo de temática e de sua problematização para se lidar com algo que é parte fundamental da própria ciência histórica - o ser humano no tempo -, mais especificamente, como os seres humanos se veem como parte de determinado tempo. O ineditismo da análise da viagem no tempo como documento histórico abre perspectivas para se entender, de uma perspectiva mais popular e menos erudita, mas nem por isso não profunda e relevante, de como largas parcelas das populações contemporâneas experimentam o tempo, por estudar a fuga do tempo e o sonho de controle do fluxo temporal, os quais, em última instância, são elementos diretos ou subentendidos presentes em todas histórias de viagem no tempo, ganha-se uma visão mais ampla e mais complexa de como nós próprios vivenciamos as mudanças e permanências, encadeamos as expectativas de futuro com nossas ações no passado e presente. Para estudo das relações e vivências humanas atuais com o símbolo Tempo, Marcel Proust e Jorge Luis Borges se encontram facilmente e tem tanta revelância quanto Robert A. Heinlein, 
Jack Finney, Arthur C. Clark, Ray Bradbury, Cyril M. Kornbluth, C. L. Moore, Henry Kuttner, Poul Anderson, Philip K. Dick, J. G. Ballard, Isaac Asimov, Ursula K. Le Guin, Richard Matheson, L. Sprague de Camp, Harry Turtledove, Robert Silverberg e Rod Serling, apenas para citar autores que utilizaram a experiência com o Tempo como forma de reflexão sobre a vida contemporânea fora do ambiente da filosofia e das ciências.

A viagem no tempo, muitas vezes com analogias à formas de deslocamento no espaço, por meio de máquinas - induzindo alguma forma de controle do fluxo temporal -, ou por meios puramente sobrenaturais e mágicos, mostram como podemos partir do presente e visitar o futuro misterioso ou mesmo voltarmos no tempo, visitando um passado já vivido ou algum contexto histórico importante. Também podemos presenciar como pessoas de outras épocas se comportariam se tivessem que viver no nosso presente.

Ao analisar a viagem no tempo para se pensar um contexto histórico nos século XIX, XX e XXI pode-se perceber quais problemas com as mudanças ou permanências individuais e, principalmente, coletivas/sociais perturbavam ou eram expostas nessas histórias, como passados, presentes e futuros ancorados numa cultura histórica, por vezes dialogando diretamente com a história tradicional das nações, reforçando-a ou a criticando, mas também com a exploração da imaginação sobre outros povos e tempos, inclusive prognósticos de futuro que são colocados como forma de contraste entre tempos e formas diversas de se ver o mundo. As histórias de viagem no tempo nascidas na modernidade, portanto, fazem parte de um grande movimento de novas relações com o tempo, ou seja, com a questão da mudança e permanência, no contexto de um mundo voltado para o futuro propagado pelo mito do progresso, um mundo articulado pela razão, indústria, ciência e tecnologia, mas que ao mesmo tempo recorre a nostalgia de forma regular, alimenta os ímpetos de retorno a um passado imaginado perdido e a impulsos ahistóricos. A viagem no tempo tem relação de como as sociedades vivenciam o Tempo, tanto enfatizando quanto o rejeitando.

A presença ou não de um artefato para a viagem no tempo, a popularmente conhecida "máquina do tempo", não é fundamental para as aventuras nas quais um ou mais personagens se descolam entre as mais diversas temporalidades; porém, a presença deste dispositivo de natureza tecnológica é um recurso que provoca outro vínculo com a viagem no tempo. Dentro da lógica das relações com a ciência e tecnologia, a figura de uma máquina do tempo nessas aventuras materializa das mais 
diversas formas o descolamento temporal, com a exibição de uma tecnologia maravilhosa, quase mágica, e reflete as relações que as sociedades estabelecem com os artefatos tecnológicos. Não é raro, em uma história de ficção científica de viagem no tempo, a máquina do tempo tornar-se uma personagem, até humanizada, como é o caso da série de ficção científica mais longeva da televisão mundial, a britânica Doctor Who, que desde 1963 tem como constante a máquina do tempo em formato de cabine de polícia inglesa, a Tardis (Time And Relative Dimension In Space) ou o DeLorean DMC-12, icônica máquina do tempo da série fílmica De Volta para o Futuro (Back to the Future, 1985-1990). Esta personificação dos artefatos tecnológicos segue a tradição do gênero ficção científica, como as diversas encarnações da nave espacial Enterprise e dos carros Mach 5, respectivamente dos universos transmídia de Jornada nas Estrelas e Speed Racer, e não rompe com a tradição universal humana em suas mais diversas e múltiplas relações afetivas com objetos e engenhos.

A presença de uma tecnologia palpável e, mais importante, manejável de transposição das barreiras entre passado, presente e futuro implica, nestas aventuras, um desejo de autoridade e controle dos devires individuais e sociais, da vida e da morte, trazidos pelo conhecimento e/ou pelas vontades humanas e não por ação sobrenatural e arbítrio de deuses. Mais que um símbolo tecnológico, a máquina do tempo representa, em sua essência, o mal-estar da civilização ocidental com a transitoriedade e a efemeridade da vida, e não é à toa nasce na Europa em finais do século XIX. Na ficção, pode-se experimentar o que já foi e o que será experimentado, ver o que já aconteceu e o que será visto, a eternidade torna-se acessível à experiência humana por meio de um engenho.

Dessa forma, temos um documento histórico que nos mostra de forma clara quais são os problemas que tal sociedade ou grupo procuram resolver na intervenção no curso da experiência humana com as mudanças, seja para contê-las, pois estariam destruindo algum elemento da sociedade do viajante, seja para presenciar outra forma de viver, seja procurando aperfeiçoar o mundo por uma intervenção direta. Quaisquer formas de participação em uma história de viagem no tempo, de personagens mais inclinados ao voyeurismo até os mais inclinados a se tornarem agentes conscientes da História, por meio da interferência direta nas temporalidades, implica no público uma reflexão e comparação com seu presente e como a mudança é percebida.

O pós-Segunda Guerra Mundial marca o desenvolvimento dos Estados Unidos da América e sua consolidação como potência mundial, juntamente com a União das 
Repúblicas Socialistas Soviéticas, ex-aliados vencedores daquele conflito. Os dois países passaram a disputar a influência e a expansão mundial dos dois modelos de sociedade idealizados, uma de base nos projetos capitalistas e outra em propostas comunistas, defendendo interesses econômicos e políticos dessas duas superpotências. Essa disputa passou a contar com armas que existiam apenas na imaginação de escritores das primeiras décadas do século $X X$ e que agora estavam prontas para realizar uma destruição do planeta numa escala extraordinária. O modelo soviético e o americano eram mais que simples propostas de defesa dos interesses nacionais dos dois países, eram duas propostas de futuro humano, duas perspectivas que se projetavam no horizonte das possibilidades para toda a humanidade: a soviética, pautada no desenvolvimento do socialismo rumo à construção de um futuro comunista, na qual não mais haveria propriedade privada e uma nova sociedade igualitária, livre e sem classes sociais prosperaria; e o americano, na promoção da economia de mercado como garantidor da prosperidade, liberdade e progresso. Portanto, a Guerra Fria era uma guerra pelo futuro, como tinha sido anteriormente, em uma escala menor, a Segunda Guerra Mundial, os EUA e a URSS se digladiavam no âmbito da retórica e em nações a serem disputadas pelos dois projetos.

Para fins de balizamento cronológico, considera-se Guerra Fria o período de embate entre EUA (e seus aliados) e URSS (e seus aliados) de 1945 até 1991, com a noção de que as conferências de Yalta e Potsdam de 1945 definiam e previam o futuro conflito e o ano de 1947, com a Doutrina Truman, como um importante marco inicial do embate entre as nações.

Muito dos temas originais da ficção científica do século XIX e das primeiras décadas do XX estavam se realizando no dia-a-dia das sociedades desenvolvidas no segundo pós-guerra, com novas armas, meios de transporte, comunicação, produção, etc. Parte do que era anteriormente apenas ficção ou estava exposto nas Feiras Mundiais pautava novas relações sociais e causava ansiedade, maravilhamento e medo nos EUA das décadas de 1950 e 1960, geralmente, os três sentimentos mistos, como, por exemplo, o desenvolvimento dos satélites e foguetes espaciais na chamada Corrida Espacial entre EUA e URSS e a possibilidade de destruição do mundo desenvolvido e da civilização, quiçá de toda humanidade, em uma guerra nuclear.

Ao mesmo tempo, a política americana pautada por uma visão anticomunista também auxiliou o aumento da tensão social e medo no bloco Ocidental, direcionado aos suspeitos de serem comunistas, agentes infiltrados, desinformantes, levando a 
um reforço de padronização de comportamentos e ideologias. Muitas vezes, a crítica à injustiças individuais e coletivas passou a ser vista nos EUA como uma traição aos valores americanos, ou mesmo entregar a nação à URSS ou ser fruto de ação da URSS - dentro da lógica da guerra secreta, o fomento de discórdias internas e externas é algo que faz parte da luta. Não só nos EUA, mas de forma semelhante, muitas vezes o movimento internacional comunista era utilizado como desculpa para desacreditar e enfraquecer críticas sociais, ideias de reformas e manter injustiças em países alinhados aos EUA, servindo aos interesses de elites dessas nações.

O caso dos EUA pós-Segunda Guerra Mundial é um exemplo de um período no qual os historiadores destacam uma grande mudança no país, como a expansão dos subúrbios com novas formas de ocupação do espaço, êxodo rural, transformações nos centros urbanos, novas organizações familiares, culto à juventude, ascensão da televisão como comunicação de massa, ansiedades referentes à Guerra Fria, o anticomunismo, o medo da destruição da civilização, alteração nas relações étnico-raciais, discussão ampliada do papel feminino na sociedade, tecnologia cada vez mais avançada, novos eletrodomésticos, acesso a alimentos, surgimento de remédios psiquiátricos, crescimento econômico, apenas para citar alguns elementos que costumam ser discutidos quando se fala desse período da história dos EUA. Portanto, para perceber o impacto dessas rápidas mudanças, cabe uma observação das histórias de viagem no tempo do segundo pósguerra, pois, como dito anteriormente, elas lidam diretamente com as mudanças e permanências e criam discursos que tanto alimentam os impulsos progressistas e conservadores das sociedades, como são alimentados por eles. Ao observar as histórias de viagem no tempo, podemos então notar, em primeira mão, como o contexto era compreendido e experimentado por largas parcelas da população, principalmente em obras de sucesso que mantiveram sua relevância posterior.

Assim, era na nova mídia do segundo pós-guerra, a televisão e na série de antologia insólita Além da Imaginação (The Twilight Zone, 1959-1964) que notamos a transmissão para um público muito maior do espírito das revistas pulps, nas quais estavam presentes o grosso das histórias de viagem no tempo na época. O programa capitaneado pelo renomado roteirista de televisão Rod Serling, unia um grande número de talentos, roteiristas, técnicos, atores e diretores, da televisão e cinema da época, e, reiteradamente, lidava com o que Serling e seus parceiros notavam como sendo problemas da sociedade americana do período e, assim, podemos encontrar 
diversos episódios que abordam com a viagem no tempo como forma de forçar no público a uma reavaliação de valores presentes, inclusive problematizando de forma irônica as noções de passado e futuro propagadas. Portanto, a série Além da Imaginação, mais do que qualquer outro documento do período, por meio da viagem no tempo, estabeleceu e apresentou para o grande público uma forma de perceber as mudanças e permanências, criticando-as e incentivando-as, por meio da relação e da articulação entre as diferentes temporalidades. Foi exposto na série um discurso geralmente orientado para um futuro aperfeiçoado do mundo.

Cabe destacar a importância de Além da Imaginação para o desenvolvimento dos gêneros horror e ficção científica na televisão, cinema, literatura, videogame, histórias em quadrinhos, etc. Muitas obras em diversas mídias lançadas até hoje, direta ou indiretamente, podem ter sua origem traçada até essa série. Por exemplo, no contexto histórico da exibição original do programa, os filmes de ficção científica no cinema tendiam a ser mais voltados ao público infanto-juvenil e, geralmente, entravam na categoria de "filmes B" e a literatura alcançava um público mais restrito, ainda que aprofundasse muito mais os temas. Já Além da Imaginação vai apresentar a ficção científica de forma mais adulta e relevante no debate público, complementado à consolidação da ficção científica no meio audiovisual. Inclusive, a série foi importantíssima para o nascimento dos filmes blockbuster na década de 70 , muitos deles, de ficção científica ou que utilizavam os elementos principais deste gênero, obras inspiradas diretamente nas tramas de Além da Imaginação e na própria forma do programa contar histórias. Apenas para citar alguns diretores influenciados diretamente pela série temos, Steven Spielberg, Joe Dante, John Landis, George Miller, George Romero, Tobe Hooper, J.J. Abrams, M. Night Shyamalan, Jordan Peele; porém, a lista de envolvidos com as mais diversas expressões artísticas que foram influenciados por Além da Imaginação é gigantesca. Na televisão atual, o sucesso da série britânica de antologia Black Mirror (2011) e o próprio retorno de Além da Imaginação (The Twilight Zone) em 2019, ainda demonstram como os temas tratados por Serling, com uma nova roupagem e adaptados a nossos tempos, ainda nos acompanham.

Assim sendo, a série Além da Imaginação produzida por Rod Serling, que escreveu a maior parte dos episódios, é um documento histórico importantíssimo pois só um programa que consegue tocar em grandes questões que afetam os indivíduos, grupos e sociedades tem a capacidade de se manter até hoje relevante. A análise da 
série revela uma forma de dar sentido ao mundo contemporâneo e expõe a experiência dos EUA no segundo pós-guerra, com relfexoes e relações que podemos estabelecer até nossos dias.

No caso, o uso dos episódios que lidam com a viagem no tempo expõe como o tema era visto no contexto histórico estudado, quais os destinos das viagens e porquê alguns protagonistas irão parar em outras épocas, o quê é procurado e exemplificado com o uso da viagem no tempo como recurso narrativo no segundo pós-guerra, deixando-nos próximos da discussão e percepção social sobre as rápidas mudanças pelas quais passava a sociedade dos EUA e quais as perspectivas de futuro a viagem no tempo dava vazão. Para melhor compreender tudo isso, iremos realizar, nós mesmos, uma viagem por conceitos e histórias, assuntos paralelos e ideias, contando a origem da viagem no tempo e sua função social, passando brevemente pelo desenvolvimento da televisão nos EUA e os principais programas percursores de Além da Imaginaçao, expondo a história da série e de Serling, e analisando os episódios.

$\mathrm{Na}$ nossa primeira parada, em Um Safari pelo Tempo, demonstra o desenvolvimento do Tempo como símbolo, as principais divisões conceituais e o conceito que melhor se adapta para se compreender a viagem no tempo. Observamos também a função simbólica do Tempo e como as novas relações com as distintas temporalidades criam novas formas científicas e artísticas de se relacionar, compreender e integrar o Tempo na experiência social.

Na nossa segunda parada, em Todo o Tempo do Mundo: a viagem no tempo, a história do desenvolvimento da ideia de viagem no tempo é aprofundada, são estabelecidas as diferenças entre formas pré-modernas de viagem no tempo ocidentais e não ocidentais - dos modelos que surgem no século XIX e se desenvolvem no século XX. Observamos também, para enfatizar a importância da ideia de viagem no tempo no mundo contemporâneo, como filósofos e cientistas geralmente se debruçam sobre o problema da viagem no tempo. Por fim, discute-se a função social da viagem no tempo, a importância do presente e como o destino da viagem, o passado ou o presente, é utilizado pelos autores dessas histórias para enfatizar relações distintas com o presente.

Fazendo uma breve terceira parada, em A Chave da Imaginação, encontramos o contexto de produção da série Além da Imaginação, o desenvolvimento da televisão nos EUA e as grandes transformações pelas quais a 
sociedade americana e o mundo passaram no segundo pós-guerra. Além disso, os programas de televisão precursores da série de Serling são apresentados a fim de inserí-lo como parte da própria evolução da mídia no contexto histórico na qual ela surgiu, um ambiente de disputa entre as mais diversas pressões antagônicas por controle e liberdade de expressão, no modelo de exploração comercial da televisão.

Já na nossa quarta parada, em Sua próxima parada, Além da Imaginação, presenciamos a história da criação da série e a visão do criador do programa, Rod Serling. Passando por sua biografia, notamos como ele e a sua série se inseriam na televisão do período e quais posições nos debates correntes na época eram tomadas tanto pelo criador quando por sua criação. Contemplamos a recepção da série e de suas mensagens por parte do público da época e somos levados a ponderar como a questão da reflexão sobre o Tempo era uma temática central ao programa.

Nossa penúltima parada será em $\mathbf{O}$ Vórtice Temporal, aqui ficaremos mais tempo examinando como a viagem no tempo se manifestou dentre as experiências com o tempo/mudança nos EUA no segundo pós-guerra. Para tanto, analisaremos os episódios da série Além da Imaginação que lidam com a viagem no tempo. A viagem ao passado, dividida em viagem ao passado nostálgico e viagem no tempo ao passado não-nostálgico, percebe como os ímpetos nostálgicos se manifestavam na sociedade que emerge nos anos 50 e início dos 60 , assim como a cultura histórica e o uso dos mitos nacionais se articulavam para dar conta de marcar a relação entre os tempos e as preocupações com as mudanças e os possíveis rumos dos EUA e o do mundo. Nos episódios em que se presencia a viagem no tempo ao futuro, poderemos notar como essa temporalidade era exposta em distinção ao trato regular do futuro sem viagem no tempo no próprio conjunto da série. Notaremos também como a ideia de progresso era exposta, criticada e reforçada nas narrativas de viagem no tempo.

O nosso final de viagem está em $\mathbf{O}$ Grande Esquema das Coisas, no qual poderemos contemplar, enfim, o caminho percorrido e pensar sobre como as narrativas de viagem no tempo somam uma maior complexidade na reflexão sobre o símbolo Tempo e as próprias relações que estebecelemos, consciente ou inconscientemente, com as mais distintas temporalidades a fim de orientar, dar sentido e até mesmo transformar nossas vidas enquanto estamos presentes no mundo. 


\section{2- Capacitor de Fluxo}

Para se compreender a gênese das histórias de viagem no tempo e realizar a reflexão sobre as articulações entre esse tipo de temática e as sociedades que criam e consomem essas histórias, foi realizada uma pesquisa inicial com coletâneas das consideradas melhores ou principais histórias na literatura. A escolha inicial de entrar em contato com o tema via obras literárias é justificada pela grande influência dessas obras na origem do tema, já que as primeiras histórias de viagem no tempo estavam em revistas e livros, e o desenvolvimento das regras e repertório sobre a viagem no tempo se deu principalmente em contos das revistas pulps e nos livros dos mesmos autores regulares dessas revistas, obras publicadas originalmente nos EUA e no Reino Unido. O próximo passo foi deixar as histórias de lado para me dedicar a observar como o tema era discutido academicamente; a primeira obra que estudei foi o livro seminal sobre o tema de Paul J. Nahin, Time Machines - Time Travel in Physics, Metaphysics, and Science Fiction (1999). A segunda edição revisada conta com um interessante prefácio do físico Kip S. Thorne, que comenta a importância da obra e, mesmo que o autor foque muito e apenas na ficção científica e na presença de equipamentos especulativos baseados em conhecimento científico para delimitar a experiência com viagem no tempo, a análise e listagem das obras mais significativas referendou algumas das observações iniciais e iluminou o caminho que estava sendo traçado, com a observação da viagem no tempo restrita a uma temática dentro do amplo campo da fiçcão científica, visão esta que, como veremos, foi abandonada com a leitura de uma documentação mais ampla e mesmo análise de comentários dos próprios criadores de literatura de ficção científica quando falavam do tema.

Ainda na perspectiva de ter uma compreensão mais geral sobre a questão, foi consultado o dicionário temático de ficção científica organizado por John Clute e Peter Nicholls, The Encyclopedia of Science Fiction (1995), no qual pude examinar tanto os verbetes relacionados à viagem no tempo quanto os referentes a obras que havia lido previamente e às obras citadas por Nahin, indisponíveis ou difíceis de serem encontradas em língua portuguesa. Entretanto, uma noção mais ampla da problemática já estava se formando para confecção da primeira versão do projeto de pesquisa, apresentada para comentários de meu amigo e orientador no mestrado, professor Dr. Marcos Antonio da Silva na Universidade de São Paulo, em finais de 2013. 
Com um olhar ampliado, mas ainda dentro do campo da ficção científica, foi decidido focar nas obras de viagem no tempo em diversas mídias no segundo pósguerra, produzidas e consumidas incialmente nos EUA, que apresentavam o potencial de fornecer informações interessantes sobre as experiências desse contexto com as mudanças. Assim, foram listadas obras de histórias em quadrinhos, literatura, cinema e televisão que lidavam com a viagem no tempo para uma futura observação.

Quando da aprovação no programa de doutorado em História Social da Universidade de São Paulo, sob orientação do professor Dr. Marcos Antonio da Silva, percebi que para poder entender o que significava a viagem no tempo, faltava-me um conceito de Tempo que desse conta de auxiliar a decodificação e até me ajudasse a compreender melhor como esse símbolo regulador/organizador social estava sendo endossado ou subvertido pelos enredos de viagem no tempo. Por fim, aderi à definição de Norbert Elias, exposta principalmente no seu livro Sobre o Tempo (1998), pois sua percepção do Tempo como um símbolo em constante desenvolvimento e adequação às mudanças as quais ele invocado a dar sentido, encontra respaldo para compreensão da viagem no tempo como uma das formas que as sociedades desenvolveram para se relacionar com este símbolo de forma profunda e criativa, subvertendo e reforçando o seu papel organizador.

Assim, após pensar sobre o conceito de Tempo baseado em Elias, por perceber a importância do papel da cultura histórica na viagem no tempo e notar similaridades nas formas de se relacionar com o Tempo nessas histórias com o trabalho do historiador, porém, livre das restrições dadas pelos documentos históricos, recorri aos textos de teoria da História, principalmente as obras de Reinhart Koselleck, Futuro Passado (2006) e O Conceito de História (2013) - esta última obra uma coletânea de textos dele e de vários autores - e às obras de François Hartog, Evidência da História (2011), Regimes de Historicidade (2013), Os Antigos, O Passado e O Presente (2003).

Para ampliar a reflexão e a ligação entre as novas relações temporais que impulsionaram o conceito moderno de História e a viagem no tempo, ambas formas de se exprimir, em última instância, a noção de Tempo que surgiu de novas relações ocidentais com as mudanças, foram obsevadas também as obras de Renán Silva, Lugar de Dúvidas (2015), e Antoine Prost, Doze Lições sobre a História (2015). Como no primeiro momento estava sendo pensado o estudo de obras literárias, cujas reflexões se estendem a outras manifestações culturais, algumas obras ajudaram à percepção de como Tempo e História se articulavam em obras ficcionais, como a obra 
de Luiz Costa Lima, História. Ficção. Literatura (2006) e a de Paul Ricoeur, Tempo e Narrativa (2010).

Enquanto leituras de textos acadêmicos e de obras literárias eram realizadas a fim de compreender melhor o impacto social das histórias de viagem no tempo e ter acesso à fontes primárias das histórias publicadas no período, bem como consultar mais documentos que podiam ser utilizados, realizei uma visita de duas semanas em outubro de 2016 a Merril Collection of Science Fiction, Speculation \& Fantasy, arquivo pertencente à rede de bibliotecas públicas de Toronto, Canadá, local no qual há versões originais conservadas dos pulps e coletâneas. Nesse arquivo, com auxílio das bibliotecárias e arquivistas, pude copiar e ter contato com as obras ficcionais de viagem no tempo publicadas antes e no segundo pós-guerra, algumas das quais havia lido em repimpressoes e versões online; tive acesso também a diversos livros de teoria sobre a viagem no tempo, tanto da Filosofia e Física quanto de Crítica Literária. Também consegui dados biográficos importantes sobre autores e pude perceber quais obras eram mais valorizadas tanto no contexto da minha pesquisa, quanto a posteriori, bem como obras consideradas mais influentes por demais pesquisadores. Para minha sorte, presenciei uma coincidência fabulosa, que a meu ver demonstra a importância do tema viagem no tempo atualmente: enquanto estava no Canadá, foi lançado o livro de James Gleick, Time Travel: A History (2016), um livro de excelente nível que acompanha a gênese das histórias de viagem no tempo modernas até o presente. Na obra, o autor realiza reflexões sobre como elas se relacionam com os mais diversos contextos históricos e sociedades e as formas de cultura histórica, ainda que o Gleick não use esse termo.

Algumas obras importantes sobre a abertura do tempo futuro na Literatura e a ideia de viagem no tempo foram estudadas a fim de aprofundar as reflexões sobre a função social da viagem no tempo e as múltiplas formas em que essas histórias se manifestavam. Muitas dessas obras, mesmo que enfatizassem a ficção científica, reconheciam que a temática da viagem no tempo, embora geralmente associada a esse gênero, acaba se manifestando em outros gêneros, como a fantasia e comédia, por exemplo. Dentre as principais obras pesquisadas para essa fase da reflexão, encontram-se o livro organizado por George E. Slusser e Eric S. Rabkin, Intersections: fantasy and science fiction (1987), o livro de Paul K. Alkon, Origins of Futuristic Fiction (2010), a obra organizado pela filósofa Susan Schneider, Science Fiction and Philosophy (2016), o livro organizado por Gary Westfahl, George E. Slusser e David 
Leiby, Worlds Enough and Time (2002), o livro organizado por Matthew Jones e Joan Ormrod, Time Travel in Popular Media (2015), os dicionários histórios de M. Keith Booker, Historical Dictionary of Science Fiction in Literature (2015), e de Brian Stableford, Historical Dictionary of Science Fiction Literature (2004), além do guia crítico de Neil Barrow, a quinta edição de Anatomy of Wonder (2004). Devemos lembrar também do trabalho pioneiro no Brasil, a dissertação de mestrado de Luiz Vadico, $013^{\circ}$ macaco ou a estratégia social de evasão do tempo: um panorama sobre o tema da viagem no tempo, baseado em filmes de produção Hollywoodiana (2000), que fez um amplo apanhado de filmes e discussões de como a viagem no tempo era discutida e apresentada no cinema comercial dos EUA, inclusive se detendo no sucesso ou não da viagem, caso planejada.

A presença de obras do século XXI e bem recentes não é apenas a tentativa dessa pesquisa de se manter atualizada, mas também é mais um exemplo de como a temática da viagem no tempo não era muito pesquisada anteriormente e vem sendo explorada cada vez mais, talvez pela percepção do seu papel fundamental como mapa das relações sociais com o Tempo, em um período marcado não só por mudanças rápidas, mas também pela falta de perspectivas, o presentismo.

Com essas leituras realizadas e uma ampla documentação que atravessava diversas mídias, percebeu-se, em conversa durante a qualificação, que o foco em um único tipo de documentação poderia deixar a pesquisa mais rica e, dentro da perspectiva da construção de uma interpretação original. Por sugestão dos professores Laura Loguercio Cánepa, Marcos Antonio da Silva e Robert Sean Purdy, a série Além da Imaginaçao (The Twilight Zone, 1959-1964) foi escolhida como fonte primária da pesquisa, pois ela lidou de forma recorrente e adulta com o tema da viagem no tempo, inspirada pela cultura literária, abordando-o tanto no modelo da ficção científica quanto no da fantasia e, incrivelmente, para nossa surpresa, mesmo sendo uma série icônica com uma enorme influência nos gêneros insólitos horror e ficção científica, dada sua relevância, há poucas pesquisas que a utilizaram como documento histórico, ou mesmo que aprofundaram os temas presentes na série.

Assim, o desafio de se analisar uma produção audiovisual televisiva e a inserção da série e da viagem no tempo nela exibida, no seu contexto histórico, tomou forma. Para tanto, foram pesquisados os primeiros momentos da televisão no mundo e nos EUA, os programas precursores a Além da Imaginação e foi analisada a influência dessa série no desenvolvimento posterior do cinema blockbuster e em 
outras manifestações culturais nas mais diversas mídias as quais foram influenciadas por essa série.

Para entender o impacto da televisão e de sua programação, foram estudados artigos com temas específicos, como o papel das empresas de revisão de conteúdo dos roteiros e da aferição da audiência, os principais roteiristas e temáticas do período e livros importantes que permitiram pensar a série e o seu criador, Rod Serling, no contexto do segundo pós-guerra, além de obras que descreviam a programação que lidava com temas afins à Além da Imaginação, antes do programa ir ao ar e durante a sua exibição. Dentre as obras, destacam-se o livro de Jeffrey Sconce, Haunted Media (2000), a quarta edição da obra de Michele Hilmes, Only Connect (2014), o livro de Gary R. Edgerton, The Columbia History of American Television (2007) e o livro de David Marc e Robert J. Thompson, Television in the Antenna Age (2005). Para complementar o estudo, assisti a programas de televisão dos mais diversos gêneros do período, disponíveis em cópias digitalizadas, por vezes restauradas, dos filmes originais (kinescope) e em lançamentos de coletâneas em DVD e Blu-ray.

Para estudo e análise da série, todos os 156 episódios foram assistidos em cópias em DVD e Bluray, incluso os extras da coleção lançada nos EUA no final de 2016, The Twilight Zone: The Complete Series Blu-ray, e listados, sendo realizada uma divisão prévia entre os episódios que lidavam de alguma forma com a relação com as temporalidades, com e sem viagem no tempo, e os episódios que não lidavam com o tema. Posteriormente, dentre os episódios nos quais foi notada que a relação entre passado, presente e futuro era fundamental para o desenvolvimento do enredo ou sua compreensão e seu impacto, foram separados aqueles de viagem no tempo, o que permitiu uma reflexão ampliada sobre quando e como o recurso a esse tema era utilizado na série, o que os distinguia e aproximava dos demais episódios que procuravam estabelecer relações entre os tempos. Com os episódios de viagem no tempo selecionados, foi realizada mais uma separação, entre a viagem no tempo ao passado e a viagem no tempo ao futuro, pois se confirmou que o destino da viagem, como já estava exposto nas obras que discutiam o tema, era importante para se compreender a articulação das distintas temporalidades com o contexto histórico de Além da Imaginação.

No decorrer das análises, mais uma divisão foi realizada, agora no campo da viagem no tempo ao passado. Muitos episódios de viagem no tempo ao passado se referiam ao problema da nostalgia das sociedades modernas; assim, foi realizado um 
estudo sobre este sentimento histórico com base no livro The Future of Nostalgia (2001), de Svetlana Boym, uma obra que indicou um norte para reflexão e melhor compreensão do uso da viagem no tempo a passados nostálgicos.

Com o esquema primário organizado e as indagações iniciais sobre os episódios anotadas, foi dado destaque às obras que analisavam a série como um todo, contando sua história até o final e listando episódios, com dados técnicos e peculiaridades, baseadas em entrevistas e documentos históricos da produção. Para não influenciar o primeiro contato com os episódios, foi deixada de lado a leitura desses compêndios até que a listagem estivesse completa, porém alguma noção, não tão completa, sobre o histórico da série era de conhecimento deste pesquisador antes mesmo de todos episódios terem sido assistidos. Foram consultados praticamente todos os livros disponíveis em língua inglesa lançados até 2018 sobre a série, em diversas edições: assim, temos as duas edições do livro de Marc Scott Zicree, a segunda e terceira edição revisada, The Twilight Zone Companion (1992 e 2018); a obra de Martin Grams Jr., The Twilight Zone: Unlocking the Door to a Television Classic (2008); a enciclipédia de Steven Jay Rubin, The Twilight Zone Encyclopedia (2018); o livro de Don Presnell e Marty McGee A Critical History of Television's The Twilight Zone, 1959-1964 (2008); e o livro de Stewart T Stanyard, Dimensions Behind the Twilight Zone: A Backstage Tribute to Television's Groundbreaking Series (2008).

Para compreender melhor quem era Rod Serling, todos esses livros, em maior ou menor grau, contam com capítulos ou trechos grandes que relatam a história do criador da série, contudo também foram lidas as biografias escritas por Anne Serling, As I Knew Him: My Dad, Rod Serling (2014), e por Gordon F. Sander, Serling: The Rise and Twilight of Television's Last Angry Man (2011). Quando os capítulos sobre Serling e a série já estavam prontos, foi lançado o livro de Nicholas Parisi, Rod Serling: His Life, Work, and Imagination em finais de 2018, autor que esmiuçou a carreira de Serling, comentando e trazendo dados de uma série de trabalhos desconhecidos ou pouco lembrados fora do grupo de fãs do autor.

Para a reflexão teórica sobre Além da Imaginação em geral, focada em temáticas, mesmo que alguns dos livros acima realizem análises críticas dos episódios, algumas mais interessantes e significativas do que outras, foram pesquisados trabalhos acadêmicos de análise da série. Assim, foi lida a tese de doutorado do brasileiro Pedro Henrique Baptista Reis, The Twilight Zone, Utopia e Construção da Identidade: Em outros mundos seremos outros homens?, defendida 
em 2014 na Faculdade dos Meios de Comunicação Social da Pontifícia Universidade Católica do Rio Grande do Sul, um trabalho que demonstra como muitas vezes outras sociedades dão mais valor a determinado documento histórico do que a própria sociedade que o produziu, o que talvez até pelo distanciamento, no caso no tempo e espaço, permite uma observação mais profunda e significativa. Cabe destaque a isso, pois pelo impacto e importância da série Além da Imaginação no desenvolvimento de narrativas insólitas audiovisuais, considero ainda insuficiente a quantidade de trabalhos que a observam como documento.

Além da tese de Reis, foi consultada outra obra pioneira no estudo acadêmico de Além da Imaginação no mundo, haja vista que foi publicada em 1990, uma obra também brasileira, o livro de Heitor Capuzzo O Cinema Além da Imaginação (1990), derivada de sua pesquisa de mestrado que investigava a linguagem cinematográfica na série, a inseria no desenvolvimento da ficção científica da época e percebia sua enorme influencia na emergência do cinema blockbuster, isso tudo, cabe lembrar, numa época de difícil acesso as fontes, o que torna o trabalho de Capuzzo ainda mais interessante.

Foram também estudados dois trabalhos teóricos sobre a série, o livro de Leslie Dale Feldman, Spaceships and Politics: The Political Theory of Rod Serling (2010), um trabalho que apresenta uma interessante leitura de como os temas em Além da Imaginaçao, no contexto histórico da série, dialogavam com as teorias políticas de filósofos como Thomas Hobbes, Karl Marx e pensadores iluministas; e a obra de David Melbye, Irony in The Twilight Zone: How the Series Critiqued Postwar American Culture (2015), uma pesquisa que tenta compreender a função social da ironia utilizando a série como exemplo máximo do uso desse recurso na condição de crítica social, analisando os episódios em campos críticos no qual a ironia é o fator articulador da série. Sua tese é que a unidade da série, dada a variedade de gêneros consagrados que encontramos representados nos episódios, é fornecida pelo uso recorrente da ironia, fundamental para uma compreensão aprofundada de Além da Imaginação e foi a perspectiva adotada nesta pesquisa.

Como pode ser visto, assim como a pesquisa sobre viagem no tempo, a maior parte das obras são recentes, o que demonstra o interesse renovado pela série que vem surgindo nos últimos anos nos EUA e no mundo, cristalizados pelo ressurigimento da última encarnação de Além da Imaginação em 2019, no ano de aniversário de 60 anos da obra. Contudo, devido ao impacto cultural da série, Além 
da Imaginação ainda é subutilizado como documento histórico e ainda pode contribuir muito mais para compreensão do contexto histórico da obra e além. Esta própria pesquisa faz parte desse movimento de redescoberta de Além da Imaginação como uma excelente fonte de pesquisa em vários campos distintos, o que prova seu enorme impacto social mundial e a relevância do trabalho de Rod Serling para compreensão do mundo contemporâneo.

Após a leitura desses livros e a inclusão do que era consultado para auxiliar a análise dos episódios de viagem no tempo na série, foi realizada uma viagem em julho de 2017 a Madison (Wisconsin, EUA), especificamente ao arquivo da Wisconsin Historical Society, instituição ligada à Universidade de Wisconsin, onde está um dos arquivos de Rod Serling, doado pelo próprio autor. Nesta instituição, tive acesso às cartas pessoais de Serling, cartas de pessoas querendo oferecer roteiros para Além da Imginaçao, além de correspondência de fãs e críticos da série, documentos de produção, roteiros originais de Rod Serling, muitos em vários estágios da produção, com anotações e observações feitas por Serling. Devido ao curto período para realização da seleção do material, apenas 15 dias, foi dada maior ênfase na documentação que envolvia o contexto de exibição da série e os episódios específicos de viagem no tempo; todavia, documentos de episódios importantes da série fora da temática da pesquisa também foram consultados. Felizmente, a Wisconsin Historical Society disponibiliza aos pesquisadores máquinas para digitalização dos documentos, que foram devidamente copiados em formato digital e totalizaram milhares de páginas para análise posterior mais detalhada, as quais ocuparam vários meses da pesquisa.

Com os documentos, pude constatar as informações presentes nos livros, principalmente as fichas de produção, em grande parte confirmando-as. No caso de dúvidas, onde a documentação não era clara ou as informações eram dependendes de uma única fonte sem outros documentos para conferir os dados, preferi omitir as informações e/ou reflexões pessoais que poderiam ser realizadas com base nestes documentos, pois não pude checá-las. Entretanto, foram poucos casos e mais relacionados a dados biográficos que não alteram o corpo da análise dos episódios de viagem no tempo.

No decorrer da pesquisa e análise dos episódios, foi percebida a necessidade de adquirir um conhecimento complementar sobre como os problemas ou mesmo o retrato da temporalidade exibida eram tratadas no contexto da série, principalmente os enredos com viagem ao passado. Assim, uma nova série de livros e artigos foram 
consultados para analisar cada um dos episódios selecionados, bem como contrastados com informações presentes nos documentos de produção e cartas para melhor compreender o impacto da mensagem do episódio ou quais razões para determinados enredos serem recorrentes ou representarem uma temporalidade de tal forma.

No mês de maio de 2018, enquanto analisava a documentação, fui informado que na cidade onde Rod Serling crescera, haveria um evento anual chamado Serling Fest, organizado pela Rod Serling Memorial Foundation, com a presença de três autores que eu havia consultado para compor a pesquisa, citados anteriormente, a filha de Rod Serling, Anne Serling, Martin Grams Jr. e Steven Jay Rubin. Assim, me dirigi para a cidade de Binghamton, NY, e participei do evento de 5 a 7 de julho, onde pude assistir a palestras e conhecer pessoalmente os autores dos livros que havia utilizado na pesquisa, além de outros pesquisadores e autores como Mark Dawidziak, Nicholas Parisi e Michael Pipher, experiência indispensável para realização da pesquisa. Coincidentemente, mesmo que a Serling Fest não tivesse como foco os episódios de viagem no tempo, as ligações de Rod Serling com a sua cidade foram ressaltadas, inclusive com testemunhos, o que me forneceu material para pensar principalmente na questão da nostalgia expressa na série. A Rod Serling Memorial Foundation trabalha para preservar as obras e a memória de Rod Serling nos EUA e atua mais enfaticamente na cidade de Binghamton e seus arredores. Nessa cidade há ainda o museu The Bundy Museum of History \& Art, que expõe e coleciona material referente a Rod Serling e Além da Imaginação. Segundo o arquivista e historiador do museu, Michael Pipher (ex-membro da Rod Serling Memorial Foundation), parte do acervo do museu foi doado para o arquivo sobre Serling em Wisconsin, local que eu havia visitado em 2017.

Já no início do ano de 2019, em janeiro, surgiu a oportunidade de viajar para a cidade de Los Angeles, onde se encontra um outro arquivo sobre Rod Serling, doado por sua viúva, Carol Serling, à University of California, Los Angeles (UCLA). Para verificar se havia algo nas cartas pessoais que poderia ajudar, entrei em contato com a coleção especial da Charles E. Young Research Library e, como a parte dos arquivos de Serling que interessava era restrito, consegui a autorização de Carol Serling e tive acesso a uma série de cartas que enfatizavam e davam maior suporte para as afirmações realizadas na pesquisa, especificamente sobre a visão política de Rod Serling e as temáticas sociais que mais o interessavam. No mesmo arquivo, 
aproveitei para observar também o arquivo de Buzz Kulik, diretor que teve enorme carreira na televisão e dirigiu nove episódios para Além da Imaginação, quatro dos quais analisados nessa pesquisa, podendo acessar mais dados sobre os três episódios que tiveram envolvimento dele e também dar mais suporte aos comentários e dados.

Isto posto, cabe ressaltar que o único arquivo público sobre Rod Serling que não cheguei a verificar foi o presente na Ithaca College Library, arquivo pertencente à faculdade de Ithaca, interior do estado de Nova York. Tentei um contato inicial em 2017, sem resposta, via formulário do site e e-mail, porém, a coleção deles que me interessava era a dos roteiros originais de Além da Imaginação e como no arquivo de Madison havia mais material, inclusive os mesmos roteiros, ao mesmo tempo que havia contatado Ithaca mandei mensagem a Wisconsin Historical Society, onde consegui um contato rápido via e-mail, algo indispensável quando temos que planejar uma viagem de tal escopo, o que me levou a decidir ir primeiramente a Madison realizar a visita inicial a um arquivo sobre Rod Serling. Posteriormente, quando estava em Binghamton, em 2018, cheguei a visitar a faculdade de Ithaca para ver a coleção dos prêmios Emmy que Rod Serling ganhou em sua carreira, expostos numa vitrine, mas nesse momento da pesquisa já tinha todos os roteiros de que necessitava e não haveria motivo para ver mais cópias do mesmo material.

Portanto, a pesquisa sobre a viagem no tempo na série, complementada por material dos arquivos, em grande parte inéditos, pôde em primeira mão perceber como o público se relacionava na época com esse tipo de história, enfatizadas pelas sugestões de histórias com essas temáticas que eram regularmente remetidos a ele e, como veremos, muitos roteiros não solicitados enviados para Serling não eram sequer abertos e eram imediatamente devolvidos. Assim, um número muito maior dessas histórias encontrava no ambiente imaginário proposto pela série vazão para se manifestarem na própria imaginação do público. Não só isso, anotações, alterações entre versões dos roteiros, comentários dos produtores e de Serling e entrevistas, por exemplo, nos permitem observar de forma ímpar a função social da viagem no tempo e como ela era utilizada para dar sentido as relações entre às temporalidades na experiência dos EUA no segundo pós-guerra, muitas das quais globalizadas, como o vínculo entre progresso e decadência e as próprias consequências da Guerra Fria.

Nesta pesquisa, foi decidido o uso de uma linguagem mais acessível, sem prejuízo das definições e precisões do vocabulário. As análises, posições e escolhas 
teóricas foram formuladas partindo-se do princípio de que a objetividade e a precisão da linguagem ampliam o acesso tanto de acadêmicos quanto de pessoas interessadas em saber mais sobre viagem no tempo e sobre a série Além da imaginação.

Os capítulos foram revisados e reescritos para tentar alcançar estes objetivos, muitas vezes expandindo as análises e inserindo mais dados para justificar melhor o que foi escrito. Outro ponto a destacar é que como esta pesquisa foi desenvolvida em uma universidade pública e por um período ter contado com apoio de bolsa de estudos federal (CAPES), há o esforço de ampliar o alcance da pesquisa na perspectiva inclusive de prestação de contas e difusão do conhecimento, tentando atrair parcelas do público não acadêmico para as reflexões e informações transmitidas neste trabalho. Reconhecendo o apelo popular que as temáticas pesquisadas possuem, porém sem banalizar ou infantilizar o texto, um dos princípios norteadores é que qualquer pessoa interessada nesta pesquisa possa entender o máximo possível e acompanhar o caminho realizado nas reflexões e análises, incluindo a adequação dos conceitos aos temas trabalhados: por isso, o cuidado expresso de sempre explicar em linhas gerais os conceitos apresentados.

Para o estudo da documentação, foi realizada a interpretação histórica da obra partindo da reflexão sobre a tríade: comentário, análise e interpretação. Os episódios e a própria série Além da Imaginaçao foram relacionados ao contexto histórico, partindo-se do princípio básico de que o comentário, a análise e a interpretação estejam justificados nos elementos intrínsecos e decodificáveis do programa de televisão. Não foi seguida uma metodologia rígida de investigação e foi estabelecido uma espécie de diálogo com a série e os episódios, a partir das observações da pesquisadora Manuela Penafria (2009, p.9), em sua proposta de uma análise interna ou externa das obras audiovisuais, o que foi realizado nos episódios pensando em dimensões textuais mais básicas e reflexões sobre poética, símbolos, sons, imagens, linguagem que expressavam a comparação entre os tempos e os propósitos da viagem em si. Assim, foi seguida uma organização criteriosa das perguntas e dos pontos que deveriam ser enfatizados para que fosse entendida como a viagem no tempo se manifestava para construir relações entre presente e passado e presente e futuro, como as mudanças estavam sendo percebidas e criticadas, quais expectativas de futuro se vislumbravam no horizonte histórico, como o passado era interpretado e resignificado pelo presente e como ele se fazia vivo. 
$\mathrm{Na}$ análise dos episódios, foram articulados a reflexão sobre o audiovisual, a decodificação imagética, com os dados adquiridos via cartas, roteiros, contos e textos da produção e, nos casos, onde se fez necessária, foi realizada a conexão do que era visto no programa com as visões mais amplas do contexto histórico e da cultura histórica. Portanto, foram correlacionados uma série de documentos, com o documento audiovisual no centro, para tentar reconstruir e propor uma análise sobre como a viagem no tempo era utilizada como ferramenta de expressar as relações entre as temporalidades no período, tanto conscientes por parte dos atores sociais quanto impulsionadas por outros elementos. Na confecção do texto, optou-se pela escolha de não se alongar na descrição dos episódios.

Para melhor compreender a viagem no tempo, foram pensados alguns elementos fundamentais, observados em todos episódios. Primeiramente, qual seria o destino da viagem e qual ponto de referência seria utilizado para marcar a viagem, e dada a estrutura dos roteiros da série, foi escolhido o protagonista como entidade referencial; assim, uma viagem no tempo de um protagonista do final do século XIX para a época de produção da série foi considerada uma viagem ao futuro, por exemplo. O segundo ponto é como se dá a viagem no tempo, por uso de máquina, por intervenção sobrenatural, por mágica, etc., pois cada forma de expressar a viagem no tempo indica uma maneira de se relacionar com o símbolo Tempo distinta, inclusive o papel desempenhado pelo protagonista. O terceiro ponto observado era qual conceito de História estava sendo utilizado para encadear as diferentes temporalidades, o que nos leva ao último ponto, a análise de como a temporalidade do protagonista e a temporalidade de destino eram retratadas, tanto no campo audiovisual quanto nos sentimentos evocados pelas cenas.

Portanto, ao observar quais funções a viagem no tempo desempenhou, críticas ou de reforço ao status quo, nos EUA dos anos 50 a meados dos anos 60, podemos pensar quais relações com o Tempo atual estão sendo problematizadas, muitas vezes sem total consciência por parte dos seus autores.

A série Além da Imaginação é um documento histórico reflexivo sobre as percepções sociais de mudança e permanência e mesmo que estas percepções estejam presentes em episódios que não lidam com viagem no tempo, elas se tornam mais claras e expostas quando tal deslocamento é chamado a surpreender o público e os próprios viajantes. 


\begin{abstract}
"About the future I only can reminisce
For what I've had is what I'll never get

And although this may sound strange

My future and my past are presently disarranged

And I'm surfing on a wave of nostalgia for an age yet to come

I look I only see what I don't know

All that was strong invincible is slain

Takes more than sunshine to make everything fine

And I feel like I'm trapped in the middle of time

With this constant feeling of nostalgia for an age yet to come"2
\end{abstract}

(Pete Shelley)

\title{
2- Um Safari pelo Tempo
}

\section{1- Checando os ponteiros}

A fim de compreender o que significa a subversão do símbolo Tempo - a "viagem no tempo"-, é necessária uma reflexão sobre o que seria o Tempo, o que nesse símbolo não só passou a incomodar tanto as sociedades contemporâneas, modernas, pós-modernas, mas também a noção de ser possível fugir de ou controlar o fluxo temporal, o domínio humano da vida. Apenas no final do século XIX, há registro histórico de uma literatura de viagem no tempo por meio de uma máquina (1881 e 1887), mesmo que o primeiro objeto em questão -um relógio - e a forma de viagem não possam ser considerados exatamente algo relacionado a conhecimento científico das leis naturais, tampouco de uma especulação tecnológica, estando mais no campo da fantasia, fato que pode ser compartilhado no livro espanhol de 1887 que apresenta a primeira máquina inventada exclusivamente para viagem no tempo, El

2 Trecho de música da banda inglesa Buzzcocks, "Nostalgia" do álbum Love Bites, 1978. Tradução nossa: "Sobre o futuro só posso relembrar/ Porque o que tive é o que nunca possuirei/ E mesmo que isso possa soar estranho/ O meu futuro e meu passado estão presentemente desorganizados/ E estou surfando em uma onda de nostalgia por uma época que virá/ Eu olho e só vejo o que não sei/ Tudo que era forte invencível está morto/ É preciso mais do que um raio de sol para que tudo fique bem/ E sinto que estou preso no meio do tempo/ Com esse sentimento constante de nostalgia por uma época que virá". 
Anacronópete, de Enrique Lucio Eugenio Gaspar y Rimbau. Além disso, o relógio, que poderia ser um pedaço de rocha, e a máquina anacronópete e a primeira incursão no tema da viagem no tempo de H.G. Wells em 1888, The Chronic Argonauts, não tiveram o mesmo impacto da máquina do tempo que Wells tornaria popular posteriormente. Entretanto, é nesse contexto das décadas finais do século XIX que a viagem no tempo sem máquina, predecessora da viagem no tempo com algum engenho, começou a se tornar mais habitual nas narrativas das mais diversas artes, das quais falaremos mais adiante.

Seja como for, com ou sem algum artefato, a narrativa de viagem no tempo sobreviveu ao modismo temático da ficção e fantasia e nos acompanha consistentemente nas mais diversas expressões artísticas desde a década de 90 do século XIX, se fazendo presente em contos, livros, obras audiovisuais, músicas, artes plásticas, jogos de videogame, sonhos, etc.

Além disso, deve ser procurada e explicitada uma definição do que seria o Tempo, principalmente um conceito que consiga, ao ser enunciado, dar conta da análise, reflexão e explicação das histórias com viagem no tempo e ajudar à compreensão das sociedades, como a nossa, que utilizam do expediente da viagem no tempo para entreter, educar e refletir sobre a nossa experiência no tempo e nossas relações com as mudanças e permanências humanas - o que é, de forma científica e autoconsciente, a preocupação do historiador e da ciência histórica, como praticada atualmente.

Portanto, mesmo que não seja do escopo desta pesquisa entrar no debate, ou de forma análoga, propor uma definição original do que seria o Tempo, faz-se necessário, ainda que de forma indireta, posicionar-se nas diversas linhas de conceitualização do que é o Tempo, procurando uma definição coerente com o objeto da pesquisa e que possa contribuir para a análise e interpretação dos documentos históricos selecionados.

\section{2- Lados do Tempo}

Segundo o historiador Eugênio Rezende de Carvalho, no próprio desenvolvimento do pensamento filosófico e científico, encontrarmos os conceitos de tempo divididos rigidamente em uma perspectiva objetivista e subjetivista do que ele é/seria. A perspectiva objetivista caracteriza o tempo como algo natural, quantitativo, 
externo à existência e ação humana, ele nasce com nosso universo, físico, real, cósmico. É o tempo das ciências (CARVALHO, 2012, p.4) exatas. Nessa definição, o tempo é determinado por referenciais da natureza, é o tempo que vemos nos calendários e relógios (sua menor unidade é o tempo de Planck), seria um tempo externo ao ser humano e a sua vida, e ainda que seja o referencial utilizado para controlar e organizar a existência, o tempo natural aparenta ser objetivo e pode ser medido por instrumentos criados para este fim. Os grandes expoentes do tempo natural são Aristóteles, Newton e Einstein (Ibid., p.2-3) e mesmo que o último cientista tenha propagado a ideia de uma nova unidade, o espaço-tempo, o papel do observador na medição do tempo e a irrealidade do tempo, sua teoria fornece dados para a existência do tempo externo à humanidade. Enfim, o tempo seria real, objetivo, não dependente dos seres humanos, "uma dimensão provavelmente discreta [que possuiu uma unidade mínima indivisível] e com certeza relativa [no sentido das descobertas e implicações dos estudos de Einstein, pois não é porque o tempo é determinado por um observador que ele deixaria de ter uma existência extrínseca]" (CHERMAN; VIEIRA, 2013, p.23).

Em contraposição, conceitos de Tempo que podem ser definidos como parte da perspectiva subjetivista, como o tempo da consciência, social, psicológico, cultural, vivido, qualitativo, imaginário, histórico (CARVALHO, 2012, p.4) dariam conta da percepção humana da passagem do tempo, ou seja, organização e percepção das mudanças, do ciclo da vida, sonhos, das mudanças sociais e individuais, seria um tempo do sujeito, que, ao contrário do tempo da natureza, passaria de forma distinta para cada pessoa, grupo social e sociedade. O grande expoente do tempo social é Santo Agostinho (Ibid., p.1-3).

Essas duas abordagens distintas e áridas de se pensar o Tempo desenvolveram, na linha subjetivista no século $X X$, a concepção de que existiriam dois tempos: um externo à humanidade, da física e do cosmos; e um tempo da percepção humana, com suas articulações temporais, ou tempo social das mudanças individuais e sociais, formulação oriunda das obras de Edmund Husserl, Henri Bergson, Gaston Bachelard e Martin Heidegger (lbid., p.3). Essa conceitualização em dois campos distintos reitera a separação ocorrida no seio do pensamento científico entre ciências naturais, exatas ou "hard sciences" e as ciências humanas, imprecisas ou "soft sciences", divisão ainda estabelecida nos ambientes das disciplinas e nas concepções populares do que seria ciência. No campo da Física, partindo da linha objetivista, 
Stephen Hawking propôs a existência de no mínimo três tempos: o termodinâmico, o cosmológico e o psicológico (HEATH; SLUSSER, 2002, p.11), que, segundo o professor de literatura Geroge Slusser e o biofísico Robert Heath seriam os três tempos passíveis de serem encontrados nas narrativas de viagem no tempo; entretanto, esses três tempos podem ser inseridos na divisão de tempo objetivista e tempo subjetivista, apenas acrescentando outro exemplo de tempo natural. Ainda segundo Eugênio Rezende de Carvalho, a partir das últimas décadas do século $X X$, diversos novos estudos passaram a superar e mediar essas linhas dicotômicas de abordar o problema do tempo, como as obras de Paul Ricœur, Mario Toboso Martín, José Carlos Reis, Guadalupe Valencia García e Norbert Elias (CARVALHO, 2012, p.5).

\section{3- Seu interior é maior do que seu exterior}

Partindo da ideia do sociólogo alemão Norbert Elias (1998) para se pensar o Tempo e as aventuras que o subvertem, o tempo é um conceito extremamente complexo, construído coletivamente pelas sociedades humanas e suas interações por milhares de gerações - seria impossível um indivíduo criá-lo sozinho. Ele incorpora a natureza e a percepção humana como marcador e organizador de eventos e das mudanças naturais e sociais, transmitindo referenciais coletivos que permitem aos indivíduos e às sociedades se localizarem nos devires.

Para o sociólogo, o tempo remete ao

[...] relacionamento de posições ou segmentos pertencentes a duas ou mais sequências de acontecimentos em evolução contínua. Se as sequências em si são perceptíveis, relacioná-las representa a elaboração dessas percepções pelo saber humano. Isso encontra expressão num símbolo social comunicável - o ideia de "tempo", a qual, no interior de uma sociedade, permite transmitir de um ser humano para outros imagens mnêmicas que dão lugar a uma experiência, mas que não podem ser percebidas pelos sentidos não perceptivos. (ELIAS, 1993, p.13)

Elias defende em sua obra "Sobre o Tempo" (1998) que a dificuldade em se definir o que seria o tempo, algo que incomoda filósofos e cientistas, é devido ao próprio processo de naturalização da percepção desse fenômeno, visto ora como algo da natureza, ora como a percepção da mudança notada por indivíduos, grupos e sociedades. 
O sociólogo destaca a importância da linguagem sobre o tempo, socialmente construída por milênios, em nossa relação com esse símbolo complexo, inclusive mostrando como as classes gramaticais acabam por definir, em um processo de naturalização, o tempo e as formas como a sociedades se relacionam com ele.

Conforme a ciência foi criando e substituindo (mas não eliminando) outros modelos de percepção e interação com o mundo, como os modelos baseados na religião, e as sociedades ocidentais foram racionalizando, ou seja, tentando administrar racionalmente a produção de riquezas e a própria vida em sociedade (característica da modernidade), o tempo baseado em referenciais naturais cada vez mais passou a regular a experiência cotidiana e por se adequar muito bem à nova realidade, passou a ser percebido como um ente que se manifesta através dos instrumentos de sua medição, ganhando vida própria e reificado nos relógios, nos smartphones, nos calendários, nas datas de lançamento de um novo filme ou série, no horário e na duração da novela, no sinal da escola, no aplicativo de transporte urbano, e não como uma criação coletiva humana com a finalidade de organizar e medir os acontecimentos, as mudanças e as permanências. O tempo é como os humanos acompanham a mudança das coisas (GLEICK, 2016, p. 269), relacionando continuidades e transformações.

Portanto, baseado no sucesso do referencial, o tempo das regularidades naturais independentes percebidas pelos humanos seria mais correto como referencial do que o tempo social ou psicológico? Essa é uma pergunta interessante, que pode ser respondida no tocante a que a regularidade dos eventos naturais escolhidos como marcadores para os acontecimentos permite uma localização dos eventos mais simplificada para sociedades cada vez mais complexas e interligadas, comunicando de forma clara a ideia de tempo. Todavia, refletindo sobre o símbolo em si, por exemplo, não notamos no dia-a-dia que o que chamamos de segundo foi padronizado em convenção do Système international d'unités (SI) no final da década de 60 do século $\mathrm{XX}$, determinado por nosso conhecimento do mundo atômico do Césio-133. Ou seja, a própria escolha do referencial da natureza, seja a astronomia ou a atomística, para determinar o tempo expõe o alto grau de complexidade de nossas sociedades e o caráter cumulativo da construção desse símbolo relacional, já que conseguimos marcar e organizar a mudança com alto grau de precisão, vista como necessária para o funcionamento satisfatório do nosso mundo e das descobertas científicas. 
O melhor referencial é o que cumpre os objetivos que determinada sociedade espera nas mais diversas situações quando o símbolo do Tempo é invocado, dando significado às ações e se localizando dentro de um eterno contínuo que vai do que já foi, ao o que é e ao que irá se tornar.

\section{4- No jardim onde os conceitos se bifurcam: tempo histórico e viagem no tempo}

Durante a Idade Média e o Renascimento, saber exatamente as horas não era uma questão muito relevante - mesmo com a invenção dos relógios mecânicos no século XIII -, tampouco era de muita utilidade a divisão do tempo em presente, passado e futuro (BOYM, 2001, p.9). Nessa perspectiva, o passado servia como aprendizagem e já estava escrito e o tempo futuro não era passível de controle humano, as coisas ocorriam por vontade divina ou caprichos do destino, a fortuna fazia parte do dia a dia das relações sociais.

Nas reflexões sobre o tempo, no decorrer do século XVIII, mudanças no Ocidente relacionados ao conhecimento científico, filosófico, transformações políticas, sociais e econômicas, bem como suas articulações, transformaram as antigas maneiras de se relacionar, experimentar e representar o tempo (ASSIS; MATA, 2013, p.14-15). Os antigos modos de representar o tempo com alegorias humanas (por exemplo, uma mulher semidespida representando o destino e velhos e jovens cegos carregando ampulhetas) se transformaram em números impessoais, claramente simbolizados nos horários dos trens. (BOYM, op. cit., p.9). Essas formas antigas de representar visualmente o tempo também foram substituídas por um símbolo forte: o movimento dos ponteiros do relógio ou, mais dramaticamente, pelo movimento do pêndulo. O tempo passou a ser impessoal e marcado por números, cada vez mais observado como algo externo ao ser humano, um tempo "real" em oposição a uma experiência humana no tempo, o tempo humano, "subjetivo".

Essas mudanças partem tanto de Newton quanto dos processos que geraram e foram gerados pela Revolução Industrial - inclusive a relação Ciência e Revolução Industrial, com a mecânica newtoniana aplicada ao desenvolvimento tecnológico (BEKAR; CARLAW; LIPSEY, 2005, p.242) -, o lluminismo, o enfraquecimento da explicação religiosa do mundo, a Geologia, recuando cada vez mais a idade de nosso planeta, e a Revolução Francesa, transformação de toda uma ordem social a partir do 
regicídio (BOYM, 2001, p.9). Tudo isso levou à abertura do tempo futuro, uma nova temporalização se formou, abandonando a concepção escatológica de História (ASSIS; MATA, 2013, p.14-15). Isso foi sentido nas transformações das antigas maneiras herdadas de se escrever História e sua função social, levando em conta que o conceito de História passou a incorporar toda experiência humana no tempo, em um processo que representou a ineficácia do uso da historia magistra vitae (passado como lição e exemplo) e o nascimento do conceito moderno de História (KOSELLECK, 2013, p.119) que incorpora essa nova temporalidade futura e a valoriza. Segundo Svetlana Boym (2001, p.9), a era moderna permitiu concepções múltiplas de tempo e tornou sua experiência mais individual e criativa.

O historiador alemão Reinhart Koselleck nos mostrou que foi criada uma noção de um tempo genuinamente histórico, um tipo de síntese entre o tempo objetivista e subjetivista. Segundo o historiador (KOSELLECK, 2013, p.127),

Desde então ["Era Moderna"] os historiadores estão obrigados a verificar relações que não se orientam mais pela sucessão natural de gerações de soberanos, pelas órbitas das estrelas ou pela mística figural do simbolismo numérico dos cristãos. A História funda sua própria cronologia.

O rompimento com uma forma de se relacionar com o tempo e as temporalidades deu origem ao tempo histórico, como nos mostra Koselleck; entretanto, esse mesmo movimento pode ser notado e, colocado como responsável por, em finais do século XIX, desenvolver o problema do Tempo com a questão da viagem no tempo, procurando um controle do fluxo temporal, muitas vezes mecânico, desdobramento lógico das maravilhas tecnológicas do mundo industrial. Não seria um absurdo pensar que as aventuras de viagem no tempo (assim como, parcialmente, as histórias que se passam no futuro), de forma, muitas vezes, não autoconsciente, traduziram a mudança nas relações com o Tempo, percebidas e sentidas anteriormente pelos historiadores, filósofos e pela ciência histórica, tanto quanto de um conhecimento oriundo da Física newtoniana, desde o século XVIII, com o direcionamento das sociedades para um futuro original e desconhecido.

Esse tempo histórico está inserido dentro do campo do tempo subjetivista ou social, porém busca realizar uma síntese das duas abordagens do tempo; isso, por si só, mostra o caráter do desenvolvimento do conceito de tempo, a complexidade de múltiplas relações que vão tornando esse símbolo cada vez mais naturalizado e adaptado à experiência cotidiana da mudança e da perspectiva de uma aceleração do tempo, isto é, a disfunção entre experiências e expectativas (ASSIS; MATA, 2013, 
p.14-15) nas sociedades contemporâneas. As experiências compreendendo e permitindo a assimilação do passado no presente e as expectativas e a forma de se pensar o futuro (BOYM, 2001, p.10).

Cabe citar como exemplos do problema do tempo nas ciências humanas as obras do filósofo alemão Walter Benjamin e sua reflexão entre as temporalidades e o progresso, a tentativa do historiador francês Fernand Braudel (1958) de definir os limites do que pode ser observado por aquele campo de conhecimento em cada duração baseada nas permanências, na mudança e nos acontecimentos, porém, sem abandonar a dicotomia entre tempo físico e tempo social. As próprias temporalidades eram hierarquizadas no que poderia ser notado de mudanças e suas velocidades, com uma valorização da longa duração, síntese do tempo natural e social, onde seriam notadas as mudanças mais profundas e lentas, talvez mais significativas ao se ter consciência do tempo humano no mundo. Outra importante contribuição na reflexão sobre a percepção do tempo nas sociedades que nascem da revolução industrial é a obra "Costumes em Comum" (1998), do historiador inglês Edward Palmer Thompson. No sexto capítulo, intitulado "Tempo, disciplina de trabalho e capitalismo industrial”, pode-se notar o caráter organizacional e coercivo desse símbolo social. Não obstante, assim como seu colega francês, Thompson não abandona a dicotomia entre tempo social e tempo natural. As propostas de um tempo histórico, uma terceira via no problema do tempo dualista, ainda partem do pressuposto de que a divisão de tendência objetivista e subjetivista exista e possa ser alinhada em uma síntese, nascida no seio da perspectiva de tempo subjetivista, reconhecendo distinções claras entre a natureza e a sociedade (CARVALHO, 2012, p. 6-7). Não é por acaso que H.G. Wells, escritor da mais influente história de viagem no tempo, também produziu livros de História geral das civilizações num período posterior de sua carreira, a popular série "História Universal" (The Outline of History, 1919-1920), o trânsito entre as formas de se experimentar e definir a ação humana no tempo já estava problematizado na obra da juventude do autor.

Tratada como um tema, recurso narrativo, gênero, subgênero (JONES; ORMROD, 2015, p.10), a depender da conceitualização, as aventuras de viagem no tempo, em perpendicular e paralelamente à História alternativa e História do futuro, são as que mais se aproximam do trabalho do historiador, pois lidam com o humano (ou um substituto) no tempo, num grau de maior liberdade com relação às temporalidades, já que, para o historiador, os documentos têm poder de veto 
(KOSELLECK, 2006, p. 188), ou seja, não se pode afirmar algo que não tenha relação com os documentos históricos, nem com a interpretação ou conclusão realizada. A imaginação do historiador é moldada pelos documentos selecionados para sua pesquisa, a arte e a História trabalham com a verossimilhança em graus diferentes. Além disso, é do conhecimento disponível em sua época, oriundo das ciências humanas, que o autor (ou os autores) de uma narrativa de viagem no tempo retira/m as informações para construção de um universo ficcional, seja para ser fiel a uma historiografia, ou para ignorá-la como recurso artístico e imaginar outros humanos, outros fatos e outras relações de causa e efeito no tempo. Os referenciais básicos são os fornecidos pelas ciências humanas, incluso Sociologia, Antropologia, Psicologia, entretanto, o peso maior é da História, visto que as relações com o tempo são parte central do foco do trabalho historiográfico.

Um bom e claro exemplo desse fato é a série de desenho animado "Peabody's Improbable History", segmento do desenho "The Rocky and Bullwinkle Show" (no Brasil o segmento é conhecido por História Improvável, na série Alceu e Dentinho), que foi ao ar na televisão americana entre 1959-1965. Nesse desenho, um cachorro gênio adota um menino humano e leva-o para passear, numa máquina do tempo, aos períodos históricos da história tradicional, apresentados no desenho de forma anacrônica com fins humorísticos, onde parte do humor é advindo da relação do que se sabe do período histórico apresentado com a subversão vista na aventura. Não só o passado, mas o futuro também é retratado pelo viés de como se interpretam as relações humanas no tempo, como um futuro inspirado pela "pré-história" e por uma catástrofe da tecnologia de inteligência artificial no jogo de videogame Horizon Zero Dawn, lançado em 2017 pela Guerrilla Games, subsidiária da megacorporação Sony. Cabe a observação de que essa forma de pensar as temporalidades e experiências humanas em relação ao conhecimento oriundo de ciências, tradição, mídia, etc. não é exclusiva das aventuras de viagem no tempo ou das que retratam outras épocas e mundos derivados de especulações sobre o nosso mundo e a nossa história; entretanto, vale o destaque ao papel fundamental desse tipo de relação nas histórias de viagem no tempo e ao grau de historicidade presente nelas.

Cabe ainda salientar a importância do tempo do mito, como explicitado por Mircea Eliade, na obra O Mito do Eterno Retorno (1981), nas sociedades que não se organizam pela História ou mesmo a rejeitam, que ele denomina de humanidade arcaica; a todo custo, elas tentam se defender do que a História significa, a mudança 
e novas experiências e há um tempo mítico, ahistórico, que é repetido e trazido à vida por meio de rituais que garantem um recomeço (ELIADE, 1981, p.19), dando sentido à existência e inserindo pessoas e eventos de destaque em arquétipos. Estes ímpetos ahistóricos em uma sociedade histórica podem ser ainda encontrados nas narrativas de viagem no tempo, porém são autoconscientes, o que indica não só que a História não substituiu formas mais antigas de se relacionar e tentar conter as mudanças, mas que a subversão do tempo em narrativas insólitas pode operar para alimentar impulsos ahistóricos.

Das múltiplas formas criadas pelas sociedades para se relacionar com o tempo (as narrativas nas diferentes temporalidades e a viagem no tempo estão aí inseridas), cabe a lembrança do papel social do arquivo, já que "arquiva-se para guardar vestígios escritos [atualmente não só] de - fixa-se uma memória, a de - uma instituição, mobilizável no futuro" (HARTOG, 2013, p.53), e das "cápsulas do tempo", objetos que guardam textos e objetos de uma época para serem abertos no futuro, representando uma forma do presente controlar a leitura que o futuro fará dele, quando esse presente já for passado. Não por acaso, cápsulas do tempo são fenômenos recentes, uma das primeira foi enterrada na Feira Mundial de Nova York em 1939 (GLEICK, 2016, p.170), e têm total ligação com a forma como as sociedades lidam com o futuro. Arquivos, cápsulas do tempo e histórias de viagem no tempo são expressões de novas relações com passado, futuro e presente e mobilizam essas três temporalidades a fim de exercerem algum controle ou influência sobre elas.

$\mathrm{Na}$ modernidade, com a abertura do tempo futuro e a lógica do progresso, o passado, que era a base para se pensar o futuro, passou a ser um tempo ultrapassado, pois a lógica do progresso implica que o exemplar ceda o lugar ao único (HARTOG, 2013, p.180). O progresso, quando se tornou ideologia do capitalismo industrial, tornou-se uma nova teleologia do tempo objetivo, uma narrativa secular global equivalente às aspirações universais da escatologia cristã (BOYM, 2001, p.10). O futuro, numa perspectiva de progresso, tem como características, "por um lado pela aceleração com que se põe em nossa frente, por outro lado pelo seu caráter desconhecido" (KOSELLECK, 2006, p.36). A distância entre o conhecido e o desejável ou indesejável cada vez aumenta mais, permitindo que o progresso e a decadência ocupem e dêem sentido a essa nova relação com os tempos. Cabe destacar que o progresso não estava apenas relacionado ao tempo, mas também ao espaço, o mundo todo passou a ser julgado pela ideologia do progresso e os mais diversos 
locais, povos e culturas eram categorizados dentro da escala de progresso no tempo e no espaço, sendo, portanto, comparados com as potências ocidentais e rotulados como bárbaros, selvagens, semicivilizados (BOYM, 2001, p.10). Nesse mesmo contexto, aprofundou-se a noção de decadência, outra forma de se relacionar com o tempo, pois toda teoria de progresso traz em si a ideia de recuo (HERMAN, 1999, p.21) e medo e ansiedade sobre o desvio do caminho da sociedade perfeita, que pode estar no retorno ao passado ou aprofundamento de relações presentes no devir.

A ideia de decadência é mais antiga e culturalmente mais esparsa do que o progresso: há ideia de decadência sem progresso, mas não há progresso sem a ideia de decadência. O historiador Arthur Herman (1999, p.22) afirma que essa noção tem raiz na reflexão da experiência humana em relação às várias transições físicas que o nosso corpo passa da infância à velhice e à lembrança coletiva de um mítico passado do qual a nossa existência seria uma versão diluída.

As aventuras de viagem no tempo operam dentro do espaço entre experiência e expectativa, só que podendo inverter as temporalidades, o futuro em uma narrativa ficcional se torna a experiência e o passado a expectativa de mudá-lo. Esse é o mote do livro de Isaac Asimov "O Fim da Eternidade" (The End of Eternity, 1955) e da série fílmica "O Exterminador do Futuro" (Terminator, 1984-...) e seus derivados, porém a capacidade de imaginar tais narrativas e o sentido da temporalidade proposto na obra está dentro do movimento da modernidade e suas novas relações com passado, presente e futuro, permitindo a compreensão e identificação do que é apresentado sobre o Tempo.

O historiador francês François Hartog identifica que no mundo atual pós-1989 houve a consolidação do presentismo, uma perspectiva de tempo e de se relacionar com ele baseada no domínio do presente para se pensar o futuro e o passado, o passado tornando-se imprevisível e a relação com o futuro partindo da meditação sobre os "efeitos deste ou daquele futuro concebível sobre o presente" (HARTOG, 2015, p.275).

O presente "tornou-se o horizonte sem futuro e sem passado, ele produz diariamente o passado e o futuro que sempre precisa [...] e valoriza o imediato" (HARTOG, 2015, p.148). Seria interessante pensar como a produção das ficções de viagem no tempo atuais lidam com essa nova relação (ou nova crise) do tempo, vide o foco e sucesso de "linhas do tempo alternativas" e "história contrafactual", que se desenvolveram no decorrer do século $\mathrm{XX}$ pelas próprias necessidades e pelos 
desdobramentos lógicos das narrativas ficcionais, mas que têm uma produção relevante exatamente no período em que Hartog identifica o fortalecimento do presentismo como principal relação contemporânea com o tempo. Pode-se destacar também o aprofundamento do pessimismo histórico e do pessimismo cultural (HERMAN, 1999, p.462) que permeiam as reflexões acadêmicas sobre a sociedade desde o século XIX, com o primeiro percebendo que a civilização ocidental está sob ataque de forças destrutivas e o segundo notando que a destruição já estava presente na origem, só restando esperar e aprofundar seu fim, ambas formas imobilizadoras que reforçam o presente estando em ascensão no contexto atual apresentado por Hartog.

\section{5- Uma dimensão da mente}

O tempo deve então ser visto como uma criação humana, uma ferramenta simbólica necessária para organizar e dar conta de situações que partem do convívio coletivo, da economia, da natureza, do universo e das transformações psicológicas e biológicas de nossos corpos. Norbert Elias propõe que a divisão em natural versus social/psicológico é uma falsa dicotomia, pois se pudesse ser visto de fora, enxergaríamos o tempo em uma quinta dimensão simbólica, onde se nota a interdependência da natureza, sociedade e indivíduos (ELIAS, 1998, p.17). Essa quinta dimensão exigiria que o ser humano se colocasse como unidade participativa, produtora e observadora do tempo, indo além da visão do tempo como uma quarta dimensão, onde o ser humano é dissociado do tempo.

Ainda segundo Elias, o conceito completo de tempo só pode sair da experiência humana com o mundo, por vezes utilizando referenciais das regularidades e mudanças naturais, por vezes das percepções humanas sociais e individuais, ou seja, o tempo é uma articulação social e habita tanto a quarta quanto a quinta dimensão (simbólica). Como resume Carvalho (CARVALHO, 2014, p.13):

o tempo seria algo integrante, sem qualquer contradição, tanto do universo pentadimensional quanto do universo quadridimensional. [...] o que chamamos tempo designaria, por um lado, uma das dimensões constitutivas do universo físico quadridimensional, que representa a totalidade do mundo perceptível, no sentido de que "tudo o que é perceptível, inclusive a realidade humana, ocupa uma posição em cada uma das quatro dimensões formadas pelo espaço e pelo tempo". Contudo, paralelamente, o tempo seria também um símbolo social e, enquanto tal, um "representante do mundo humano de cinco dimensões". 
Para Elias, o tempo ocupa tanto a quarta dimensão da Física quanto uma quinta dimensão simbólica, visto que o que denominamos "dimensão" nas ciências naturais, pode ser simplificado no número necessário para localizarmos algo com certa precisão (CHERMAN; VIEIRA, 2013, p.22-23), o que faz do tempo uma quarta dimensão temporal para as três dimensões espaciais. Ademais, a quinta dimensão simbólica seria algo humano, uma percepção necessária que orienta a ação humana no universo e, mesmo que Elias tenha abstraído o papel do observador no tempo proposta da Física moderna, sua ideia de uma quinta dimensão simbólica que incorpora não só o tempo, unifica as noções de tempo natural e tempo social, demonstrando a complementariedade dessas unidades em um conceito mais amplo da experiência com/no tempo.

O tempo se manifesta nas sociedades contemporâneas por meio de símbolos reguladores retirados da experiência e observação tanto do mundo físico (como ano, dia, hora, minuto e segundo), quanto do social (como antes, depois, presente, passado e futuro). Há uma articulação entre o humano e o físico para dar conta de comunicar alguma informação ou regular um aspecto da vida e da experiência dos seres humanos. Ao se falar dos símbolos do tempo, existe a implicação de uma enorme quantidade de informação acumulada que passa despercebida aos interlocutores: por exemplo, o conhecimento dos movimentos das estrelas e de nosso planeta no Universo, dos processos biológicos da vida e do mundo atômico. Além disso, o tempo permite aos grupos humanos relacionar processos, utilizando uma padronização que possa encaixar outros, a fim de serem medidos (CARVALHO, 2014, p.5; ELIAS, 1998, p. 39-40).

Nas aventuras de viagem no tempo, por mais que possam existir datas específicas do retorno no tempo ou do avanço ao futuro, como a apresentação da data completa da viagem de Marty McFly ao passado de 1955 (de 6 de novembro a 12 de novembro), em De Volta Para o Futuro (Back to the Future, 1985), e ao futuro de 2015 (21 de outubro), em De Volta Para o Futuro II (Back to the Future Part II, 1989), ou a especificação do ano 802.701 d.C. na obra literária seminal de H.G. Wells, A Máquina do Tempo (The Time Machine, 1895), a relação não se dá com os dias, meses e anos do calendário, mas sim com as noções de passado e futuro, ancoradas na percepção da mudança.

Os conceitos de passado, presente e futuro estão associados às relações temporais que os grupos humanos estabelecem entre as mudanças e o devir ao qual 
um grupo se submete, eles são sempre dependentes de um referencial humano vivo (Ibid., p.9) e da experiência. De acordo com Elias, não faria sentido utilizar esses referenciais para se lidar com processos da natureza. Essa delimitação conceitual, por mais que possa ser alvo de críticas, está em conformidade com as aventuras de viagem no tempo, que reforçam esse caráter dependente de um ser vivo inteligente (no caso da ficção, não necessariamente humano) que define as diferentes relações entre as temporalidades.

Em um universo estático, onde não ocorressem processos de mudanças para serem utilizados como referencial para mais mudanças e acontecimentos, ou se esses processos não tivessem uma regularidade percebida pelos grupos humanos, não existiria o tempo (CARVALHO, 2014, p.5), pois além de ser impossível criar o conceito de tempo, dada a necessidade de regularidades referenciais, este conceito seria inútil.

\section{6- Para que tudo não aconteça de uma só vez}

A escolha de uma ideia de tempo que parta da reflexão de Norbert Elias, restrita ao nosso objeto de pesquisa, e não outros pensadores citados é a adequação daquele universo conceitual para se pensar a viagem no tempo, escapando da armadilha da divisão do tempo natural e do tempo social (incluso o chamado tempo histórico, derivado do tempo social, que muitas vezes não se nota assim, pois articula o natural e o social) e reforçando o caráter de construção coletiva do conceito tempo. Ademais, essa definição fornece uma pista e explica parcialmente o aparecimento, nos anos finais do século XIX, das narrativas ficcionais que subvertem o tempo e seu florescimento posterior, porque estão na raiz dessas aventuras novas relações sociais e individuais com o símbolo do tempo, seu domínio cada vez maior sobre aspectos da vida, a ampliação do conhecimento do mundo natural e humano proporcionada pelas ciências, a noção de progresso e decadência e a tensão na adequação do tempo com a experiência das sociedades contemporâneas, modernas ou pós-modernas, noções que são partes fundamentais do Tempo como símbolo proposto por Elias. Entretanto, deve-se destacar que futuros desenvolvimentos científicos, no caso da Física, por exemplo, podem comprovar a existência do Tempo como entidade externa ao ser humano, o que não invalidaria por completo o exposto, visto que o tempo manteria seu caráter simbólico nas múltiplas relações humanas para as quais é invocado a organizar e dar sentido. 
Ponderando sobre o tempo, cabe o cuidado apontado pelo historiador colombiano Renán Silva referente à linguagem: já que aquele referencial é um símbolo que está em constante desenvolvimento - assim como a linguagem -, deve ser dada atenção ao sentido de Tempo expresso em uma narrativa, relacionando-o com seu contexto. Por exemplo, o sentido de Tempo no início do século XX, em determinada obra, pode ou não ser o mesmo utilizado atualmente (sem ignorar, no caso, o problema da tradução de outra língua), já que a "linguagem põe em contato com outras formas de perceber, com as formas de representar, com as formas como uma sociedade fala de si mesma" (SILVA, 2015, p.78).

O mais interessante, segundo o que podemos observar tanto na documentação selecionada quanto na forma mais geral em que o tema da viagem no tempo é desenvolvido desde o século XIX, é que esse tipo de história também se relaciona com a dicotomia do natural versus social, geralmente concordando e escolhendo um dos lados (ou os dois), objetivista ou subjetivista, ou, de forma mais usual, operando no tempo histórico, para servir de pano de fundo ou de mote principal da narrativa de subversão do tempo. A complexidade da discussão do que é o tempo não está fora das narrativas de viagem no tempo, logo, deve ser observado com atenção qual o papel desse viés em uma história que tem como característica a subversão do mesmo.

A hipótese proposta é que as noções de contemporâneas temporalidade se estabeleceram no século XVIII e seus desenvolvimentos e crises são as responsáveis por novas relações do Ocidente com o símbolo Tempo, abrindo espaço para as histórias de viagem no tempo, as quais tentam, das mais diversas formas, resolver conflitos na relação individual e social com o tempo e a mudança. Portanto, mesmo que as relações com o tempo como símbolo possam estar mudando, como a noção de "presentismo" parece nos mostrar, o desenvolvimento do conceito de Tempo não se coloca como empecilho para a compreensão integral das aventuras de viagem no tempo, algo que exigisse um cuidado maior com a linguagem sobre o tempo, visto que nossas sociedades ainda fazem parte ativa desse processo de abertura para futuros e passados, encarados atualmente como campos de possibilidades. O cuidado na análise da viagem no tempo com o conceito de tempo empregado e/ou proposto pelas narrativas que se propõem a subverter a percepção humana do tempo deve existir como princípio básico teórico metodológico da escrita historiográfica, "parte constitutiva do trabalho do historiador" (Ibid., p.91), porém, devemos considerar-nos parte do processo que proporcionou o conceito apresentado, já que não estamos 
lidando com noções de tempo anteriores à modernidade, mas sim com seu desenvolvimento como símbolo complexo, adaptado às experiências das sociedades atuais.

Portanto, os documentos históricos e as narrativas de viagem no tempo de nossa periodização partem de um contexto histórico ocidental de foco no futuro, com o presente cada vez mais se expandindo, o que consolida a análise de Elias sobre o tempo, vide seu ajuste e desenvolvimento como símbolo social que comunica, transmite e cria uma relação com a ordenação dos acontecimentos e da mudança.

\section{7- História do século futuro}

As histórias de viagem no tempo surgiram e se desenvolveram na Europa e nos Estados Unidos nas últimas décadas do século $X I X$ e no início do século $X X$. A origem dessa temática, sua motivação, verossimilhança e aceitação pelo público têm o ponto de partida numa série de mudanças gradativas ocorridas no continente europeu desde o final da Idade Média, que transformaram o tempo passado em um local ultrapassado, desatualizado, superado e o tempo futuro no campo misterioso das possibilidades, próspero, desenvolvido. Além disso, paulatinamente, passou a ser admissível para parcelas daquelas sociedades a exploração ficcional primeiramente do tempo futuro e, posteriormente, como desdobramento e uma ampliação de novas relações com as temporalidades, o rompimento do fluxo do presente, com a viagem no tempo. Essas mudanças estão associadas a novas relações que surgiam na Europa - e compartilhadas pelos Estados Unidos da América - referentes a economia, política, cultura, ciência e tecnologia.

A base principal, mas não única, da relação Ocidental com o tempo estava pautada no cristianismo, o tempo dividido em dois eventos singulares, com a abertura de um novo período tendo por início a vida, morte e ressurreição de Jesus Cristo e o seu final previsto, com o retorno do Filho de Deus feito homem no Juízo Final, encerrando esse tempo (HARTOG, 2013, p.89-90), e por consequência lógica, completando a própria História. O presente era apenas o tempo de aguardo, um tempo intermediário do fim, a ocorrer em um esperado futuro, existindo, portanto, uma articulação entre o presente, o passado e o futuro na eternidade (Ibid., p.92), domínio dos desígnios de Deus. Os exemplos passados de Cristo e dos santos forneciam um modelo de conduta para este presente de esperança pelo encerramento do tempo. 
A própria noção de que nada de novo poderia ocorrer no presente e futuro, segundo o princípio bíblico expresso no livro de Eclesiastes, "O que foi tornará a ser, o que foi feito se fará novamente; não há nada novo debaixo do Sol" (BÍBLIA, Eclesiastes, 1,9), e o modelo predominante da historia magistra vitae, que procurava retirar lições do passado para servir ao presente, fornecia substrato à noção de que o próprio futuro antes do Apocalipse não seria diferente. A sondagem do futuro antes dos eventos escatológicos da Bíblia, poderia ser realizada pelos profetas, praticantes da retórica deliberativa, magos, adivinhos e astrólogos, sempre com o presente e passado orientando a leitura do futuro, como, por exemplo na profecia, na qual se procuram sinais presentes e passados previstos anteriormente para a realização de algo no porvir. Na retórica deliberativa, focada em proposições dirigidas ao futuro, a narração não teria muito objetivo, pois segundo o filósofo Aristóteles, não se pode narrar fatos futuros, que ainda não ocorreram, e, portanto, os exemplos na narração deveriam ser usados com cuidado e utilizando os fatos passados como modelo (ALMEIDA, 2009, p.69-92), a lembrança do passado deveria ajudar os ouvintes do discurso a fazer planos melhores para o futuro (ALKON, 2010, p.3). Ou mesmo na astrologia, onde há um modelo de mundo, que incorpora toda experiência possível, só cabendo ao bom astrólogo conseguir correlacionar a posição dos astros com o que já é dado conhecido.

O mesmo pode ser notado em outras formas de previsão do futuro que utilizam técnicas como leitura quente (hot reading) e a leitura fria (cold reading), ou seja, respectivamente, o uso de informações retiradas do individuo sem que ele saiba e a análise de uma série de dados da pessoa que procura saber o futuro, extrapolando essas informações em um futuro possível, habitualmente apelando a generalidades (ROWLAND, 2014, p.15; p.24-127). As técnicas modernas de previsão utilizando gráficos, pesquisas e dados e modelos científicos, são mobilizadas para prever o funcionamento e desdobramentos das instituições sociais e da natureza, geralmente orientadas para a prática política e econômica. Essa é uma prática de construção e domínio de uma ordenação do futuro representativa de novas relações com o tempo; logo, se estabelecendo como um prognóstico informado distinto das formas mais focadas no cotidiano individual, conduzido pelo passado e justificados pela magia ou superstição, como os modelos citados anteriormente.

Não há uma noção exclusiva de temporalidade operando no ocidente, o cíclico e o linear atuam para dar sentido à vida. O filósofo britânico Hugh Rayment-Pickard, 
em seu livro The Myths of Time: From Saint Augustine to American Beauty (2004), identificou, na Bíblia e no ocidente cristão, quatro tipos de tempo em operação: o catastrófico, ou seja, como o tempo afeta o corpo físico e o fim do tempo; o apocalítico, o tempo de espera do momento da revelação; kairíaco, os momentos icônicos que permitem a noção histórica; e o profético, a tentativa de se moldar o tempo e não esperar por ele (RAYMENT-PICKARD, 2015, p. 10).

Paulatinamente, após o Renascimento, foram abertas fendas cada vez maiores na forma dominante de se experimentar o tempo presente como momento de espera pelo fim, norteado por exemplos retirados do passado. A perspectiva do Fim do Mundo se tornou cada vez mais distante, e com essa noção, um futuro novo pode surgir no horizonte das expectativas, um tempo desconhecido, lugar das maravilhas ou dos pesadelos, associando ao futuro a nascente ideia de progresso dos séculos XVIII e XIX; o tempo de espera pelo fim, o tempo apocalíptico, cada vez mais ia sendo alargado.

O contato dos europeus com os habitantes do chamado Novo Mundo nos séculos XV e XVI, sem que fosse percebido por seus contemporâneos, ao interpretar os "selvagens" e colocá-los num sentido e modelo de mundo pré-existente, do cristianismo e da História como lição modelar de conduta, criou a noção de que os tempos seriam diferentes. Ao comparar os povos encontrados em América, África e Ásia, principalmente as civilizações urbanizadas desses continentes, com os antigos europeus, sobretudo os gregos e romanos, "contribuía-se imperceptivelmente para a construção da importante e nova ideia de que o afastamento no espaço equivale à distância no tempo" (HARTOG, 2003, p.131). A raiz da ideia moderna das diferenças entre os tempos teria sua semente plantada e se desenvolveria não só na Filosofia, mas também na Cultura Popular, como nos mostra a Literatura, a partir das Grandes Navegações e do domínio europeu sobre locais cada vez mais distintos do globo. Os exemplos das tentativas e dificuldades de localizar os novos povos e culturas no que já era conhecido pelos europeus podem ser claramente observados nas ilustrações e na Literatura sobre as novas terras; nas gravuras, encontram-se povos indígenas de aspectos europeus greco-romanizados, por vezes apenas com cabelos, cores e roupas diferentes. E, para citar um exemplo literário, pode-se notar o desenvolvimento cognitivo de novas relações entre Europa e mundo, a necessidade de se dar sentido ao novo, no relato da viagem de Vasco da Gama e sua tripulação na Índia, no final do século $\mathrm{XV}$, quando em contato com um mundo alienígena de Calicute os marinheiros 
visitaram o que para eles era uma igreja anexa a um mosteiro e até viram santos cristãos de vários braços adornando as igrejas (MARQUES, 1999, p.76-77).

Além dessa nova relação com o tempo gerada pelos contatos/conquistas coloniais, há também a importância de uma série de eventos correlacionados, como a "ascensão do capitalismo e seus hábitos orientados para o trabalho, como o trabalho em turnos com um olho no relógio enquanto se projetam ganhos financeiros" (ALKON, 2010, p.47), pois é no futuro que o lucro do investimento em uma economia de mercado se realiza e o prognóstico informado representa uma maior chance de dividendos. Não só isso, a extrapolação do passado geológico, inicialmente como tentativa de conciliar os dados da Bíblia com o nascente desenvolvimento do conhecimento científico, ampliou as perspectivas temporais, principalmente as orientadas ao futuro (Ibid., p. 46), como na obra polêmica na época, e elogiada por Sir Isaac Newton, "Sacred Theory of the Earth", publicada em duas partes (1681-1689), de Thomas Burnet. A especulação teológica vai sendo substituída pela especulação sobre a ciência e tecnologia (CLAEYS, 2013, p.163).

Somam-se a consolidação da economia de mercado e o desenvolvimento da tecnologia e da prática científica, os levantes políticos do século XVIII, as propostas iluministas e o desenvolvimento semiautônomo de obras literárias que, cada vez mais, tornavam palatáveis histórias que se passavam não mais no passado real ou idealizado, mas em um futuro a ser construído ou idealizado, como nos mostra o crítico literário Paul K. Alkon, em seu livro “Origins of Futuristic Fiction” (2010), publicado originalmente em $1987^{3}$.

Enquanto as sociedades europeias e suas colônias ainda aprendiam e tentavam compreender as mudanças que ocorriam a passos largos e às vistas de suas elites e parcelas cada vez maiores do povo, a Arte, por sua vez, prevendo de forma sensível a novidade da abertura do tempo futuro para o extraordinário, insólito e o desconhecido, passou a traduzir em suas obras literárias o desconforto e oportunidades propostas por esse novo tempo; na comodidade de um livro, podia se vislumbrar o devir e/ou escapar do presente. Paralelamente a essa abertura do tempo futuro, ocorreu um fascínio pela Idade Média, nostalgicamente vista pelo olhar romântico, e o interesse por culturas não-ocidentais (HERMAN, 1999, p.57); dentro

\footnotetext{
3 Para essa pesquisa, foi utilizada a versão de 2010 do livro de Alkon, que reproduz
} integralmente, sem acréscimos, a obra de 1987. É seguinda a paginação da versão mais atual. 
desse processo de grandes mudanças, as relações temporais e espaciais serviam a todos os gostos expressos socialmente, ansiedade, endosso, medo e fuga.

Dois subgêneros literários independentes, por vezes interconectados, podem ser considerados a base para a gênese e o desenvolvimento das aventuras de viagem no tempo, não só por conterem elementos explorados ou criticados nas obras que lidam com o deslocamento inabitual pelo tempo, mas também por terem criado ambiente favorável à aceitação desse tipo de história. São eles as narrativas utópicas e a ficção futurística, geradoras do repertório familiar sobre as temporalidades cujo desenvolvimento seria de fundamental importância para as viagens no tempo.

Figura 01 - Estátua de Zeus, gravura de Martin van Heemskerk, 1572, publicado em uma série de maravilhas do mundo antigo.

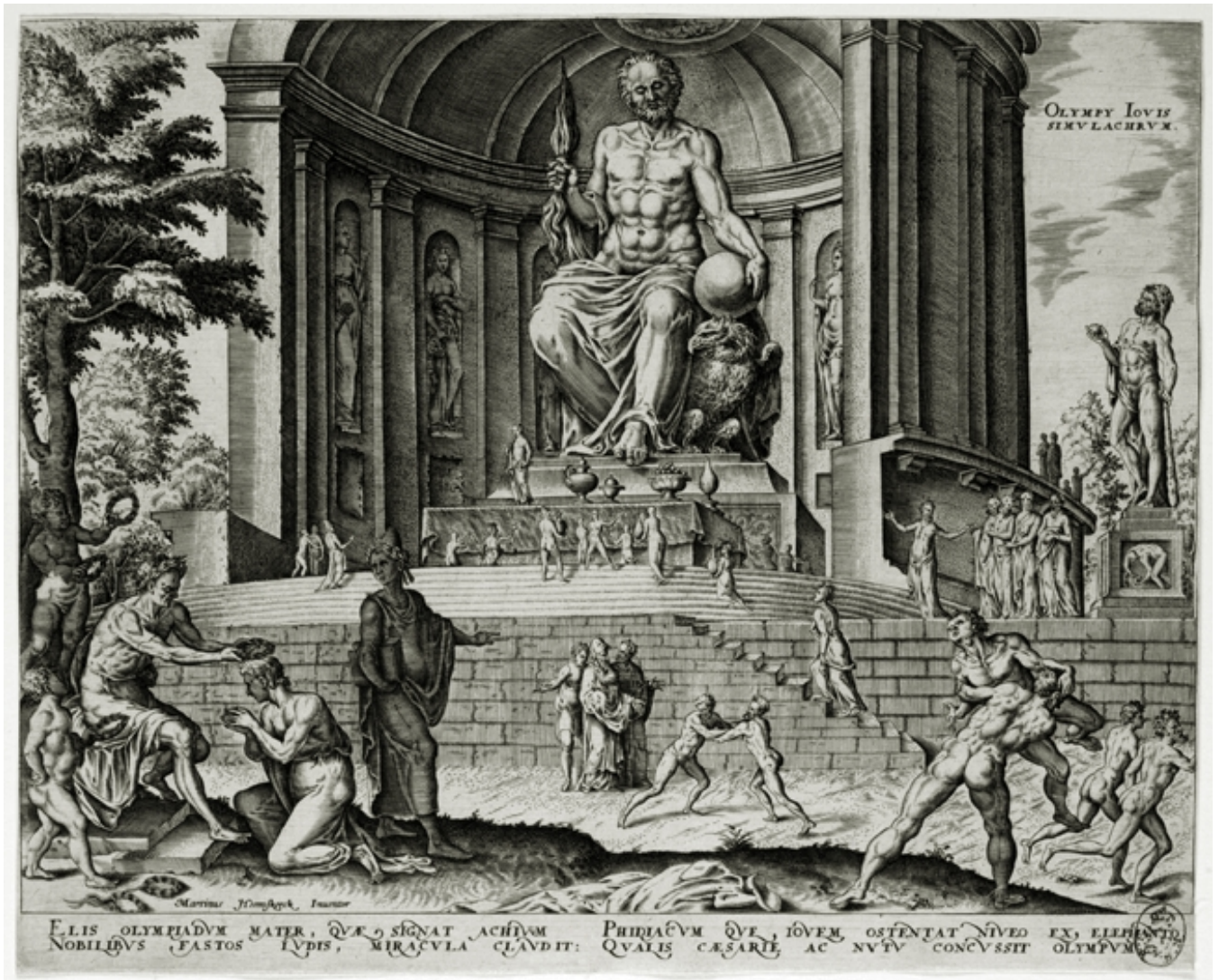

Fonte: Tutt'Art@ by Maria Laterza. ${ }^{4}$

\footnotetext{
${ }^{4}$ Disponível em: http://www.tuttartpitturasculturapoesiamusica.com/2015/08/Maartenvan-Heemskerck-Wonders-World.html. Acesso em: 09 de maio de 2017.
} 
Figura 02- Gravura de Arnoldus Montanus publicada em "De Nieuwe en Onbekende Weereld" (O Mundo novo e Desconhecido), de 1671. Nota-se na representação do deus asteca da guerra Huitzilopochtli um diálogo com as formas de retratar a antiguidade europeia, além da associação com as características demoníacas dos deuses pagãos, estas também inspiradas nas representações de deuses antigos. Montanus nunca visitou a América.

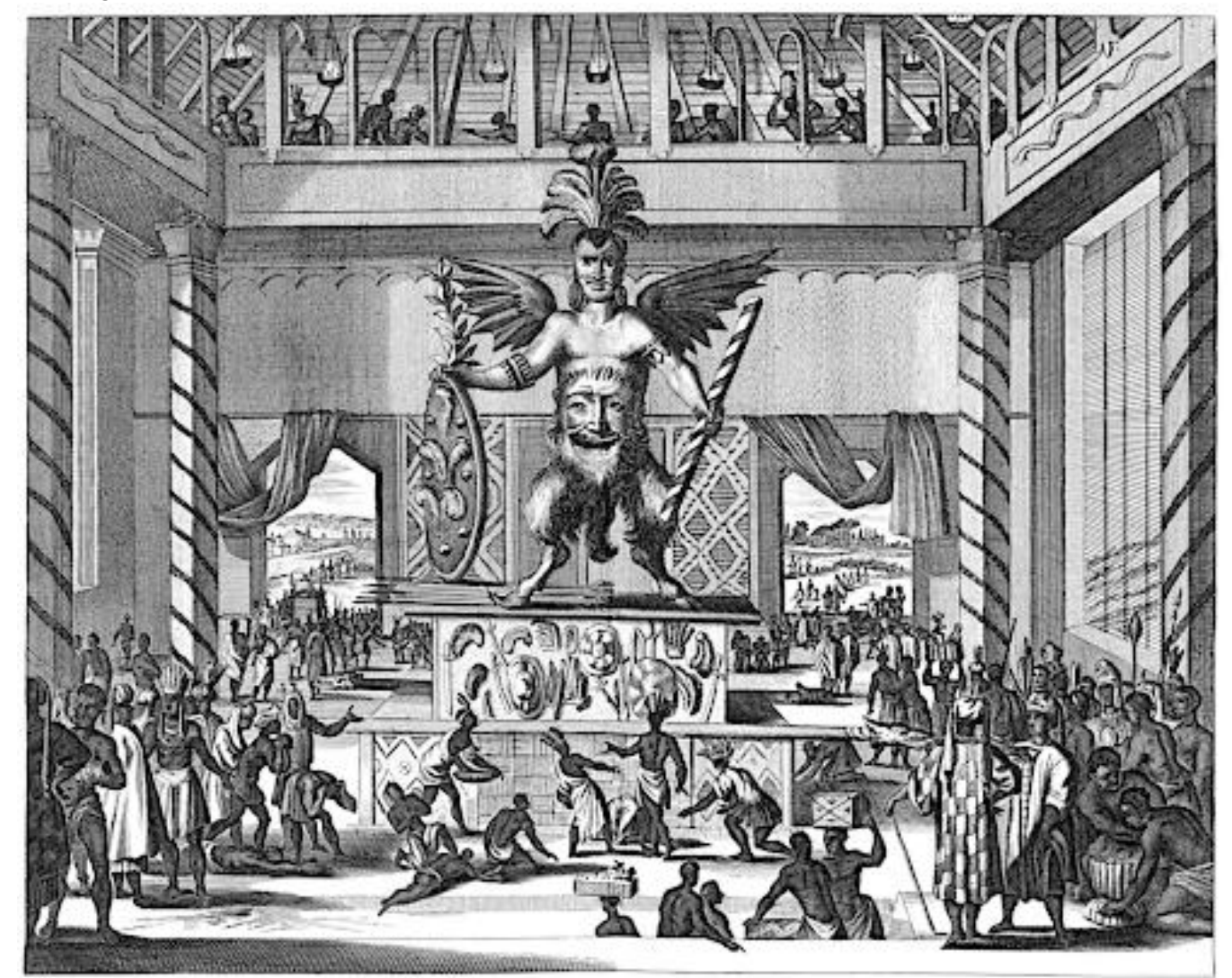

Fonte: Biblioteca Digital Mundial e FOBO. ${ }^{5}$

\section{8- Tempo de Utopia}

A ideia de utopia - bem antes da famosa Utopia, de Thomas More publicada em 1516 originalmente em latim - faz parte da experiência humana no mundo e motiva o aperfeiçoamento das relações entre os humanos e com a natureza, existindo, portanto, bem antes de o conceito se formar. Como nos mostra o historiador britânico Gregory Claeys (2013, p.15), utopia "é uma estrela polar, um guia, um ponto de referência do mapa comum de uma eterna busca pela melhora da condição humana". Na tradição Ocidental, A República de Platão é o mais importante texto pré-More que influenciou a imaginação europeia por uma organização social idealizada de modelo utópico (BOOKER, 2015, p.313).

5 Disponível em: https://www.wdl.org/pt/item/518/ e http://www.fromoldbooks.org/MontanusAmerica/pages/03000000-worship-the-god/\#details. Acesso em: 09 de maio de 2017. 
As propostas utópicas estão relacionadas e serviram historicamente não exatamente para se pensar um mundo perfeito e impossível, o paraíso perfeito, ou um "lugar nenhum", como a anglicanização do grego outopos (STABLEFORD, 2004, p.365) pode indicar, mas sim, um reconhecimento de limites humanos - quais são os limites é o alvo de discussões - e uma proposta que privilegie o coletivo, balanceando as discórdias advindas da vida social e buscando alguma forma de relações mais igualitárias no seio de uma sociedade, "em geral, tornando mais iguais a propriedade e as classes sociais" (CLAEYS, 2013, p.8) e oferecendo "uma solução para graves problemas sociais e políticos" (Ibid., p.144).

O mundo imaginário da utopia não tem uma base em nosso tempo, visto que as instituições encontradas nas narrativas à la Thomas More não se moldaram por eventos ocorridos em nosso passado, tampouco do desenvolvimento social. O tempo da utopia espacial é um tempo privado, desconectado do tempo do leitor (ALKON, 2010, p.126-127). Entretanto, na ideia de utopia, é estabelecida uma relação temporal para sustentar a narrativa, e mesmo que a experiência, a cidade, ou o local idealizados só estejam representados no espaço e pertençam a um tempo particular, dissociado da experiência social, temos uma variação do passado, presente ou futuro idealizados. Sempre é realizada uma comparação, pelo público de uma obra utópica, com seu presente, de forma indiferente se o que movimenta a utopia é a imaginação, o conhecimento histórico ou o puro mito; a proposta utópica propõe um mundo ordenado possível, seja em um futuro a se construir ou em um retorno ao passado já conhecido, em um tempo futuro.

Podemos considerar uma ideia de futuro patente em qualquer proposta utópica, pois é nesse tempo que uma cópia da utopia estará finalizada se dado início a sua construção pelo presente; entretanto, no campo literário, pode-se encontrar a passagem do "lugar nenhum", o espaço idealizado, para o "tempo nenhum", nas novas relações de tempo, percebidas pelas sociedades do século XVIII e pelo esgotamento narrativo, clichê, de se localizar a utopia em algum rincão perdido do planeta, o que, com o domínio europeu e, posteriormente, americano das partes mais remotas do mundo, tornava a questão da verossimilhança cada vez mais complicada. Com a passagem da utopia para a ucronia, as sociedades aperfeiçoadas orientadoras de nosso mundo passaram a se localizar no futuro ou em tempos alternativos.

O pensamento utópico ocidental padrão era dirigido ao passado, porque é neste tempo que podiam ser encontrados os modelos para o presente e futuro, como 
nos mostra não só a prática da História na forma de historia magistra vitae. A humanidade pós-Juízo Final, com o mundo feito Paraíso, também é um modelo voltado para o passado, para a recuperação de um passado melhor que só poderá ser alcançado no futuro. A novidade desenvolvida nos séculos XVIII e XIX foi que, junto com o passado idealizado, surgiu um futuro idealizado dentro de espaços reais ou imaginários, ou seja, a utopia idealizou todas as novas relações temporais modernas, tanto influenciando a perspectiva do progresso quanto sendo alimentada por ele.

Figura 03 - Capa americana da primeira utopia bolchevique, Krásnaya zvezdá (Estrela Vermelha, tradução nossa) de Alexander A. Bogdanov. O livro, publicado em 1908, lança a utopia socialista bolchevique para Marte. Os marcianos encontrados pelo russo representam um ideal de sociedade.

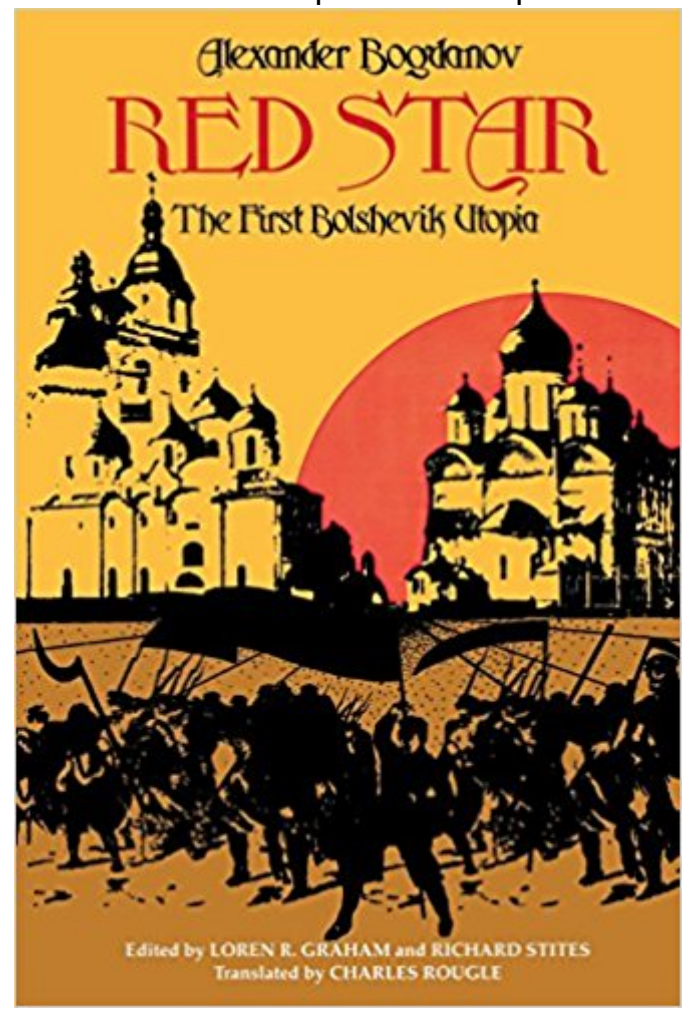

Fonte: Loja Amazon. ${ }^{6}$

O termo "uchronie", ucronia, foi cunhado pelo filósofo Charles Bernard Renouvier em 1857 para conceitualizar o novo subgênero literário que ficcionalmente altera algum desdobramento de fatos passados e dá origem a uma nova linha do tempo, com outros desenvolvimentos, uma realidade aperfeiçoada, utópica, em relação aos desdobramentos históricos de nosso universo. Atualmente, esse tipo de obra é geralmente denominado história alternativa (ALKON, 2010, p.115-116) e pode

\footnotetext{
${ }^{6}$ Disponível em: <https://www.amazon.com.br/Red-Star-Bolshevik-History-Politicsebook/dp/B00GIN4NJC/>. Acesso em: 09 de maio de 2017.
} 
ou não manter o princípio utópico na apresentação do universo alternativo, vide as obras que perpassam as mais diversas mídias com narrativas ocorrendo em um mundo na qual a Alemanha nazista venceu a Segunda Guerra Mundial. Como exemplos interessantes dessa temática, vale destacar a obra literária de Philip K. Dick, "O Homem do Castelo Alto" (The Man in the High Castle, 1962), que inspirou uma série homônima (2015), apresentando uma discussão sobre a natureza da realidade e do tempo, e o jogo de videogame Wolfenstein: The New Order, 2014, no qual até uma versão de The Beatles surgiu na década de 60, com o quarteto de Liverpool formando os Die Käfer (Os Besouros) e cantando em alemão músicas como "Mond, Mond, Ja, Ja" (Lua, Lua, Sim, Sim) no álbum "Das Blaue U-Boot" (O Submarino Azul).

Figura 04 - Capa da edição brasileira do livro de história alternativa do jornalista e escritor britânico Robert Harris, "Fatherland" de 1992, adaptado em filme pela HBO em 1994. A obra explora um mundo onde a Alemanha vence a Segunda Guerra Mundial e, em 1964, a investigação de um assassinato de um oficial nazista coloca as novas relações diplomáticas da Alemanha com os EUA em risco ao tocar na questão do que teria ocorrido com os judeus.

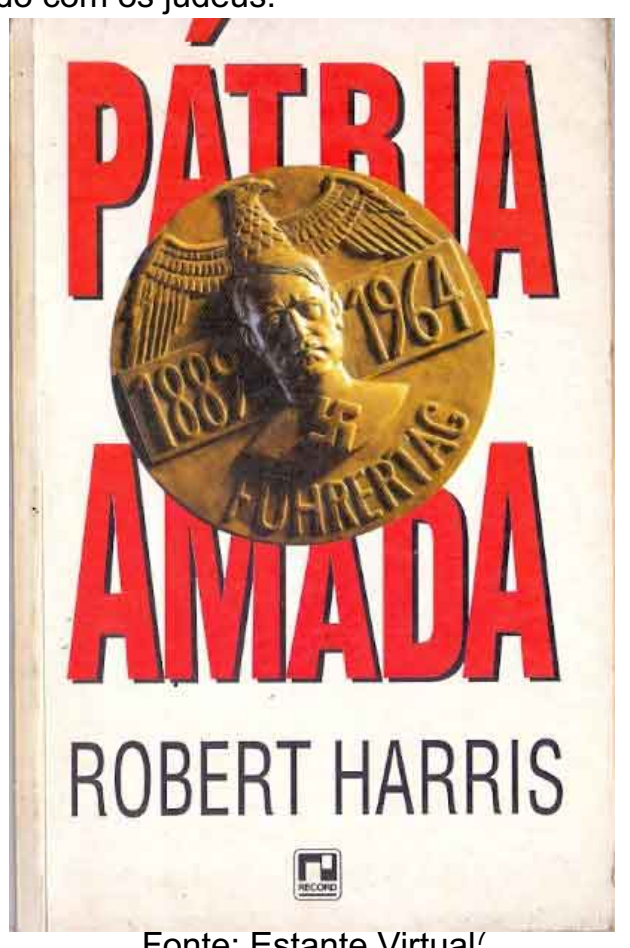

Fonte: Estante Virtual'.

O próprio criador do conceito, Renouvier, em 1876, escreveu sua ucronia, “Uchronie (I'Utopie dans I'histoire): esquisse historique apocryphe du développement

\footnotetext{
${ }^{7}$ Disponível em: <https://www.estantevirtual.com.br/b/robert-harris/patriaamada/1993881642>. Acesso em: 09 de maio de 2017.
} 
de la civilisation européenne tel qu'il n'a pas été tel qu'il aurait pu être"8: seu livro imagina as decorrências de uma alteração na História Romana, com Marco Aurélio sendo sucedido por Ávido Cássio e não Cómodo, o que permitiu o Renascimento ter surgido séculos antes, abreviando a Idade Média. O objetivo de Renouvier era o uso da ucronia como uma forma científica de se abordar o problema historiográfico da seleção e análise dos fatos históricos, pois o historiador, ao extrapolar o passado e escrever uma história alternativa, teria facilitado a identificação de pontos de divergência cruciais na História (ALKON, 2010, p.116), garantindo ao cientista uma reflexão sobre a casualidade. Esta perspectiva ainda é utilizada academicamente, por vezes denominada História contrafactual, uma "ficção científica histórica", no sentido que extrapola o conhecimento e interpretação dos fatos passados para imaginar novas correlações e refletir sobre a mudança, pensando, como já estava no próprio título da obra de Renouvier: o que não foi, mas poderia ter sido.

Assim como no século $X X$ há uma proliferação de realidades alternativas distópicas, o oposto ocorria nos séculos XVIII - "como lembra Raymond Trousson [historiador belga] era a época de ouro da utopia" (ALKON, 2010, p.117) - e XIX, quando a utopia passa a ocupar definitivamente um lugar no tempo e não mais no espaço. A primeira obra identificada no modelo do conceito de ucronia proposto por Renouvier, composta em 1836 por Louis Geoffroy, na França, "Napoléon et la conquête du monde, 1812-1832: histoire de la monarchie universelle"9 ${ }^{9}$ é uma história alternativa de como seria o mundo se Napoleão tivesse vencido a Campanha da Rússia em 1812, conquistado a Inglaterra e criado uma monarquia universal francesa (Ibid., p.115). Porém, se considerarmos o conceito de ucronia, conforme alguns críticos passaram a conceituar no século $\mathrm{XX}$, como não só histórias alternativas mas também utopias que se passam no futuro (lbid., p.116), a primeira obra significativa seria o romance publicado anonimamente em 1771 de Louis-Sébastien Mercier, "L'An 2440, rêve s'il en fut jamais" ${ }^{10}$ (o autor só assinou seu nome na edição de 1791). Havia também na Grã-Bretanha obras anteriores à de Mercier que lançavam a utopia para

\footnotetext{
${ }^{8}$ Ucronia (a Utopia na história): esboço apócrifo do desenvolvimento da civilização europeia que não foi mas que poderia ter sido [tradução nossa]

${ }^{9}$ Napoleão e a conquista do mundo, 1812-1832: História da monarquia universal [tradução nossa]

${ }^{10}$ O Ano 2440, se é que foi um sonho [tradução nossa]
} 
o futuro, entretanto elas se desenvolveram devido à repressão estatal (ROBERTS, 2005, p.74-75): o futuro foi usado como subterfúgio para se evitar problemas.

Figura 05 - Nova York na década de 60, parte do Grande Reich Nazista. Anúncio da segunda temporada da série inspirada no livro de Philip K. Dick, "O Homem do Castelo Alto". O tema de uma realidade alternativa na qual os nazistas venceram a guerra permite a criação de histórias intrigantes com bastante ação, mistério e aventura.

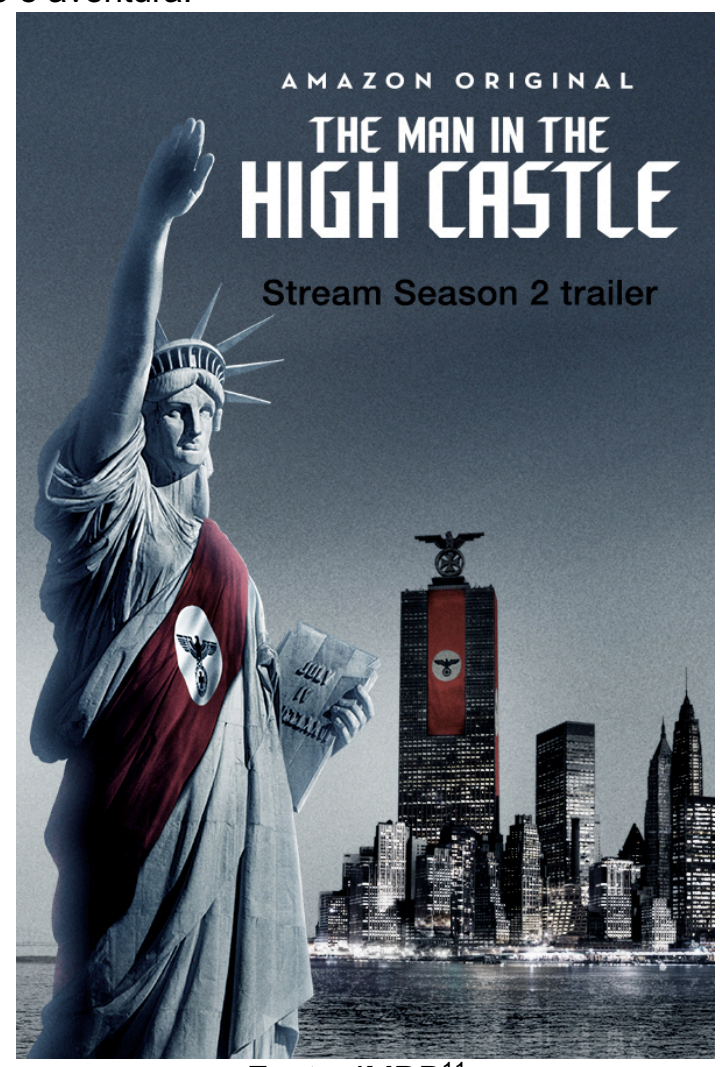

Fonte: $\mathrm{IMDB}^{11}$.

O livro de Mercier, propunha um futuro melhorado no espaço conhecido de seus leitores, Paris e o mundo, partindo do desenvolvimento causal pautado na história do presente de seu público, extrapolando como seria melhor o futuro caso as ideias iluministas defendidas por Mercier e seus contemporâneos fossem aplicadas. É desenvolvida uma relação histórica, as ideias do presente do autor se realizam no futuro, o lugar real é feito estranho pela atualização realizada pelo progresso no tempo (ALKON, 2010, p.128).

A crítica ao presente francês pré-revolucionário e, com certeza, sua proposição de um futuro utópico, levaram o livro a ser banido da França, logo após a sua publicação, a ser colocado na lista de livros proibidos pela Inquisição em 1773 e

\footnotetext{
${ }^{11}$ Disponível em: http://www.imdb.com/title/tt1740299/?ref_=nv_sr_1. Acesso em: 09 de maio de 2017.
} 
passível de pena de prisão e multa para quem o distribuísse em Madri em 1778, onde a obra foi considerada blasfema. Apesar disso, foi um livro de enorme sucesso na Europa, com onze edições em francês entre 1771 e 1799, traduções em holandês, alemão e italiano, além de duas traduções para o inglês, nas quais a data foi arredondada para 2500, "Memoirs of the Year 2500". O nome original no ano 2440 se relacionaria ao ano do nascimento do oculto autor (o que os leitores não tinham como saber), com o enredo se passando sete séculos após o referido marco. Porém, não há como ter certeza dos motivos que levaram Mercier a escolher essa data e, ao ser publicado na Inglaterra, os editores também não entenderam as razões do ano específico 2440 e acabaram por arredondar para 2500 (ALKON, 2010, p.123). A obra de Mercier foi o primeiro romance utópico publicado na América do Norte, editado na Filadélfia em 1795 e George Washington e Thomas Jefferson tinham cópias do romance (Ibid., p.117).

Segundo Alkon (2010, p.121), é o primeiro livro que coloca um ano futuro como título, o que já impõe ao leitor, na própria capa, uma reflexão sobre o tempo, característica que continuou sendo marcante na literatura do século $\mathrm{XX}$, por exemplo: a distopia mais significativa, “1984” (Nineteen Eighty-Four, 1949), de George Orwell (pseudônimo de Eric Arthur Blair), adquiriu boa parte de seu peso ao colocar uma data em seu título, indicando uma relação temporal, oposta ao livro de Mercier, pois enquanto 2440 é o devir a ser atingido, 1984 é o futuro a ser evitado (mesmo que o ano de 1984 já tenha passado, essa relação temporal se mantém na obra, na ideia de antecipação). A obra de Mercier uniu utopia, futuro e progresso, gerando "uma enxurrada de imitações em holandês, alemão e outros idiomas" (CLAEYS, 2013, p.166).

Apenas no século XIX, os temas científicos se tornaram mais comuns nas utopias em geral, e cada vez mais o "lugar nenhum" passou a ser substituído por um tempo diferente, tornando o presente uma etapa para o futuro proposto nas obras utópicas e, cada vez mais, as máquinas ocuparam lugar predominante como símbolo de progresso futuro, dado que as máquinas maravilhosas partiam da extrapolação da experiência social do período, com novas máquinas surgindo e causando espanto nas sociedades industriais ou em vias de industrialização. Nisso, as obras de Júlio Verne, mesmo que narrativamente, as maravilhas tecnológicas estivessem localizadas no presente ou passado recente do leitor, indicavam uma relação de perspectiva de progresso a ser alcançado em um futuro, como a viagem espacial, a exploração 
submarina e até da geologia. Esse fascínio pelas máquinas na relação com o tempo foi completado em finais do século XIX, na obra de H.G. Wells, a Máquina do Tempo (1895), que mesmo não tendo inventado a ideia de um engenho humano ser responsável pelo deslocamento no tempo, desenvolveu e popularizou a ideia, atrelando a viagem no tempo à ficção científica, por sua descrição em vocabulário científico de um conceito de Tempo, a presença do artefato e o diálogo com as teorias científicas de sua época.

Com o sucesso da ideia de progresso no século XIX, "os críticos da urbanização e da industrialização começam a expressar, em literatura utópica, sua oposição à modernidade" (CLAEYS, 2013, p.159) e em finais do século XIX, distopias se estabelecem como um subgênero literário, reagindo às propostas eugênicas e do darwinismo social tanto quanto do movimento socialista. A distopia, ou antiutopia, cada vez mais passou a pautar as relações das sociedades com Estado, poder, tecnologia, práticas econômicas e políticas, geralmente mostrando como propostas utópicas podem ser desviadas ou sua realização criar o efeito inverso do que o pretendido. Georges Claeys (2013, p.175) chama a atenção para o fato de que a raiz do pensamento distópico pode também ser associada à influência e às especulações oriundas da obra de T.R. Malthus, "Ensaio sobre o Princípio da População" de 1789 (An Essay on the Principle of Population), pois seria o destino de toda sociedade, principalmente as prósperas, a superpopulação, com guerras, fome e doenças. Enquanto nas utopias, reduzindo as obras a sua essência, podemos encontrar Paraísos profanos, nas distopias enfrentamos um Apocalipse, ou mesmo Infernos laicos.

No desenvolvimento dos temas utópicos e distópicos no século $\mathrm{XX}$, há uma predominância da distopia como mais apropriada às interpretações das experiências sociais com o poder totalitário, tecnologia e ciência a serviço da opressão humana, descrença ou crença em uma natureza humana mais ou menos incontrolável e violenta, a destruição da natureza, mas também é característica das obras utópicas não terem muito desenvolvimento de enredo, drama e pouca ação, o que não é o caso das distopias, que são mais fáceis de desenvolverem conflitos e atraírem mais a atenção do público. Portanto, não podemos creditar totalmente a ascensão das distopias a apenas um descontentamento frente ao mundo e à ideia de decadência ocidental herdada das propostas do século XIX, há um elemento da própria narrativa e do esgotamento dos temas utópicos que torna a distopia mais interessante para o 
público leitor. Não só isso, o avanço das ciências humanas, permitia prognósticos cada vez mais científicos sobre a sociedade e os indivíduos, o foco no escapismo, as análises psicológicas e a categorização marxista dos chamados "socialistas utópicos" deram à utopia um ar de inocência e infantilidade, retirando sua verossimilhança. Todavia, os ideiais utópicos não foram totalmente abandonados pelas sociedades contemporâneas, podendo ser encontrados mais facilmente em obras de ficção científica.

Figura 06 - O livro do escritor de fiç̧ão científica utopista, Kim Stanley Robinson, The Years of Rice and Salt (Os anos de Arroz e Sal, tradução nossa). Lançado em 2002, apresenta um passado e futuro alterativos. A obra de história alternativa parte da ideia de que a Peste Negra teria matado $99 \%$ dos europeus na Idade Média e acompanha o desenvolvimento das sociedades mundiais do ponto de vista das pessoas comuns. Conhecido por sua utopia marciana, Robinson costuma apresentar temas utopistas em suas premiadas ficções.

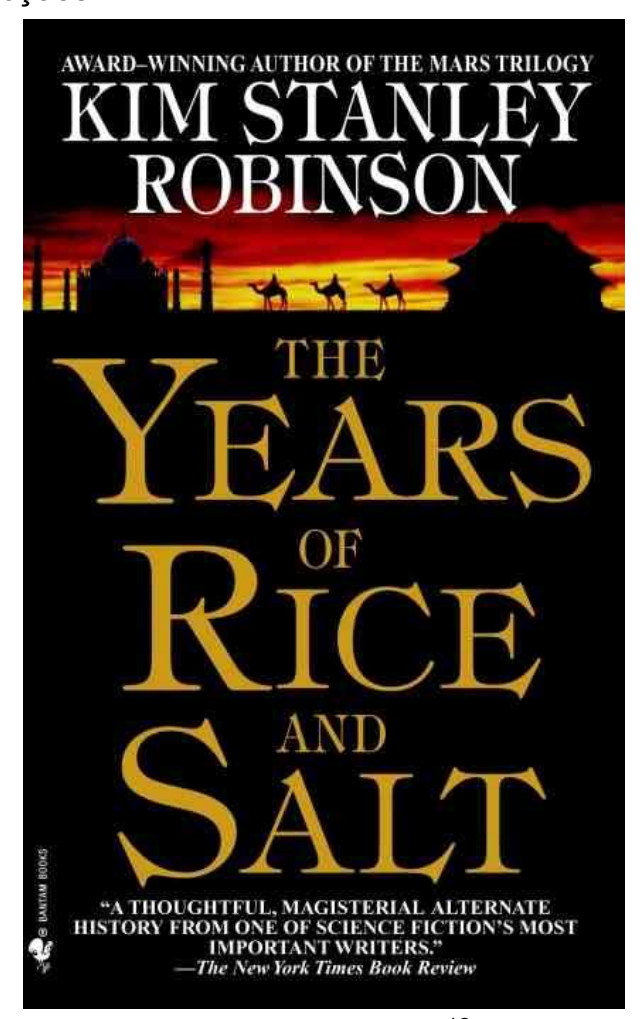

Fonte: Loja Amazon ${ }^{12}$.

O pensamento utópico, a grosso modo, pode ser reduzido a duas linhas, nas quais as propostas irão se articular apontando para diferentes temporalidades na tentativa de resolução dos mesmos problemas, partindo do mesmo diagnóstico da fragmentação da sociedade e comunidades. A linha orientada para o futuro procuraria na ciência e na tecnologia atual e a ser construída, na organização planejada de ações

12 Disponível em: https://www.amazon.com/Years-Rice-Salt-StanleyRobinson/dp/0553580078/. Acesso em: 09 de maio de 2017. 
inéditas e/ou ousadas, a resolução dos problemas enfrentados pelas sociedades. Já a outra linha seria orientada para o passado, tentando manter ao máximo o que está sendo perdido e recuperar formas de organização passadas, tradicionais (CLAEYS, p.209-210). Ao se pensar uma obra utópica ou com elementos desse subgênero, como algumas histórias de viagem no tempo, deve-se considerar qual das duas linhas predomina no pensamento do autor da proposta.

\section{9- Ficção Futurística}

Como o professor de Literatura inglesa Paul K. Alkon definiu, por ficção futurística, determinam-se as "narrativas em prosa que explicitamente se passam no tempo futuro" (2010, p.3). Esse tipo de obra pode ou não estar relacionado com a literatura utópica/distópica ou com a ficção científica, tendo suas experiências anteriores aos dois gêneros temáticos citados.

A ficção futurística, ao lançar o relato para o futuro, ajudou na construção da nova relação moderna das temporalidades ocidentais, ao mesmo tempo que permite ao historiador notar como o tempo futuro foi se abrindo, o que no século XVIII, segundo Koselleck, Hartog e outros historiadores, embasou o nascimento de uma nova definição de História e a noção de um tempo histórico orientado para o futuro.

Geralmente, é creditado, como Alkon propõe, que o panfleto de seis páginas de Francis Cheynell, Aulicus his dream, of the king's sudden comming to London, de 1644, e o livro incompleto de Jacques Guttin, Epigone, histoire du siécle futur, de 1659, são os dois exemplos literários conhecidos de trabalhos que se passam no futuro antes do século XVIII. Já o professor de Literatura inglesa e escritor Adam Charles Roberts mostra, em seu livro The History of Science Fiction (2005), que já existiam mais exemplos contemporâneos e até anteriores às duas obras citadas por Alkon de narrativas futurísticas: "especular sobre possíveis futuros (seculares) é uma função tão necessária à habilidade humana de planejamento e estratégia que seria surpreendente se eles estivessem ausentes da literatura anterior" (ROBERTS, 2005, p.76). Sem entrar no debate do campo literário sobre qual foi a primeira obra realmente a transmitir um sentido e localizar sua narrativa no futuro não-escatológico, pode-se notar que ocorreu um processo no qual cada vez mais autores passaram a ancorar suas narrativas em um tempo futuro, distinto fundamentalmente do presente devido à aceitação ou rejeição do conceito/mito de progresso e de decadência. 
Outra questão a ser levantada é a da transferência do espaço para o tempo, o tempo da possibilidade futura passou a ocupar a antiga fórmula do espaço imaginário; porém, sem a substituír, uma vez que a localização de narrativas em espaços imaginários, com ou sem relação temporal, ainda é comum. E como nota Alkon (2005, p.42), as primeiras obras não tinham a preocupação em articular passado, presente e futuro, o que dava a noção de que o recurso narrativo de localizar uma obra no futuro estava cumprindo a mesma função do espaço, já que não havia conexão entre o que era lido e uma perspectiva histórica. Por exemplo, cabe citar novamente o livro de Guttin de 1659, o qual indiretamente comprova a tese de Koselleck de que não havia ainda a noção moderna de tempo histórico: as obras paulatinamente localizaram o futuro em um sentido histórico, relacionando-o com o presente e o passado do leitor, fato a ser notado mais claramente em escritos do século XIX.

O nascimento de ficções sucedendo-se no futuro pode ser creditado às mudanças sociais advindas do capitalismo, à novas concepções de tempo e espaço, à percepção social das mudanças, à Revolução Industrial e às revoluções políticas do século XVIII. Seria reduzir o papel da própria percepção artística deixar de considerar também como fundamentais para esse novo processo as "teorias do século XVIII sobre o sublime que criaram uma estética favorecendo narrativas estranhas" e "o encorajamento de experimentação formal" (ALKON, p.111-112) ocorrido na Inglaterra, criando um clima literário cada vez mais incentivador a esse tipo de obra, que por todas as razões citadas acima conseguia, cada vez mais, transmitir verossimilhança para o público.

No desenvolvimento da Literatura, a liberdade proporcionada pelo futuro permitia a criação de histórias para defender e reforçar o mito do progresso, construindo obras que levavam os céticos em relação esse mito a se utilizarem do mesmo subterfúgio, o futuro, para refutar o progresso, ao mesmo tempo em que o futuro permitia o desenvolvimento da fantasia. Essa via de mão dupla foi mais claramente estabelecida no final do século XIX (Ibid., p.192). O apelo à fantasia é tão característico nos contos sobre o futuro quanto uma apologia ou crítica ao progresso, apontando "um movimento em direção à metaficção - isso é, em direção às várias técnicas pelas quais um título pode convidar mais do que desencorajar à percepção de sua própria ficcionalidade e sua relação com outros livros" (Ibid., p.193).

Nas décadas finais do século XIX, já havia um cenário literário propício e receptivo para o impacto da obra de H.G. Wells, criando em um romance serializado 
uma viagem ao futuro controlada pelo ser humano por meio de uma máquina maravilhosa especificamente feita para a exploração temporal, o que tornou mais difícil para os outros autores justificarem suas narrativas de deslocamento dos personagens ao passado ou ao futuro por outros meios que não uma tecnologia $\mathrm{e}$ uma ciência extrapolativas. Mesmo assim, a presença da máquina e força da explicação inspirada na ciência (ou em sua linguagem), não substituiu totalmente os meios mágico-religiosos de se viajar no tempo como anjos, fantasmas, objetos, sonhos, por exemplo. 
“- É maravilhoso - continuou - ver todos vocês aqui esta noite. Sim, absolutamente maravilhoso.

Porque sei que muitos de vocês vêm aqui diversas vezes, o que eu acho realmente fantástico, vir

aqui e assistir o fim de tudo, e então retornar para casa, para suas próprias eras... e construir

familias, lutar por novas e melhores sociedades, combater em guerras terriveis em nome do que vocês acham certo... isso realmente nos traz esperança no futuro de todos os viventes. A não ser, é claro - e apontou para o redemoinho que relampejava acima e ao redor deles -, pelo fato de sabermos que não haverá futuro algum..." (Max Quordlepleen - O Restaurante no Fim do Universo, Guia definitivo do Mochileiro das Galáxias, 2016, p. 197)

"When a man changes the past he only affects his own past - no one else's. The past is like memory. When you erase a man's memory, you wipe him out, but you don't wipe out anybody else. You and I have erased our past. The individual worlds of the others go on, but we have ceased to exist" 13 Israel Lennox (inventor de uma máquina do tempo e desaparecido desde 1975 no conto de Alfred Bester, The Man Who Murdered Mohammed,1958)

\section{3- Todo o Tempo do Mundo: a viagem no tempo}

\section{1- Escolhendo os equipamentos}

As origens das histórias de viagem no tempo geralmente são traçadas até às décadas finais do século XIX, quando, ao contrário das obras que se passavam em um futuro mais ou menos distante ou em um presente feito futuro, ou no passado histórico, ou ficcional/mítico, mas com seres do próprio tempo, as histórias passaram a exercer um controle maior do fluxo temporal e apresentar personagens se deslocando de forma não convencional no fluxo temporal, indo do presente ao passado ou se movendo ao futuro fora do padrão um de segundo de cada vez. No mundo Ocidental e em suas áreas de influência, as histórias de viagem no tempo se tornam mais palatáveis ao público devido às novas relações com o tempo realizadas pelas sociedades industrias via trabalho e tecnologias, pelo conhecimento da natureza advindo das ciências e pela valorização dessas aventuras. Porém, pode-se traçar as raízes para essa subversão do fluxo temporal para bem antes do século XIX e pensar,

\footnotetext{
${ }^{13}$ Quando um homem muda o passado ele somente afeta seu próprio passado - o de ninguém mais. O passado é como a memória. Quando você apaga a memória de um homem, você o apaga, mas não apaga mais ninguém. Você e eu exterminamos nosso passado. Os mundos individuais dos outros continuam, mas nós deixamos de existir. [tradução nossa].
} 
partindo do conceito de Elias, o tempo como uma construção coletiva humana complexa e que marcar alguma forma de tempo é fundamental nas relações dos seres humanos com o mundo e indicativo de como se articulam as noções e percepções de mudança/permanência de dada sociedade.

Além disso, deve-se ter em conta que as décadas finais do século XIX e as primeiras do século $X X$ representaram mudanças radicais na forma científica de concepção da matéria, do espaço e do tempo (STERN, 1947, p.XXI), como, por exemplo, a tentativa de se determinar a velocidade da luz, os raios $x$, a radiação, $a$ mecânica quântica e a teoria da relatividade. Essas e outras novidades iriam influenciar autores e encontrar respaldo em uma forma popular de se relacionar com o conhecimento científico, inteligível para os não iniciados.

Juntamente com as descobertas científicas, uma série de novos desenvolvimentos artísticos também mudaram as formas das populações se relacionarem com o tempo, matéria e espaço. Foi no século XIX que se desenvolveram a fotografia - com o registro de um momento fixo do tempo e espaço - , o fonógrafo e gramofone - com registros sonoros a serem escutados na ordem e da forma desejada - , as histórias em quadrinhos - narrativas que implicam em uma forma ímpar de relação temporal com os saltos entre quadrinhos e a exigência de uma construção mental da passagem do tempo e espaço de um quadro para o outro - e o cinema, denominado no início do século XX de Sétima Arte - com imagens em movimento fazendo um recorte espaço-temporal passível de todo tipo de nova experiência temporal, acelerando ou retardando o movimento ou mudando a relação causa e efeito, por exemplo.

Para simbolizar essa grande mudança, podemos destacar o ano de 1895 como um marco fundamental na nova relação das sociedades modernas com o Tempo: o sucesso da história em quadrinhos Yellow Kid, nos EUA, abrindo o campo para esse tipo de arte ( $\mathrm{COUCH}, 2007$, p.73), a exibição pública do primeiro filme dos irmãos Lumière no Grand Café do Boulevard des Capucines em Paris, França, e a publicação seriada e em livro de A Máquina do Tempo, de H.G. Wells, em Londres e EUA.

Todavia, a imaginação humana sobre o tempo não é exclusividade das sociedades industriais europeias ou americana em um período de grandes mudanças paradigmáticas. Logo, podemos encontrar subversão e negação do símbolo Tempo, geralmente ligado ao conhecimento religioso e aos contos folclóricos, com os objetivos de ampliar a divindade de figuras sagradas ou o caráter não usual dos contos 
folclóricos, servindo, por exemplo, ao entretenimento e à transmissão de lições de cunho ético-morais, reforçando as tradições, comprovando doutrinas e orientando grupos humanos para a vida, as mesmas funções sociais que encontramos na viagem do tempo secularizada na contemporaneidade.

Figura 07 - Capa da coletânea organizada pelo escritor e historiador Philip Van Doren Stern, Traveles in Time (1947), uma das primeiras coletâneas de contos de viagem no tempo. Detalhe na capa para uma versão moderna do Pai Tempo (tempo em si antropomorfizado), escapando de homens tentando capturá-lo, com sua ampulheta marcando a morte. A viagem no tempo retratada, em última instância, como desafio à morte trazida pela passagem do tempo.

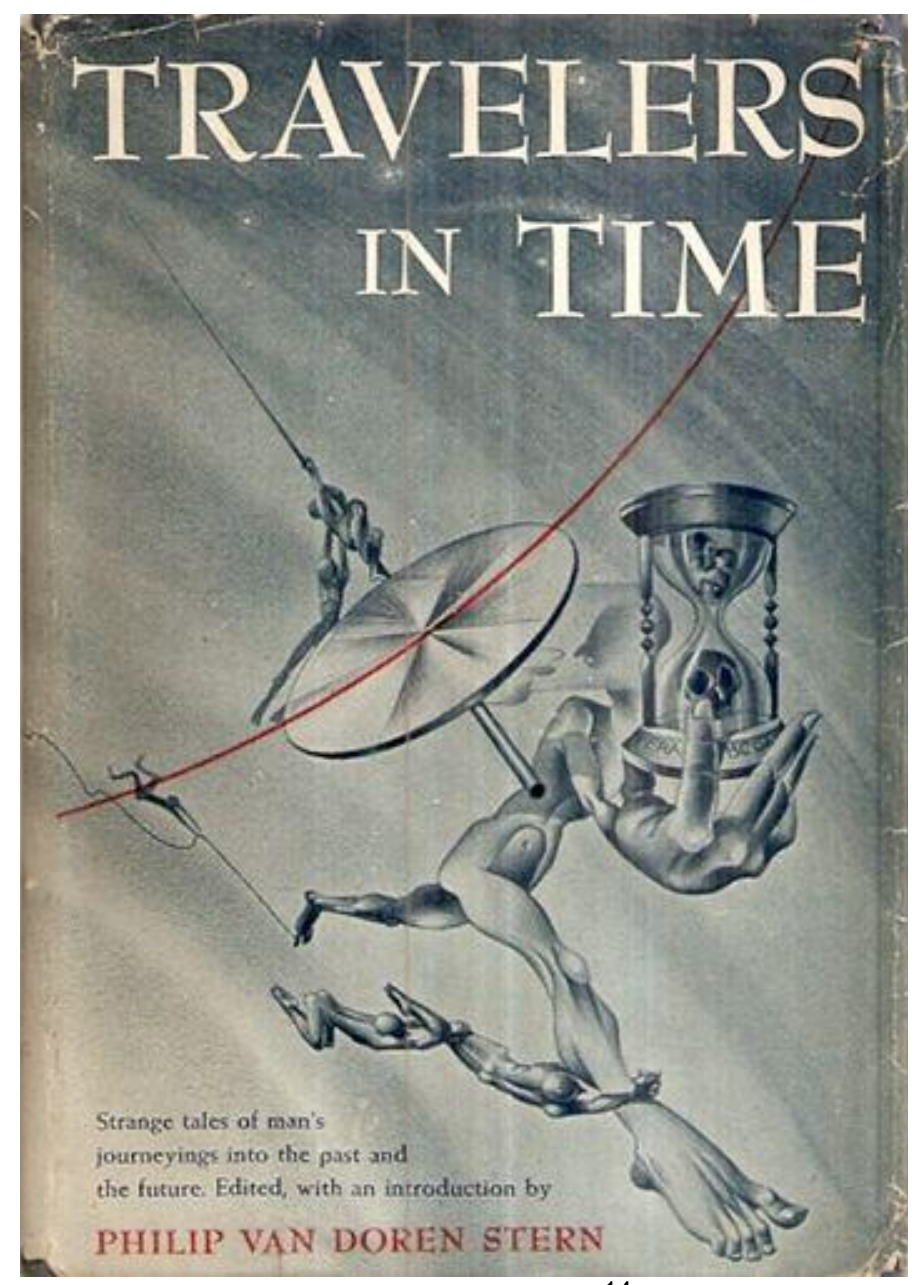

Fonte: Abebooks ${ }^{14}$.

Os professores Matthew Jones, Joan Ormrod (2015, p.11) e Paul J. Nahim (1999, p.10) destacam algumas histórias religiosas e do folclore mundial anteriores ao século XIX que trazem alguma forma de experiência não usual com o tempo. Porém, para Nahim, essas histórias não teriam ligação com a viagem no tempo em si, pois o

${ }^{14}$ Disponível em: https://www.abebooks.com/servlet/BookDetailsPL?bi=14782000333.

Acesso em 09 de maio de 2017. 
foco seria mais no caráter fora do tempo do que uma viagem. O pesquisador vai além e não considera viagem no tempo de ficção científica narrativas que não tenham alguma forma de máquina que possa ser explicada pelas leis da física atuais ou antigas e suas extrapolações. Esse recorte pode acabar restringindo o objeto de estudo e não leva em consideração o caráter fluído dos gêneros, suas intersecções e a própria relação com o público e a sua comercialização, muitas vezes não diretamente ligada com o conteúdo (ALTMAN, 1999 apud JONES; ORMROD, 2015, p.7).

Nos limites pantanosos da fantasia e da ficção científica, habita a viagem no tempo, comumente vista pelo público, de forma correta, como parte do campo temático abordado pela ficção científica. Cada história de viagem no tempo constrói uma estrutura que dá suporte a uma lógica interna e à falta de base imediata no real, em tese, aproximaria mais da fantasia do que da ficção científica (JOHSON, 2013, p.X), principalmente se, ao categorizarmos uma obra como ficção científica, for exigido uma prática científica e tecnologia real a ser extrapolada ou mesmo usada nesse tipo de aventura. Contudo, devemos nos ater à reflexão sobre a viagem no tempo como um ponto de intersecção de fantasia com ficção científica e, para fins de demarcação de terreno, cabe a observação de que na Literatura, os "escritores de ambas as formas fazem uso da mesma metafísica e daí compartilham das mesmas técnicas literárias" (LEIBY, 1987, p.107), além do trânsito dos autores em diversos gêneros.

A tendência maior de se associar a viagem no tempo com a ficção científica não se dá por acaso ou por uma falta de conhecimento. Essa associação também não está somente na constatação direta, em primeira mão, de que muitas histórias de ficção científica apresentam histórias de viagem no tempo com máquinas ou alguma forma explicada derivada do conhecimento científico, ou mesmo do fato singular que utilizamos o nosso conhecimento coletivo, repertórios e competências leitoras acumuladas no contato direto ou indireto com essas obras, já entendendo a forma pela qual se dá a viagem no tempo na narrativa, justificando-na por alguma ciência ou tecnologia de base real ou imaginária, sem necessitarmos maiores explicações. Todavia, parte dessa associação entre ficção científica e viagem no tempo reside na própria atração gerada pela ficção científica, a qual, em sua origem, traz consigo uma preocupação com a temporalidade, dado que a relação presente e futuro foi mais significativa do que preocupações com o espaço sideral ou outros temas geralmente 
associados ao gênero (WESTFAHL, 2002, p.2), e isso foi de extrema importância para seu florescimento e sua manutenção, seu caráter antecipador da modernidade.

O acadêmico americano Gary Wesley Westfahl (2002, p.2) identificou duas premissas geralmente aceitas que explicam a conexão da ficção científica com a viagem no tempo: a primeira seria o papel do influente editor Hugo Gernsback, na época do estabelecimento do gênero nas pulps nas primeiras décadas do século $X X$, no sentido de legitimar a noção da ficção científica como uma "literatura de ideias", fortalecendo o papel da especulação científica, o que a viagem no tempo proporciona em larga escala; e a segunda, o fato de que a ficção científica cresceu popularmente não de textos acadêmicos, mas sim em relação direta com outros gêneros literários anteriores, como a utopia, a sátira, o melodrama, o conto de viagem, etc., incorporando elementos desses gêneros na temática da viagem no tempo e se adaptando ao gosto do autor e público. Por isso, é tão difícil delimitar as histórias de viagem no tempo na rigidez de um gênero: elas podem servir a qualquer gênero, a depender da criatividade do autor. Vide os exemplos de histórias de amor, conhecidas também por "timeslip romance" (romance de deslize temporal), que envolvem um amante presente em outro tempo, como no sucesso do filme Em Algum Lugar do Passado (Somewhere in Time, 1980), estrelado por Christopher Reeve e adaptado do livro de Richard Matheson (1975).

Porém, como no exemplo citado, no qual não há máquina do tempo e o viajante volta ao passado por auto hipnose, se alguém perguntasse como seria possível tal salto para o passado, recorreríamos a um jargão pseudocientífico, já adquirido pela cultura da viagem no tempo, a fim de gerarmos um argumento mais verossímil, ou seja, não se conseguiria atualmente a mesma receptividade da justificativa para esse deslocamento no tempo da história de Matheson, se afirmássemos que Deus quis fazer o herói voltar ao passado para conhecer o grande amor de sua vida. Essa explicação, se for retirada a influência cultural e a permanência dessas histórias, seria tão boa quanto qualquer outra, mas mais difícil de convencer a maior parte do público contemporâneo, e ainda por cima, nesse caso, a viagem no tempo só daria um colorido especial a uma história clichê de romance impossível.

Apesar de toda fluidez possível, deve-se reconhecer a influência de H.G. Wells e sua máquina do tempo de finais do século XIX. O impacto da sua obra para a reflexão sobre o tempo e sobre a existência utilizando o recurso da viagem no tempo e da máquina marcou o terreno, servindo de modelo a ser refutado ou reforçado até 
hoje. Entretanto, histórias que apresentam experiências insólitas no tempo não são uma exclusividade do ocidente industrial do século XIX, já que a viagem no tempo se adequa às formas pelas quais o tempo é percebido e experimentado, adaptando-se a ou contestando as relações de temporalidade de dadas sociedades.

\section{2- Deslocamento temporal antes da viagem no tempo}

Cabe destacar alguns exemplos mundiais anteriores ao século XIX. Na Índia há a história do Rei Kakudmi, como pode ser lida no livro Srimad-Bhagavatam (Bhagavata Puraṇa) datado de cerca do século X (SRIMAD, s.d., n.p). Essa história relata a ida do monarca ao Brahmaloka, mundo celestial mais alto do Hinduísmo, perguntar ao Brahma com quem sua filha deveria se casar. O deus estava fazendo uma apresentação musical e Kakudmi teve que aguardar o fim da música para conversar. Encerrado o evento, o rei finalmente foi informado por um risonho Brahma que vinte e sete catur-yugas teriam decorrido enquanto ele estava lá esperando e os pretendentes já estariam mortos e esquecidos (cada catur-yuga corresponde aproximadamente a 4,32 bilhões de anos solares, um deslocamento de 116,64 bilhões

de anos!). O pobre rei, ao voltar para o mundo humano, deparou-se com uma humanidade degenerada, com violência, traição, decadência física e moral. Esse exemplo apresenta o tempo correndo de forma distinta para humanos e deuses, marcando de forma clara a efemeridade da existência, além de explicar o casamento da princesa e o ciclo do tempo. Além disso, a passagem dos tempos gera uma óbvia comparação com o fenômeno da dilatação do tempo descoberto pela Física moderna.

No Japão, a história de Urashima Taro, originária de registros folclóricos realizados no século VIII, também apresenta uma passagem de tempo distinta entre dois mundos. Em sua versão mais comum, ao ajudar uma tartaruga filhote, que na verdade era filha do imperador do mar, o homem é levado ao fundo do oceano no palácio do Rei-Dragão onde é recebido com festas e fica lá por alguns dias. Sentindo saudade de casa pede para voltar e, antes de partir, ganha da princesa uma arca que só deveria ser aberta quando estivesse velho. Retornando ao lar, ninguém o reconhece e o pobre Urashima Taro descobre que seus familiares já estavam mortos e se passaram trezentos anos. Esquecendo a orientação da princesa, ele abre a arca e dela sai uma fumaça que o faz envelhecer instantaneamente. Nessa história o lapso temporal aparece como exemplo da saudade das raízes em um mundo de constantes 
mudanças e perdas, no caso, relacionadas ao fato de se estar fora da sua sociedade natal e retornar anos depois para se sentir um estranho ${ }^{15}$. Há também a reflexão sobre a juventude e velhice, a ideia de que a juventude pode ser perdida pela desatenção, representada pelo abrir da arca.

Uma versão dessa lenda japonesa se tornou famosa no Brasil no final da década de 60 e anos 70, quando o simpático japonês se tornou garoto propaganda dos quatro voos semanais diretos Rio de Janeiro-Tóquio da empresa de aviação Varig, com letra e música compostos por Archimedes Messina (autor do jingle do Café Seleto e da abertura do Programa Silvio Santos, "Silvio Santos vem aí") e cantado pela nipo-brasileira Rosa Miyake - Messina ainda iria vencer em 1970 o prêmio de jingle brasileiro do ano com essa música (LESSER, 2007, p.16; TAIRA, 2018, p.3035). No comercial, Urashima Taro passeia por todo Brasil até se tornar velho e sente saudade do lar, em clara alusão à imigração japonesa. Na arca, em vez de encontrar a velhice e a passagem do tempo, o japonês encontrava uma passagem de avião da Varig e a juventude para poder voltar para casa e ser feliz, ou seja, viajar rejuvenesce, mensagem oposta a lenda original. Como veremos mais adiante, no episódio de Além da Imaginação The Odyssey of Flight 33 (A Odisseia do Voo 33), associar o avião à viagem no tempo nem sempre pode ser uma boa ideia publicitária, a aeronave corre o risco de ficar perdida para sempre.

No Oriente Médio, na tradição islâmica, encontramos uma interessante história descrita nas Hádices e apenas citada no Corão sobre uma viagem noturna de Maomé (Lailat al-Mi'rāj), uma jornada em duas partes, a Isra - a ida a Jerusalém (Bayt alMaqdis) - e a Miraj - a visita aos sete céus. Habitando Meca e com poucos seguidores, Maomé teria sido visitado pelo anjo Gabriel e um animal fantástico, chamado Buraq, e em uma única noite, montado no animal, visitou Jerusalém e os sete céus, apreciando as maravilhas e lá encontrando Adão, Abraão, Jesus e Moisés, dentre outros. No sétimo céu, depois de atravessar portões, sempre acompanhado do anjo Gabriel e do Buraq, negocia com Alá, sob orientação de Moisés, a quantidade de

\footnotetext{
${ }^{15}$ O mesmo tema pode ser encontrado, não como descolamento temporal, mas dimensional, no episódio The Parallel (1963), de Além da Imaginação, escrito por Rod Serling, onde um astronauta em retorno à Terra vai parar em uma dimensão paralela, onde tudo é parecido mas com algumas diferenças que causam desconforto no homem, em uma história em consonância direta ao tema do retorno para casa dos veteranos da Segunda Guerra Mundial e seus estranhamentos decorrentes da vida doméstica (MELBYE, 2016, 2623)
} 
orações diárias que deveriam ser feitas, reduzidas de cinquenta para cinco. Para os muçulmanos, o Domo da Rocha, em Jerusalém marca o local onde se crê que o profeta Maomé subiu aos céus: além disso, a data da jornada noturna de Maomé é um dia comemorado no calendário islâmico. Essa jornada espiritual de Maomé utiliza o fluxo do tempo, experimentado de forma distinta pelo profeta, para reforçar a importância de sua viagem e de sua mensagem, pois só Deus teria o controle do tempo e só a vontade de Deus explicaria como Maomé teria conseguido o feito de realizar tal viagem fantástica em apenas uma única noite.

$\mathrm{Na}$ tradição ocidental, encontramos casos de dorminhocos que acordam em outra época, algo similar ao que hoje na ficção científica é tradicionalmente conhecido por "animação suspensa", esta explicada, porém, por uma ciência e tecnologia especulativa. Uma das lendas mais famosas dentro dessa perspectiva de viagem no tempo é a dos Sete Dorminhocos do Éfeso, que faz parte do Cristianismo e do Islamismo. Na sua versão mais conhecida, sete jovens fugindo, da perseguição aos cristãos no Império Romano, cerca de 250 d.C., entram numa caverna para rezar, escapando do paganismo do imperador e dormem. O imperador manda bloquear a caverna e os jovens ficam dormindo lá dentro por duzentos anos. Passado o tempo, a terra tem um novo dono que resolve abrir a caverna, encontrando para sua surpesa os sete jovens que acordam em um mundo já cristão. O grupo vai para a cidade onde as pessoas estranham seu comportamento e o uso de moedas antigas, conta sua história para o bispo local e os sete jovens morrem logo em seguida. Essa história, de provável origem dos cristãos sírios, foi popularizada por São Gregório de Tours em seu livro De gloria martyrum (cerca de 590 d.C.) e tem como objetivo principal comprovar o valor de se manter cristão frente às dificuldades. Deus deixou-os dormindo em um período crítico para o Cristianismo, preservando seus corpos, para que reforçassem a veracidade de sua mensagem para a humanidade séculos depois. A passagem do tempo nesse conto religioso comprova o poder divino, o milagre e a verdade da fé; porém, encontramos nele a questão da mudança, operando como reflexão histórica, já que ocorre totalmente no passado do ouvinte ou leitor e reforça a linha do tempo e a escatologia cristã.

Na histórica folclórica da Bela Adormecida, registrada e escrita em 1696 por Charles Perrault no conto "A Bela Adormecida do Bosque" (Contos da Mamãe Gansa), também somos apresentados a algo similar à "animação suspensa". Nessa história, a pobre princesa dorme por cem anos, fato este não incluso na versão similar anterior 
de Giambattista Basile (1634), Sol, Lua e Talia (Pentamerão), na qual não há preocupação em fixar uma quantidade de tempo para o sono da moça. Entretanto, essa passagem do tempo, os cem anos de sono, não implica em um mundo transformado quando a malfadada princesa é acordada pelo príncipe e tem que enfrentar a ira da rainha. O salto temporal experimentado pela Bela Adormecida serve mais como forma de explicar a passagem de gerações e a não relação sanguínea entre o príncipe e a princesa, do que propor um mundo novo com outras instituições ou tecnologias. As pessoas envelhecem e morrem, sociedade e natureza são essencialmente imutáveis.

Figura 08 - Letra da música de Messina composta para propaganda da Varig, cantada pela apresentadora Rosa Miyake em japonês e português.

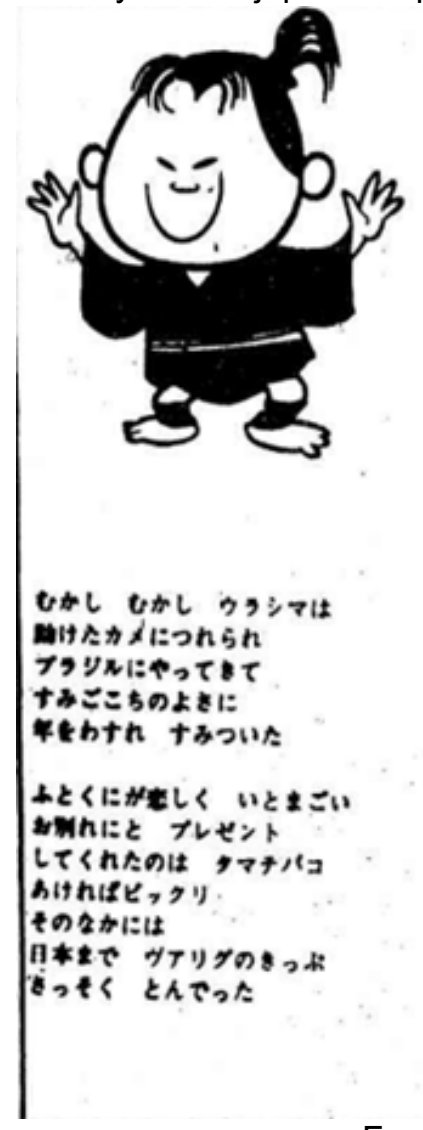

Fonte: Fã clube Varig ${ }^{16}$

\section{URASHIMA TARO}

Urahima Tars

Um pobre pescador,

Salvou uma tartaruga

Ao Bruil

Pelo reino encantado.

Ele se spaizonou

E por equil ficou.

Passaram muitos anon

De repente, a audede cherou

De presente tie zanhou.

Ao abri-la quanta slegria,

Vibrou seu corechlo.

$$
\text { de Varit. }
$$

E voou fells para o Japlo

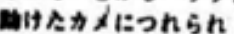

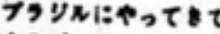

ナネここらのよをに

Th TஆつแA

Ac 2 is

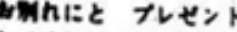

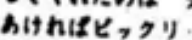

เのタかには

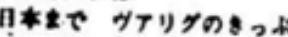

Esses exemplos demonstram que a concepção de tempo fluído é mais universal do que costumamos considerar. Entretanto, não devemos deixar de anotar uma diferença antagônica entre essas antigas narrativas que envolvem alguma forma de experiência com e no tempo e as narrativas específicas de viagem no tempo

\footnotetext{
${ }^{16}$ Disponível em: <http://www.varig-airlines.com/pt/marketing.htm>. Acesso em: 25/09/2017.
} 
desenvolvidas a partir do século XIX. Há uma mudança de grau e complexidade, advinda dos novos usos do símbolo tempo e das formas de perceber as transformações. O tempo do mito, folclore ou mesmo de religiões históricas encontrou um parceiro que aprofundou a questão da mudança, a noção de progresso.

Uma história que apresenta a relação presente, passado e futuro nos moldes que serão desenvolvidos posteriormente, porém dentro de uma tradição do folclore mundial e diretamente ligada com os Sete Dorminhocos do Éfeso, encontra-se no livro Rip Van Winkle (1819), do historiador, escritor e diplomata americano Washington Irving. O enorme sucesso dessa história, que apresenta um preguiçoso dorminhoco que acorda no futuro (passado para o leitor), é um exemplo de como a mudança geral do mundo, além do individual ou próximo, tornou-se um dos temas mais explorados quando se faz uso da viagem no tempo nas artes. A obra conta a história do fazendeiro que não gosta de trabalhar e, para escapar das cobranças da esposa, vai para uma montanha e encontra homens com roupas antigas, jogando um tipo de boliche, gerador de sons de trovões. Ao beber uma espécie de aguardente que o estranho grupo consumia, dorme e acorda vinte anos depois, porém envelhecido. Nesse processo, Van Winkle adormece na colônia britânica e acorda nos EUA, encontra seus filhos adultos e vai morar com a filha, passando a contar sua história para os visitantes da vila. A passagem no tempo reforça a permanência de Van Winkle, que continua sendo uma constante, algo imutável, em um mundo que mudou (similar a Urashima Taro), porém sua caracterização é mais cômica que negativa e nos leva a simpatizar com o protagonista.

Pode-se notar no desenvolvimento da viagem no tempo, cada vez mais, a articulação das mudanças individuais no tempo, com questões de mudanças políticas, econômicas e sociais de outras temporalidades, ausentes ou não centrais nos exemplos dados. Nota-se que as experiências do tempo dessas histórias envolvem o transporte para o futuro, o que já era especulado pelos mitos, pela prática profética e/ou pela escatologia religiosa; mais do que viagem no tempo, encontramos indivíduos dando saltos involuntários no tempo. No século XIX, a viagem no tempo emergente atenderá às novas relações temporais de um mundo onde a mudança é constante e aceita como inevitável por largas parcelas da população, além de incorporar novas noções de tempo e espaço. O deslocamento pelo tempo passa a ser similar à locomoção pelo espaço, podendo-se controlar até os rumos da viagem, em uma lógica 
confluente com a do mundo da produção industrial: o controle e a organização cada vez maior da natureza e da sociedade.

O passado é visto como etapa percorrida do presente e do futuro e um viajante que visita o futuro não se deparará apenas com a tristeza de refletir sobre seus amigos e familiares mortos há muito, mas também encontrará novas instituições, outras relações políticas, econômicas e sociais, até poderá encontrar outros seres humanos e seus descendentes. Fatos estes bem distintos do exemplos da Bela Adormecida, habitante do tempo do folclore, no qual mesmo tendo passado cem anos dormindo não encontra um mundo diferente, ou do tempo mítico cíclico hindu expresso na história citada do rei Kakudmi, que ao retornar para o mundo humano se surpreende com a decadência que vê, pois seu salto temporal o fez pular vários yugas, indo parar no último dos quatro yugas antes de uma eterna renovação do ciclo, o kali yuga. 0 conhecimento dos yugas enfatiza a repetição e não a novidade.

\section{3- Ajustando a linha do tempo}

No século XIX, podemos localizar, no campo literário, obras que esboçam e aprofundam novas relações com o tempo, incluindo formas de viagem, compondo uma série de subversões no fluxo temporal que ganharão corpo e serão mais desenvolvidas após H.G. Wells popularizar o conceito de uma máquina do tempo em 1895, máquina que implica um controle direto da viagem, não mais dependente de alguém que vai dormir, sonhos, drogas, anjos, bruxaria e mágica. Dentre as obras que exploraram essa abertura do tempo futuro e novas relações com o passado cabe destacar o já citado Rip Van Winkle (1819), de Washington Irving, o livro de Charles Dickens, Um Conto de Natal (A Christmas Carol), lançado em 1843, Uma História das Montanhas Ragged ( $A$ Tale of the Ragged Mountains), de Edgard Allan Poe, publicado em 1844, a obra póstuma do botânico francês Pierre Boitard Paris avant les hommes, de 1861, o conto The Clock That Went Backward, de Edward Page Mitchell publicado anonimamente em 1881, Looking Backward, de Edward Bellamy, escrito em 1888, o livro de Mark Twain Um lanque na Corte do Rei Artur (A Connecticut Yankee in King Arthur's Court), de 1889, apenas para citar exemplos da tríade do pensamento ocidental, Inglaterra, França e Estados Unidos. Também podemos encontrar exemplos no século XIX na literatura russa de Alexander Veltman, pioneiro da ficção científica russa com Predki Kalimerosa: Aleksandr Filippovich Makedonskii (1836), e 
na espanhola de Enrique Gaspar y Rimbau, que em seu El anacronópete, de 1887, criou o registro mais antigo de uma máquina do tempo, fato confirmado por Andy Sawyer, bibliotecário da Science Fiction Foundation Library localizada na Universidade de Liverpool (WESTCOTT, 2011). O livro de Gaspar y Rimbau é uma interessante obra humorística escrita um ano antes da primeiro publicação de uma máquina do tempo por Wells no conto The Chronic Argonauts (1888), cuja obra teria sido escrita ainda em 1887, o que disputaria por meses e dias o pioneirismo na invenção de uma máquina do tempo com Gaspar y Rimbau, mas The Chronic Argonauts só foi publicado entre abril, maio e junho de 1888 (DOUBLEDAY, 1995, p.25), oito anos antes do livro seminal do próprio Wells, A Máquina do Tempo (The Time Machine, 1895). Tanto El anacronópete e The Chronic Argonauts não alcançaram o mesmo sucesso, disseminação e influência da obra de 1895 A Máquina do Tempo.

Os livros de Irving, Dickens, Bellamy e Twain tiveram muita influência e alcance, porém foi o livro de H.G. Wells que popularizou o conceito de viagem no tempo e exerceu influência inegável nessa temática. Publicado até o fim em cinco partes na revista The New Review, de janeiro a maio de 1895, e no mês de maio do mesmo ano em duas edições, uma americana e outra inglesa, A Máquina do Tempo foi a primeira obra a sintetizar de forma crítica a literatura utópica do século XIX em uma distopia cética do mito do progresso. O próprio viajante do tempo anônimo afirma que era leitor de utopias e tentou explicar o que viu no futuro por meio do que aprendera previamente nesse tipo de obra, "lendo 802.701 D.C. [o ano futuro no qual se passa a maior parte da aventura] como uma refutação do otimismo utópico sobre a humanidade superar as suas diferenças" (DERRY, 1995, p.18). Além disso, a aventura de Wells popularizou a ideia de uma máquina do tempo: ao contrário de outras histórias nas quais a viagem no tempo era dependente de anjos, sono e sonhos, relógios mágicos e fantasmas, a concepção de um artefato para se viajar no tempo implica um controle humano intencional do fluxo temporal, fazendo do tempo um objeto de gerência, uma analogia explícita relacionada ao controle e domínio do espaço, cujos símbolos no século XIX são o barco a vapor e, ainda mais patente, a ferrovia, fazendo do tempo um objeto a ser administrado em um grau muito mais incisivo do que a organização do horário da economia capitalista.

A concepção do tempo nessa obra é a do tempo histórico, a relação entre experiências (passado) e expectativas (futuro), dentro de um universo newtoniano de 
tempo natural, com uma descrição da viagem no tempo com uma clara analogia que pode ser estabelecida com a ideia da longa duração de Braudel, expressa em seu ensaio de 1958, "História e Ciências Sociais: a longa duração" (BRAUDEL, 1986, p.739), proposta acadêmica bem posterior à obra de Wells, da qual se destacarão elementos mais adiante que podem ser relacionados à viagem no tempo. Vemos na obra o tempo das grandes mudanças não só advindas da ação humana no mundo, mas também das forças da teoria darwinista (uma espécie pode ser substituída por outra mais adaptada ao ambiente) e da entropia. Não só isso, a história de Wells fazendo uso e desenvolvendo o linguajar científico de Charles Howard Hinton, matemático e escritor de ficção científica, tornou a noção de uma máquina do tempo psicologicamente plausível (STABLEFORD, 2004, p.355).

Wells introduziu a noção do tempo como uma quarta dimensão, explicando por meio do viajante uma nova visão que iria se tornar ciência apenas no século $X X$, dado resultado do trabalho do matemático Minkowski com a teoria da Relatividade Especial de Einstein, publicado em 1908. Ambos cientistas não foram influenciados pelo livro de Wells e não consta que "A Máquina do Tempo" tenha sido lida por eles e, por mais interessante que poderia ser, Wells não influenciou a teoria moderna do tempo e espaço (RUSSELL, 1995, p.33): seu universo é ainda pré-relativístico, da Física clássica.

Em "A Máquina do Tempo", ao descrever o tempo como quarta dimensão, Wells tinha mais o objetivo de tornar verossímil a máquina fantástica, dando um ar de ciência e retirando da noção da quarta dimensão o ar de um espaço sobrenatural, ideia em voga na era vitoriana, por exemplo, no movimento espiritualista (GLEICK, 2016, p.7-8). Contudo, Wells, em obras posteriores, não abandonou a noção da quarta dimensão como dimensão espacial, como em The Plattner Story (1896) e em O Homem Invisível (The Invisible Man, 1897), demonstrando que criar um universo ficcional crível ao leitor era sua primeira preocupação, e não o fazer científico.

Outro fato de destaque na obra primordial de Wells foi dar à ficção científica "um de seus mais significativos artifícios facilitadores" (EDWARDS; STABLEFORD, 1995, p.1227), a máquina do tempo. Segundo a opinião do escritor e sociólogo britânico Brian Stableford, "algo não mais racionalmente plausível do que os fantasmas de Charles Dickens em Um Conto de Natal, porém mais adequado aos temas da ficção científica, um gênero reconhecido por sua especulação tecnológica" (2004, p.355). 
Podemos identificar no livro de Wells o diálogo quase literal com as teorias sobre a degeneração formuladas e desenvolvidas no século XIX, acompanhando a crise dos ideias do liberalismo clássico que pareciam não fornecer caminhos de uma sociedade estável e segura (HERMAN, 1999, p.140), reforçando o pessimismo sobre a modernidade com a ideia de que as transformações econômicas e sociais do mundo industrial estavam gerando o oposto da evolução e progresso: os trabalhadores explorados estariam parindo descendentes atávicos, regredindo a humanidade a um estado primitivo e pré-humano, e a elite reproduzindo seres degenerados devido à falta de esforço.

Este é exatamente o mundo futuro encontrado pelo viajante do tempo, um planeta definhando e ocupado por duas espécies degeneradas descendentes dos humanos modernos, os elois e o morlocks; os primeiros, anões habitantes da superfície de beleza clássica e mente infantil; os segundos, criaturas cinzas e feias, bárbaros de pouca visão, morando no subterrâneo e se alimentando dos elois, aos quais forneciam tudo de que precisassem. Não só isso, o romance está dentro da noção de ascensão e queda, divulgada pelo historiador iluminista Edward Gibbon nos seis volumes de História do Declínio e Queda do Império Romano (The History of the Decline and Fall of the Roman Empire, 1776-1788), obra que teve um forte impacto no imaginário ocidental moderno, pois mostrava que "todos impérios e sociedades chegam a um fim, um ponto sem volta, após o qual devem ser substituídos por algo diferente" (Ibid., p.35). A Máquina do Tempo, então, especulava sobre o que seria essa nova sociedade a substituir o mundo ocidental industrial.

Um fator interessante da obra de Wells, mesmo tendo inserido elementos que podem ser encontrados em diversas histórias posteriores, foi a não abordagem de um dos principais problemas relacionados às viagens no tempo, o problema dos paradoxos. Como veremos, a solução de paradoxos foi um dos atrativos que levaram autores de ficção científica se envolver com a ideia de viagem no tempo. Esse dado pode ser um indicativo que Wells "não sabia como responder a esses quebra-cabeças causados pela viagem no tempo" (NAHIM, 1999, p.55) e demonstra como essa noção ainda estava se desenvolvendo na mentalidade ocidental, criando novas formas de se experimentar e subverter as temporalidades, algo extremamente inovador para uma sociedade como a vitoriana que, em linhas gerais, considerava a noção de viagem no tempo uma afronta (lbid., p.22) dado o absurdo de se propor algo dessa 
natureza. Esse fato pode ajudar a entender a preocupação de Wells em explicar os conceitos que criou para a viagem no tempo.

Figura 09 - Pôster do filme de 1960 de A Máquina do Tempo (The Time Machine), estrelado por Rod Taylor e Yvette Mimieux e dirigido por George Pal. Nesse pôster a máquina do tempo é bem diferente da exibida no filme, substituindo o visual vitoriano icônico da máquina, um trenó com um grande disco simulando um relógio de ponteiros, cadeira vermelha, marcador tricolor e alavanca por algo parecido com um carro americano da década de 50 com tecnologia espacial.

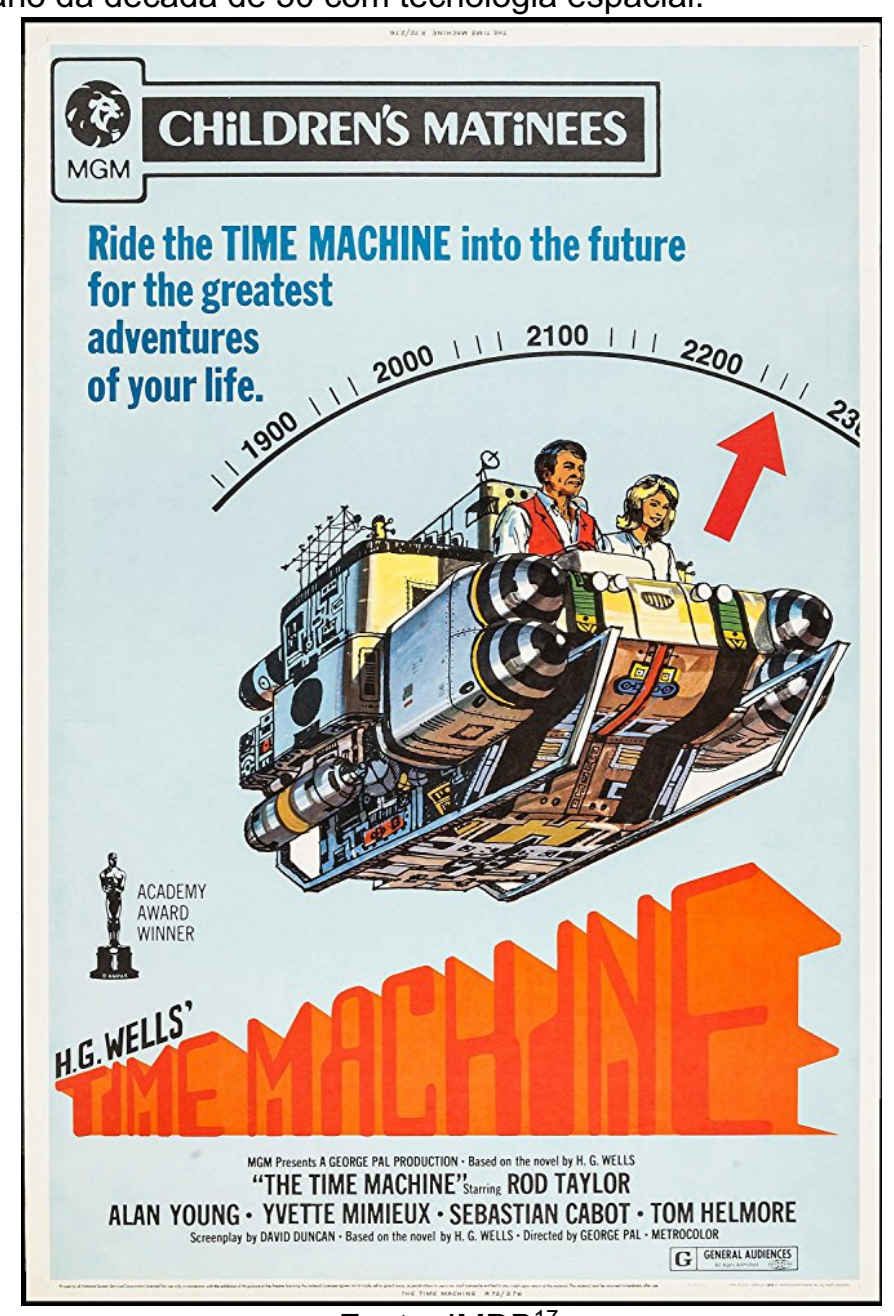

Fonte: IMDB $^{17}$

Pelas razões citadas e as habilidades literárias de H.G. Wells, a obra foi um sucesso imediato, com análise elogiosa publicada até na revista científica Nature (NAHIM, 1999, p.145). Wells não criou e desenvolveu outras histórias com tal engenho, inclusive retornando ao tema gasto do dorminhoco que acorda no futuro em When the Sleeper Wakes (1898) - reescrita em 1910 com novo título, O Dorminhoco (The Sleeper Awakes) - , indicativo que ele próprio não confiava na sua invenção nem

${ }^{17}$ Disponível em: <https://www.imdb.com/title/tt0054387/mediaviewer/rm2879403008>. Acesso em 09 de maio de 2017. 
percebeu o impacto de sua obra, deixando para o século $X X$, nas pulps, o fortalecimento e a exploração da ideia de uma máquina do tempo, com escritores, em linhas gerais, pouco ousados até à década de 20 (EDWARDS; STABLEFORD, 1995, p.1227). O sucesso do livro e a ideia de uma máquina do tempo abriu espaço para uma série de cópias, influenciando até hoje obras que atravessam diversas mídias e inspiram a criatividade de artistas, filósofos e cientistas.

Figura 10 - A viagem no tempo foi explorada e teve seus elementos mais marcantes desenvolvidos em revistas como estas.

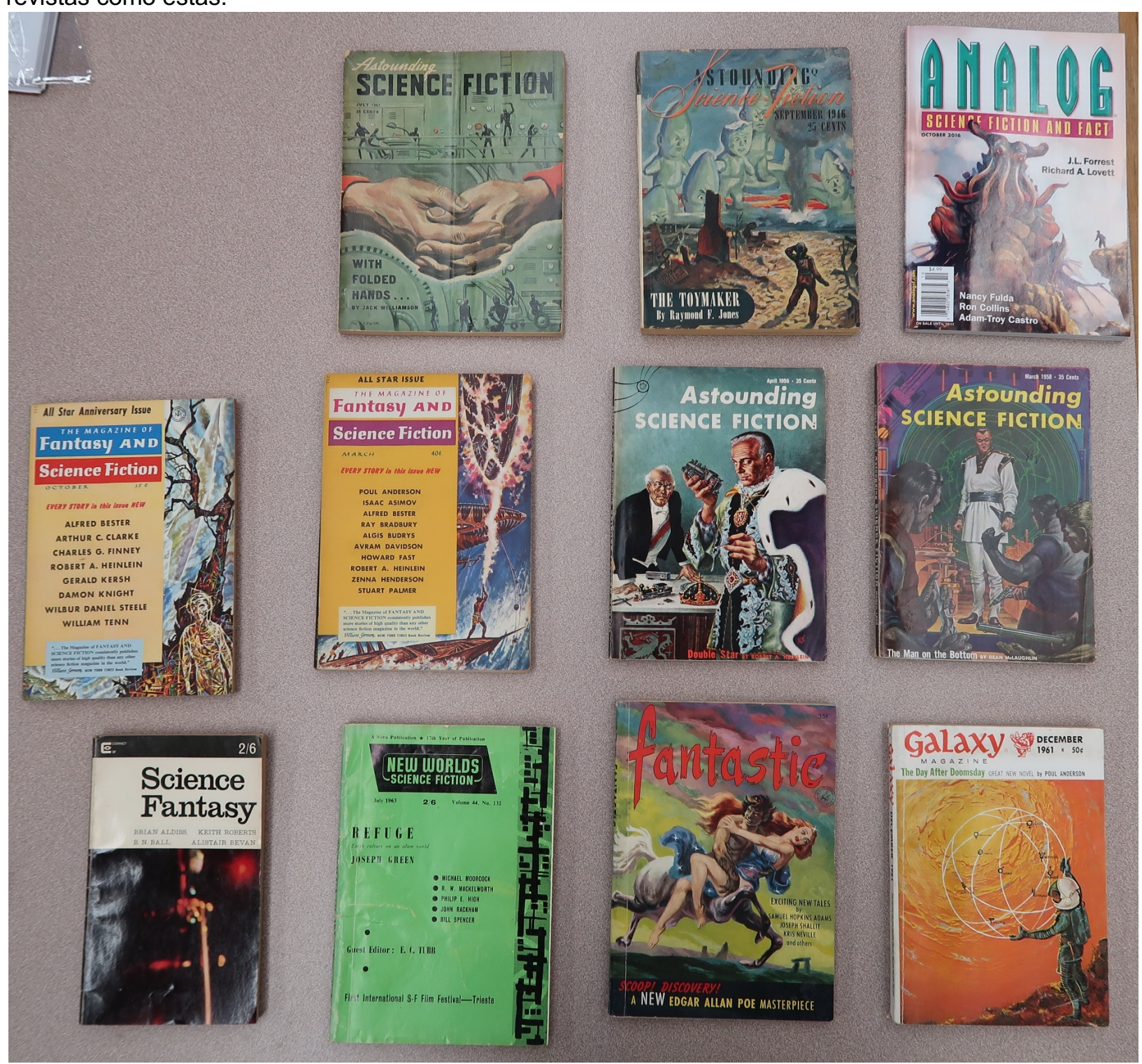

Fonte: fotografia tirada pelo autor (Merril Collection of Science Fiction, Speculation \& Fantasy, Toronto, ON, Canadá, 2016).

Assim como o símbolo Tempo se desenvolve e se adapta, a ideia de subversão do fluxo temporal também compartilha a mesma sina. No caso da relação moderna 
com a mudança, a viagem no tempo não só faz sentido, mas pôde florescer e levantar questões sobre as nossas relações entre presente, passado e futuro, orientando a nossa atuação no tempo. Esses temas estão presentes nas histórias folclóricas e religiosas citadas, não com o mesmo grau e peso da atração moderna por esse tipo de história, por isso podemos identificar essas narrativas como proto-histórias de viagem no tempo, inserindo-as em uma linha do tempo marcada por Antes de Wells e Depois de Wells, mais como facilidade de localizar e representar a temática e indicar o sucesso desse tipo de narrativa do que reforçar o ineditismo de Wells.

Conforme vimos, a afirmação comum da viagem no tempo como fenômeno nascente nas sociedades industriais ocidentais, ou seja, a não existência desse tipo de deslocamento em lendas (RUSSELL, 1995, p.24), é incorreta e deve ser colocada em perspectiva e relativizada. As histórias antes das décadas finais do século XIX devem ser inseridas no conceito de tempo e nas mudanças sociais implícitas nesse símbolo, já que tal viagem, se desenvolvida, opera nas relações com o tempo (mudança) de dada sociedade, indicando qual é o papel social dos tempos e suas relações de localizar e orientar a mudança, tanto individuais quanto coletivas, bem como, nas sociedades industriais, o controle total dos próprios rumos da existência.

\section{4- Uso da viagem no tempo}

Mais que mera fantasia escapista e negadora da realidade, o aparecimento da viagem no tempo representa um mundo no qual esse símbolo é visto cada vez mais como um problema, e mesmo internalizado e sentido como parte da natureza, apresenta-se como algo a ser domado. De forma secular, só a viagem no tempo garantiria alguma forma de controle e imortalidade, visto a capacidade de superação dos limites do pouco tempo da nossa existência individual e a brevidade das instituições sociais em comparação com a idade do universo.

Escritores que lidaram diretamente com o tema, seja escrevendo aventuras, seja organizando coleções, deixaram-nos suas impressões das funções desempenhadas por esse tipo de narrativa nas sociedades atuais, demonstrando autoconsciência paralela e complementar à reflexão acadêmica. Para o roteirista e diretor de cinema Rian Johnson, de Star Wars: Os Últimos Jedi (Star Wars: The Last Jedi, 2017) e Looper: Assassinos do Futuro (Looper, 2012), a viagem no tempo é uma ferramenta narrativa maleável, de uso amplo e as obras podem ser unificadas apenas 
pelo elemento de algum grau de construção de um mundo, ou seja, a exigência de alguma forma de imaginação sobre um mundo futuro, passado e presente a serem criados nessas histórias, porém seus usos são os mais diversos e trazem pouca coisa em comum (JOHSON, 2013, p.X). Essa noção já estava presente bem antes, como expressa pelo escritor Ralf Milne Farley (pseudônimo de Roger Sherman Hoar) em sua coletânea de contos escritos entre 1935 e 1942, publicado em 1950 - The Omnibus of Time, que utilizou livremente as mais variadas teorias sobre o tempo em seus contos, com a preocupação final na lógica interna da narrativa e não em escolher uma das teorias como verdadeira. Nessa obra, o autor que era matemático, até criou um anexo explicando, com suas palavras, os conceitos de tempo de Einstein, H.G. Wells, Riemann, Eddington e da décima primeira edição da Enciclopédia Britânica, grafada incorretamente como "Encylopedia". A proposta do autor ao invocar a viagem no tempo, usando os mais diversos recursos - às vezes até contraditórios -, não é algo incomum e pode ser facilmente encontrada em outros escritores e roteiristas que lidaram com o tema da viagem no tempo, como Robert Silverberg e Rod Serling, para citar dois que produziram obras com esse tema no período estudado. Johnson ainda considera que a viagem no tempo não é algo estranho para nosso cérebro, pois estamos acostumados a pensar no passado e futuro a todo momento e que a viagem no tempo nos permite imaginar ir fisicamente para o passado ou futuro, alertando-nos que a tentativa de se alterar eventos em outras épocas pode não dar certo e que nosso lugar é no presente (Ibid., p.XII) -, seja para aceita-lo e aprender a viver nele, seja como local desejável da mobilização para mudança.

O desenvolvimento de mais de um século desse tipo de aventura, é importante destacar, criou algumas regras de formas verossímeis e aceitas, celeremente reconhecidas pelo público, sobre como se pode dar a viagem no tempo, ou seja, as regras que explicam a viagem no tempo devem ser observadas como parte de uma construção social entre autores e público, articuladas com uma noção de tempo, podendo em graus diferentes ser baseadas ou não em princípios científicos, a gosto de determinada parcela do público a ser atingido, que variavelmente exige ou não mais "realidade" e "ciência" na aventura.

Uma questão a ser abordada é por que diversos autores fizeram e fazem uso da viagem no tempo, o que nesse recurso narrativo atraiu tanto produtores culturais e a atenção do público após o século XIX, em um enredo fantasioso representativo das relações individuais e coletivas com o tempo. De acordo com diversos autores 
atuantes no segundo pós-Guerra, havia a necessidade, mesmo que temporária, de fuga da "armadilha do tempo", como afirmou o escritor Philip Van Doren Stern em prefácio escrito em 1946 e publicado na sua coletânea Travelers in Time (1947), "advinhos e historiadores ganham a vida devido ao irrepreensível desejo da humanidade em conquistar o tempo e fugir do aqui e agora" (STERN, 1947, p.XV): ele próprio, além de escrever e editar obras ficcionais, era um historiador da Guerra Civil americana. Essa ideia da viagem no tempo representar a fuga e o controle do indivíduo sobre o tempo, visto que a maior parte dessas histórias é focada em um único indivíduo (mesmo quando há tropas e "polícias do tempo"), faz parte de uma sociedade na qual se nota um controle e a previsibilidade cada vez maior da natureza. Se o espaço fora conquistado por trens, automóveis, navios, aviões e foguetes, por que razões o tempo, visto como algo externo ao ser humano, não poderia ser domado e controlado, gerando benesses aos capazes de manipulá-lo? Para o escritor Robert Silverberg (1977, p.9), somente a viagem no tempo mostraria o futuro em si, já que os outros temas da ficção científica, com robôs, naves e mutantes, apresentariam apenas fragmentos do porvir.

Já Isaac Asimov, renomado escritor e referência na literatura de ficção científica, reconhecia que os escritores desse gênero, quando sabem que algo é impossível, tomam extremo cuidado em utilizá-lo nas suas histórias, porém não seria o caso da viagem no tempo, uma das poucas exceções à regra para Asimov, pois as situações empolgantes geradas pelos enredos com viagem no tempo atrairiam os autores de ficção científica (ASIMOV, 1981, p.7). O próprio Asimov geralmente criticava a viagem no tempo, mas a criação de "situações empolgantes" com certeza o fez se manter ativo nesse tipo de temática.

Essas posturas representam as duas esferas que se complementam e explicam a criação e recepção desse tipo de histórias pelas sociedades contemporâneas: primeiramente, um desejo do leitor, e do(s) autor(es), de escapar(em) do mundo controlado cada vez mais pelos instrumentos reificadores do tempo e entrar em contato com mundos imaginários do passado ou futuro, mesmo que por um breve momento, e, por fim, reforçam ou atenuam o caráter coercivo do tempo (o passado não pode ser mudado, o futuro é inevitável); em segundo lugar, os elementos criados pela imaginação de uma viagem no tempo atraem escritores dispostos a discutir, resolver ou problematizar os paradoxos causados por esse tipo de viagem, como nos expõe Peter Haining (1997, p.9), prolífico escritor inglês e editor 
da coletânea Timescapes - Stories of Time Travel, ao comentar uma possível forma da pessoa se tornar seu próprio avô sem viagem no tempo (com uma complicada relação de casamentos entre a família), a atração da viagem no tempo para os escritores foi o desafio de lidar com os paradoxos criados por esse tipo de enredo e explorar as novas concepções sobre matéria, tempo e espaço desenvolvidas no final do século XIX e início do XX.

Escritores e suas obras também tentam desfazer nossas noções de causa e efeito, além de explorar as múltiplas linguagens artísticas para representar a mudança de temporalidade em suas criações: aqui, temos desde mudanças no estilo de escrita de uma obra impressa, até alterações estéticas em obras audiovisuais para representar a viagem em si e o período onde o viajante foi parar. Ademais, nessa segunda esfera, o público também espera esses elementos nas aventuras de viagem no tempo. Ou seja, pode-se afirmar que as histórias de viagem no tempo atendem a expectativas sociais e individuais do público e dos autores na reação com o tempo, a exploração do insólito e as experiências na linguagem, como os exemplos acima ilustram, além de que essa temática, em comparação com outras narrativas fantásticas, torna as histórias mais íntimas e pessoais (WESTFAHL, 2002, p.4), já que falam das relações e abstrações que todos experimentamos e compartilhamos.

Um ponto complementar na relação das sociedades e indivíduos com o símbolo Tempo é expresso muitas vezes nesse tipo de obra; o já citado caráter de fuga e negação ou problematização do que é dado está totalmente a par com a concepção que indivíduos e sociedades criam a sua própria História, não havendo um passado e futuro escritos previamente. Inclusive, essa ideia é um clichê muitas vezes expresso por personagens dessas histórias, como em "De Volta Para o Futuro Parte III" (Back to the Future Part III, 1990), onde temos o seguinte diálogo no final do filme, quando Jennifer Parker pergunta ao Dr. Emmett Brown o que significa o fato de um papel que estava escrito um texto, retirado por ela do futuro, estar em branco no presente e recebe como resposta: "Significa que seu futuro ainda não foi escrito. O de ninguém foi. Seu futuro é o que você fizer dele. Então, façam um bom futuro, vocês dois"18.

Podemos encontrar uma variante dessa ideia de se criar o próprio destino, se reinventar e rejeitar a fortuna não só nas obras de viagem no tempo, mas no jogo de

18 Tradução nossa. No original: It means your future hasn't been written yet. No one's has. Your future is whatever you make it. So make it a good one, both of you. 
poker, no qual o jogador pode trocar as cartas recebidas, não aceitando o fado. Não por acaso, segundo o historiador David Schwartz (informação pessoal) ${ }^{19}$, o jogo de poker desenvolvido nos EUA no século XIX incorpora essa tentativa de controle do destino e é um dos símbolos das histórias de velho oeste americano, onde o mito reafirma a conquista do oeste como um local de controle de seu próprio destino e reinvenção, parte do imaginário dos EUA como a terra das oportunidades. A mesma tentativa de controle dos rumos da existência opera na viagem no tempo e talvez seja o principal atrativo moderno para esse tipo de temática em um mundo de mudanças rápidas e imprevisíveis, por melhores que possam parecer os prognósticos de economistas, cientistas e futurólogos de plantão.

\section{5- Água e Metal: a viagem no tempo na Filosofia e na Física}

O mundo acadêmico tem se debruçado sobre a problemática da viagem no tempo, influenciado por uma cultura global moderna que aderiu a esta ideia, pois ela expressa relações significativas com o símbolo Tempo. Entretanto, cada campo do saber aborda o problema por ângulos distintos, sendo os mais significativos os dos filósofos e os físicos, os primeiros tendem a analisar a possibilidade lógica da viagem no tempo e os segundos a possibilidade nas teorias que explicam o funcionamento do universo (EFFINGHAM; 2015, p.20). O filósofo Nikk Effingham (2015, p.20) destaca que o papel do filósofo é fundamental para que o físico não perca tempo analisando ideias ilógicas, pois se algo não passa pelo crivo da lógica filosófica, não é factível pela abordagem científica, ou seja, uma ideia pode ter lógica e ser impossível pelas leis naturais, porém o oposto é impossível.

A filosofia se debruçou na tentativa de explicar se a viagem no tempo é logicamente possível e na resolução dos paradoxos criados por tal viagem. $O$ paradoxo mais famoso e clichê da temática é o chamado "paradoxo do avô": um viajante volta ao passado e mata seu avô antes dele ter conhecido sua avó, impedindo então o seu próprio nascimento. As formas de se escapar desse paradoxo variam da ideia de que na verdade o avô do viajante do tempo não seria o avô real, ele teria matado ou alguém parecido ou sua linhagem não descendia daquele homem; da

\footnotetext{
${ }^{19}$ Vídeo comissionado especialmente para o The Mob Museum, em Las Vegas. Informação recebida de Claire White, Educational Programs Manager, em 9 de Agosto de 2017.
} 
noção de que algo no momento impediria o viajante de matar o avô, a arma falharia, alguém impediria, etc.; da existência de diversos universos, o multiverso, e ao matar o avô, o viajante teria criado um novo universo onde ele não existiria, mas que não seria o seu universo de origem. Outros paradoxos interessantes, que podem ser gerados pela viagem no tempo, são a criação de seres e eventos que são sua própria causa e efeito, como a história final sobre esse tema escrita por Robert A. Heinlein, All you Zombies - (1959), ou a existência de objetos ou dados que existem sem sermos capazes de determinar quem os criou, exemplificado no conto também de Heinlein, By His Bootstraps (1941).

No campo da Física, nas primeiras décadas do século $X X$, estava prevista a ideia de viagem no tempo ao futuro, pois na Teoria da Relatividade Restrita ou Teoria Especial da Relatividade de Einstein, de 1905, e na Teoria da Relatividade Geral, de 1915, existe a ideia da dilatação do tempo, que prega que os intervalos de tempo marcados por um observador em repouso são maiores que os intervalos de tempo marcados por um observador em movimento com velocidade próxima à da luz (a velocidade da luz é impossível de ser superada). O tempo correria de formas distintas também em campos gravitacionais; além disso, um viajante que fosse exposto a velocidades próximas à luz veria seu relógio mostrar horas enquanto para os que não foram expostos a mesma velocidade se passariam décadas, essa, inclusive, é a premissa do filme O Planeta dos Macacos (Planet of the Apes, 1968). Ou seja, teoricamente, pode-se viajar para o futuro, mesmo que a nossa tecnologia atual não permita tal viagem da mesma forma das obras ficcionais, ela é viável e ocorre na natureza.

O problema principal para uma explicação com base na ciência estaria na viagem ao passado, por isso também a atenção dada a esse tipo de viagem pelos filósofos que costumam analisar a lógica dessa proposição, principalmente a geração de paradoxos. Já na Física, pode-se encontrar formas de viagem ao passado, como a famosa solução para a equação de campo de Einstein, realizada pelo matemático Kurt Friedrich Gödel em 1949, que apresentava um universo onde existiriam curvas temporais fechadas (CTC - closed timelike curve), implicando que seria possível a volta ao passado, pelo menos na teoria, se o universo se comportar como a descrição de Gödel, ou outros modelos que permitam a formação e/ou manutenção de curvas temporais fechadas. As questões da formação de paradoxos e da transmissão de 
informação ao passado na presença de uma CTC também são exploradas pelos físicos.

Cabe lembrar que dependendo da proposta de viagem no tempo, a quantidade de energia e tecnologia para realizar algo dessa monta, e sem considerarmos a transposição no tempo de um ser vivo que assim permanecesse durante a viagem, a alteração de leis da Física, criação de buracos de minhoca (Ponte de Einstein-Rosen ou wormholes), velocidades mais rápidas que a luz, tornam esse tema um tabu dentro da Física, como relata o físico brasileiro Marcelo Novello (2005, p.21). Geralmente, as extrapolações de leis da Física que permitem a viagem no tempo são encontradas, vulgarizadas e popularizadas pelas obras de ficção científica, realizadas, inspiradas ou sob supervisão de cientistas, como o filme de Christopher Nolan, Interestelar (Interstellar, 2014), inspirado na obra de Kip Thorne, teve o próprio físico, ganhador do Nobel em 2017 como consultor científico e produtor executivo. As obras ficcionais pautaram tanto a temática que o próprio físico Marcelo Novello relata em seu livro um caso anedótico no qual fora procurado por um homem que queria alguma forma de contato com seu pai no passado, pois ele falecera sem contar onde tinha deixado um cofre com bens (NOVELLO, 2005, p.28-29) - uma versão ficção científica para os casos de familiares que buscam um contato sobrenatural com parentes mortos com a mesma intenção.

Stephen Hawking, em seu famoso artigo sobre a impossibilidade das leis da Física permitirem a viagem no tempo ao passado - o que ele chamou de "Conjectura de proteção cronológica"-, "Chronology protection conjecture" (HAWKING, 1992, p.603-610; 2005, p.110), fez referência direta à ficção científica ao afirmar, na introdução de seu texto, que "Parece que há uma agência de proteção cronológica que evita o aparecimento de curvas temporais fechadas, tornando então o universo seguro para os historiadores"20 (Id., 1992,p.603, tradução nossa), fazendo alusão direta à ideia difundida na ficção científica de viagem no tempo de alguma organização que zela pela manutenção da ordem no tempo. Após apresentar uma série de fórmulas e teorias da física relativística e quântica, concluiu seu texto: "Também há

\footnotetext{
20 No original: "It seems that there is a chronology protection agency which prevents the appearance of closed timelike curves and so makes the universe safe for historians".
} 
uma forte evidência experimental favorável à conjectura devido ao fato de que não fomos invadidos por hordas de turistas do futuro" (Ibid., p.610, tradução nossa). ${ }^{21}$

\section{6- Fluxos}

Na observação de qualquer história de viagem no tempo, deve-se ter em conta qual é a forma proposta de deslocamento, mesmo que não seja apresentada nenhuma diretamente, pois a forma de viagem no tempo demonstra não só em qual gênero podemos inserir determinada obra, como alguns podem apressadamente pensar, mas sim qual é a noção de tempo, controle humano da vida e da natureza, progresso, ciência e tecnologia que a obra nos apresenta, contrapondo com aquilo a que somos expostos durante da viagem.

Em linhas gerais, como citado anteriormente, o desenvolvimento de mais de cem anos de narrativas com viagem no tempo deu origem a um repertório e à elaboração de regras gerais de como a viagem no tempo funciona, esses padrões foram definidos na relação entre obras e público, sendo que é característica do público de ficção científica exigir alguma regra de viagem no tempo embasada na extrapolação ou em princípios de base científica (JOHNSON, 2013, p.X).

Portanto, em cada obra, as regras que explicam o deslocamento no tempo, apresentadas mais ou menos diretamente ou implícitas, são originárias de uma tradição narrativa, desempenhando função escolhida pelo autor. A forma de viagem no tempo e a viagem em si devem ser entendidas como parte do discurso apresentado pela narrativa: um mesmo artefato pode significar ideias e ter funções totalmente distintas a depender da obra, mesmo funcionando da mesma forma e com base nos mesmos princípios; por exemplo, o já citado DeLorean DMC-12, o carro de aspecto futurista já obsoleto em 1985, ironicamente popularizado como a icônica máquina do tempo do filme De Volta Para o Futuro (o carro foi fabricado entre 1980 e 1983), representa, dentre outras coisas, a promessa de um futuro falido; já na história em quadrinhos True History of Superman and Batman (HAMILTON, 1956), somos apresentados a uma máquina do tempo em forma de trono dourado reforçando a

\footnotetext{
${ }^{21}$ No original: "There is also strong experimental evidence in favor of the conjecture from the fact that we have not been invaded by hordes of tourists from the future".
} 
autoridade do futuro, o mito do progresso com aspectos associados à divindade, à riqueza e ao poder.

Os propósitos da viagem, o sentido - passado ou futuro- , as formas de se deslocar e a explicação das regras da viagem que podemos assimilar da obra devem ser observados como parte de uma conversa com outras histórias e o repertório do público, representando problemas que a obra quer apresentar ou discutir com as temporalidades e as experiências humanas, individuais e sociais, bem como criatividade do(s) autor(es) em apresentar a ideia de forma verossímil, sem deixar de lado o significado dentro da narrativa, o recurso de se recorrer à viagem no tempo, para contar uma história.

Um elemento que podemos considerar unificador em todas aventuras que apresentam alguma forma de viagem no tempo é o peso do presente, ele serve de referencial não só da narrativa, mas também da experiência de dado indivíduo ou sociedade que entra em contato com uma obra dessa temática, pois a leitura da viagem no tempo é sempre feita na relação e reflexão dos múltiplos presentes - o presente do autor, o presente do leitor, o presente da diegese - com a temporalidade para a qual o viajante se desloca.

Logo, a viagem no tempo, mais que uma especulação sobre o futuro e o passado, ou imaginação de como poderíamos mudar nossa vida individual e coletiva, é principalmente sobre como nos relacionamos com o presente. Não é por acaso que em grande parte das histórias, o problema principal da viagem no tempo é corrigir alguma alteração intencional ou não que destruirá o presente. A subversão do fluxo do tempo nessas aventuras é usualmente parcial e serve como válvula de escape das relações modernas com a mudança e o mito do progresso, pois se temos uma lição de moral generalizada em grande parte dessas narrativas é a de que nosso lugar é o presente, como já apresentado no comentário de Rian Johnson. A alienação do presente, uma fuga do presente ou controle do tempo (mudança) não termina bem. Não é a toa que Paul Nahim (1999, p.4) identifica, corretamente, que na maior parte das histórias de viagem no tempo que tentam alterar o passado, o modus operandi é uma versão atualizada do tema do folclore dos três desejos, no qual alguém recebe três desejos de uma entidade mágica e acaba utilizando o último desejo para desfazer os efeitos não intencionais danosos dos dois primeiros; temática presente por exemplo, no conto sobrenatural A Pata do Macaco (The Monkey's Paw, 1902), de W. W. Jacobs, e o episódio da segunda temporada de Além da Imaginação The Man in 
the Bottle (O Homem na Garrafa, em tradução livre), escrito por Rod Serling em 1960. Ambas histórias são releituras contemporâneas do conto de fadas cujo modelo pode ser encontrado em obras com viagem no tempo.

$\mathrm{Na}$ narrativa de viagem no tempo, tão importante quanto identificar os rumos da viagem (passado ou futuro), ou qual o conceito de tempo empregado (social, natural, histórico ou todos esses), é notar como são apresentadas as estruturas temporais. George Slusser e Robert Heath (2002, p.13) nos fornecem três modelos básicos para se pensar essa questão: o primeiro seria o "modelo A Máquina do Tempo", em referência ao universo fechado da obra de Wells; nesse modelo, podese mover pelo tempo, porém nada pode ser alterado; o segundo, "o modelo O Som do Trovão", em referência ao universo apresentado pelo conto homônimo de Bradbury, nesse modelo o tempo se divide em ramos, ao se alterar algo o viajante se desloca para outra linha do tempo afetada pela mudança, geralmente ocorre na viagem ao passado; por fim, o "modelo solipsista", um universo onde não só os eventos acontecem apenas para o viajante, a própria noção de passagem do tempo é individual, esse último modelo é o mais recentemente explorado por autores.

Outro tema que também aparece em graus diversos, mesmo que implicitamente, nas histórias de viagem no tempo, é a discussão do fatalismo versus livre-arbítrio. Em linhas gerais, as narrativas permitem ou não a alteração do fluxo temporal - vide os modelos apresentados por Slusser e Heath acima -, se não permitem termos um universo fatalista, como, por exemplo, na versão de Além da Imaginação (The Twilight Zone) da década de 80, o episódio "O Único e Eterno Rei" (The Once and Future King, 1986), escrito por George R.R. Martin, no qual a identidade real de Elvis Presley é colocada em dúvida em uma história em que um cover e fã do Elvis volta no tempo e acaba matando o Elvis real, ocupando seu lugar em uma história circular, no qual se pressupõe, ao final, que o cover fã de Elvis nunca foi fã do Elvis real mas sim de si mesmo, comportando-se como sabia que tinha sido a vida do cantor e ator. Exemplos de livre-arbítrio, ou universos que permitem alterações, podem ser vistos nos casos já citados de "De Volta para o Futuro" e o famoso conto de Ray Bradbury, "O Som do Trovão" (The Sound of Thunder, 1952), onde um covarde caçador viaja ao período Cretáceo para matar um tiranossauro e ao fugir do animal, pisa em uma borboleta, alterando todo desenvolvimento evolutivo da Terra, resultando no seu presente na eleição de um presidente fascista e na mudança gramatical da língua inglesa, o que nos leva a imaginar que muito mais coisas teriam 
se alterado devido à morte da borboleta, só não somos apresentados a elas, pois o conto termina com a morte do caçador amador por um irritado guia de caça. Podemos encontrar uma síntese das duas visões em algumas histórias, onde existem fatos que podem ser mudados (fatos que atingem um ou um pequeno núcleo de indivíduos) e outros que são fixos (fatos que implicam grandes transformações coletivas), como podemos ver na adaptação do livro de Stephen King, Novembro de 63 (11/22/63, 2011), em minissérie homônima estrelada e produzida por James Franco em 2016.

Uma sátira aos problemas comuns das histórias de viagem no tempo, fatalismo ou livre arbítrio, e a criação de paradoxos está presente no segundo volume da série de Douglas Adams "Guia do Mochileiro das Galáxias", o livro "O Restaurante no Fim do Universo" (The Restaurant at the End of the Universe, 1980), mostra de forma paradigmática que tudo que pode ser mudado já foi alterado e não devemos nos preocupar com isso:

Um dos maiores problemas encontrados em viajar no tempo não é vir a se tornar acidentalmente seu pai ou sua mãe. Não há nenhum problema em tornar-se seu próprio pai ou mãe com que uma família de mente aberta e bem ajustada não possa lidar. Também não há nenhum problema em relação a mudar o curso da história - o curso da história não muda porque todas as peças se juntam como num quebra-cabeça. Todas as mudanças importantes já ocorreram antes das coisas que deveriam mudar e tudo se resolve no final. (2016, p.184)

\section{7- Categorias e sentidos da viagem no tempo}

A viagem no tempo, seja ao passado ou ao futuro, pode ser inserida em determinadas categorias, segundo David A. Leiby (1987, p.107), encontramos

histórias que usam o tempo como análogo do espaço; histórias que
especulam a natureza do tempo; histórias que especulam o fim do
homem; histórias que engajam o leitor a se enterrar em paradoxos;
histórias que especulam a casualidade ao introduzir ciclos temporais
fechados [ing: loops] e mundos alternativos; e histórias que parecem estar
preocupadas em fornecer passeios históricos.

Todavia, cabe lembrar que essas categorias não são estanques e servem mais como formas de nos fazer refletir sobre o foco principal da viagem no tempo apresentada por determinada narrativa, orientando a sua interpretação e função, visto que determinadas histórias podem, e isso é o comum, ser inseridas em uma ou mais dessas categorias. A organização da temática da viagem no tempo pode variar, permitindo a separação das narrativas por forma de descolamento, pela presença de 
máquina, pela motivação da viagem (acidental ou intencional), pela ligação com outros gêneros estabelecidos, etc., de acordo com o que se deseja observar.

Ampliando o apresentado por Leiby, os acadêmicos ingleses Matthew Jones e Joan Ormord (2015, p.6-7) sistematizaram as formas mais usuais de viagem no tempo encontradas em textos de mídia em uma tabela que nos permite notar a enorme variedade com a qual o tema se apresenta. Eles estruturaram as narrativas em tema, tipo e catalizador, dando exemplos de filmes, séries, livros e jogos de videogame de cada tipo apresentado. Cabe lembrar que podemos encontrar outras formas não apresentadas nessa tabela de viagem no tempo e a pretensão dos autores é exemplificar obras a que geralmente somos expostos em qualquer forma de mídia; além disso, algumas obras transitam por uma ou mais categorias. Porém a tabela abaixo abrange todas as obras que serão apresentadas na série "Além da Imaginação", que se encaixam perfeitamente nesses exemplos, servindo de norte ao ser capaz de muitas vezes indicar qual era o problema invocado e discutido ao se recorrer à viagem no tempo.

TABELA I - Algumas das várias formas de viagem no tempo em textos de mídia. Reproduzido e traduzido para o português com autorização dos autores. Os títulos de jogos eletrônicos foram deixados em inglês.

\begin{tabular}{|l|l|l|l|}
\hline \multicolumn{1}{|c|}{ Tema } & \multicolumn{1}{c|}{ Tipo } & \multicolumn{1}{c|}{ Catalisador } & \multicolumn{1}{c|}{ Exemplos } \\
\hline Biológico & Hereditariedade & Genes & $\begin{array}{l}\text { Questão de Tempo } \\
\text { Te Amarei para } \\
\text { Sempre }\end{array}$ \\
\hline Biológico & Mutação & Genes & $\begin{array}{l}\text { X-Men: Dias de um } \\
\text { Futuro Esquecido }\end{array}$ \\
\hline Biológico & Loop temporal & $\begin{array}{l}\text { Sangue } \\
\text { alienígena }\end{array}$ & No Limite do Amanhã \\
\hline Enigmático & Carma & Má conduta & Feitiço do Tempo \\
\hline Enigmático & Amor & Caixa de correio & A Casa do Lago \\
\hline Enigmático & Não-explicado & Não-explicado & $\begin{array}{l}\text { De Caso com o Acaso } \\
\text { Meia-Noite em Paris }\end{array}$ \\
\hline Mente & Meditação & Hipnose & $\begin{array}{l}\text { Em Algum Lugar do } \\
\text { Passado }\end{array}$ \\
\hline Mente & Memória & Diários & Efeito Borboleta \\
\hline
\end{tabular}




\begin{tabular}{|c|c|c|c|}
\hline Tema & Tipo & Catalisador & Exemplos \\
\hline Mente/Tecnologia & Memória & $\begin{array}{l}\text { Aparelho } \\
\text { experimental }\end{array}$ & A Pista \\
\hline Mundo Natural & $\begin{array}{l}\text { Fratura no } \\
\text { Espaço-tempo }\end{array}$ & Aurora boreal & Fenda No Tempo \\
\hline Mundo Natural & Clima & Tempestade & $\begin{array}{l}\text { Nimitz - De Volta ao } \\
\text { Inferno }\end{array}$ \\
\hline Sobrenatural & Mágica & $\begin{array}{l}\text { Punhal/Areia do } \\
\text { tempo }\end{array}$ & $\begin{array}{l}\text { Príncipe da Pérsia: As } \\
\text { Areias do Tempo }\end{array}$ \\
\hline Sobrenatural & Mágica & Feitiço & $\begin{array}{l}\text { Os Visitantes: Eles } \\
\text { Não Nasceram } \\
\text { Ontem! }\end{array}$ \\
\hline Sobrenatural & Música & $\begin{array}{l}\text { Instrumento } \\
\text { mágico }\end{array}$ & $\begin{array}{l}\text { The Legend of Zelda: } \\
\text { Ocarina of Time }\end{array}$ \\
\hline Sobrenatural & Paranormal & Fantasmas & $\begin{array}{l}\text { O Retrato de Jennie, } \\
\text { Houve uma Vez um } \\
\text { Milagre, O Jardim da } \\
\text { Meia-Noite }\end{array}$ \\
\hline Tecnologia & Invenção & $\begin{array}{l}\text { Máquina do } \\
\text { Tempo }\end{array}$ & $\begin{array}{l}\text { A Máquina do Tempo, } \\
\text { Command \& Conquer: } \\
\text { Red Alert }\end{array}$ \\
\hline Tecnologia & Lazer & $\begin{array}{l}\text { Banheira de } \\
\text { hidromassagem }\end{array}$ & A Ressaca \\
\hline Tecnologia & Mídia & Controle Remoto & $\begin{array}{l}\text { A Vida em Preto E } \\
\text { Branco, Click }\end{array}$ \\
\hline Tecnologia & Telecomunicações & Rádio & Alta Frequência \\
\hline Tecnologia & Telecomunicações & Cabine telefônica & $\begin{array}{l}\text { Doctor Who, Bill \& } \\
\text { Ted - Uma Aventura } \\
\text { Fantástica }\end{array}$ \\
\hline Tecnologia & Loop temporal & $\begin{array}{l}\text { Aparelho } \\
\text { experimental }\end{array}$ & Contra o Tempo \\
\hline Tecnologia & Transporte & $\begin{array}{l}\text { Máquina do } \\
\text { tempo alienígena }\end{array}$ & Doctor Who \\
\hline Tecnologia & Transporte & Carro & De Volta Para o Futuro \\
\hline Tecnologia & Transporte & Trenó & $\begin{array}{l}\text { A Máquina do Tempo } \\
\text { (1960) }\end{array}$ \\
\hline
\end{tabular}




\begin{tabular}{|l|l|l|l|}
\hline \multicolumn{1}{|c|}{ Tema } & \multicolumn{1}{|c|}{ Tipo } & \multicolumn{1}{c|}{ Catalisador } & \multicolumn{1}{c|}{ Exemplos } \\
\hline Tecnologia & Transporte & Nave espacial & Jornada nas Estrelas \\
\hline Tecnologia & Transporte & Trem & $\begin{array}{l}\text { De Volta Para o Futuro } \\
\text { Parte III }\end{array}$ \\
\hline Tecnologia & Realidade Virtual & $\begin{array}{l}\text { Mundos } \\
\text { simulados }\end{array}$ & $13^{\circ}$ Andar \\
\hline Tecnologia & Identidade virtual & $\begin{array}{l}\text { Interface no } \\
\text { computador }\end{array}$ & Lucy \\
\hline
\end{tabular}

Fonte: (JONES; ORMORD, 2015, p.6-7)

Por mais categorias que possamos criar para organizar e ponderar sobre mais de cem anos desse tipo de história e o fator do peso dos vários presentes como importantes na relação público e obra, a viagem no tempo pode se dirigir sempre a dois sentidos da nossa experiência com o tempo: ao passado e ao futuro. Não importa, em última instância, se o presente ou passado apresentados são mais embasados na experiência histórica de dada sociedade ou puramente alternativos-especulativos, ou se o futuro apresentado tem muito a marca de determinada época, um futuro do passado. De forma direta, a viagem no tempo só pode transportar o viajante para o futuro ou o passado, sempre vistos do ponto de vista do indivíduo ou grupo que se deslocou, ou seja, uma viagem de um ente futuro ao presente é uma viagem ao passado e de um ente passado ao presente é uma viagem ao futuro. Ademais, as funções de cada temporalidade na discussão do presente são distintas, e por mais que um ou mais viajantes se desloquem do futuro ao passado ou do passado ao futuro (como o caso da série fílmica De Volta para o Futuro), o tempo de origem e destino desempenha um papel do que quer se discutir sobre o presente. Não só isso, como veremos adiante, os episódios da série Além da Imaginação que apresentam viagens no tempo mostram de forma paradigmática as diferentes relações com o tempo realizadas pela humanidade quando se apresenta uma viagem ao futuro ou ao passado; são esses dois destinos, que evocam outros propósitos narrativos encontrados na série.

Outra questão que devemos ter em conta é a das múltiplas relações com o tempo as quais podemos encontrar nas aventuras de viagem no tempo: cíclico, progressivo, fechado, simultâneo. Porém, o sentido da viagem é sempre para o antes ou para o depois, utilizando personagens como referenciais delimitadores para 
estabelecer essa alteração temporal, pois para um personagem, o deslocamento pode ser para o passado enquanto para outro o deslocamento se dá para o futuro, tudo isso ocorrendo na mesma história! Por exemplo, em Bill \& Ted - Uma Aventura Fantástica (Bill \& Ted's Excellent Adventure, 1989), os dois heróis são levados de 1988 a 1805 por Rufus, um agente de 2688. No passado, encontram Napoleão Bonaparte na Áustria e o levam para 1988; para Napoleão, ele fez uma viagem ao futuro, para Rufus todo filme se passa no passado; e para Bill e Ted, eles levam os personagens históricos do passado para o presente. Como o foco da obra é Bill e Ted, as relações temporais se dão com o presente servindo de ponto de referência para relações com o passado (antes) e o futuro (depois), demonstrando o cuidado que se deve ter em determinar a priori o sentido de uma viagem no tempo, visto que, por definição, como já expresso, o sentido da viagem passa a representar funções distintas na narrativa.

Cabe destacar que uma determinada obra pode escapar do modelo geral que será apresentado, geralmente de forma irônica, na tentativa de homenagear ou descontruir um tropo narrativo, o que não é o caso dos episódios de Além da Imaginação. Entretanto, a discussão das diferentes especificidades e concepções exploradas por uma viagem no tempo ao futuro ou ao passado serve como pano de fundo para se refletir sobre o que poderá ser encontrado em uma história de viagem no tempo.

\section{8- Sonhos sobre o futuro}

As histórias de viagem no tempo com destino ao futuro tendem a explorar um tempo no qual conflitos, instituições, problemas ou potencialidades do presente já se encontram realizados, "um lugar onde seu mundo presente [do viajante do tempo] tornou-se completamente realizado" (CLUTE, 1994, p.643). Ela evoca a relação entre passado e presente com o futuro para gerar um efeito no público, que irá comparar e se relacionar com o viajante, por vezes sentindo o deslocamento e alienação, por vezes se maravilhando e se assustando com o que pode ser apresentado. Assim como histórias que se passam diretamente no futuro, muitas vezes, a viagem ao futuro será usada para fins didáticos não só dos campos éticos-morais, mas também de conceitos científicos.

A viagem ao futuro em si é uma aceleração da experiência habitual com o tempo, já que ao marcar as mudanças, seja no campo natural ou social, comparamos 
um estado anterior com um posterior, cuja reificação pode ser encontrada na passagem dos segundos de um relógio- não por acaso um objeto, especialmente sua versão com ponteiros e pêndulos, utilizado à exaustão na descrição visual da viagem no tempo. Esse sentido da viagem, em teoria, não viola de forma radical nossa experiência com o tempo, apenas a antecipa.

Segundo John Clute (Ibid., p.643), as histórias de viagem no tempo ao futuro se passam em três campos: o futuro próximo, o futuro médio e o futuro distante. Cada um desses futuros, quando invocado por um ou mais autores de obras de viagem no tempo, desempenha funções distintas na narrativa e pode ser mapeado da forma como comumente pode ser encontrado.

O futuro próximo serve, de forma genérica, para discutir o enfrentamento do viajante com a sua própria mortalidade: um exemplo paradigmático é a viagem ao futuro realizada por Ebenezer Scrooge, no livro de Dickens Um Conto de Natal (1843). Na obra, o Fantasma do Natal Futuro transporta Scrooge para ver os efeitos de sua ação no mundo, o fantasma silencioso leva o velho a ver o desprezo que seus semelhantes teriam por ele após sua morte, caso ele não mudasse seu comportamento egoísta e mesquinho. O fantasma não só mostra a lápide do velho sovina, mas também é descrito com a aparência da própria morte, de manto negro. Portanto, pode-se notar que esse tipo de história tem uma valorização da experiência individual com o tempo e mesmo que se apresente um futuro socialmente, institucionalmente ou tecnologicamente muito distinto, não se sobrepõe à reflexão sobre o papel do indivíduo no futuro. Esse futuro próximo não costuma ser muito comum nas aventuras de viagem no tempo (CLUTE, 1994, p.645) pois os autores conseguem explorar essas questões relacionadas com a efemeridade da vida e a reavaliação comportamental utilizando histórias que se passam no próprio presente ou diretamente no futuro próximo, sem precisar servir-se do artifício de transporte ao futuro.

Já o futuro médio é o local onde o nosso presente estaria realizado e resolvido (Ibid., p.645), ele reforça a comparação feita diretamente com o que pode ser notado no presente, lá se constatam os efeitos diretos de ideias, ideologias, propostas, fatos e ações. Um exemplo desse futuro médio pode ser encontrado na comédia de ficção científica O Dorminhoco (Sleeper, 1973), dirigida, escrita e estrelada por Woody Allen. Nessa comédia, um dono de loja de comida saudável falece durante uma cirurgia e seu corpo passa por um processo de criogenização, sendo revivido, para sua 
surpresa, duzentos anos depois por rebeldes que lutam contra um governo totalitário num mundo distópico. O filme apresenta uma visão cética sobre o desenvolvimento, noções de progresso, modismo alimentício, grupos políticos, etc., estabelecendo bem o distanciamento que coloca o personagem de Allen como um ser deslocado em uma nova sociedade, tentando entendê-la com a sabedoria do século $X X$. O futuro médio não costuma ser o objetivo de uma viagem no tempo (lbid., p.645): além disso, a maior parte das histórias que se passam no futuro, sem o uso de máquina do tempo, ocorrem no futuro médio, o que torna redundante o recurso daquele instrumento quando já se pode criar um enredo que se passa no futuro com seres do futuro, cumprindo a mesma função sem ter que recorrer à viagem no tempo, um elemento de potencial problemático, principalmente na explicação e criação de verossimilhança. Entretanto, deve-se atentar quando a viagem no tempo aparece no tempo médio; nesse caso, há alguma forma de tentativa de apresentar um ente presente em um futuro deslocado, reforçando o pensamento histórico e a contraposição entre alguma visão presente em um futuro.

Figura 11 - O sovina Scrooge (Reginald Owen, a esquerda) é levado ao futuro próximo pelo Fantasma do Natal Futuro, retratado como a Morte. Cena do filme da MGM, Noite de Natal (A Christmas Carol, 1938), dirigido por Edwin L. Marin.

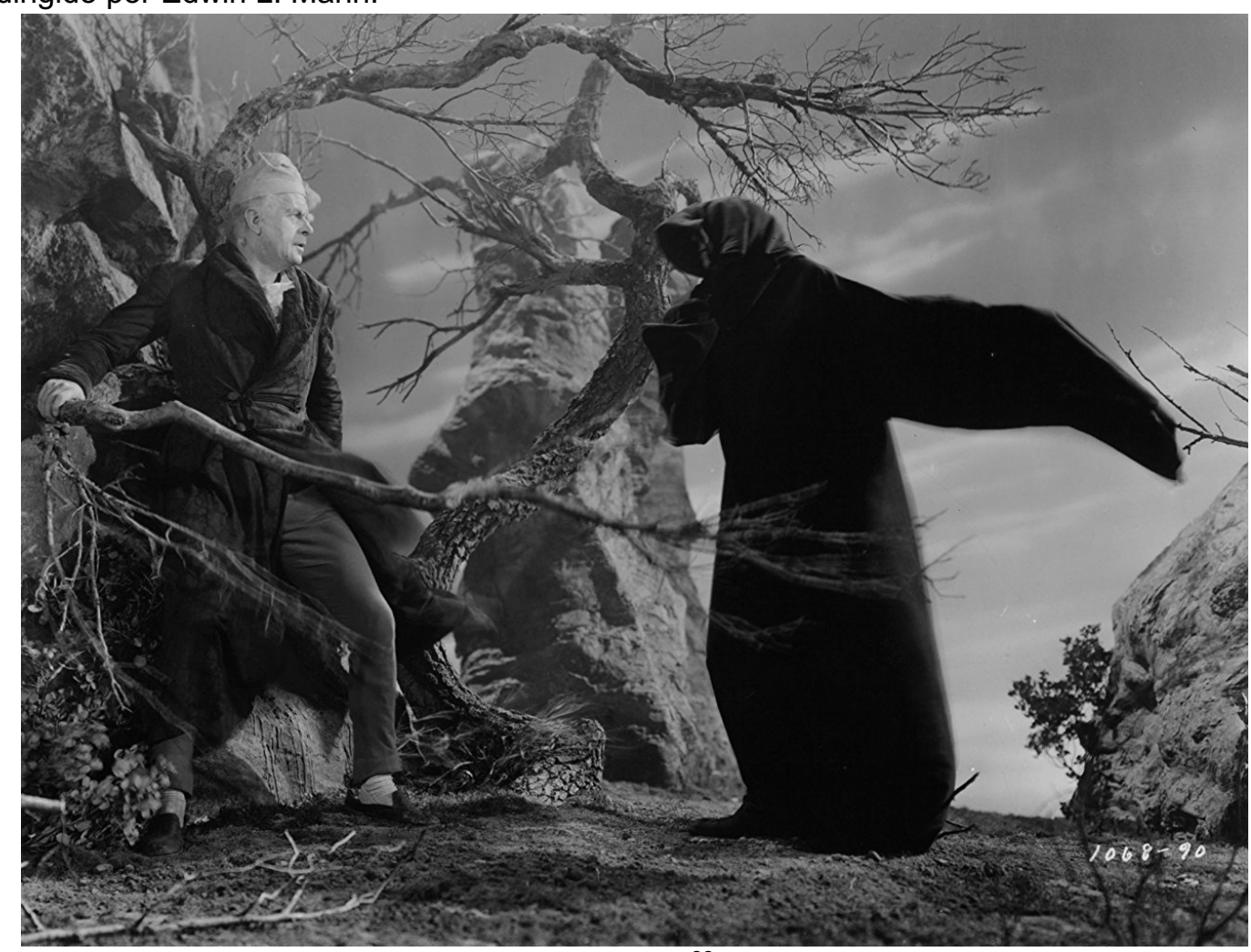

Fonte: IMDB22

22 http://www.imdb.com/title/tt0029992/?ref_=nv_sr_1 
Por último, temos o futuro distante: nessa temporalidade, encontra-se o fim do tempo, geralmente apresentado de forma melancólica, reforçando ao mesmo tempo a tentativa humana de encontrar alguma forma de imortalidade no domínio completo do tempo e uma melancolia pelo fim de tudo. O exemplo citado na epígrafe deste capítulo, a referência ao livro segundo da série O Guia do Mochileiro das Galáxias, é paradigmático da viagem no tempo ao futuro distante, no qual se fecha a história. A apresentação de um futuro distante é um dos temas desenvolvidos no livro A Máquina do Tempo, no décimo primeiro capítulo, onde o viajante presencia o fim melancólico de tudo, relata a visão de um sol avermelhado agigantado, seguido de uma escuridão eterna em um planeta Terra cansado e estático. O viajanta descreve o que vê:

[...]É difícil dar uma ideia da imobilidade daquele ambiente. Todos os sons humanos, os balidos de ovelhas, o canto dos pássaros, o zumbido dos insetos, toda a agitação que percebemos ao fundo durante toda a nossas vidas - tudo se extinguira. A escuridão foi se tornando mais densa, e os flocos de neve mais abundantes, dançando diante dos meus olhos; e o ar foi ficando mais gelado. Por fim, de um em um, em rápida sucessão, os cumes brancos das colinas distantes foram sendo absorvidos pelas trevas. A brisa se encorpou num vento lamentoso. Vi a sombra central do eclipse deslizando sobre o solo na minha direção. Um instante depois, apenas as estrelas pálidas no alto ficaram visíveis. Tudo o mais era uma obscuridade sem nenhum raio de luz. O céu era de um negror total. (WELLS, 2010, p.128)

O futuro distante, segundo Clute (1994, p.645), na ficção científica genérica do século $X X$, passa a significar um retorno ao útero. Nessa perspectiva, notamos a ligação da viagem ao futuro distante com outro subtema, associado à escatologia secular, da Terra Moribunda (Daying Earth), criação de um futuro no qual o autor explora um mundo ficcional afetado pelo fim do tempo ou da vida no planeta (não necessariamente a Terra) causado por efeitos das leis naturais, esgotamento de recursos, efeitos de tecnologias, etc.

Essas divisões de futuros em próximo, médio e distante não necessariamente podem ser definidas apenas pela apresentação de uma cronologia mesurável por números e calendários, por exemplo. A distinção de um futuro entre próximo, médio e distante é dependente de como a viagem ao futuro e o futuro encontrado são expostos na história e servem mais para identificar e pensar sobre os principais temas apresentados quando temos contato com uma narrativa de viagem ao futuro.

Esses três campos futuros podem ser vistos como um futuro individual: o próximo; o futuro social: o médio; e, por fim, o futuro distante: o tempo da natureza. Assim, pode se estabelecer um paralelo com a proposta de interpretação das durações/temporalidades de Fernand Braudel (BRAUDEL, 1986, p.7-39) para se 
pensar o passado. Essa proposta não é relacionada pelo historiador com as narrativas de viagem no tempo, mas sim o campo de percepção das mudanças e do trabalho dos cientistas que lidam com o tempo; entretanto, a reflexão sobre tempo demarcado em durações com propósitos distintos está presente nas obras ficcionais que lidam diretamente com o problema do tempo e nossas múltiplas experiências e relações com esse símbolo, já que cada duração engloba o que é de mais interessante ser explorado ao se recorrer à viagem no tempo.

O apelo das histórias que se passam no futuro está tanto em imaginar as mudanças e permanências provenientes de nosso presente quanto em ver o nosso lugar na história (JONES; ORMROD, 2015, p.5), o domínio, mesmo que apenas voyeurístico, do devir impossibilitado por nossa mortalidade

Na série Além da Imaginação, encontramos episódios que se passam no futuro médio dos protagonistas. Em geral, as apresentações desses futuros permitem, de forma mais clara e direta, o cumprimento da proposta didática modelar e moralista da série de Rod Serling, subvertendo o ordinário a partir de pessoas comuns da sociedade americana - e não heróis ou pessoas excepcionais -, aproximando os temas tratados de problemas individuais e coletivos e propondo uma reflexão indicativa de uma mudança de postura de parcelas do público. Como veremos, o futuro pode servir de ajuda para o passado, ou ser um tempo que abandonou a ignorância e o medo do presente. Esses são exemplos de alguns temas explorados na série, quando ocorre um deslocamento em direção ao futuro do personagem em destaque.

\section{9- Onde se encontra o passado}

Como os desafortunados personagens do conto de Alfred Bester The Man Who Murdered Mohammed, de 1958 (O Homem que Matou Maomé), aprenderam a duras penas após cometerem "cronocídio" - matar-se por alterar o passado -, a viagem no tempo ao passado viola o sentido de nossa experiência no tempo. Enquanto a viagem ao futuro é mais aceleração do que transgressão, a viagem ao passado é a pura forma de violação, criando "um mundo da imaginação onde vale tudo, mas por fim nada conta" (CLUTE, 1994, p.646). Ao se poder alterar o passado e, por consequência o presente, a viagem ao passado subverte as noções de ética e moral - não é à toa que os viajantes do tempo que alteram o passado de forma mesquinha, na história de 
Bester citada acima, são punidos gravemente com uma existência fantasma por toda eternidade.

O poder de alterar o passado, o rompimento da cadeia de casualidade e as implicações desse tipo de viagem atacam a base do pensamento moderno sobre a percepção da mudança, principalmente em uma sociedade em que nos percebemos como fruto de um sentido de história no qual o passado é distinto e originário de um presente que por sua vez se tornará passado, gerando um novo presente e futuros inéditos, campos de possibilidade cuja origem pode ser traçada no passado. Em uma sociedade com noção de tempo repetitiva, mítica ou circular, não seria um problema, pois existe uma ampla ordem histórica definida, como no exemplo do Hinduísmo citado anteriormente, e tudo que ocorrer no futuro deveria estar previsto e seria passível de ser incorporado socialmente não como uma experiência única, mas a se repetir em outro ciclo vindouro ou trazido à vida por meio de rituais.

A viagem ao passado subverte a expressão ocidental moderna do símbolo Tempo, sendo, portanto, uma nova forma - ficcional - de se relacionar com ele, refletindo sobre a noção do passado ser inacessível e suprimido do campo da experiência futura. Por mais que as histórias de viagem no tempo ao passado possam reforçar essa forma de rebeldia contra a manifestação moderna de tempo, ela serve mais como válvula de escape temporária da experiência moderna com o tempo, muitas vezes acabando por reforçar a noção de imutabilidade ou inevitabilidade do presente. A ficção pode permitir uma experiência em primeira mão de protagonistas deslocados no tempo e até mesmo imaginar a alteração do passado com resultados no presente dos viajantes, porém a valorização desta alteração do presente por meio da interferência no passado não é muito bem-sucedida em grande parcela dessas histórias. Em parte, isso pode ser explicado pela criação dos paradoxos, que poderiam minar alguma experiência de verossimilhança, porém há um fator mais importante, essas histórias estimulam a imaginação de uma fuga de um presente indesejado e/ou opressor, ao mesmo tempo que nos ensina a aceitá-lo e nos adaptarmos.

O acadêmico John Clute (1994, p.646) identificou dois tipos mais comuns de viagem no tempo ao passado: a primeira, no qual existe alguma forma de polícia do tempo que evita as alterações ao passado; a segunda, onde não há preocupação em se alterar o presente, o passado é o local de fuga do presente, um tempo visto de forma nostálgica, uma escapada muitas vezes apenas temporária e que pode levar a perigos não intencionais que devem ser corrigidos. Essas duas perspectivas mais 
comuns reforçam a impossibilidade de se viver no presente, porém encontramos mais elementos importantes nessas aventuras. Algumas obras invocam também algo semelhante à "Lei de Convervação da Realidade", criada pelo escritor Fritz Leiber em 1958 no conto The Big Time (SLUSSER; HEATH, 2005, p.19); nesta lei, o universo se ajusta para impedir a alteração do fato passado. Isso também serve como elemento de verossimilhança, pois as nossas sociedades e Ciência funcionam com a concepção de que o passado é dado e impossível de ser alterado, vide a proposta da "conjectura de proteção cronológica" de Hawking, citada anteriormente. Além disso, uma separação em passado distante, médio e próximo para analisar essas narrativas, algo que faz mais sentido para viagens no futuro, não funciona tão bem para se pensar a viagem padrão ao passado, pois esta viagem explora mais outros elementos nas histórias, como a causalidade, o fatalismo, o livre-arbítrio, os paradoxos, a cultura histórica e a nostalgia.

Assim, determinados períodos históricos atraem mais viajantes "em decorrência do seu potencial melodramático, como a época dos dinossauros e a visitação a pessoas famosas" (EDWARDS; STABLEFORD, 1995, p. 1228, tradução nossa). Porém, deve-se entender também a viagem ao passado como uma ponte entre a cultura histórica de determinada sociedade diretamente com o presente, alterando ou reforçando concepções dominantes dos períodos históricos, personagens e fatos de dada sociedade. A viagem ao passado é sempre uma viagem a formas de se interpretar o passado, não com a exigência de um historiador, mas em direta consonância com o trabalho do historiador, pois para tornar o passado verossímil, alguma forma de conhecimento oriundo do saber historiográfico deve ser explorada, por mais ficcional que seja a história ou mais absurdos que os fatos históricos sejam descritos. Além disso, a viagem no tempo ao passado serve às sociedades modernas como transmissora e espelho de uma versão do passado não científico, popular e geralmente associado à cultura histórica dominante e à história tradicional, historicizando determinada sociedade ao criar referenciais comuns, escolher personagens históricos heroicos, ou não, associando-os a determinados períodos, selecionar fatos a serem compartilhados coletivamente, diluindo ou reforçando os conflitos encontrados no passado. Nessas narrativas, o viajante no tempo, um ser entre o presente e o passado, é o fio condutor da reflexão e das formas de olhar sobre o passado. 
Um exemplo do explanado acima, referente ao imaginário contemporâneo acerca da sociedade viking, é o conto O Homem que Chegou Cedo, de Poul Anderson (The Man Who Came Early, 1956). Essa história é contada da perspectiva de um viking medieval sobre seu estranho encontro e convivência com um homem incomum que se identificava como sargento (sardjant para o viking) do exército dos EUA na base da Islândia. O conto nos apresenta uma aventura no passado no qual entramos em contato com a sociedade e cultura viking com um grau de verossimilhança de livro didático de História. Por mais que toda viagem no tempo opere no mesmo campo da reflexão histórica, a viagem no tempo ao passado é a mais diretamente associada ao trabalho do historiador em interpretar outras sociedades no tempo.

O grau de crítica ao passado também é variável nas aventuras de viagem no tempo, normalmente é feita comparação no campo tecnológico, científico e cultural para se destacar como no presente encontramos melhores condições em algum dos campos, como uma sociedade menos preconceituosa, ou melhores condições de higiene ou melhores máquinas - noções consonantes com a lógica do progresso -, porém não é raro nos depararmos com a ideia de que o presente está degenerado e a falta de coisas "modernas" é o atrativo estimulante da imaginação de como a vida seria mais simples, mais saudável e mais humana, um passado nostálgico.

Muitas vezes, somos lembrados de ou forçados a imaginar como levaríamos vantagem por ter um conhecimento do presente em um passado mais simples, desenvolvendo tecnologias, tornando-nos líderes de um povo visto como atrasado, ou tomando decisões capitalistas. É comum encontrarmos comentários sobre como seria bom poder voltar no tempo para comprar ações de determinadas empresas, utilizando o conhecimento atual do mercado de ações, ou mesmo realizar apostas sabendo os resultados dos campeonatos esportivos e até adquirir obras de artistas que se tonariam famosos e importantes quando eles ainda eram desconhecidos.

Portanto, em geral, as histórias de viagem no tempo ao passado reforçam o valor de se aprender a viver no presente, compreendê-lo e/ou aceitá-lo, corrigindo e desafiando os paradoxos mais do que apresentando situações de sucesso em alterar o passado e o presente - por mais que essas obras dependam do estímulo a nossa imaginação de que alterar o passado transformaria e/ou nos daria controle do presente. Na série Além da Imaginação, o passado pode tanto ser apresentado como um local de aventura que obrigatoriamente permite a comparação das temporalidades, mas também discute a nostalgia, expondo a sua função na sociedade 
americana da época e critica determinadas concepções sobre o passado, relação causa e efeito e valores humanos, na perspectiva de apresentar uma reflexão sobre o presente, permitindo ao público reavaliá-lo e transformá-lo.

Para aprofundar o tema mais importante e regular das viagens no tempo ao passado de Além da Imaginação, uma breve conceitualização de nostalgia será discutida mais adiante, pois os episódios de viagem no tempo nostálgicos se destacam dos demais, mesmo que a viagem no tempo ao passado em geral possa despertar elementos nostálgicos no público que escapam à intencionalidade do autor.

Figura 12 - Na história em quadrinhos Die Now, Live Later!, Superman é levado ao passado por um alienígena. Essa aventura conta o papel desconhecido pela História da participação do super-herói no processo de independência dos EUA. Na imagem, Superman participa da assinatura da Declaração da Independência com os Pais Fundadores no Segundo Congresso Continental. A presença de Superman nesse evento reforça o caráter divino do herói e sua associação direta com os EUA.

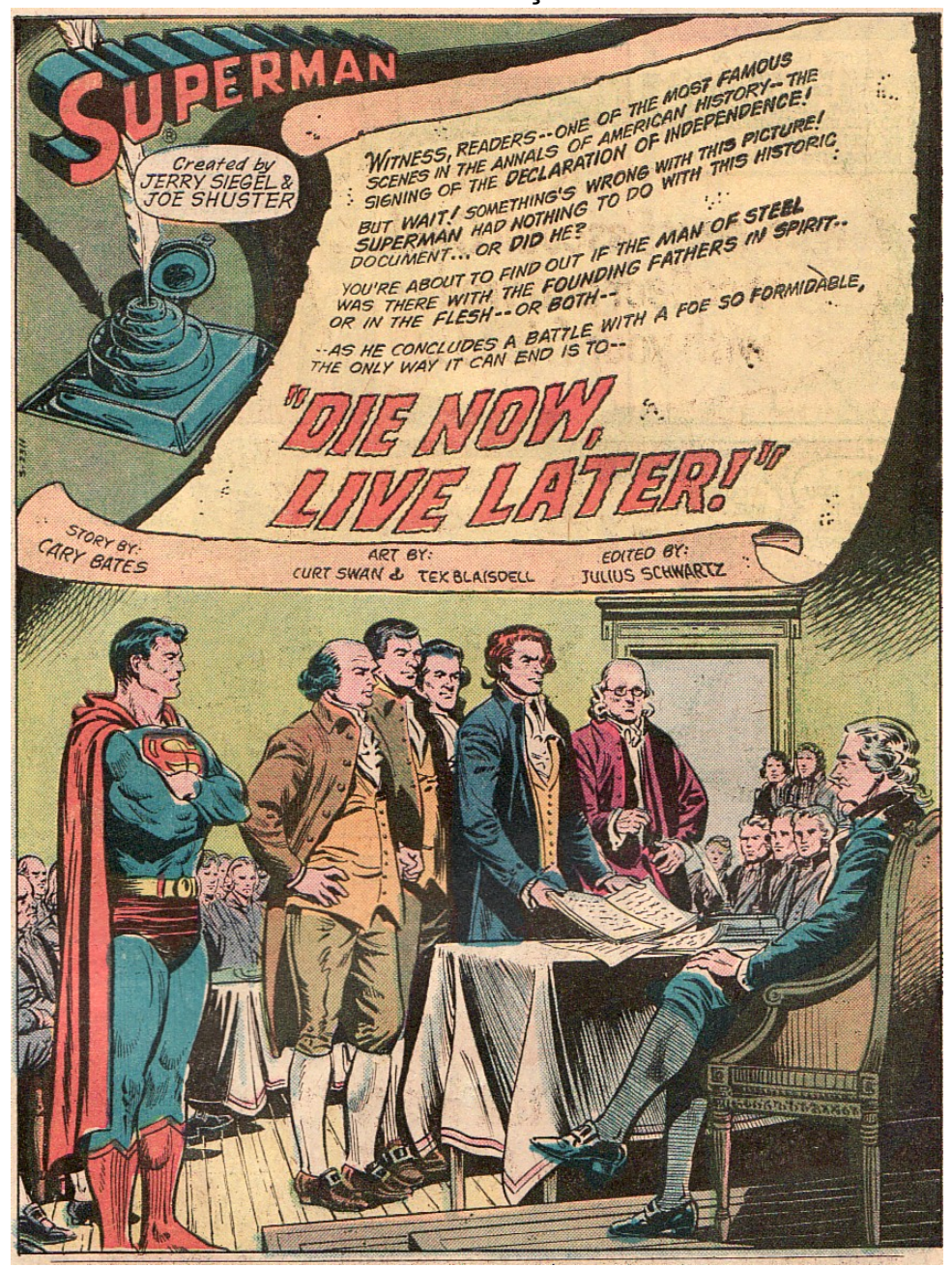

Fonte: Action Comics 463, setembro 1976 (BATES, 1976) ${ }^{23}$.

${ }^{23}$ Disponível em: https://readcomiconline.to/Comic/Action-Comics-1938/Issue463 ? id $=25695 \&$ quality=hq\#2 


\subsection{0- Todo o Tempo}

Assim, mais que apenas inovações literárias (e posteriormente audiovisuais), expandindo a exploração da linguagem e do tempo futuro nas obras ficcionais e revisitando o passado dentro da perspectiva de uma época superada, seja para reafirmar essa visão ou para anacronicamente negá-la, as histórias de viagem no tempo são fruto e elementos retroalimentativos das novas relações com o tempo, desenvolvidas nas sociedades europeias e cujo florescimento se deu nas sociedades industriais ocidentais do século XIX. O próprio desenvolvimento dessas narrativas e a sua aceitação por mais de cem anos são indicativos de que esse processo de desenvolvimento e problematização de nossas experiências com o tempo, por mais intuitivas que sejam, ainda se encontra ativo nas sociedades contemporâneas e, mais importante, cumpre papel fundamental para reforçar esse símbolo tão caro ao funcionamento de nossas sociedades, o Tempo. 
"It's a different world today

I just don't understand

It's a different world today

And I just don't understand"24

(Joey Ramone)

\section{4- A Chave da Imaginação}

\section{1- O Meio Termo entre Luz e Sombras: o contexto do segundo pós-guerra}

A década de consolidação do poder americano no segundo pós-guerra, os anos 50, se aproximava do final. Por mais de dez anos, a economia dos Estados Unidos da América cresceu de forma arrebatadora; por exemplo, no período pós-segunda guerra, o salário médio do trabalhador aumentou $60 \%$ e mesmo com crises econômicas ocasionais, com o aumento da inflação e custo de vida - como na recessão de 1953 a 1954 no pós-guerra da Coréia e na recessão de 1957 a 1959 que elevou o desemprego a 7\% (HILMES, 2014, p.203)-, no contexto econômico geral, o desemprego e a inflação se mantiveram baixos. Esse período entre o fim da Segunda Guerra Mundial e a década de 60 ficou conhecido como a "Era de Ouro do Capitalismo" (MARGLIN, 2000, p.23), claro que mesmo com a melhoria geral, nos anos 60, um quinto dos americanos, principalmente, idosos e minorias étnicas, estavam abaixo da linha da pobreza definida pelo governo (BRINKLEY, 2016, p.694). Os EUA experimentaram o aumento do poder aquisitivo de muitas famílias e um crescimento populacional (a geração baby boomer); estes eram eventos conectados, pois as famílias perceberam que podiam manter mais crianças que as gerações anteriores, algo sem precedentes na história da nação e que mudaria profundamente o país. Essas crianças futuramente desenvolveriam, em parte, suas identidades a partir dos programas a que assistiam na televisão e dos produtos que consumiam, propagandeados ou derivados de programas televisivos. Essa geração passou a ganhar presentes regularmente, costume reservado anteriormente apenas para o dia

\footnotetext{
${ }^{24}$ Trecho da música de Joey Ramone "Venting (It's a Different World Today)" do álbum póstumo "Don't Worry About Me" (2002). É um mundo diferente hoje/ Eu simplesmente não entendo/ É um mundo diferente hoje/ E eu simplesmente não entendo [tradução nossa].
} 
do aniversário ou datas especiais (EDGERTON, 2007, p.186). Um dado apontado pela historiadora Michele Hilmes apresenta que entre 1947 e 1960, mais de 77 milhões de crianças nasceram, fato que marcaria profundamente a cultura americana (2014, p.167).

Do final da Segunda Guerra Mundial até o lançamento da série Além da Imaginação (The Twilight Zone) na televisão americana em 1959, a sociedade americana passou por enormes mudanças, capitaneadas pelo desenvolvimento econômico, como a expressiva ampliação do consumo de bens diversos, como televisores e outros eletrodomésticos cada vez mais desenvolvidos tecnologicamente, os quais prometiam facilitar a vida dos lares americanos; lares, que por sua vez, eram cada vez mais suburbanos, em amplos espaços produzidos em massa, afastados dos grandes centros e organizados ao redor das famílias nucleares, fato que desestruturou a forma anterior de identidade social centrada na comunidade, excluindo os idosos do convívio diário com a família (MELBYE, 2016, I.530). O símbolo da família americana nuclear, no período em que Além da Imaginação foi ao ar, era o de famílias "isoladas, sexualmente cobradas, resguardada por abundância e protegida contra o desastre iminente [guerra atômica] pelas maravilhas da tecnologia moderna" (MAY, 1999, apud MELBYE, 2016, I.3906, tradução nossa).

Por outro lado, a Guerra Fria se agravava, com a probabilidade de um conflito nuclear com a União Soviética cada vez mais próxima no horizonte das possibilidades. O conflito não se restringia à Terra, o próprio universo fazia parte desse enfrentamento. O espaço sideral, aparentemente, seria conquistado e militarizado, com a corrida espacial oficialmente dando frutos com o lançamento dos dois satélites soviéticos Sputnik em 1957 e as respostas americanas com o Explorer 1, lançado em 1958, além da assinatura, no mesmo ano, do National Aeronautics and Space Act, que deu origem à NASA.

Nesse contexto global do segundo pós-guerra, os EUA ocuparam o local do antigo Império Britânico, como "portadores da bandeira da democracia ocidental pelo mundo" (BOOKER apud MELBYE, 2016, I.2264), e passaram a ampliar sua influência no chamado Terceiro Mundo, lidando com aceitação e resistências a seu poder. Assim, os EUA se consolidavam como o líder do bloco Ocidental, antagonizando com a URSS no papel de nação orientadora do progresso da humanidade; entretanto, havia a impressão nos EUA de que o poder americano no mundo, que seria uma extensão natural de sua vitória na Segunda Guerra Mundial, estava enfrentando 
muitas dificuldades para realmente se estabelecer, pelo menos da forma esperada pelas elites políticas e econômicas dos EUA e por parcelas significativas da população americana em geral, dentro da lógica do excepcionalismo americano, a noção de que o povo e as instituições americanas eram virtuosos per se e tinham por destino transformar o mundo.

Quando foi lançada a série Além da Imaginação, desde seis anos antes, os EUA tinham como presidente um herói da segunda guerra mundial, o general cinco estrelas, Comandante Supremo dos Aliados, David Dwight Eisenhower, carinhosamente denominado "Ike". Entretanto, nem o suposto prestígio do presidente podia salvar os americanos dos múltiplos dilemas enfrentados cotidianamente em direção a uma sociedade aperfeiçoada, problemas que cada vez mais pareciam ser de difícil solução. "Ike" inclusive chegou a ser acusado de integrar uma conspiração comunista pelo líder de um grupo radical de direita, em um contexto no qual setores de direita que, descontentes com o governo federal e movidos por soluções simples para um mundo complexo, se reorganizaram de forma militante e emergiram no final da década de 50, retomando muitas questões do "segundo medo vermelho/ second red scare" ou macarthismo dos anos iniciais da década de 50.

O mundo ordeiro, tecnológico e próspero propagado nessa época pelo Estado, parte da mídia e políticos, a se realizar no futuro, recebia duras críticas tanto de movimentos à esquerda quanto à direita do espectro político, como, por exemplo, condenações dirigidas ao conservadorismo, à alienação de indivíduos e grupo sociais, ao anticomunismo militante, ao racismo disseminado na sociedade americana, às armas nucleares, ao controle social, à sujeição da mulher ao papel doméstico, à vigilância, aos conflitos internacionais, à intolerância, à padronização das esferas da vida, às próprias bases do capitalismo (como a geração de lucros pelas relações de trabalho), ao desenvolvimento tecnológico, bem como a uma frouxidão nas relações internacionais com a URSS, à instituição de políticas que iriam contra os princípios de responsabilidade individual (que se assemelhariam às propostas soviéticas), à liberdade de organização, à centralização do poder federal e ao enfraquecimento das forças armadas.

Cabe lembrar que o próprio termo "anticomunismo", nesse contexto dos anos 50 , que se estende à década de 60 , deve ter seu significado ampliado; segundo a historiadora Lisa McGim (2014, p.182), este termo incorporava outras preocupações 
e posturas, como as polêmicas sobre a regulação estatal de aspectos econômicos, culturais, sociais e a questão da igualdade racial.

Atualmente, essa época de incertezas para muitos que a viveram como adultos, por ser supostamente ordeira e próspera, é alvo de sentimentos nostálgicos, motivados pelo consumo de reprises de programas icônicos de televisão que representavam e fortaleciam o ideal suburbano, e de outros artefatos culturais do período, como, por exemplo, a música e a moda, tomados por parte do público presente como retratos da realidade vivida, além, claro, da memória afetiva de muitos que eram crianças na época, protegidos do mundo pela ação dos familiares e o próprio sentimento de saudade da infância. Esse é um processo retroalimentado pela mídia, que reproduz essas imagens e narrativas em outras obras atuais ambientadas no período, reforçando a veracidade de um passado ficcional nostálgico ${ }^{25}$.

A série Além da Imaginação, em tal contexto, faz parte desse amplo movimento de crítica a seu tempo, pautada pelo campo da esquerda americana (democrata) e, mais que mero entretenimento escapista, pode ser vista como um local de ceticismo em relação às noções de que tudo estava perfeito ou caminhando para a perfeição, e que os americanos (principalmente a classe média) da época eram o auge da civilização e polidez, além de que a solução do "problema soviético", seja em casa, ou no exterior, levaria, por si só, a humanidade - lideradas pelos EUA - a seu período de maior glória.

Mesmo que a série Além da Imaginação não possa ser considerada uma produção de ficção científica per se, como veremos adiante, ela foi vendida pelo próprio Rod Serling e pela emissora como inserida no gênero e incorporou muito de seus temas, explorando o gênero em seus aspectos críticos e atraindo escritores, diretores e atores que trabalhavam regularmente com ficção científica, atendendo aos anseios de parte da sociedade americana da época, ávida por uma série que

\footnotetext{
${ }^{25}$ Um bom exemplo disso, é o filme De Volta Para o Futuro (1985), quando Marty McFly volta no tempo para 1955 e anda pelo centro da cidade, ele vê um posto de gasolina da Texaco onde os frentistas fazem referência não a um posto de gasolina real da época, mas ao quarteto que cantava a apresentação do programa Texaco Star Theater (1948-1956) fazendo propaganda dos serviços e dos tipos de gasolina dos postos Texaco. No filme um carro para e é atendido por quatro frentistas que cuidam de cada parte do carro descrita na música do programa da década de 50 , reforçando a nostalgia por um serviço de posto de gasolina ficcional! E pelos anos 50, "mais humanos"!
} 
retratasse com qualidade os temas apresentados nas obras literárias do gênero em questão.

O contexto era propício para temas inspirados e derivados da ficção científica, seja na Literatura, nas Histórias em Quadrinhos, na Televisão e no Cinema, não só pelo potencial de elementos desse gênero estarem se tornando realidade - como já estavam, cada vez em menor tempo desde o avanço industrial-, mas também como forma de mediar um mundo com cada vez mais máquinas maravilhosas e foguetes, ampliando o alcance da crítica mais enfática da ciência e tecnologia, mais facilmente compreendida pelas massas pelo exemplo do desenvolvimento armamentício da Segunda Guerra Mundial cujo fechamento do conflito com a bomba atômica marcava o fim de uma pseudo inocência da prática científica e da criação de novas tecnologias.

A noção da tecnologia e prática científica como positivas era amplamente difundida com mais facilidade pela modernidade antes da Segunda Guerra Mundial; entretanto, cabe afirmar que mesmo contestada nesse momento histórico com mais força, a noção da tecnologia como positiva e da ciência como verdade inconteste acrítica não foi extinta e ainda pode ser facilmente encontrada nas sociedades contemporâneas. A ficção científica era claramente um dos fóruns de discussão e crítica social nesse contexto histórico, juntamente com o horror e a fantasia, que exprimiam as ansiedades sobre todo esse desenvolvimento e as perspectivas de destruição do mundo: seja por armas criadas pelo ser humano, mas também invasão estrangeira e de outros protagonistas sociais, mudanças aceleradas (in)desejáveis, alienação, aceitação ou rejeição do impulso da sociedade rumo a uma conformidade, adequação das necessidades ou vontades individuais à rotina e aos papeis sociais delimitados, destruição da natureza e o contato com seres extraterrenos, esses últimos cada vez mais tornando-se parte de uma religião do progresso, substituindo e complementando os antigos mitos de fantasmas, anjos, demônios e deuses.

Entretanto, para entender como a série de antologia Além da Imaginação - série composta de episódios com histórias diferentes, com mudanças de elencos, cenários, diretores, etc.- veio a se tornar um referencial da fantasia, horror e ficção científica na televisão, sendo geralmente associada unicamente a este último gênero, um breve contexto da mídia no período deve ser apresentado, bem como os programas que regularmente exibiam temas de ficção científica, suspense e mistério, inclusive para o público infanto-juvenil, e criaram a cultura televisiva que receberia e daria prosseguimento à proposta de Serling, de formar um público que cada vez mais 
aceitava a "suspensão da descrença" necessária para o engajamento com esse tipo de narrativa fantástica.

\section{2- Nova Contribuição para o Entretenimento Familiar: a nascente televisão}

A proposta de uma forma de mídia que transmitisse imagem e som já estava presente no horizonte das expectativas tecnológicas do século XIX, quando da organização dos sistemas de telégrafo (EDGERTON, 2007, p.17), ampliados pelos princípios tecnológicos desenvolvidos nas últimas décadas do século XIX, devedores do avanço no conhecimento coletivo humano sobre eletricidade dos séculos anteriores. Portanto, assim como o avião, a ideia da televisão foi uma "concepção internacional desde o início, devido principalmente ao crescimento e influência de uma comunidade científica transnacional (Ibid., p.19). E foi nas grandes empresas americanas que o incentivo ao desenvolvimento tecnológico se daria, por meio da atuação de cientistas e engenheiros trabalhando arduamente em laboratórios de empresas como Radio Corporation of America (RCA) e a General Electric, por exemplo. Portanto, a televisão pertencia à indústria desde o início (HILMES, 2017, p.164) e isso marcou a forma como ela seria apresentada pela sociedade e se desenvolveria nos EUA - e no mundo.

O desenvolvimento da televisão e sua chegada nos lares mundiais seria apenas uma questão de tempo, algo deixado para o futuro. Essa associação da televisão com um futuro, seja utópico (com a possibilidade de se levar informações, entretenimento, unir as famílias nucleares e educar as massas de forma mais efetiva que qualquer mídia jamais criada) ou distópico (alienar as pessoas, vigilância e controle), fazia parte do próprio desenvolvimento da nova tecnologia na lógica de progresso moderno. Segundo o historiador Gary R. Edgerton, em seu livro The Columbia History of American Television, em perspectiva adotada por esta pesquisa, a televisão "como uma tecnologia é muito mais que apenas uma câmera e um receptor; ela é um processo de concepção, invenção, comercialização, produção de programas e inovação constante" (EDGERTON, 2007, p.57). 
Nos EUA, a própria exibição pública da televisão na Feira Mundial de Nova York de 1939 pela RCA/NBC ${ }^{26}$, inclusive com a transmissão do evento, trazia todo o ar de futuro a ser realizado; cabe destacar que um dos pavilhões mais visitados dessa Feira Mundial foi exatamente o da RCA, com a televisão (EDGERTON, 2007, p.15); a exposição foi de 30 de abril de 1939 até 27 de outubro de 1940, propondo um mundo de possibilidades futuras, o qual foi destruído pela Segunda Guerra Mundial iniciada poucos meses após a abertura do evento.

Figura 13 - Rip Discovers Radio, uso da figura de Rip Van Winkle no panfleto distribuído pela RCA no seu pavilhão da Feira Mundial de $1939^{27}$.

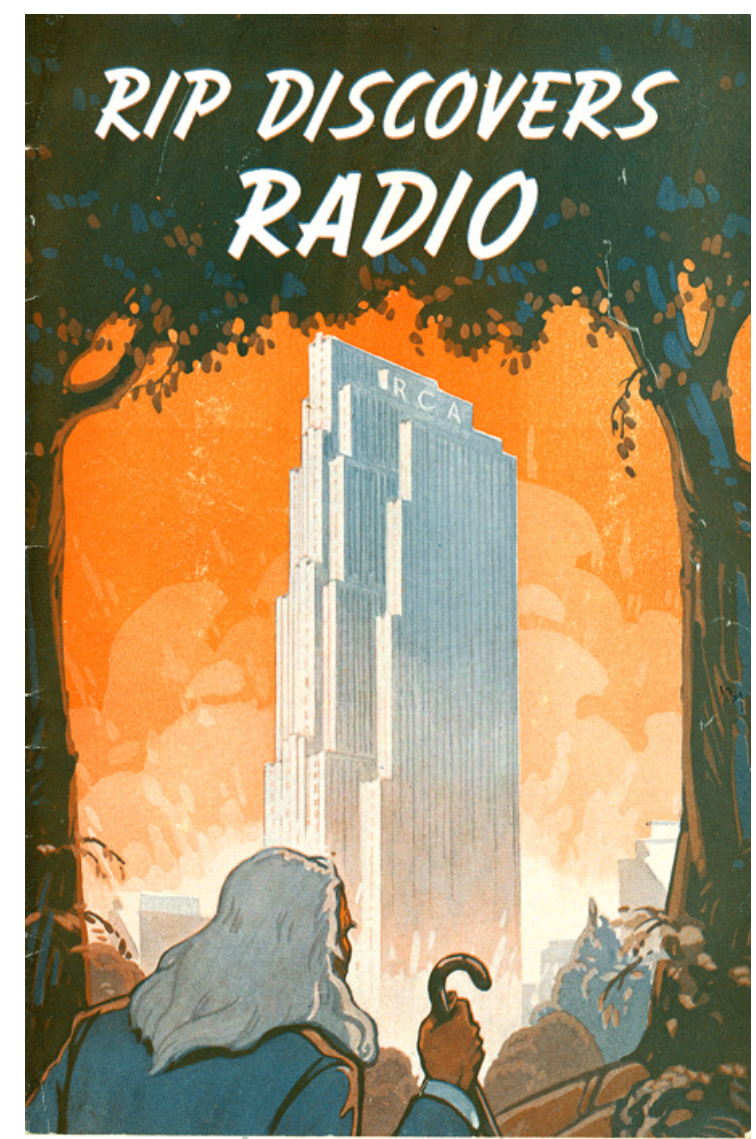

Fonte: 1939 New York World's Fair (2018)

\footnotetext{
${ }^{26}$ A National Broadcasting Company (NBC), foi fundada em 1926, com participação da RCA, General Electric e Westinghouse, como solução para disputas comerciais entre empresas e acusações de monopólio oriundas do governo (EDGERTON, 2007, p.32).

${ }^{27}$ Rip Van Winkle dorme no final do século XIX e acorda em 1939. Surpreso, visita o prédio da RCA em Nova York e aprende sobre a história da RCA, o desenvolvimento e o uso do rádio. A invocação do personagem reforça a ideia de progresso e avanço tecnológico. O panfleto pode ser visto integralmente em http://www.1939nyworldsfair.com/worlds_fair/wf_tour/zone4/rip/rip.aspx
} 
A televisão como instrumento acessível de mídia de massa nos EUA é um produto do segundo pós-guerra e, mesmo com o advento de aparelhos à venda para o público, as transmissões nas décadas de 30 e 40 eram restritas a cidades como Nova York ou voltadas a testes. Durante a Segunda Guerra, a transmissão televisiva chegou a ser extremamente reduzida e voltada a testes e operações militares, com a proibição de novas autorizações para abertura de emissoras. Somente após a Segunda Guerra Mundial, a televisão foi explorada, incorporando tecnologias desenvolvidas para o uso militar durante o conflito e sendo financiada com parte dos lucros que as empresas que desenvolviam as tecnologias desse veículo receberam do governo americano no esforço de guerra; por exemplo, a RCA, que desenvolvia tecnologia para televisão, triplicou suas receitas e mais que dobrou seus lucros entre 1942 e 1944 (SOBEL apud EDGERTON, 2007, p.74).

O acesso a televisores e programação foi se tornando mais possível paulatinamente com a inauguração da pioneira rede DuMont Television Network, que também fabricava televisores, e as transmissões regulares dos grandes conglomerados de comunicação, que dominavam o rádio, como a Columbia Broadcasting System (CBS), a American Broadcasting Company (ABC) e a National Broadcasting Company (NBC). As redes foram auxiliadas pela ação da Federal Communications Commission (FCC), Comissão Federal de Comunicações em tradução literal, agência governamental reguladora das transmissões, formada em 1934, substituindo a antiga Federal Radio Commission, atuante desde 1927 (EDGERTON, 2007, p.8). Essa comissão, que durante a Segunda Guerra havia desautorizado a abertura de novas emissoras, repetiu a ação em outro contexto entre 1948 e 1952, paralisando a autorização para inaugurar novas emissoras e redes, ou o desenvolvimento de outras propostas de exploração da televisão, pois estava organizando a distribuição dos sinais, que em cidades como Nova York estavam se sobrepondo, causando interferência; havia também discussão do padrão de televisão a cor a ser adotada, o UHF e frequências reservadas para fins educativos (Ibid., p.105; HILMES, 2014, p.178). Essa pausa na ampliação da mídia fez crescer principalmente o poder das três grandes emissoras, ABC, NBC e CBS, que puderam se estabelecer e organizar a indústria sem correr riscos (Ibid., p.178-182). Durante os primeiros anos do segundo pós-guerra, a expansão da televisão foi desigual e não havia uma "televisão nacional", já que boa parte dos EUA não recebia os sinais e tampouco possuía emissoras próprias; por vezes, isso foi ocasionado pelo bloqueio de licenças 
do FCC, mas também devemos considerar a falta de investimentos em comunidades que trariam baixo retorno financeiro e por influência de uma visão negativa da cultura comercial de massa e conservadorismo de pessoas, principalmente das zonas rurais (EDGERTON, 2007, p.105).

Com o encerramento das operações da DuMont Television Network em 1956, aquelas três grandes empresas passaram mais ainda a dominar o mercado, com emissoras próprias - geralmente nas grandes cidades - e venda de conteúdo para emissoras menores, afiliadas, que retransmitiam de costa a costa os programas. A série Além da Imaginação foi exibida originalmente pela CBS e afiliadas entre 19591964, no contexto de domínio das "três grandes", proeminência que só seria perdida na década de 1980 (EDGERTON, 2007, p.278).

Um exemplo da expansão vertiginosa dessa mídia após a Segunda Guerra mundial pode ser visto na quantidade de televisores comercializados: em 1950, 9\% dos EUA tinham televisores, cerca de 3,875 milhões de lares, nas cidades onde havia sinal, $45 \%$ das famílias tinham comprado televisores, com média de uso diário de três horas e vinte e quatro minutos; já no final de 1952, um terço dos lares americanos tinham televisores passando em 1955 a $67 \%$ casas americanas com televisores e, no final dos anos 50, quase $90 \%$ dos lares americanos estavam conectados pela televisão. No final da década de 50 e início dos anos 60, 90\% das casas tinham um ou mais televisores nas áreas metropolitanas, e nas áreas não urbanizadas o índice chegava a 85\% (GOLDFIELD, 1960, p.520; 1961, p.516); a televisão se fazia presente em quase todo território, interligado de costa a costa por cabos instalados em 1951 (STERLING; KITTROSS apud EDGERTON, op.cit., p.90; GOMERY apud Ibid., p.90; Ibid., p.96, 105, 107). Portanto, em 1959, quando Além da Imaginação foi pela primeira vez ao ar, a televisão estava passando pelo processo de se tornar realmente nacional.

Inicialmente, o centro das transmissões americanas era a cidade de Nova York, que desfrutava do protagonismo inicial na nova mídia por ser o centro da cena de rádio e teatro dos EUA e local sede dos testes das décadas anteriores com a nova mídia. A produção inicial televisiva era dependente da tradição teatral nova-iorquina, o vaudeville e a Brodaway, e a de Chicago, com a "Escola de Chicago" de atuação (Ibid., p.161). Contudo, durante a década de 50, o protagonismo da indústria televisiva foi se deslocando para a costa oeste dos EUA, para Hollywood, com a entrada no mercado televisivo dos grandes estúdios de cinema e a migração de atores, técnicos e autores de Nova York para Los Angeles (GRAMS JUNIOR, 2008, p.16), bem como 
a abertura de estúdios voltados exclusivamente para a produção televisiva a fim de desfrutar a proximidade com a indústria cinematográfica para seu próprio benefício, com acesso facilitado a atores, diretores e técnicos de cinema, como, por exemplo, a inauguração do CBS Television City em 1952 e o NBC Color City em 1955. Esse fato foi fundamental na produção da série Além da Imaginação, filmada quase inteiramente nos estúdios da MGM.

Os estúdios de cinema de Hollywood tiveram muito de suas ambições iniciais na nova mídia talhadas por ações da FCC. Na época, a agência, que estava sujeita a pressões públicas e privadas externas, privilegiou as emissoras de rádio que investiram no desenvolvimento da tecnologia de transmissão da televisão; porém, mesmo dentro do modelo proposto de organização do sistema de televisão americano, com foco no investimento e controle privados, havia conflitos entre as próprias redes de rádios e outros interessados em ingressar na oferta televisiva, como as definições dos padrões a serem adotados. A própria competição dos interessados nos anos de 1930, devido à relutância do FCC em tomar decisões que podiam desagradar grupos poderosos, atrasou a introdução da televisão nos EUA (EDGERTON, 2007, p.9).

Havia um receio de que a nova mídia seria completamente dominada pelos estúdios, caso fosse autorizada a formação ou compra de emissoras de televisão pelos maiores dentre eles, já que estes tinham como modus operandi práticas monopolistas e geradoras de trustes, noção reforçada nesse momento histórico pela condenação da indústria cinematográfica em 1948 no famoso caso United States v. Paramount Pictures, Inc., cujo efeito foi a alteração de toda a forma de produção, exibição e distribuição, encerrando a Era de Ouro do cinema hollywoodiano (Ibid., p.182). O FCC também proibiu experimentos dos estúdios com transmissão de filmes para salas de cinema e sistema de televisão a cabo (HILMES, 2014, p.170).

Todavia os estúdios não ficaram de fora da nova mídia, e aos poucos marcariam e ampliariam seu espaço: foi através da rede $A B C$ que os estúdios entraram com mais força na nova mídia. Inicialmente, a Paramount Pictures havia investido no desenvolvimento da televisão e detinha ações da DuMont e outras emissoras próprias à rede PTN (Paramount Television Network), o que era visto pelo FCC como parte da DuMont, restringindo a expansão das duas redes distintas, pois existiam regras sobre o tamanho que uma empresa podia ter. Com o desmembramento do sistema de estúdios, no final da década de 40 , do conglomerado 
da Paramount, foi formada a United Paramount Theater (UPT), empresa dedicada à exibição dos filmes no cinema, mas que não podia produzir filmes. Em 1953, a UPT adquiriu a rede $A B C$, em ação aprovada pelo FCC. Posteriormente, com o compra da rede $A B C$ pela UPT e o crescimento da $A B C$, a Paramount Pictures não autorizaria a DuMont a se fundir com a rede $A B C$ temendo ações antitruste. Em 02 de abril de 1954, Walt Disney faria um acordo com a rede ABC para produzir o programa Disneyland e outras minisséries, inclusive com participação de $35 \%$ no futuro parque Disneyland em Los Angeles, um modelo de posteriores acordos entre Hollywood e as três grandes (EDGERTON, 2007, p.182-186;189). Suceder-se-iam no ano seguinte acordos da Warner Bros. Television com a rede ABC para produzir séries e exibir filmes. Inicialmente, a força de Hollywood na televisão se deu no campo da produção de conteúdo, que paulatinamente acabou por ocupar boa parte da programação, indo de $40 \%$ dos programas de horário nobre (das 19:00 às 23:00 horas) em meados dos anos 50 para 71\% da produção em 1957 (Ibid., p.193) e no final dos anos 50, a maioria dos programas dessa faixa de horário já eram produzidos em filme por Hollywood, chegando a 90\% do horário nobre em 1965 (HILMES, 2014, p.170, 220). A produção hollywoodiana acabou substituindo os programas ao vivo de Nova York e Chicago.

Os estúdios de Hollywood não só traziam novos patamares na produção, mas também reduziam os riscos financeiros das emissoras, já que dividiam os custos. 0 crescimento vertiginoso da produção hollywoodiana para a televisão entre 1955 e 1958 provocou a falência de pequenas produtoras de conteúdo televisivo ou sua venda para grupos maiores (EDGERTON, op. cit., p.251)

Sobre a exibição dos filmes cinematográficos de Hollywood na televisão, cabe o comentário que somente no início da década de 60, filmes pós-1948 hollywoodianos foram transmitidos, pois os contratos dos atores, após esse ano, indicavam remuneração caso os filmes chegassem a ser exibidos naquele veículo. Além disso, os produtores não consideravam que o público se interessaria muito em ver filmes que já teriam visto no cinema recentemente e os preços cobrados pelos estúdios para o aluguel tornavam mais barato refazer o filme em uma peça televisiva (Ibid., p.250). Essas noções só seriam desafiadas à partir de 1961 com o lançamento de NBC Saturday Night at the Movies pela NBC.

Da mesma forma como a indústria do cinema americano na década de 30 fez sua autocensura, com a adoção do Motion Picture Production Code, e a indústria de histórias em quadrinhos adotou o Comics Code Authority em 1954, ambas para evitar 
ações governamentais, após acusações de grupos de pressão - inclusive violentas- , a televisão também tinha seu documento orientador das produções, baseado nos códigos já existentes no rádio, o Code of Practices for Television Broadcasters. A autocensura do meio foi criada no final de 1951 e adotada em 1952 pela National Association of Radio and Television Broadcasters, entidade do setor que representava emissoras de rádio e televisão, desde 1958 denominada National Association of Broadcasters (NAB). Além de preocupações de cunho moralista, como a orientação para que se evitassem cenas em banheiros com vasos sanitários e casais dormindo juntos em camas de casal, o documento regulava também como a propaganda deveria ser exibida na televisão, inclusive com a duração relacionada ao tempo do programa; por exemplo, à noite, um programa poderia ter de seis a dez minutos de propagandas e durante o dia, de dez a quatorze (HILMES, 2014, p.199). Porém a única punição para não aceitação do código era a remoção do selo da NAB da programação, o que, segundo a historiadora Michele Hilmes (op. cit., p.200), nem era notado pela maioria da audiência. Esse tipo de iniciativa auto-regulatória de proteção da mídia e dos negócios envolvidos é algo comum nos EUA, onde as próprias empresas evitam a intervenção legislativa ao adotarem alguma forma de resposta às demandas sociais e de grupos de pressão que poderiam exigir ações governamentais.

Somando-se à autocensura, existia também a legislação da agência reguladora para as emissoras e, assim como o rádio, a televisão estava sob olhares e ouvidos atentos da FCC. Esse órgão estatal do governo federal tem até hoje como uma de suas múltiplas funções impor as leis que proíbem obscenidade, indecência ou profanidade (FEDERAL, 2016, p.1., tradução nossa) nas transmissões de rádio e televisão, bem como organizar a competição no mercado, o uso das frequências e locais de atuação das emissoras. Um exemplo importante de atuação da FCC na televisão na década de 50 foram os privilégios e favorecimentos para que as "três grandes" dominassem o mercado, seja ao proibir novas licenças, deixando o meio livre para crescimento da influência das "três grandes" sem ameaça, ou nos casos de fraudes nos programas de perguntas e respostas, comprar o lado das emissoras e culpabilizar o modelo de influência dos patrocinadores que dominava o meio, ocasionando a centralização do poder de decisão da programação nas grandes emissoras (HILMES, op. cit., p.167).

Às atividades da FCC e ao respeito ao Code of Practices for Television Broadcasters, somava-se uma força tão, ou mais poderosa: o peso dos 
patrocinadores e das agências de publicidade. As agências representantes dos patrocinadores e as próprias empresas que patrocinavam os programas exerciam um controle que superava a censura estatal e a autocensura das emissoras e seus departamentos de Standards and Practices, já que, enquanto o cinema, as revistas e as histórias em quadrinhos recebiam receitas diretas de seu público, as transmissões televisivas, mais custosas de que o rádio, chegavam nas casas gratuitamente, o que aumentava consideravelmente a dependência do financiamento de empresas e o grau de comprometimento criativo envolvido. Os patrocinadores não se limitavam aos intervalos comerciais ou a inserir o nome junto ao nome no programa, como o Alcoa Presents: One Step Beyond, série de antologia sobrenatural que incorporava o nome da indústria de alumínio americana em seu título, um lugar comum presente na televisão da época que indicava o modelo de desenvolvimento desse veículo nos EUA, por via exclusivamente privada, bancada com dinheiro dos anunciantes. A influência ia bem além, eles também interferiam diretamente na dinâmica da narrativa e organização da programação, censurando qualquer elemento considerado contrário aos interesses comerciais dos patrocinadores, o que ia da exclusão ou diluição de qualquer tema polêmico e controverso, ou com potencial de causar alguma discussão, até alterações realizadas movidas por gostos pessoais ou questões de competição de mercado entre concorrentes.

Rod Serling, o produtor e principal roteirista de Além da Imaginação, não se privava de relatar o que ocorria e criticava publicamente o modelo americano de exploração da televisão, por meio da interferência direta dos patrocinadores na programação (na época, era muito discutido o modelo britânico, com a separação rígida entre criadores e patrocínio e as possibilidades que poderiam advir com a televisão paga); para ele, o próprio patrocinador deveria se restringir aos comerciais, pois seria escolha deles patrocinar programas dramáticos, vistos como de prestígio, e deviam respeitar a forma de se contar histórias (AURTHUR; SERLING; TUNICK; et al., 1960, p.19).

Alguns casos citados por Serling dessa interferência nos mostram o grau de ingerência nos programas desempenhados pelos executivos das empresas e seus prepostos nas agências de publicidade, como: o fato dele ser obrigado a alterar as palavras "American" e "lucky" de um roteiro, pois o programa era patrocinado por uma fabricante de cigarros que via que o uso dessas palavras conotava suas concorrentes; ser obrigado a remover quaisquer palavras e itens, como garrafas de Coca-Cola, que 
pudessem identificar um roteiro como se passando no sul dos EUA, para evitar associação com o caso de espancamento de negros, pois segundo os publicitários, a Coca-Cola era bebida do sul (Ibid., p.3;11); ou ver removido o icônico Edifício Chrysler do cenário de Nova York, pois o programa seria patrocinado pela Ford, (ZICREE, 1992, p.14); ou mesmo ter que reclamar do mau gosto representado pela ideia da Kimberly-Clark de inserir propaganda de papel higiênico no canto da tela de Além da Imaginação, durante a exibição dos créditos finais (GRAMS JUNIOR, 2008, p. 59).

Uma crítica realizada por Rod Serling, e apoiada pelo público televisivo do período, era que esse conjunto de interferências infantilizava a programação televisiva e desrespeitava o público, ao tratá-los como ignorantes não capazes de ver algo que fugisse da literalidade mais óbvia. Posteriormente, quando estourou um escândalo dos programas de perguntas e respostas (quiz show) combinados nos anos 50, fato que chegou a ser investigado pelo governo, as emissores colocariam toda a culpa da fraude nos patrocinadores e utilizariam esse fato para se apresentarem como íntegras e enfraqueceriam a influência dos anunciantes, retomando o controle da programação com apoio do FCC e um novo modelo de patrocínio que não deixava mais o programa aos cuidados de um único anunciante e era mais parecido com as propagandas de revistas (HILMES, 2014, p. 200, 213).

Nesse cenário, cabe destacar que no início da década de 50 , não havia tanto controle externo do material exibido nas peças dramáticas televisivas, os patrocinadores não chegavam a interferir muito nas obras e maiores interferências no conteúdo advindas do FCC só ocorreriam a partir de 1960 (SANDER, 2011, p.82-83; p.139). O papel dos patrocinadores e publicitários, ainda se adaptando aos potenciais da nova mídia de massa, era limitado, pois as formas de se fazer propaganda na televisão e seu potencial como ferramenta de propaganda ainda estavam sendo testados. O diretor de televisão que iniciou sua carreira nesse contexto Fielder Cook, acertadamente, comentou (SANDER apud MALBYE, 2016, I.534) que uma certa liberdade na mídia televisiva só existia pela própria novidade da televisão, já que ainda não existiam convenções específicas para o meio (MALBYE, op. cit., I.530). Porém, durante a década de 50, a influência dos patrocinadores nas produções seria cada vez mais onipresente e censora, o que provocou sérios conflitos com um grupo de jovens roteiristas, que viram o potencial da nova mídia e desejavam elevar o nível das produções, apresentando discussões sobre questões sociais e humanas com realismo, enfrentando o poder dos executivos e patrocinadores - e entidades 
governamentais - na delimitação dos temas a serem exibidos pela televisão. Esses roteiristas trabalhavam com bastante liberdade criativa e suas obras se chocavam com obras que seguiam fórmulas consolidadas no rádio ou no cinema hollywoodiano (HILMES, 2014, p.185).

Dentre esses novos talentos, encontramos Rodman Edward Serling - o já citado, Rod Serling -, acompanhado por Paddy Chayefsky e Reginald Rose. Como curiosidade, os três autores chegaram a ter diversos roteiros adaptados no Brasil para o programa da TV Tupi "TV de Vanguarda”, que foi ao ar entre 1950 e 1964 (SOUZA, 2011, p.133). Entretanto, essa busca por uma televisão mais próxima da chamada alta cultura era também interesse de alguns executivos, como Paul Weaver, chefe de programação da NBC, que tinha intenções bem semelhantes às desses roteiristas pioneiros, a de, via televisão, transformar a sociedade e a cultura americana para melhor. Entretanto, cabe lembrar que, durante o contexto da exibição de Além da Imaginação, a balança do poder estava cada vez mais pendendo para os executivos das emissoras em detrimento dos patrocinadores, devido à disseminação na televisão de novas formas de comercialização dos programas.

O professor e pesquisador M. Keith Booker destaca o papel da série / Love Lucy (1951-1957), programa de enorme sucesso, feito por um estúdio periférico de Hollywood, no desenvolvimento da televisão americana do período, não só pelo modelo de comédia de situação que se tornou, mas também por indicar o caminho para a indústria televisiva, pois, ao ser a primeira série de sucesso a ser totalmente filmada em uma época de programas ao vivo, permitia reprises e a comercialização dos episódios para qualquer emissora interessada (BOOKER apud MELBYE, 2016 I., 3941), o que se tornaria padrão do modelo comercial da televisão americana.

A televisão foi fundamental na formatação do mundo dicotômico e paradoxal da Guerra Fria, ao mesmo tempo alienando e acalmando, afastando o público dos horrores mundiais diários, mas também assustando e estimulando a crítica e a mobilização do presente, como relata Gary R. Edgerton:

\begin{abstract}
A televisão era um tipo de abrigo antibombas de fantasia, mostrando dançarinos e fantoches dançando - um perfeito tranquilizante para uma nação preocupada sobre comunistas na porta e subversivos debaixo das camas. E ainda assim touxe a realidade da guerra, política e o mundo real para dentro das salas pristinas suburbanas (EDGERTON, 2007, p.109).
\end{abstract}

Nesse contexto, portanto, a televisão também passou pela histeria anticomunista do período, o chamado "segundo medo vermelho/ second red scare", 
com a investigação do House Un-American Activities Committee (HUAC), Comitê dos Representantes (deputados) no Congresso dos EUA, criado em 1938, que investigava ações ligadas a subversão ou traição nacional realizada por cidadãos suspeitos de terem ligações com ou serem comunistas. Reestabelecido em 1946 no contexto de Guerra Fria e fortalecido pela explosão da bomba atômica soviética e a vitória dos comunistas na China, ambos fatos de 1949, o comitê mirou a televisão nos anos 50. Além disso, as emissoras obrigaram seus funcionários a assinarem votos de lealdade aos EUA (EDGERTON, 2007, p.149), procuravam demonstrar patriotismo na programação e reproduziam a ideologia estatal em inúmeras transmissões a fim de demonstrar lealdade, como, por exemplo, a veiculação de mensagens nacionalistas em programas infantis e a ampla compra, por emissoras menores, de programas com temática anticomunista, espionagem e infiltração, nos primeiros anos da década de 50 (HILMES, 2014, p.195).

Contudo, observada de forma mais ampla a década de 50, não eram raras peças televisivas extremamente ousadas ao contestar o clima de caça às bruxas e, inclusive, a televisão americana do período teve um papel fundamental na desconstrução do populista senador Joseph McCarthy que levou a sua perda de popularidade, como, por exemplo, a reportagem do popular programa do jornalista Edward R. Murrow, See It Now da CBS (09/03/1954), que criticou duramente McCarthy e seus modi operandi (BAYLEY, 1981, p. 192; EDGERTON, op. cit., p.148) e com a ABC transmitindo os Army-McCarthy Hearings (abril a junho de 1954). Como afirma o professor Thomas Doherty em seu livro Cold War, Cool Medium (2003), ao contrário do que o senso comum possa implicar, a televisão durante a Guerra Fria foi um espaço incentivador da expansão da liberdade de expressão e do respeito às diferenças (DOHERTY apud EDGERTON, op. cit., p.140); porém, essa ousadia era sempre observada com olhar atento dos patrocinadores, salvo quando algum programa conseguia passar sua mensagem de forma tão dissimulada e/ou alegórica e dentro dos padrões já reconhecidos, que era autorizada. Cabe lembrar que o foco principal dos programas na época era o de atingir a classe média americana branca, que em 1960, no contexto da exibição original de Além da Imaginação, era parte significativa dos $60 \%$ da população americana que possuia rendimentos de classe média, ou seja, entre USD\$3.000,00 a US\$10.000,00 anuais (HILMES, 2014, p.204). Havia uma cultura tácita na televisão de se evitar temáticas e histórias baseadas em questões raciais, principalmente dos afroamericanos; porém, essa 
tendência se estendia a nativoamericanos, latino-americanos e ásio-americanos, o que provocava a quase total ausência de pessoas com essas características na televisão do período, salvo quando retratados de forma não ameaçadora, calcada no folclore e estereótipos tradicionais (EDGERTON, op. cit., p.240), como, por exemplo, o caso dos negros, que contavam piadas e cantavam na tradição americana do menestrel. A televisão do período, em linhas gerais, refletia a segregação existente na sociedade. Esse tipo de caracterização padrão era desafiada na série Além da Imaginação, de forma consciente, em vários episódios que davam o protagonismo e características positivas a grupos excluídos socialmente - e também da grande mídia da época.

A própria cobertura televisiva nos programas de notícias do movimento dos direitos civis na década de 50 e início dos anos 60 era a de geralmente apresentar o problema racial americano como algo regional e localizado, de forma distante e sem problematização (EDGERTON, 2007, p.238). Todavia, nas emissoras e na programação local, fazia-se presente uma maior variedade étnica e racial nos programas de televisão.

Sobre os espectadores, dentro de uma perspectiva do crescimento do mercado de pesquisas (ligado ao consumo), desde 1950, a Nielsen fazia a aferição da audiência dos programas de televisão por família, incluindo os programas noturnos em 1959, fornecendo para as emissoras dois dados a serem analisados, o ratings e o share. O ratings é uma porcentagem calculada do número de casas que assistiram a determinado programa em relação ao total de casas com televisão que existem. Já o share é a porcentagem calculada do número de casas que assistiram a determinado programa em relação ao total de casas com televisão que estavam efetivamente ligadas no momento (Ibid., p.243). O objetivo da recolha dos dados era sua utilização pelas agências de publicidade e pelos produtores. Os primeiros, para determinar quais programas patrocinarem e manterem o patrocínio (privilegiando o ratings ou o share, ou os dois números de acordo com os interesses da campanha publicitária); e os segundos, para criarem programas que pudessem ser atrativos para as agências de publicidade.

Como a audiência desejável para as agências e para as emissoras era sempre baseada na maior quantidade possível de famílias assistindo aos programas, quanto maiores os números, melhor; entretanto, na época, agências e produtores não se detinham muito a outros fatores que podem significar o sucesso de um programa com 
um rating ou share longe dos programas mais assistidos. Esse fato só iria ser alterado durante a década 60 , com a recolha de dados da audiência por segmentação demográfica (BUZZARD, 2012, p.71; EDGERTON, op. cit., p.247-275), ferramenta mais interessante para os publicitários alocarem seus patrocínios com o que teria mais chance de atingir os seus consumidores reais ou potenciais, aumentando a variedade dos anúncios vendidos pelas agências e facilitando para os produtores, que passaram a criar programação específica para os segmentos mais desejáveis de serem atingidos pelas agências de publicidade. Porém, nos primórdios da televisão, a segmentação já era realizada por bloco de horário: por exemplo, o foco em propagandas de comida e brinquedos nos programas infantis, pois as crianças, desde o início da televisão, já eram consideradas uma audiência separada das demais (EDGERTON, 2007, p.179), e o sempre foco nas mulheres, responsáveis pelas compras da casa (HILMES, 2014, p.172). Cabe sempre lembrar que esses dados estavam sujeitos a todo tipo de manipulação e interferência das redes e chegaram a ser investigados no início dos anos 60 (Ibid., p.215, 235).

Em uma sociedade cada vez mais pautada pela adesão ao consumismo, até porque, cabe lembrar, os adultos da época passaram em sua grande maioria pelas privações oriundas da Crise de 1929 e agora desfrutavam de um momento ímpar de poderem consumir novos bens e artigos anteriormente restritos aos mais abastados, a televisão foi fundamental como ferramenta mediadora para grupos que faziam a transição para a classe média, fornecendo novos valores e auxiliando o distanciamento de antigos costumes e valores (EDGERTON, op. cit., p.125), como viver afastado de outros membros da família, possuir casa própria, ter acesso ao ensino superior, por exemplo.

Uma grande mudança cultural se engendrava, com uma sociedade mais escolarizada e com crescente mobilidade social. O autor George Lipsitz em Time Passages - Collective Memory and American Popular Culture (2001, p.39), cita o uso das comédias de situação étnicas de classe trabalhadora, famosas no período inicial da televisão, como uma forma das largas parcelas da audiência facilitarem suas transições para a classe média, ao mesmo tempo em que tensões como preconceito, desigualdades e o mundo do trabalho eram ignorados (EDGERTON, op. cit., p.130131). A televisão em seu horário-nobre, das 19:00 até às 23:00 horas, reforçava a visão de um país em que o público podia almejar e se sentir como parte integrante, o mundo de boa vida simbolizado por homens e mulheres bonitos (BARNOUW apud 
EDGERTON, op. cit., p.247), onde os problemas podiam ser resolvidos de forma satisfatória e mantendo a ordem desejada, antes de irem dormir para um novo dia de trabalho. Ademais, dentro da perspectiva apontada pela historiadora Michele Hilmes (2014, p.7), o mundo da televisão, geralmente exibindo uma vida próspera e consumista, era parte de um projeto social de conversão dos americanos a um novo tipo de vida, dissonante em relação ao realmente enfrentado pela maioria da população.

Esse contexto costuma ser denominado carinhosamente de Era de Ouro da Televisão; porém, há a crítica ao uso desse termo para a programação dos anos 50 pois, muito do que foi exibido nessa época foi perdido: estima-se que apenas $5 \%$ dos dramas televisivos estão disponíveis (EDGERTON, 2007, p.194; JOHNSON, 2007, p.55). Além disso, tais dramas são o tipo de obras mais utilizadas na categorização do período como Era de Ouro, muito pouco para se avaliar uma produção tão grande como se as demais obras perdidas tivessem a mesma qualidade, porque muito desses $5 \%$ foram preservados exatamente por serem considerados por pessoas da época como objetos dignos de preservação devido a suas qualidades.

Durante a exibição original de Além da Imaginação, entre 1959 a 1964, o tipo de programa para adulto que mais fazia sucesso eram os westerns (Ibid., 197), como se pode ver na compilação dos programas mais assistidos no período (MCNEIL, 1996, p.1146-1149); inclusive o ápice dos westerns se deu na temporada de 1959-1960, quando foi lançado Além da Imaginação. E, mesmo que em um possível imaginário historicizado corrente sobre os anos 50 as comédias de situação ocupem um lugar de grande atenção - e passam a ser vistas incorretamente como retrato documental das famílias da época-, era o western o gênero predominantemente consumido nos anos 50 e 60.

Esse gênero era extremamente popular e se relacionava, por um outro tipo de abordagem, com os problemas enfrentados pelos EUA na Guerra Fria e com as mudanças sociais aceleradas; no caso da Guerra Fria, a apresentação de um conflito entre bem e mal, de apelo nostálgico a tempos mais simples, sintetizados na noção de cowboys livres contra índios, em uma batalha pelo cumprimento do destino manifesto americano e a propagação da noção de que o que fosse bom para o homem branco americano seria por extensão, bom para a humanidade (HILMES, 2014, p.224). Outra questão seria transportar os conflitos e problemas sociais dos anos 50 e 60 para um passado heroico idealizado e resolvê-los de forma direta, dura e 
definitiva (Ibid., p.224), inclusive transportando conflitos raciais da época para o passado, utilizando muitas vezes os indígenas como substitutos dos afroamericanos para criticar a segregação e o preconceito.

O próprio Serling desenvolveria, em paralelo às últimas temporadas de Além da Imaginação, um western centrado nos personagens para a CBS, The Loner (19651966). A série, lançada no ano seguinte ao fim de Além da Imaginação, foi também cancelada pela CBS. Cabe destacar que vários episódios de Além da Imaginação faziam alusão ao gênero western, muitas vezes criticando a abordagem infantilizada dos programas do tipo, dirigidos para o público adulto como o episódio da terceira temporada Showdown with Rance McGrew (1962), no qual um fantasma de bandido do velho oeste americano transporta um ator, que representava um marshall, ao passado para que aprenda como era realmente o mundo naquela época, pois os bandidos não estavam satisfeitos em ver como eram retratados na televisão. Aliás, essa crítica à forma como a televisão lidava com determinados temas, gêneros e valores era constante na série, mostrando que, muitas vezes, os comentários dos episódios de Além da Imaginação não são necessariamente dirigidos a comportamentos individuais ou grupos específicos, mas à própria mídia e à forma como a televisão manipulava a mensagem a ser transmitida.

A televisão também foi responsável por novas relações entre os americanos e seus representantes políticos. A partir da popularização da televisão, os candidatos e membros eleitos deveriam aprender a falar de frente para as câmeras, utilizar técnicas de comunicação adquiridas dos apresentadores de programas de televisão, usar maquiagem, colocar-se disponível para aparecer na televisão, organizar o espaço, exibir propagandas com tempo e locais certos, novas formas e dinâmicas de fazer campanha. Por exemplo, pela primeira vez, a Convenção Nacional do Partido Republicano de 1952, que oficializou Einsenhower como o candidato à presidência, foi transmitida ao vivo e a partir desse momento, o chefe do executivo nunca mais poderia dar-se ao luxo de se abstrair da televisão, conforme ficou claro na ascensão de Einsenhower à presidência, o qual teve, a duras penas, aprender a utilizar a televisão para se comunicar, e "lke" foi o primeiro presidente eleito nesse novo mundo da televisão. Já em 1960, John F. Kennedy dominava a mídia com muito mais facilidade e faria uma campanha exemplar na televisão, ofuscando um Richard Nixon que não percebia todo potencial da televisão, como no caso do famoso debate entre Kennedy e Nixon televisionado e também transmitido por rádio, no qual quem assistiu 
deu a vitória no evento para Kennedy e quem ouviu deu a vitória para Nixon (EDGERTON, 2007, 205, 231-232; HILMES, 2014, p.216).

Esse período também favoreceu o aparecimento de programas de notícias e documentários, que ampliaram o alcance e a importância das notícias exibidas na televisão, além do poder das emissoras, já que o público americano passou cada vez mais a depender da televisão como fonte primária de notícias (EDGERTON, op. cit., p.233).

A exibição original de Além da Imaginação entre 1959 a 1964 faz parte de um contexto mais amplo de estabelecimento de uma maior maturidade da mídia, com controle ampliado do conteúdo, definição da forma que a televisão será explorada como cultura popular, maior percepção dos gostos da audiência, organização da comercialização do conteúdo, desenvolvimento de fórmulas e ampliação do poder das três grandes emissoras, integrando um período de expressivas transformações da sociedade americana. Todos esses elementos encontrarão eco e serão depurados na série de Rod Serling, que, de certa forma, pode ser vista como síntese crítica de um período.

\section{3- Noventa por cento de tudo que se faz é porcaria?}

A televisão americana de finais da década de 40 e década de 50 tinha receio de lançar séries com temática de ficção científica para adultos, havia a crença de que os patrocinadores só se interessavam por esse tipo de programa esporadicamente e o nicho de consumidores potenciais que desejavam assistir a programas com esses temas não daria o retorno em audiência esperado (GRAMS JUNIOR, 2008, p.16). O próprio Rod Serling, respondendo a uma carta em 1960 que sugeria contos e autores de ficção científica para Além da Imaginação, afirmou que estava sendo extremamente difícil vender um conceito de ficção científica para seus patrocinadores (SERLING, 1960d, p.1). Além disso, as séries adultas dedicadas a ficção científica que surgiram enfrentavam um dilema problemático: quanto mais fielmente adaptavam as obras literárias e lidavam com a extrapolação científica ou mesmo tentavam fundamentar a fantasia, recebiam elogios de autores e fãs, mas acabavam por alienar parte do público que esperava mais ação (TELOTTE, 2008, p.57).

Entretanto, a temática da ficção científica não estava restrita a séries que lidavam exclusivamente com ela, existiram episódios pontuais em programas de 
antologia dramática para adultos. Assim como em outras mídias da época, como o cinema, as revistas e as histórias em quadrinhos, a ficção científica e seus elementos mais marcantes, como foguetes, naves, alienígenas e viagem no tempo, eram dirigidos mais ao público infanto-juvenil, em óperas espaciais, e foi para esse público que os primeiros programas desse gênero foram realizados, atingindo os adultos por extensão - em plena consonância com o cinema B dos anos 50. Como veremos, o caminho seguido por Além da Imaginação foi pavimentado por uma série de programas pioneiros, tanto os criados visando ao público infanto-juvenil, quanto os programas de adultos.

A primeira série de ficção científica de televisão dos EUA foi Captain Video and his Video Rangers, exibido pela emissora DuMont entre 1949-1955 de segunda a sexta-feira. O pesquisador de história da televisão americana Vincent Terrace (2011, p.240-241; 2016, p.33) relata que inicialmente a série só se chamava Captain Video e exibia antigos westerns, com a apresentação do Captain Video; porém, com o crescimento da emissora de televisão, a série passou a exibir também as aventuras do próprio Captain Video, incluindo ao nome do programa, em algum momento impreciso, "and his Video Rangers", fazendo referência aos aliados do herói. A série apresentava de forma contínua as aventuras do capitão Vídeo e seus amigos que, de uma base secreta em uma montanha, lutavam pela lei e pela ordem ao combater vilões e suas criações maléficas em um futuro distante. O renomado escritor Isaac Asimov chegou a assinar um roteiro para a série chamado I, Tobor (1953), sobre um robô manipulado para atacar os heróis. Em pequenos intervalos intitulados "Video Ranger Message", eram transmitidas mensagens patrióticas para as crianças com curiosidades sobre a história dos EUA voltadas à preservação das tradições, além de mensagens moralizantes e educativas, como, por exemplo, contra o preconceito racial e religioso. Além das aventuras regulares diárias, a série se desdobrou num especial que passava aos sábados alternados com uma história completa, o The Secret Files of Captain Video e, em 1951, foi criada uma série de cinema chamada "Captain Video: Master of the Stratosphere", produzida pela Columbia Pictures Corporation. Ainda no mesmo ano, a editora Fawcett Comics lançou revistas em quadrinhos do Captain Video. A série teve enorme sucesso entre o público infantil, mas os adultos também a acompanhavam regularmente.

Outra série voltada ao público infanto-juvenil que também recebia atenção de adultos nesse período era a Space Patrol, exibida na rede ABC entre 1950-1955 e 
que assim como Captain Video, foi transmitida ao vivo e gerou produtos derivados como histórias em quadrinhos. Aproveitando as rádios da rede $A B C$, foi produzida uma série de Space Patrol no rádio, algo que a DuMont não tinha pois, não era dona de emissoras dessa natureza. Distribuída nacionalmente pela $A B C$ em cópias kinescope, era exibida inicialmente por 15 minutos diários em Los Angeles e posteriormente foi feita uma versão de 30 minutos para ser apresentada aos sábados (TERRACE, 2011, p.1490-1491; 2016, p.178-179). A história consistia nas aventuras de membros da United Planets, uma ONU do espaço, que no século XXX, enfrentava vilões espaciais viajando na nave Terra IV.

Outra série de temática semelhante às duas citadas, feita em filme para ser vendida no sistema de syndication (sistema de distribuição onde as emissoras compram os direitos de exibição de programas sem precisar produzí-los), era Rocky Jones, Space Ranger, que teve duas temporadas filmadas em 1954 e alguns dos episódios reunidos para formar filmes para televisão. Na série, acompanhamos as aventuras de Rocky Jones e dos Space Rangers, que defendem o United Worlds of the Solar System, um tipo de EUA do sistema solar (TERRACE, 2011, p.1292).

Os dois principais modelos de óperas espaciais exibidos na televisão do período, Buck Rogers in the 25th Century e Flash Gordon, também tiveram suas versões televisivas na primeira metade da década de 50. Buck Rogers in the 25th Century, adaptação do personagem de sucesso em literatura, rádio e série de cinema da Universal Pictures (1939), criado por Philip Francis na novela Nowlan Armageddon 2419 A.D, publicada na edição de agosto de 1928 na pulp Amazing Stories. A série do jovem do século XX em animação suspensa que acorda no futuro para lutar contra o mal foi exibida pela ABC entre 1950-1951 e até o momento não foram encontradas cópias em kinescope das tranmissoes ao vivo (WEITEKAMP, 2013, p.12). Já Flash Gordon, adaptação da tira de jornal de Alex Raymond e exibido em três séries de cinema produzidas pela Universal Pictures (1936, 1938 e 1940), teve sua série cinematográfica exibida na televisão na década de 50 e ganhou também a sua versão exclusiva para televisão realizada entre 1954-1955. De forma semelhante a Rocky Jones, Space Rangers, a série das peripécias de Flash Gordon também foi elaborada para ser vendida no sistema de syndication para emissoras interessadas, filmada na Alemanha Ocidental e na França, em co-produção franco-germano-americana para economizar o máximo possível, (DIXON, 2008, p.97-99). Com alterações em relação 
ao material original, a série apresentava as aventuras de Flash Gordon e sua tripulação, agentes do Galaxy Bureau of Investigation, para manter a paz no universo.

Ainda na linha dos heróis espaciais de organizações à la ONU e OTAN, Tom Corbett, Space Cadet foi uma série originária na televisão que passou por todas as redes da época, $C B S, A B C, N B C$, DuMont, além de migrar para outras mídias ao se tornar série em rádio, tiras de jornal, histórias em quadrinhos e até música. Exibida entre 1950 a 1955, contava a história de um grupo de cadetes da Space Academy (local nos EUA onde eram treinados os Solar Guards), seus superiores e instrutores e suas aventuras na academia e pelo universo para proteger a Solar Alliance (TERRACE, 2011, p.1544-1545; 2016, p.184-185). Uma premissa semelhante pode ser vista em Rod Brown of the Rocket Rangers, exibida pela CBS entre 1953-1954, onde se podia assistir às aventuras do herói Rod Brown e seus amigos para proteger a United Solar System (Id., 2008, p.1292; 2016, p.168-170).

Juntamente com aventuras de heróis defensores do universo em tempos futuros, que viajavam por planetas e luas encontrando, ajudando e combatendo alienígenas, uma série, também dirigida ao público infanto-juvenil, se destacava nesse meio, pois não só apresentava um tipo heroico distinto, mas também o espaço e tempo das suas histórias não eram os usuais. O nome do programa era Captain Z-Ro, um programa de viagem no tempo, com exploração do tempo e espaço, inclusive o presente. De sua base misteriosa em um local não mapeado na Terra, perto de um vulcão soltando fumaça, Captain Z-Ro e seu assistente mirim Jet, com ajuda ocasional da equipe de Captain Z-Ro, podiam se teletransportar para qualquer lugar da Terra no presente ou passado. Eles resgatavam artefatos antigos, voltavam ao passado da humanidade, conheciam personagens históricos e pessoas dos mais diversos povos, demonstravam ou contestavam a veracidade de livros de história e corrigiam fatos históricos, interferindo no passado para salvar pessoas, além de poder assistir à história via um tipo de televisão. A principal intenção do programa, como descobrimos na narração gritada na abertura, era a de "aprender com o passado para planejar o futuro". Em sintonia com seus colegas das aventuras espaciais do futuro, suas indumentárias reforçavam a associação com os heróis siderais - mesmo que seu bigode e cavanhaque destoassem do padrão - e ele também tinha um foguete, o RX99, que permitia a pesquisa espacial. Inicialmente, Captain Z-Ro foi exibido ao vivo em São Francisco de 1951 a 1953, em 150 episódios de 15 minutos; posteriormente, foi recriada em Los Angeles com outro elenco e distribuída nacionalmente em 
kinescope. Entre 1955-1956, foram distribuídos 26 episódios de 30 minutos filmados, e Captain Z-Ro se manteve no ar até 1960 em reprises (MILLER; RIPER, 2012, p.216). O herói dessa série tinha um papel de gênio das ciências humanas e exatas e estabelecia uma relação professor e aluno com seu assistente mirim, enfatizando a necessidade de conhecimento de História, Geografia, Astronomia, Biologia e etc. como fundamental para orientação das ações humanas, o que era o oposto da mensagem das outras séries de heróis espaciais (Ibid., p.225), as quais reforçavam o papel da criança crescer e se tornar um bom cidadão. Não que Captain Z-Ro negasse isso, mas acrescentava a importância da inteligência, consoante ao contexto social do segundo pós-guerra, onde a ciência e o cientista passavam a ser politicamente valorizados (MILLER; RIPER, 2012, p.220), para a própria sobrevivência dos EUA no mundo da Guerra Fria.

No contexto histórico dos programas apresentados, outros heróis, compartilhavam o mesmo imaginário do publico desses capitães, tenentes, soldados e guardas intergalácticos, como o herói veterano de guerra oriundo do rádio, quadrinhos, livros e série de cinema, o Captain Midnight, (CBS, 1954-1956), "dedicado à causa da liberdade e justiça". Nas séries citadas, não era raro um alienígena do mal ou vilão humano ser apresentado falando com sotaque alemão ou russo (salvo Flash Gordon, que foi filmado na Alemanha com atores nativos) e amigos com sotaque americano (SAMUEL apud MILLER; RIPER, op. cit., p.134); além disso, existe o padrão de todos de qualquer planeta ou país obviamente sempre falarem ou entenderem inglês, clichê até hoje parodiado. Muitas dessas séries não tinham maiores preocupações com o conhecimento da época sobre o espaço, como fica claro ao se ver a falta de indumentária espacial básica, como capacetes. Além disso, essas séries demonstravam para o público que o universo, ou nosso mundo (externo aos EUA) era um lugar perigoso (Ibid., p.134), e só os valores éticos e morais representados pelos heróis e seus aliados, como lealdade, patriotismo, obediência a hierarquia, confiança, respeito, amizade, autossacrifício, garantiriam a sobrevivência dos EUA e a criação/manutenção de seu poder global em uma era de incertezas.

Outra questão que pode ser observada nessas séries é a popularidade dos temas espaciais, e mesmo que se possa afirmar que muitos desses programas desprezavam e não tinham cuidado com o conhecimento científico e que a conquista do espaço seja uma metáfora para o poder dos EUA no mundo, há o elemento de aventura rumo ao desconhecido e o interesse pelo desenvolvimento real que ocorria 
na época, extrapolado por esses programas infanto-juvenis. Ademais, as séries criadas inicialmente para o público jovem masculino também faziam sucesso com as garotas e os adultos, o que demonstra os desejos de um amplo público em se relacionar com essa temática, bem como o interesse pelos temas da exploração espacial associados às ansiedades dos primeiros anos da Guerra Fria, como o medo em relação a um conflito nuclear, tema abordado tanto de forma direta quanto metafórica por essas séries. Parte do público adulto que cresceu assistindo a Flash Gordon e Buck Rogers nas séries de cinema também era movido pelo apelo saudosista gerado por essas produções (MILLER; RIPER, 2012, p.7).

Mesmo que possamos traçar a importância das séries infanto-juvenis para o futuro das temáticas da ficção científica na televisão americana, existiram algumas delas dirigidas exclusivamente ao público adulto, mas que, em situação inversa, atingiam também o público jovem. Essas séries não só viviam de histórias originais, mas também transportavam para a televisão as tradições do rádio (TELOTTE, 2008, p.10), adaptando histórias de grandes escritores e roteiros do rádio para a televisão. Mesmo não tendo vida longa, ou uma grande popularidade na televisão do período, as produções conseguiram atrair escritores e atores renomados (Ibid., p.10). E foi exatamente a baixa popularidade referente à expectativa das emissoras e à própria temática, que muitas vezes não era levada a sério (em comparação com as outras séries de antologia de dramas de prestígio que surgiram na mesma época, aclamadas pela crítica), que criou os receios dos patrocinadores e emissoras em investir em programas do tipo, além do fato desse gênero de programa, se for realizado com bons valores de produção, gerava mais gastos que o normal para criação de cenários e efeitos especiais verossímeis. No contexto dessas séries, primeira década pós Segunda Guerra Mundial, a literatura encontrava um caminho mais popular fora das pulps de nichos, como indicado, por exemplo, pela presença de contos de Jack Finney, Kurt Vonnegut e Ray Bradbury em publicações que atingiam outros públicos, como as revistas femininas, caso da já citada McCall's, e as revistas de variedades e atualidades consumidas aos milhões pela classe média, como a Collier's e a Saturday Evening Post (GRAMS JUNIOR, 2008, p.14), demonstrando que as temáticas tratadas por essas histórias fantásticas, como fim do mundo por conflito nuclear, viagem no tempo, discussão sobre a ciência e tecnologia, cada vez mais faziam sentido para largas parcelas da população e para os editores das revistas, mas não para 
patrocinadores e executivos de televisão. Ainda não era chegada a época do prestígio dos temas fantásticos no mundo audiovisual.

No campo das produções dirigidas ao público adulto, Lights Out, advinda do rádio, era uma série de mistério, crimes, suspense e sobrenatural. Originalmente, um especial encomendado pela NBC em 1946, virou série regular entre 1949-1952 (TERRACE, 2011, p.877), com 160 episódios transmitidos ao vivo em Nova York e distribuídos nacionalmente em kinescope, atualmente boa parte perdidos (STEVENS; LANGFORD, 2017, n.p.). Ocasionalmente, essa série de antologia, apresentava episódios de ficção científica adaptados de proeminentes escritores do período, como o episódio The Martian Eyes (1950), sobre um estranho professor que, ao ter que usar óculos infravermelhos para uma estranha doença ocular, descobre que marcianos se infiltraram na Terra. Parecidos com os humanos, mas com um terceiro olho só visto sob luz infravermelha, eles dominaram a humanidade, incentivando guerras e comportamentos que as pessoas não teriam normalmente, uma premissa parecida com o filme "Eles Vivem" (They Live, 1988). Esse interessante episódio paranoico, tema recorrente no período, era uma adaptação do conto Don't Look Now de Henry Kuttner (1948), estrelado por Burgess Meredith, ator que futuramente faria parte de episódios memoráveis de Além da Imaginação. Inclusive esse cenário do alienígena com um terceiro olho no meio da testa, agora um venusiano, e o tema da paranoia da infiltração seriam ironizados onze anos depois no episódio da segunda temporada de Além da Imaginação Will the Real Martian Please Stand Up? (1961), escrito por Rod Serling.

Voltando ao início da década de 50, no ano de 1951, duas séries de antologia para adultos seriam exclusivamente dedicadas a temas de ficção científica; ambas foram ao ar com diferença de poucos meses, a primeira lançada em 3 de agosto de 1951, Tales of Tomorrow foi exibida pela ABC até 1953, em transmissões ao vivo com adaptações de histórias clássicas do gênero e roteiros especialmente produzidos para a série (TELOTTE, 2008, p.333). Os episódios eram apresentados às sextas-feiras em horário nobre, produzidos por Mort Abrahams, com roteiros assinados por grandes nomes do gênero, na época reconhecidos pelos fãs, como Arthur C. Clarke, Theodore Sturgeon, Cyril Kornbluth, dentre outros. Além disso, a série foi palco das primeiras atuações profissionais nas telas de James Dean, Paul Newman e Leslie Nielsen (TIBBETTS, 2008, p.381,383). Essa série se tornou um modelo para as séries posteriores que aproveitaram o mesmo formato de antologia de 30 minutos (cerca de 
23 minutos para o episódio mais os comerciais), como Além da Imaginação; inclusive o episódio What you Need, adaptado de conto de Henry Kuttner e C. L. Moore, esteve presente em ambas as séries, roteirizado por Mel Goldberg para Tales of Tomorrow (1952) e por Serling em Além da Imaginação (1959). Essa série valorizava em suas histórias temas humanísticos, sem muita preocupação com ciências "duras" ou tecnologia fantástica, sendo uma série que lidava com o lado escuro do ser humano e seus preconceitos ao mesmo tempo em que dava vazão aos temas da Guerra Fria, como ansiedade nuclear, discos voadores (que na época dominavam os jornais), medo de invasão, paranoia e receio da nova tecnologia, como a televisão, que entrava na casa das pessoas com potencial de se tornar um instrumento de vigilância, como demonstrado pelo professor John C. Tibbetts $(2008$, p.379, 383) em sua análise de episódios da série realizada quando do relançamento parcial em DVD. Infelizmente, parte dos oitenta e cinco episódios, filmados em kinescope, continuam perdidos (Ibid., p.392) até o momento (junho 2019).

A segunda série de antologia de ficção científica para o público adulto do ano de 1951, Out There, foi lançada em 28 de outubro e experimentou uma curta vida, sendo cancelada com apenas doze episódios exibidos. Out There, uma das primeiras séries a incorporar efeitos especiais filmados numa produção ao vivo (TERRACE, 2011, p.1151), foi ao ar pela CBS até janeiro de 1952 no final das tardes de domingo, e tentava levar para a televisão o melhor dos autores da literatura da época e produções próprias, com roteiros adaptados de obras de Ray Bradbury e Robert Heinlein. Segundo Geoffrey Stevens (2017, n.p.), os episódios sobreviventes estão preservados na Biblioteca do Congresso dos EUA.

Outra série dirigida ao público adulto em meados da década de 50 foi a Science Fiction Theater, no gênero antologia em 78 episódios, que teve sua primeira exibição entre 1955-1957. O programa foi produzido para ser vendido no sistema de syndication pela Ziv Television Programs. As novidades da série foram a sua primeira temporada filmada em cores (o que foi abandonado nas temporadas subsequentes a fim de cortar gastos de produção), o caráter semidocumental dos episódios apresentados e uma preocupação real com a ciência, "demonstrando a potencial flexibilidade da narrativa de ficção científica ao apresentar uma variedade de tipos de história enquanto tratava vários de temas sérios e oportunos". (TELOTTE, 2008, p.10). Com poucos efeitos especiais, a série tinha um apresentador, Truman Bradley, que transmitia informações sobre ciência e tecnologia antes de introduzir a história da noite 
que expandia as noções vistas previamente, "narrativas que exploravam as maravilhas da ciência, que na maior parte dos casos acabava causando mais mal do que bem" (DIXON, 2008, p.105). Science Fiction Theater era produzida e teve muitos episódios roteirizados por Ivan Tors, um diretor, produtor e roteirista de origem húngara, atuante nos temas fantásticos e que, a título de curiosidade, veio a falecer no Brasil em 1983, aos 66 anos, de ataque cardíaco enquanto pré-produzia um programa de televisão (FRASER, 1983). No elenco da série, encontramos DeForest Kelley, Gene Barry, Kenneth Tobey, Otto Kruger, Vincent Price, dentre outros. Um dos episódios mais interessantes dessa série é Time Is Just a Place (1955), a adaptação do conto de Jack Finney Such Interesting Neighbors (1951) sobre vizinhos suspeitos de serem viajantes no tempo. Concordando com a opinião do professor Wheeler W. Dixon (2008, p.105), o conceito da série é melhor do que foi a sua execução, que transmite a impressão de ter sido feita apressadamente e sem cuidados.

Cabe o destaque a outras séries que foram associadas e comparadas a Além da Imaginação pois visavam a atingir o mesmo público sedento pelo desconhecido, insólito e o misterioso e utilizaram muitas vezes os mesmos recursos narrativos. Uma das séries de antologia mais importantes do período a lidar com mistério, comédia, crime, drama, horror e ocasionalmente ficção científica, como viagem no tempo, alienígenas e androides, era a série de antologia Alfred Hitchcock Presents. A série de sete temporadas era apresentada pelo renomado diretor de cinema Alfred Hitchcock, que chegou a dirigir alguns episódios, aparecendo de frente para as câmeras para introduzir as histórias e para concluí-las, às vezes comentando o que se passou após o fim do episódio e ironizando os patrocinadores. Alfred Hitchcock Presents foi exibida originalmente pela CBS de 1955 a 1960 em cinco temporadas, passando para a NBC de 1960 a 1962, que apresentou as duas últimas, em episódios no formato de 30 minutos filmados. Após 1962, a série passou a apresentar episódios de uma hora, alterando seu nome para The Alfred Hitchcock Hour, em três temporadas de 1962 a 1965 (ROMAN, 2005, p.231). Havia muitas semelhanças entre essa série e Além da Imaginação de Serling, não só pela presença de escritores, atores e diretores em ambas as séries, algo não restrito ao período quando as duas estavam no ar concomitantemente, mas, principalmente, com a presença do final surpresa, o reforço do símbolo autoral na figura do apresentador, a ironia e as situações semelhantes que podiam ser vistas em ambas as séries, como a adaptação do conto "Um incidente na ponte de Owl Creek" (An Occurrence at Owl Creek Bridge, 
1890) exibidas em versões distintas em 1959 na série de Hitchcock e em 1963 em Além da Imaginação, sendo que essa última versão era uma produção francesa adquirida pela produtora de Rod Serling exclusivamente para fazer parte da série.

Outro programa que também pode ser comparado a Além da Imaginação foi Um Passo Além (Alcoa Presents: One Step Beyond, 1959-1961). Lançada anteriormente no mesmo ano de Além da Imaginação, era uma série mais focada no sobrenatural, exibindo recriações de eventos supostamente reais (docudramas) apresentados por John Newland (TERRACE, 2011, p.1139) de forma semelhante a Serling.

Uma abordagem séria do tema espacial, lançada menos de um mês antes de Além da Imaginação, Men into Space (CBS, 1959-1960), dramatizava a corrida espacial da época se passando em um futuro indeterminado e propondo uma possível conquista do espaço, mas perdeu apelo pelos feitos dos astronautas reais do período (MCCURDY apud MILLER; RIPER, 2012,p.95).

As séries apresentadas aqui, apenas exemplos significativos no contexto histórico do nascimento e exibição de Além da Imaginação, indicam que existia uma cultura televisiva sobre temas fantásticos que abriu espaço para a produção de Serling ser exibida em 1959 (TELOTTE, 2008, p.11), e, mesmo que a maior parte da abordagem dessas temáticas pendesse mais para as crianças e jovens ou fossem formuláicas, o interesse era amplo o suficiente para que os roteiros de Serling e outros, em Além da Imaginação, ressoassem no desejo primordial do público em ser maravilhado e surpreendido, além do desafio dirigido à audiência de pensar e considerar novas ideias e reformular opiniões e conceitos sobre todos os aspectos da vida individual e coletiva na época. Portanto, essas séries pioneiras desempenharam um papel muito importante e, sem querer desmerecer as ações de Rod Serling em tentar vender sua série que acabou por se tornar um referencial da fantasia, horror e ficção científica televisiva, além de uma marca poderosa, a existência de outras séries, específicas ou não, ao abrirem espaço no meio televisivo, demonstram que havia um clima propício e até de aguardo de um material que, respaldado por um roteirista renomado, levasse o fantástico a um tratamento adulto e relevante como a série Além da Imaginação costuma ser considerada, o que na época era algo restrito aos prestigiados programas de dramas de antologia ao vivo. A série de Serling ajudaria de forma contundente a abertura da mídia para mais programas fantásticos, exibidos 
tanto após o cancelamento do programa quanto durante a exibição original da série,

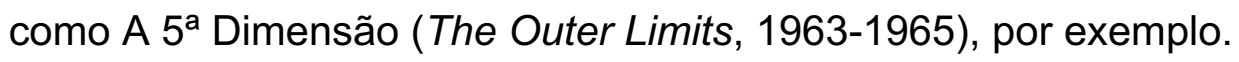

Boa parte dos programas citados não costumam ser lembrados na história da televisão americana, ou mesmo com qualquer ligação com Além da Imaginação, isso pode ser explicado por pelo menos três razões principais: primeiramente, os temas estavam muito ligados a um determinado público que os consumia exaustivamente em uma série de mídias distintas e marcados em um contexto histórico específico, no caso, o desenvolvimento espacial, que ao se tornar parte do passado, passou a ser de interesse mais dos historiadores do que do público em geral; em segundo lugar, muitas das histórias com apelos mais gerais continuaram a ser exploradas em novos programas e filmes, que foram introduzindo outros elementos, dando um sentido de inocência a muito desses programas que eles não tinham na época; e por último, mas não menos importante, o caráter efêmero geral de muitas dessas produções que, por terem sido transmitidas ao vivo ou contarem com cópias precárias, acabaram perdidas ou preservadas em locais de difícil acesso.

Colocado em perspectiva, Além da Imaginação não é uma ruptura na abordagem dos temas insólitos na televisão, mas uma continuidade com qualidade, que ampliou o interesse por essas temáticas, ao mesmo tempo em que elas se desenvolviam em outras mídias, como o cinema e a literatura. Além disso, como nos mostra o pesquisador David Melbye, a série deve ser vista mais como um amplo documento do clima cultural do período, do que como uma mera manifestação autoral de Serling (2016, I.300). A equipe formada por técnicos, atores, diretores e roteiristas, deu o tom cinematográfico geral da série, com uma estética muito próxima ao cinema noir e uma boa qualidade final expressa por parte significativa dos episódios. Ademais, Além da Imaginação tinha disponível um orçamento maior que muitas das séries citadas anteriormente (porém sempre abaixo do esperado pelos envolvidos). Todos esses elementos foram grandes responsáveis pela manutenção de Além da Imaginação como material relevante, sem esquecer as reprises em sistema de syndication após o cancelamento da série em 1964 e a parcela da audiência que cresceu assistindo à série nas décadas de 60 e 70, valorizando o programa dentro da perspectiva das manifestações nostálgicas contemporâneas. 
"You wake up lost in an empty town Wondering why no one else is around Look up to see a giant boy You've just become his brand new toy No escape, no place to hide Here where time and space collide

You have entered the Twilight Zone Beyond this world strange things are known Use the key, unlock the door See what your fate might have in store Come explore your dreams' creation Enter this world of imagination"28 (Rush)

\section{5- Sua próxima parada, Além da Imaginação}

\section{1- Uma placa adiante}

A série Além da Imaginação foi exibida originalmente na televisão americana entre 02 de outubro de 1959 e 19 de junho de 1964 em cinco temporadas, com um hiato entre a terceira e quarta temporada de seis meses entre meados de 1962 e início de 1963, além de reprises entre as temporadas. Após a exibição inicial na rede CBS, a série foi vendida em syndication, o sistema de venda de programação que implica no fato de qualquer emissora poder negociar com a produtora do programa e adquirir os direitos de exibição, sem precisar estar ligada à emissora que produziu ou comprou a série incialmente. No caso de Além da Imaginação, uma coprodução entre a CBS e a Cayuga Productions, após o cancelamento da série, os direitos foram vendidos por

\footnotetext{
${ }^{28}$ Música da banda canadense Rush presente no álbum 2112, lançado em 1976, com músicas inspiradas em temáticas de ficção científica. Na faixa The Twilight Zone é feita uma homenagem a série, no trecho selecionado há referência ao contexto geral da série e ao episódio Stopover in a Quiet Town (1964). "Você acorda perdido em uma cidade vazia/ Se perguntando por quê não há ninguém/ Olha para cima e vê um garoto gigante/ Você agora se tornou seu brinquedo/Sem escapatória, sem lugar para se esconder/ Aqui onde o tempo e o espaço colidem/ Você entrou em Além da Imaginação/ Além desse mundo coisas estranhas são conhecidas/ Use a chave, abra a porta/ Veja o que o destino lhe reservou/Venha explorar a criação de seus sonhos/ Entre nesse mundo da imaginação" [tradução nossa].
} 
Serling, dono da Cayuga Productions, e passaram a pertencer integralmente à CBS. Esta empresa, por sua vez, negociou a série com emissoras menores que, por exemplo, podiam transmitir os episódios na ordem que desejassem, cortando trechos e inserindo os comerciais que bem entendessem.

O sucesso de Além da Imaginação não foi alcançado em sua primeira exibição, não que o período 1959-1964 fosse um fracasso, mas todos os envolvidos esperavam uma audiência maior e mesmo que tivesse uma audiência substancial, em média de dezoito milhões de espectadores por episódio (ZICREE, 1992, p.1), a série não conseguia crescer da forma planejada. Ninguém esperava o sucesso que ela teria após o syndication, superando sua exibição original e, assim como ocorreria posteriormente com Jornada nas Estrelas (Star Trek, 1966-1969), foi nas reprises infindáveis, muitas vezes editadas, feitas por emissoras menores, que a série teve seu reconhecimento ampliado e se tornou uma das mais icônicas da história da televisão, uma marca fortíssima dos temas ligados a ficção científica, horror e fantasia.

\section{2- Audiência e participação}

Sobre a audiência da série de antologia em sua exibição original, entre 1959 e 1964, cabe lembrar que, como dito anteriormente, a aferição da audiência era realizada por família e não segmento, o que contava para os patrocinadores e para a emissora era a audiência total. Entretanto, havia um público bem diverso, com alto poder aquisitivo e de decisão e de compra, que assistia à série, como pode-se ver nas cartas endereçadas ao programa. Uma parcela significativa do público comprometido com a série, dando sugestões, criticando e comentando episódios, era formada por donas de casa e homens com nível superior, além das crianças.

$\mathrm{Na}$ interação entre o público e a série, principalmente da parcela jovem da audiência, é notável o grande envolvimento que ela suscitava. Como exemplo, em carta não datada e respondida por Rod Serling em 11 de janeiro de 1961 (1961c, p.1), o jovem Thomas Broddle afirmava que só havia perdido três episódios desde que a série fora ao ar em 1959, esperava que um novo livro de contos adaptados da série fosse lançado e fazia algumas perguntas, dentre as quais uma a respeito do ano em que o episódio Eye of the Beholder se passaria - Serling respondeu que seria em qualquer ano que ele imaginasse a partir de 1970-, além de pedir uma foto autografada, o que foi atendido, e informações sobre fã-clubes, algo que Serling 
afirmou saber que existiam vários mas não onde eles se localizavam. Outras crianças deixavam claro que os pais as autorizavam a ficar até tarde para assistir a Além da Imaginação, como uma menina de dez anos, que afirmou que era privilegiada pois seus pais deixavam-na assistir à série às 9:30 PM, um horário bem avançado para uma criança de sua idade, segundo a garota (FLOR, 1961, p.1).

Outro menino, de treze anos, escreveu em fevereiro de 1961 que Além da Imaginação era, para ele, o melhor programa da televisão, mas seus pais cada vez mais não lhe permitiam assistir, pois consideravam o programa mórbido e que iria distorcer a mente do menino; ele desejava saber se Serling achava que os pais dele estavam certos, ou se corretos estavam os críticos de televisão que, de forma unânime, o recomendavam (JAECKEL, 1961, p.1). Serling responderia à carta quase um mês depois, sugerindo que o jovem informasse aos pais para eles verem no periódico TV Guide as informações sobre o episódio da semana e decidissem se permitiriam o garoto assistí-lo; além disso, ele informou que o programa tinha um considerável público infanto-juvenil e era recomendado pela Associação de Pais e Mestres, informações fornecidas na tentativa de que o jovem convencesse os pais de que seu programa não Ihe causaria nenhum dano (SERLING, 1961e, p.1).

Já dois anos antes, em 31 de dezembro de 1959, um jovem de quatorze anos afirmou que sua mãe o deixava ficar acordado no horário do programa, pois o programa era muito bom e falava que Serling tinha muita imaginação e que não havia perdido até o momento nenhum episódio (SANTANELLO, 1959, p1).

Outros exemplos interessantes, no campo da crítica a Além da Imaginação: em 19 de novembro de 1960 uma dona de casa, mãe de uma criança especial, escreveu, expressando estar extremamente ofendida com Serling por ter colocado no episódio Nick of Time o ator William Shatner falando para a atriz que contracenava com ele: "Pare de me tratar como uma criança retardada". Na carta, ela explicava que seu marido e ela ficaram chateados e revoltados e que Rod Serling não precisava usar esses termos pois seu programa era bom (KASANDA, 1960, p.1-3). Serling respondeu explicando para a senhora que o roteiro não era de sua autoria (o roteiro era de Richard Matheson, mas ele não fala na carta) e que o autor era uma ótima pessoa e nunca faria algo com a intenção de ferir ninguém, ele se desculpou em nome da série, garantindo que em mais nenhum projeto dele tal ofensa se repetiria, e, por fim, agradecia ter sido chamado a atenção (SERLING, 1960i, p.1). Em carta de três de novembro de 1961, uma outra dona de casa, indignada com o episódio "It's a Good 
Life", afirmou que o programa em questão defendia a ideia de que as crianças estão controlando os pais e os pais modernos são fantoches; o que realmente o episódio apresentava, criticando a dinâmica da família nuclear americana da época, porém, tal retrato das crianças e das famílias ofendeu as sensibilidades e a dona de casa chegou a afirmar que Serling deveria deixar sua máquina de escrever e conhecer famílias americanas reais, pois as crianças eram produtos de Deus e do amor e não seres degenerados, como Serling as estava retratando, segundo a visão enviesada da senhora (HENDERSON, 1961, p1). Outra carta, redigida de forma impecável, criticou duramente a representação do homem que tem uma segunda chance na vida e se torna o Papai Noel no episódio natalino The Night of the Meek (1960), pois ele era bêbado e o programa estaria ensinando as crianças a terem nojo dos mais velhos (HANSEN, 1960, p.1). Outro homem, após assistir ao episódio The Shelter (1961), sobre a destruição das relações humanas frente a um possível ataque nuclear e a disputa pelo uso do abrigo nuclear da única família da vizinhança que o construíra, chegou à conclusão de que o erro principal do pai da família do episódio era não possuir armas e afirmou que já tinha comprado rifles e munição suficiente para proteger o abrigo nuclear de sua família (SMYTH, 1961, p.1).

Nas cartas, também se pode complementar o envolvimento e a aceitação de Rod Serling pela comunidade fã de ficção científica, como notamos pelos convites enviados ao escritor (ARCHER, 1960a, p.1; 1960b, p.1; 1960c, p.1; 1960d, p.1) para que recebesse pessoalmente o prêmio Hugo que vencera em 1960 por melhor apresentação dramática por Além da Imaginação - ele se desculpou pois não poderia comparecer - (Serling ganharia também pela mesma categoria o Hugo em 1961 e 1962). O relacionamento positivo de Serling com os fãs de ficção científica também se manifestava nos empréstimos dos roteiros para fã-clubes mais gerais de ficção científica e não só de Além da Imaginação (como existiam vários na época) e o envio regular de fotos autografadas, além do recebimento recorrente de comentários, sugestões, elogios e críticas muito características dessa comunidade, como, por exemplo, a carta datada de 5 de março de 1960, enviada em papel timbrado da The Chicago Science Fiction League e assinada por Earl Kemp (1960, p.1), que comentava como a ficção científica era tratada na televisão e afirmava que "Além da Imaginação é uma peça de rara magnificência, combinando integridade e bom gosto em proporções corretas para um divertimento relaxante"; posteriormente, Kemp criticaria a fotografia da série e o uso de cenários da MGM reconhecíveis e queria 
saber mais sobre o envolvimento de Rod Serling com a comunidade fã de ficção científica e da convenção onde eram dados os prêmios Hugo, além de oferecer ajuda do seu grupo para promover a série. Serling respondeu que tinha contato com os organizadores da convenção, agradeceu os elogios e se desculpou pelos cenários, acusando restrições orçamentárias para o reuso ou a simplicidade dos mesmos (SERLING, 1960c, p.1). Outros fãs elogiavam os esforços e perguntavam quando histórias clássicas do gênero, escritas por Ray Bradbury e Robert Heinlein, dentre outros, seriam adaptadas na série (GALVIN, 1959a, p.1).

A série, pela temática fantástica, também atraía o interesse de pessoas autodidatas, fãs que se descreviam como portadoras dos mais variados distúrbios, ou grupos de pesquisas de pseudociências famosas na época, como percepção extrasensorial e ufologia. Não era raro Serling receber roteiros não solicitados, escritos por pesquisadores desses temas, ou sugestões de ideias, ou mesmo informações sobre pesquisas e "provas" que estavam surgindo nessas áreas, a fim de que usasse a informação para tornar a série mais verossímil, ou até viam em Serling alguém com os mesmos interesses e que poderia gostar da informação.

Em relatório para Rod Serling não datado, mas pelo texto em período compreendendo a primeira temporada, 1959-1960, sua secretária exclusiva para lidar com cartas de fãs, Connie Olmsted, informava que a maior parte das cartas recebidas eram de donas de casa, mas havia uma grande quantidade de cartas de doutores, dentistas, sacerdotes, adolescentes, fazendeiros e grupos de trabalhadores em escritórios e de aulas de escrita para televisão escrevendo em forma de petição. Havia poucas reclamações, sobre horário, fãs de ficção científica desejando um material mais desafiador, sobre o título e o fato de que o programa foi considerado inteligente demais para eles. Já as aprovações eram em número consideravelmente maiores e elogiavam a criatividade, a exigência de se pensar e até o bom gosto dos comerciais exibidos. (OLMSTED, [1959?], p.1-3). Para se ter uma noção, foram recebidas mais de duas mil cartas de fãs por Rod Serling entre 18 de novembro de 1959 e 21 de dezembro do mesmo ano (ROD..., [1960?], p.1).

A presença de um público infanto-juvenil significativo, ou seja, o apelo da série no mundo infanto-juvenil, consumidor ávido da temática na própria televisão, demonstra o papel formativo desempenhado por Além da Imaginação não só no campo ético-moral, como era de interesse de Serling, mas também em como se relacionar com as obras fantásticas. Serling e o produtor Buck Houghton se 
surpreenderam com a apreciação da série pelo público infantil e não esperavam atingir diretamente esse público, possivelmente sem ainda compreender a mudança pela qual o fantástico passava no segundo pós-guerra como fórum do zeitgeist ou o próprio fato de que as crianças consumiam os mesmos programas noturnos que os adultos ${ }^{29}$. Serling e suas secretárias passariam os próximos anos a enviar fotos autografadas para jovens dos quais recebiam cartas com ideias para histórias, elogios, perguntas sobre episódios, pedidos de autorização para formar fã clubes e declarações amorosas de garotas pré-adolescentes. Ainda, sobre as cartas, é importante destacar que antes mesmo de a série ir ao ar, foi estabelecida uma política sobre as respostas às cartas de fãs, com endereçamento daquelas que Serling e Houghton não quisessem responder para uma equipe responsável por respostas, pessoais ou padrões, e envio de cartões de agradecimento (GRAMS JUNIOR, 2008, p.57).

Não só fãs de diversos gêneros, faixas etárias, etnias e raças, além de aspirantes a roteiristas ou roteiristas profissionais e seus agentes enviavam cartas a Rod Serling; agentes de atores famosos e em ascensão no período, bem como atores amadores e profissionais, se comunicavam regularmente com Rod Serling, na categoria de produtor executivo e proprietário da Cayuga Productions, oferecendo-se para trabalhar na série, demonstrando o prestígio do programa, visto pela comunidade de atores na época como algo diferente. Alguns atores tentaram mais de uma vez negociar sua participação, como DeForest Kelley, que futuramente faria o icônico Dr. Leonard McCoy na série Jornada nas Estrelas (Star Trek, 1966-1969), inclusive com seu agente informando que o ator era fã da série em carta endereçada diretamente a Serling em 20 de junho de 1960, e que gostaria de pessoalmente discutir a possibilidade de fazer um episódio (WILKINS, 1960a, p.1; 1960b, p.1).

Dos prêmios mais conhecidos, a série Além da Imaginação venceu três Emmys no total em suas cinco temporadas, dois para Serling pelo conjunto de roteiros $(1960,1961)$ e um para o diretor de fotografia George T. Clemens (1961), um Globo de Ouro pelo trabalho de produção de Serling, e três Hugo por apresentação

\footnotetext{
${ }^{29}$ O professor Edgerton destaca a pesquisa sobre a audiência infanto-juvenil que o sociólogo Leo Bogart realizou na década de 50 que demonstrou que em 1952 o programa mais popular entre as crianças de ambos os sexos até 10 anos era The Howdy Doody Show, e entre 11 e 16, I Love Lucy e Texaco Star Theater, programas voltados para os adultos. Se Rod Serling ou Buck Houghton tiveram acesso a essa pesquisa nada encontrei, mas talvez se a tivessem analisado, não ficassem tão surpresos com a audiência atingida.
} 
dramática de ficção científica (1960,1961 e 1962). O Hugo ainda não tinha adquirido o prestígio atual, mas foi um reconhecimento importante da comunidade fã de ficção científica que costumava ser extremamente crítica em relação às obras apresentadas em quaisquer meios.

O nome do criador e principal roteirista da série, Rod Serling, se tornou parte da cultura americana, associado à Além da Imaginação (ZICREE, 1992, p.2). Os próprios livros, teses e artigos que discutem a série citam o papel autoral de Serling, demonstrando como Além da Imaginação, de certa forma, expressava uma maneira de ver o mundo consoante com a do próprio Serling, mesmo quando escritos por outros roteiristas ou tivessem elenco e diretores desenvolvendo ou alterando os roteiros, impressão que era reforçada não só pelo envolvimento do roteirista e criador com a produção e autoria de maior parte dos roteiros, mas principalmente por seu papel de narrador e apresentador do programa. Um exemplo dessa impressão eram as cartas de telespectadores dirigidas a Serling para questionar, criticar e comentar aspectos de episódios que não tiveram participações diretas de Serling, que, por sua vez, gentilmente encaminhava as cartas para os roteiristas e/ou respondia, como citado anteriormente, que não era o autor de determinado episódio. Entretanto, sua persona pública ficou marcada de forma indelével pela série, o que é patente ao se assistir às tentativas de se refazer Além da Imaginação nas décadas de 80, 2000 e 2010, pois, nessas séries, mesmo que existam versões atualizadas para seus roteiros antigos, falta algo indescritível e muito mais profundo que apenas o papel da fotografia e do preto-e-branco na série original; falta a presença de Serling, tanto como apresentador icônico quanto como criador do conceito da Zona Crepuscular, tradução literal do título original da série em inglês The Twilight Zone.

Os trabalhos realizados por Serling na "Era de Ouro" construíram sua carreira como roteirista respeitado no meio e colocaram em foco o papel do roteirista de televisão, ente não muito lembrado ou conhecido pelo público geral. Seu reconhecimento no meio e pelo público - mesmo que não conhecessem seu rosto, mas apenas os créditos nos programas - vinha de antes da série Além da Imaginação, momento em que, finalmente, seu rosto se tornou reconhecível ao grande público graças a sua onipresença de frente às câmeras em anúncios dos próximos episódios e na própria série como anfitrião, iniciada de forma satírica no final da primeira temporada e depois incorporada nas quatro temporadas seguintes, já que na primeira temporada, só se ouvia sua voz narrando a introdução e o desfecho dos episódios. 
Portanto, para melhor compreender a relação de Serling, Além da Imaginação, outros grandes artistas e seu contexto, a fim de retirar da série dados que nos permitam entender melhor as relações com tempo, História e mudança no período, é necessária uma breve passagem pela ascensão de Serling na televisão americana, como ele conseguiu criar e ser referência em uma série que lidava com temas não relegados como exemplos de qualidade e dramaticidade séria e adulta, saindo de uma carreira de sucesso em programas respeitados pela crítica, mas fadados à extinção em uma mídia em constante inovação. Como alguém que levava dramas humanos e conflitos reais para os lares dos americanos na década de 50 terminaria expressando sua crítica social, usando ficção científica, horror, mistério e fantasia?

\section{3- Aquele homem branco de terno que fuma}

Rodman Edward Serling nasceu em uma família judaica de classe média no Dia de Natal de 1924 em Syracuse, uma cidade do estado de Nova York. Ele tinha um irmão mais velho chamado Robert Jerome Serling e ambos se tornariam escritores. Sua família se mudou para Binghamton, estado de Nova York, quando ele tinha dois anos e foi nessa cidade que Rod Serling passou sua infância e adolescência. Por toda sua vida, essa cidade e seus arredores seriam referenciais valorizados pelo autor, como veremos de forma clara em Além da Imaginação.

Binghamton e sua região, área conhecida como Triple Cities (Cidades Triplas) (Binghamton, Johnson City e Endicott), não sofreram tanto como o resto do país com a crise de 1929, as indústrias locais se mantiveram saudáveis naquele período (SANDER, 2011, p.20), principalmente a Endicott-Johnson Corporation, famosa indústria capitaneada por George F. Johnson (1857-1948), que aplicava na região com uma visão de melhorar as condições dos trabalhadores com o investimento em bibliotecas, parques, transporte, habitação, atendimento médico, ao mesmo tempo que mantinha a fidelidade de seus contratados, dentro da perspectiva do Square Deal (ZAHAVI, 1988, p. 37-62; p.126-149).

Na escola, o jovem Serling fez parte do grupo de debates e escreveu no jornal da instituição, demonstrando preocupação social e ativismo. Sua postura frente à entrada dos EUA na Segunda Guerra Mundial foi de apoio total e até desejava se alistar no último ano do ensino médio, sem o completar, o que foi desaconselhado por um professor. Assim, no dia seguinte a sua conclusão do período escolar, ele se 
alistou no exército com a intenção de combater os nazistas - o fato de ser de família judaica tornava a questão ainda mais pessoal. Porém, após seu período de treinamento como paraquedista, foi enviado ao teatro de guerra no Pacífico em 1944 , nas Filipinas. Sua experiência presenciando os horrores da guerra o marcou psicológica e fisicamente de forma profunda por toda sua vida, um ferimento no joelho acompanharia Serling, causando quedas inesperadas (SANDER, 1992, p.47). Os temas ligados a dilemas e crítica da guerra e à busca da humanidade em momentos absurdos de violência estão presentes de forma clara na série Além da Imaginação, inclusive uma das primeiras citações na televisão ficcional americana sobre a guerra do Vietnã se deu em Além da Imaginação, no episódio In Praise of Pip exibido em setembro de 1963, inclusão esta que foi um pedido da emissora.

Figura 14 - Arco celebrando o Square Deal em Endicott (NY). Dois arcos semelhantes foram erguidos pelos trabalhadores da Endicott-Johnson Shoe Company em homenagem a George F. Johnson na região das Triple Cities.

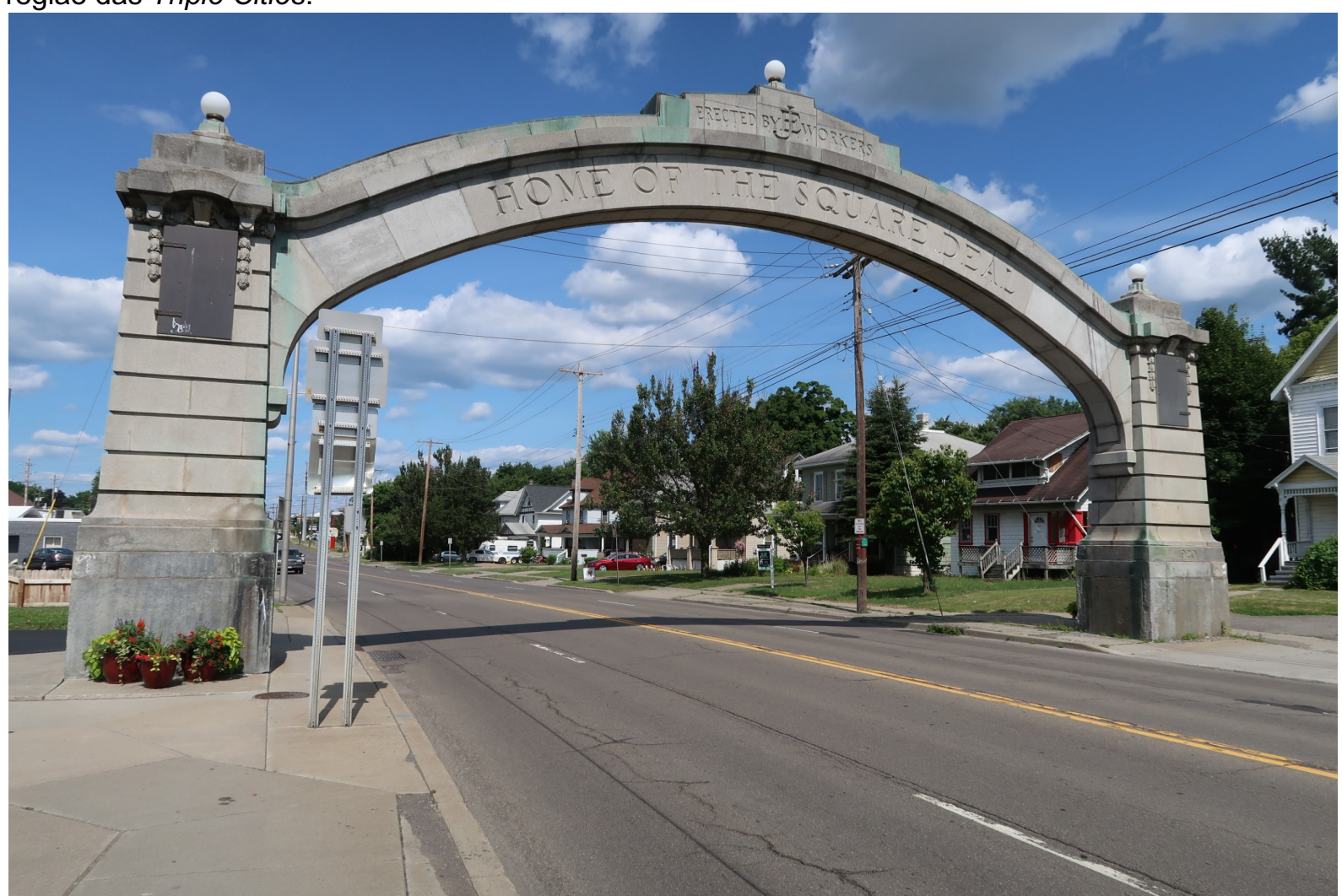

Fonte: fotografia tirada pelo autor (Endicott, NY, EUA, 2018)

Após a Segunda Guerra Mundial, ele participou das forças de ocupação no Japão, deixando o exército em 1946. Tendo concluído sua fase militar, entrou na Antioch College, em Yellow Springs, Ohio, uma faculdade conhecida no período por ser um ambiente liberal, paga com um financiamento para feridos na guerra e pela 
G.I. Bill, a Servicemen's Readjustment Act of 1944 (Lei de reajuste dos militares de 1944, em tradução livre), uma legislação voltada à inserção dos soldados veteranos na sociedade que, por exemplo, ajudava na compra de imóveis, fazendas ou abertura de negócios ao emprestar dinheiro com juros baixos e, principalmente, financiava os estudos em todos os níveis (EUA, 1944); um dado de 1947 mostra que 49\% dos alunos matriculados nas faculdades americanas eram veteranos da Segunda Guerra Mundial (EDGERTON, 2007, p.156). A lei "ajudou a democratizar o sonho americano de ser dono de uma propriedade e viver uma boa vida" (Ibid., p.156).

Serling, inicialmente, tinha a intenção de se tornar professor de Educação Física, mas sua vida no ambiente acadêmico o levou a abandonar suas intenções originais ao ampliar seu interesse por teatro, radiodifusão e literatura. Mudando sua formação para Literatura, Serling se graudou com o título de Bacharel em Artes em 1950.

Entretanto, antes de concluir sua graduação, ele já encontrava espaço no meio do rádio e televisão locais e se profissionalizava, inicialmente na rádio do campus, dirigindo, atuando e escrevendo roteiros, passando por estágio e trabalhos em outras estações de rádio, em programas não transmitidos nacionalmente, cujos custos eram pagos pelas próprias emissoras, sem interferência de patrocinadores (GRAMS JUNIOR, 2008, p.1). Essa experiência nos meios de comunicação foi fundamental e seria aproveitada ao máximo no futuro, principalmente a forma de se conceber e organizar histórias. Ademais, os roteiros dessa primeira fase de sua carreira seriam constantemente reescritos e reaproveitados quando seu nome fosse conhecido nacionalmente.

O maior sucesso de Serling no período de estudante na faculdade foi ter ficado em segundo lugar no concurso de roteiro do Dr. Christian, um programa da rádio CBS sobre um médico de cidade do interior, que resolve problemas dos seus pacientes e da cidade usando bom senso. Serling foi receber o prêmio em Nova York e teve seu roteiro transmitido nacionalmente em novembro de 1949 (ele já havia tido roteiro transmitido nacionalmente em um programa menor no mesmo ano), sua história para o Dr. Christian era referente a um pugilista com leucemia que treina um novo boxeador. O tema do pugilismo e boxeadores também acompanharia Serling em sua carreira (ele próprio fora pugilista no exército, tendo seu nariz quebrado); o boxeador foi utilizado por Serling em diversas obras para discutir a questão do recomeço, da alienação, do preconceito, da fé, da integridade e da obsolescência. 
Ainda no período da faculdade, conheceu sua esposa Carol Serling, convertendo-se ao Unitarismo, corrente teológica cristã que prega, dentre outras coisas, que Jesus era um homem inspirado por Deus, mas não Deus encarnado, além de não aceitar a ideia de Deus se manifestar na trindade Pai, Filho e Espírito Santo, sendo Deus uma única entidade. Serling, porém, nunca foi assíduo em sinagogas ou igrejas, mesmo que financiasse projetos judaicos e cristãos.

Figura 15 - Recreation Park em Binghamton (NY), local onde Serling cresceu. Na fotografia, o coreto do parque e a construção que abriga o carrossel (a direita no fundo). A experiência da infância e juventude nessa cidade seria sempre retomada em Além da Imaginação. Uma versão cenográfica desse parque está presente no episódio Walking Distance da primeira temporada da série.

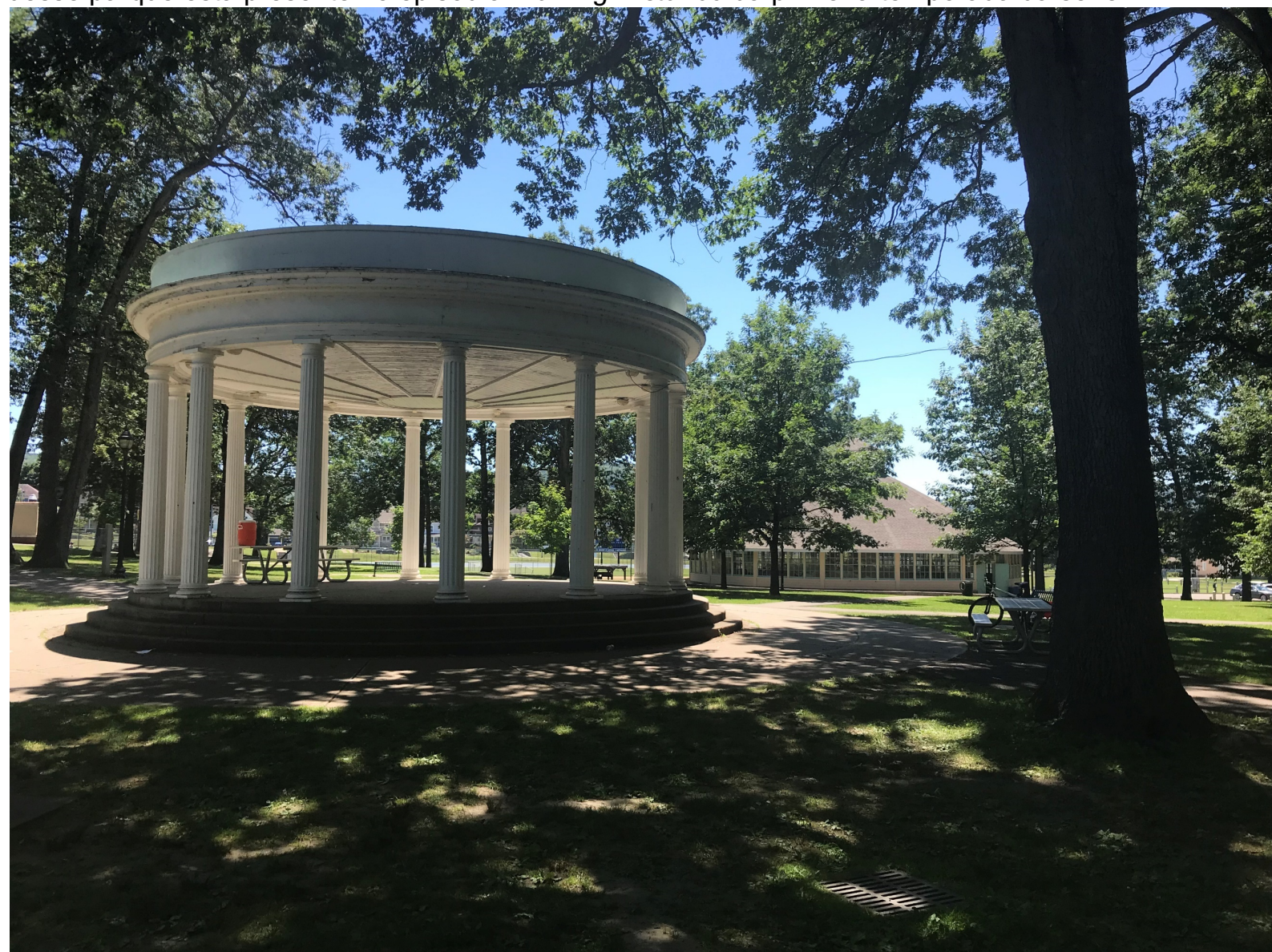

Fonte: fotografia tirada pelo autor (Recreation Park, Binghamton, NY, EUA, 2018)

Em 1950, ele foi contratado pela Crosley Broadcasting Corporation em Cincinnati, Ohio, emissora que tinha a rádio WLW e a televisão WLWT, ambas em nível local. Em seu primeiro trabalho profissional na WLW, Serling escrevia roteiros de documentários, guias de viagem e programas de comédia. Ao mesmo tempo, vendia roteiros dramáticos para a concorrente, a WKRC-TV, também de Cincinnati, 
produtora de programas que apresentavam o tipo de material dramático de seu interesse.

Como explicado pelo pesquisador Martin Grams Junior (2008, p.7), o processo de vender uma ideia que virasse roteiro para um programa dramático se iniciava com a submissão para um produtor ou editor de história de um texto com no máximo vinte páginas que contivesse a narrativa, explicasse as mensagens transmitidas pela história, técnicas de câmera que seriam necessárias ou outros dados relevantes da transmissão. Em caso da proposta ser aceita, se não fosse considerado experiente, o autor da ideia não fazia o roteiro e, muitas vezes, os programas tinham seus próprios roteiristas contratados, que transformavam a ideia em um material para apresentação final.

Procurando alcance para suas obras, Serling decidiu se tornar escritor autônomo, não desistindo após receber inúmeras rejeições de emissoras e produtores. Nesse período, segundo o professor de comunicação da University of Cincinnati-Blue Ash College, H. Michael Sanders, Serling fez as primeiras versões de roteiros que reescreveria com mais habilidade durante sua carreira, sendo extremamente bem-sucedido no processo de reutilização de ideias e cenários em outros contextos (KIESEWETTER, 2014). Para vender suas ideias, Serling recorreu em 1950 à agente Blanche Gaines em Nova York, que intermediava a venda dos roteiros para os programas de televisão de antologia dramática ao vivo, símbolos da televisão nova yorkina. Foram nesses programas que Rod Serling faria fama durante a década de 50.

Serling conseguiu vender roteiros para os dramas ao vivo que preenchiam a programação de todos os canais, demandando sempre novos materiais e abrindo espaço para mais roteiristas. Mesmo com baixa qualidade artística, ou inovação, ou mesmo limitado desenvolvimento dos personagens, os roteiros de Serling dessa fase - e os mais simplórios de sua carreira televisiva - sempre buscavam discutir e apresentar a condição humana e chegar em uma verdade emocional (ZICREE, 1992, p.7); isso não era comum na maior parte dos programas televisivos do início da década de 50 e abriu espaço para Serling no meio da nova mídia ascendente.

O primeiro grande momento na televisão para Serling foi a exibição de seu roteiro Patterns (Padrões, em tradução livre) no programa Kraft Television Theater, prestigiosa série de antologia dramática ao vivo, pioneira ao ir ao ar ainda em 1947 (TIBBETTS, 2008, p.380), um programa patrocinado pelo conglomerado alimentício 
Kraft Foods, que nomeava a atração. Em Patterns, apresentava-se a tocante história de um jovem que é contratado para substituir um antigo executivo em uma grande corporação e tem seus valores éticos e morais testados pelo inescrupuloso presidente da empresa, apontando não só questões individuais dos dilemas dos personagens, que poderiam ser transportadas para quaisquer relações de poder do mundo contemporâneo, mas principalmente o episódio acabava por fazer uma asserção clara sobre o mundo corporativo desumano fortalecido no segundo pós-guerra, em uma trama na qual se constrói um ciclo infernal movido pela racionalização pura capitalista das relações de trabalho, valorizando a competição e descartando qualquer pessoa, na narrativa, devido a idade e por manter valores morais humanísticos, que potencialmente perturbassem a busca da ampliação dos negócios e lucros.

Recebida com elogios pelo público e pela crítica da época, a apresentação original foi transmitida ao vivo em 12 de janeiro de 1955 e reencenada em 9 de fevereiro do mesmo ano, algo incomum na televisão americana (ZICREE, p.9). No concurso do Prêmio Emmy em 1956, Serling competiu em duas categorias, pelo roteiro de Patterns, em "Melhor Roteiro Original de Televisão", e em "Melhor Adaptação" com The Champion, a tragédia de um inescrupuloso pugilista que usa as pessoas a seu redor, uma versão televisiva da história Champion de Ring Lardner, previamente adaptada em filme de mesmo nome em 1949 (no Brasil, intitulado O Invencível). Serling ganharia seu primeiro prêmio Emmy de sua carreira pelo roteiro original de Patterns (acumularia seis Emmy em sua vida) e perderia o de roteiro adaptado, esse Emmy sendo dado para Paul Gregory e Franklin J. Schaffner pelo roteiro de The Caine Mutiny Court-Martial (A Corte Marcial do Motim do Caine). Patterns foi adaptado para o cinema pela MGM, com roteiro de Serling, e lançado em 27 de março de 1956 em Nova York, recebendo no Brasil o título de A História de um Egoísta.

No mesmo ano de 1956, o prestígio de Serling seria ampliado não só pelo prêmio referente ao ano anterior e por seus roteiros, mas com a nova proposta ambiciosa e pretenciosa da rede CBS de lançar um programa reunindo os melhores atores, diretores, roteiristas e técnicos para produzir dramas de qualidade nunca vistos na televisão, o programa Playhouse 90 (1956-1960), que se tornaria posteriormente um dos pontos altos da "Era de Ouro". Playhouse 90 trazia a novidade de em vez dos tradicionais 60 minutos de performances dramáticas que existia na época, a CBS, toda semana, exibiria programas ao vivo e em filme de uma hora e trinta minutos - 
para cada três episódios ao vivo, o quarto seria feito em filme, plano abandonado no ano seguinte com gravações em videoteipe -, com orçamento considerado alto para a época de USD 10.000,00, realizados no recém inaugurado complexo Television City em Los Angeles.

Rod Serling, contratado com exclusividade pela CBS após o sucesso de Patterns, tinha seus roteiros frequentemente encenados em Playhouse 90, inclusive a estreia do programa era uma adaptação de Serling para o thriller da Guerra Fria, Forbidden Area (Área Proibida, em tradução literal), de Pat Frank, lançado no mesmo ano, dirigido por John Frankenheimer e estrelado por Charles Bickford, Charlton Heston, Diana Lynn, Tab Hunter, Victor Jory e Vincent Price.

Transmitido ao vivo, Forbidden Area é uma obra que faz parte do clima da Guerra Fria, utilizando todos clichês de histórias de espionagem ao apresentar um espião soviético "ilegal" - agentes do bloco soviético com documentos forjados de cidadão americano, falantes de inglês sem sotaque e totalmente integrados a sociedade americana- , plantado no Strategic Air Command para fornecer aos pilotos dos bombardeios americanos bombas de pressão escondidas em garrafa térmicas de café que seriam abertas durante o voo e explodiriam as aeronaves. O plano estava em andamento avançado quando é descoberto por acidente e um contra-ataque para impedir os soviéticos é feito, causando uma alteração na liderança do governo da URSS que, por fim, cancela as suas intenções. A obra termina com um indicativo de paz no devir, reforçada pela ação do presidente dos EUA, que vai contra seus líderes militares, desejosos da destruição da URSS, pois no futuro poderia haver paz entre as duas nações, assim como ocorrera com o ex-inimigo anteriormente odiado, 0 Japão. A estreia de Playhouse 90 não recebeu críticas entusiasmadas como o esperado e do tamanho das pretensões do programa que, na noite de seu lançamento, foi anunciado por Jack Palance como a mais importante nova série dramática da televisão.

Já o segundo episódio semanal ao vivo de Playhouse 90, agora um roteiro original de Rod Serling, o drama "Requiem for a Heavyweight" (Réquiem para um Peso-pesado, em tradução literal), foi exibido 11 de outubro de 1956, extremamente elogiado tanto pela crítica especializada quanto pelo público (ZICREE, p.12). Dirigido por Ralph Nelson e elenco composto por Ed Wynn, Jack Palance, Keenan Wynn e Kim Hunter, mostrava a história do boxeador McClintock, que perde uma luta e tem sua carreira encerrada por ter sofrido danos neurológicos que poderiam cegá-lo ou 
mesmo matá-lo se continuasse lutando. McClintock tenta organizar sua nova vida, tendo que lidar com seu empresário, que vislumbra uma carreira na luta-livre combinada para recuperar dinheiro que havia perdido em apostas com a máfia, o que não é aceito pelo boxeador. Ele acaba rompendo o relacionamento com seu empresário e "cutman" (assessor que cuida dos machucados entre os rounds das lutas) ao ter sua confiança abalada quando descobre que a perda de dinheiro de seu amigo para a máfia envolvia a aposta em sua derrota em sua última luta. Porém, paralelamente, McClintock encontra o auxílio de uma agente de empregos que o ajuda a ganhar confiança e fazer a transição para uma carreira ensinando crianças. $O$ drama do pugilista McClintock venceu cinco prêmios Emmy dos sete pelos quais competia, o segundo de Serling. Posteriormente, Requiem for a Heavyweight foi encenado em países europeus e, assim como Patterns, transformado em filme homônimo em 1962 (No Brasil, Réquiem Para um Lutador), com roteiro de Serling e dirigido novamente por Ralph Nelson, além da atuação de Anthony Quinn e Cassius Clay (encenando a si próprio, antes de se converter ao islamismo e passar a se chamar Muhammad Ali). Os bastidores da produção de Requiem for a Heavyweight na Playhouse 90 foram explorados no docudrama The Man in the Funny Suit, escrito e dirigido por Ralph Nelson e transmitido na Westinghouse Desilu Playhouse em 1960.

No ano de 1957, Serling era um nome extremamente respeitado no meio artístico e, nas suas viagens para a Califórnia, acabou trocando a agente Blanche Gaines pela Ashley-Steiner Agency, agência que seria responsável pela negociação de seus contratos de trabalho durante a exibição de Além da Imaginação. A justificativa dada era a de que como os principais programas agora estavam do outro lado do país, não havia mais necessidade de representação em Nova York. Dentre os principais roteiros de Serling na televisão nesse mesmo ano, estão a adaptação do conto de Ernest Lehman, o drama The Comedian (O Comediante, em tradução literal) e The Dark Side of the Earth (O Lado Escuro da Terra, em tradução literal). The Comedian foi dirigido por John Frankenheimer e estrelado por Mickey Rooney, sendo exibido no Playhouse 90 dia 14 de feveireiro de 1957. A história, que venceria o terceiro Emmy de Serling (o episódio venceu no total dois Emmy), apresentava um narcisístico comediante que ganha seu próprio programa de televisão e abusa de todos que o rodeia, principalmente seu irmão. Já The Dark Side of the Earth, aclamado pela crítica no período, foi também exibido no Playhouse 90 em 19 de setembro de 
1957 e exibia um drama que se passava durante a fracassada Revolução Húngara contra os soviéticos de 1956.

Em 19 de junho de 1958, foi ao ar A Town Has Turned to Dust (Uma cidade virou poeira, em tradução literal), roteiro de Serling que mostrava uma história de racistas de uma cidade pobre que descontam a raiva de seus fracassos nos imigrantes mexicanos. Essa obra, que discutia o ódio e a questão racial, foi modificada por Serling após sofrer pressões dos patrocinadores, pois a sua intenção original era a de retratar uma história semelhante ao caso de Emmett Till, jovem negro linchado em Money, Mississipi em 1955, o que era considerado polêmico demais pelos anunciantes, e foi mais um dos embates que desanimavam Serling entre a posição de autor, de um lado, e os patrocinadores e executivos, de outro. Roteiros anteriores, que foram também revisados por pressões de patrocinadores e emissoras, a ponto de se tornarem meros vultos das intenções originais de Serling, foram The Arena, exibido em abril de 1956 no programa Studio One, um drama que se passava no mundo político de Washington, e Noon on Doomsday, tentativa prévia de Serling de discutir o caso de Emmett Till exibido também em abril de 1956 no programa The United States Steel Hour (SANDERS, 1992, p.230-231). As interferências intrusivas em seus roteiros e os constantes embates para defender suas visões o incentivaram a se dedicar à busca da liberdade criativa, que ele encontraria futuramente em Além da Imaginação (ZICREE, 1992, p.14-15).

Rod Serling escreveu no total, entre 1957 a 1960, dez roteiros para Playhouse 90 e o último episódio para a famoso programa da Era de Ouro foi assinado por ele, fechando a série de antologia que estreara anos antes. O drama In the Presence of Mine Enemies (Na presença de meus inimigos, em tradução literal), exibido em 18 de maio de 1960, é uma história que se passa no Gueto de Varsóvia durante a ocupação da Polônia na Segunda Guerra Mundial. A abordagem de Serling recebeu elogios pela caracterização profunda dos personagens e os dilemas enfrentados. O roteiro de In the Presence of Mine Enemies foi refeito em um filme para televisão nos EUA em 1997, dirigido pela diretora Joan Micklin Silver. O último episódio original de Playhouse 90 foi transmitido dois dias antes do episódio de Serling para Além da Imaginação, $A$ Passage for Trumpet, o trigésimo segundo da primeira temporada. 


\section{4- Submetido para a sua aprovação}

Em meados de 1957, Rod Serling iniciou negociações com a CBS para a realização de uma nova série de ficção científica e fantasia, aproveitando seu prestígio como roteirista. Foi divulgada publicamente a informação no início de 1958 de que Serling preparava uma série para a CBS chamada The Twilight Zone (GRAMS JUNIOR, 2008, p.17,22), em tradução literal, Zona Crepuscular - no Brasil, a série receberia futuramente o título de Além da Imaginação

A ideia de Serling de alterar o rumo de sua carreira de roteirista, deixando em segundo plano histórias ancoradas em temáticas realistas vistas como adultas, focando em narrativas insólitas, se deu por sua percepção de que os temas que mais gostaria de discutir não recebiam tanta atenção dos censores ao serem retratados como algo fantástico, pois na época podia-se confundir as diversas censuras ao propor algo que supostamente não tinha base no real e tampouco ligação com pessoas ou instituições concretas, mas seriam obras ditas apenas imaginárias que demandavam uma interpretação não literal e subjetiva, interpretações essas que podiam ser rejeitadas mais facilmente ao serem identificadas com os temas a serem evitados por motivos sociais e políticos. As falsas noções dessas temáticas como deslocadas do real e infantis eram incentivadas irônica e cinicamente por Serling, como ele o fez em na entrevista ao jornalista Mike Wallace no programa The Mike Wallace Interview, da ABC, em 22 de setembro de 1959, ao concordar com o apresentador que perguntara se ele havia desistido de fazer programas sérios na televisão.

Serling se interessava pelos temas fantásticos e sabia seu potencial crítico e de entretenimento, tendo escrito roteiros já no início da carreira lidando com ficção científica, além de ser leitor de pulps em seu período formativo. Ao mesmo tempo, ele também notou que os dramas ao vivo estavam sendo cancelados e que a sua busca por qualidade na televisão em temas de teor mais realista seria fadada ao fracasso, com cada vez mais interferência dos patrocinadores e executivos nos programas.

A série Além da Imaginação, se fosse realizada como ele intencionava, lhe daria uma enorme liberdade criativa e garantiria seu trabalho, escrevendo sobre os temas humanos que gostava de discutir, utilizando o fantástico e insólito como subterfúgio. Curiosamente, inclusive por causa de Além da Imaginação, tornou-se mais claro para o público e para os executivos, patrocinadores e censores o uso que 
pode ser feito de obras com o disfarce de serem apenas imaginárias e falsamente sem base na realidade, deslocadas das questões do dia-a-dia. Porém, a possível conclusão de que Além da Imaginação lidava com temas polêmicos enganando a audiência da época, composta inclusive dos censores, ao recorrer a alegorias, não é de todo real e deve ser vista com cuidado. Como atestam cartas enviadas para Serling, inclusive por crianças e jovens, o público que interagia com a série muitas vezes demonstrava textualmente compreender suas mensagens críticas, mesmo que não concordasse com a abordagem ou a visão política expressa. Ademais, existem indicativos de que parcelas do público desenvolviam uma relação literal com o exposto, mas as nuances não passavam desapercebidas. Por exemplo, nota-se em diversas cartas elogiando os episódios The Monsters are Due on Maple Street e Eye of the Beholder pela forma como esses episódios criticaram os preconceitos e a paranoia e não pela forma que lidaram com o medo de alienígenas ou pessoas com feições suínas. Um jovem estudante do ensino médio, em 1961, comentava que os americanos ignorantes talvez reconhecessem Rod Serling no futuro não só como um "grande escritor de fantasia e imaginação, mas também seriam capazes de analisar as alegorias que estavam incutidas em suas histórias" (HICKEY, 1961, p.1, tradução nossa).

O que o recurso ao horror, ficção científica e fantasia fornecia ao retratar questões potencialmente controversas de forma alegórica eram melhores explicações para possíveis críticas e contestar ações visando à censura, o que era reforçado em Além da Imaginação pelo uso recorrente da ironia, forma tradicional de transmitir crítica social. Outro recurso era o uso de elementos previamente associados com escapismo e entretenimento descompromissado, utilizando o próprio preconceito do meio como forma de buscar uma liberdade de expressão (MELBYE, 2016, I.605). Cabe deixar claro que, ao adquirir maior experiência como roteirista, Rod Serling se autocensurava conscientemente, tendo noção de até onde podia levar a crítica ou as formas de expor determinadas situações na televisão (GRAMS JUNIOR, 2008, p.103).

Durante a longa negociação, Serling escreveria pilotos que teriam elementos utilizados posteriormente no desenvolvimento da série, reaproveitando ideias. $O$ primeiro roteiro abandonado após as negociações preliminares da série, segundo o pesquisador Martin Grams Junior. (Ibid., p.22), era a história de um executivo que escapava das pressões diárias do seu trabalho em Nova York ao sonhar no trem durante a viagem diária que fazia entre a cidade e sua casa em Connecticut. Esse 
conceito se tornaria depois $A$ Stop at Willoughby, trigésimo episódio da primeira temporada de Além da Imaginação. Outro piloto escrito nesse interim foi I Shot An Arrow Into The Air (sem relação com o episódio homônimo lançado na primeira temporada), um roteiro com ideias semelhantes ao filme de Robert Wise, O Dia em que a Terra Parou (The Day the Earth Stood Still, 1951), sobre satélites e a chegada de um alienígena que faz amizade com um jovem na Terra e descobre que os humanos ainda não estão prontos para as maravilhas de seu planeta, deixando com o menino a oportunidade de realizar uma mudança de mentalidade na humanidade e o fim do ódio entre os povos (fim da Guerra Fria). O roteiro termina mostrando o futuro, no qual o jovem, agora astronauta adulto, faz contato com os alienígenas que retornaram. Esse piloto foi abandonado e nunca chegou a ser filmado, porém, parte da premissa foi reutilizada no episódio da terceira temporada de Além da Imaginação The Gift.

O roteiro não datado de I Shot An Arrow Into The Air tinha a presença de uma versão para a narração da abertura da série, indicando o que seria a Twilight Zone/Zona Crepuscular e um narrador apenas no início do episódio, sem o retorno no final, o contrário do que foi utilizado na série produzida, onde a voz do narrador era ouvida tanto no início, para apresentar o enredo, quanto na conclusão, geralmente reforçando de forma poética o que foi visto. O texto original do episódio piloto, que seria em parte adaptado com intenções irônicas no episódio homônimo da primeira temporada, dizia:

O tempo pode ser a qualquer momento. Podemos chamá-lo hoje, ou amanhã, ou depois de amanhã. Os diretores podem ser você ou eu, ou qualquer espectador para uma cena em que um homem, a criança do século $\mathrm{XX}$, continue seus primeiros, incertos, instáveis, mas esperançosos passos rumo ao céu.

Como o cone da "Flecha Dez" é um dispositivo pequeno, circular e metálico conhecido como satélite, feito pelo homem, ele foi construído de modo que seu interior seja um ambiente em que a vida humana possa existir. É uma viagem relativamente curta de seus quartéis para a plataforma de lançamento, talvez apenas uma centena de metros. Mas a jornada é consideravelmente mais longa quando medida em termos de anos de trabalho, tempos de falhas, momentos sem fim de esperanças frustradas. Porque esta não é a primeira Flecha. Ela foi enviada para o céu uns doze anos antes.

Um descendente anterior chamado Flecha Um então ocupou o local, nariz para cima elegante, uma caneta-tinteira elegante, branca e graciosa que se esforça para deixar a Terra. 
Isso foi há doze anos. Este foi o começo. ${ }^{30}$ (SERLING, 1958r6, p.I-1-I$3 \mathrm{~A}$, tradução nossa)

Em plena negociação com a CBS, com uma ideia mais definida para a série, Serling trabalhou no roteiro de The Happy Place, uma distopia depressiva sobre um futuro onde os mais velhos de 60 anos eram eutanasiados, sua proposta de primeiro episódio para Além da Imaginação ${ }^{31}$. Um tema problemático para ser o episódio que venderia a série para os patrocinadores, que provavelmente não estariam dispostos a associar seu nome com a morte de idosos na mão do Estado: por isso e questões de gostos de executivos, a emissora não teve interesse em produzí-lo, rejeitando o roteiro - Serling tentaria futuramente utilizar o material na quarta temporada de Além da Imaginação, quando a série teria uma hora de duração, mas o texto foi novamente rejeitado pela CBS (GRAMS JUNIOR, 2008, p.25,29). Sem um roteiro capaz de vender a série, ela não sairia do papel e, sem desistir, Rod Serling, apresentou um novo roteiro para a CBS. Parte do conceito de The Happy Place foi reaproveitado posteriormente em Além da Imaginação, no episódio da segunda temporada The Obsolete Man.

\footnotetext{
${ }^{30}$ No original: The time might be any time. We could call it today, or tomorrow, or the day after tomorrow. The principals could be you or I, or any onlooker to a scene where a man, the twentieth century infant, continues his first, unsure, unsteady but hopeful steps into the sky. As the cone of the "Arrow Ten" is a small, circular, metal device known as Satellite, man made.It has been constructed so that in its interior is an enviroment in which human life can exist. It is a relativity short trip from his barracks to the launching pad, perhaps only a hundred yards. But the journey is considerably longer when measured in terms of years of work, times of failures, endless moments of frustated hopes. For this is not the first Arrow. That was sent up into the sky some twelve years before. An early descendent called the Arrow One then occupied the spot, nose skyward a sleek, White, graceful fountain pen straining to leave the earth. This was twelve years ago. This was the beginning.

${ }^{31}$ A reflexão sobre a idealização do novo e da juventude como valores inquestionáveis em oposição a um mundo antigo e idoso que deveria ser apagado, de forma muito semelhante a ideia de Serling em finais dos anos 50 , foi discutido por autores sem qualquer contato pessoal direto, como, por exemplo, a obra do escritor argentino Adolfo Bioy Casares, Diário da Guerra do Porco (Diario de la guerra del cerdo) de 1969, indicando uma polêmica debatida com preocupação pelas artes.
} 


\section{5- O Elemento do Tempo}

Em uma nova tentativa de vender a série, Serling reaproveitou um roteiro seu que narrava uma viagem no tempo a Pearl Harbor em 1941 chamado The Time Element. Essa história havia sido escrita por Serling em 1951, após o termino da faculdade, para o programa de dramas de antologia The Storm, da WKRC-TV de Cincinnati. Ele expandiu o material para uma hora, ajustou a história e submeteu o roteiro para a CBS com a intenção de que o piloto fosse aceito pela diretoria da CBS. Intitulado The Twilight Zone: The Time Element (ZICREE, 1992, p.16), o roteiro foi comprado e arquivado. Além da Imaginação ficava cada vez mais distante de ser realizada, porém um programa de antologias exibido pela própria CBS provaria que a proposta de Serling para a série fantástica teria apelo comercial.

Figura 16 - Desi Arnaz apresenta o episódio The Time Element para Westinghouse Desilu Playhouse, com a sombra de um relógio de pêndulo ao fundo, símbolo retomado à exaustão para representar fisicamente a passagem do tempo.

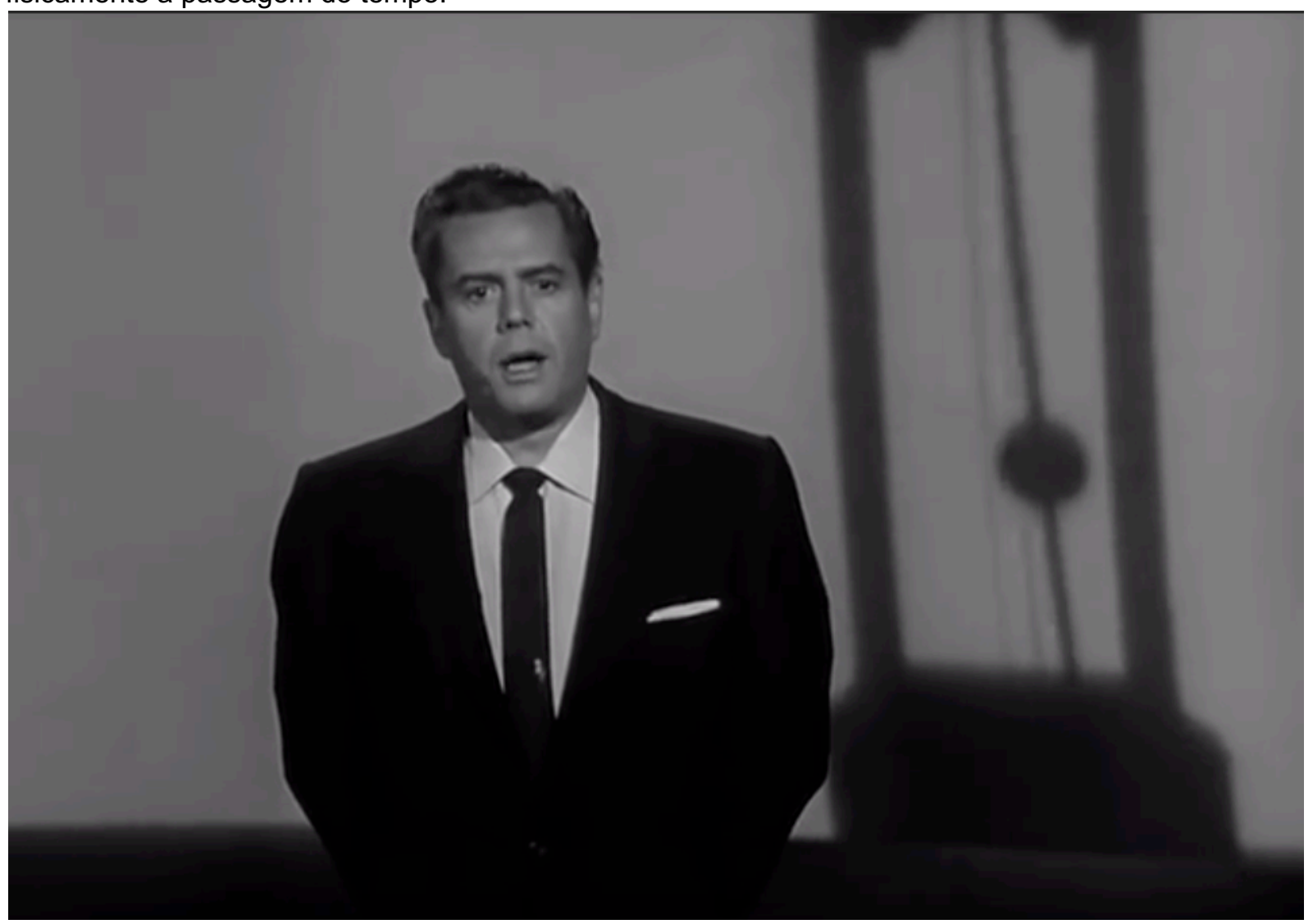

Fonte: elaborado pelo autor (Blu-ray, The Twilight Zone: The Complete Series, CBS, 2017)

O roteiro de Serling The Time Element acabou sendo um episódio de sucesso da série de antologia Westinghouse Desilu Playhouse, criada por Desi Arnaz e 
produzida pela Desilu Productions em 1958, produtora dele e de sua esposa Lucille Ball. A Desilu Productions foi uma influente produtora criada em 1950 para produzir atuações de Desi e Lucille, que se tornaram estrelas da série icônica da "Era de Ouro", a comédia de situação I Love Lucy (1951-1957), e produziu na década de 60, dentre outras séries famosas, Jornada nas Estrelas (Star Trek, 1966), Os Intocáveis (The Untouchables, 1959) e Missão Impossível (Mission: Impossible, 1966). No final da década de 50, a Desilu Productions rivalizava de igual para igual com os grandes estúdios de Hollywood na produção de material televisivo, tanto em qualidade quanto em relevância (EDGERTON, 2007, p.132).

A série de antologia da Desilu, exibida entre 1958 e 1960 pela CBS, tinha a proposta de apresentar, a cada quatro semanas, três dramas seguidos e uma comédia de situação estrelada pelo casal de proprietários. Bert Granet era um dos produtores da série, que tentava dar prestígio a um programa sem pretensões artísticas, contratando grandes nomes do cinema para estrelar os episódios e comprando roteiros de escritores renomados na televisão (ZICREE, 1992, p.17). Granet, ao saber por Serling que a CBS havia comprado o roteiro The Time Element e não o utilizou, adquiriu o roteiro da CBS e o produziu para o programa da Desilu.

O drama The Time Element foi exibido dia 24 de novembro de 1958 no Westinghouse Desilu Playhouse e obteve enorme apoio do público, recebendo a maior quantidade de cartas do programa no ano, com elogios também da crítica. Nessa história de Serling, um homem perturbado procura um psiquiatra para relatar um sonho realista que vem se repetindo há uma semana e o incomoda profundamente: o médico, cético, acredita que o sonho recorrente é um símbolo para perturbações no subconsciente do homem, que todo dia sonha que acorda em um hotel em Honolulu, Havaí, dia 6 de dezembro de 1941, um dia antes do ataque Japonês a Pearl Harbor. Ele primeiramente duvida do deslocamento no espaço, pois estava em Nova York e não sabe como acordou no Havaí, mas depois descobre, ao ser confrontado por informações no bar, inclusive ao ler um jornal havaiano do dia 6 de dezembro de 1941, que o deslocamento se deu também no tempo. Nesse sonho, primeiramente tenta utilizar seu conhecimento futuro para apostar em esportes, mas depois, com dó de um casal recém-casado cujo marido é marinheiro do encouraçado USS Arizona - bombardeado pelos japoneses em Pearl Harbor -, tenta alertar as pessoas, sendo ridicularizado e chega até a apanhar. Em todo o sonho, o homem acorda sempre no momento em que aviões de guerra japoneses sobrevoam o hotel 
em direção à base americana na manhã do dia 07 de dezembro de 1941, e ele tem certeza de que o sonho não acabou, ele estava acordando antes do encerramento do sonho. A fim de provar que tem certeza de que o sonho é a realidade, revela ao psiquiatra que nunca tinha ido para Honolulu na vida e, não só isso, teria feito uma pesquisa do nome de um marinheiro que conhecera no sonho e descobrira que ele foi morto no ataque a Pearl Harbor. O médico e o paciente continuam conversando até que o homem dorme no divã e tem novamente o mesmo o sonho que agora chega ao seu final derradeiro: ele morre no ataque, quando aviões japoneses metralham o hotel.

No momento da morte do homem, o psiquiatra acorda de um cochilo e se vê sentado de fronte a um divã vazio. Surpreso, ele procura pelo consultório o homem e confirma na agenda que não tinha pacientes marcados para o dia. Indo para um bar a fim de beber e pensar no que ocorrera, supondo que a visita do estranho paciente era um mero sonho durante seu cochilo no consultório, vê a fotografia de um homem familiar na parede do estabelecimento. Ao perguntar ao barman quem é o homem da foto, descobre que ele foi morto em Pear Harbor e tinha o mesmo nome de seu paciente desaparecido.

O episodio para Desilu, The Time Element, não foi a primeira experiência de Serling com temas derivados da ficção científica, mas é interessante notar que a série Além da Imaginação foi criada com a temática da impossibilidade da subversão da História e das temporalidades como noções a serem exploradas, com a resposta do público e crítica demonstrando o poder mobilizador desse tipo de enredo nas sociedades modernas. Mais comentários sobre The Time Element serão realizados adiante, quando o episódio será inserido no corpo das relações e funções da viagem no tempo propostas na série Além da Imaginação como formas de se relacionar com o tempo no contexto histórico do segundo pós-guerra.

\section{6- Diretamente de outra dimensão}

O sucesso de The Time Element dissolveu quaisquer dúvidas existentes na CBS sobre a proposta de Rod Serling de lançar um programa que toda semana exibiria um episódio diferente com algo fantástico para o público adulto. A rede, assim, decidiu encomendar um piloto de Além da Imaginação para tentar viabilizar a série, colocando-a no mercado sujeito ao interesse dos patrocinadores. Como já dito, no período, havia bastante preconceito e dúvidas sobre o interesse dos patrocinadores 
sobre séries que tivessem quaisquer indicativos de ficção científica, inclusive em The Time Element houve interferência da agência McCann-Erickson, representante da Westinghouse, que não desejava um final aberto, deixando para o público decidir o que vira e fez retirar do roteiro o alerta inócuo que o viajante no tempo faria aos militares, pois não queria correr o risco deles se sentirem ofendidos, já que a Westinghouse detinha contratos governamentais no Departamento de Defesa (ZICREE, 1992, p. 18; GRAMS JUNIOR, 2008, p.31-32). Não é à toa que Desi Arnaz, na conclusão do episódio, dá a sua opinião sobre o que aconteceu e, ao comentar o final misterioso, fornece uma explicação com base no real para ser seguida pelo público: o psiquiatra havia sonhado de tanto ver a foto do homem no bar, uma interpretação de cunho psicologizante, apelando para o inconsciente. O peso de sua interpretação ofuscava seu breve comentário de que queria saber se quem assistiu tinha outra explicação, antes de anunciar, com a sua esposa, a propaganda da nova geladeira da Westinghouse e o programa da próxima semana, em um ambiente não muito incentivador de reflexão. Entretanto, o público realmente se sentiu intrigado pelo episódio, e as reações da audiência recebidas pela CBS, exemplificadas nas cerca de 64.000 cartas sobre o episódio que chegaram à emissora em dois dias (Ibid., p.33), demonstram que a explicação de Desi Arnaz, para muita pessoas, não tinha importância e demonstrava mais o medo por parte dos produtores de lidar com narrativas com final aberto à interpretação do que uma efetiva aceitação por parte do público da explicação proposta; não deveria ser, assim, menosprezada a participação do público no ato de se assistir à televisão. Tal comportamento de medo em exibir programas fantásticos com finais não ancorados no real, por parte das redes de televisão, no contexto dos anos 50, era justificado: repetiam-se casos de tentativas que recebiam reações negativas por parte do público que não entendia o programa (Ibid., p.592).

Como o episódio The Time Element já havia sido exibido, um outro roteiro precisava ser desenvolvido para Além da Imaginação. Baseado em matéria que teria lido na revista Time sobre pesquisas de isolamento com astronautas, Serling escreveu o roteiro que tinha todos os elementos para vender a série e agradar aos nãoinclinados a aceitar o fantástico. Uma história com um encerramento claro, não deixando espaço para conclusões exorbitantes sobre o final e ancorada no racional, explorando elementos de ficção científica sem ser uma ficção científica per se. 
Rod Serling se aproximou de escritores de obras fantásticas para mostrar o projeto de Além da Imaginação, sua intenção era a de ganhar o respaldo e apoio da comunidade de escritores e dos fãs, ambos os grupos extremamente céticos com o potencial de uma nova série televisiva. Outra intenção de Serling, de cunho mais prático, era a de montar um núcleo criativo que estivesse afinado com sua proposta de levar material de qualidade artística através dessa mídia, tentando reproduzir na televisão o espírito das obras publicadas principalmente nas revistas pulp. Para isso, convidou um grupo de escritores, conhecidos por diversos nomes como "The Southern California School of Writers" ou só por “The Group”, cuja missão era a de produzir material fantástico de qualidade, exercendo enorme influência não só na literatura, mas também na produção de roteiros para cinema e televisão (CONLON,1999, n.p; STANYARD, 2007, p.18-19). O grupo, entre o início dos anos 50 até meados da década de 60, chegou a reunir, dentre outros, Ray Bradbury, Charles Beaumont, Richard Matheson, William F. Nolan, George Clayton Johnson, Jerry Sohl, Robert Block e Harlan Ellison. Rod Serling apresentou alguns de seus roteiros prontos de Além da Imaginação para membros do grupo, que acharam o material com qualidade boa o suficiente para se unirem ao projeto. Beumont, Matheson e, num primeiro momento, Bradbury passaram a cooperar com Serling e juntos, sob julgo final do roteirista "invasor" de um novo território, definiram a estrutura geral da série. No contexto das décadas de 50 e 60, os trabalhos de escritores ligados a The Group foram muito influentes e estariam presentes na televisão nas séries Alfred Hitchcock Presents, Alcoa Presents: One Step Beyond, $5^{\text {a }}$ Dimensão (Outer Limits) e Jornadas nas Estrelas (Star Trek), por exemplo.

Dos roteiros da futura série, o trio Beaumont, Matheson e Serling formaria o núcleo criativo, definindo as linhas gerais e assinando a maior parte dos episódios mais memoráveis. Serling escreveu noventa e dois dos cento e cinquenta e seis exibidos, seguido de Beaumont, creditado em vinte e dois (com presença de ghostwriter) e Matheson, com quatorze roteiros e dois episódios adaptados de seus contos. Eles eram seguidos por George Clayton Johnson, pupilo de Beaumont, que fez sete roteiros e Earl Hamner Jr., escritor não ligado a "The Group", autor de oito roteiros. Os roteiros da série que não foram escritos pelo trio criativo ou adquiridos por indicação direta deles eram obtidos por intermédio direto de agentes ou pela procura do trio por autores de histórias que achavam que dariam um bom episódio na fórmula da série. 
Segundo o historiador Keith Booker, a fórmula da série consistia no modelo comum de três atos divididos da seguinte maneira: no início do episódio se definia uma situação insólita, o segundo ato dramatizava e elaborava essa situação e no ato final, haveria uma reviravolta no enredo para tornar a situação mais intrigante (BOOKER apud MELBYE, 2016, I.308). Porém, como destaca Melbye, ao mesmo tempo em que devemos reconhecer que há sim a divisão da narrativa na forma convencional de três atos, essa fórmula não dá conta da série vista como um todo, já que nem todos episódios contam com um final com reviravolta (Ibid., l.332). O fator unificador dos roteiros é o uso da ironia; a presença desse artifício narrativo capaz de comunicar as intenções críticas é o aspecto mais formuláico da série, compartilhado pelos diversos roteiristas, mantendo a intenção original de Além da Imaginação, a de ser um ambiente de crítica social (Ibid., I.283; I.1271).

\section{7- Onde está todo mundo?}

O episódio Where is Everybody? (Onde está todo mundo?) foi aceito pela CBS para apresentar a série ao mercado. O piloto foi dirigido por Robert Stevens, respeitado diretor da série Alfred Hitchcock Presents e estrelado por Earl Holliman, do filme Planeta Proibido (Forbidden Planet, 1956) e de séries de televisão. A trilha sonora era assinada por Bernard Herrman, um dos maiores compositores de rádio, cinema e televisão da história americana, no período, estava em plena parceria com Alfred Hitchcock e já era um compositor renomado. A fotografia era de responsabilidade de Joseph LaShelle, famoso por seu trabalho em filmes noir, vencedor do prêmio Oscar pela fotografia de Laura (Laura, 1945) e fotógrafo de episódios de Alfred Hitchcock Presents. Para a gravação do piloto, foram escolhidos os estúdios ao ar livre da Universal International Studios, que forneciam todos os ambientes necessários para a trama (ZICREE, 1992, p.22), dentre eles a famosa Courthouse Square, presente em vários filmes como Gremlins (1984) e De Volta Para o Futuro (Back to the Future, 1985) (GRAMS JUNIOR, 2008, p.36). Os demais 155 episódios subsequentes seriam quase que todos filmados na MGM, empresa que na época era dona de seis estúdios distintos em Culver City, no condado de Los Angeles, totalizando cerca de 175 acres ou 708.200 m2 (BINGEN; SYLVESTER; TROYAN, 2011 , p.10). Na produção do episódio piloto, houve preocupações da emissora referentes ao custo do projeto final, pois o piloto custou cerca de USD $\$ 75.000$, um 
valor considerado alto na época que, atualizado em valores corrigidos pela inflação, corresponderiam atualmente a cerca de USD $\$ 630.000,00$, um valor baixo para os padrões de hoje das séries americanas de televisão ou streaming, nas quais qualquer episódio passa da casa dos milhões de dólares, como, por exemplo extremo, os episódios da série Game of Thrones (2011-2019), que na primeira temporada tiveram custo médio de 6 milhões de dólares, chegaram a cerca de 15 milhões em 2019, em dados publicados pela imprensa (MARTIN, 2019, n.p.).

O primeiro episódio de Além da Imaginação, Where is Everybody?, é a história de um homem que acorda em uma cidade deserta sem saber quem é e onde está e, ao tentar achar pistas da sua identidade e do local onde se encontra, vê indícios de presença humana recente. $O$ episódio mantém um tom de mistério, com elementos que remetem ao clima apocalíptico e paranoico da Guerra Fria, induzindo o espectador a tentar entender e explicar o que poderia estar acontecendo. $O$ final, como citado anteriormente, é uma história ancorada no mundo real: descobre-se que o homem faz parte de um experimento para astronautas numa câmara de isolamento, ou seja, estávamos presenciando o estado mental, sonho, mundo criado pelo cérebro de um homem em completa solidão. Como dado de curiosidade, na adaptação em livro desse episódio, publicada em abril de 1960, Serling introduziu um elemento de dúvida para o leitor: o astronauta, após acordar do teste militar, encontra em seu bolso um bilhete de teatro que pegara no mundo do sonho, um indicativo da preferência de Serling por um tipo de final que estimulasse alguma forma de reflexão por parte do público, como demonstrado em sua larga obra.

O tempo total de ensaio e filmagem para conclusão de Where is Everybody? foi de nove dias no início de dezembro de 1958, três deles para edição, dublagem e inserção da música. Posteriormente, o episódio foi levado para Nova York, onde ficavam as sedes das grandes agências de publicidade do período, e teria sido vendido em seis horas (ZICREE, 1992, p.22), um feito considerado bom na época. A narrativa foi exibida para o público como primeiro episódio de Além da Imaginação em 2 de outubro de 1959. Nesse meio tempo, entre a produção do piloto e o início da série, com os contratos entre a produtora Cayuga Productions, criada por Serling para fazer a série, e a CBS confirmados, outros episódios seriam filmados e novos roteiros adquiridos e escritos pelo autor.

No acordo final entre a Cayuga e a CBS, a produção ficaria sob a responsabilidade da produtora de Serling, que também seria responsável por escrever 
$80 \%$ dos roteiros da primeira temporada. O financiamento era fornecido totalmente pela CBS, que detinha o direito de aprová-lo. A propriedade da série foi dividida meio a meio entre Cayuga e a CBS, e os lucros rateados em $40 \%$ para Cayuga e $60 \%$ para CBS, com a posse dos negativos originais pertencendo à empresa de Serling e a exclusividade da distribuição sob controle da CBS por cinquenta anos (GRAMS JUNIOR, 2008, p.37-38). Esse tipo de contrato era padrão no período, e após dois meses da assinatura dos documentos, a equipe para realizar a primeira temporada de Além da Imaginação estava completa.

\section{8- Produções Cayuga}

Com os primeiros vinte e seis episódios contratados, Serling precisava de um produtor e sua primeira opção foi William Edwin Self, o recém contratado produtor executivo na CBS, que produzira Where is Everybody?. Self preferiu manter sua posição na CBS e indicou para Serling o produtor Archible Ernest "Buck" Houghton, homem que começara sua carreira nos bastidores de Hollywood até galgar posições na televisão, ex-editor de roteiros do programa Schiltz Playhouse of Stars. Buck Houghton seria peça fundamental em Além da Imaginação, formando uma excelente parceria com Serling nos 102 episódios que produziu, tendo a palavra final sobre todos os elementos da série: roteiros, elenco, músicas, diretores, edição, cenários e reprises no intervalo entre as temporadas. Além disso, foi ele que montou a primeira equipe de produção, responsável pelo tom cinematográfico característico da série seguido nas outras temporadas, com, por exemplo, o maquiador Bob Keats e o diretor artístico William Ferrari, ambos trazidos por Houghton da MGM, e o diretor de fotografia George T. Clemens, advindo do Schiltz Playhouse of Stars e que futuramente venceria um prêmio Emmy pelo seu trabalho em Além da Imaginação, em 1961. Quase toda a equipe que trabalhou no programa era oriunda da Meridian Productions e Schiltz Playhouse of Stars (GRAMS JUNIOR, 2008, p.51).

Foi de Houghton, por exemplo, a escolha de filmar a série nos estúdios da MGM, pois o produtor e Serling concordaram que um estúdio de cinema seria o local ideal onde poderia ser encontrado tudo que era necessário para realização de Além da Imaginação, como os diversos cenários, figurinos e adereços exigidos para uma série de antologia desse tipo, que podiam ser alugados (Ibid., p.51-52). Vinte episódios seriam feitos antes do lançamento da série ao público, com o cronograma 
padrão de um dia de ensaio e três dias de filmagem, iniciadas em junho de 1959 (ZICREE, 1992, p.35). Serling acompanhava de perto a série, chegando a seguir as filmagens, porém, seu cargo de produtor executivo era mais simbólico e a equipe formada e a ação de Buck Houghton mantinham a qualidade do programa.

Para revisão dos roteiros, foram contratados os serviços da consultora de Forest Research, empresa de Kellam de Forest, que tinha um escritório na Desilu e na época cuidava da biblioteca de pesquisa da RKO, fornecendo seus serviços para os roteiros da Desilu e outras produções que alugassem suas instalações. Rod Serling teve contato com a empresa quando da produção de The Time Element.

A de Forest Research dominava o campo de pesquisa de roteiros e examinava os textos, buscando inconsistências e erros, verificando os dados apresentados nas histórias, como nomes de personagens, possíveis conflitos legais, contexto histórico e social, geografia e conceitos científicos, sugerindo alternativas ao autor (KMET, 2012 , n.p). A pesquisa custava USD $\$ 30,00$ por roteiro e levava cerca de dez horas, porém, caso fosse necessário mais tempo, uma taxa adicional poderia ser cobrada. (GRAMS JUNIOR, op. cit., p.55). A aprovação dos roteiros pela de Forest Research era de extrema importância, pois mostrava que os cuidados devidos foram tomados na produção e indicava que não ocorreriam problemas, ou se ocorressem, não era intencional, como o fato de inserir o nome de uma pessoa viva que pudesse vir a reclamar posteriormente quando visse o programa no ar (KMET, op. cit., n.p).

$\mathrm{Na}$ primeira temporada da série, foram introduzidas para o público as características do programa, com o modelo definido por Serling, em parceria com os escritores Charles Beaumont e Richard Matheson. Como já explanado, havia os três atos e a marcante presença da ironia, com finais expondo uma reviravolta no enredo. A reviravolta não era novidade na cultura popular da época, mas encaixava muito bem com as narrativas moralizantes da série ao provocar, em contato com a ironia, uma resposta crítica dos espectadores ao conteúdo apresentado (MELBYE, 2016, I.276). Outro ponto era mostrar personagens aparentemente comuns nos episódios, pessoas com as quais a audiência podia identificar características nela mesma ou em seus pares; as locações também podiam ser facilmente reconhecidas pelo público em seu dia-a-dia, poucos são os episódios que se passavam em locais fantásticos, a grande maioria tem como cenário os lugares padrões frequentados pelos americanos na época, casas de subúrbios, centros de cidades, bares, carros, zonas rurais, rodoviárias. A Zona Crepuscular, tradução literal de Twilight Zone, podia estar em 
qualquer lugar e qualquer pessoa estava sujeita a passar por uma depuração dessa zona.

Nos meses enquanto a série era filmada e aguardava o lançamento no horário das sextas-feiras às 22:00 horas, foi dado início à campanha de sua divulgação na mídia, reforçando o papel autoral de Serling, que dava entrevistas sobre a nova série e escrevia artigos, justificando inclusive sua escolha por se expressar utilizando a ficção científica, gênero com o qual a série passou a ser associada já na época de seu pré-lançamento. Uma das apresentações de Serling na televisão, que seria importante para a publicidade da série, foi a sua participação no programa de entrevistas The Mike Wallace Interview, exibido nacionalmente em 22 de setembro de 1959 pela rede ABC (GRAMS JUNIOR, 2008, p.63-64). No programa apresentado pelo jornalista Mike Wallace, Serling falou sobre a futura série Além da Imaginação, discutiu a influência da censura na televisão, falou do trabalho de escritor e fez comentários sobre seu sucesso (THE MIKE..., 1959). Sobre a questão do horário, cabe destacar que em algumas cidades, os episódios não eram transmitidos no mesmo horário e dia, e podiam ser exibidos com uma ou mais semanas de atraso em relação aos grandes centros da rede CBS (GRAMS JUNIOR, op. cit., p.747-750).

Rod Serling, seguindo orientações de seus amigos do The Group, passou a adquirir contos diversos de ficção científica publicados nas pulps específicas do gênero, adquirindo roteiros ou entrando no mercado para comprar os direitos de obras de Philip K. Dick, Arthur C. Clarke, C. L. Moore e Henry Kuttner e Robert A. Heinlein. O próprio Beaumont, a fim de atrair a simpatia da comunidade leitora para o novo programa e propagandear a série, encarregou-se de explicar o conceito de Além da Imaginação em um ensaio intitulado The Seeing $I$, publicado na revista pulp de ficção científica The Magazine of Fantasy and Science Fiction de dezembro de 1959 (PROSSER, 2010, p.33).

Com referência aos roteiros, desde o primeiro anúncio divulgado na imprensa sobre a futura série, em 1958, e continuando por todo período de exibição de Além da Imaginação, foram enviados pelo correio a Serling e à produção milhares de ideias para episódios e roteiros não solicitados. Em 1960, Serling afirmaria, em uma carta para um aspirante a roteirista que teve seu roteiro rejeitado, que recebia mais de duzentos manuscritos por semana (SERLING, 1960b, p.1); em 1963, voltaria a afirmar a outro aspirante que recebia mais de quinhentos manuscritos por semana (SERLING, 1963b, p.1). Havia o risco, já largamente conhecido pela mídia e de ciência dos 
produtores de programas de televisão, que caso fosse ao ar algo minimamente semelhante a uma ideia de enredo ou sugestão de programa que estivesse em um material enviado pelo correio, era costume o programa ser processado como se tivesse copiado a ideia; isso era ainda mais claro em envios de materiais não solicitados. Para evitar essa situação, os roteiros eram devolvidos aos remetentes sem serem abertos com um aviso por escrito repetindo o título da proposta que informava que não haviam sido lidos; as cartas com sinopses ou sugestões recebiam a resposta de que a série não estava no mercado para comprar ideias, mesma informação que ia anexa aos roteiros devolvidos. Parte dos roteiros, sinopses ou sugestões de histórias eram enviados por agentes profissionais, representantes de escritores renomados e esse material costumava receber maior atenção (GRAMS JUNIOR, 2008, p.101), juntamente com os enviados por amigos ou conhecidos de Serling ou pessoas indicadas. Os roteiros não solicitados também eram encaminhados para os editores de história na MGM, Del Reisman e Dick McDonagh, que enviavam as devidas rejeições. As cartas de resposta com registro no corpo da mensagem dos títulos dos roteiros não lidos eram arquivadas para fornecer possíveis respaldos legais (lbid., p.101).

Havia um modelo de resposta que as secretárias utilizavam quando recebiam histórias não solicitadas. Em carta enviada a um aspirante a roteirista em 1961, está presente o padrão que seria seguido em cartas enviadas por adultos: "O senhor Serling gostaria de agradecer-lhe por mandar sua história, mas nós devemos devolvêla sem ler. Nós adquirimos todo o material necessário para nossa atual temporada e o período de renovação de Além da Imaginação e não estamos mais no mercado para qualquer história." (OLMSTED, 1961, p.1) Para o público infanto-juvenil que se sentida empolgado em compartilhar histórias com o autor da série, havia também um modelo de resposta que respeitava esse público ao retribuir o carinho e imaginação das crianças: "Obrigado por sua carta e por me mandar sua história que era muito imaginativa. Infelizmente, nós não podemos usar em nosso programa porque nós compramos todo material que precisamos para nossa temporada atual e o período de renovação. Mas eu apreciei muito o seu interesse" (SERLING, 1961d, p.1). Ademais, dependendo do período do ano poderiam ser realizadas alterações no formato, como incluir informações sobre a renovação ou não da série.

A acusação de plágio aos programas de televisão era comum e o próprio Serling não escaparia disso, principalmente ao deixar claro em suas entrevistas que 
valorizava os novos talentos e criticava abertamente a mídia da qual fazia parte por não dar abertura a novos roteiristas, fato que o tornava o destinatário ideal para cartas que cobravam coerência entre seu discurso e ações. Serling também foi regularmente acusado de plágio por recebimento de roteiros não solicitados, devidamente devolvidos por sua equipe, acusações a que respondia prontamente e, muitas vezes, de forma ríspida. Seus agentes também respondiam às indagações de escritores que suspeitavam que seus roteiros ou sugestões de ideias haviam sido copiados, especificando a origem da ideia do episódio suspeito de plágio e procurando demonstrar o engano do querelante.

O agente Sam Kaplan, representante de Serling, respondeu a uma carta de 1961 na qual um senhor chamado Allan Amenta afirmava ter criado uma ideia similar ao episódio Long Distance Call e submetido uma sinopse para apreciação de Serling. Kaplan afirmava que, por sua orientação, Serling não lia submissões ou sinopses enviadas diretamente a ele e as devolvia sem abrir. No decorrer da carta, explicava que a história era da lavra de Charles Beaumont e William Idelson e que quaisquer similaridades eram fruto de coincidência, mas que se Amenta não estivesse satisfeito com a resposta para informá-lo, Kaplan passaria o caso para os advogados que lidariam com o caso diretamente (KAPLAN, 1961, p.1-2). Esse episódio também seria questionado por outro suposto autor que teria enviado uma sinopse, ele inclusive levaria o caso adiante, contratando advogado (GRAMS JUNIOR, 2008, p. 388). Cabe afirmar que a premissa do episódio, no qual uma criança que conversa por um telefone de brinquedo com a avó recém falecida, não era tão criativo assim e demonstra não só a limitação temática, mas também as relações complexas das tecnologias de comunicação com o misticismo nas sociedades contemporâneas.

Em carta endereçada a Art Hostetler em 9 de julho de 1963 (SERLING, 1963c, p.1-2), Serling responderia duramente à acusação de que teria se apropriado indevidamente da ideia supostamente enviada por Hostetler para criar o episódio The Bard, onde Shakespeare é invocado por um aspirante a roteirista e enfrenta o mercado dramático televisivo dos primeiros anos da década de 60. Na carta, Rod Serling afirma que recebia de 400 a 500 cartas por semana e passava horas que deveria estar criando respondendo a elas, tempo que estaria usando para responder a carta acusatória. De forma irônica, responde que é preciso muita imaginação para transformar duas ou três linhas de uma carta em um episódio de uma hora e que o episódio foi uma porcaria e que se tivesse realmente roubado a ideia do outro, nenhum 
dos dois poderia se orgulhar. Além disso, conta que teve inicialmente a ideia em 1957 e a trabalhou durante os anos, destacando que nunca roubou de ninguém e rejeitava completamente a acusação de ter cometido, segundo Serling na carta, o pior crime de que se pode acusar a um roteirista.

Nenhum roteiro ou ideia para episódios de Além da Imaginação foi adquirido por meio de autores dos mais diversos graus de profissionalismo que enviavam roteiros ou propostas de enredo pelo correio, a grande maioria na verdade eram aspirantes a escritores, donas de casa, médicos, militares, idosos, jovens e crianças, alguns até oferecendo ideias gratuitamente, por vezes sonhos que tiveram, ou algo não comum que teriam presenciado ou de que teriam ouvido falar e achavam que seria interessante ser contado na série. Os jovens e crianças, empolgados com a série, ofereciam suas ideias e parte de histórias de graça.

Entretanto, as acusações mais profundas de plágio eram dirigidas a Serling por escritores nos bastidores. No final de 1960, Charles Beaumont, profundamente ligado à comunidade literária de ficção científica e fantasia, descreveu para Serling suas tentativas de acalmar os ânimos de seus colegas que viam algumas ideias semelhantes aparecerem na série e afirmava que toda sexta-feira, após Além da Imaginação ir ao ar, recebia inúmeras ligações de escritores indignados com supostos plágios de Serling. Beaumont, porém, defendia o amigo, mas suspeitava que, de tanto ler as histórias de seus colegas, Rod Serling estaria inconscientemente misturandoas em sua mente e as apresentando na série como suas, o que Serling falaria que era possível raramente, e não da forma recorrente que seu amigo considerava. Os escritores eram estimulados a pensar de forma acusatória por Frank Gruber, escritor famoso por suas histórias de mistério, e Ray Bradbury, amigo de Beaumont que, depois de ver suas histórias não sendo transformadas em episódios e alguns temas apresentados semelhantes ao seu trabalho, passou a divulgar nos círculos literários do gênero que Rod Serling os plagiava (GRAMS JUNIOR, 2008, p.106-110). O próprio Bradbury tinha negociado, sem sucesso, uma série de ficção científica antes de Serling com a CBS e era presença no meio televisivo da época com roteiros para programas como Playhouse 90 e Alfred Hitchcock Presents.

No final de 1960, após receber a carta de Beaumont, Serling tentaria colocar um ponto final nas acusações de Bradbury, em uma longa carta datilografada. Normalmente, suas cartas eram ditadas e datilografadas por secretárias. Ele explicou para o famoso autor de ficção científica que não era plagiador e o que o deixava mais 
indignado no comportamento do escritor era sua falsidade, pois, em encontros públicos, sorria e cumprimentava Serling, enquanto nos bastidores, jogava a comunidade de escritores contra ele. Rod Serling, honesta e humildemente, costumava reiterar por toda sua carreira como roteirista que era um "Johnny-comelately", um recém-chegado no gênero ficção científica e, em suas cartas para os colegas escritores, afirmava corretamente que muitos dos temas ou artifícios usados nas histórias eram impossíveis de não se repetirem. Por exemplo, ao utilizar a figura do robô que não sabe que é robô, foi acusado de roubar a ideia de um conto que também tinha um robô que não tinha consciência de sua identidade artificial, mas esta era a única semelhança, ou seja, eram coincidências nas fronteiras temáticas do gênero.

Tal situação, o fato de ser constantemente acusado de farsante no meio literário, causava grande tristeza a Serling, provocando até uma breve desistência da série no final dos anos 60 . Com o passar do tempo, alguma solução foi encaminhada e um episódio de Bradbury realmente foi feito, I Sing the Body Electric (1962). Serling sempre afirmaria em suas cartas que desejava que os casos suspeitos fossem resolvidos com uma conversa e explicava de onde fora retirada a história suspeita de plágio, porém afirmava que caso o escritor não se contentasse com a explicação, que entrasse na justiça. Das acusações de plágio, apenas uma foi levada adiante contra Serling e ele teve que negociar devido ao episódio The Parallel; todavia, a observação de Serling sobre os temas serem limitados é válida e é pouco provável que ele tenha plagiado essa história (ZICREE, 1992, p.95).

Todo esse problema com a comunidade escritora, certamente, envolvia questões de ego, como o próprio Beaumont e Serling reconheceram, mas a comunidade de fãs recebeu muito bem a série Além da Imaginação, vendo como um programa de alto nível de qualidade, o que foi expresso pelo sucesso dos livros escritos por Serling adaptando os roteiros para contos, venda de produtos derivados, como álbum de músicas inspiradas na série sem relação com os episódios, a formação de inúmeros fã-clubes e os três prêmios Hugo seguidos recebidos por Serling por "melhor apresentação dramática" e mesmo que não tenha ido pessoalmente recebê-los, nota-se o carinho da comunidade nas cartas informando da premiação e o convidando insistentemente para o evento (ARCHER, 1960a,p.1; 1960b, p.1; 1960c, p.1; 1960d, p.1). 


\section{9- Um espaço da mente}

A série teve cinco temporadas de 1959 a 1964, totalizando 156 episódios, 150 em filme e seis em videoteipe, com intervalo de seis meses entre a terceira e a quarta temporada (1962-63).

A primeira temporada foi composta de 36 episódios, abrangendo muitos dos mais conhecidos da série, como Walking Distance, a história de um executivo que volta ao passado e encontra a si próprio quando menino; Time Enough at Last, sobre um leitor voraz que passa o resto da vida sem poder ler após sobreviver sem óculos à destruição atômica; The Hitch-Hiker, uma jovem que foge de um misterioso caroneiro enquanto viaja atravessando os EUA; The Monsters Are Due on Maple Street, a suspeita de uma invasão alienígena ativa a paranoia de uma pacífica comunidade; e A Stop at Willoughby, um publicitário que sonha estar no passado durante a viagem de trem diária para casa. Os episódios da primeira temporada demarcaram o terreno da série, demonstrando qualidade e também respeito aos temas tratados, o que foi notado pela crítica especializada e pelo público, que reiteradamente elogiava Além da Imaginação como uma série inovadora.

$\mathrm{Na}$ segunda temporada, foram realizados 29 episódios, exibidos primeiramente de setembro de 1960 a junho de 1961. A diminuição em relação à quantidade de episódios encomendados, em comparação com a primeira temporada, era estipulada em novos contratos de renovação para a série, de acordo com os interesses da CBS, que inicialmente tinha contratado dez episódios, com perspectiva de mais episódios produzidos a depender da audiência (GRAMS JUNIOR, 2008, p.85). O anúncio final da renovação para a segunda temporada foi realizado em 21 de junho de 1960 (ZICREE, 1992, p.131), antes do último episódio da primeira temporada ser exibido em $1^{\circ}$ de julho. Nessa temporada, foi introduzido o tema musical do francês Marius Constant para a série, substituindo a primeira versão feita por Hermman. Esse novo tema se tornaria um dos símbolos de Além da Imaginação, sendo posteriormente introduzido na cultura popular americana ao ser cantarolado pelas pessoas como sinal de que estavam vendo ou ouvindo algo estranho ou inexplicável (STANYARD, 2007, p.7). Além disso, é nessa temporada que Rod Serling se torna o apresentador de frente às câmeras. No último episódio da primeira temporada, $A$ World of His Own, ele teve uma participação cômica metalinguística, interpretando a si mesmo na história de um roteirista que dá vida aos personagens que imagina ao gravá-los em um 
gravador de fitas, mas salvo esse exemplo, na primeira temporada, Serling só era ouvido narrando a introdução e a conclusão dos episódios e só podia ser visto após os créditos finais, para anunciar o episódio da próxima semana. A presença física de Serling em meio aos cenários para apresentar os personagens e concluir ironicamente os episódios se tornou uma marca da série e, mesmo não sendo novidade na época, acabou por ofuscar os concorrentes na memória popular; inclusive, há o caso anedótico relatado por Marc Scott Zicree (1992, p.XII) que um menino, quando dormia e tinha pesadelos, eles eram apresentados por Rod Serling.

Nessa temporada, também foram feitos os citados seis episódios em videoteipe a fim de realizar um teste para reduzir os gastos com a série, o que realmente foi uma economia. A introdução regular das fitas na televisão americana havia se iniciado em 1957, quando a CBS e a NBC passaram a usar frequentemente esse recurso, principalmente para programas de esporte e notícias. O uso de videoteipe em dramas não era algo regular e uma das razões eram os interesses dos produtores e os acordos sindicais (GRAMS JUNIOR, 2008, p.103), mesmo que muitas vezes a qualidade da produção fosse exatamente a mesma de qualquer programa ao vivo. Entretanto, há uma disparidade patente de qualidade entre esses episódios e os realizados em filme nos estúdios da MGM e do piloto na Universal. Os seis episódios são: The Lateness of the Hour (1960), uma garota se revolta com sua família elitista servida por robôs; Static (1961), um idoso ouve programas do passado no rádio; The Whole Truth (1961), um vendedor de carros é obrigado a falar a verdade ao comprar um carro mágico; The Night of the Meek (1960), um Papai Noel de loja de departamentos fracassado tem uma segunda chance ao substituir o verdadeiro Papai Noel; Twenty Two (1961), uma mulher se recupera no hospital onde passa a ter um pesadelo recorrente sobre a morte; e Long Distance Call (1961), menino ligado à avó ganha de presente um telefone de brinquedo e passa a conversar com ela pelo aparelho após a morte dela. Esses episódios foram gravados nos estúdios da Television City da CBS em Los Angeles, local que limitava os espaços físicos e cenários, como um programa ao vivo de televisão, com os cortes de câmera realizados durante a gravação sem a direção de fotografia. Após essa experiência fracassada, desde o início vista com antipatia por Serling e Houghton, ao acompanhar os resultados finais, tornou-se óbvio para a CBS que a economia não compensava a queda da qualidade de imagem e som, mudando a identidade visual da série, algo que a diferenciava no período e era uma de suas marcas mais notáveis, até hoje 
identificável. Os episódios mais conhecidos dessa temporada são: Eye of the Beholder, a história de um mundo totalitário que valoriza a beleza e a perfeição; The Invaders, os humanos invadem um planeta e lutam contra uma caipira gigante; The Odyssey of Flight 33, um avião se perde no tempo; Long Distance Call, descrito acima; The Mind and the Matter, no qual um homem lê livro que ensina poder da mente e tenta ajustar o mundo aos seus gostos; e The Obsolete Man, a história de um mundo futuro totalitário que procura eliminar o que é considerado velho e ultrapassado, todos gravados em película.

A terceira temporada, exibida de setembro de 1961 a junho de 1962, totalizou 37 episódios, com uma nova sequência de apresentação inserindo um cone espiralado; não era, porém, a abertura que se tornaria mais icônica da série. Essa temporada marcou o final da sequência mais criativa de Além da Imaginação e o período de maior envolvimento de Serling com a série, que até então tinha o costume de acompanhar as filmagens e conversar com os atores e diretores nos estúdios, fazendo revisões de última hora nos roteiros. Como notou Zicree, após essa temporada, a "série se tornaria um programa diferente" (1992, p.294, tradução nossa) e durante a temporada, já havia a noção de que não existira uma renovação da série (GRAMS JUNIOR, 2008, p.116). Dentre os episódios mais significativos, cabe apontar: The Shelter, sobre os dilemas de uma família e seus vizinhos a respeito do uso de abrigo nuclear na expectativa de um ataque atômico; It's a Good Life, a história de um menino com poderes mentais que escraviza os adultos de sua cidade; DeathsHead Revisited, um nazista escondido volta para visitar o campo de extermínio e encontra os fantasmas do passado; Five Characters in Search of an Exit, um palhaço, um mendigo, um gaiteiro de fole, um major do exército e uma bailarina se encontram presos em uma sala com um buraco distante no teto e tentam descobrir onde estão, quem são e como foram parar lá; Kick the Can, no qual idosos no asilo se tornam novamente crianças; To Serve Man, uns alienígenas oferecem ajuda para os humanos mas os querem como alimento; e I Sing the Body Electric, na qual uma família recebe uma robô que ocupa o papel da mãe falecida, acompanhando as crianças até o fim da juventude.

Com dificuldades para acertar os patrocinadores da quarta temporada, a CBS sem aviso prévio, colocou uma nova série no lugar de Além da Imaginação nas sextasfeiras à noite, chamada Fair Exchange (Troca Justa, em tradução literal), uma comédia de situação de uma hora de duração que brincava com a ideia de duas 
famílias, uma em Nova York, EUA, e outra em Londres, Inglaterra, combinarem fazer uma troca das filhas adolescentes por um ano. Assim, parecia ter fim Além da Imaginação, sem nenhum cancelamento formal.

Nesse meio tempo, enquanto Serling tentava reverter o provável cancelamento da série, ele informou ao produtor Buck Houghton que não haveria problema se ele arrumasse outro emprego, já que não existia nada confirmado sobre Além da Imaginação e, a princípio, todos os profissionais ligados à série estavam desempregados. Houghton aceitou um emprego na Four Star Productions, deixou Além da Imaginação e, posteriormente, com a renovação da quarta temporada, não retornaria, mas indicaria a Serling a contratação do produtor Herbert Hirschman, o que foi acatado. Enquanto a situação complicada era negociada com a CBS, Serling aceitou um cargo de professor no Antioch College em Yellow Springs, do outro lado do país, onde lecionaria Mass Media (Mídia de massa, em tradução literal) e Writing in Dramatic Form (Redação na Forma Dramática, em tradução livre) de setembro de 1962 a janeiro de 1963. O roteirista justificou sua escolha por lecionar em sua antiga faculdade devido a estar fatigado com a rotina da série semanal, além do desejo de uma mudança de local ao sair de Los Angeles e ter uma oportunidade de aprender coisas novas (ZICREE, 1992, p.293). Passado esse período de professor de nível superior, no seu retorno a Los Angeles, Rod Serling passaria a devolver os trabalhos dos alunos pelo correio, alguns com pedidos de desculpas por não ter tido tempo de ler e, consequentemente, sem qualquer avaliação.

Por fim, a CBS acabou renovando Além da Imaginação, agora com uma hora de duração cada episódio, em um contexto no qual os dramas de meia hora eram raros e as séries de antologia eram substituídas cada vez mais por séries com continuidade (WHITTY, 2016, p.5). Além disso, a série Alfred Hitchcock Presents, de mesmo formato de Além da Imaginação, já tinha feito a transição para uma hora em 1962. Seja como for, uma série de uma hora de duração era a intenção original de Serling já em 1957 e uma proposta semelhante foi discutida pela CBS com Houghton no final da segunda temporada.

A ideia original de uma hora era anterior inclusive ao estabelecimento com Beaumont e Matheson da fórmula da série na meia hora contratada pela emissora para ir ao ar em 1959. Os episódios de meia hora eram um tipo de narrativa enxuta, criando o clima para o final surpresa, que dificilmente se sustentaria em uma hora, tipo de conclusão que acabou sendo perdida ou diluída nessa temporada. Foram 
encomendados dezoito episódios para serem exibidos na meia temporada a se iniciar em janeiro de 1963. Nessa quarta temporada, a série perdeu o The do nome, por provável decisão de Hirschman e aceitação por parte de Serling (GRAMS JUNIOR, 2008, p.125), passando a se chamar em inglês Twilight Zone, e o horário foi alterado: em vez das sextas-feiras às 22:00 horas, a série passou para as quintas-feiras às 21:00, com opinião de Serling de que parte do público jovem das sextas-feiras seria perdido (ZICREE, 1992, p. 299). Foi introduzida uma outra sequência de apresentação, com nova narração e identidade visual, com a porta, a janela, o olho de boneca, a boneca articulada de cabelos longos, o relógio de pêndulo e a "misteriosa" equação da relatividade $\mathrm{E}=\mathrm{mc}^{2}$ flutuando no espaço sideral, não nessa ordem.

Figura 17 - Olho e equação flutuando no espaço, sequência de apresentação icônica da série Além da Imaginaçao criada na quarta temporada.

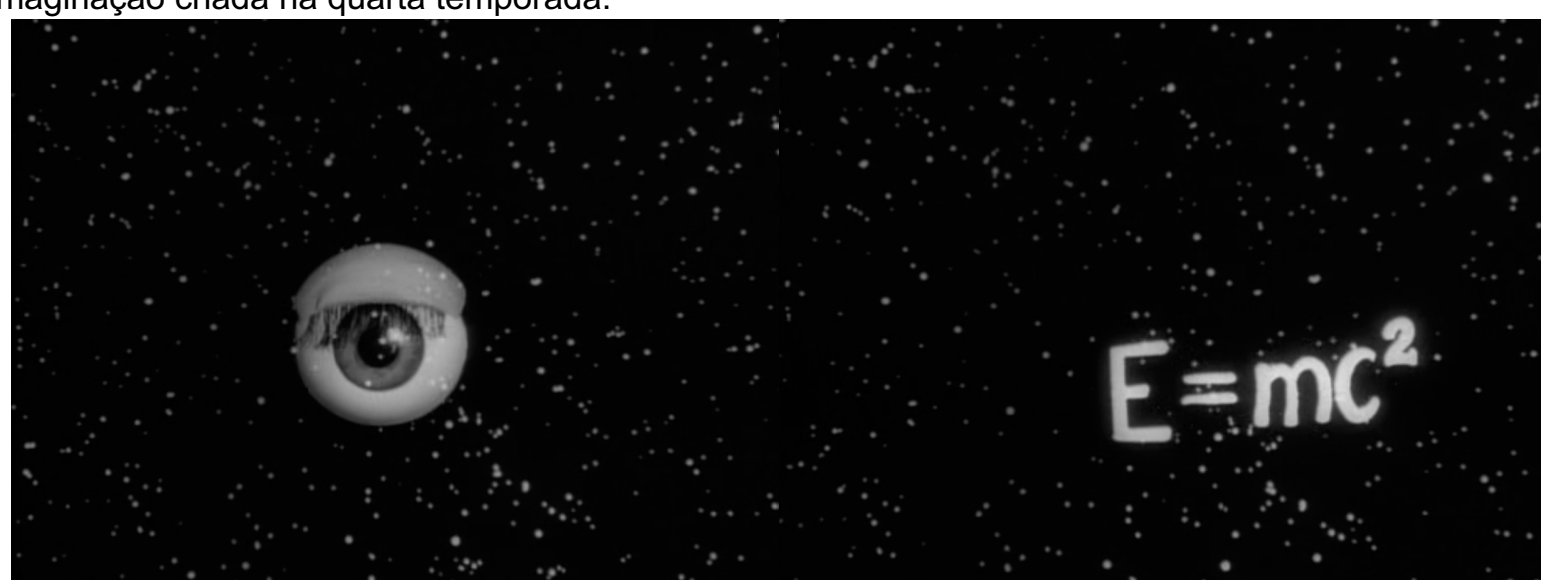

Fonte: elaborado pelo autor (Blu-ray, The Twilight Zone: The Complete Series, CBS, 2017)

Figura 18 - Olho disparando laser na equação: alusão a Além da Imaginação na sequência de abertura da série de desenho animado da Cartoon Network Inc., Rick and Morty (2013), programa de comédia que, nos seus episódios, ironiza os clichês, os temas e as obras insólitas.

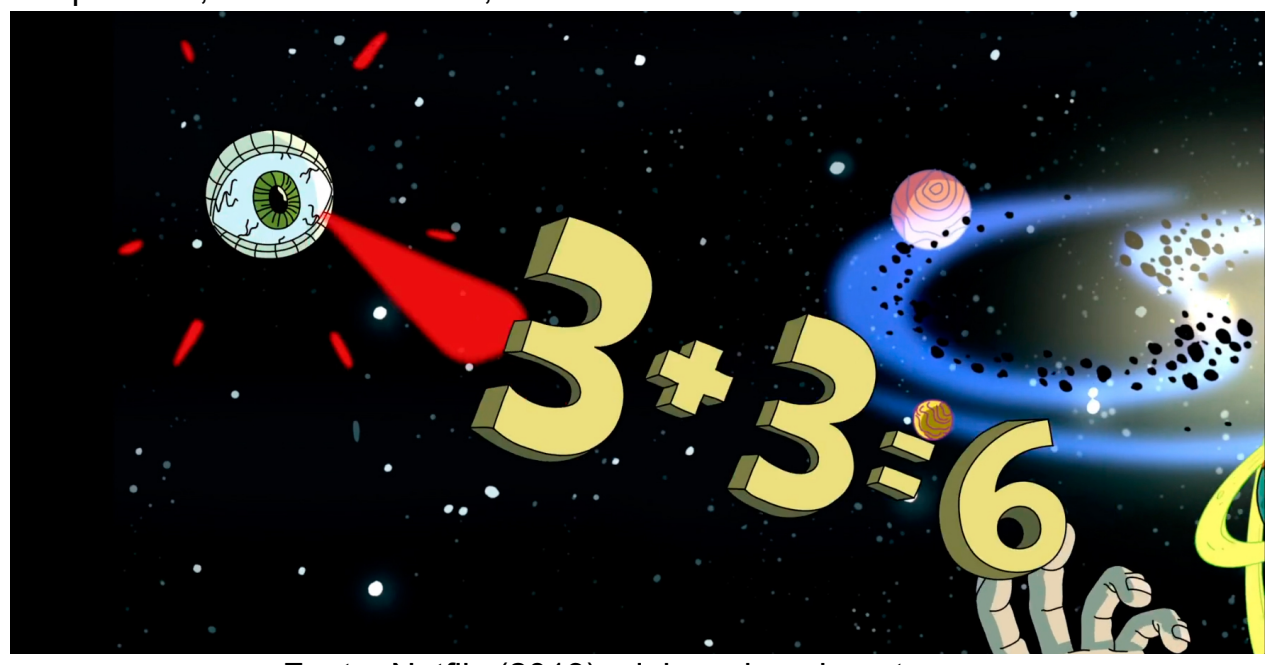

Fonte: Netflix (2013), elaborado pelo autor. 
Os dramas de uma hora de duração traziam a chance de desenvolver melhor os personagens e cenários, porém os episódios dessa temporada não conseguiram sustentar os efeitos dos finais surpresas dos programas anteriores. Além das mudanças na forma que a série vinha apresentada ao público, a maneira de produzir os episódios também mudou, o cronograma de filmagem marcava os episódios para serem filmados paralelamente, o que impossibilitava George T. Clemens de ser o diretor de fotografia dos dezoito episódios (ele assinaria nove nessa temporada), e por sua indicação, foi contratado Robert Pittack, diretor de fotografia de cinema que fez sua passagem para a televisão na década de 50 e que já o havia substituído em um episódio na terceira temporada (Person or Persons Unknown). Pittack alternou com Clemens a direção de fotografia, assinando nove episódios na quarta temporada e se mantendo vinculado à série, trabalhando posteriormente em dez episódios na quinta temporada, com uma participação na série (direção de fotografia) totalizando vinte episódios.

Os episódios dessa temporada levavam oito dias para ficarem prontos, as filmagens ocupavam seis dias, mais o dia de ensaio e o da escolha de cenários (Zicree, 1992, p.297). Nessa temporada, destacam-se os episódios The Thirty Fathom Grave; sobre um som estranho captado de um submarino afundando na Guerra do Pacífico; He's Alive, sobre a ascensão do fascismo nos EUA por meio de um jovem problemático e do fantasma de Hitler; Death Ship, uma nave espacial que encontra a si própria acidentada em um planeta remoto no espaço; Jess-Belle, uma história de inveja envolvendo bruxaria; The Parallel, um astronauta volta para casa após uma missão e descobre que foi parar em uma dimensão paralela; On Thursday We Leave for Home, uma equipe de resgate encontra humanos em um mundo insalubre passando por dificuldades extremas e tenta convencer o autoproclamado líder que todos devem partir; e The Bard, conta a história cômica de um aspirante a roteirista fracassado que invoca Shakespeare para escrever seus roteiros para televisão.

Essa discrepante quarta temporada marcou o afastamento cada vez mais notório de Serling da série, como provam suas narrações que, caracteristicamente, nas temporadas anteriores, se passavam em meio aos cenários, sendo substituídas por filmagens em fundo cinza, realizadas a toque de caixa antes dos episódios terem sequer seus roteiros produzidos. Serling continuaria enviando os roteiros (oitos dos dezoito episódios foram de sua autoria) e se desanimando com a produção de Hirschman. Porém, ele também estava envolvido com outros trabalhos, como sua 
atuação docente e a roteirização do livro de Charles W. Bailey II e Fletcher Knebel, Seven Days in May de 1962, adaptado no filme dirigido por John Frankenheimer, Sete Dias de Maio (Seven Days in May, 1964), um drama da Guerra Fria. O filme, apoiado pelo presidente Kennedy (MULLOY, 2017, p.67), que nunca chegou a vê-lo finalizado, se passa no futuro e mostra uma conspiração entre militares para realizarem um golpe militar na presidência dos EUA após o presidente fazer um acordo de paz com a URSS, um tema muito discutido no momento de realização da obra, quando se temia a infiltração de ideias da extrema-direita nos meios militares, cujo símbolo máximo, poucos anos antes, foi o caso jurídico da acusação de que o general radical de direita Edwin Anderson Walker estava doutrinando suas tropas com material de organizações anticomunistas extremistas (o que era algo aceitável à luz do próprio documento secreto do governo dos EUA, NSC-68, que orientava as ações estatais na Guerra Fria) e influenciando os votos dos soldados nas eleições (lbid., p.42-45). Posteriormente, Walker se tornaria um político polêmico radical de direita. Somandose a esse receio da radicalização dos militares que podiam se sentir tentados a tomar o poder via golpe de estado, o assassinato de John F. Kennedy no final de 1963 e as teorias de conspiração subsequentes dariam um senso de urgência a mensagem do filme de Frankenheimer quando de seu lançamento, em 1964.

Ainda em 1963, uma baixa mais grave e triste ocorreria na série sem que o público se desse conta: Charles Beaumont passou a sentir efeitos de uma doença neurodegenerativa que cada vez mais iria debilitá-lo, sem ser diagnosticada. O escritor, então com 34 anos de idade, aos poucos, foi perdendo a capacidade de falar, se concentrar e escrever histórias. A partir de 1963, suas obrigações com diversas séries passaram a ser cumpridas por seus amigos no meio, que o ajudavam, escreviam os roteiros e assinavam seu nome (ghostwritting), recebendo metade do valor da venda dos roteiros, em uma prática não aceita pelo sindicato dos roteiristas (ZICREE, 1992, p.353-356). Beaumont viria a falecer em 1967, aos 38 anos.

Com episódios de uma hora, distintos do clima geral da série, e em outro dia e faixa de horário de exibição, houve perda de audiência (PRESNELL; MCGEE, 1998, l.434) mas não a ponto de ser um desastre, o que era um medo real da produção. Entretanto, as expectativas de ampliação do alcance da série, como era esperado pela CBS quando a renovou, não se concretizaram. Após conflitos referentes à personalidade do produtor Hirschman e ao aumento dos custos de produção (GRAMS JUNIOR, 2008, p.126), ele finalmente foi dispensado da série para produzir na NBC e 
Bert Granet, o produtor do drama para televisão The Time Element, assumiu a produção dos últimos cinco episódios da temporada. Porém, a série não foi cancelada ao final de sua quarta temporada e a CBS encomendaria em abril de 1963 uma quinta temporada (ZICREE, 1992. p.360; GRAMS JUNIOR, op. cit., p.139), agora voltando ao formato e dias originais, episódios de trinta minutos e às sextas-feiras à noite, contudo o horário em relação às três primeiras temporadas seria antecipado, $21 \mathrm{~h} 30$ em vez das $22 \mathrm{~h}$.

A última temporada da série foi ao ar de 27 de setembro de 1963 a 19 de junho de 1964, totalizando 36 episódios. O produtor Bert Granet sairia da série após treze episódios, trocando de série na CBS para ganhar mais dinheiro, fato que abalou as relações entre Serling e Granet até o fim da vida de ambos. Para substituí-lo, foi contratado William Froug.

Em entrevista concedida a Stewart T. Stanyard e publicada no livro Dimensions Behind The Twilight Zone (2007, p.122-129), Bert Granet, falecido em 2002, confirmou o abalo do relacionamento dos dois, afirmando que Serling levou a sua saída da série para o nível pessoal, considerando uma traição. Porém, ao mesmo tempo, em várias respostas às perguntas de Stanyard, demonstrou que também ainda guardava um certo rancor de Serling e relativizou sua participação na série como apenas um trabalho dentre muitos que fizera em um programa nada especial de televisão, mídia que, deixa claro, apresenta material de baixa qualidade, como no trecho abaixo:

[...]Eu não estou decorando a Capela Sistina, eu só estou fazendo um programa de televisão. Quando as pessoas começam a se levar a sério demais [citando diretamente Serling] - eu posso entender o cinema, quando você trabalha em um filme por um ano, um ano e meio - em terem altos princípios, e eu geralmente fiz o melhor com o pouco de habilidade que tinha. Porém, um programa de televisão é bobagem fatiada diariamente. (Ibid., p.127, tradução nossa).

$\mathrm{Na}$ tentativa de ampliar a audiência na última temporada, foi realizado um audacioso plano de publicidade, exposto em carta pelo assessor de imprensa Henry C. Rogers em 1963 (1963, p.1-11). Esse plano consistia de várias etapas a serem realizadas cronologicamente, que, segundo Rogers, teriam sucesso em elevar a audiência da série, vista como problemática desde a primeira temporada, e dos demais programas, também patrocinados pela Procter \& Gamble, que viriam em seguida.

A primeira etapa seria uma campanha de abertura, na qual Rod Serling escreveria um artigo para ser distribuído para a imprensa, acompanhado de uma foto, 
e daria entrevistas, indicando que a "imaginação científica" tornou-se a "realidade científica".

O segundo passo seria uma exibição itinerante que viajaria por mercados chave a serem escolhidos, explorando essa noção da "imaginação científica" tornar-se a "realidade científica", com exemplos desde Júlio Verne, passando pelo cinema de Méliès, histórias em quadrinhos e projetos da corrida espacial. As emissoras locais divulgariam a exposição, aproveitando para fazer propaganda da série, a qual poderia ser combinada com o terceiro passo para maior efetividade.

O terceiro ponto da campanha era a turnê da "mulher do amanhã: princesa twilight", com a apresentação de uma mulher supostamente do futuro que iria usar roupas especiais de tecidos novos, criados pela figurinista Edith Head, com maquiagem e cortes de cabelos futuristas. Além disso, ela utilizaria diversas tecnologias que levaria em sua bolsa e seria acompanhada em sua turnê pelo ambiente da mulher do futuro, com mobília também futurista, como a cadeira em que sentaria ao dar entrevistas, em ação publicitária com revistas de alcance nacional. A "princesa twilight" deveria aparecer na série e falaria nas entrevistas e ao público da vida no futuro lançando mão de informações dadas por Serling e autoridades científicas. Ela deveria ser alta, pois as mulheres do futuro seriam mais bem nutridas e saudáveis, além de inteligente e sagaz. Até um computador portátil seria utilizado pela garota nas entrevistas para, a partir de variáveis referentes aos entrevistadores, falar sobre como seria o futuro deles.

O quarto ponto seria a realização de entrevistas simultâneas com oito jornalistas ao mesmo tempo pelo telefone, etapa que deveria ser realizada quando a temporada já estivesse no ar.

O último passo seria uma turnê de Rod Serling durante uma semana ao longo da temporada para mercados chave a fim de promover a série, utilizando seu prestígio no meio jornalístico para atrair atenção para o programa televisivo.

As ideias absurdas de publicidade soavam como algo que poderia fazer parte de um roteiro da própria série para ser devidamente criticado como despropositado. Da campanha publicitária proposta, apenas temos certeza da realização de uma versão bem distinta do plano original da Princesa Twilight, renomeada Miss Twilight Zone e alterada em sua ação primária por interferência de Serling: foi contratada uma estudante de astrofísica da UCLA (Universidade da Califórnia em Los Angeles) chamada Virginia Louise Trimble, para viajar pelo país dando entrevistas sobre a 
série, ciências e política - e não desfilando como se fosse de quinhentos anos do futuro no padrão imaginado de mulher de classe média para o período. Posteriormente, Trimble alcançaria uma carreira acadêmica de sucesso no campo da astrofísica e não se sabe se essa promoção chegou a interferir na audiência (GRAMS JUNIOR, 2008, p.142-144), que se manteve sempre abaixo das expectativas da CBS e de Serling.

A quinta temporada demonstrava o esgotamento da fórmula, inclusive com a repetição de temas já tratados por outros episódios, mas mesmo assim, apresentou alguns dos episódios mais lembrados e interessantes da série, como: Nightmare at 20,000 Feet, um homem com medo de voar de avião é atormentado por visões de um gremlin aprontando na asa do avião; Number 12 Looks Just Like You, a história de mundo totalitário que valoriza a uniformidade de padrões de beleza; An Occurrence at Owl Creek Bridge, homem executado durante a Guerra Civil dos EUA escapa mentalmente do seu destino; I Am the Night_Color Me Black, o ódio mundial passa a deixar o planeta às escuras; Stopover in a Quiet Town, um casal é capturado por alienígenas gigantes e colocado em uma cidade cenográfica perfeita; e Come Wander with $\mathrm{Me}$, um músico folk procura músicas no interior para comprar e se torna o tema de uma balada.

Após cinco anos, a série não seria renovada para uma sexta temporada. Já no início do ano de 1964, enquanto a quinta temporada ainda estava em exibição, foi anunciada a programação do segundo semestre da CBS e Além da Imaginação não estava na lista. Em primeiro de abril de 1964, o vice presidente da costa oeste da CBS, John T. Reynolds, agradeceu Serling pelos serviços prestados à emissora, e teceu elogios à qualidade da série, lamentando seu cancelamento, deixando as portas abertas para futuros projetos e reconhecendo que Além da Imaginação tinha uma capacidade incrível de se regenerar, talvez até pudesse voltar ao ar no final do ano (REYNOLDS, 1964, p.1), o que nunca aconteceria.

A série foi comercializada mundialmente, com enorme sucesso e atualmente, ela ainda é um referencial, associada ao imaginário televisivo mais amplo, principalmente ao gênero ficção científica, além de ser um paradigma de série de antologia fantástica e uma marca forte de propriedade da CBS, encarnada desde os anos 60 em filme, em mais três séries (1985-1989; 2002-2003; 2019-) e todo tipo de produtos, como revistas, livros, camisetas, bonecos e jogos. A série ainda é exibida na televisão paga dos EUA e como tradição iniciada há mais de vinte anos na televisão 
americana, o canal pago Syfy faz na virada do ano uma maratona de episódios do programa Além da Imaginação original, indo do dia 31 de dezembro até 2 de janeiro. Em 2018, foi anunciada uma nova versão da série para o novo mundo da televisão sob demanda, lançada em abril de 2019, produzida por Jordan Peele e distribuída mundialmente por serviços de streaming.

\subsection{0- O que pode ser encontrado além da imaginação}

Ainda antes da confirmação do final de Além da Imaginação, Serling tentou vender uma versão da série para a rival $A B C$, o que pode ter influenciado a decisão da CBS em cancelar a série (GRAMS JUNIOR, 2008, p.147). O nome sugerido para esse novo programa foi dado pelo presidente da emissora, Witches, Warlocks and Werewolves (Bruxas, Bruxos e Lobisomens, em tradução literal), um título retirado do livro de contos editado por Serling em 1963, Triple W: Witches, Warlocks and Werewolves, indicando uma série com apelo mais sobrenatural. Serling não gostou do título e propôs o nome Rod Serling's Wax Museum (O Museu de Cera de Rod Serling, em tradução literal), mantendo um apelo sobrenatural como se pode notar pela longa tradição do horror associado aos museus de cera, tema explorado inclusive no episódio de Além da Imaginação The New Exhibit, no qual um empregado de museu de cera se torna um assassino serial influenciado por sua relação com as estátuas de criminosos do passado. Além disso, na proposta de Rod Serling, as apresentações com sua presença, de forma semelhante a Além da Imaginação, seriam filmadas em um castelo das Mil Ilhas, fronteira dos EUA com Canadá, onde ele faria comentários sobre a história em meio a estátuas de cera representando os personagens do episódio, reforçando o tom assustador. Após Serling criticar publicamente o projeto que estava negociando, pois achava que a emissora queria algo de baixa qualidade, filmes "C", como Serling falou em entrevista (ZICREE, 1992, p.429), e as notícias de jornais da época que afirmavam que Além da Imaginação não gerava lucros (GRAMS JUNIOR, 2008, p.151), a ABC cancelou a negociação.

Com o cancelamento de Além da Imaginação, Serling vendeu sua parte na série para a CBS, fato do qual ele iria se arrepender posteriormente, após presenciar o sucesso que sua série atingiria, pois na época não achava que ela geraria dinheiro e, ademais, fora orientado por seus agentes e advogados a realizar a venda pois existia a crença de que a negociação posterior em syndication mais cobriria os gastos 
da CBS do que geraria lucros (PRESNELL; MCGEE, 1998, I. 490-498). Já no final de 1965, George D. Faber, diretor de relações com clientes da CBS Films Inc., informou a Serling que a audiência de Além da Imaginação em syndication em todos os locais era excelente (FABER, 1965, p.1).

Posteriormente, Rod Serling continuou ocupado, produzindo roteiros, aparecendo em propagandas, narrando programas e até apresentando um game show. Seus próximos trabalhos com temas fantásticos mais significativos foram a versão do roteiro do filme O Planeta dos Macacos (Planet of the Apes, 1968), escrita em 1964 (ADAMI, 2015, p.82-84), que posteriormente foi passada a Michael Wilson, mas mantendo parte da proposta de Serling, inclusive o final com a Estátua da Liberdade; o telefilme Night Gallery (1969), com três histórias sobrenaturais escritas por Serling e dirigidas por Boris Sagal, Steven Spielberg (em seu primeiro trabalho como diretor profissional) e Barry Shear. O sucesso desse telefilme foi responsável pela série homônima que foi ao ar entre 1969-1973, exibida no Brasil com o nome Galeria do Terror, incorporando a ideia das estátuas de cera de seu projeto anterior, substituindo-as por pinturas. Porém, o papel de Rod Serling na série de antologia, no decorrer do programa, passou a ser de mero apresentador dos episódios e ele tinha pouca ou nenhuma influência na produção, mesmo em seus próprios roteiros, bem distinto de sua participação em Além da Imaginação.

De sua intenção para um filme para cinema de Além da Imaginação, planejado ainda na década de 60 enquanto a série estava no ar, uma das sequências acabou se tornando o filme para televisão Time Travelers, em 1976 (GRAMS JUNIOR, 2008, p.149). Uma história de viagem no tempo na qual dois cientistas de um mundo assolado por uma epidemia voltam para 1871 na tentativa de encontrar a cura. O filme foi levado ao ar após ser adquirida por Irwin Allen, produtor da série Túnel do Tempo (The Time Tunnel, 1966-1967), que chegou a utilizar adereços e cenários de sua série de dez anos antes.

$\mathrm{Na}$ década de 70, Serling narraria e apresentaria diversos documentários de pseudociência, como UFOs: Past, Present, and Future (1974), The Outer Space Connection (1975), UFOs: It Has Begun (1979), esse último finalizado quatro anos após sua morte. Essas obras eram filmes voltados à especulação sobre vida alienígena e à promoção de noções do tipo "eram os deuses astronautas", popularizada na época pelos livros de Erich von Däniken. 
Rod Serling faleceria após ter tido dois ataques cardíacos e se submeter a uma cirurgia do coração em 28 de junho de 1975, tendo um derradeiro ataque na mesa de operação. Ele deixou um legado fundamental para o desenvolvimento da televisão como mídia de massa, tornando-se um exemplo de autor que fazia parte do grupo de pessoas ligadas à indústria televisiva que tentou, de forma explícita, elevar a qualidade da nova mídia, aproveitando a capacidade de unir o melhor do rádio, da literatura e do cinema.

\subsection{1- O insólito de Serling}

Rod Serling se colocava como um intruso, um forasteiro e um novato no meio fantástico, fato que foi usado contra ele por autores da área, até porque seu encontro com essa temática como principal forma de expressão, em Além da Imaginação, se deu quando já era um roteirista de televisão extremamente respeitado e o próprio Serling reiterada e humildemente assumia que não estava muito familiarizado com a literatura atual do gênero, expressa no período principalmente nas pulps. Exemplos do estranhamento de críticos e parcela do público com o que parecia a eles uma mudança e um desperdício do talento de Serling permeavam todo o contexto da série, mesmo que em geral ela fosse elogiada. Em 1960, um homem mandou uma mensagem para Serling elogiando seu roteiro para In the Presence of Mine Enemies no Playhouse 90 e admitindo o erro de julgamento sobre sua capacidade como roteirista pois, ao assistir Além da Imaginação, pensou que as qualidades dele como escritor haviam se deteriorado (SAK, [1960?], p.1). Já em 28 de junho de 1961, entre a segunda e a terceira temporada da série, Serling recebeu um cartão que expressa de forma clara a visão preconceituosa que ele enfrentava sobre o fantástico; essa visão foi relatada não nos primeiros episódios, nos quais fazia sentido realmente haver dúvidas sobre a qualidade, mas em um momento em que a série já contava com 65 episódios, muitos, os mais memoráveis. O cartão começa com uma longa pergunta retórica, realizada por uma mulher que provavelmente não assistia a Além da Imaginação e expressava o que era uma opinião corrente sobre o insólito em geral:

Por que você desperdiça seus talentos em histórias estranhas, quando você pode, como você fez no passado, nos dar pessoas vivas atuais que respiram, lutam, sofrem, emergem como seres humanos tridimensionais, de carne, ossos, espírito, aquecidos e iluminados pela caneta talentosa de um roteirista? (UNGAR, 1961, p.1, tradução nossa) 
Rod Serling afirmava utilizar conscientemente os elementos de horror, fantasia e ficção científica como pretexto para apresentar ao público questões profundas de forma alegórica as quais, devido à censura das emissoras e dos patrocinadores, não podiam ser expressas de forma realista no meio dramático regular. Ele sabia perfeitamente que esse tipo de narrativa deve ter uma razão e deve fornecer para o público alguma alternativa para explicar o enredo, ideia exposta textualmente por Serling em resposta a uma carta enviada pelo aspirante a roteirista Gordon L. Swirsky em 1963 (SERLING, 1963b, p.1). Obviamente, há um elemento de verdade nesse encontro de Serling com o fantástico, porém ele sempre se interessou pela temática, e mesmo quando ainda iniciava sua carreira e a desenvolvia em obras que seriam julgadas como mais sérias, ao escrever dramas, sempre propunha narrativas com elementos insólitos, indicando que parte de suas colocações sobre usar esses temas para dizer o que não podia ser dito de forma clara continha uma parcela de autodefesa para justificar seus gostos que podiam sofrer preconceito por parte dos diretores, produtores, patrocinadores e pelo público, além de diferenciar seu material de obras infanto-juvenis ou de qualidade duvidosa que abundavam nas mais diversas mídias da época.

Como revelado pelo irmão de Rod Serling a Zicree (1992, p.4), eles costumavam ler e discutir todos os pulps de ficção científica publicados durante seu período infanto-juvenil. Na época da faculdade e recém-formado, trabalhando na rádio, ele chegou a submeter histórias (rejeitadas) que envolviam fatos inexplicáveis ou estranhos; inclusive, em 1950, enviou um roteiro para Lights Out (GRAMS JUNIOR, 2008, p.13), um programa de televisão de antologias que lidava com muitos dos temas tratados em Além da Imaginação.

Rod Serling também chegou a enviar dois resumos de histórias submetidos em 1952 para o programa de ficção científica Tales of Tomorrow, via contato com o produtor do mesmo, Mort Abrahams, em Nova York, uma proposta chamada The Oath (O Juramento, em tradução literal), sobre um cirurgião tcheco em Praga que deve decidir se salva ou não a vida do comissário, ex-colega de faculdade, mas membro do governo totalitário responsável por quebrar seus dedos por desavenças políticas. O cirurgião resolve ajudar seu ex-colega, correndo o risco de ser rejeitado por seus companheiros rebeldes. Pela descrição do roteiro, o único elemento próximo à ficção científica seria a distopia, ou talvez a cirurgia a ser realizada ou a habilidade do cirurgião. A outra proposta seria mais calcada no filme O Dia em que a Terra Parou 
(The Day the Earth Stood Still, 1951), intitulada A Gift for a Metal Monster (Um Presente para um Monstro de Metal, em tradução literal), contava a história de um cientista que desejava inventar um robô e é contatado por um robô alienígena que explica sua missão na Terra de sondar os humanos para avisar seus mestres se a humanidade merece ou não ser exterminada, explicando para o cientista que até o momento ele só encontrara evidências para destruí-la, devido às guerras e armas que vira. O robô decide ficar mais alguns dias para analisar melhor os seres humanos e, acompanhando a família do cientista, ganha de Natal um beijo da filha dele. Ao ver a demonstração de afeto, afirma que a Terra pode ter um futuro positivo e decide ir embora a fim de avisar seus mestres para esperarem mais um tempo antes de tomar uma decisão. (Ibid., p.11-13). A mesma noção básica estará presente em um dos pilotos propostos para Além da Imaginação no final da década, I Shot an Arrow Into the Air e no episódio da série em 1962, The Gift. Seja como for, as duas propostas foram rejeitadas no início da década de 50, mas não esquecidas por Serling.

Em 1953, encontramos um roteiro de Rod Serling que apresentava mágica e comédia. Em 5 de agosto, foi ao ar, em Kraft Television Theatre, o episódio, Old MacDonald Had A Curve, sobre um velho ex-jogador de baseball vivendo em uma casa de repouso, exagerando as histórias de seu tempo profissional (SANDER, 1992, p.92). Ao machucar seu ombro, o idoso consegue lançar uma bola curva e voltar a ter uma carreira, porém seu ombro é deslocado novamente e retorna ao normal, fazendo o senhor perder sua habilidade mágica. Desolado, mas com dinheiro, ele se anima em poder ajudar a casa de repouso e ser um símbolo positivo para os demais idosos. Por fim, ele desloca seu ombro uma terceira vez e ganha novamente seu poder. Esse roteiro contém uma abordagem do mundo do baseball, com alguns pontos em comum no episódio The Mighty Casey, da primeira temporada de Além da Imaginação, em 1960.

Ainda no mesmo ano, Serling apelou para o suspense, seu roteiro Nightmare at Ground Zero (Pesadelo no Ponto Zero em tradução literal) foi exibido ao vivo em 18 de agosto de 1953, no programa Suspense da CBS (SANDER, 1992, p.227). Esse episódio era uma trama estranha e simples, muito aquém do trabalho que tornaria Serling famoso, porém notam-se os ingredientes de tensão narrativa para deixar o público interessado em seu desfecho, algo que Serling desenvolveria posteriormente em Além da Imaginação. Em Nightmare at Ground Zero, somos apresentados a um bonequeiro excêntrico, que faz manequins para uma casa de teste atômico, 
trabalhando para os militares no ponto zero do título da narrativa. O homem, cansado de ser cobrado por sua esposa, que não o acompanha no amor por fazer bonecos, leva a moça junto na entrega dos bonecos para a casa que seria explodida no teste de uma bomba atômica no dia seguinte. Aproveitando que ela dormia após tomar um remédio, troca-a por um dos manequins, deixando-a na casa do teste atômico e condenando a pobre mulher à morte. Retornando da viagem, ele tem uma recaída moral e resolve voltar para salvá-la. Ao entrar na casa alvo de teste atômico, encontra a moça ainda dormindo e ao acordá-la, revela que a deixara para morrer, mas havia tido uma crise de consciência e voltara para salvá-la. Ambos conseguem escapar de carro a tempo e, com a explosão atômica de fundo, o casal resolve continuar junto, agora com confiança mútua. Um ponto zero na relação dos dois, duplo sentido com o nome dado ao local de explosões.

Outro roteiro desse período que incorporava a moda dos discos voadores, iniciada no final da década de 40 e que ainda era forte nos anos 50 , foi o drama U.F.O. (O.V.N.I., em tradução literal), exibido dia 6 de setembro de 1954 no programa Studio One Summer Theater (Ibid., p.229), série que substituía Westinghouse Studio One nos meses quentes (TERRACE, 2011, p. 1030). Nesse roteiro, temos a história de um editor de jornal de uma pequena cidade falida, que começa a inventar que coisas fantásticas estariam acontecendo na região, tentando fazer a publicidade da cidade. Entretanto, um dia, um disco voador cenográfico cai de um caminhão e uma confusão atinge seus cidadãos e o mundo (GRAMS JUNIOR, 2008, p.14). Esse roteiro foi adaptado pelo programa da TV Tupi em TV de Vanguarda em 17/08/1958 com o título "Eu Vi um Disco Voador", produzido por Cassiano Gabus Mendes e adaptado por Walter George Durst, com elenco composto por Célia Rodrigues, Eduardo Abas, Geraldo Louzano, Henrique Martins, Jaime Barcelos, Luís Orione, Néa Simões, Odilon del Grande e Romano Luís (SOUZA, 2011, p.133).

Em 1956, Serling escreveu uma adaptação para o cinema do romance apocalítico ecológico britânico The Death of Grass (R.U.) /No Blade of Glass (EUA), no Brasil "Chung-Li - A Agonia do Verde" (1980) uma história apocalíptica na qual um vírus (Chung-Li), ao entrar em contato com pesticidas, sofre mutação e começa a devastar as colheitas, levando a Inglaterra ao caos, destruindo a civilização. Sabendo que o governo irá atacar as cidades com bombas de hidrogênio, dois amigos reúnem suas famílias para encontrar refúgio e sobreviverem em uma fazenda isolada no norte da Inglaterra. No livro, acompanhamos a luta pela sobrevivência dos personagens em 
um pesadelo onde os valores éticos e morais são testados para garantir a sobrevivência do grupo. O roteiro de Serling para essa história acabou não sendo produzido, porém demonstra o interesse do autor por temas ligados à destruição da civilização e à relação entre os valores humanos em um mundo onde eles são colocados à prova ou não têm mais valor, temas que serão explorados em seus roteiros de Além da Imaginação. O livro No Blade of Glass foi adaptado para o cinema em 1970, com o título em português de A Mais Cruel Batalha, uma coprodução angloamericana, dirigida por Cornel Wilde, que também fez o roteiro.

\subsection{2- Fábulas de Esopo modernas}

O título em inglês da série The Twilight Zone, em tradução literal Zona Crepuscular, pode fazer referência ao espaço no céu ocupado pela luz do sol no momento de seu nascer ou seu ocaso, ao nível mais baixo do oceano que a luz pode alcançar e um campo intermediário entre duas situações distintas (STANYARD, 2007, p.7), esse último sentido consoante à proposta da série de Rod Serling de apresentar histórias ocorrendo em um espaço de intercâmbio entre a vida diária e o desconhecido de natureza fantástica. A noção de uma twilight zone como espaço intermediário entre dois universos distintos, não necessariamente ligados ao sobrenatural, tem origem ficcional registrada na primeira década do século $X X$, como apresentado no romance de Roger Carey Craven, In the Twilight Zone, publicado em 1909, e podemos encontrar uma noção mais próxima da popularizada por Serling, no artigo também intitulado In the Twilight Zone, publicado em 1918 na revista The Lotus Magazine, por Henry McDonald Spencer, que ao comentar sobre o conhecimento científico de sua época em um artigo explorando a realidade baseada em evidências de fenômenos sobrenaturais promovidos pelo movimento espiritualista, afirmou a noção dessa twilight zone de forma bem semelhante à apresentação da série de Rod Serling cinquenta anos depois. Para Spencer (1918, p.353-354), "até recentemente o mundo acadêmico como um todo tratava com desprezo ou completa indiferença todos esses fenômenos obscuros que ocupam a twilight zone, a Terra de ninguém entre o campo já conquistado pela ciência e o território negro do misticismo, ignorância e 
superstição"32. Cabe destacar que, mesmo com o uso esporádico anterior na língua inglesa da expressão twilight zone com a mesma intenção, foi a série que inseriu essa noção de forma contundente na cultura americana.

O roteiro piloto I Shot an Arrow Into the Air, em sua primeira página, descrevia uma versão da introdução que explicava o que seria a zona crepuscular a ser visitada nos episódios (GRAMS JUNIOR, 2008, p.23). Lá, pode-se ler, em fala do narrador a ser vista durante uma sequência lenta mostrando os céus: "Há uma sexta dimensão além da conhecida pelo homem. Ela fica em uma área ilimitada cheia de luz e sombras. Entre o que o homem experimentou e o que o homem pode sonhar. Entre o que alcançou e o que irá atingir. Entre ciência e superstição. Entre o poço de seus medos e a luz do sol de seu conhecimento. Essa área é chamada de Zona Crespucular!"33. Posteriormente, Serling faria alterações nessa narração na apresentação dos episódios, como corrigindo a informação da sexta dimensão para quinta, pois havia se confundido, mas mantendo o conceito apresentado acima (ZICREE, 1992, p.24). Como Serling explicaria a quinta dimensão para ele seria tudo que a imaginação contém. A sequência apresentada dava a impressão de que o público estava se deslocando em forma de uma viagem a um local fantástico, marcada pelo aviso: "Sua próxima parada, a Zona Crepuscular! ${ }^{34 " . ~}$

Serling afirmou durante sua vida que pensava ter inventado a expressão twilight zone, até que foi informado mais tarde que o termo era associado à aeronáutica, utilizado na força aérea da época exatamente para designar um espaço no céu durante os voos (STANYARD, 2007, p.7), sem quaisquer relações com seu uso do termo. Como dado do contexto histórico, esse espaço no céu, como relatado pelo expiloto John Womack em suas memórias (2011), apresentava um enorme desafio de navegação durante a Guerra Fria, pois os aviões que levavam só os equipamentos

\footnotetext{
32 [tradução nossa] No original: Up to quite a recent date the learned world as a whole treated with scorn or complete indifference all those obscure psychical phenomena which occupy the Twilight Zone, the No Man's Land between the ground already conquered by science and the dark territory of mysticism, ignorance, and superstition.

${ }^{33}$ Tradução livre da narração presente na página do primeiro roteiro para o episódio citado, em versão não datada: There is a sixth dimension beyond that which is known to man. It lies in a boundless area full of light and shadow. Between what man has experienced and what man can dream. Between his grasp and his reach. Between science and superstition. Between the pit of his fears and the sunlight of his knowledge. This area can be called the Twilight Zone! ${ }^{34}$ Tradução livre do texto final da narração utilizada na primeira temporada, com variações nas demais: Next stop, the Twilight Zone!
} 
que sobreviveriam a ataques nucleares recorriam apenas às posições dos astros para se localizarem, o que na zona crepuscular era de extrema dificuldade (WOMACK, 2011, p.136-138).

Como dado de curiosidade anedótica, uma mulher, em 5 de novembro de 1959, escreveu a Rod Serling, quando já havia notícias da baixa audiência da série, para falar de sua carreira como escritora, porém ao elogiar a série e falar que ela e o marido estavam divulgando-a para seus conhecidos, contou que muitas pessoas não assistiam à série devido ao título, pois tinham as ideias mais estranhas sobre seu significado. Ela relata que uma garota não queria assistir à série, pois achava que era um programa sobre bebês nascendo sem dor $(\mathrm{GOOCH}, 1959$, p.1-2), confundindo Twilight zone com Twilight sleep, técnica do início do século $\mathrm{XX}$ de sedação com narcóticos da mulher antes do parto que prometia uma experiência indolor para a mãe.

Entretanto, se analisarmos essa zona crepuscular, podemos encontrar algo bem mais profundo do que apenas um espaço intermediário onde coisas incomuns podem acontecer. Ela está ancorada no pensamento utópico ocidental, não sendo por si um local utópico, mas um ambiente que auxilia o avanço da utopia no mundo externo à zona crepuscular, procurando gerar uma sociedade onde as pessoas sejam livres para procurar seus interesses desde que não causem danos aos demais, à sociedade e ao mundo a seu redor (MELBYE, 2016, I.4675).

O universo moral da zona crepuscular, que perpassa todos os episódios da série, opera com a lógica de ser um lugar de observação, punição e depuração das falhas humanas individuais e coletivas, buscando eliminar comportamentos vistos como antissociais, preconceituosos, racistas, cruéis, humilhantes, degradantes, contrários aos direitos humanos e danosos à comunidade, não só dos personagens ou do estado, mas principalmente da audiência, já que em alguns episódios presenciamos sofrimento do protagonista como forma de a zona crepuscular expor os pecados da sociedade. Procurando restaurar um equilíbrio na sociedade, os culpados devem ser punidos e as vítimas compensadas pelo mal que passaram (MELBYE, 2016, I.1657); a função desse local intermediário entre a realidade e o imaginário é de "corrigir desequilíbrios morais em uma base individual" (Ibid., I.2818). Não é à toa que a série Além da Imaginação pode ser considerada uma parábola moderna. Às audiências eram reservadas o papel de aprenderem com o que era visto na série e alterarem os seus comportamentos por meio da reflexão sobre enredos que, mesmo 
não apresentando mundos utópicos, expressavam uma proposta utópica, da busca de aperfeiçoamento humano e social.

Em uma comparação baseada em grande parte nos episódios com personagens que se enquadram nos comportamentos vistos como danosos ao coletivo e ao indivíduo na crítica social proposta pela série, a zona crepuscular de Serling cumpre o mesmo papel para uma sociedade secularizada moderna pósholocausto do purgatório da tradição católica. Se para o Catolicismo este é o local onde os resquícios de pecados devem ser exterminados por meio de orações e punições, para que quando a alma acendesse ao paraíso ela estivesse pura de quaisquer traços do mal; na série, esse espaço serve para que os personagens sofram os efeitos de suas ações frente ao mundo e à sociedade em geral. Se eles conseguem superar seus traços danosos, podem receber uma segunda chance e voltar renovados para o convívio social; caso sucumbam a suas personalidade ou seus comportamentos nocivos, não conseguem mais sair desse espaço, e mesmo que essa linha possa ser vista mais claramente nos episódios assinados por Serling, ela está presente permeando o conjunto da obra de forma evidente. Ao assistir a Além da Imaginação, nós, o público, de certa forma, fazemos o papel das pessoas que rezam pelas almas do purgatório ou aprendemos como evitá-lo.

\subsection{3- O bardo}

As ações da zona crespuscular se alinhavam diretamente à atuação de Serling na sociedade de seu tempo; portanto, não é despropositado reafirmar o papel autoral que possa ser atribuído à série e aos demais roteiros desse autor, tanto na televisão quanto no cinema: há uma repetição de seleção e formas de se abordar os problemas enfrentados pelas pessoas de sua época, os desafios das sociedades contemporâneas e os dilemas humanos mais amplos, como a questão das armas nucleares, as relações de trabalho e a efemeridade da vida na Terra

Em seu livro Spaceships and Politics - The Political Theory of Rod Serling, a cientista política Leslie Dale Feldman identifica nesse escritor um pensamento negativo sobre a natureza humana e uma noção mecanicista sobre o mundo que o colocariam na tradição do filósofo britânico Thomas Hobbes. A autora consegue associar temas dos episódios com uma visão que enfatiza a natureza beligerante, violenta e gananciosa do ser humano, esta natureza que só pode ser controlada por 
ameaça de coerção (FELDMAN, 2010, I.166). Porém, Sering tentaria compensar sua visão negativa com cenários mais otimistas, como se tentasse se desculpar por ter essa visão. Feldman define Serling como um "hobbesiano apologético" (Ibid., I.1107).

Pensando a série Além da Imaginação como parte significativa da produção de Rod Serling e comparando-a com as temáticas e críticas que realizou em boa parte de sua obra global, podemos identificá-lo como um artista que utilizava sua produção para tentar aperfeiçoar o debate público de seu tempo, seja se colocando como um anti-fascista, defensor da democracia e dos direitos humanos, de acordo com o desenvolvimento tecnológico e científico utilizado para humanização e não destruição da vida por guerras ou contra quaisquer tipos de preconceitos, valorizando a individualidade e as liberdades individuais desde que não causem danos a coletividade e ao indivíduo, além de ser um extremo defensor da liberdade de expressão.

Dentro da perspectiva preponderante de seu tempo nos EUA, Rod Serling rejeitava qualquer forma de coletivismo estatal imposto ou uso incorreto do poder (Ibid., I.2126), e, como apresentado em Além da Imaginação, contrário à noção de que o Estado tivesse o poder de decidir quem pode ou não viver, mesmo que seja a decisão sobre o destino de um assassino. Na série, a pena de morte pode ser dada pela Zona Crepuscular no modelo ético e moral do programa, mas não pelo Estado: a pena capital dada pelo governo é exposta de forma negativa. Entretanto, Serling não era anti-Estado, longe disso, ele estava alinhado à noção de um estado que defendesse os mais vulneráveis e interviesse nas relações sociais geradoras de ódio, preconceito, desigualdade econômica e social, desrespeito aos direitos humanos e ignorância em geral.

Durante o período em que realizou Além da Imaginação, e mesmo depois, Rod Serling estava ligado à esquerda hollywoodiana, apoiando-a financeiramente, emprestando materiais, defendendo pautas multiculturais da ONU, dando palestras e participando de eventos ligados a sindicatos e organizações. Além disso, regularmente financiava ações voltadas à defesa da liberdade de expressão, direitos civis e se envolvia em embates públicos, procurava ter bom senso e defender os valores nos quais acreditava, como gravar mensagem publicitária gratuita pedindo contribuição para a Rádio Europa Livre (PATTERSON, 1960, p.1), sem saber que na época a CIA usava a ajuda do público para esconder seu investimento na rádio, que era transmitida para os países do bloco soviético (PUDDINGTON, 2000, p.19) e fazia 
parte da guerra psicológica, sendo criticada por setores da direita por não ser suficientemente anti-comunista (Ibid., p.73-88). Por vezes, Rod Serling recebia cartas de pessoas e organizações de direita criticando suas posturas públicas, em entrevistas para jornais e televisão, ou mensagens e interpretações -ocasionalmente, exageradas ou incorretas - de suas obras.

Um exemplo de seu envolvimento com causas sociais era o empréstimo de episódios de Além da Imaginação, mais claramente críticos das condições sociais para sindicatos e grupos militantes, como se pode ver em carta enviada a Rod Serling por Sam Kaplan em $1^{\circ}$ de julho de 1964 em resposta ao pedido de Rod Serling para que emprestassem uma cópia do episódio Brain Center at Whipples para o sindicato dos açougueiros, pois ele prometera ao sindicato que uma cópia seria enviada. Kaplan alertava Serling para o fato de que a CBS não desejava emprestar o programa para o sindicato e a emissora daria uma desculpa burocrática genérica, pois o episódio lidava com automação industrial e desemprego advindo dela e "alimentar esse tipo de material para um sindicato estava sujeito a questionamentos particularmente sérios devido ao fato de que os compradores da emissora eram os fabricantes" (KAPLAN, 1964, p.1, tradução nossa) e que ele sentia que seria de interesse de Serling manter distância em relação a qualquer tipo de campanha sindical contra desemprego causado pela tecnologia.

Suas ligações com o Partido Democrata não eram segredo. Por exemplo, Rod Serling foi roteirista do documentário Let Us Continue (1963), encomendado pelo governo federal americano para apresentar o recém empossado presidente Lyndon Baines Johnson, logo após o assassinato de Kennedy (SANDERS, 1992, p.193) e, em 1967, participou ativamente da campanha para reeleger pela terceira vez o então governador democrata do estado da Califórnia, Pat Brown, que seria derrotado pelo adversário republicano, o ator Ronald Reagan. Entretanto, como se pode ver de forma clara em sua obra, principalmente em Além da Imaginação, ele não era um repetidor de políticas partidárias e suas críticas diretas e irônicas eram duramente dirigidas também contra políticas do governo de Kennedy, como, por exemplo, a questão da construção de abrigos nucleares nos lares americanos, algo incentivado por aquele presidente (ROSE, 2001, p.2-4) e duramente criticado na série no episódio The Shelter (1961), ou a crítica presente de forma direta em diversos episódios da série contra o investimento em armamentos ou retórica de guerra, noções que, por exemplo, eram contrárias à campanha presidencial de Kennedy, explorando o falso 
conceito do missile gap, uma ideia de que a URSS tinha mais armas atômicas que os EUA e era necessário um maior investimento bélico para garantir a deterrance, uma política da Guerra Fria de expandir a quantidade dos arsenais bélicos, com a noção de que o inimigo seria dissuadido de atacar.

Essas políticas eram criticadas regularmente na série nos episódios que utilizavam a Segunda Guerra e a Guerra Civil Americana como palcos para demonstrar a bestialidade das guerras, além de narrativas que mostravam destruição nuclear ou um mundo bem próximo dela. Essa política de enfrentamento da Guerra Fria foi incentivadora de eventos como a Crise dos Mísseis Cubanos em 1962 (LEBOW; STEIN, 1995, p.162). Ao mesmo tempo, a série valorizava as políticas federais de enfrentamento do racismo, ao não só dar o papel de protagonismo para atores negros, mas também criticar duramente, de forma geral e regular, preconceitos.

Todavia, pessoas ligadas ao pensamento anticomunista também encontravam episódios para elogiar, fazendo interpretações que ligavam os temas a sua causa, principalmente no campo da crítica que Serling apresentava aos regimes totalitários. Por exemplo, após a exibição do episódio The Obsolete Man, em 1961, que apresenta um estado totalitário que elimina as pessoas com comportamentos considerados obsoletos, Serling receberia cartas elogiando o que viam como uma conexão possível entre o mundo futuro apresentado pela série e o domínio comunista (AMMERMAN, 1961, p.1; CRAWFORD, 1961a, p.1; 1961b, p.1).

A postura de Serling no decorrer da Guerra Fria era a de que os EUA corriam muito mais risco com a ascensão de uma direita radical que retirasse direitos e perseguisse ideias dissonantes - até dentro do próprio campo de ideias de direita do que de uma infiltração ou chegada ao poder do comunismo. Ele via a ameaça comunista como exclusivamente externa (SERLING, 1961g, p.1-4). Isso pode ser notado de forma clara em suas críticas públicas à John Birch Society (JBS), organização com foco em atividades educacionais com visão anticomunista, radical e populista, liderada por Robert W. Welch Jr., fundada em 1958 e ostracizada à partir de 1968 (a JBS ainda existe), que procurava denunciar uma ampla conspiração comunista totalitária de domínio dos EUA e do mundo, expondo inimigos internos e externos dos EUA. Foi o próprio Welch Jr, em obra autoral de meados dos anos 50 pré JBS, que chegou a acusar o presidente republicano Einsenhower e outros membros de seu governo de serem simpatizantes comunistas. No contexto das décadas de 50 e 60, a John Birch Society não chegava a ser a mais extrema 
organização de direita nos EUA e parte do seu discurso antissistema já fazia parte do vocabulário político padrão da época, só variando no grau enfático promovido por aquela entidade (MULLOY, 2014, p.171); porém, devido a sua própria forma militante de agir com campanhas diretas e incessantes, passou a se tornar a cara para ser atacada e criticada de um movimento mais amplo que, segundo o historiador D.J. Mulloy (Ibid., p.11), pode ser visto como a transição da velha direita americana conservadora dos anos 40 e 50 para a direita dos anos 70 e 80.

Rod Serling, ao denunciar publicamente os métodos da JBS e acusá-la de ser uma ameaça à democracia, pois utilizava os instrumentos de seus inimigos declarados para conseguir seus objetivos e não reconheciam posições políticas distintas das próprias defendidas com veemência radical pelo grupo, tornava clara sua posição política, corroborando o que pode ser visto de forma geral na série Além da Imaginação, bem como noutras obras de Serling. Em carta dirigida ao editor do jornal Los Angeles Herald-Express, em março de 1961, na qual enviava uma critica à coluna de George Todt, este defensor de visão que dissociava as opiniões mais polêmicas do líder das dos liderados e afirmava que o público deveria conhecer a JBS por si, e não pela imprensa da época que a criticava duramente, Rod Serling defenderia a ideia, expressa por editorial do jornal Los Angeles Times na mesma semana, de que a batalha dos EUA contra a subversão deveria ser condizente com a tirania da direita, tanto quanto prontamente era reconhecida na esquerda, pois a democracia seria dependente da observância das leis e grupos não deveriam decidir quem deveria ser julgado, quais seriam as acusações e o grau das punições. Além disso, a liberdade de expressão deveria ser resguardada e não vista como perigosa por grupos que a confundiam com traição. Serling receberia cartas de membros e simpatizantes da John Birch Society, criticando suas posições, muitas vezes de forma acusatória, mas também para mostrar que a organização na verdade era patriótica e pacífica. Ele respondeu em 1964 a uma simpatizante da JBS que havia lido não só observações referentes à investigação do Congresso sobre a JBS, mas também uma série de panfletos e os livros do grupo, The Politician e o Blue Book (SERLING, 1964, p.1-3).

Cabe lembrar que Serling, na década de 50, posicionava-se radicalmente contra a chamada lista negra, lista de pessoas envolvidas com a indústria de entretenimento que, por supostas ou reais ligações com ideias ou grupos comunistas, eram impedidas de trabalhar. Sua opinião, expressa publicamente, era a de que, se realmente houvesse um crime, a pessoa deveria ser colocada na prisão e não proibida 
de trabalhar, pois se as ações não eram suficientes para colocar na cadeia ninguém deveria ter privado de seu direito de se sustentar (SERLING,1959, p.6).

A noção de que a América corria o risco de se tornar fascista não era exclusividade de Serling, que seguia análises compartilhadas tanto por parcelas da direita quanto pela esquerda sobre a ascensão de grupos de extrema direita militantes, vistos como pontas de lança de um movimento que levaria a um golpe militar de estado ou avanço do fascismo na América dos finais dos anos 50 e primeiros anos da década de 60, causando a perda dos valores que diferenciariam os EUA. Esse temor, mais do que mera precaução, demonstra que as chagas do recente "segundo medo vermelho" custavam a ser cicatrizadas e se faziam presentes regularmente no debate público e que havia o temor de que, a qualquer momento, a nação poderia se encontrar imersa em um novo momento de paranoia, perseguição, com um aumento da retórica belicista, em um contexto imprevisível, onde os armamentos tiveram um enorme desenvolvimento, como os misseis balísticos intercontinentais.

Serling era constantemente cobrado para retratar mais a URSS em suas histórias e deixar de lado o nazismo, que já tinha sido vencido. O roteirista explicava que era dever não só manter viva na memória coletiva as atrocidades nazistas, mas também que servisse como alerta para os EUA, pois o nazismo ainda estava vivo em setores da sociedade. Por exemplo, respondendo a uma carta que acusava a série Além da Imaginação de fazer parte dos "programas de horror atômicos" que incentivavam o derrotismo, sugeria censura e afirmava que havia muito mais críticas na televisão ao nazismo do que ao comunismo, Serling expressou sua visão de que:

é melhor lembrar que as duas ideologias [comunismo e nazismo] são
dedicadas à eliminação do homem livre. E a causa do homem livre [nome do
remetente] não pode ser promovida por sua sugestão de censura a livros
escolares e sua rejeição implícita do direito à divergência. Quando esse
direito é sacrificado, nós podemos nos encontrar muito bem em um governo
muito parecido com o da União Soviética (SERLING, 1960e, p.1-2).

Cabe destacar que tal noção, expressa por Serling na resposta acima, estava em voga no contexto da produção de Além da Imaginação, como se pode observar no influente e erudito livro da filósofa Hannah Arendt, publicado em 1951, As Origens do Totalitarismo (Elemente und Ursprünge totaler Herrschaft, 1951).

Rod Serling acreditava que as instituições americanas eram fortes o suficiente para se defenderem de possíveis ameaças dos comunistas e, além disso, não via 
nenhum sinal de grande infiltração a ponto de subvertê-las, como propagado por pessoas de direita. Além disso, notava que as associações como a JBS operavam de forma a desrespeitar as leis e a Constituição do próprio país que juravam proteger. Como exemplo, citava ligações de telefone noturnas e cartas não assinadas acusando-o de ser simpatizante comunista, campanhas que afirma que sofrera, além de ver professores tendo que se justificar porque citaram as Nações Unidas, médicos vilanizados por sugerirem programas de saúde mental, funcionários públicos caluniados por defenderem a fluoretação da água. Portanto, o principal perigo para os EUA era o crescimento desse tipo de comportamento que minava as instituições democráticas.

Essas opiniões eram correntes no debate político do período, defendidas publicamente tanto por republicanos quanto por democratas, além de jornais e estrelas de Hollywood, e não eram exclusivas de Serling, como podemos ver, por exemplo, expressas no jornal The New York Times de 2 de março de 1962 (EXCERPTS..., 1962), que reproduzia trechos do panfleto escrito pelo padre católico John F. Cronin, no qual denunciava os grupos de extrema-direita por utilizarem lógica falha ao acusarem membros do governo de simpatizantes ou aderentes a políticas falsamente atribuídas a socialistas ou comunistas, tais como o fim da segregação racial e os direitos civis, e minarem as instituições americanas, o que as deixariam fracas para lutar contra o comunismo internacional, este sim, segundo o católico, uma ameaça ao mundo que estaria sendo ignorada pelos americanos do período, em troca de uma ameaça interna débil ou até mesmo inexistente.

Não só em documentos pessoais sobre esse tema observamos a opinião de Serling, ela é reiterada em vários episódios de Além da Imaginação, os quais apontam os cuidados que seus contemporâneos deveriam ter para não dar poder a grupos totalitários, principalmente ligados ao discurso da direita anticomunista da época, bem representado pela John Birch Society, como o episódio Four O'Clock (1962), da terceira temporada, apresentando um paranoico homem que, de seu apartamento, caça subversivos e pessoas que considera más e os denuncia publicamente. Ou o episódio da quarta temporada, anteriormente citado, He's Alive (1963), no qual o fantasma de Hitler ajuda a fortalecer um movimento fascista. Assim, havia um amplo propósito de criticar quaisquer formas de autoritarismo, incluindo o de esquerda, como a crítica dirigida a Fidel Castro no episódio The Mirror (1961), da terceira temporada, com o alerta nietzschiano dado ao recém empossado líder da Revolução Cubana (e 
a qualquer pessoa com pretensões políticas) de que "Quem deve enfrentar monstros deve permanecer atento para não se tornar também um monstro. Se olhares demasiado tempo dentro de um abismo, o abismo acabará por olhar dentro de ti” (NIETZSCHE, 2001, p.89). No episódio, o abismo é substituído por um espelho.

Se colocarmos essa discussão em perspectiva do que estava acontecendo no mundo na década de 60, em referência aos riscos às democracias - como a tentativa de golpe militar na França contra a presidência de Charles De Gaulle, o Putsch d'Alger, de 1961, e as quebras institucionais e ditaduras que marcariam os países do continente americano nos anos seguintes-, vemos as razões para a ansiedade e a ênfase de Serling na mensagem de que só uma sociedade democrática garantiria a existência da civilização, os prognósticos para as democracias ocidentais não eram os melhores.

\subsection{4- Entre os gêneros}

Para fazer essa análise do seu contexto histórico-social, a série recorreu aos temas fantásticos, focando no lado humano, interagindo com o desconhecido, sem a preocupação de causar choque ou maravilhamento por sustos e/ou recursos puramente advindos do campo dos efeitos especiais. O próprio orçamento da época não permitia isso e mesmo se tivesse acesso a efeitos caros, não era a intenção de Serling e seus pares criar uma série desprovida de discussão das condições humanas, o que era constantemente reiterado pelo autor (GRAMS JUNIOR, 2008, p.vii) e pode ser visto na produção final de forma cristalina, mesmo em episódios que não chegam a ser considerados exemplos de criatividade.

Como é uma série de antologia que teve um número considerável de episódios, a depender das intenções do pesquisador, podem ser realizados distintos recortes temáticos para organizar a produção, agrupando os episódios em temas afins, com a presença do mesmo episódio em vários campos distintos. Esses agrupamentos já existiam na própria produção da série, como na seleção das reprises. Por exemplo, Buck Houghton, em uma classificação temática dos episódios para uma matéria publicitária, o que para ele provava sua teoria de que existiam poucos artifícios a serem utilizados que distinguiam a "fantasia de uma forma realística de contar a mesma história" (HOUGHTON, 1961, p.1), organizava-os por doze temas, alguns curiosos: I- Pessoas Possuindo Poderes Mágicos; II- Senhor Morte, seu emissário, ou 
temas pós-morte; III- Um retorno ao passado; IV- Indo para trás e para frente no tempo; V- Uma pessoa não é ela mesma, mas também uma extensão de si; VI- Uma máquina com atributos humanos; VII- Uma verdadeira era espacial é presumida existir no tempo da história; VIII- Truques relativos ao tamanho; IX- A "bomba" é o modus operandi; X-Aberrações mentais e sonhos; XI- Fenômenos naturais insólitos; XII- Sem classificação (lbid., p.1-4).

Outros autores destacam elementos semelhantes para agrupar os episódios, permitindo-nos uma visão geral de como as mais diversas temáticas se fizeram presentes na série. Por exemplo, o autor Stewart T. Stanyard (2007, p.33-56) agrupou os episódios em campos intercambiáveis, baseados diretamente nos elementos claros do enredo, como: o indivíduo, a morte, a mentalidade de grupo, a psique humana, a habilidade supernatural, o comportamento antissocial, a malevolência, a autodestruição, a redenção, os universos alternativos, a viagem no tempo, a viagem espacial, alienígenas e criaturas, o ser humano contra a máquina, os objetos encantados, a mágica. Já Don Presnell e Marty McGee (1998, I. 5650-5900) são bem mais específicos, organizando os episódios por gêneros, temas e enredos, como episódios que falam sobre atuação, anjos, boxe, demônios, etc., reconhecendo que o mesmo episódio possa estar em várias categorias distintas. Para o escritor e roteirista Marc Scott Zicree, uma característica marcante da série e o tema predominante que perpassa os episódios é o da alienação (ZICREE, 1992, p.XII), uma alienação em todos os campos, fruto das articulações modernas, "do homem em relação a seu trabalho, de si mesmo e de seus semelhantes" (FELDMAN, 2010, I. 2651), porém a alienação, mesmo sendo um tema importante em muitos episódios e um indicativo de caminho a se abordar criticamente os episódios, não está expressa diretamente em todos os episódios, dando lugar a um fator aglutinador mais forte, como veremos adiante.

Há a noção comumente aceita, principalmente na cultura histórica dos programas televisivos, de que Além da Imaginação é uma série de ficção científica (MELBYE, 2016, I.438). Entretanto, Além da Imaginação é uma série de antologia, que não se colocava como pertencente a um único gênero, sendo este alterado em cada episódio. Portanto, ela escapa de uma categorização mais comum, ampliando a dificuldade que já existe regularmente para inserir as produções culturais nos gêneros pré-estabelecidos. Em Além da Imaginação, mesmo que sejamos tentados a qualificála como uma "série fantástica", fazendo uso do termo guarda-chuva "fantástico", 
englobando a fantasia, o horror e a ficção científica, isso não estaria exatamente correto e diversos episódios escapariam dessa classificação, tendendo mais para as categorias da comédia, do western e da obra de guerra. Inclusive, os gêneros estabelecidos, por vezes são retomados de forma propositalmente satírica ou anacrônica. Portanto, apenas buscar elementos de gêneros reconhecidos e localizálos na série não dá conta da riqueza do material, correndo-se o risco de, ao tentarmos separá-los em caixas, não notarmos uma unidade notável que perpassa os episódios e nos coloca como participantes ativos da Zona Crepuscular.

Alguns pontos são relevantes para compor esse sentimento de unidade em Além da Imaginação, ou seja, as linhas gerais que podem ser notadas pela observação dos 156 episódios e que dão a identidade para a série. Dentre esses pontos, cabe retomar elementos já comentados anteriormente e eliminar uma das características mais lembradas da série que aparentemente, porém de forma não global, dariam a ela uma linha mestra.

Iniciamos a reflexão de qual seria a unidade dos episódios pela eliminação de um elemento que está presente nos episódios mais memoráveis e se tornou uma característica marcante da série, que é o final com uma reviravolta irônica no enredo. Entretanto, por mais tentador que possa parecer, alguns episódios, como já dito, não têm essa reviravolta e isso não está presente na quarta temporada, na qual encontramos uma quantidade significativa de episódios sem esse recurso narrativo, como, por exemplo, Jess-Belle (1963) e Printer's Devil (1963), mas também de histórias espalhadas por todas as temporadas da série como, por exemplo, Long Distance Call (1961), The Passersby (1961), I Sing the Body Electric (1962) e The Bewitchin Pool (1964). Portanto, essa é, sim, uma característica da série, porém não definidora e elemento que permita retirar dela um sentido de conjunto mais amplo, já que os episódios que não se encaixassem no modelo "final com reviravolta no enredo" seriam eliminados. Como ainda nos mostra David Melbye (2016, I.622-981), esse tipo de final já tinha uma longa história na tradição cultural moderna ocidental, com os contos de O. Henry ${ }^{35}$, Somerset Maugham, Guy de Maupassant, filmes como Páginas da Vida (O. Henry's Full House, 1952) e o uso comum desse recurso nas séries de melodramas de suspense americanas anteriores, como a Alfred Hitchcock Presents.

35 O conto de O. Henry, O Presente dos Magos (The Gift of the Magi, 1905), serviu de inspiração para o episódio da última temporada de Além da Imaginação, The Long Morrow (1964), discutido no capítulo sobre viagem ao futuro. 
Portanto, quando Além da imaginação foi ao ar, já havia "estratégias bem estabelecidas para a televisão" (MELBYE, 2016, I.981) para o uso no final da história da reviravolta irônica.

O primeiro ponto que dá unidade a Além da Imaginação é a presença de Serling como narrador/apresentador, como nome associado à autoria da série e, mesmo que isso deva ser relativizado, pois a série era um trabalho coletivo, há uma unidade e uma identificação singular da mesma que é trazida por sua onipresença. Seu carisma e sua postura cínica, com leve ar misterioso de guia do espectador por alguma história inédita e insólita, de alguma forma, criava uma identidade visual e auditiva tão ou até mais reconhecível quanto um logotipo. Cabe recordar que quando a série perdeu o The do título, isso passou quase despercebido, porém Rod Serling não interagindo com o público em meio aos cenários na quarta temporada, na qual o título sofreu alteração, causa até hoje um certo estranhamento.

O segundo ponto que cabe destacar são os "valores de produção", como o recurso à linguagem de Hollywood clássico nos episódios; mesmo que eles não tenham relação direta de concordância com as temáticas e propostas de obras cinematográficas anteriores, são extremamente bem fotografados, com atores renomados, cenários caprichados, etc. A própria manutenção de um núcleo criativo pelos anos da série confere a Além da Imaginação um clima singular, similar aos trabalhos artísticos de cinema e literatura (MELBYE, 2016, I.447).

O terceiro ponto de unidade é a presença da Zona Crepuscular em operação para trazer ou restabelecer alguma forma de ordem no mundo. Por vezes, ela atua por meio da intervenção de algum personagem que interage com o protagonista, mas também se manifesta como o próprio ambiente para onde os personagens são transportados, como outros planetas e tempos e, não raro, surge no próprio ambiente familiar do público e do personagem, como terminal de ônibus e bares, alterando a percepção regular desses locais pela ocorrência de pequenos fatos estranhos.

Já o último ponto, o ponto mais importante que podemos considerar como fundamental para a unidade da série, é o emprego da tradição irônica, como bem notado pelo professor especialista na crítica de Além da Imaginação David Melbye, em seu livro Irony in the Twilight Zone (2016), que demonstra de forma convincente um novo caminho para nos aproximarmos da análise da série, permitindo amarrar todos os episódios em uma grande proposta irônica de crítica da sociedade americana no segundo pós-guerra, sem ter que apenas recorrer à constatação de que a série 
invoca diversos gêneros para apresentar histórias imaginativas e provocantes. A função da ironia na série era o abalar e subverter as expectativas da audiência, forçando uma reflexão e reavaliação sobre todos os elementos cotidianos, o que nem sempre tinha efeito desejado, como a carta de Bonnie Lee (1960, p.1-3), endereçada a Serling, na qual uma jovem indignada, após chorar de tristeza, escreveu ameaçando nunca mais assistir à série, abalada emocionalmente e indignada com a crueldade de Serling no final irônico surpresa do episódio Time Enough at Last, no qual um simpático leitor ávido (Burgess Meredith) sobrevive sozinho à destruição nuclear e encontra todos os livros do mundo que queria ler sem mais sofrer cobranças sociais, mas acaba quebrando os seus óculos por descuido, o que o incapacita de ver e, consequentemente, poder ler os livros que tanto desejava.

Ainda sobre a questão da ironia, David Melbye, identificou cinco tipos de ironias principais com as quais os episódios manipulam as expectativas da audiência e abrem espaço para o pensamento crítico: 1) tecnológica, a ideia de que o avanço tecnológico, em vez de reduzir o trabalho, facilitar e melhorar a vida humana, podia alienar as pessoas, ser utilizado para opressão e destruição e aumentar a quantidade de trabalho (MELBYE, 2016, I.1734); 2) invasão, critica ao medo estabelecido na época da invasão soviética e de outros povos/protagonistas, mostrando que o próprio povo americano, ao desejar se definir em oposição ao "outro", pode ser seu próprio inimigo ou ser ele mesmo o invasor destruidor (Ibid., I.2404; I.2484); 3) marcial, a noção de futilidade de qualquer conflito armado e dos valores/dilemas morais envolvidos em situação de conflito (Ibid., I.2714; I.3191); 4) sociopolítica, a concepção de que qualquer forma de totalitarismo, a adesão a ideologias conformistas e preconceituosas, o não respeito aos outros membros da comunidade são ações inadmissíveis (MELBYE, 2016, I.3433; I.3629; I.3818); 5) doméstica, a pretensão do segundo pós-guerra de que a vida suburbana em famílias nucleares bem definidas e a busca de um refúgio em relação aos problemas do mundo exterior, levaria à angústia pessoal (Ibid., I.3891).

Portanto, em Além da Imaginação, Rod Serling e outros autores, dentre escritores, diretores, atores e técnicos, expressaram suas visões sobre todas as questões que estavam sofrendo as mais amplas transformações no período, bem como os principais dilemas enfrentados por largas parcelas da população americana - por que não mundial, dado o sucesso da série em mercados tão diversos como o brasileiro e australiano. Não é à toa, então, a recorrência a histórias que subvertem 
as temporalidades, dado que é um dos meios de tornar mais claro para o público a questão da mudança, expressando a nostalgia, o medo e o enfrentamento das mudanças, a mudança de perspectivas e a própria possibilidade de aperfeiçoamento social, principalmente pela alteração na forma dos indivíduos pensarem e se relacionarem. 
"Only yesterday when I was sad

And I was lonely

You showed me the way to leave

The past and all its tears behind me

Tomorrow may be even brighter than today

Since I threw my sadness away

Only yesterday"36

(Carpenters)

\section{6- O Vórtice Temporal}

\section{1- Introdução à viagem no tempo em Além da Imaginação}

De todos temas explorados pela série Além da Imaginação, como robôs, fantasmas, alienígenas, poções mágicas, planetas inóspitos, guerra, medo, paranoia, etc, nenhum é mais recorrente do que as relações entre as temporalidades. Sejam histórias que remetem diretamente a outros tempos, passando-se no passado, como episódios que transcorrem na Guerra Civil Americana e durante a Segunda Guerra Mundial, ou no futuro, quando o ser humano consegue construir robôs indistinguíveis dos humanos e chega a viajar para outros planetas, sejam enredos de viagem no tempo ou explorando a própria noção de tempo cíclico.

Para se ter uma noção, dos 156 episódios da série, encontramos 74 onde alguma relação com o tempo e as temporalidades são fundamentais para compreensão e desenvolvimento do enredo. Não por acaso, o tempo é um problema sério recorrente na série e, como vimos anteriormente, a própria série tem sua origem com uma proposta de episódio piloto sobre viagem no tempo e no primeiro episódio de Além da Imaginação, Where is Everybody? (1959), o militar passa por uma experiência de isolamento que altera a percepção de tempo e espaço, no qual, mesmo que a observação do tempo não seja fundamental para a compreensão da reviravolta no final da narrativa, já é demonstrada en passant a problemática entre o tempo do

\footnotetext{
${ }^{36}$ Ainda ontem quando eu estava triste/ e estava sozinha/ Você me mostrou o caminho para deixar/ o passado e todas as lágrimas para trás/ O amanhã pode ser ainda mais alegre que hoje/ Desde que eu joguei minha tristeza fora/ Ainda ontem [tradução nossa]. Música do dueto de irmãos do Carpenters para o álbum Horizon, lançada em 1975.
} 
relógio e o tempo do sonho, utilizada para reforçar o mistério e surpreender a audiência com a forma subjetiva de se marcar o tempo do episódio.

Cabe reforçar que o tema da viagem no tempo, como forma de explorar a relação individual e coletiva com a mudança, era algo conscientemente explorado por Rod Serling. Ao mesmo tempo em que trabalhava em Além da Imaginação, ele foi contratado para transformar o livro de Pierre Boulle, Planeta dos Macacos (La Planète des singes, 1963) (ADAMI, 2015, p.82). Seu roteiro para o livro utilizava a viagem no tempo como instrumento de crítica social e, mesmo que não tenha sido produzido, sua versão serviu de inspiração e norte para os demais roteiros e a própria representação da viagem no tempo, já que o final icônico do filme O Planeta dos Macacos (Planet of the Apes, 1968) tornou-se uma referência clássica do cinema da Guerra Fria e de viagem no tempo, em geral ao terminar com a revelação irônica e surpresa da Estátua da Liberdade enterrada na areia no ano de 3978, indicando que a história do filme se passava no futuro da própria Terra e não em outro planeta, no espírito da série Além da Imaginação.

$\mathrm{Na}$ tabela abaixo, estão incluídos os episódios que apresentam alguma relação com o tempo fundamental para a compreensão de seu enredo e/ou nos quais essa relação desempenhe algum papel fundamental nas ações da Zona Crepuscular, sendo sua própria manifestação ou ambiente de sua depuração. Da listagem, foram excluídos os episódios considerados de viagem no tempo, alvo de uma tabela específica.

TABELA 2- Exploração das Distintas Temporalidades em Além da Imaginação

\begin{tabular}{|l|l|l|l|}
\hline \multicolumn{1}{|c|}{ Nome do Episódio } & Temporada & $\begin{array}{c}\text { Data de } \\
\text { Exibição }\end{array}$ & \multicolumn{1}{|c|}{ Relação com o Tempo } \\
\hline Where is Everybody? & Primeira & $02 / 10 / 1959$ & Tempo da mente \\
\hline Mr. Denton on Doomsday & Primeira & $16 / 10 / 1959$ & Passa-se no passado \\
\hline The Sixteen-Millimeter Shrine & Primeira & $23 / 10 / 1959$ & $\begin{array}{l}\text { Atriz nega o presente e quer voltar a } \\
\text { glória passada }\end{array}$ \\
\hline Escape Clause & Primeira & $06 / 11 / 1959$ & $\begin{array}{l}\text { Homem faz acordo para viver para } \\
\text { sempre }\end{array}$ \\
\hline Time Enough at Last & Primeira & $20 / 11 / 1959$ & Busca de controle do tempo livre \\
\hline Perchance to Dream & Primeira & $27 / 11 / 1959$ & Tempo social do sonho \\
\hline Judgment Night & Primeira & $04 / 12 / 1959$ & Tempo cíclico \\
\hline The Purple Testament & Primeira & $12 / 02 / 1960$ & $\begin{array}{l}\text { Passa-se no passado, previsão de } \\
\text { morte no futuro-fatalismo }\end{array}$ \\
\hline Elegy & Primeira & $19 / 02 / 1960$ & $\begin{array}{l}\text { Futuro, astronautas encontram o } \\
\text { passado, na verdade um cemitério }\end{array}$ \\
\hline Long Live Walter Jameson & Primeira & $18 / 03 / 1960$ & $\begin{array}{l}\text { Homem que não envelhece - } \\
\text { historiador }\end{array}$ \\
\hline A Passage for Trumpet & Primeira & $20 / 03 / 1960$ & $\begin{array}{l}\text { Fuga do presente e nova chance na } \\
\text { vida }\end{array}$ \\
\hline
\end{tabular}




\begin{tabular}{|c|c|c|c|}
\hline Nome do Episódio & Temporada & $\begin{array}{l}\text { Data de } \\
\text { Exibição }\end{array}$ & Relação com o Tempo \\
\hline King Nine Will Not Return & Segunda & $30 / 09 / 1960$ & Fuga mental para trauma do passado \\
\hline The Eye of the Beholder & Segunda & $11 / 11 / 1960$ & Passa-se no futuro \\
\hline Nick of Time & Segunda & $18 / 11 / 1960$ & $\begin{array}{l}\text { Controle da vida pela previsão do } \\
\text { futuro }\end{array}$ \\
\hline A Most Unusual Camera & Segunda & $16 / 12 / 1960$ & $\begin{array}{l}\text { Câmera tira foto do que vai acontecer } \\
\text { em } 5 \text { minutos no futuro }\end{array}$ \\
\hline Twenty-Two & Segunda & 10/02/1961 & Pesadelo premonitório impedido \\
\hline Shadow Play & Segunda & $05 / 05 / 1961$ & Tempo cíclico \\
\hline The Obsolete Man & Segunda & $02 / 06 / 1961$ & Passa-se no futuro \\
\hline Two & Terceira & 15/09/1961 & Passa-se no futuro \\
\hline The Passersby & Terceira & $06 / 10 / 1961$ & $\begin{array}{l}\text { Passa-se no passado, fantasmas na } \\
\text { Guerra Civil }\end{array}$ \\
\hline Deaths-Head Revisited & Terceira & 10/11/1961 & $\begin{array}{l}\text { Fantasmas do passado cobram a } \\
\text { conta do presente }\end{array}$ \\
\hline The Midnight Sun & Terceira & 17/11/1961 & Passa-se no futuro \\
\hline Still Valley & Terceira & 24/11/1961 & Passa-se no passado \\
\hline Nothing in the Dark & Terceira & $05 / 01 / 1962$ & $\begin{array}{l}\text { Aceitação do ciclo da vida - fim com } \\
\text { a morte }\end{array}$ \\
\hline Kick the Can & Terceira & $09 / 02 / 1962$ & Velhos voltam a ser crianças \\
\hline $\begin{array}{l}\text { The Last Rites of Jeff } \\
\text { Myrtlebank }\end{array}$ & Terceira & $23 / 02 / 1962$ & $\begin{array}{l}\text { Passa-se no passado, morto volta a } \\
\text { vida }\end{array}$ \\
\hline The Trade-Ins & Terceira & $20 / 04 / 1962$ & $\begin{array}{l}\text { Aceitação da passagem de tempo- } \\
\text { envelhecimento }\end{array}$ \\
\hline Young Man's Fancy & Terceira & $11 / 05 / 1962$ & Negação da vida adulta \\
\hline I Sing the Body Eletric & Terceira & $18 / 05 / 1962$ & $\begin{array}{l}\text { Passa-se no futuro, passagem do } \\
\text { tempo da relação família e robô }\end{array}$ \\
\hline The Changing of the Guard & Terceira & $01 / 06 / 1962$ & $\begin{array}{l}\text { Feitos realizados durante a vida de } \\
\text { uma pessoa, fantasmas do passado }\end{array}$ \\
\hline In His Image & Quarta & $03 / 01 / 1963$ & $\begin{array}{l}\text { Memórias falsas do passado na } \\
\text { mente de um robô servem de } \\
\text { identidade }\end{array}$ \\
\hline The Thirty Fathom Grave & Quarta & $10 / 01 / 1963$ & $\begin{array}{l}\text { Culpa de feitos passados cobra a } \\
\text { conta do presente }\end{array}$ \\
\hline He's Alive & Quarta & $24 / 01 / 1963$ & $\begin{array}{l}\text { Ódio faz fantasma de Hitler rondar o } \\
\text { presente }\end{array}$ \\
\hline Death Ship & Quarta & $07 / 02 / 1963$ & Tempo cíclico \\
\hline Miniature & Quarta & $21 / 02 / 1963$ & $\begin{array}{l}\text { Relacionamento com boneca do } \\
\text { século XIX, fuga do cotidiano }\end{array}$ \\
\hline The New Exhibit & Quarta & $04 / 04 / 1963$ & $\begin{array}{l}\text { Assassinos famosos da história se } \\
\text { manifestam na obsessão de um } \\
\text { homem do presente }\end{array}$ \\
\hline $\begin{array}{l}\text { On Thursday We Leave for } \\
\text { Home }\end{array}$ & Quarta & $02 / 05 / 1963$ & Passa-se no futuro \\
\hline Passage of Lady Anne & Quarta & $09 / 05 / 1963$ & $\begin{array}{l}\text { Progresso torna as coisas velhas, } \\
\text { navio do passado }\end{array}$ \\
\hline The Bard & Quarta & $23 / 05 / 1963$ & $\begin{array}{l}\text { Invocação de personalidades do } \\
\text { passado }\end{array}$ \\
\hline In Praise of Pip & Quinta & $27 / 09 / 1963$ & $\begin{array}{l}\text { Pai vê o filho como era quando } \\
\text { criança }\end{array}$ \\
\hline Steel & Quinta & $04 / 10 / 1963$ & $\begin{array}{l}\text { Passa-se no futuro, obsolescência do } \\
\text { progresso }\end{array}$ \\
\hline A Kind of Stopwatch & Quinta & $18 / 10 / 1963$ & Cronômetro que para o tempo \\
\hline The Old Man In The Cave & Quinta & $08 / 11 / 1963$ & Passa-se no futuro \\
\hline Probe 7, Over and Out & Quinta & $29 / 11 / 1963$ & $\begin{array}{l}\text { Aparenta se passar no futuro, mas é } \\
\text { passado }\end{array}$ \\
\hline $\begin{array}{l}\text { A Short Drink from a Certain } \\
\text { Fountain }\end{array}$ & Quinta & $13 / 12 / 1963$ & $\begin{array}{l}\text { Adulto se torna bebê e esposa troféu } \\
\text { deve se tornar adulta }\end{array}$ \\
\hline
\end{tabular}




\begin{tabular}{|l|l|l|l|}
\hline \multicolumn{1}{|c|}{ Nome do Episódio } & Temporada & $\begin{array}{c}\text { Data de } \\
\text { Exibição }\end{array}$ & \multicolumn{1}{|c|}{ Relação com o Tempo } \\
\hline $\begin{array}{l}\text { Ninety Years Without } \\
\text { Slumbering }\end{array}$ & Quinta & $20 / 12 / 1963$ & $\begin{array}{l}\text { Idoso acredita que irá morrer quando } \\
\text { seu relógio de pêndulo parar de } \\
\text { funcionar }\end{array}$ \\
\hline $\begin{array}{l}\text { The Self-Improvement of } \\
\text { Salvadore Ross }\end{array}$ & Quinta & $17 / 01 / 1964$ & $\begin{array}{l}\text { Compra e venda de tempo (idade } \\
\text { física) }\end{array}$ \\
\hline Number 12 looks just like you & Quinta & $24 / 01 / 1964$ & Passa-se no futuro \\
\hline $\begin{array}{l}\text { An Ocurrence at Owl Creek } \\
\text { Bridge }\end{array}$ & Quinta & $28 / 02 / 1964$ & $\begin{array}{l}\text { Tempo social - sonho/imaginação } \\
\text { durante a morte }\end{array}$ \\
\hline Queen of the Nile & Quinta & $06 / 03 / 1964$ & $\begin{array}{l}\text { Mulher que não envelhece por } \\
\text { mágica - "vampira" }\end{array}$ \\
\hline What's in the Box & Quinta & $13 / 03 / 1964$ & $\begin{array}{l}\text { Televisão mostra o passado, } \\
\text { presente e futuro do dono. }\end{array}$ \\
\hline The Encounter & Quinta & $01 / 05 / 1964$ & $\begin{array}{l}\text { Passado cobra seu preço do } \\
\text { presente }\end{array}$ \\
\hline Mr. Garrity and the Graves & Quinta & $08 / 05 / 1964$ & $\begin{array}{l}\text { Passa-se no passado, mortos voltam } \\
\text { a vida, esconder o passado }\end{array}$ \\
\hline The Brain Center at Whipples & Quinta & $15 / 05 / 1964$ & Passa-se no futuro \\
\hline Come Wander With Me & Quinta & $22 / 05 / 1964$ & Música prevê o futuro - fatalismo \\
\hline
\end{tabular}

Fonte: elaborado pelo autor

O entendimento do tempo como fator opressor, algo que pode ser sugerido na série, não passou despercebido pelo público e mesmo sendo algo reiterado na experiência humana com esse símbolo, ganha uma profundidade na modernidade. Um exemplo contundente disso está presente na carta de uma menina de dez anos, enviada três anos após cancelamento da série Além da Imaginação para Rod Serling. Ela assistia às reprises sem saber que a série havia sido cancelada anos antes e propôs para a série um enredo de um homem não pontual, que recebia constantes ligações do "Tempo" para fazer as coisas; um dia, quando recebeu uma ligação do "Tempo" para falar que era hora dele morrer (time to die), ele saiu correndo e foi atropelado por um carro (SMITH, 1967, p.1). Serling, graciosamente, respondeu à menina que achou a história fascinante e que era uma pena que não estava mais no ar, senão ele poderia tê-la usado (SERLING, 1968, p1). Essa proposta da história antecipa poeticamente a ideia de Norbert Elias em Sobre o Tempo (1993, p.13-14) de que quem não aprende a noção de tempo das sociedades contemporâneas, encontra problemas sérios para viver nela. Não é à toa que a menina cria uma lição de moral sobre o tempo personificado orientando uma pessoa que não consegue se adaptar à coerção desse símbolo e à impossibilidade de fugir dele. O fato dela ter mandado essa proposta para Serling mostra como a série irá também reforçar o símbolo Tempo como fundamental para organização da sociedade e da vida social no período, pois a garota sentiu que o tema interessaria à série não só pelo aspecto punitivo, mas 
provavelmente pela reiteração do símbolo Tempo que permeava toda a série, outro ponto que ligava Além da Imaginação com o universo infanto-juvenil do período.

Reforçando o tempo como instrumento de coerção, existem três episódios que apresentam um tempo cíclico ou circular, como artificio narrativo, e mesmo não sendo episódios de viagem no tempo, per se, eles implicam um tempo fechado que reforça a punição, muitas vezes mental, a que estão submetidos os personagens. O uso do tempo cíclico na série reforça a ideia do mito do trabalho de Sísifo, um castigo eterno que os personagens são condenados a repetir e do qual não conseguem escapar, visto que é uma punição dada pela Zona Crepuscular à falhas morais. Essa noção de que um tipo de tempo cíclico é um castigo que impede a mudança, juntamente com a ideia de alienação e opressão das pessoas sujeitas a esta forma de contemplação do tempo são incorporadas ao tempo cíclico pelo mundo moderno como contraposição crítica ao tempo do relógio e do progresso, associadas à concepção da repetição diária dada pela rotina do trabalho e pelos propósitos capitalistas, cuja expressão talvez mais extrema (repetição ad aeternum e alienação), fora do mundo das narrativas de ficção científica, está presente na obra do filósofo Albert Camus O Mito de Sísifo (2010). O reforço de uma noção de tempo cíclico como um claro juízo e/ou reação à noção de progresso e futuro modernos, não está presente nos exemplos prémodernos e de povos não europeus, citados anteriormente, estes que percebiam as mudanças como parte de um tempo cíclico que servia como forma referencial social e individual ligada à natureza. Portanto, a utilização do tempo cíclico por sociedades nas quais existe a perspectiva de um futuro distinto e singular, concepção oriunda da Europa dezoitocentista, é utilizada como resistência, crítica, oposição ou provocação à concepções de mudanças constantes inéditas das experiências individuais e sociais, ou seja, do próprio progresso.

Em Além da Imaginação, o tempo cíclico é utilizado atuando em indivíduos, na forma de um pesadelo, ou seja, na forma de um mundo que opera no tempo psicológico/humano. Os personagens que passam por essas experiências são retirados do fluxo de tempo "normal" dos demais seres humanos, a fim desses indivíduos serem punido à la Sísifo, servindo de exemplo para o público. Um bom exemplo, é o do Capitão Lanser, preso eternamente na noite de 1942, tentando em vão alertar suas vítimas antes do desastre que causara, condenado a repetir seus atos covardes no episódio Judgment Night (1959) da primeira temporada da série. No caso, a própria noção de tempo é utilizada para alimentar a ironia proposta na série, 
causando estranhamento em uma sociedade orientada ao tempo como flecha. Assim, o tempo cíclico na série de Serling é um tempo que é rejeitado como forma coletiva de se relacionar com o mundo externo à série, só existindo como punição individual, ou na forma de um inferno particular.

O tempo cíclico é explorado como parte do tempo subjetivo, tempo que é relegado ao fantástico, pois provoca o espectador ao frustrar sua expectativa sobre o tempo. Porém, em Além da Imaginação, o tempo psicológico (não cíclico) por si não é muito aproveitado e apenas dois episódios fazem relação direta ao tempo subjetivo e não-histórico, utilizados como artifício de surpresa no roteiro: o citado primeiro episódios Where is Everybody? (1959) e o curta-metragem francês An Ocurrence at Owl Creek Bridge de 1962, exibido como episódio de Além da Imaginação em 1964, um sonho de fuga que se passa quase inteiramente na mente de um condenado à morte nos instantes que precedem sua queda durante um enforcamento.

Em Além da Imaginação, a exibição de outras temporalidades e relações com o tempo, como a viagem no tempo ou o tempo cíclico, servem ao objetivo principal da série em fazer a depuração de seu contexto; portanto, por ser uma época marcada pela mudança e os medos e ansiedades, não é de se estranhar que essa temática se faça presente e seja explorada regularmente na série, como forma de criticar tanto a rejeição da mudança quanto a direção que as mais diversas mudanças estavam tomando ou poderiam tomar, inclusive com retrocessos nos direitos humanos e liberdade das sociedades.

A apresentação da série reforçava a estranheza e indicava o fato de se estar indo para um local onde as próprias formas de perceber e viver as temporalidades poderiam ser subvertidas. Tanto na narração quanto visualmente, havia indicações de que a percepção de tempo do público seria surpreendida; por exemplo, na terceira temporada, ouve-se Rod Serling apresentar o que era a Zona Crepuscular enquanto a câmera, e o público, abandonam um cone espiralado alusivo ao tempo, reforçando o sentido de um percurso que nos levaria a alguma forma de revelação (MARTIN, 2012, p.718) e, a partir da quarta temporada, um relógio pendular flutuando no espaço com os ponteiros se movendo a uma alta velocidade cumpre esse papel. Pela descrição da Zona Crepuscular dada por Serling na abertura, sabe-se que ela seria atemporal e infinita.

Dos 74 episódios que utilizam o tempo e a relação das temporalidades para passar sua mensagem, 19 apresentam diretamente um deslocamento no tempo ou 
algum elemento facilitador que permite o contato dos personagens com outras épocas, passado ou futuro, que são fundamentais para o desenvolvimento da trama. Colocando o foco nos protagonistas, 13 dos 19 episódios de viagem no tempo tem como destino o passado, confirmando a noção expressa por Clute (1994, p.646) de que há em linhas gerais uma predominância da viagem ao passado nas obras que lidam com viagem no tempo e a maior parte dessas narrativas se passam no passado médio. Além disso, no caso de Além da Imaginação, a formação e a resolução dos paradoxos gerados pela viagem no tempo ao passado não é o problema principal enfrentado pelos personagens, geralmente o conflito se manifesta na impossibilidade de alteração das temporalidades por meio da viagem no tempo; assim, encontramos representando essa ideia de forma clara o chamado paradoxo do predestinado, no qual a tentativa de se evitar algo por meio da viagem no tempo acaba, por fim, causando aquilo. Esse elemento enfatiza a proposta dos episódios de expor a viagem no tempo como uma forma de refletir e forçar a reavaliação de comportamentos e ações presentes, ao expor um passado social complexo imutável.

Abaixo, temos em uma tabela a listagem dos episódios da série que lidam diretamente com a viagem no tempo. Foi realizada uma adaptação, inspirada na tabela anteriormente apresentada, de autoria dos pesquisadores Joan Ormrod e Matthew Jones (2015), acrescentando mais informações sobre os episódios de Além da Imaginação.

Tabela 3- Episódios de Viagem no Tempo de Além da Imaginação

\begin{tabular}{|c|c|c|c|c|c|c|}
\hline $\begin{array}{c}\text { Nome do } \\
\text { Episódio }\end{array}$ & Temporada & $\begin{array}{c}\text { Data de } \\
\text { Exibição }\end{array}$ & Tema & Catalisador & Sentido & Roteirista \\
\hline $\begin{array}{c}\text { Walking } \\
\text { Distance }\end{array}$ & Primeira & $30 / 10 / 1959$ & Nostalgia & $\begin{array}{c}\text { Visita a } \\
\text { cidade da } \\
\text { infância }\end{array}$ & Passado & Rod Serling \\
\hline $\begin{array}{c}\text { The Last } \\
\text { Flight }\end{array}$ & Primeira & $05 / 02 / 1960$ & Heroísmo & Nuvem & Futuro & $\begin{array}{c}\text { Richard } \\
\text { Matheson }\end{array}$ \\
\hline $\begin{array}{c}\text { Execution } \\
\begin{array}{c}\text { A Stop at } \\
\text { Willoughby }\end{array}\end{array}$ & Primeira & $01 / 04 / 1960$ & Punição & $\begin{array}{c}\text { Máquina do } \\
\text { Tempo }\end{array}$ & Futuro & Rod Serling \\
\hline $\begin{array}{c}\text { The Trouble } \\
\text { With } \\
\text { Templeton }\end{array}$ & Segunda & $06 / 05 / 1960$ & Nostalgia & Trem & Passado & Rod Serling \\
\hline
\end{tabular}




\begin{tabular}{|c|c|c|c|c|c|c|}
\hline $\begin{array}{l}\text { Nome do } \\
\text { Episódio }\end{array}$ & Temporada & $\begin{array}{l}\text { Data de } \\
\text { Exibição }\end{array}$ & Tema & Catalisador & Sentido & Roteirista \\
\hline Back There & Segunda & 13/01/1961 & $\begin{array}{l}\text { Mudar o } \\
\text { passado }\end{array}$ & Tontura & Passado & Rod Serling \\
\hline $\begin{array}{c}\text { The Odyssey } \\
\text { of Flight } 33\end{array}$ & Segunda & $24 / 02 / 1961$ & $\begin{array}{l}\text { Perdido no } \\
\text { tempo }\end{array}$ & $\begin{array}{c}\text { Corrente de } \\
\text { ar }\end{array}$ & Passado & Rod Serling \\
\hline Static & Segunda & 10/03/1961 & Nostalgia & Rádio & Passado & $\begin{array}{c}\text { Charles } \\
\text { Beaumont }\end{array}$ \\
\hline $\begin{array}{l}\text { A Hundred } \\
\text { Yards over } \\
\text { the Rim }\end{array}$ & Segunda & 07/04/1961 & Resiliência & Deserto & Futuro & Rod Serling \\
\hline $\begin{array}{c}\text { The Rip Van } \\
\text { Winkle } \\
\text { Caper }\end{array}$ & Segunda & $21 / 04 / 1961$ & Ganância & $\begin{array}{l}\text { Animação } \\
\text { Suspensa }\end{array}$ & Futuro & Rod Serling \\
\hline $\begin{array}{c}\text { Once Upon a } \\
\text { Time }\end{array}$ & Terceira & 15/12/1961 & $\begin{array}{c}\text { Apreciar } \\
\text { seu tempo }\end{array}$ & $\begin{array}{c}\text { Máquina do } \\
\text { tempo }\end{array}$ & Futuro & $\begin{array}{l}\text { Richard } \\
\text { Matheson }\end{array}$ \\
\hline $\begin{array}{l}\text { A Quality of } \\
\text { Mercy }\end{array}$ & Terceira & 29/12/1961 & $\begin{array}{l}\text { Ponto de } \\
\text { vista }\end{array}$ & Binóculo & Passado & Rod Serling \\
\hline $\begin{array}{c}\text { Showdown } \\
\text { With Rance } \\
\text { McGrew }\end{array}$ & Terceira & $02 / 02 / 1962$ & $\begin{array}{c}\text { Mitos } \\
\text { sobre o } \\
\text { passado }\end{array}$ & Mágica & Passado & Rod Serling \\
\hline $\begin{array}{c}\text { No Time Like } \\
\text { the Past }\end{array}$ & Quarta & 07/03/1963 & $\begin{array}{l}\text { Mudar o } \\
\text { passado }\end{array}$ & $\begin{array}{c}\text { Máquina do } \\
\text { Tempo }\end{array}$ & Passado & Rod Serling \\
\hline $\begin{array}{c}\text { Of Late I } \\
\text { Think of } \\
\text { Cliffordville }\end{array}$ & Quarta & 11/04/1963 & $\begin{array}{l}\text { Mudar o } \\
\text { passado }\end{array}$ & $\begin{array}{l}\text { Pacto com } \\
\text { diaba }\end{array}$ & Passado & Rod Serling \\
\hline $\begin{array}{c}\text { The } \\
\text { Incredible } \\
\text { World of } \\
\text { Horace Ford }\end{array}$ & Quarta & 18/04/1963 & Nostalgia & $\begin{array}{l}\text { Visita ao } \\
\text { bairro da } \\
\text { infância }\end{array}$ & Passado & $\begin{array}{l}\text { Reginald } \\
\text { Rose }\end{array}$ \\
\hline $\begin{array}{l}\text { The 7th is } \\
\text { Made Up of } \\
\text { Phantoms }\end{array}$ & Quinta & 06/12/1963 & $\begin{array}{l}\text { Mudar o } \\
\text { passado }\end{array}$ & Mágica & Passado & Rod Serling \\
\hline $\begin{array}{l}\text { The Long } \\
\text { Morrow }\end{array}$ & Quinta & 10/01/1964 & Amor & $\begin{array}{c}\text { Viagem ao } \\
\text { espaço/ } \\
\text { animação } \\
\text { suspensa }\end{array}$ & Futuro & Rod Serling \\
\hline $\begin{array}{l}\text { Spur of the } \\
\text { Moment }\end{array}$ & Quinta & $21 / 02 / 1964$ & $\begin{array}{l}\text { Mudar o } \\
\text { passado }\end{array}$ & $\begin{array}{c}\text { Passeio a } \\
\text { cavalo }\end{array}$ & Passado & $\begin{array}{c}\text { Richard } \\
\text { Matheson }\end{array}$ \\
\hline
\end{tabular}

Fonte: elaborado pelo autor 
Como pode-se notar pela lista acima, muitas das formas de viagem no tempo escapam da simples adesão destes episódios a um determinado gênero, mas, em consonância com os demais episódios da série, inclusive nos casos acima nos quais máquinas do tempo se façam presentes, há uma valorização maior dos meios mágicos e fenômenos sobrenaturais do que tecnológicos para o deslocamento no tempo e estes, quando são utilizados, não têm seu funcionamento explicado e podemos inferir como funcionam devido à convenções e o próprio desenvolvimento de estratégias leitoras do público geradas pelas explicações prévias de como se daria a viagem no tempo em obras de ficção científica.

Os roteiros autorais e adaptações literárias de Rod Serling, ou dos demais colaboradores, que envolvem narrativas de viagem no tempo aderem à noção do tempo histórico, a noção de tempo mais comum que podemos encontrar nas histórias de viagem no tempo e que está a par com o contexto moderno da obra, ou seja, utilizam-se referenciais do tempo natural a fim de se discutir as questões das permanências e mudanças entre passado, presente e futuro, na perspectiva orientada em grande parte dos episódios para a reflexão sobre as ações humanas no tempo propondo a mudança no devir com aperfeiçoamento do presente. Por exemplo, no episódio The Last Flight (1960), escrito por Matheson e exibido na primeira temporada, um piloto da Primeira Guerra Mundial, que escapou covardemente deixando seu amigo para morrer, vai para o futuro (presente da série) onde ganha noção de autosacrifício e observa os avanços tecnológicos e as relações humanas que deveria criar com sua morte no passado- no caso, sua morte ao salvar o amigo em vez de fugir.

$\mathrm{Na}$ série, a viagem ao passado invoca os marcos da história tradicional ou nacional americana e, muitas vezes, o conflito a ser enfrentado pelo personagem está diretamente ligado à relação entre os tempos com suas devidas mudanças tecnológicas, códigos éticos e morais, moda, relações econômicas, etc.

Assim como a questão da viagem no tempo pode implicar o controle humano sobre o símbolo Tempo, em Além da Imaginação, esse controle, mesmo quando tentado, é ineficiente e inútil. Os próprios episódios nos quais há um controle do período da viagem, ou das intenções de um personagem ao ir ou recorrer ao passado ou ao futuro, demonstram-se infrutíferos, danosos e perigosos. O que faz sentido pela própria proposta da série de depurar ações e propostas correntes no segundo pósguerra americano e mundial, o tempo não é algo capaz de ser dominado ou controlado pelo ser humano e a própria viagem no tempo na série é utilizada pedagogicamente 
em muitos dos episódios nos quais é apresentada e reforça que o lugar de ação do viajante deve ser o seu próprio presente.

Devido ao fato da série apresentar múltiplas formas de deslocamento pelo tempo, tanto artificiais, criadas pelo ser humano, quanto naturais e misteriosas, não existe uma unidade nas formas de viagem no tempo nem de sua função pedagógica na narrativa. Por exemplo: no episódio Once Upon a Time (1961) há intenções irônicas na comparação entre os tempos apresentados e uma homenagem ao cinema mudo (incluso a estrela do cinema mudo Buster Keaton), com a própria mudança de linguagem cinematográfica para marcar a distinção entre o século XIX e o XX.

Cabe marcar que os 19 episódios onde os personagens vão para outras épocas são documentos de uma reflexão sobre o presente enfrentado pelos americanos e sua própria história e perspectivas de futuro nas décadas de 50 e início dos anos 60 (parte das questões são mais gerais que poderiam ser estendidas a parcelas significativas da humanidade). Esses episódios retratam a profunda mudança pela qual a sociedade americana passou no segundo pós-guerra, com a suburbanização, os conflitos da Guerra Fria, o crescimento das corporações e uma perceptível ampliação da racionalização das relações de trabalho, bem como alterações nas relações sociais desse mundo em constante mudança, algumas das quais poderiam ocasionar sua destruição a qualquer momento. Não é por acaso que em um episódio no qual há uma viagem ao futuro aos moldes do dorminhoco ou animação suspensa, o presente de onde saíram os personagens é visto como bárbaro e absurdo. Isto é distinto na série, já que os episódios no qual o futuro é retratado com personagens do futuro - sem viagem no tempo- são, em geral, negativos sobre o aperfeiçoamento humano, com distopias ou mesmo problemas presentes, mas com tecnologia aperfeiçoada ou especulativa. Mesmo no caso dos viajantes que vão dos séculos anteriores ao presente da série, o presente feito futuro para o personagem principal muitas vezes é visto de forma positiva, implicando que na série, a viagem ao futuro, ao contrário dos episódios que se passam no futuro, é usada para reforçar os avanços humanos, contrapondo-se com as noções mais críticas a noção de progresso que encontramos nos demais episódios que se passam no futuro. Ou seja, em linhas gerais, a viagem ao futuro, em Além da Imaginação, implica algo positivo sobre a humanidade que será encontrada, porém os episódios que se passam no futuro são pessimistas sobre o mundo apresentado. 
O presente, como já citado anteriormente, é o problema nas histórias de viagem no tempo de Além da Imaginação: nas que se dirigem ao passado, deve ser aperfeiçoado no campo individual ou coletivo; nas de viagem ao futuro, é sempre problemático e deve ser superado. Essa noção é consoante à ideia de progresso, por mais críticas que a série em seu conjunto possa tecer a ela. A viagem no tempo, bem como sua visão sobre a humanidade, não está fora da proposta de Serling na série de aperfeiçoar as relações humanas e tornar a mídia televisão significativa no debate sobre as condições humanas.

Dentro da noção de que a série usou a viagem no tempo para tentar aperfeiçoar as relações presentes, tanto mudanças de posturas éticas e morais de indivíduos, quanto coletivas, como a questão da exploração realizada no mundo do trabalho capitalista, nota-se a forte presença da nostalgia em vários episódios que lidaram com a viagem no tempo. Entretanto, mesmo que flerte com a nostalgia, nos moldes dos contos literários do período de Bradbury e Finney, o que pode dar a impressão de que a série fortalecia a nostalgia, por fim ela é criticada, com esses episódios mostrando, em geral, o anacronismo de modelos vistos como positivos do passado, inclusive propagados pela televisão da sua época-como, o já citado, sucesso dos westerns -, e a impossibilidade de retorno físico, mental, individual ou coletivo para esses modelos.

Em Além da Imaginação, o tempo seguido nas histórias de viagem no tempo é o histórico com uma visão crítica à noção de progresso, que não a descarta por completo, mas procura sua plena realização por meio do aperfeiçoamento individual e das condições sociais, derivadas pelas ações de indivíduos corrigidos pela Zona Crepuscular, dentro de uma proposta utópica mais ampla.

Durante a exibição da série, os episódios de viagem no tempo iriam atrair a atenção e estimular a imaginação do público, reforçando o impacto que essa temática desempenha em sociedades que notam que seus referenciais estão sendo alterados profundamente. Além de que, se pensarmos na perspectiva do conceito de tempo de Norbert Elias, como um símbolo que irá se adequar às condições e necessidades das sociedades de marcar as mudanças, apresentando assim uma crescente complexidade, o apelo dessas historias para retratar e dar sentido à realidade e à experiência social do período é fundamental.

O próprio Rod Serling recebia inúmeras propostas de roteiros sobre a viagem no tempo e responderia às cartas que já havia lidado com o tema muitas vezes, como 
uma mensagem de novembro de 1959, na qual afirma não só isso mas também que ficaria longe dessa temática por um tempo por tê-la explorado várias vezes (na primeira temporada, antes da carta, só um episódio de viagem no tempo havia ido ao ar, Walking Distance, em 30 de outubro, de mais 31 que completariam essa temporada). Curiosamente, a maior parte dos episódios com essa temática ainda estava por vir nas demais temporadas, porém o mesmo argumento expresso por Serling em 1959 pode ser visto em 1963, enquanto a série aguardava sua quinta temporada, agora sim melhor justificado com um conjunto sólido de episódios desse universo já exibidos na série. Um jornalista havia dado a sugestão de um episódio de viagem no tempo "reversa", na qual a pessoa do presente, em vez de fugir de seus problemas presentes no passado - o que, segundo ele, havia sido explorado muitas vezes na série -, levasse seus problemas com ele, explorando a reação do passado à coisas como "bombas nucleares, aviões a jato e Castro" (LADD, 1963, p.1). Rod Serling afirmaria que havia explorado o tema da viagem no tempo à exaustão e evitaria essas histórias nos 26 episódios encomendados, até então, para a quinta temporada, mesmo que tenha achado fascinante a proposta e gostaria de falar com Bill Ladd, o autor da carta, editor de televisão do jornal The Louisville Times, de Louisville, Kentucky, caso fosse voltar ao tema no futuro (SERLING, 1963a, p1).

Dentro da proposta da série, a viagem no tempo era a forma mais clara e foi muito bem utilizada para discutir as questões das mudanças. Isso era compartilhado diretamente entre autor e público da época, como se apresenta, por exemplo na sugestão de história feita por dois meninos de uma narrativa de viagem no tempo na qual um homem decide inventar uma máquina do tempo para ver como seus pais eram quando adolescentes e descobre, para sua tristeza, não só que o seu amado pai era o chefe de uma gangue, mas assiste a sua morte pela polícia ao tentar roubar um banco (ANTONOFF; FREEMARK, 1961, p.1-3). Essa sugestão de história expressa a curiosidade infantil sobre o passado e a descoberta de que o passado não era necessariamente motivo de orgulho, ideia que foi expressa na série de forma clara nos episódios que lidavam com a História dos EUA, não só os de viagem no tempo. Em outra carta, esta de um adulto, um ensaísta regular da revista de fãs de filmes Films in Review, Edward Connor, um organista de igreja (SLIDE, 2018, n.p) de Nova York fã de cinema, entrou em contato com Serling em fevereiro de 1961, destacando que notou que muitos roteiros de Além da Imaginação apresentavam viagens no tempo para o passado e para o futuro e "erros no tempo"; portanto, achava que Serling 
poderia se interessar pelo artigo que escrevera para a edição futura da revista, a ser lançada em março do mesmo ano, intitulado Of Time and the Movies, cujo título original Films in 4-D, revelava, fora trocado pelo editor da revista. No artigo, Connor apresentava como o tempo havia sido tratado no cinema e sugeria alguns enredos que, segundo ele, ainda não haviam sido explorados sobre viagem no tempo. Em sua carta, ele não oferecia nenhuma história para Serling, mas informava que se ele tivesse acesso à revista, iria achar o artigo interessante e provocante, útil para a imaginação de Serling (CONNOR, 1961, p.1).

Outros fãs pediam textualmente mais histórias de viagem no tempo, principalmente as crianças, o que é um indicativo que reforça a interação do público infanto-juvenil com a série, questão explorada anteriormente, mas também reforça a noção de como a viagem no tempo atinge em cheio a imaginação sobre o símbolo Tempo, principalmente para parcelas da população que ainda estão aprendendo a se adequar a esse símbolo, auxiliando a reflexão e adequação para um mundo que abraça a mudança como algo desejável, dentro da lógica do progresso - não é a toa que encontramos crianças compreendendo de forma clara e adorando episódios nostálgicos, como pode indicar o sucesso da coletânea de contos adaptados dos episódios Stories from the Twilight Zone (1960). A obra escrita por Rod Serling ${ }^{37}$, continha em suas páginas uma adaptação de Walking Distance, à primeira vista um enredo de apelo adulto. Esse livro não só fez sucesso entre as crianças, mas também foi adotado por inúmeras escolas da época, como atestado por cartas de estudantes, muitas destas enviadas como lição de casa, comentando o que foi lido com Serling.

$A$ viagem no tempo também apelava a casais que assistiam à série e discutiam a questão, desenvolvendo histórias com o tema, como a carta enviada para Serling em fevereiro de 1960, que sugeria um enredo no qual um relógio digital elétrico, "moderno, sem ponteiros", ao ser manipulado por um personagem escapista, tornase uma máquina do tempo. Ao brigar com a esposa e escapar para o passado para esfriar a mente, ele fica preso no passado "mais ou menos no período da Guerra Civil", pois não havia eletricidade para alimentar o relógio (DEAR..., 1960, p.1-2). Mesmo que tal ideia em si não tenha sido aproveitada de forma nenhuma na série, seu espírito em relação à viagem no tempo ao passado está presente em Além da Imaginação.

${ }^{37}$ Rod Serling publicaria por contrato com a Bantam Books três livros de contos adaptados diretamente de seus roteiros, Stories from the Twilight Zone (1960), More Stories from the Twilight Zone (1961) e New Stories from the Twilight Zone (1962). 
Como foi bem entendido pelo público, não de forma totalmente consciente, a fuga do presente e dos problemas diários é punida, algo notado pelo casal ao sugerir tal sinopse para Rod Serling utilizar como quisesse e alterar o que achasse necessário. $O$ fato de acharem que ele se interessaria por essa história criada em uma conversa de casal demonstra o apelo desse tipo de narrativa para dar sentido para uma sociedade que flertava com a nostalgia devido às rápidas mudanças e à perspectiva de fim do mundo atômico ou distópico, mas, ao mesmo tempo, necessitava superar esses ímpetos para sua própria sobrevivência, reforçando esse elemento de negação à fuga para um passado idealizado - transmitido pela cultura histórica, aí inclusos a história tradicional (escolar e literária) e a mídia.

Figura 19 - "Tempo era o tirano que tinha que ser detido!" Capa da revista de histórias em quadrinhos publicada entre 1962-1979 pela Gold Key Comics. Na edição de maio de 1976, Joshua Wise, operário em uma fábrica de relógios, descobre como somos controlados pelos relógios que manipulam o tempo.

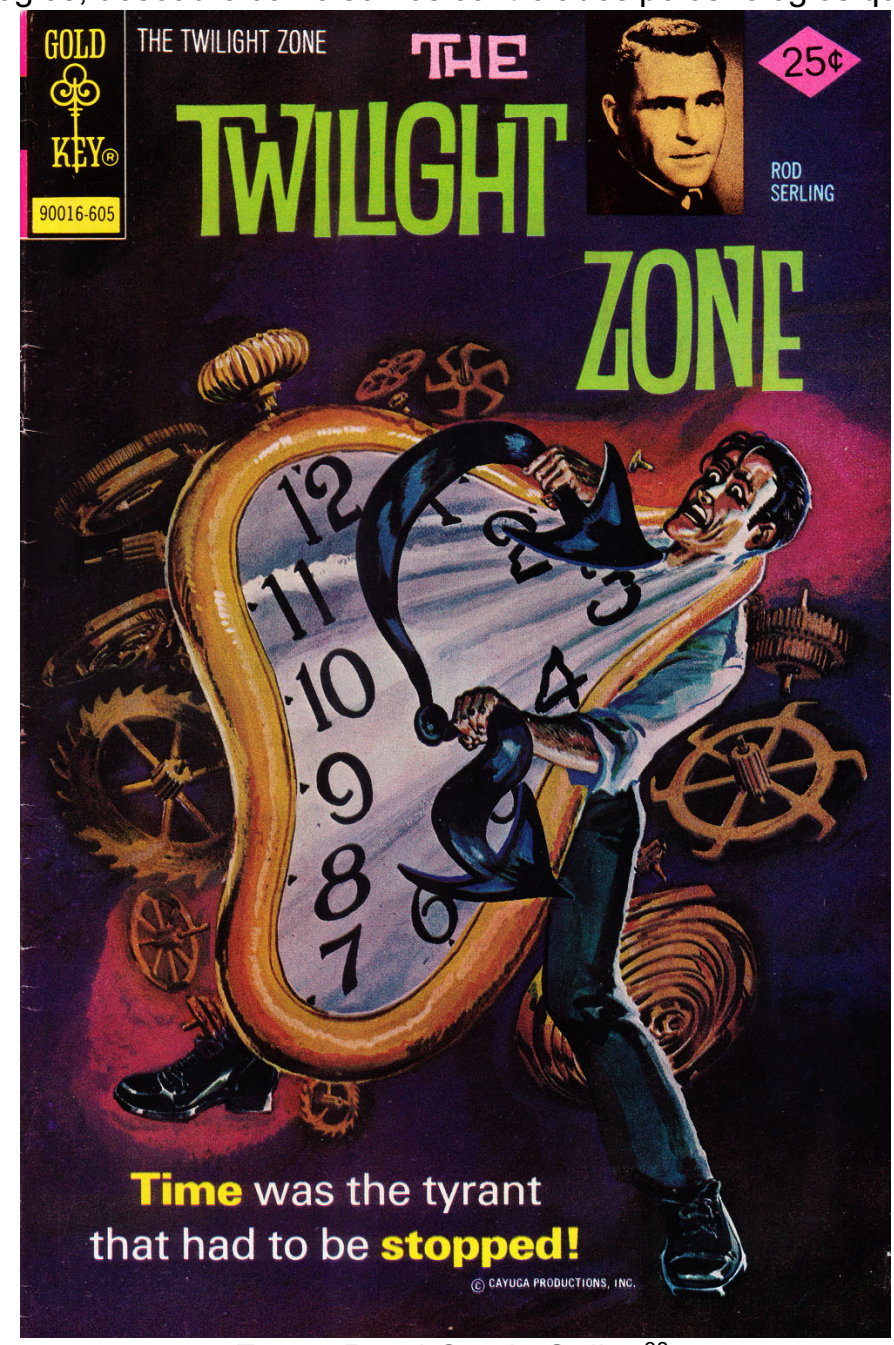

Fonte: Read Comic Online ${ }^{38}$

38 Disponível em: <https://readcomiconline.to/Comic/The-Twilight-Zone-1962/Issue70 ? $\mathrm{id}=143460>$. Acesso em: 05/01/2019 
Havia também a sugestão de contos e autores que lidavam regularmente com o tema: em 1960, Serling recebeu uma carta irônica propondo uma aposta de dez dólares que ele não conseguiria adaptar a icônica história de Ray Bradbury O Som do Trovão, em Além da Imaginação. Serling responderia de forma jovial que o autor da carta havia vencido antes de propor a aposta, pois ele havia tentado enfaticamente adquirir a história, mas Bradbury dissera que tinha outras intenções, provavelmente um filme. Isso exemplifica não só a importância desse conto no cânone de obras importantes sobre viagem no tempo, ao ser indicado e reconhecido por Serling, mas como o público via a série como local ideal para transmissão de ideias provocantes e ousadas sobre a mudança, expressas nessa história de viagem no tempo.

A presença de Jack Finney na série para as histórias de viagem no tempo também era recomendada a Serling, como o seu nostálgico conto The Third Level. Serling se interessava por essas histórias, mas não teria conseguido negociar nenhuma obra desse autor devido ao preço pedido. Para um fã que sugeriu essa história por achá-la perfeita para a série, Serling se justificou, escrevendo que por muito tempo a desejava para o programa mas não conseguiu comprá-la, e brincando com o fã afirmou que a carta mostrava que ambos pensavam igual (SERLING, 1960a, p.1) - a história tinha os elementos que poderiam estar perfeitamente na série. Entretanto, se analisarmos a história, ao contrário dos enredos que flertam com a nostalgia, mas na última hora, na reviravolta irônica, a negam, esse conto de Finney reforça a nostalgia por um passado americano idílico de finais do século XIX que, durante a série de Serling, será tanto visto como inacessível quanto criticado. Contudo, a percepção de que a nostalgia era incentivada pela série era padrão, e isto era devido ao peso que a história dava para o passado idílico, reforçada pelo roteiro e expressa pela própria linguagem cinematográfica da série representando o passado como local mais calmo, deixando a crítica dessa noção para os minutos finais. Além disso, essa representação do passado alimentava a nostalgia e gerava uma historização no público, que se identificava com ou rejeitava a narrativa em nível pessoal, em um mundo do segundo pós-guerra visto como inquieto, competitivo e ameaçador. Esse passado exibido pela série chegava até a causar irritação em parte do público, por exemplo, um jovem de 23 anos, em 4 de julho de 1960, escreveu para Rod Serling elogiando e criticando os episódios exibidos até então e reclamou que a série usara várias vezes a noção de viajar do presente agitado para um passado sereno, algo de que ele não gostava mais (GALVIN, 1960, p.1), provavelmente devido 
à repetição do tema em um contexto histórico amplo marcado pela nostalgia e fuga do presente, porém as intenções da série em discutir a nostalgia eram mais profundas.

\section{2- A viagem no tempo e a nostalgia}

Não raro, podemos encontrar na viagem no tempo uma aproximação nostálgica com o tempo de destino do viajante, tanto em histórias que foquem no deslocamento ao passado, quanto ao futuro. Cabe lembrar que os retratos nostálgicos em obras ficcionais não estão limitados à viagem no tempo, recurso ou tema utilizado, muitas vezes, para reforçar as intenções dos autores ao propor ambientes e situações onde a nostalgia será alvo de alguma abordagem crítica ou complacente.

O passado geralmente é o alvo mais óbvio de um retrato nostálgico nas obras; entretanto, o futuro também pode ser retratado partindo do mesmo sentimento ao evocar no público presente sentimentos de saudade ao apresentar um futuro contendo personagens, estruturas e/ou instituições do passado restauradas e/ou tornadas vivas novamente. Um exemplo seriam os múltiplos planetas e povos encontrados nas obras transmídia Jornada nas Estrelas (Star Trek). Já, de uma forma não direta, a proposta de futuros pode despertar sentimentos nostálgicos ao nos depararmos com a imaginação dos devires de outras épocas e sociedades, prognósticos da ficção científica ou de obras artísticas ou científicas que flertam com a temática- futuros imaginados no passado que não se concretizaram, com tecnologias, pessoas, figurinos e modelos arquitetônicos que nunca existiram ou tiveram alcance limitado, reforçando o sentimento de inadequação do tempo presente que não se tornou ou nunca se tornará o futuro apresentado em determinada obra; além disso, tal observação traz à tona a saudade por um passado no qual se imaginava tal futuro, agora sentido como inacessível.

A série Além da Imaginação explorou as formas nostálgicas de relação com o passado em diversos episódios exclusivamente observando o passado e não o futuro. Além disso, utilizou de forma recorrente e incisiva à viagem no tempo para representar as relações entre presente e um passado nostálgico, tornando clara uma discussão anterior à série referente às manifestações nostálgicas modernas, permanente e significativa nas relações modernas com o tempo. A série de Serling incorporou o problema da percepção e aceitação das mudanças individuais e coletivas no contexto histórico-social do programa de televisão, reforçando uma abordagem sobre o 
problema da nostalgia vendo-o como um peso a ser superado, por vezes com a morte do nostálgico.

Para se compreender como a nostalgia se manifesta na série, devemos observar como se desenvolveu esse sentimento de saudade por algo que não existe mais ou nunca existiu (BOYM, 2001, p.XIII) e como a nostalgia tornou-se uma marca das sociedades globais contemporâneas, pois como afirmou a professora de Literatura Svetlana Boym, referência no estudo da nostalgia e da modernidade, "o século XX começou com uma utopia futurista e terminou com nostalgia" (Ibid., p.XIV). A série Além da Imaginação se encaixa perfeitamente no estudo da professora Boym, publicado no livro The Future of Nostalgia (2001), sobre esse sentimento de defesa que surge em tempos de grandes mudanças rápidas, em um contexto intermediário claro de resistência à pressões nostálgicas, que, posteriormente, seriam vitoriosas no mundo globalizado, como percebido por Boym em finais do século XX e início do XXI. Como, por exemplo, atualmente, podemos encontrar uma nostalgia globalizada: há toda uma cultura histórica global, divulgada principalmente pelos produtos culturais americanos, como filmes e séries de televisão, que criaram uma visão dos anos 50 que desperta a nostalgia dos americanos e de outras sociedades por um passado estável, no qual o bem e o mal são bem definidos, onde se dança ao som do rock'n'roll e se desfruta de uma cultura adolescente com corridas de carro e cinemas drive in repletos de filmes de discos voadores e criaturas assustadoras; o nostálgico não necessariamente precisa ter nascido nos EUA, tampouco ter vivido nos anos 50.

Sobre a nostalgia, a própria etimologia da palavra traz consigo uma relação com o passado, ela é uma criação pseudo-grega do médico suíço Johannes Hofer, em 1688. A palavra é formada de nostos, que significa voltar para casa, e algia, saudade no sentido de uma dor, e era uma doença caracterizada pela tristeza derivada do desejo de se retornar à terra natal (Ibid., p.1). Inicialmente europeia - em oposição à velha Europa, as novas nações do continente americano formavam as suas identidades negando pressões nostálgicas ${ }^{39}$-, e utilizada tanto para reforçar e desafiar as ideias nascentes de patriotismo e nação.

39 É pertinente pensar que a própria proposta de se pensar a História do Brasil do alemão Carl Von Martius, de 1845, que definiu o povo brasileiro como parte do "encontro, da mescla, das relações mútuas e mudanças" (MARTIUS e RODRIGUES, 1956, p.442) de três raças distintas (com o sangue português guiando a novidade), faz parte desse movimento anti-nostálgico das 
No século XIX, a nostalgia se espalha pelo mundo, perdendo seu caráter de patologia e entrando no rol das emoções genuínas humanas. Segundo Boym (2001, p.7), a difusão da nostalgia pelo mundo, muito mais do que uma explicação sobre alterações na relação com o espaço tem a ver com uma nova relação com o tempo, pois é uma emoção histórica, não limitada à história individual. É um sentimento de perda coletivo e não necessariamente se sabe o que foi perdido ou como encontrar. A nostalgia, em linhas gerais, reflete a impossibilidade de retorno a um mundo encantando com fronteiras e valores claros (Ibid., p.8), o que pode ser visto de forma clara nas histórias de viagem no tempo nostálgicas de Além da Imaginação, onde essa impossibilidade será brevemente subvertida para, por fim, na conclusão do episódio, ser reforçada de forma contundente por ações da Zona Crepuscular.

Cabe o destaque ao fato de que esta impossibilidade de retorno a um passado idealizado reforça a reflexão sobre o sucesso dos westerns na década de 50 dos EUA e sua relação com o mundo da Guerra Fria, no qual esse gênero, devido a sua clareza na definição de heróis e vilões, propondo um passado onde os problemas são claros, sem tons de cinza, e passíveis de resolução, alimentava exatamente esse sentimento do público, que notava o mundo cada vez mais complexo e aleatório e encontrava nesse gênero um mundo perdido que acalmava as tensões e dilemas diários.

Assim como o conceito de progresso, a nostalgia parte do princípio da irreversibilidade e ineditismo da experiência no tempo, ela é uma consciência do processo de mudança expressa socialmente de forma sensível. A emoção histórica da nostalgia é uma saudade do encolhimento do espaço de experiência (permite a assimilação do passado no presente) que não mais se vê no horizonte de expectativas (forma de se ponderar o futuro) (Ibid., p.10). De forma geral, o ritmo dos avanços técnicos e científicos e a dinâmica do mundo industrial e sua expansão estão na raiz do aumento de intensidade da saudade das pessoas por um passado visto como mais socialmente coeso e ancorado em tradições vistas como atemporais, destruídas pela velocidade da mudança.

A concepção moderna de tempo, com a abertura do futuro e do progresso, está na base tanto do pensamento do progresso, com a busca constante de novidade e ruptura com o passado, como do tempo anti-moderno da tradição, no qual o passado,

nações americanas, visto como a abertura de uma nova experiência na história humana, como Martius deixa bem claro em seu artigo. 
visto como estável, deve ser repetido/recuperado; essas duas visões dicotômicas compartilham e são fruto da mesma mudança na relação com o tempo, como nota o filósofo Bruno Latour (LATOUR apud BOYM, 2001, p.19).

A nostalgia demorou a entrar com força na cultura americana; os Estados Unidos da América no início do século XIX, em geral, se viam como uma nação que não tinha a necessidade de um passado, os EUA seriam uma "nação da natureza". Essa definição nacional ahistórica teria permitido a nacionalização do mito do progresso e a criação do American Way of Life, modo de vida americano, com o empreendedor e o cowboy como símbolos desse modo de vida (BOYM, 2001, p.1718). Porém, como se pode notar por obras de sucesso da cultura popular de massa americana do segundo pós-guerra, esse foi o momento no qual os EUA abraçaram de forma mais contundente a nostalgia. Não por acaso, como destacado anteriormente por Boym, esse foi um contexto histórico de grandes transformações e incertezas, como o impacto da Guerra Fria e a perspectiva da não existência de um futuro para a civilização no caso de um conflito com armas nucleares.

Em meados do século $X X$, os símbolos do American Way of Life já estavam historicizados: o cowboy e o empreendedor do passado, símbolos de liberdade e inventividade, cada vez mais davam lugar aos trabalhadores urbanos, sujeitos aos rígidos horários das fábricas e escritórios e aos presidentes de grandes corporações sem face. Se a nostalgia tem por característica a perda do seu objeto de desejo e seu deslocamento espacial e temporal (Ibid., p.38), por meio das obras da cultura popular de massa, como, por exemplo, programas de televisão, parcelas significativas da população americana encontraram alento e sedativo das pressões diárias do mundo dos anos 50 e início dos anos 60 no final do século XIX e nas primeiras décadas do século XX. Isso não era sentido como uma reação nostálgica, pois quanto mais relações nostálgicas são encontradas em dada sociedade, mais fortemente ela é negada (Ibid., p.XIV).

\section{3- As duas faces da nostalgia}

Segundo Boym (2001, p.41), podemos encontrar duas tendências nostálgicas operando no mundo pós-século XVIII; essas tendências alimentam a saudade e lidam com esse sentimento de formas distintas; uma seria a "nostalgia restaurativa" e a outra a "nostalgia reflexiva". A primeira tendência colocaria a ênfase no nostos e teria a 
intenção de reconstruir o lugar da memória perdida; a segunda enfatizaria o algia, lidando com a lembrança e a perda. Essas duas abordagens da nostalgia serão exploradas em Além da Imaginação com ambas propostas compartilhando os mesmos episódios e, em geral, uma crítica da primeira (restaurativa) em favor da segunda (reflexiva), o personagem buscando alimentar a nostalgia restaurativa e a Zona Crepuscular, com seu papel educativo/socializador/punitivo, dando-Ihe a nostalgia reflexiva.

A nostalgia restaurativa se ocupa da reconstrução de um suposto passado, fornecendo uma experiência pessoal com o objeto desejado ou símile e pode ser encontrada na reconstrução de monumentos históricos, valorização de mitos e símbolos nacionais, fornecendo ao nostálgico uma experiência do passado, eternamente estável, visto nesta tendência como um valor para o presente (lbid., p.49). Além disso, cabe destacar que a nostalgia restaurativa leva-se a sério e que a indústria da cultura de massa geralmente reforça essa tendência e a explora, não só em recriações pseudo-históricas que podem ser encontradas em obras audiovisuais ou arquitetônicas, mas também na reprodução e comercialização de qualquer artefato original ou réplica de qualquer civilização passível de interessar um consumidor ávido por possuir um objeto que evoca outros tempos e valores.

Já a nostalgia reflexiva tem maior ligação com a memória individual e cultural, enfatizando o tempo histórico e subjetivo, valorizando os fragmentos da memória e sem o foco de recuperar o que fora perdido, mas sim "meditar sobre a história e a passagem do tempo" (Ibid., p.49), reafirmando a impossibilidade de retorno ao passado. Ao contrário da nostalgia restaurativa, essa tendência não necessariamente se leva a sério, podendo ser irônica ou humorística, e não vê na reconstrução física do passado perdido algo que faça acalmar a saudade; seu local não é a reconstrução, mas sim a ruína, e não é o lar perdido, ele não existe mais mesmo que possa fisicamente estar no mesmo espaço. É uma lamentação profunda que cumpre o papel do luto (Ibid., p.55) por um tempo perdido, mas que pode deixar aberta uma proposta de futuro, como pode-se notar na série Além da Imaginação.

A série Além da Imaginação irá se adequar à tendência nostálgica reflexiva e a viagem no tempo irá fortalecer a crítica a um espírito restaurador da nostalgia, pois o que é a viagem no tempo senão a mais perfeita forma de se experimentar a nostalgia. Ela permite o acesso a mais que mera reconstrução do passado no presente, mas sim a vida no próprio passado e fuga completa do presente inadequado. A série de Serling 
não só irá apresentar os limites dessa perfeita restauração do passado ao se viver no próprio tempo e espaço fruto da saudade, ele demonstrará, pela interferência da Zona Crespuscular, os perigos reais dessa restauração, como a importação de valores contrários aos direitos humanos, também obrigando à aceitação da irreversibilidade do passado e a impossibilidade de se melhorar o presente alterando traumas passados: eles seriam necessários para a construção do futuro.

O caso de Além da Imaginação é emblemático, pois a série se contrapôs, com sucesso, a noções amplamente divulgadas na época pela cultura de massa, como os westerns, porém sem negar a História, não aceitando a premissa de que os EUA fossem eminentemente uma nação voltada para o futuro ou ahistórica, mas sim com um rico passado que poderia ser alvo de um sentimento nostálgico, a ser canalisado para a construção de uma alteração nas ações presentes a fim de construir um futuro melhor. Destaca-se a ideia repetida em diversos episódios que se passam no passado, não só nos de viagem no tempo, que nessa temporalidade se realizavam várias injustiças ainda presentes em graus distintos, portanto, longe de qualquer idealização.

Já em 1958, antes mesmo da série ir ao ar, Rod Serling escreveu um esboço de enredo para um episódio chamado You Must Go Home Again (Você Deve Retornar Para Casa, em tradução livre). O episódio que não chegou a ser roteirizado, como descreve Grams Junior. (2008, p.572-573), apresentava um soldado de um futuro distante problemático, devastado por uma guerra, que resolve voltar para o passado e viver nos finais do século XIX em uma pequena cidade dos EUA. Lá, passa a viver de forma plena e feliz, nunca mais retornando para seu tempo, mesmo que seja pedido que retorne a sua época. Esse modelo de enredo de viagem no tempo ao passado nostálgico pode ser encontrado diluído em outros episódios da série, produzidos posteriormente, abordados por Rod Serling de forma mais crítica - um indicativo da própria maturidade do roteirista e produtor executivo de Além da Imaginação.

Em correspondência datada de 22 de janeiro de 1970, Rod Serling, respondendo a uma carta de um fã que indagara sobre se o autor do livro The President Plane is Missing, Robert J. Serling, era seu irmão, além de tecer comentários elogiosos sobre diversos episódios da série Além da Imaginação (exibida na época em infindáveis reprises por todo mundo), comentando os sentimentos aflorados por eles, afirmou a importância da nostalgia como tema que o inquietava: 
[...] Eu acho que todo escritor tem o sua própria preocupação - sua própria referência especial - ou você pode chamar de sua preocupação pessoal. Comigo é a nostalgia [grifo no original]. É essa jornada contínua, impossível e fantasiosa para a outra época passada. Seus carrosséis, algodão doce e inocência e seneridade. São todas as coisas que se foram e não são mais encontradas atualmente. Ambos itens que você mencionou são sintomáticos dessa minha fome. E ambos [Walking Distance e A Stop At Willoughby], na minha opinião, são os melhores contos que eu escrevi em uma confusão de ficção de segunda categoria pelas quais eu sou responsável. (SERLING, 1970, p.1-2, tradução nossa) ${ }^{40}$

A série Além da Imaginação lidou diretamente com o tema da nostalgia de forma crítica, enquanto o pensamento nostálgico era incentivado no período, como atestado pelo sucesso do western. A série de Serling iria flertar com o tema, a fuga da realidade do segundo pós-guerra americano, trazendo os personagens - e o público - para refletir que tal forma nostálgica de se ver o passado é danosa na construção de um futuro melhor para todos, este futuro aperfeiçoado dentro do espectro humanista da série, é expresso tanto no conjunto dos episódios quanto no comportamento e nas crenças pessoais de Rod Serling e de muitos dos demais envolvidos com a série.

Os episódios que abordam diretamente a nostalgia e expressam uma preocupação sobre esse tema são Walking Distance, A Stop At Willoughby, The Trouble With Templeton, Static e The Incredible World of Horace Ford. Os episódios Walking Distance e A Stop At Willoughby estão entre os mais famosos da série, citados por Serling como exemplo de qualidade, e não à toa são extremamente semelhantes; contudo, a ênfase e o grau de reflexão sobre a nostalgia nestes dois episódios são distintos e complementares. Estas duas histórias, inclusive, foram juntadas na malfadada proposta de venda da série para a televisão britânica BBC, na qual os programas teriam uma hora de duração, compostos de dois episódios com temas afins (SERLING, 1963d, p.1).

Cabe destacarmos os episódios que lidam com o passado pelo viés da nostalgia a fim de percebermos como a série pensa seu contexto e explora as

\footnotetext{
${ }^{40}$ No original: [...] I guess every writer has his own hang-up - his own special reference - or you might call it his personal preoccupation. With me it is nostalgia [grifo no original]. It's that continuing, impossible and fanciful journey back to the other time. It's merry-go-rounds, cotton candy, and innocence and senerity. It's all the things that have flown by and are not to be recaptured in this day. Both the itens you mention are symptomatic of that hunger of mine. And both [Walking Distance e A Stop At Willoughby], in my view, were the best short stories I've ever written in a welter of altogether second-rate fiction that l've been responsible for.
} 
questões das mudanças dos EUA no segundo pós-guerra, claramente utilizando a viagem no tempo e seus elementos simbólicos para intensificar a mensagem de que seria natural o flerte com o passado, mas ele deveria ser superado para a construção de uma sociedade melhor e uma vida mais adequada dos indivíduos nostálgicos no presente, que deveriam canalizar seus sentimentos para a transformação do futuro e não fugir para o passado.

\subsection{1- Walking Distance}

O epísodio "Walking Distance" foi o $5^{\circ}$ a ser exibido em Além da Imaginação, no dia 30 de outubro de 1959. Ele foi filmado em quatro dias, de 25 a 30 de junho de 1959, nos estúdios da MGM. Estrelado por Gig Young, Frank Overton, Irene Tedrow e Michael Montgomery, dirigido por Robert Stevens, que havia previamente dirigido o episódio piloto “Where is Everybody?". A trilha sonora original é de Bernard Herrmann, compositor da trilha da apresentação da primeira temporada. O custo total de produção foi de USD \$74.485,68 (GRAMS JUNIOR, 2008, p.181; ZICREE, 1992, p.41; RUBIN, 2018, p.397).

Seu título pode ser traduzido como "Uma Distância Caminhável”, "Uma Curta Distância", em referência tanto direta ao caminho de uma milha e meia $(2,4 \mathrm{~km})$ que o personagem principal anda a pé para chegar à cidade de sua infância, quanto ao simbolismo de uma curta distância ao passado dado pela imaginação e por sentimentos nostálgicos.

Nesse episódio escrito por Rod Serling, com as últimas revisões realizadas no dia do início das filmagens, 25 de junho, somos apresentados à história de Martin Sloan, um vice-presidente de uma agência de publicidade de Nova York de 36 anos de idade, que chegou ao topo de sua profissão. Cansado e à beira de um ataque de nervos, ele pega seu carro e dirige sem destino, saindo da cidade grande para o interior, chegando, sem querer, próximo à cidade onde crescera, Homewood. Deixa o carro para trocar o óleo e lubrificar em um posto de gasolina e caminha em direção à cidade. Notando que a cidade se encontrava exatamente como ele lembrava antes de mudar - como a drogaria onde passava a infância tomando sorvete com refrigerante ${ }^{41}$

\footnotetext{
${ }^{41}$ Nos EUA as drogarias por muito tempo funcionavam também como uma lanchonete, sendo um local de encontro dos jovens.
} 
-, ao ver sua versão jovem entalhando o nome no coreto do parque, percebe que tinha ido parar no passado. Sem sucesso, Sloan tenta conversar com seu eu jovem, mas acaba assustando o garoto. Indo para sua antiga casa, entra em contato com seus pais, já falecidos no seu tempo de origem, que estranham um homem adulto na porta de casa afirmando ser seu filho e acabam mandando-o embora, assustados. Martin Sloan resolve passear pela cidade, preenchido pela saudade do verão de sua juventude, ouvindo música do calíope ${ }^{42}$, comendo doces e tentando recuperar algo perdido em sua vida. Ao anoitecer, no carrossel da cidade, tenta novamente contatar o jovem Martin, mas novamente o menino se assusta e sai correndo, ferindo gravemente sua perna, dor sentida simultaneamente pelo Sloan adulto. O menino é levado embora e Martin adulto, desolado, é encontrado por seu pai; este sabia quem ele era, pois tinha visto os documentos na carteira perdida pelo homem que apareceu na sua casa afirmando ser seu filho. O pai informa a Martin que o jovem irá se recuperar, mas irá mancar um pouco, e dá uma lição de moral em seu filho, exortandoo para que ele retorne a seu tempo: lá ele deveria procurar a satisfação que sentira vivendo no passado. Martin retorna para o presente tendo aprendido a lição, com a dor na perna como lembrança.

Para esse episódio, o relatório da CBS, produzido pelo departamento de autocensura, liberando o episódio, informava as alterações que deveriam ser realizadas no roteiro inicial de abril de 1959 antes de ser filmado, como o cuidado costumeiro de evitar identificação visual de produtos no posto de gasolina, inclusive a máquina de cigarros não deveria ter indicação de nenhuma marca, máquina esta que tinha o espelho a ser utilizado na cena da ida de Martin Sloan para a cidade. Também deveriam ser removidos do roteiro os diálogos que falavam "voltar ao útero" e "Ah, meu Deus!", além de reafirmar que os ângulos da filmagem deveriam obscurecer a mutilação na perna do Martin garoto, evitando assim qualquer diálogo que pudesse adquirir uma interpretação blasfema e exibição de sangue ou machucados capazes de impressionar a audiência (MORRIS, 1959, p.1).

O roteiro do episódio apresentava uma ordem diferente nas cenas, organizadas de forma mais lógica na versão exibida na televisão. No roteiro revisado de

\footnotetext{
42 Instrumento musical que em suas versões antigas utilizava o vapor que passava por apitos produzindo sons, posteriormente substituído por gás comprimido. O calíope pode ser tocado por uma pessoa com um teclado ou ser totalmente mecanizado e visualmente lembra um órgão. Seu uso era muito difundido nos circos nos EUA.
} 
25/06/1959, após conversar com o menino que brincava com bolinhas de gude, Martin Sloan se dirigiria diretamente para sua antiga casa onde teria o encontro com seus pais e veria o carro novo de seu vizinho, modelo 1934. No episódio finalizado essa sequência só ocorreria após o passeio dele pelo parque, onde ele se vê entalhando o nome no coreto, surpreende-se e assusta seu eu passado. Caso tivesse visto seus pais primeiro ele já saberia que estava no passado e sua reação ao se ver jovem, ficaria confusa. No roteiro, essa sequência do parque com poucas mudanças fazia parte do ato dois do episódio.

Já na narração de abertura do episódio, realizada por Serling, somos introduzidos ao problema principal do personagem - e de seu contexto histórico. Martin Sloan é um executivo facilmente identificável pelo público como alguém de sucesso, um Mad Men (em referência à avenida de Nova York famosa por suas agências de publicidade e a associação dos publicitários com loucos). A falta de sentido e as múltiplas pressões do presente levam-no a um "êxodo", uma fuga, lembrando o livro homônimo da Bíblia que descreve a fuga dos hebreus da escravidão:

Martin Sloan, trinta e cinco anos. Ocupação - Vice-Presidente de uma
agência de publicidade responsável pela mídia. Esse não é apenas um
passeio de domingo para Martin Sloan. Ele talvez não sabe ainda...mas é um
êxodo. Em algum lugar na estrada, ele está procurando por sanidade. E, em
algum lugar da estrada - ele irá encontrar algo a mais [tradução nossa]. ${ }^{43}$
(SERLING, 1959r15)

O epílogo expõe o que o personagem viveu e conclui relativizando o sentimento explorado no programa, demonstrando que o flerte com a nostalgia em um mundo em constante mudança é algo natural, mas que não deve ser levado a sério, a ponto de colocar em perigo o futuro, deve-se sorrir ao se ter saudade do passado e viver no presente:

Martin Sloan, trinta e cinco anos. Vice-presidente responsável pela mídia.
Bem-sucedido em muitas coisas - mas não em algo que muitos homens
tentam alguma vez em suas vidas - tentar retornar para o lar. E como, todos
homens, talvez exista uma ocasião... talvez um dia numa noite de verão...
quando ele observar o que ele está fazendo e escutar a música distante do
calíope - e ouvir as vozes e risadas das pessoas e os lugares do passado.
E, talvez, por sua mente passe um desejo errante... que um homem não deve
envelhecer - nunca ultrapassar os parques e os carrosséis de sua juventude.
E ele irá sorrir então, também, porque ele saberá que isso é apenas um

${ }^{43}$ No original: "Martin Sloan, age thirty-six. Occupation - Vice President, ad agency in charge of media. This is not just a Sunday drive for Martin Sloan. He perhaps doesn't know it at the time... but it's an exodus. Somewhere up the road, he's looking for sanity. And, somewhere up the road - he'll find something else." 
desejo errante. Algum lampejo de memória, realmente não muito importante. Algum fantasma sorridente que pode atravessar a mente de um homem... que são uma parte da Zona Crepuscular [tradução nossa]. ${ }^{44}$ (Ibid)

O tema da alteração do destino também é importante ser destacado, pois a viagem ao passado, nesse episódio, encontra-se no campo de uma fuga do presente sem a tentativa de alterá-lo ou impedir seus desdobramentos. Ou seja, em nenhum momento era intenção de Martin Sloan impedir que ele mesmo se tornasse um publicitário ou levasse a vida que levava no presente, ele também não tem nenhuma intenção de impedir eventos ou alterar os desdobramentos da História. Sloan apenas desejava reencontrar o verão do seu passado, experimentar as mesmas sensações que tinha em um mundo protegido, que não existia mais.

Este episódio permite a alteração do passado; entretanto, devemos considerar essa mudança no sentido de que não se pode fazer tal retorno a um passado individual repleto de sentimentos nostálgicos e voltar ao presente sem alguma ferida. Há sempre uma marca profunda que fica dessa busca pessoal por um lugar no mundo quando se mexe com sentimentos que, o episódio deixa claro, devem ser apreciados com cuidado, caso contrário, se a pessoa ficar presa à saudade do passado, as feridas podem ser fatais. No episódio, essa manifestação de tipo psicológica se torna física e palpável. Portanto, a alteração do passado individual se encontra mais no campo de um tipo fantástico de terapia do que realmente de reforçar uma noção de que o ser humano controla o tempo, ou mesmo pode flertar com tal controle, já que, como vemos, Martin Sloan não tem a intenção expressa de alterar o passado e/ou seu presente e futuro. Ele era movido por dois desejos: experimentar as sensações do passado e avisar o seu eu mais jovem para apreciar o verão e aproveitar a juventude ao máximo, pois no mundo adulto dos EUA do final dos anos 50 , não haveria mais lugar para se apreciar a vida. A própria consequência danosa de sua aventura no passado, sua perna machucada, não parece ter alterado o destino de Martin Sloan, o

\footnotetext{
${ }^{44}$ No original: "Martin Sloan, age thirty-six. Vice president in charge of media. Successful at most things - but not at the one effort that most men try at some time in their lives - trying to go home again. And also, like all men, perhaps there will be an occasion... maybe a summer night sometime... when he'll look up at what he's doing and listen to the distant music of a calliope - and hear the voices and the laughter of the people and the places of his past. And perhaps across his mind there'll flit a little errant wish... that a man might not have to become old-never outgrow the parks and the merry-go-rounds of his youth. And he'll smile then, too, because he'll know it is just an errant wish. Some wisp of memory, not too important, really. Some laughing ghost that could cross a man's mind... that are a part of The Twilight Zone."
} 
que seria verdadeiro se a história seguisse o modelo citado anteriormente exposto no conto O Som do Trovão, de Ray Bradbury, no qual uma única alteração no passado desencadeia uma onda enorme de alterações temporais.

Na última versão do roteiro de Serling, em cena não filmada, o filho contaria ao pai que ele já havia falecido, o que, no episódio finalizado, foi trocado pela bela cena quando o filho encontra os pais pela primeira vez e os vê através da tela da porta; a cena mostra o casal com um aspecto de fantasmas, indicando ao público que ambos estão mortos no presente de Sloan, sem precisar explicitar o fato por meio de diálogos.

A viagem no tempo ao passado, nesse episódio, dá-se por alguma ação mágica da Zona Crepuscular durante a caminhada do personagem e não por uma máquina do tempo, porém seu retorno ao presente se dá pelo carrossel, este brinquedo transformado em uma máquina do tempo mágica. A apresentação da sua travessia para o passado reforça o aspecto de fantasia, Martin Sloan se dirige ao caminho que levava a sua antiga cidade, visto através do espelho da máquina de cigarros do posto de gasolina, em alusão à viagem fantástica do livro Alice Através do Espelho (e o que ela encontrou lá), de Lewis Carroll (1871), como notado por Zicree (1992, p.43). A presença dos espelhos como símbolo do reflexo da busca interna do personagem principal por um lugar seu em um mundo competitivo e em constante mudança está mais explícita nos roteiros e no conto publicado posteriormente no livro Stories from the Twilight Zone, de 1960. Inclusive, a proposta de Serling para a narração inicial se dava quando Sloan se olhava no retrovisor do carro, representando de forma clara a procura do seu eu no passado.

Como já dito, a viagem de volta para o presente se realiza no movimento realizado pelo carrossel, outro símbolo explorado no episódio que não só desempenha o papel de representar um elemento de uma infância inocente perdida, mas também reforça o símbolo da permanência, com os cavalos que andam em círculos sem sair do mesmo lugar e o próprio movimento de um tempo imutável.

O fato de após ter a conversa com o pai o carrossel voltar a se movimentar sozinho e Martin subir nele rapidamente, dando quase um salto para retornar ao presente, reforça o movimento do relógio, pois o carrossel, dessa vez, não dá uma volta completa, mas em meia volta a cena muda para a drogaria no presente, ao som de uma melodia genérica de rock'n'roll.

Uma sugestão ou explicação plausível de que a viagem no tempo seria psicológica, passando-se na imaginação de um homem estressado, não é 
corroborada com o que é exibido no episódio, mesmo que tal noção possa ser induzida pela narração final. O problema da perna de Sloan não estava presente quando ele saiu do carro e andou pela cidade, inclusive a descida do banco da drogaria no presente, que causa um desconforto ao homem, não ocorreu no banco da drogaria do passado, do qual ele desce com grande agilidade. Essa visão de que realmente ocorreu uma viagem no tempo foi confirmada por Rod Serling em palestra dada em Sherwood Oaks College em $1975^{45}$.

Figura 20 - Assistimos a ida de Sloan para Homewood do passado pelo espelho da máquina de cigarros.

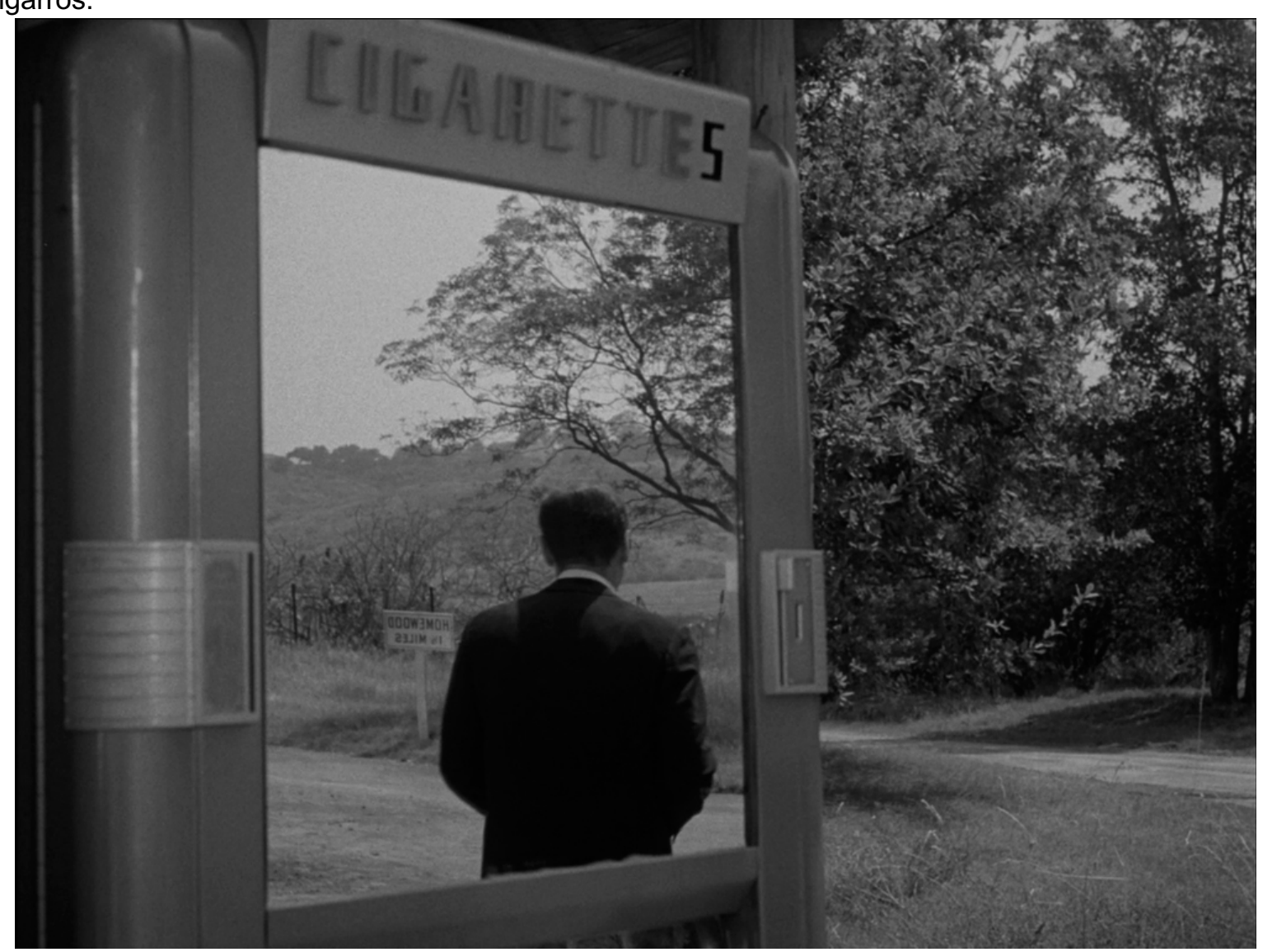

Fonte: elaborado pelo autor (Blu-ray, The Twilight Zone: The Complete Series, CBS, 2017)

Os autores Gordon F. Sander, Anne Serling, a filha de Rod Serling, Michael Pipher, historiador do arquivo sobre Serling no The Bundy Museum of History and Art (Binghamton, NY) e Marc Scott Zicree, autor, pesquisador e crítico da série, são unânimes em relatar que esse episódio era o que tinha mais relação com a vida e

${ }^{45}$ Trecho da palestra de Rod Serling na faculdade Sherwood Oaks College (Los Angeles, CA) em 1975 disponível como extra do episódio Walking Distance na coletânea The Twilight Zone: The Complete Series, CBS, 2016. Blu-ray. 
experiências de Rod Serling em toda a série. O próprio Serling comentaria isso em entrevistas, citando como tivera a ideia de representar Homewood como a cidade onde passara sua juventude, Binghamton, cidade do interior do estado de Nova York. Essa cidade, atrelada à experiência nostálgica, esteve presente por toda a curta vida de Serling que no verão, durante e após Além da Imaginação ter sua primeira exibição, se deslocava de Los Angeles para o lago Cayuga, local a pouco mais de cem quilômetros de Binghamton com a família, e dirigia sozinho para a cidade, circulando em suas ruas, apreciando o local, tentando recuperar alguma experiência do passado e de sua juventude pré-fama, em relato de Michael Pipher, confirmado por sua filha na Serling Fest 2018, realizada em Binghamton de 5 a 7 de julho de 2018. O pensamento nostálgico era caro a Rod Serling, como podemos notar na última entrevista dada por ele, a 4 de março de 1975, pouco mais de três meses antes de sua morte, ocorrida no final do mês de junho do mesmo ano. Na entrevista à jornalista Linda Brevelle, da revista Writer's Digest, ao ser questionado se ele pudesse viver em outra época, qual época seria, Serling respondeu que se ele tivesse os meios, gostaria de viver na época vitoriana, em uma cidade pequena, com coretos e verão, sem as doenças da época, uma forma mais simples de existência (BREVELLE, apud RUBIN, 2018, p. 334-335).

O retorno à década de 30 (1934 no episódio) é significativo, representa o retorno à juventude dos que se tornavam adultos na década de 50 , observada pelo olhar nostálgico reflexivo e faz referência direta a experiência do jovem Serling e de sua cidade, mais protegidos dos efeitos da Crise de 1929. No episódio, não existe em nenhum momento quaisquer retratos dos problemas reais enfrentados pela maior parte das pessoas na década de 30 , lembrando que as políticas do New Deal, na tentativa de recuperar a economia americana e melhorar as condições de vida dos trabalhadores, foram iniciadas em 1933 e aprofundadas a partir de 1935. Um elemento pessoal dessa fuga para um passado nostálgico estaria relacionado às formas com as quais Serling passaria a lidar com o sucesso de sua própria carreira profissional, de um aspirante a roteirista nos anos 40 a um dos principais roteiristas de programas renomados e respeitado pelo seu meio no final dos anos 50 , além de produtor de sua própria série de televisão, tendo que lidar com todo tipo de pressão. Como diz a sua narração final para o episódio, o ímpeto nostálgico era um mero devaneio, cuja origem estava em se viver em um mundo adulto em constante transformação e concorrência implacável. 
Figura 21 - Detalhe da pintura do carrossel reproduzindo cena do episódio Walking Distance no Recreation Park de Binghamton (NY). Esse parque, com coreto e carrossel se encontra recriado no episódio. Atualmente, após a restauração, os painéis do carrossel são decorados com cenas de Além da Imaginação (apenas um dos painéis tem um tema medieval do cavaleiro salvando a dama).

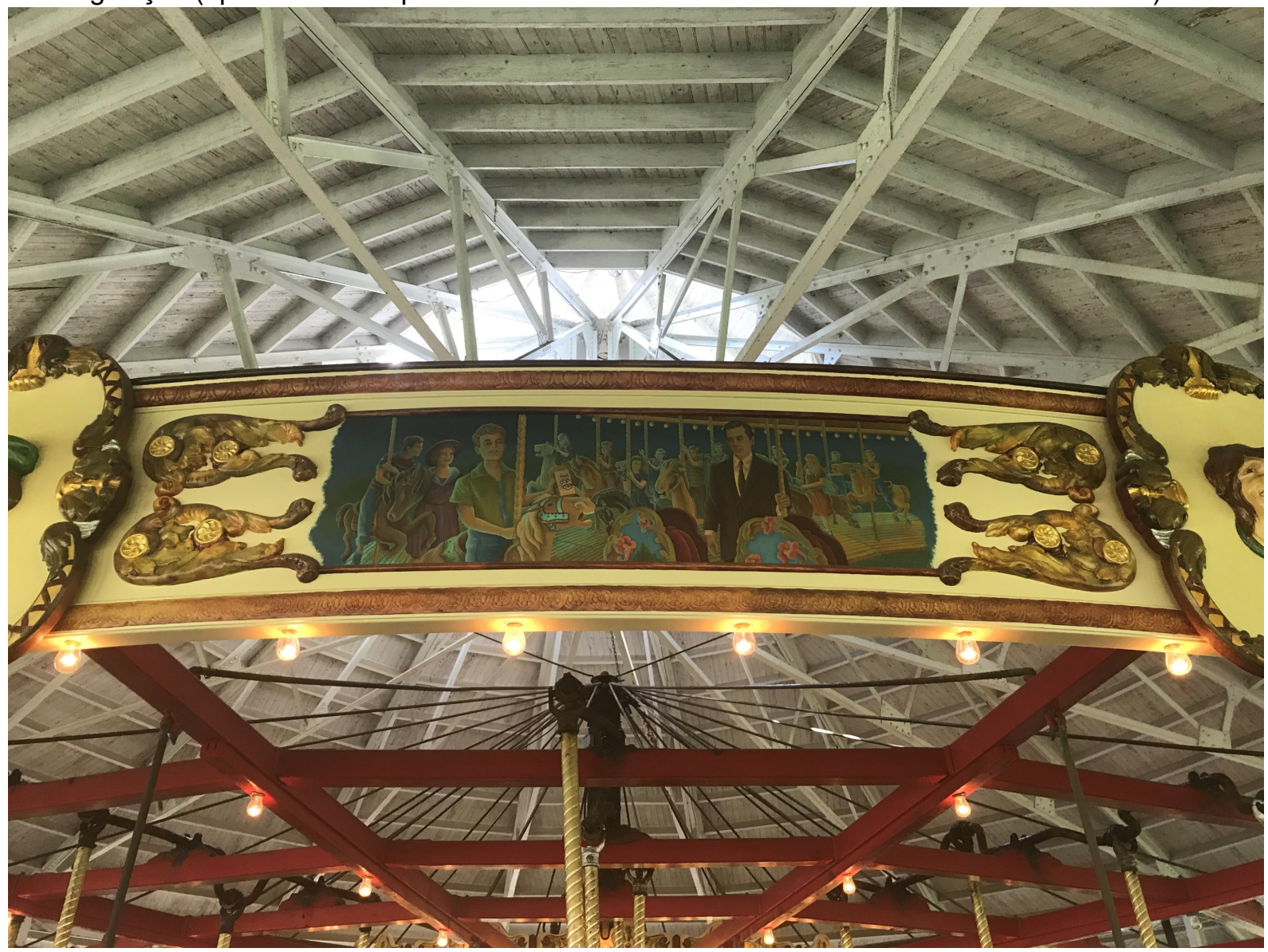

Fonte: fotografia tirada pelo autor (Recreation Park, Binghamton, NY, EUA, 2018)

Como curiosidade da experiência com o tempo moderno, no ano idealizado no episódio, 1934, foi lançado o musical na Broadway "Anything Goes" (equivale à expressão brasileira "vale tudo"), cuja canção título, composta e cantada por Cole Porter, ironizava a sociedade americana da época da depressão ao comparar um passado mais lógico e íntegro, com um presente atribulado e cômico, no qual "valeria tudo" (CHADWICK, s.d, n.p). A música seria regravada por Frank Sinatra e outros músicos em meados da década de 50 , e mostra que o presente, no qual "valeria tudo" em comparação com um passado nostálgico, é cada vez lançado mais pra frente.

As reações a esse episódio na época, e sua presença constante em listas dos melhores episódios da série, tanto por aspectos técnicos, atuação, trilha sonora e direção, mas também pela história em si, que por meio da união destes elementos conseguiu ter um efeito capaz de mobilizar o público, demonstram não só como o 
processo de passagem para a fase adulta pode ser traumático para os seres humanos, mas também em como essa passagem se dá em um mundo em constantes transformações e pressões, como ocorria nos EUA do contexto da série.

A viagem de Sloan representa tanto a tentativa de escapar do mundo competitivo do capitalismo americano do segundo pós-guerra quanto de um mundo tão mudado em apenas vinte e cinco anos que parecia ser irreconhecível. O sermão dado pelo pai de Martin Sloan restabelece a relação do filho com seu presente, pois seria lá que ele deveria procurar o que estava procurando no passado - acolhimento e alegria -, inclusive com a perspectiva de mudar sua vida. Portanto, não seria alterando o passado ou vivendo no passado que ele preencheria um vazio existencial dado pela vida corporativa nos anos 50 , mas sim mudando seu presente. O passado é analisado a fim de se construírem perspectivas e consciência para transformar as condições presentes; para Sloan, essa transformação se daria no campo individual, mas implicaria em uma mobilização coletiva para um futuro mais agradável.

Ao transmitir a ideia de que se deve viver no presente, alterando-o, esse episódio não reforça uma visão de que o passado seria melhor, pois o presente seria capaz de proporcionar as mesmas condições, só cabendo ao incomodado procurar melhor, ou seja, rejeitar o mundo competitivo capitalista americano. O fato de Serling escolher um publicitário de sucesso para procurar fugir de sua atividade, profissão criticada geralmente por Serling por sua interferência inculta na arte e cultura, explorando a ignorância, reforça sua crítica ao cotidiano, pois indica que o melhor dos mundos propagados por setores da cultura americana do período seria uma mera propaganda. Essa profissão seria alvo de depuração em outro episódio envolvendo a nostalgia na mesma temporada, $A$ Stop at Willoughby, com um publicitário decidindo abandonar o mundo empresarial ao ter que criar um programa de televisão adequado aos patrocinadores.

O papel do pai no episódio é muito importante, dentro das convenções e expectativas sociais daquele perfil no contexto histórico americano dos anos cinquenta, exposto visualmente, por exemplo, pelo fato de que na primeira vez em que ele aparece, inclusive está segurando um cachimbo. A figura do pai é calcada na expectativa do papel paterno padrão, propagada pela própria televisão do período, como, por exemplo, o pai da série Leave It to Beaver (1957-1963) ou da série que teve enorme sucesso ao ser exibida no Brasil, Papai Sabe Tudo (Father Knows Best, 19541960). Sua fala mansa e paciente com o homem adulto que se identifica como sendo 
seu filho indica racionalidade e autocontrole, não encontrados na mãe, mais emotiva e reativa ao falar com seu filho adulto, não crendo ser ele a versão adulta de seu filho de onze anos. No final do episódio, ao confirmar a identidade do homem, é quem aconselha e orienta o seu filho, uma conversa de homem para homem, que pode ser vista no contexto como o reestabelecimento de Martin Sloan como um homem adulto responsável, pois ele fugiu ao passado para buscar sensações da infância e rejeitar o mundo adulto.

Esse episódio, visto com o conjunto da série e inserido na própria biografia e produção de Serling, permite-nos observar a apresentação e demonstração de uma tese clara de que há um mal-estar que permeia o final da década de 50 , que deve ser resolvido pelas pessoas de sua época em sua época e não pelo caminho das sensações nostálgicas, negando e fugindo dos problemas. Além disso, como proposto corretamente por Zicree (2018, p.37-40), podemos acompanhar no conjunto da obra de Serling a ascensão dessa noção de executivo de sucesso que sofre pressões do mundo corporativo e o término de sua carreira em três programas distintos, de épocas diferentes: a chegada ao topo de um jovem executivo, humano e leal, que tem que lidar com a competição desumanizadora empresarial, exposta na obra Patterns (Kraft Television Theatre, 1955), já estabelecido no topo, ele tenta escapar para o passado nostálgico em Walking Distance (1959) e veríamos seu novo lampejo nostálgico, agora, prestes a se aposentar e ser substituído na empresa, em um mundo muito mais cruel, no episódio They're Tearing Down Tim Riley's Bar (Galeria do Terror, 1971). Uma observação em seguida dos três episódios demonstra a profunda crítica que Serling estabelecia do desenvolvimento e dos prognósticos para a sociedade americana, ao mesmo tempo o uso da fuga nostálgica como forma de reflexão, pois os dois episódios nostálgicos dessa saga do executivo visto como bem-sucedido utilizam a nostalgia reflexiva, para propor a mudança.

Cabe destacar como o passado é retratado e o efeito dessa representação no contexto de exibição da série, que pode ajudar à compreensão do sucesso desse episódio e seu apelo: o retrato do mundo de 1934 está aberto a nuances interpretativas por parte do público, também encontrando eco nos nostálgicos que procuravam recriar um passado idealizado. O episódio, mesmo que critique a nostalgia restaurativa, no modelo de lição de moral exposto pela série (porém, sem a reviravolta irônica do final característica), reforçado pelo fato do personagem adquirir um ferimento marcante por toda a vida, acaba por enfatizar uma visão idealizada do 
passado. A pequena cidade de Homewood em 1934 é exposta como um lugar positivo, de preços baratos, crianças brincando sem preocupações, adultos passeando calmamente, carrossel, algodão doce, pessoas amigáveis, parques, uma comunidade idealizada nos moldes do que as famílias do período procuravam encontrar nos subúrbios, permitindo a nossa conclusão de que a mudança para os subúrbios realizados por milhares de americanos no segundo pós-guerra tem um elemento nostálgico. O subúrbio, sua existência e comunidade, era reiteradamente exposto e criticado pela própria série em episódios de autoria de Rod Serling, como The Monsters Are Due on Maple Street (1960) e The Shelter (1961), dentre outros, o que demonstra que essa conclusão não seria a intenção de Serling. Portanto, o episódio crítico à nostalgia restaurativa não consegue se libertar totalmente das formas de pensar dessa abordagem nostálgica, o que é retrato de como a nostalgia e a viagem no tempo expõem relações complexas com o símbolo Tempo.

A viagem no tempo, nesse episódio, é utilizada para reforçar a diferença entre os tempos e, na perspectiva moderna, fazer uma crítica não à noção de progresso, mas a desvios dessa noção que estariam ocorrendo no contexto da experiência do segundo pós-guerra: o mundo da Guerra Fria e da ascensão do capitalismo americano não era um lugar de músicas de calíope, algodões doces e carrosséis, mas eles podiam ser encontrados novamente no futuro, caso o presente desejasse mudar para uma nova experiência.

O episódio, tanto nas cartas de Beaumont informando Serling das conversas sobre plágio quanto na de fãs da série, seria associado ao trabalho de Jack Finney e Ray Bradbury. Parcelas do público notaram similaridades entre Walking Distance e o livro de Ray Bradbury de 1957 Licor de Dente-de-leão (Dandelion Wine), como o tom nostálgico desse escritor e o ambiente de cidade pequena que podia ser encontrada diretamente na obra de Serling. Outra referência à obra deste escritor seria o uso de um brinquedo de parque como instrumento relacionado com o tempo: no conto de Bradbury, The Black Ferris, publicado na revista Weird Tales de maio de 1948, há uma roda gigante que, dependendo do sentido de seu girar, faz os anos passarem ou regredirem para quem está sentado nela - algo que não tem muito a ver com o episódio de Serling, mas foi visto como um empréstimo da obra de Bradbury. De Jack 
Finney, seria destacado como principal cópia de Serling o tema da fuga do presente para um passado nostálgico, tão presente em seus contos, como The Third Level ${ }^{46}$.

O próprio escritor e amigo de Rod Serling Charles Beaumont acreditava que, por ler muitas obras, Serling estaria copiando os escritores, de forma subconsciente e por osmose. Em sua carta endereçada a Serling, explicando que estava difícil defendê-lo, pois a comunidade dos escritores de ficção científica da Califórnia estava cada vez mais acusando-o de plágio nos círculos literários, datada de 3 de dezembro de 1960, Beaumont escreveria o que ouvira sendo propagado sobre Walking Distance, e concordava em parte, "Um furto claro de Bradbury. O tema, o clima, o carrossel, a ideia de um homem voltando no tempo e se vendo jovem, o trabalho de convencer seus pais de que ele é seu filho...tudo obviamente Bradbury." (BEAUMONT, 1960, p.2) Rod Serling, de forma contundente explicaria tanto a Bradbury e a Beaumont, em cartas separadas, de onde tirara a ideia. Para ambos, afirmou que nunca lera a obra que era comparada ao episódio, o que retirava a acusação de uma influência "subconsciente". Ele explicava que, ao passear no verão nas ruas da cidade onde crescera, Binghantom, o que fazia todo ano nas férias, ao ver o carrossel em condições deploráveis, sentindo o clima da cidade de sua juventude, foi acometido por sentimentos nostálgicos e resolveu traduzí-los em seu roteiro (SERLING, 1960g, p. 1-4; 1960h, p.1-8). De forma interessante, cabe notar, Serling utilizou o episódio como forma de observar criticamente tal experiência, um devaneio de um homem no meio de enormes pressões, com as quais lidava diariamente no meio televisivo. Posteriormente, Serling e Bradbury fariam as pazes e se respeitariam como colegas escritores, segundo relato de Grams Jr., que entrevistou Bradbury ${ }^{47}$. Marc Zicree (2014), amigo de Bradbury em seus últimos anos de vida, afirmou que a relação teve uma melhora, mas no decorrer da série, Bradbury se decepcionaria com Rod Serling ao ter o seu roteiro para o episódio / Sing the Body Electric não filmado de forma integral, como prometido por Serling. Outros escritores também afirmariam que Serling copiara ideias deles (CAHN, 2014, p.20) para compor o enredo de Walking

\footnotetext{
${ }^{46}$ O escritor Stephen King, em seu livro de ensaios Dança Macabra (2013), publicado em 1981, consideraria esse conto de Finney um exemplo do que Além da Imaginação poderia ter sido, além de comentar que Serling teria uma mente irmã da de Finney e que as obras desse escritor ecoariam nos melhores episódios de Além da Imaginaçao. Para King (2013, p.276), Serling e Finney deram nova direção à literatura fantástica ao não se preocupar em explicar nada, tampouco pedir desculpas.

${ }^{47}$ Relato de Grams Junior ao ser indagado por mim na Serling Fest 2018 em Binghantom, NY.
} 
Distance. Como curiosidade, no episódio há uma homenagem a Bradbury: uma das ruas de Homewood, chama-se Dr. Bradbury, algo que, caso Serling fosse realmente um plagiador - e ele não era-, seria um ato de cinismo.

Figura 22 - Momento de tomada de consciência de Martin Sloan, ao ser orientado por seu pai (a esquerda) no passado. Carrossel parado e a iluminação indicam um momento de suspensão no fluxo temporal.

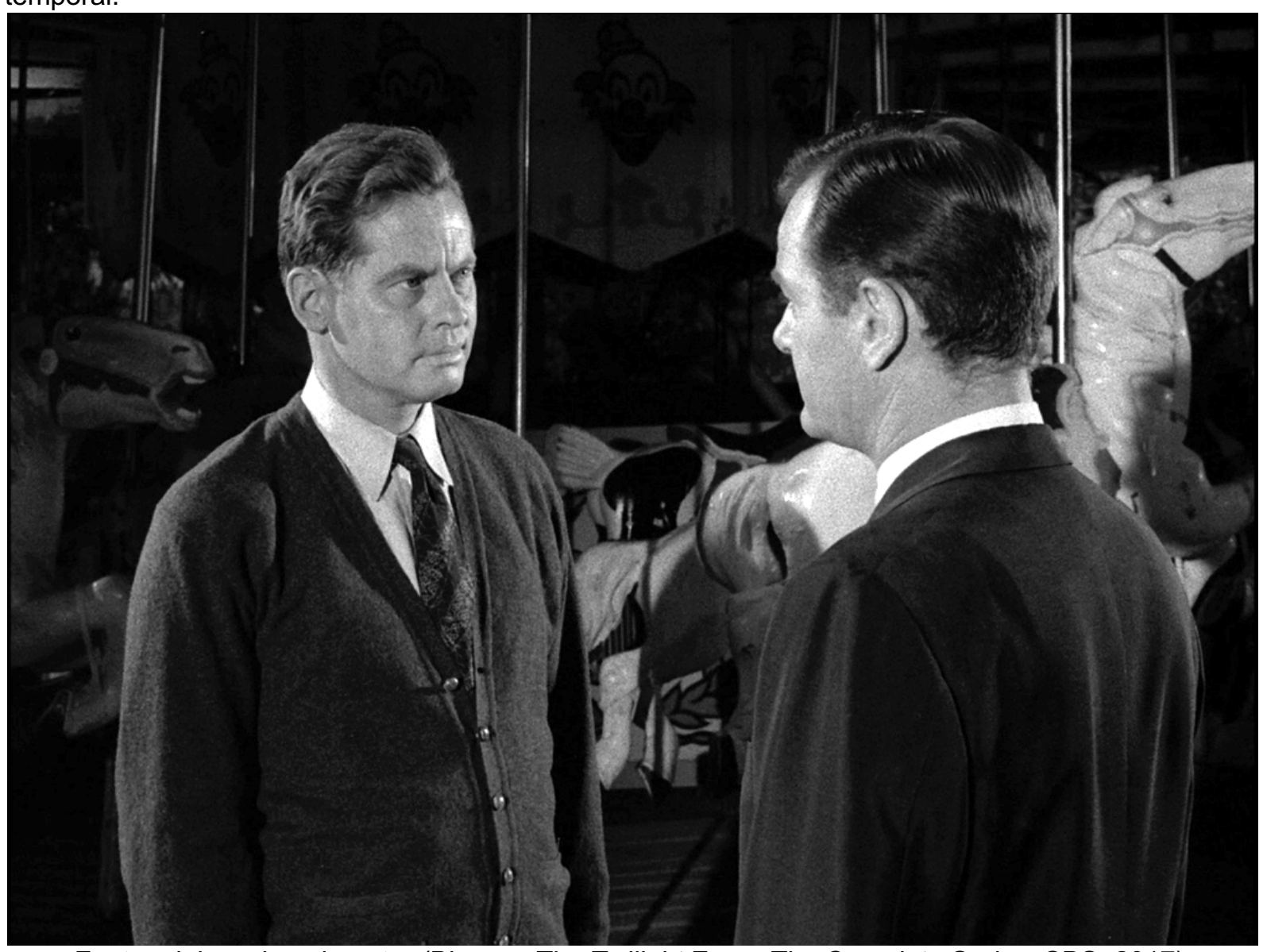

Fonte: elaborado pelo autor (Blu-ray, The Twilight Zone: The Complete Series, CBS, 2017)

Desconsiderando a acusação de plágio como algo pouco provável, já que elas estavam mais pautadas por questões de ego do que realmente cópias de ideias originais, salvo alguns símbolos utilizados de forma similar ou situações semelhantes, cabe destacar que tais sentimentos nostálgicos eram comuns na época e são condizentes com o que é esperado em sociedades que passam por transformações rápidas e cujos membros sentem profundamente uma saudade de um modo mais simples, buscando um mundo estático no presente. O que exemplifica a difusão de uma década de um passado nostálgico que tocava os adultos com saudade de uma infância idealizada, fortalecida pela experiência dessa geração na Segunda Guerra Mundial, pelas responsabilidades adultas e pelas grandes transformações e 
perspectivas de futuro dadas pela década de 50, como o crescimento econômico, aliado com a destruição da civilização proposta pelas tensões da Guerra Fria. Mesmo com o desemprego e as condições precárias da vida, em uma visão colorida do passado, 1934 se colocava como mais adequado à existência do que 1959.

O fato da presença do carrossel em um ambiente nostálgico estar no conjunto das acusações de plágio, identificado como um símbolo de Tempo em uma história de viagem no tempo (substituindo outros brinquedos de parque com a mesma forma, como a roda gigante do conto de Bradbury de 1948), representa tanto uma realidade das cidades americanas de terem esse tipo de artefato disponível nos parques e feiras, mas também como esse símbolo de tempo circular e infância era forte e mobilizador de sentimentos nostálgicos. Cabe destacar, no mesmo contexto histórico do segundo pós-guerra, o livro de Salinger de 1951 O Apanhador no Campo de Centeio (The Catcher in the Rye), que apresenta o carrossel como figura central de sua narrativa sobre se tornar adulto no mundo ocidental moderno; inclusive a primeira edição tem um cavalo de carrossel desenhado na capa, e, para citar o autor envolvido na polêmica do plágio, a mesma noção do carrossel, um símbolo da passagem do tempo, (suas voltas representando a passagem do tempo) também pode ser encontrada no romance de Bradbury de 1962, Algo Sinistro Vem por Aí (Something Wicked This Way Comes). O símbolo do carrossel será muito explorado no século XX para representar a experiência humana individual e coletiva com o tempo, principalmente como objeto de reflexão sobre a noção dos tempos distintos inéditos e impossíveis de serem repetidos, criticando ou reforçando estas noções.

No episódio Walking Distance, é no carrossel que Martin Sloan aprende a lição de que deve procurar alegria e contentamento no seu presente e não no passado, os altos e baixos da vida, representados pelo movimento dos cavalos, são naturais da existência e ele deve procurar construir sua vida fazendo algo que lhe agrade. Além disso, ele não teria o direito de tirar a experiência do jovem Martin ao interferir falandoIhe que deveria aproveitar a vida, o que poderia alterar toda existência do Martin adulto e fazer o adulto ficar preso no carrossel do passado, em um ciclo eterno sem saída. Martin Sloan encontra a saída e aprende uma dolorosa lição.

Enquanto esse episódio abre a perspectiva de mudança do presente da experiência americana e mundial dos anos 50 , realizada no presente, outro episódio escrito por Serling na mesma temporada não seria tão animador sobre essa 
perspectiva de se conseguir reverter a desumanização realizada pelo crescimento da sociedade americana da época.

Figura 22 - Capa da primeira edição do livro O Apanhador no Campo de Centeio com o cavalo do carrossel, símbolo do ciclo da vida explorado no romance de Salinger e no episódio Walking Distance de Rod Serling.

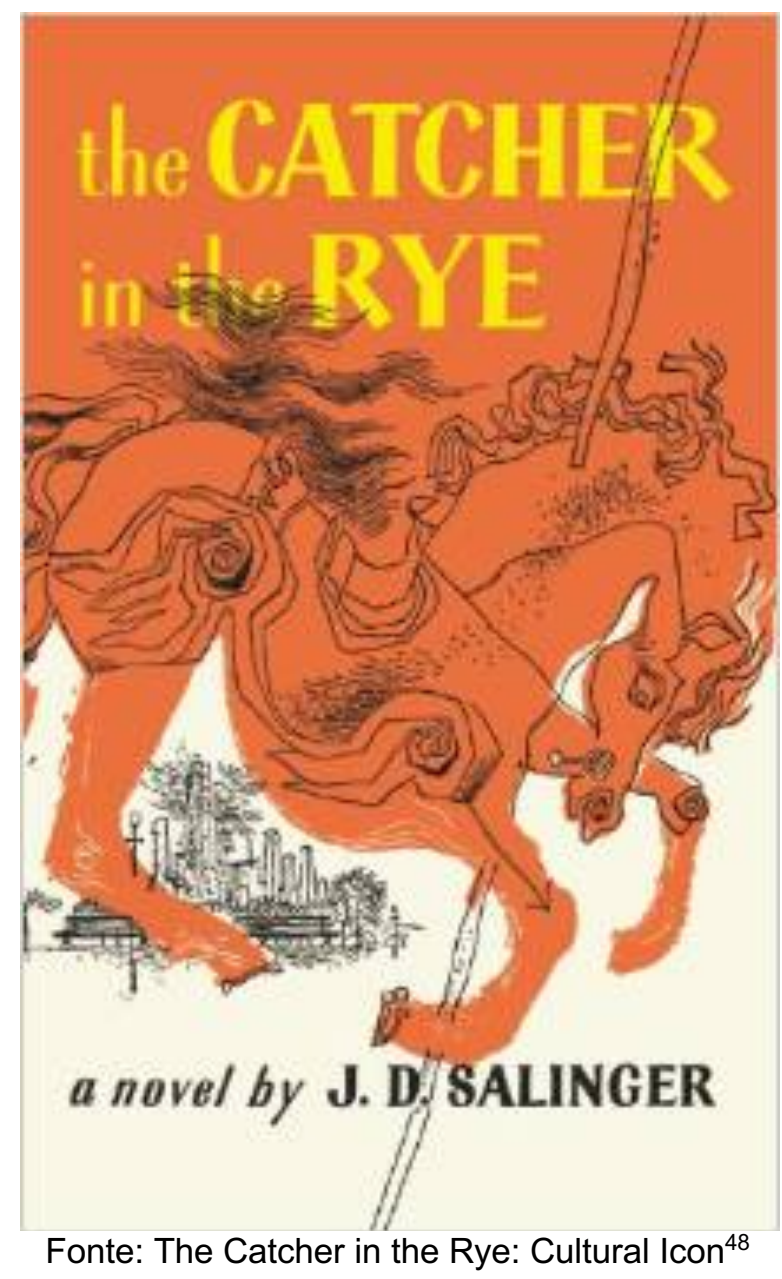

\subsection{2- A Stop at Willoughby}

A Stop at Willoughby, o $30^{\circ}$ episódio da série Além da Imaginação, foi exibido após Walking Distance. Ambas histórias se complementam como nenhum outro par de episódios da série e não é à toa que estavam programados para serem exibidos juntos no malfadado plano de venda da série para a televisão inglesa. Cabe destacar que uma versão preliminar dessa história era a proposta inicial de piloto para Além da Imaginação assim que foi aprovada pela CBS. O roteiro original foi reescrito por Serling, reduzindo a trama de 60 para cerca de 30 minutos (GRAMS JUNIOR, 2008,

48 Imagem disponível em: https://catcherculturalicon.weebly.com/changing-covers.html 
p. 283). O episódio foi filmado no mês de março de 1960 e foi ao ar dia 6 de maio desse ano, com direção de Robert Parrish, estrelado por James Daly, Patricia Donahue e Howard Smith. O custo total do episódio foi de USD\$ 51.501,46 (GRAMS JUNIOR, op.cit., p. 282; ZICREE, 1992, p.117).

O publicitário Gart Williams sofre pressões no seu trabalho altamente competitivo, é enganado por seu pupilo, o que causa a perda de uma conta de empresa automotiva milionária, e sofre com seu chefe impiedoso, que expõe uma filosofia de trabalho desumana a qual não agrada Williams. Em casa, sua esposa também cobra uma postura competitiva no trabalho, ela não gosta de seu marido, mas do sucesso e dos bens materiais que o acompanham. Seu único momento de paz e fuga é no trem enquanto faz o trajeto do trabalho para casa: ao cochilar no trem, ele de forma recorrente acorda num antigo vagão na estação de uma cidade chamada Willoughby no passado e observa um ambiente idílico pela janela. Willoughby é uma cidade de final do século XIX, calma e pacífica, local dos sonhos de Williams, mas ele resiste em descer e sempre acaba acordando no trem rumo a sua casa no presente. Cada vez sofrendo mais com seu trabalho, que o estava deixando doente mental e fisicamente, e após não encontrar respaldo para suas reclamações por parte de sua esposa, pensando em abandonar a publicidade, cochila novamente no trem e acorda em Willoughby; dessa vez, ele decide descer e passa a viver em um passado idealizado, no qual todos gostam dele. Na realidade, ele pulara do trem em movimento na viagem que sempre fazia entre trabalho e casa, e seu corpo sem vida é recolhido, ironicamente, pela funerária de nome Willoughby \& Son Funeral Home.

Segundo o autor do livro Twilight Zone Encyclopedia (2018), Steve Rubin, esse episódio pode ter sido inspirado pelo musical de sucesso Brigadoon, de Alan Jay Lerner e Frederick Loewe (RUBIN, 2018, p.363). Lançado no teatro em 1947 e posteriormente adaptado para o cinema pela MGM em 1954 com o mesmo título (no Brasil, o filme recebeu o nome de A Lenda Dos Beijos Perdidos), foi dirigido por Vincente Minnelli e estrelado por Cyd Chariss, Gene Kelly e Van Johnson. Brigadoon, apresenta uma história que se passa na cidade fantástica na Escócia que dá título à obra, um local idílico parado no tempo que aparece apenas um dia a cada cem anos. Em 2000, foi lançado um filme para a televisão americana adaptando $A$ Stop at Willoughby, chamado For All Time, dirigido por Steven Schachter, o filme manteve a ideia do lugar da fuga do presente ser o final do século XIX. 
Em A Stop at Willoughby, somos expostos a outro executivo da publicidade, o executivo de uma agência de Nova York, Gart Williams, outro Mad Men que se encontra descontente com seu cotidiano de trabalho e, principalmente, com os rumos do mundo e de seu lugar nele. Nessa história, o retorno ao passado se dá por meio de sonhos no trem no trajeto entre seu trabalho em Manhattan e sua casa: todo dia, após o trabalho estressante, ele cochila e se vê num vagão de trem antiquado de madeira, onde está só com o condutor que anuncia a chegada na cidade maravilhosa em outro tempo no qual se pode viver uma vida gratificante e plena.

O executivo cada vez mais se encontra nesse sonho recorrente onde sua hesitação em descer do trem no passado é punida por situações presentes mais insuportáveis. Por fim, ele desce do trem no passado e encontra um ambiente receptivo. Porém, como revelado ao final, ele pulara do trem em movimento no presente, tendo morte instantânea, e o nome da cidade fantástica é o sobrenome dos donos da agência funerária que retiram seu corpo sem vida da neve.

Esse final com uma reviravolta irônica remete à ideia de que nostalgia restaurativa só pode ser alcançada pela morte. Enquanto Sloan de Walking Distance, recebeu uma lição valiosa de aprender a viver no presente, possivelmente mudando sua vida, Gart Williams não teve a mesma sorte. Aquele mundo que ele procurava nos cochilos durante viagem diária de volta para casa não irá ser visto nunca mais, em uma mensagem pessimista de Serling sobre o presente. Pode-se considerar que a Zona Crepuscular, nesse episódio, agiu com complacência para com Williams, pois ele tinha abandonado seu emprego, perdido sua esposa e nada mais restava a ele no presente; de certa forma, ele ficou vivo no passado de seus sonhos enquanto, no presente, seu corpo faleceu - inclusive, essa noção pode ser inferida na narração final de Serling e é explícita na versão adaptada do programa em livro.

Nesse episódio, em relatório anexado ao roteiro datado de 26 de maio de 1960, de autoria de Buck Houghton (GRAMS JUNIOR, 2008, p.283), há a informação de que o roteiro era elogiado como um dos melhores de Além da Imaginação, porém existia a preocupação com a falta de familiaridade do tema com os adolescentes e que o final depressivo podia ir contra o material. Talvez essas sejam as razoes para que na versão literária fique claro que ele ficou vivendo no passado (SERLING, s.d., c2). Na conclusão da narração proposta para o episódio, ele teria realmente morrido 
[...] "Senhor Gart Williams que agora pode nos contar o que acontece no além... porque isso também é parte da... Zona Crepuscular!"(tradução nossa ${ }^{49}$ ).

Com certeza, a escolha de publicitários para expor o sentimento nostálgico do contexto americano de fins da década de 50 traz uma ironia consigo, pois eram os publicitários, símbolos de uma sociedade orientada ao consumo, vazia e falsa, os grandes criticados por Serling em sua carreira na época devido à interferência das agências de publicidade da televisão. É simbólico que Williams decida abandonar aquela vida de vez quando foi pressionado por seu chefe a criar um programa de televisão que se adequasse aos patrocinadores. Enquanto Sloan, de Walking Distance recebe a orientação de procurar o mundo feliz no presente e futuro, Williams acaba sucumbindo à nostalgia por um período até anterior a sua infância, um contexto no qual os EUA se desenvolviam, antes da ascensão da sociedade da qual fazia parte e desejava escapar.

A oposição entre as épocas é marcada tanto pela tecnologia, trem antigo oposto ao novo, quanto pelo aspecto da cidade pacata Willoughby, pequena e amigável, oposta ao mar de prédios de Nova York. A estação do ano e o horário do dia também são utilizados como recursos que fortalecem a oposição entre um mundo ideal e o real: o mundo presente dos anos 60 está no inverno, no mês de novembro, indicado pela neve na janela e escuro pela noite, o mundo do passado está em julho, no verão e é retratado durante o dia.

De todo modo, seja a conclusão de que ele realmente morrera, dando um fim a sua existência, ou a de que ele passou a habitar a Zona Crepuscular que atendeu a e estimulou seu desejo de fuga da sua época, há uma clara observação no episódio de que o presente é problemático, desumanizador e repleto de pressões opressivas, com o mundo "se movendo rápido demais", competitivo, e que escapar ao passado, exposto como mais simples e adaptado às necessidades das pessoas, é um apelo irresistível. Por outro lado, o fato de Williams sucumbir à nostalgia se torna um exemplo dos perigos de se envolver com esse sentimento a ponto de perder o contato com o presente.

A aventura de Williams reforça a ideia de como a nostalgia deve ser alvo de uma reflexão crítica, reflexão esta que permite a Sloan, de Walking Distance, procurar

\footnotetext{
${ }^{49}$ Nos dois roteiros (4/1/1960 e 26/5/1960) lemos: [...] Mr. Gart Williams who might now tell us what awaits us in the beyond... because this too is a part of... The Twilight Zone!
} 
no seu presente uma melhoria das situações que o afligiam; já para Williams, que construiu uma vida muito enraizada nas propostas do mundo presente - se casar com uma mulher bonita , ser um executivo de sucesso em Manhattan, morar em uma casa de rico em uma cidade de elite (Westport, Connecticut), desenvolver uma úlcera (condição associada ao mundo dos executivos) -, seria apresentada a fuga suprema, até para não repetir o episódio Walking Distance, a vida na nostalgia restaurativa, em Willoughby, único lugar onde ele poderia ter uma vida plena, fora da vida em seu contexto histórico opressivo.

A esposa de Williams, Jane, aparenta ser uma alpinista social, a descrição dela no roteiro de Serling de 4 de janeiro de 1960 a caracteriza como "esposa gélida; ela Ihe deu a úlcera" (SERLING, 1960r3, p.1), incentivando-o a se adaptar ao mundo corporativo para seu próprio benefício material. Ela não tem empatia nem simpatia pelo seu marido, é um ser perdido em festas e bebidas, retratada como uma crítica ao que realmente se tornariam as mulheres em um ambiente no qual fosse seguida a ideologia vigente na época sobre o papel da mulher como restrita ao lar e cuidando da família; soma-se a isso a caracterização popular clichê da esposa fútil, troféu dos "bem sucedidos".

O presidente da empresa, Misrell, é um personagem abjeto, que inspira a antipatia por parte do público, retrato da face mais desprezível do capitalismo, o homem mesquinho que busca o lucro puro à custa do bem estar de todos e cujo mantra push, push, push ${ }^{50}$ (RUBIN, 2018, p.363) repetido a fim de fazer o espectador antagonizá-lo, é um dos elementos que mostram a desumanização do ambiente de trabalho, tema explorado por Serling em outros episódios da série e, de forma mais clara, no seu roteiro já citado de Patterns (1955). Push, Push, Push seria o mantra dos rumos de um mundo que destrói a humanidade e, que, por sua vez impulsiona a nostalgia, como movimento de reação legítimo. Williams e Misrell despertam emoções distintas no público, que deve escolher o lado de Williams.

Uma tríade do mal pode ser vista como responsável pela tentativa de fuga do presente: a esposa fria, materialista e alpinista social, o presidente da empresa mesquinho e prepotente e o próprio trabalho desumanizador e desonesto. Eram estes três elementos que mantinham Williams vivendo uma vida de aparências, sem ter

\footnotetext{
${ }^{50} \mathrm{Em}$ tradução livre: ter esforço, impulso e energia, indicando o trabalho árduo que ele espera de seus funcionários e uma direção de movimento
} 
acesso a sua própria essência livre de procurar algo que lhe agradasse, o que ele irá procurar - e encontrar- no passado nostálgico, como podemos observar, por exemplo, na descrição do próprio personagem sobre o que viu em Willoughby, "[...] a rua principal parecia... parecia uma pintura da Currier and Ives [empresa que imprimia pinturas e fazia litografias retratando elementos da vida dos EUA de meados do século XIX até início do XX] (SERLING, 1960 r2, p.17).

Figura 24 - Misrell (em pé a esquerda) é o símbolo das pressões modernas implacáveis no mundo do trabalho. Um dos motivos de Williams (em pé a direita) querer escapar do seu presente.

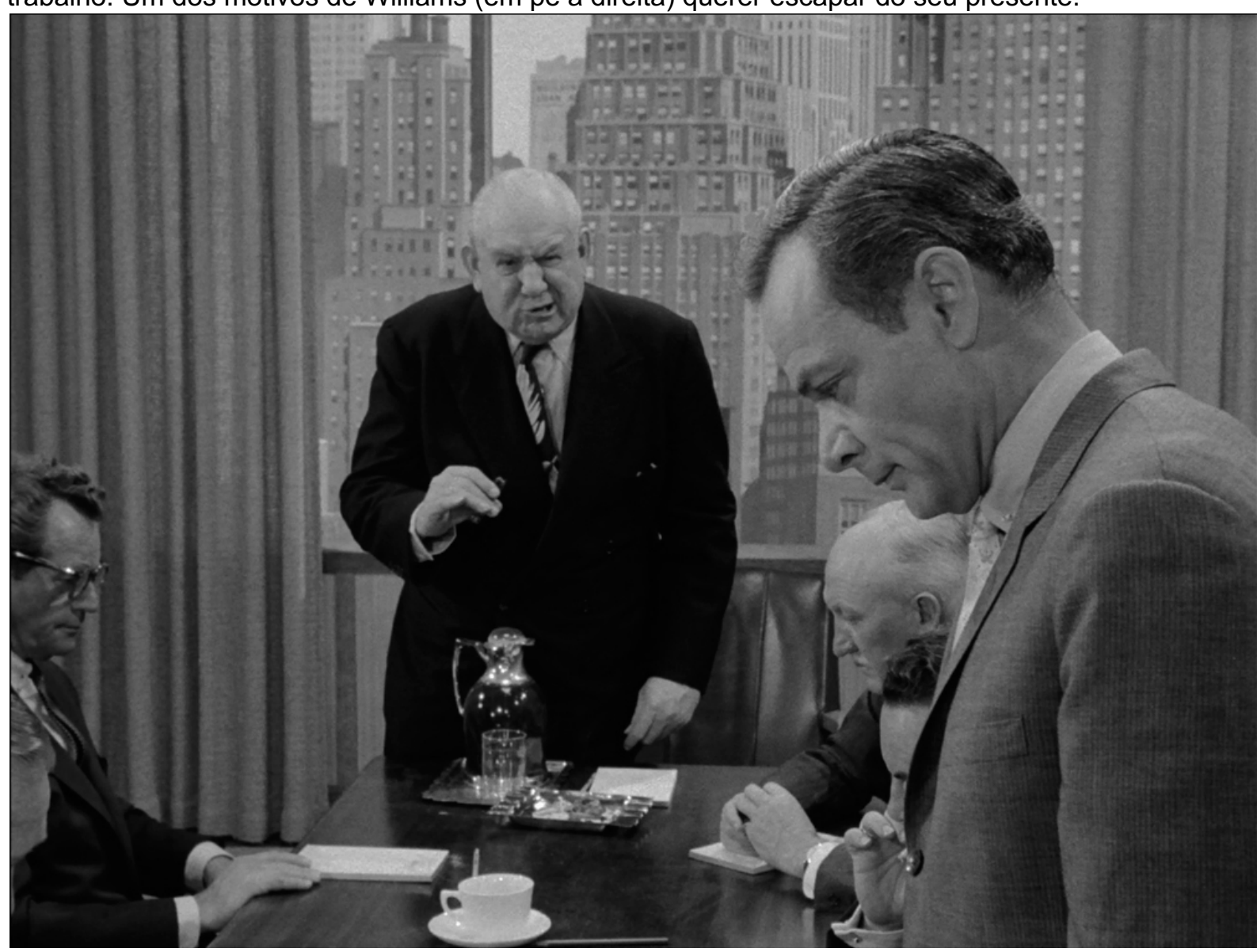

Fonte: elaborado pelo autor (Blu-ray, The Twilight Zone: The Complete Series, CBS, 2017)

Mesmo que a viagem no tempo seja sonho, o que indica que o passado experimentado é fruto de sua imaginação, o trem é utilizado como local onde a relação entre os tempos será explorada, não por acaso Williams acorda num vagão de madeira em um trem no passado. Cabe lembrar o símbolo do trem na cultura das sociedades industriais, desde sua origem, como elemento reificador dos valores da nova sociedade que nascia: aceleração, progresso e civilização, um símbolo do tempo como flecha. $O$ trem, as mudanças, que para muitos deveriam ser desaceleradas e/ou 
contidas, são impossíveis de serem controladas, como a conclusão do episódio demonstra de forma clara e irônica.

A narrativa nostálgica tinha mais apelo ao mundo adulto, novamente incorporando elementos autobiográficos de Rod Serling, complementados, assim como Walking Distance, por dados de sua vida. Percebe-se a inadequação que era sentida pelo autor no mundo competitivo da televisão e demais corporações do período. Serling, em carta datada de 9 de janeiro de 1961 (SERLING, 1961b, p.1), respondendo a uma carta de fã que afirmara que entendia o apelo de se querer escapar da vida e que até o autor devia sentir isso, disse que o fã estava correto em supor isso, pois o episódio retrataria um desejo enraizado e um desejo dele de retornar a uma serenidade que de alguma forma parecia que havia desaparecido. Para complementar, existe uma cidade de Willoughby, no estado de Ohio, que segundo Grams Jr. (2008, p.284) ficava no caminho que Serling realizava no início de sua carreira, quando vivia em Ohio e ia para Nova York; além disso, a própria rota de Williams apresentada no episódio, entre Nova York e Westport, era realizada por Serling quando ele produzia roteiros para televisão. Estes elementos autobiográficos, mesmo que desconhecidos do público, reforçam a conexão pessoal entre autor e obra.

Uma das razões da fuga de Williams para o passado idílico era exatamente não ser uma pessoa competitiva, capaz de passar por cima dos outros para conseguir o que desejava, exatamente o que seu mundo exigia. Cabe lembrar que quando somos apresentados ao personagem de 38 anos (no conto em livro publicado posteriormente a idade foi alterada para 41), ele acaba de ser usado e descartado por seu pupilo que o abandona e ainda leva a conta milionária da empresa de carros para outra agência, sendo advertido, posteriormente, por acreditar nas pessoas. Acreditar em valores como honestidade e gratidão tornaria qualquer pessoa não apta a ascender no mundo capitalista - estes valores só podem ser encontrados no passado idealizado, na fuga da velocidade das mudanças do segundo pós-guerra.

Novamente, somos apresentados a um passado superior ao presente, mais calmo, mais humano, com as pessoas recebendo-o pelo nome, com banda tocando no coreto, crianças voltando da pescaria (o roteiro as chama de Garoto Um - Tom Sawyer e Garoto Dois - Huck Finn, em referência aos personagens de Mark Twain), um local com clima de paz, amizade, acolhimento e serenidade. Quando William sai do vagão e desce finalmente em Willoughby, a nostalgia é reforçada pelos sons do 
passado: em um coreto uma banda toca "Oh! Susanna" e, assim que o homem começa a se deslocar pela pequena cidade, a banda passa a tocar "Beautiful Dreamer", ambas músicas tradicionais americanas compostas por Stephen Foster no século XIX. Elas realçam a força do ambiente tradicional idealizado do passado dos EUA e a última música realça também o caráter de Willoughby ser um sonho.

Figura 25 - Em Willoughby, no passado idealizado, Williams pode viver plenamente.

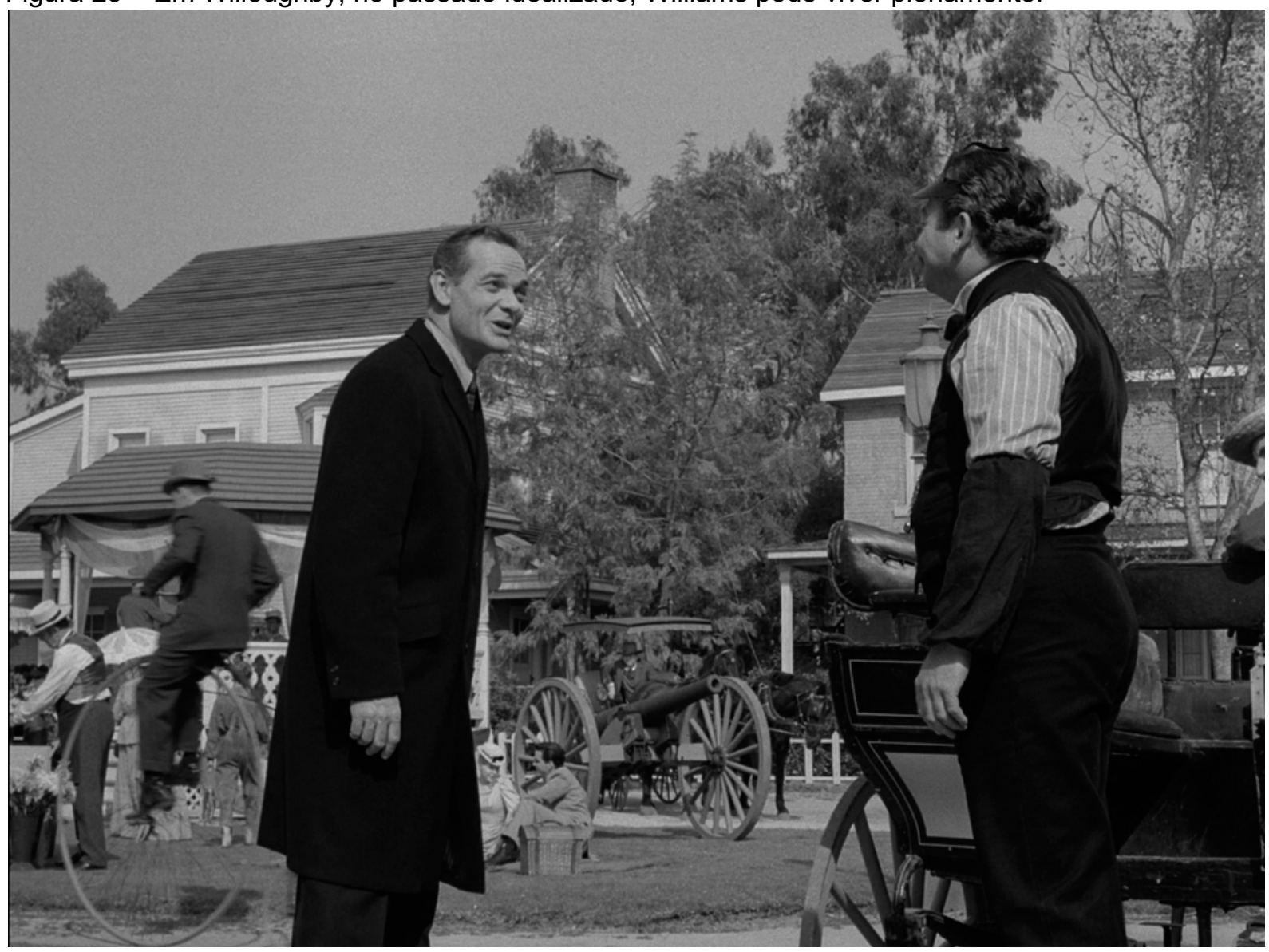

Fonte: elaborado pelo autor (Blu-ray, The Twilight Zone: The Complete Series, CBS, 2017)

O reforço da ideia de superioridade do passado apresentado, mesmo que inalcançável para o público, está presente por todo episódio, por vezes em detalhes como o fato de no presente, visto por dentro do trem, o mundo lá fora ser escuro e frio, com neve batendo na janela e Williams, antes de cochilar, fecha a cortina da janela do presente; ao acordar no passado, abre-a, com a escuridão e a neve substituídas por raios de luz.

Esse episódio não explora nenhuma questão da formação de paradoxos possíveis pela presença do homem no passado, nem escolhe explicar se o passado a que assistimos faz parte do sonho de um homem bom demais para o mundo onde 
está inserido, se realmente ele viajou ao passado, ou mesmo se ficou em algum paraíso do desejo criado como recompensa por sua humanidade pela Zona Crepuscular, uma forma de crítica da série às pessoas do mundo corporativo. No roteiro de 4/1/1960, havia a indicação de quando ele estivesse no trem e cochilasse, algum som parecido com o eco da movimentação de um trem dentro de um túnel fosse se tornando mais claro para o público, culminando com o personagem acordando no vagão antigo no passado, dando o efeito de viagem no tempo, o que no episódio não foi realizado, mas sim inserida uma música que instiga a curiosidade.

A inserção de $A$ Stop at Willoughby como história de viagem no tempo pode ser justificada pela relação entre presente (crítica) e passado (idealizado/nostálgico) por que passa o personagem e a qual somos obrigados a realizar com a depuração/reflexão. São dois tempos em velocidades diferentes, ligados pelo trem, sem uma perspectiva de destino positiva. Não é à toa que Serling afirma na narração inicial (ele ainda não aparecia para fazer a introdução dos episódios fisicamente) que Williams estava em uma busca desesperada por sobrevivência. Em uma relação paradoxal, a sobrevivência seria a morte, a morte do presente e o retorno de alguma forma de passado, que o episódio reconhece ser impossível, concluindo a história de Williams em tom de lamentação, com a imagem sobreposta da pequena e calma cidade com o letreiro do carro funerário.

Por meio das cartas enviadas a Rod Serling, pode-se perceber o impacto que esse episódio teve com o público, inclusive Serling afirmou que era um dos melhores da série até então (SERLING, 1961a, p.1) e houve mesmo quem gostaria não só de viver em um lugar como Willoughby mas que fosse feita uma continuação, apresentando a vida de Williams no passado (ALSUP, [1961?], p.1).

Portanto, ele teria viajado não diretamente para o passado histórico, mas sim para uma idealização nostálgica criada em sua mente, um sonho de um lugar melhor onde todos o conhecem pelo nome, o que provaria que o lugar não seria real (ZICREE, 1992, p.118). Nesse episódio, o sonho de fuga para um lugar melhor parte de uma perspectiva criada pela cultura histórica, reforçada no episódio. A própria preocupação em colocar um ano preciso e a localização do sonho de fuga em um lugar no passado mostram como aquele mundo não existiria mais no segundo pós-guerra, mas faria parte da experiência histórica da sociedade americana. De certa forma, Willoughby é o sonho de um retorno último ao paraíso perdido, gerado pela impossibilidade da felicidade e da realização humana plena no presente e futuro, pois é a falta de 
perspectivas de mudanças positivas no mundo competitivo do capitalismo e sua propagada "aceleração" que levam Williams a buscar alento na nostalgia - chegando às últimas consequências. $\mathrm{O}$ apelo da mensagem desse episódio junto ao público demonstra a percepção das perspectivas de futuro de parte da sociedade americana e a rejeição ao mundo e a vida cotidiana.

\subsection{3- The Trouble With Templeton}

Na segunda temporada de Além da Imaginação, o tema da aceitação do presente pelo uso da viagem no tempo, nos moldes de Walking Distance, é retomado no episódio The Trouble With Templeton, exibido em 09 de dezembro de 1960, 9 episódio da segunda temporada e $45^{\circ}$ da série. A história do velho ator que deve aprender a conviver com as mudanças do presente, no mundo e em sua carreira, aceitar as perdas da vida e as chances perdidas no passado foi drigida por Buzz Kulik, estrelada por Brian Aherne e Pippa Scott. Os custos totais de produção foram de USD $\$ 50.183,23$ e a filmagem foi realizada em outubro de 1960 (GRAMS JUNIOR, 2008, p.342; ZICREE, 1992, p.169).

O velho ator teatral Booth Templeton não se adequa ao presente, sente-se inútil e ultrapassado, mesmo o seu trabalho não o incentiva mais. Booth sente saudade da década de 20, principalmente de sua falecida esposa Laura, mulher que tanto amava. Ao chegar atrasado ao primeiro ensaio da nova peça da qual iria participar, leva uma bronca do jovem e promissor diretor, que não teria considerado sua história. Este fato reforça seu sentimento de inadequação ao presente e ao tentar sair do teatro, é transportado para 1927. Indo procurar Laura, vai a um bar/restaurante onde a encontra, junto com amigos, todos já falecidos no tempo original de Booth. Laura, ao contrário do que lembrava, o trata muito mal: ela o despreza e não lhe dá atenção, seus modos são rudes, bem distintos do que afirmava sua memória afetiva. Desanimado com a experiência, retorna para o teatro e se vê novamente no presente, porém, ao observar com atenção um maço de papeis que pegara de Laura no passado, vê que na verdade era um roteiro de teatro informando o que deveria ser feito quando Booth aparecesse no passado. Ou seja, ele deveria ser tratado mal e expulso do passado para ensiná-lo a aprender a aceitar as mudanças. Agora animado e feliz por fazer parte do elenco de uma nova peça de teatro, Templeton passa a ver 
a vida de uma forma positiva e não se sente mais um inútil perante o mundo, nem deixa a saudade do passado dominá-lo.

O roteiro desse episódio, não é de Rod Serling, porém, a temática se adequa perfeitamente ao tema da nostalgia representado na série, reforçado pela presença da viagem no tempo, que amplia a relação da experiência individual do personagem com sua história de vida e elementos das mudanças mais amplas no mundo dadas pela relação entre passado e presente.

Foi E. Jack Neuman o roteirista de The Trouble with Templeton. Este autor na época havia escrito uma série de roteiros para diversos programas de televisão e enviou uma sinopse de enredo, em maio de 1960, chamada What Do You Hear?, sendo, então, contratado para fazer o roteiro do episódio, que até a véspera da filmagem se chamava originalmente The Strange Debout (NEUMAN, 1960; GRAMS JUNIOR, 2008, p. 345). Neuman era um amigo do produtor Buck Houghton (ZICREE, 1992, p. 170) e esta foi sua única contribuição para Além da Imaginação. O pesquisador Martin Grams Jr. (2008, p.344) nota que este episódio, ao apresentar um teatro com o mesmo nome do teatro que aparece no episódio piloto, Savoy Theatre, fato complementado pela recorrência de intervenções similares em outros programas da série, seria um indicativo de que Rod Serling pode ter realizado revisões em roteiros de outros autores, o que nesse caso não seria de se estranhar, pois o episódio era de claro apelo para Serling e parece ser um roteiro dele próprio, com um enredo e um tipo de mensagem que o acompanhou por toda a sua carreira de roteirista, como a tentativa de recuperar uma vida individual ou coletiva que não existia mais no presente, utilizando a viagem no tempo para criticar essa temporalidade e controlar os impulsos nostálgicos, atendendo parcialmente a seu apelo, para por fim colocá-lo sob guarda da perspectiva progressista da nostalgia reflexiva.

O roteirista E. Jack Neuman afirmou sobre o roteiro que ele "havia geralmente brincado com a noção de que 'Você não pode voltar para casa', o que na verdade deveria ser, 'Você não deve voltar para casa, nunca'” (ZICREE, 1992, p.170). Enquanto a primeira frase ao enfatizar o "não pode", implica apenas a aceitação da mudança e irreversibilidade, a segunda noção de "não deve-nunca", explorada no episódio, reforça a crítica aos sentimentos nostálgicos e à saudade que limita a aceitação das condições presentes. Como podemos presenciar essa ideia no episódio de forma didática, o passado expulsa o viajante no tempo pois sabe que aquele lugar 
e tempo não mais lhe pertencem, porém se sente mal por isso, pois entende o apelo que o passado nostálgico apresenta nas sociedades modernas.

O diretor da peça na qual Booth trabalhava era Arthur Willis, um jovem talento, arrogante e prepotente, trazido pelos patrocinadores em substituição ao antigo diretor antes do primeiro dia de ensaio, pois geraria mais lucros. Esse elemento inicial, posteriormente relativizado pelo próprio episódio, passa uma primeira impressão de que o presente é um local desumano e cada vez mais baseado na concorrência. $A$ própria contratação do diretor é expressa, inclusive em diálogos, com o sucesso da novidade, da energia e da vitalidade. Quando questionado pelo diretor se ele estava pronto para trabalhar junto com todos, respeitando suas ordens, Templeton sai correndo e ao deixar o teatro pela porta dos bastidores, que dá na rua, se encontra no passado, em 1927.

Figura 26 - Laura se abana com o roteiro de como as pessoas do passado deveriam se comportar quando Templeton retornasse para os anos 20 . Um surpreso Templeton não sabia que estava sendo desprezado por todos no passado por algo combinado.

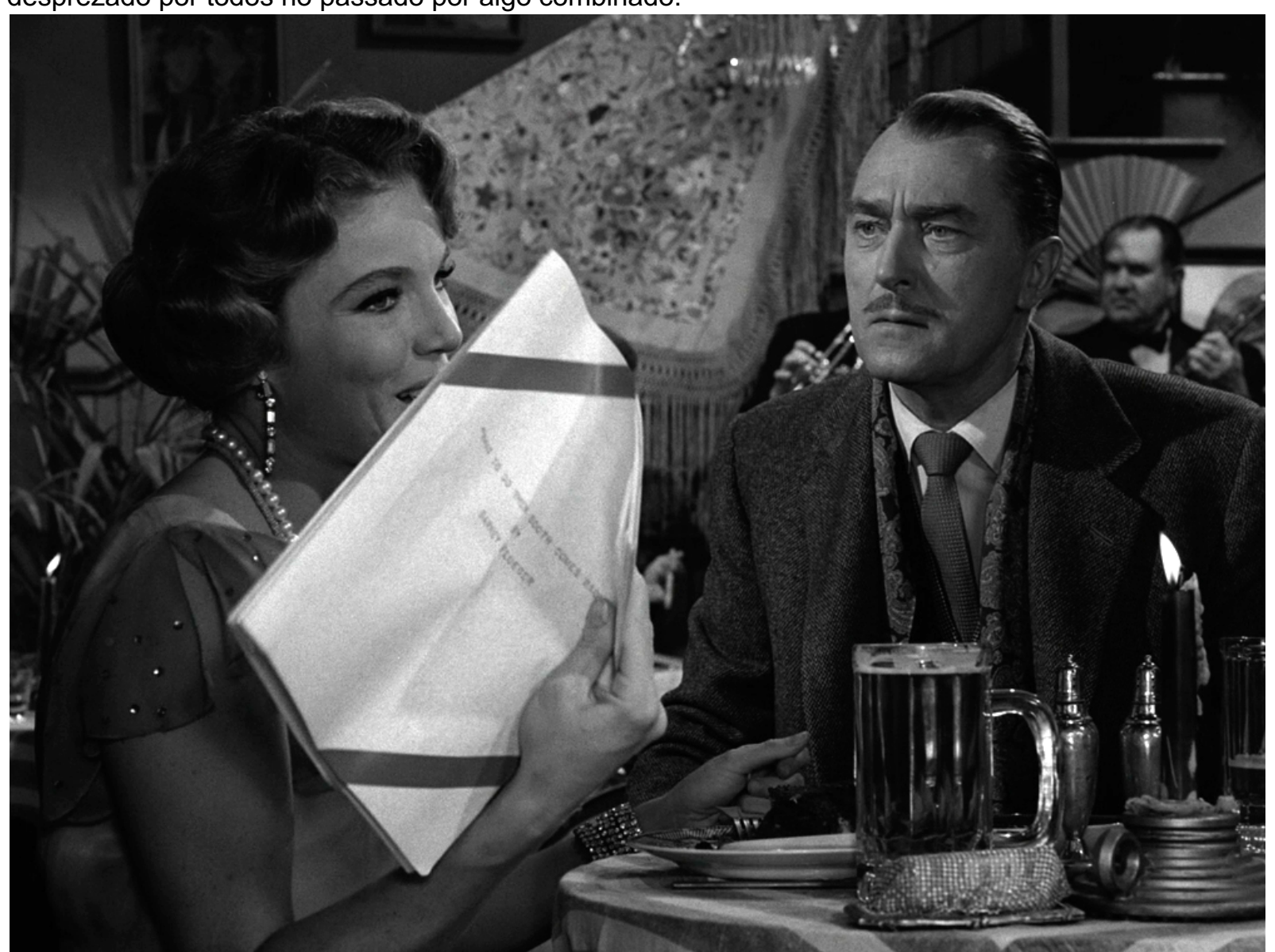

Fonte: elaborado pelo autor (Blu-ray, The Twilight Zone: The Complete Series, CBS, 2017) 
O próprio prédio do teatro serve como máquina do tempo neste episódio. É o atravessar a porta que indica o rumo da viagem, transformando a noção de se abrir a porta para o passado,- ou seja, de se ponderar sobre as experiências da vida e as relações entre passado (quem fomos), e presente (quem somos agora)-, em uma manifestação literal. Esses elementos fazem sentido ao se considerar o teatro como um símbolo para a vida do personagem principal, que não só é um ator, mas indica que sua passagem pela existência foi de atuação, muito além do plano profissional. Seu retorno ao passado o faz ganhar consciência de quem ele é e o que deveria fazer; portanto, é óbvio que se o teatro é a vida do personagem, as portas dão acesso aos diversos momentos experimentados por Templeton.

Em um mundo orientado para o progresso, o velho é sempre descartável e um empecilho, o que este episódio tenta conciliar por meio do reconhecimento e aceitação final do ator Templeton para seu atual momento no teatro da vida, agora com confiança renovada para não aceitar imposições, fazendo o diretor e o patrocinador reconhecerem seu valor e respeitarem-no. A viagem no tempo cumpre o papel de demonstrar que o local da vida do viajante, no caso nostálgico, é o presente.

O passado para onde Booth Templeton vai parar é o da década de vinte, nos EUA do período da "lei seca" (Prohibition), período entre 1920-1933 onde o processo de fabricação, transporte, importação e comercialização de bebidas alcoólicas foi proibido em nível federal nos EUA. A trama se passa em um speakeasy (bares escondidos ilegais que vendiam bebidas alcoólicas), reforçando a representação da cultura histórica desse contexto como um período alegre, pré-Crise de 1929. Essa oposição entre passado alegre e presente problemático é enfatizada no episódio a fim de que o personagem fique em paz com o presente e o aceite. No passado, em 1927, Templeton se encontra com seu melhor amigo e sua esposa, ambos vivos, o local do bar/restaurante secreto está esfumaçado, reforçando, por vezes, a noção de que estamos vendo fantasmas. Os próprios entes passados utilizam a atuação - cabe lembrar que ao retornar ao presente, o velho ator vê em seu bolso o roteiro que as pessoas do passado estavam seguindo- para fazê-lo aceitar que as coisas mudam, rejeitando seus ímpetos de fuga. Novamente, nos deparamos com a crítica da nostalgia restaurativa proporcionada pela viagem no tempo, pois ele não pode viver no passado. A atuação das pessoas no passado, especialmente sua esposa e seu melhor amigo, cumpre a mesma função do diálogo entre pai e filho em Walking Distance, o flerte com o passado deve servir para alterar o que é realizado no 
presente. Assim como Sloan naquele episódio deveria procurar os algodões doces e carrosséis no presente, Templeton deveria procurar se portar como alguém de sua idade e experiência, encontrando satisfação no presente.

Como Serling afirma na narração do episódio, Booth Templeton se encontrava descontente e desejoso de reviver o passado. Nesse episódio, a Zona Crepuscular se localiza no passado e a viagem no tempo experimentada por Templeton serve como terapia para ele aceitar a mudança e se adequar a seu presente. Ao contrário de Williams em Willoughby, ele não morre no final, retratando a impossibilidade de um retorno a um mundo sem mudanças, mas sim, ganha consciência da irreversibilidade do tempo e de que deve renovar sua experiência e ver o presente de forma positiva.

Portanto, de forma similar à proposta de Walking Distance, o passado é um local de reflexão e acerto de contas - e em ambos episódios, aprendemos que o protagonista não é bem-vindo no passado. Os impulsos nostálgicos de Templeton pela década de 20, à primeira vista alegre e na qual ele tinha amigos e companheira, são rejeitados em um plano pensado do passado para fazê-lo aceitar o presente e começar uma nova fase em sua vida, ou seja, ele deve observar/experimentar o que já passou a fim de mudar para viver no presente e não continuar lamentando as perdas trazidas no tempo ou mesmo ficar vivendo para sempre em um passado nostálgico, como Williams de A Stop at Willoughby.

Esse episódio também propõe uma visão poética da função social das artes: é a atuação da sua esposa e de seu amigo, por mais dolorida que possa ser para Booth Templeton, que o faz ganhar consciência. É prova disso, o fato dele descobrir posteriormente que o desprezo de sua amada e a falta de simpatia ou empatia de seu melhor amigo faziam parte apenas de um plano maior da Zona Crepuscular para devolvê-lo ao presente renovado. É por meio do que é fornecido pelas artes, como sentimentos, experiências e a reflexão sobre eles, que aprenderíamos a viver melhor e a ganhar consciência de nosso lugar no mundo.

\subsection{4- Static}

O uso da viagem no tempo para reforçar a noção de nostalgia restaurativa, o único caso na série, aparecia no episódio Static, filmado no começo do ano de 1961 em 10 de março, foi o $56^{\circ}$ episódio do programa e $20^{\circ}$ na segunda temporada da série. Com custo total de USD\$36.286,66 (GRAMS JUNIOR, 2008, p. 379), o programa foi 
dirigido por Buzz Kulik e estrelado por Dean Jagger e Carmen Mathews. Este é um dos seis episódios realizados em videoteipe com a intenção de reduzir os custos da série, utilizando os estúdios da própria CBS em Los Angeles e não filmado na MGM.

Ed Lindsay é um idoso que mora em uma pensão, sentindo uma saudade incontrolável do passado, sentimento canalizado para a época em que o rádio reinava triunfante como mídia mais importante. Lindsay tem total desprezo pela televisão, nova mídia que ocupou o lugar do rádio. Movimentado pela nostalgia, enquanto os demais habitantes da pensão se entretêm com a televisão, ele se tranca no quarto e se ocupa em ouvir seu antigo rádio. Para seu divertimento, o rádio começa a transmitir programas antigos, diretamente do passado, porém, quando Ed chama alguém para ouvir com ele, o rádio só transmite estática. Vinnie Brown, a ex-namorada de Lindsay que morava na mesma pensão, com a qual ele não se casou quando mais jovem, começa a se preocupar com a saúde mental do homem e, para tentar ajudá-lo, manda o rádio embora sem que ele saiba. Desconsolado, Lindsay vai atrás do rádio e o recupera do lixo, reinstalando-o em seu quarto. Ao ligar o rádio, Ed e Vinnie são transportados ao passado, agora rejuvenescidos e, ao som do rádio, ganham ambos a chance de um recomeço.

O episódio Static foi adaptado por Charles Beaumont de um conto não publicado de seu amigo Oceo Ritch com mudanças significativas (ZICREE, 1992, p.184). Ritch participaria mais uma vez da série de forma não oficial, sendo o ghostwriter do episódio Dead Man's Shoes (1962), assinado oficialmente por Charles Beaumont no período de doença desse escritor.

O tema da nostalgia não era estranho a Beaumont, segundo dados obtidos pela leitura do livro de Marc Zicree (1992, p.185); ele escreveu um livro de ensaios relacionados diretamente ao pensamento nostálgico, em grande parte recolhidos de textos publicados anteriormente na revista Playboy; o livro de título sugestivo Remember? Remember? (em tradução livre: Você se lembra?), foi publicado em 1963. Em um dos ensaios presentes nessa obra, Beaumont comentava sobre a importância do rádio na cultura americana pré-televisiva e como era difícil alguém explicar isso para quem não teve contato com ela (BEAUMONT apud ZICREE, 1992, p.185). Essa nostalgia da era do rádio e uma vida vista como aberta a oportunidades perdidas permeia todo o episódio, concluindo com a viagem no tempo do nostálgico, pois apenas indo para o passado, Ed Lindsay poderia seguir por um caminho na vida que, por medo e receio, não seguiu. Não haveria mais espaço no mundo para os 
sentimentos românticos gerados no contexto histórico do rádio, no presente e no futuro.

Utilizando um objeto nostálgico, o rádio, artefato capaz de trazer saudade aos que o utilizavam devido a sua substituição pela televisão como forma de mídia mais popular e significativa, esse episódio irá apresentar uma viagem no tempo no final do episódio para marcar a força da nostalgia restaurativa trazida ao se escutar essa mídia. Como a nostalgia se manifesta pelos sentidos, a audição do passado seria capaz de fazer aflorar sensações que não podem ser mais experimentadas, não têm mais lugar, e tampouco retornarão com o mesmo peso social em uma perspectiva futura de domínio do audiovisual (televisão) sobre o auditivo (rádio).

Ao contrário de todos episódios nostálgicos de viagem no tempo, nenhum dano é causado ao sonhador nostálgico, que tem sua experiência com a Zona Crepuscular recompensada no final. Esse é o único caso na série em que a viagem no tempo é utilizada de forma a alimentar a nostalgia restaurativa, dentro da perspectiva de que, para os idosos em um mundo em constante transformações rápidas, seria injusto ou até cruel rejeitar os ímpetos de arrependimento por caminhos da vida não percorridos. $\mathrm{Na}$ série, a nostalgia restaurativa, desde que realizada pelos idosos, contrabalancearia o problema dos idosos em um mundo orientado para as mudanças, que despreza os entes mais antigos, relegando-os a casas de repouso ou os infantilizando, algo que era corrente na sociedade americana do período (MELBYE, 2016, I.4539). Outros episódios, como The Sixteen-Millimeter Shrine (1959) e Kick the Can (1962), também recompensam os nostálgicos, porém sem utilizar o artifício da viagem no tempo, uma forma geralmente usada para enfatizar uma reflexão sobre o presente e seus rumos.

Além disso, o episódio tem como subtexto a crítica ao que era produzido na televisão. Serling, reiteradamente, em sua carreira, foi um crítico da maior parte da produção dessa mídia e falava abertamente sobre os problemas que notava na programação televisiva, tanto em entrevistas, como a já citada no programa The Mike Wallace Interview, como por meio de suas obras artísticas. Também era corrente nos meios intelectualizados do período, inclusive visão de Estado, que a televisão emburrecia as massas. Essa crítica está exposta claramente nesse episódio, que já começa, de forma nada sutil, criticando a mídia, exibindo as pessoas que moram numa pensão, alienadas assistindo, a um western na televisão e depois ao comercial de um cigarro de clorofila que não tem cheiro ruim, seguido por uma série de 
programas apresentados como bobos. O episódio apresenta uma reflexão sobre os EUA do início da década de 60, onde os supostos sentimentos humanos trazidos pelo rádio, são substituídos pela televisão, preocupada somente com o lucro, imbecilizando a sociedade.

Obviamente, o rádio era explorado comercialmente nos EUA e é passível de ser inserido na mesma crítica que é feita a televisão, mas é característica do próprio pensamento nostálgico idealizar os elos de ligação com um passado também idealizado, imaginado como sem conflitos e positivo, oposto à decadência que seria trazida pelas mudanças. A presença de discursos como o apresentado em Static é outro exemplo que demonstra o quão nostálgico foi esse contexto, em reação direta às ideias de progresso circulantes na época.

O personagem principal de Static prefere o rádio devido à baixa qualidade que nota na televisão. O retorno ao passado nostálgico, o ponto de inflexão que poderia fazê-lo se casar com o amor de sua vida - não ter se casado é uma dor que carrega - é também a busca de uma mídia de maior qualidade, ou seja, o passado é utilizado como forma de crítica ao presente, com a intenção de que a televisão tivesse uma melhor programação.

Figura 27- A nostalgia pode se manifestar pelo acesso a artefatos do passado. O velho rádio de Ed começa a receber transmissões diretamente do passado objeto de desejo do homem idoso.



Fonte: elaborado pelo autor (Blu-ray, The Twilight Zone: The Complete Series, CBS, 2017)

O retorno ao passado do Ed Lindsay para 1940 também é emblemático: uma volta ao mundo anterior à participação dos EUA na Segunda Guerra Mundial tem a ver com a rejeição óbvia do mundo oriundo do pós-guerra, a idealização de um período não comumente visto como local nostálgico por excelência é justificada pelo amor perdido, a busca de uma segunda chance na vida e pela relação afetuosa com 
o rádio. Static não explora o mundo do passado, em oposição aos demais episódios nostálgicos nos quais o ambiente do passado é apresentado com mais detalhes, porém pode-se ver que o espaço da pensão no passado é melhor, mais novo e claro, em oposição ao presente escuro e gasto, em uma clara mensagem que reforça a nostalgia restaurativa realizada pela viagem no tempo.

O episódio induz o espectador a imaginar que Ed seguiu um outro rumo em sua vida, longe de se manter um solteiro vivendo em uma pensão. Ao voltar ao passado, ele rejuvenesce e pôde criar um novo futuro para si, casando-se com o amor de sua vida. Essa conclusão é reforçada pela narração final de Serling, na qual afirma que "tudo que Ed Lindsay sabia é que ele desesperadamente queria uma segunda chance e ele finalmente a conseguiu, por uma estranha e maravilhosa máquina do tempo chamada rádio, na Zona Crepuscular" (tradução nossa) ${ }^{51}$.

Deve-se considerar também que sua implicância com o presente se dava, em parte, por ser solteiro, em uma clara mensagem conservadora, em um contexto histórico no qual é esperado que homens e mulheres se casem e formem famílias nucleares, com papéis bem definidos, tema que seria explorado com mais força em outro episódio nostálgico de viagem no tempo na quarta temporada, o próximo a ser discutido neste capítulo.

Tanto o conto não publicado de Oceo Ritch quanto o episódio estabelecem uma conexão com um conto de Jack Finney de dez anos antes: I'm Scared, publicado na revista Collier's em 15 de setembro de 1951. Enquanto a obra de Finney é crítica à nostalgia, revelando as reflexões de um personagem que ouve no rádio programação oriunda do passado, em uma resposta mágica do universo aos ímpetos nostálgicos da sociedade (que por estar cada vez mais nostálgica iria causar a destruição do próprio tempo), o episódio procura outro caminho para abordar a nostalgia. Esse conto apresentava uma visão crítica da nostalgia, o que não era o padrão das demais obras de Finney, que costumavam valorizar e recompensar os personagens nostálgicos, dando-Ihes uma viagem ao passado, na perspectiva da nostalgia restaurativa, no qual o passado era sempre superior ao presente. Porém, no conto citado, não há uma viagem no tempo, apenas o rádio que estimula a nostalgia até o personagem se dar conta dos problemas desse sentimento. Já na série, a nostalgia é recompensada.

\footnotetext{
${ }^{51}$ No original: "[...]All Ed Lindsay knows is that he desperately wanted a second chance and he finally got it, through a strange and wonderful time machine called a radio, in the Twilight Zone."
} 
Cabe destacar que Rod Serling estava familiarizado com a produção de Jack Finney, inclusive havia tentado adquirir o direito de contos de viagem no tempo nostálgicas para adaptar para Além da Imaginação, e desistido devido aos valores que Jack Finney teria pedido. Segundo Grams Jr. (2008, p.381), dias depois do episódio ir ao ar, um homem teria acusado o episódio de ser um plágio de uma história sua, mas a reclamação foi rejeitada e não foi adiante.

A ideia do uso da tecnologia como entidade capaz de captar elementos do passado, de forma sobrenatural, faz parte do desenvolvimento das tecnologias de comunicação desde o século XIX. Portanto, o episódio é parte de uma longa tradição ocidental de "mídia assombrada", que incorporou elementos religiosos, de folclore e lendas urbanas no desenvolvimento das tecnologias de mídia e suas relações com as sociedades, como demonstrado pelo historiador Jeffrey Sconce em seu livro Haunted Media: Electronic Presence from Telegraphy to Television (2000).

Outra referência que cabe ser citada é a pesquisa de Serling sobre os programas de rádio que poderiam ser ouvidos durante o episódio (GRAMS JUNIOR, 2008, p.381). Ele tinha grande conhecimento do mundo do rádio e seus primeiros trabalhos de roteirista foram nessa mídia, demonstrando que mesmo o roteiro tendo sido escrito por seu amigo Beaumont, o episódio ressoava de forma pessoal para Rod Serling, alimentando uma nostalgia restaurativa que ele, em suas obras, procurava reprimir e criticar.

Esse episódio expressa literalmente a noção do rádio como uma máquina do tempo, ampliada pelo fato de ser capaz de inclusive retirar a idade do nostálgico. Há a dimensão revelada do poder da mídia de levar sentimentos e sensações de outras épocas para um público presente, operando nas formas que as sociedades estabelecem para se relacionar com o tempo. Assim como a metáfora da televisão como uma "janela para o mundo", a mídia em geral também cumpriria o papel de uma "janela para o passado", obviamente com essa janela se abrindo para diversas cenas, criadas através das intenções humanas.

\subsection{5- The Incredible World of Horace Ford}

O último episódio que retrata alguma forma de viagem no tempo nostálgica apareceu na quarta temporada, também criticando a nostalgia em sua perspectiva restaurativa. The Incredible World of Horace Ford foi o $15^{\circ}$ episódio exibido para essa 
temporada singular e $117^{\circ}$ na série, levado ao ar em 18 de abril de 1963 . O roteiro é de Reginald Rose, roteirista de televisão respeitado por Serling - em 1962, ele chegou mesmo a provocar Serling para que ele se "distanciasse de ficção científica e retornasse a suas raízes dramáticas (GRAMS JUNIOR, 2008, p.591)-, incorpora muitos elementos explorados na série como a viagem nostálgica ao passado. $O$ programa, dirigido por Abner Biberman e estrelado por Par Hingle, Nan Martin e Ruth White, foi filmado no mês de setembro de 1962 e custou USD\$100.210,34 (Ibid., p.589; ZICREE, 1992, p.336).

Horace Ford é um designer de brinquedos infantilizado, que vive recordando com carinho sua infância. Desgostoso com seu chefe e com as obrigações do mundo adulto, inclusive matrimoniais, ele resolve ir até à rua do bairro pobre onde crescera. Chegando lá, percebe que foi parar no passado, revendo com outro olhar seu ambiente infantil e seus supostos amigos. Na rua do passado, acaba perdendo seu relógio antes de retornar para casa no presente e um colega de infância o segue e devolve o relógio para sua esposa. Ford repetidamente faz o mesmo caminho por várias noites e os mesmos fatos se repetem, ele sempre voltava para o mesmo momento e perdia o relógio, que era devolvido para sua esposa, em casa, por uma criança de vestes antiquadas. O desgosto de Ford com sua vida afeta seu trabalho, deixando-o irritadiço e ele, por fim, acaba sendo demitido no dia de seu aniversário. Sem perspectivas e sem saber da festa surpresa de aniversário que sua esposa havia organizado, Ford retorna para a sua antiga rua, novamente indo para o passado, porém, dessa vez ele fica mais tempo e percebe de forma dolorosa como suas memórias da infância eram falsas: ele, na verdade, sofria na mão de crianças mais velhas maldosas. Na sua casa do presente, sua esposa e seus amigos o esperam quando bate à porta a mesma estranha criança, que devolve um relógio infantil à mulher; ela imediatamente percebe que algo de muito grave estava se passando e sai em busca de seu esposo, resgatando-o do passado.

O roteiro foi comprado de Reginald Rose pelo produtor de parte significativa da quarta temporada, Herbert Hirschman (ZICREE, 1992, p. 338). O programa The Incredible World of Horace Ford era uma refilmagem do roteiro de Reginald Rose, apresentado previamente em 1955 no programa Studio One (Ibid., p.337); na versão original o final era distinto : Horace se torna uma criança e apanha dos seus pares infantis do passado, não retornando nunca mais para o presente. O fato de sua esposa, Laura, receber somente um relógio do Mickey Mouse no lugar do relógio 
regular de bolso do marido é uma clara alusão a que o homem ficou preso na infância para sempre, longe de poder ser resgatado. Uma dura lição para quem rejeita crescer no contexto dos anos cinquenta dos EUA. Já a versão da história para Além da Imaginação apresentou um final positivo para o personagem, por exigência de Hirschman (Ibid., p. 338) ${ }^{52}$, que não considerava a proposta original como totalmente dentro da proposta de Além da Imaginação (GRAMS JUNIOR, 2008, p.593), inclusive criticando o fato do elemento de fantasia - o relógio sendo levado para a esposa destruir o que para ele era uma história que apresentava uma "clássica descrição da esquizofrenia" (HIRSCHMAN, 1962a, p.2).

Horace Ford trabalha em uma empresa de brinquedos fazendo projetos de novos produtos como se estivesse construíndo para ele próprio brincar. Ele não consegue deixar sua infância no passado, romantizando-a, vendo como o melhor momento de sua vida e desejoso a todo custo de viver como se criança fosse, inclusive se comportando como uma criança birrenta no trabalho e em casa. Ford se rebela contra as mudanças e responsabilidades esperadas de um adulto no mundo do segundo pós-guerra americano: trabalhar duramente e sustentar a família.

Ele é casado e mora com a mãe, algo que no contexto histórico e social da série é outra indicação do episódio que estamos vendo uma criança adulta. Sua mãe cozinha para o casal e reforça seu comportamento infantil, mesmo com Horace Ford prestes a completar 38 anos de idade. Tudo que acontece em sua vida presente é sempre comparado com lembranças da infância brincando com colegas na rua e recordações escolares. É esse passado que a todo momento é chamado para dar sentido às situações que Horace Ford deve enfrentar em sua vida adulta, para teste de paciência das pessoas que convivem com ele, principalmente sua esposa, seu amigo e seu chefe no escritório.

Ele sente saudades de ter 10 anos de idade, uma "época maravilhosa", segundo o próprio personagem. Sua nostalgia é focada nas experiências de quando vivia na rua Randolph, uma região paupérrima na época de sua infância, colorida pelo olhar nostálgico. Um passado pobre e miserável, visto nostalgicamente, em um presente muito melhor não valorizado, sem perspectiva de futuro para Horace, pois ele está preso nas recordações.

\footnotetext{
${ }^{52}$ Como curiosidade, cabe destacar que Reginal Rose preferia o final original, opinião expressa em entrevista a Marc Zicree (In: ZICREE, 1992, p.338).
} 
O episódio mostra que o comportamento de Horace Ford não tem relação direta com as pressões do seu trabalho: seu chefe é extremamente compreensivo e todos gostam dele, como indicado pelos amigos presentes na festa surpresa. Seu problema é mais profundo, ele está preso na infância e não consegue sair, seu sentimento nostálgico é alimentado cada vez mais no contato recorrente com o passado na rua Randolph. A relação "passado infantil desejado" e "presente adulto de inadequação" se intensifica cada vez mais, provocando acessos de raiva e reforçando sua alienação autoinfligida.

Figura 28 - Horace Ford é apresentado como um palerma típico, restringindo a identificação do público com o personagem, ao contrário dos demais protagonistas de viagem ao passado nostálgico.

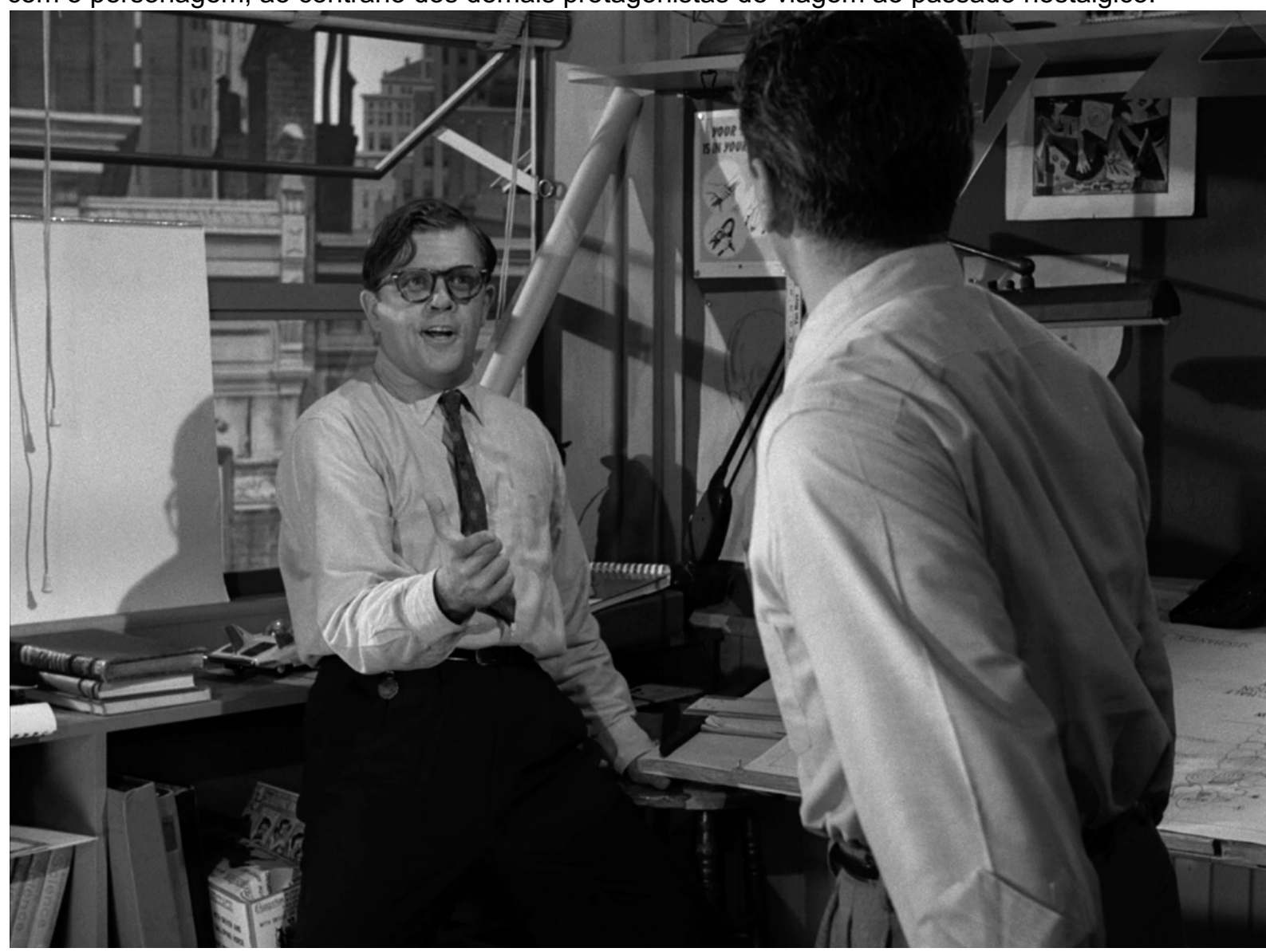

Fonte: elaborado pelo autor (Blu-ray, The Twilight Zone: The Complete Series, CBS, 2017)

Sua relação no trabalho com o chefe repete a dinâmica do mundo escolar, o chefe é retratado em cenas cômicas como se fosse um diretor ou professor de escola preocupado com o comportamento irritadiço e infantil de Horace Ford e disposto a orientá-lo. Horace se mostra cada vez mais resistente ao chefe como um estudante que não quer participar da aula, fazendo birra para não refazer o projeto do robô de brinquedo. A proximidade do seu aniversário de 38 anos enfatiza o absurdo desse 
comportamento e o caráter apalermado do protagonista, caráter este exposto pelo episódio tanto como sendo psicológico quanto físico/corporal.

Assim como a viagem ao passado de Martin Sloan, em Walking Distance, Horace Ford é transportado ao passado de forma mágica ao sair de casa para ir à rua Randolph. Não nos é mostrado como ele vai para o passado e ao contrário dos episódios da primeira temporada nas quais o espelho, o carrossel ou o fechar da cortina do trem indicam a viagem no tempo, nenhuma forma artística de representar essa viagem nos é exposta: ele fecha a porta de casa no presente e já aparece andando na rua do passado, cabendo a nossa imaginação supor como se deu esse caminhar entre seu lar e a decadente rua de seu afeto.

Sua viagem ao passado é recorrente, no primeiro momento ele não suspeita que havia viajado no tempo, mas ao ver um amigo de infância e ser reconhecido por ele, Horace ganha a consciência de que algo estranho estava se passando. Não nos é informado diretamente por meio de diálogos ou preocupações claras em datar a viagem o ano para qual Horace é transportado, mas um pôster de cinema colado como parte do cenário na rua indica uma possível data, o passado mostrado seria o ano de 1935, data de lançamento do filme "Devoção de pai" (O'Shaughnessy's Boy), dirigido por Richard Boleslawski, que conta a história de um pai e filho sendo reunidos após uma série de desastres e mentiras. Isso é um indicativo de como a preocupação do episódio é retratar o tempo social. Pode-se notar o contexto e identificar o ano por meio do conhecimento do cinema, mas isso não é importante, o principal é a questão da nostalgia, as mudanças individuais e sociais no contexto dos EUA no século XX, com o reconhecimento de que largas parcelas da população podiam fazer dos bairros do passado, violentos, sujos e decadentes (ambientes da crise econômica) em comparação com o sonho dos subúrbios do presente/futuro, limpos, organizados, com a natureza controlada (ambientes da prosperidade), reforçando reflexões no público da origem social de várias famílias que tinham se originado de ambientes assim e agora viviam em um mundo, propagado pela própria televisão, visto como infinitamente melhor.

De forma também mágica, seu amigo de infância, criança, aparece em sua casa para devolver o relógio que Horace Ford havia deixado cair na rua quando as crianças trombaram com ele. Como ele entrega para a esposa de Horace, alguma forma de comunicação entre passado e presente ocorre, porém ela não é explorada 
no episódio, servindo para reafirmar a viagem do personagem como real e não psicológica.

Na sua segunda investida no passado, ele ouve as crianças comentando que não foram convidadas para a festa de seu aniversário, o que é tanto um fato do passado doloroso e escondido de sua memória, como uma metáfora para não estarem presentes no seu aniversário de 38 anos que seria comemorado em breve, pois ele deveria deixar de ficar preso ao mundo infanto-juvenil que tanto é parte fundamental de sua personalidade.

Em todos os três momentos onde volta para o mesmo dia no passado na rua Randolph, quanto vai olhar o relógio de bolso, ele é derrubado sem querer por seus colegas de infância que passam correndo, brincando. Posteriormente, quando volta ao lar, é um de seus amigos meninos que devolve o relógio a sua esposa. Esses elementos na trama reforçam a noção de que Horace Ford negava a passagem do tempo e cada vez que a criança aparece em sua porta tentando devolver o relógio, seria uma tentativa malfadada de fazê-lo perceber que o tempo passa através da interferência de sua esposa, compartilhando a responsabilidade com ela.

As coisas devem mudar e ele crescer e aceitar suas responsabilidades masculinas adultas, esperadas no contexto americano do início dos anos 60 . Na sua última viagem, Horace, após ganhar consciência de sua memória falsa sobre suas experiências como criança, pega seu relógio de pulso caído no chão, indicando que ele agora aceitou a passagem do tempo, resgatado por Laura.

O fato de Laura receber de forma recorrente o relógio que Horace Ford perde na rua cada vez que retorna ao passado é uma certa de forma de aviso de que algo relacionado ao tempo está ocorrendo e demonstrando que Ford não estava sonhando e realmente estava fazendo expedições ao passado. $O$ aviso derradeiro se dá quando Horace Ford não retorna ao lar para sua festa surpresa de aniversário e o menino novamente aparece na porta do apartamento, porém entrega para Laura um relógio do Mickey Mouse, citado anteriormente no episódio por Horace Ford em suas memórias nostálgicas. Ao ver o relógio, Laura percebe que algo a mais que as características excêntricas do seu marido estava em operação, ele precisava realmente de sua ajuda e corre para rua Randolph, indo parar no passado - também de forma não explicada.

Lá, ela consegue resgatar seu marido e ter uma relação saudável com ele. Obviamente, esse episódio a representa no final como incorporando os valores 
esperados para uma boa esposa no contexto da série, mesmo que existam lampejos de autonomia e independência em seu comportamento.

A esposa o ama profundamente e realmente tenta ajudar Horace Ford, ela é peça fundamental para que ele se torne um adulto; entretanto, em um primeiro momento, ela não sabe o que fazer para apoiá-lo e tenta procurar ajuda médica. 0 episódio apresenta a noção de que quando ela reconhece sua própria importância na composição do casal e não tentar ser apenas uma mera substituta para a mãe - algo que ela tampouco fazia bem, pois ambos moravam com a mãe dele controladora-, a mulher cumpre um papel social fundamental e pode salvá-lo. A mãe, é uma figura que trata Horace como uma criança e não um adulto, manipulando as emoções de Ford. Assim, o primeiro passo da esposa para resgatar seu marido é se impor para sua sogra.

Figura 29 - O relógio do Mickey Mouse indica que Ford estava preso no passado de sua infância.

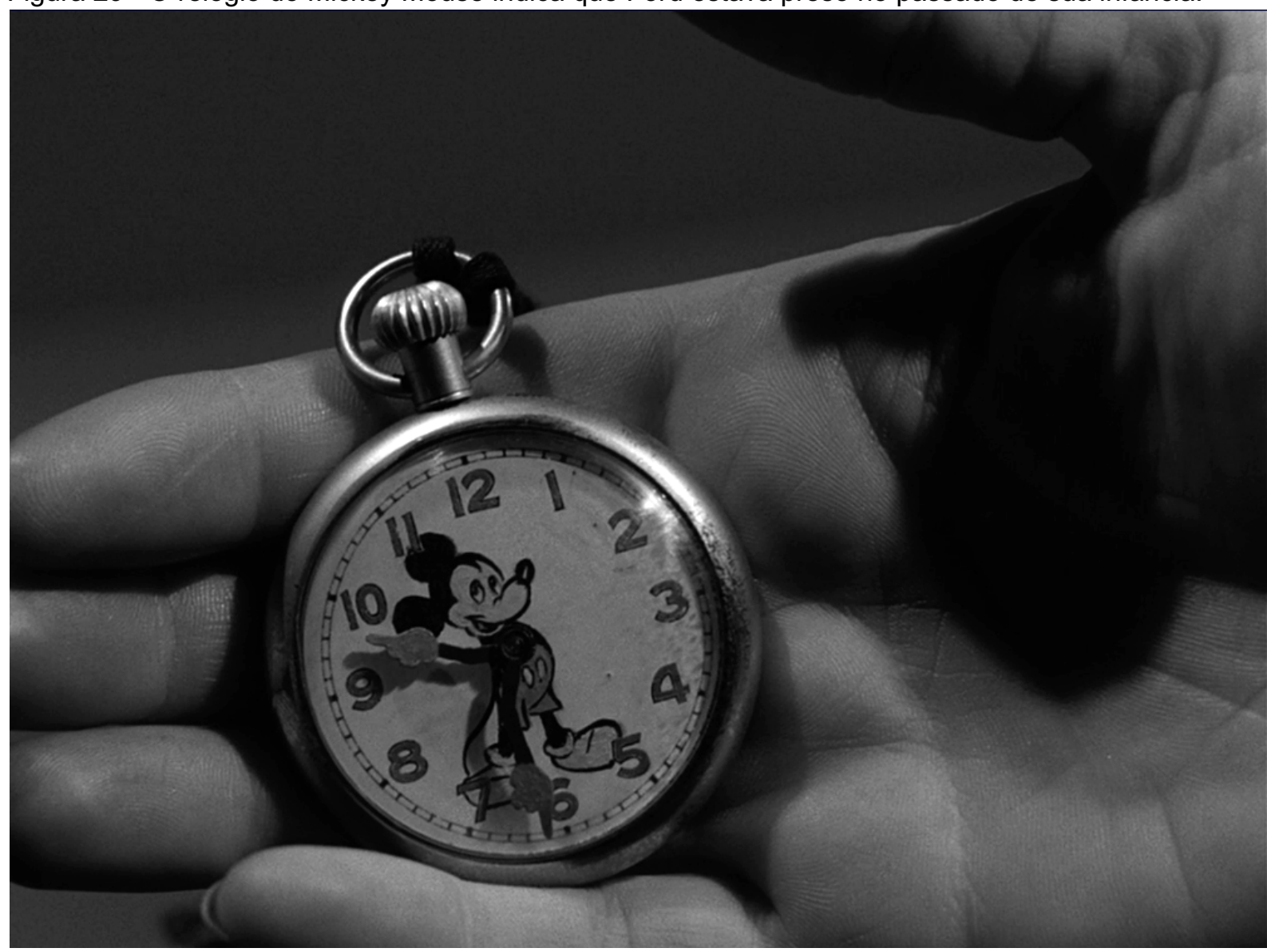

Fonte: elaborado pelo autor (Blu-ray, The Twilight Zone: The Complete Series, CBS, 2017)

O passado da infância de Horace Ford era horrível e, por tentar escapar do presente se infantilizando, ele se negava a reconhecer os abusos que sofrera dos 
seus pares, bem como o ambiente problemático onde crescera. A Zona Crepuscular agiu então para ensiná-lo, na perspectiva de ser um local de reintrodução do individuo na sociedade por meio de uma terapia fantástica, que ele deveria crescer e que a nostalgia restaurativa - a tentativa de viver como se fosse uma criança e o seu sofrimento para tentar realizar isso no presente, alienando-o de seus amigos, chefe e esposa- seria um erro pois era baseada em falsas acepções sobre o passado. No caso desse episódio, só com o abandono do passado imaginado ele pode se tornar um adulto e uma pessoa melhor. Sua ida ao passado serve para dar consciência de seus erros na percepção do presente.

Ao contrário dos demais episódios nostálgicos de viagem no tempo, o passado não é retratado de forma acrítica ou com ares que possam indicar uma superioridade perante o presente, como os demais episódios - local tranquilo, alegre, calmo, quente, ensolarado. A rua Randolph é uma rua empobrecida, suja, com poças de água, desrespeito, furtos, bêbados, com características reconhecíveis dos bairros onde habitavam os trabalhadores americanos nas grandes cidades, em um contexto de crise econômica da década de 30. Um lugar que a própria visão por parte do público serve para desconstruir as falas e expressões nostálgicas de Horace Ford, a ideia exposta de forma clara no episódio é que seria impossível sentir saudade daquele ambiente caso a experiência da nostalgia não colorisse a memória, induzindo uma idealização do passado.

O retrato do passado neste episódio está mais condizente com a viagem ao passado não nostálgica apresentada nos demais episódios de Além da Imaginação, como veremos mais adiante. Nos episódios não nostálgicos per se, o passado é retratado de forma crítica e muito longe do paraíso esperado por possíveis idealizações desta temporalidade por parte da audiência ou por visões simplistas e apaziguadoras dos conflitos e problemas, oriundas da cultura histórica dominante ou mesmo da História tradicional, por exemplo.

Tal episódio não critica as mesmas instituições do contexto histórico da série, como os demais episódios nostálgicos. Ele fala mais sobre estados mentais do personagem principal, que não enfrenta nenhum problema econômico ou desejo de escapar do seu trabalho - ele ama seu trabalho de projetar brinquedos -, mesmo que haja indicação de que sua revolta contra o mundo adulto possa estar relacionada à exigência de seu chefe que refaça os planos de um boneco de robô, pois o plano estava complexo demais e iria encarecer muito o produto final, Horace já nos é 
apresentado como uma criança grande antes de sua discussão com o chefe ocorrer e a tal fato não é dada tanta importância.

Portanto, The Incredible World of Horace Ford nos revela o conceito e o que era esperado por um homem adulto no contexto da série, pois é no conflito entre mundo infantil contra mundo adulto que é estabelecido o problema e onde a interferência da Zona Crepuscular irá operar. Ser um homem adulto é cuidar da família, provendo segurança para seus dependentes, trabalhar duro para sustentálos, manter amizades adultas sem brincadeiras realizadas por crianças e se adequar ao coletivo.

Na perspectiva dos demais episódios da série, The Incredible World of Horace Ford destoa do pensamento padrão que podemos identificar nos textos de Rod Serling sobre a questão da fuga para o passado se dar para um passado idílico por não adequação do personagem a um presente opressor que possa ser compartilhado pela audiência, sendo esta levada a se identificar com o protagonista. O episódio foca a sua crítica nas relações familiares, reforçando as noções dominantes da época sobre a importância da família nuclear como base da vida casada e da manutenção da sociedade, todos os problemas de Horace Ford tem como origem nas suas relações com a mãe e a esposa e não com o mundo corporativo ou pressões desumanizadoras. Cabe destacar que Serling, antes mesmo do lançamento de Além da Imaginação em 1959, teve acesso ao kinescope da versão da história para Studio One e a rejeitou com a explicação de que o enredo era semelhante a Walking Distance, prometendo posteriormente utilizar a história de Rose (GRAMS JUNIOR, 2008, p.591), o que é um indicativo não só do respeito de Serling por seu colega, mas também de que elementos da narrativa faziam parte do esperado em um episódio para Além da Imaginação, principalmente o mistério da viagem no tempo ao passado e o final original que demonstrava a impossibilidade da vida mais simples da infância no presente do segundo pós-guerra e de certa forma punia o protagonista antissocial. Assim, nota-se uma desarmonia deste episódio com as demais propostas nostálgicas de Serling e com o corpo crítico geral da série, essa desarmonia é relativamente geral na quarta temporada, amplificada por não ser um roteiro de Serling e pela exigência da mudança do final ter surgido por influência da produção. 


\section{4- Zona nostálgica}

Esses episódios comprovam a percepção de Boym de expor como operam duas formas distintas de nostalgia no discurso moderno; a série irá de forma mais geral criar pontes entres essas duas formas, reforçando a crítica. Nota-se à primeira vista um aceno e reconhecimento do apelo à nostalgia restaurativa, principalmente como passado é apresentado nesses episódios (salvo em The Incredible World of Horace Ford), como locais e tempos que realmente eram como a memória afetiva dos personagens indicava, porém a fuga para o passado capaz de atender o sentimento de perda, na verdade, serviria de lição para que o nostálgico aprendesse a viver no presente e mesmo o transformasse, como vemos em Walking Distance e Trouble with Templeton, ou enfatizar para o público que tal passado nunca mais iria retornar, como em $A$ Stop at Willoughby.

Mesmo que o passado não fosse o mar de rosas imaginado pelo protagonista de The Incredible World of Horace Ford, a viagem ao passado nostálgico é usada nos mesmos moldes de crítica, pois nós notamos que o passado não é bom, mas o personagem principal se identifica com ele e parece não observar diretamente os problemas de sua percepção daquele tempo. Portanto, a perspectiva da série é a da nostalgia reflexiva, ou seja, utilizar essa apresentação de tempos distintos e a busca por experiências calcadas na saudade a fim de inspirar no telespectador a reavaliação desses sentimentos, orientando-os para o presente e futuro a construir e não uma lamentação pelas perdas, uma perspectiva progressista. O único episódio que destoa parcialmente do conjunto é o Static, mas, como explicado, ele se alia à tendência da série de dar uma segunda chance para os idosos excluídos no contexto do segundo pós-guerra, criando uma nova linha do tempo a ser seguida pelo nostálgico, que para viver no passado é rejuvenescido. Portanto, nesse caso, a nostalgia restaurativa se manifesta para corrigir uma injustiça para com o protagonista, nos moldes da ação da Zona Crepuscular e não para corrigir o protagonista, como é o caso dos outros episódios desse grupo.

O desenvolvimento do pensamento nostálgico faz parte do próprio movimento de desenvolvimento do símbolo Tempo e seu uso, como visto, é extremamente importante como válvula de escape para populações de sociedades orientadas para mudanças rápidas, implacáveis e irreversíveis. Não se dá por acaso, portanto, o enorme apelo desse tipo de narrativa no contexto do segundo pós-guerra e a 
permanência principalmente de Walking Distance e A Stop at Willoughby, ambos roteiros do nostálgico autoconsciente Serling, nas listas de episódios mais importantes da série, regularmente reassistidos e comentados pela comunidade de fãs da série e do fantástico na televisão.

\section{5- O país estrangeiro}

As histórias de viagem no tempo ao passado sem discutir explicitamente a nostalgia também foram regulares na série. Esses episódios fazem parte da proposta mais ampla da série de apresentar a Zona Crepuscular como local de aventura e humanização por meio de eventos fantásticos.

No conjunto dos episódios que serão tratados aqui, o passado é apresentado na fórmula da Zona Crepuscular. Essa temporalidade faz os protagonistas reavaliarem seus comportamentos, aprenderem algo sobre o mundo e si mesmos, podendo retornar ao presente aperfeiçoados ou sucumbir na experiência vivida. Em oposição a visão nostálgica (mais proeminente na série e, geralmente, explorando um passado superior ao presente), o passado nos episódios não nostálgicos é apresentado como mais complexo, muitas vezes como o "país estrangeiro" 53 , dialogando de forma direta com a cultura histórica para criar a verossimilhança da transposição dos tempos, algo que não é salientado nos episódios nostálgicos.

Foram sete episódios, presentes a partir da segunda temporada da série, que retrataram uma viagem no tempo ao passado. Estas viagens nos indicam tanto a cultura histórica do contexto americano dos anos 50, quanto quais problemas enfrentados pela sociedade dos EUA poderiam ser observados com a viagem ao passado. São eles: Back There (1961), The Odyssey of Flight 33 (1961), A Quality of Mercy (1961), Showdown with Rance McGrew (1962), No Time Like the Past (1963), Of Late I Think of Cliffordville (1963) e The 7th is Made Up of Phantoms (1963).

No contexto da exibição original de Além da Imaginação, a viagem no tempo ao passado não nostálgico foi apresentada como forma de dialogar com a cultura histórica dominante, apresentando outras perspectivas sobre o passado, exibindo passados tanto problematizados como locais de aventuras e explorando os problemas

\footnotetext{
${ }^{53}$ Alusão à famosa citação do escrito L. P. Hartley em O Mensageiro (The go-between, 1953): "The past is a foreign country; they do things differently there". Em tradução livre: O passado é um país estrangeiro, lá eles fazem as coisas de forma diferente."
} 
presentes que levam muitos desses viajantes a terem experiências no passado. Assim, dentre esses episódios, encontramos diversas formas de se relacionar com o passado, inclusive por meio de máquinas construídas para se viajar no tempo ausentes nas viagens ao passado nostálgico -, representantes reificadores da ideia de controle humano sobre as mudanças.

O primeiro episódio de viagem no tempo ao passado não nostálgico da série foi de autoria de Rod Serling, ele foi exibido na segunda temporada, e lidou com o tema da imutabilidade do passado coletivo, utilizando o assassinato do presidente Lincoln em 1865 como um ponto de divergência traumático da História dos EUA o qual, se alterado, iria transformar totalmente os rumos dos EUA. Cabe lembrar que, posteriormente, na cultura dos EUA, outro assassinato presidencial, o de John $F$. Kennedy, em 1963, se destacaria também como evento coletivo traumático e seria alvo de explorações por viajantes no tempo ávidos por impedir a morte do presidente. Isso se deu, pois esse assassinato, registrado em filme e exibido até hoje ad nauseam, é capaz de gerar histórias com mais reviravoltas e surpresas, ser cercado de conspirações, ter em seu meio um personagem carismático envolto por uma aura de político promissor e por fazer parte de um período visto como mais inocente, em oposição aos conflitos que se passaram posteriormente na sociedade dos EUA nos anos 60. Um exemplo de obra atual que parte da premissa de alteração do passado muito semelhante ao episódio citado de Serling, mas tendo como foco o assassinato de J.F.K., é o famoso livro de Stephen King, Novembro de 63 (11/22/63, 2011), posteriormente adaptado em minissérie por James Franco, 11.22.63 (2016). Por ser um tema fantástico irresistível na cultura americana, o assassinato de Kennedy em Dallas foi abordado na segunda encarnação da série Além da Imaginação nos anos 80, no episódio exibido em 1986, Profile in Silver, onde um historiador do século XXII, descendente de Kennedy, acaba interferindo no seu assassinato em 1963, com efeitos desastrosos para a linha do tempo e forçando uma troca de lugar do historiador com o presidente para salvar seu antepassado e corrigir os rumos da história, impedindo uma guerra nuclear devastadora da vida na Terra, em um roteiro assinado por J. Neil Schulman.

Mesmo um episódio que exploraria a mudança do presente por meio da viagem ao passado, como Of Late I Think of Cliffordville, não demonstra alterações nas condições sociais e econômicas do mundo do presente, muito pelo contrário, a viagem 
serve para mostrar que indivíduos não têm o poder isoladamente de alterar grandes sistemas, no caso, o capitalismo corporativo americano do segundo pós-guerra.

Haja visto que estas viagens não conseguem alterar profundamente as condições do presente, ou são necessárias para que o presente se mantenha, a série Além da Imaginação optou por exibir uma visão fatalista da existência, reforçando a mensagem que estava subentendida em quase todos os episódios nostálgicos da impossibilidade de se mudar significativamente o presente por meio de uma alteração no passado, cabendo ao público realizar a reflexão entre os tempos para criar alguma forma de consciência que o impelisse para alterações individuais e coletivas que poderiam melhorar as relações humanas, na perspectiva humanista da série.

Outras questões que surgem nessa coletânea de episódios, como a consistente crítica à guerra e ao comportamento belicista em geral, fazem uso do passado como local de reflexão sobre como são realizadas as guerras e o papel dos valores éticos e morais, algo de extrema urgência a ser discutido no contexto histórico da série, um contexto tanto do discurso de despedida de Dwight D. Eisenhower em 1961 (que pedia a atenção dos americanos para com o "complexo militar-industrial" capaz de minar as instituições democráticas), quanto da presença no horizonte de expectativas de uma guerra nuclear.

\subsection{1- Back There}

Apenas na segunda temporada, apareceria um episódio de viagem no tempo ao passado não preocupado com a questão da nostalgia, que, como vimos, era uma questão cara a Rod Serling no trato do passado. Antes desse episódio, o tema da viagem no tempo já havia sido exibido em cinco episódios na primeira temporada, em três dos quais o destino da viagem são passados nostálgicos e os demais para o futuro do protagonista.

Back There, que pode ser traduzido como "Lá Atrás", foi o $13^{\circ}$ episódio da segunda temporada e $049^{\circ}$ da série. Escrito por Rod Serling, dirigido por David Orrick McDearmon e estrelado por Russell Johnson, Carol Eve Rossen, John Lasell, Lew Brown, Bartlett Robinson e Paul Hartman, Back There foi filmado no mês de setembro de 1960, e exibido em 13 de janeiro de 1961, com custo total de USD\$47.090,82 (GRAMS JUNIOR, 2008, p. 355). 
No clube masculino de elite, o Potomac Club, Peter Corrigan e seus colegas debatem sobre a viagem no tempo. Na saída do clube, Peter passa mal e se vê no passado, no dia do assassinato de Lincoln. Sabendo o que ocorrerá no Ford Theatre, Peter tenta avisar a polícia, mas quase todos guardas duvidam dele, apenas um jovem policial acredita nele, mas, mesmo com a simpatia desse homem, ele é preso por estar supostamente bêbado. Presenciando toda a cena, encontra-se um estranho homem, de nome Wellington, que resolve retirar Corrigan da cadeia, assumindo sua custódia. No quarto de Wellington, enquanto tentava explicar para o estranho homem o que se passaria dentro de poucas horas, Corrigan é drogado e dorme, descobrindo da pior forma que o seu benfeitor era na verdade John Wilkes Booth, o homem que assassinaria Lincoln no teatro à noite. Quando acorda, poucos minutos antes dos gritos que o presidente foi assassinado sejam ouvidos, Peter percebe que era tarde demais, ele não conseguiu alterar o destino de Lincoln. Voltando para seu tempo, para surpresa de Peter, no círculo de seus colegas no Potomac Club se encontra um novo membro: um antigo funcionário humilde era agora um rico membro da elite de Washington D.C.. A explicação: ele era um descendente do policial que acreditou em Peter e tentou por sua conta impedir a morte de Lincoln. O policial não conseguiu evitar Booth de assassinar o presidente, mas ganhou uma promoção por seus esforços.

Segundo Grams Jr. (2008, p.356) que teve acesso aos relatórios de produção do episódio, a ideia inicial de Serling era vender a história com uma hora de duração para outro programa, intitulada originalmente Afterwards (Posteriormente, em tradução literal); o roteiro foi reescrito para Além da Imaginação com o novo título e reduzido para 23 minutos.

$O$ roteiro demonstra o cuidado que os autores devem ter ao se escrever uma viagem no tempo: na versão datada do roteiro de 28 de julho de 1960, há um índice com as correções devidas para evitar o anacronismo e, assim, ser mais verossímil. Esse tipo de "erro" não passava desapercebido pelo público e seria o tipo de coisa observado pela consultora de Forest Research. No caso, não dá para saber se as alterações foram sugeridas pela revisão da empresa, ou foi algo que Serling pesquisou. No roteiro citado, pode-se ler:

\footnotetext{
Para se ajustar ao período da peça, por favor despromova os policiais de Washington D.C. assim:

Mude todas as referências de "Police Captain" para "Police Sergeant" [grifos no original]

Mude todas as referencias de "Police Officer" para "Patrolman"
} 
$\mathrm{E}$ :

Mude todas as referências de "Landlady" no Hotel de Wellington para "Chambermaid"

Mude todas as referências de "Washington Club" para "Potomac Club"54 (SERLING, 1960r4, p.1)

A viagem no tempo é retratada inicialmente pelo desfocar da câmera e a presença da música de Jerry Goldsmith; aos poucos, vemos a lâmpada elétrica da porta do clube de homens se transformar em uma lâmpada a gás. Conforme a câmera volta para o protagonista, notamos que a fachada do clube de homens se tornou mais simples, e Peter estranha estar vestido automaticamente com outra roupa. Assim, percebemos que um deslocamento temporal se deu por essas comparações realizadas, algo reforçado quando a câmera mostra a rua por onde anda um confuso protagonista e observamos homens e mulheres com roupas antigas e carruagens trafegando, algo não condizente com o ano de 1961, citado anteriormente no episódio. O público, antes mesmo do personagem, já tem consciência do que se passara, algo construído desde o primeiro diálogo no clube de homens sobre viagem no tempo e reforçado tanto pela narração de Serling, quanto pelo repertório formado pela cultura audiovisual.

Seu retorno ao presente também se dá de forma mágica: ao esmurrar a janela do quarto de Booth, lamentando por não ter sido escutado, Peter é transportado ao presente, golpeando a porta do clube Potomac. $O$ fato de $o$ antigo atendente ser agora um dos membros do clube de homens ricos e o lenço de Booth de posse de Corrigan no presente são indicativos de que a viagem no tempo foi real e não uma imaginação do protagonista.

A ideia de se voltar no tempo para impedir o assassinato de Lincoln não era novidade no contexto da série. No ano de 1950, foi ar no programa de rádio The Mysterious Traveler uma história chamada The Man Who Tried to Save Lincoln (O Homem que tentou salvar Lincoln, em tradução literal), posteriormente adaptada no programa Suspense em 1962 (GRAMS JUNIOR, 2008, p. 357). Outra obra que

\footnotetext{
54 Tradução livre de: In order to conform to the period of the play, please demote the Washington, D.C. policemen as follows:

Change all references to "Police Captain" to "Police Sergeant"

Change all references to "Police Officer" to "Patrolman"

And:

Change all references to "Landlady" in Wellington`s Hotel to "Chambermaid"

Change all references o "Washington Club" to "Potomac Club"
} 
explorava a mesma temática no contexto histórico da série foi o conto The Assassin (O Assassino, em tradução literal), de Robert Silverberg, publicado originalmente na revista Imaginative Tales de julho de $1957^{55}$.

Esse episódio também dialoga com o roteiro de Serling para The Time Element, (comentado anteriormente). Assim, como naquela história onde ninguém acredita no viajante no tempo que informa que Pear Harbor será atacada, Peter é visto como um bêbado e colocado na prisão, com quase todo mundo achando seus alertas parte do efeito do álcool no corpo.

Figura 30 - O assassino de Lincoln, John Wilkes Booth (em pé), coloca drogas na bebida que oferece a Corrigan (sentado) para que ele não consiga salvar o presidente, não sem antes saber tudo que o homem do futuro sabia sobre o assassinato que ocorreria em algumas horas.

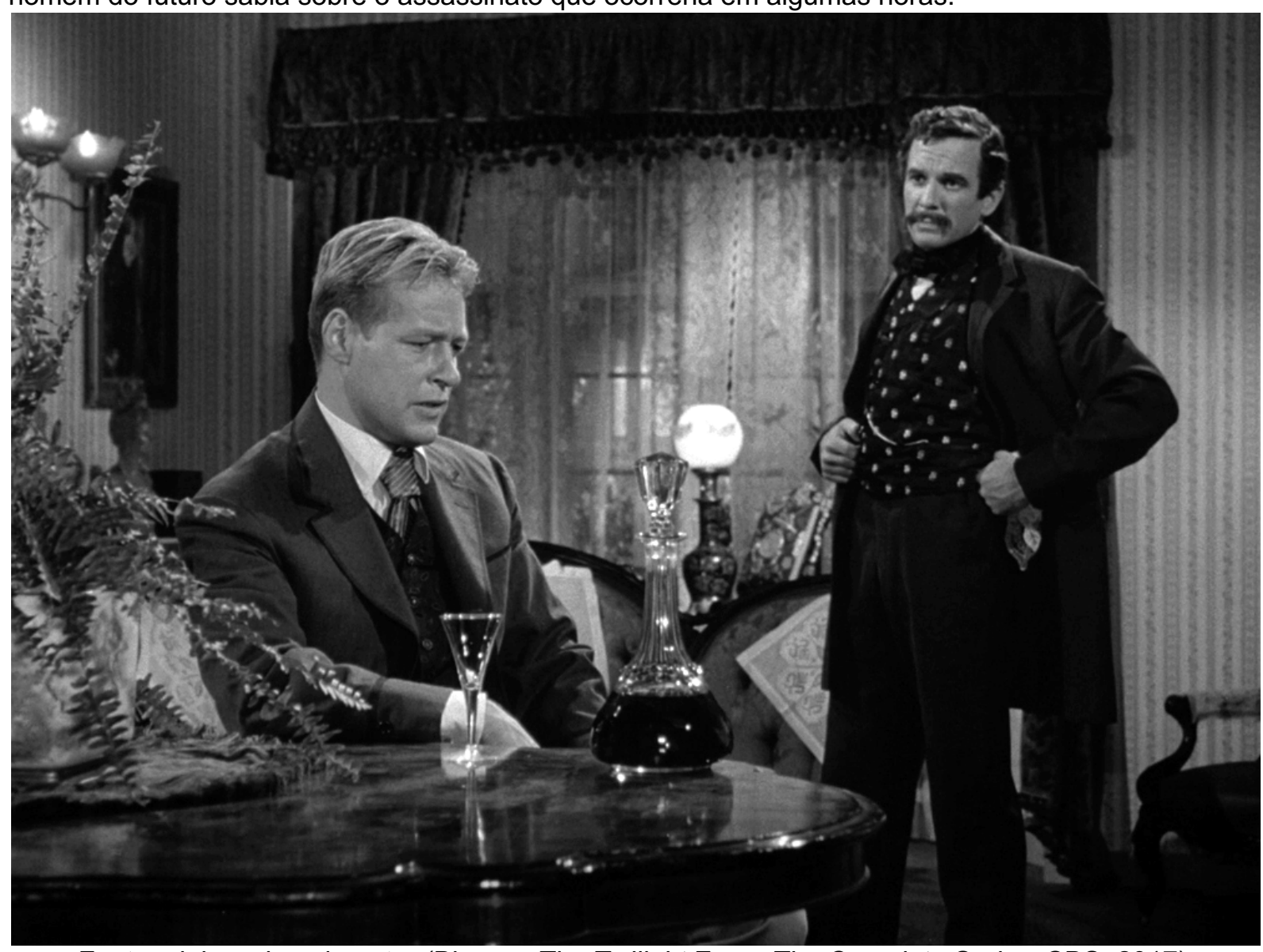

Fonte: elaborado pelo autor (Blu-ray, The Twilight Zone: The Complete Series, CBS, 2017)

O fato da busca por recuperar a imagem de Lincoln no contexto da Guerra Fria demonstra tanto a importância simbólica desse presidente na História dos EUA,

55 Tive acesso a esse conto na reimpressão presente no livro de 1981 organizado por Isaac Asimov e Martin H. Greenberg, Travels Through Time, no início da pesquisa sobre viagem no tempo. 
quanto passa a mensagem de que talvez a solução para os problemas enfrentados no contexto histórico da série necessitassem de um novo Lincoln -herói da democracia americana - para serem resolvidos, como disse um artigo publicado no New York Times de 12 de fevereiro de 1955; Lincoln por suas qualidades como simplicidade e até por sua rusticidade, era um símbolo americano e parte de seu folclore (THE THE LINCOLN..., 1955, p.14). Segundo o historiador Merrill D. Peterson (1994, p. 332), a fama de Lincoln teve seu ápice em 1959, quando fazia 150 anos de seu aniversário e a própria década de 50 e início dos anos 60 foi marcada por uma série de novas publicações e exposições sobre ele, como a abertura de toda sua casa em Springfield, Illinois, para visitas em 1955 (Ibid., p.312). Seu símbolo era regularmente utilizado no contexto da série na cultura americana como um herói dos valores democráticos, cultura cristã e da igualdade racial (isto iria ser alterado no decorrer dos anos 60); além disso, sua imagem era invocada na cruzada anticomunista da Guerra Fria como um símbolo dos valores americanos e era regularmente utilizada por políticos que queriam posar como seguidores de valores atribuídos ao presidente assassinado no século XIX (lbid., p.311-373). Portanto, salvar Lincoln da morte no passado representaria salvar o que Lincoln representava na cultura americana do período, e o fato do episódio mostrar que ele não poder ser salvo, deixa em aberto a interpretação possível de que cabe ao presente a recuperação desses valores ou mesmo a impossibilidade de retorno desses valores. Seja como for, caberia ao presente procurar seu rumo em direção a uma sociedade aperfeiçoada.

A alteração do status social do porteiro William, que se torna um multimilionário, por interferência de Peter no passado, serve tanto para demonstrar a tese de que não se pode controlar o tempo quanto para criticar os ricos da época: eles seriam bem sucedidos não por talento nato ou habilidade, mas por fatores de pura sorte, algo que descontruía o mito americano do self-made man, ou seja, os homens que tiveram uma origem sem privilégios e triunfaram na sociedade por seus esforços individuais e não por ações externas - êxito que pode ser calculado em dinheiro. Isso é reafirmado no final do episódio quando, no presente, Corrigan conversa com seus colegas sobre formas de se adquirir uma fortuna e William, presente entre eles, se orgulha de tê-la herdado.

Como será visto em outro episódio de viagem no tempo ao passado, também escrito por Serling, Of Late I Think of Cliffordville, a série Além da Imaginação não valorizava a noção de self-made man e a viagem no tempo ao passado foi utilizada 
na série como forma de expor a ideia de que todos poderíamos ascender socialmente ou empobrecer, por ação do acaso em um grande sistema complexo e não por nossas intenções/habilidades - algo reiterado pela falha de Peter em evitar a morte de Lincoln, cuja malfadada tentativa causou efeitos sequer considerados pelo protagonista. Outro ponto é que a Zona Crepuscular acabou recompensando o pobre garçom devido a seu antepassado policial ter demonstrado confiança em Corrigan e por sua posição social humilde, criando uma nova linha do tempo, na qual ele faz parte da elite econômica e pode frequentar o clube de cavalheiros, o que, de certa forma, acaba expondo como as pessoas se adequam a diferentes papeis sociais, relativizando a noção de valores intrínsecos às pessoas, visto que a humildade do porteiro sumiu na linha do tempo onde o homem se tornou um multimilionário.

Figura 31 - Apenas alterações nos rumos de indívudos são permitidas, fatos que afetam a sociedade como um todo são impossíveis de serem alterados. Mesa do clube antes da viagem no tempo (esquerda) e no retorno de Corrigan, quando o simples funcionário do clube agora é um distinto membro da elite da capital americana.

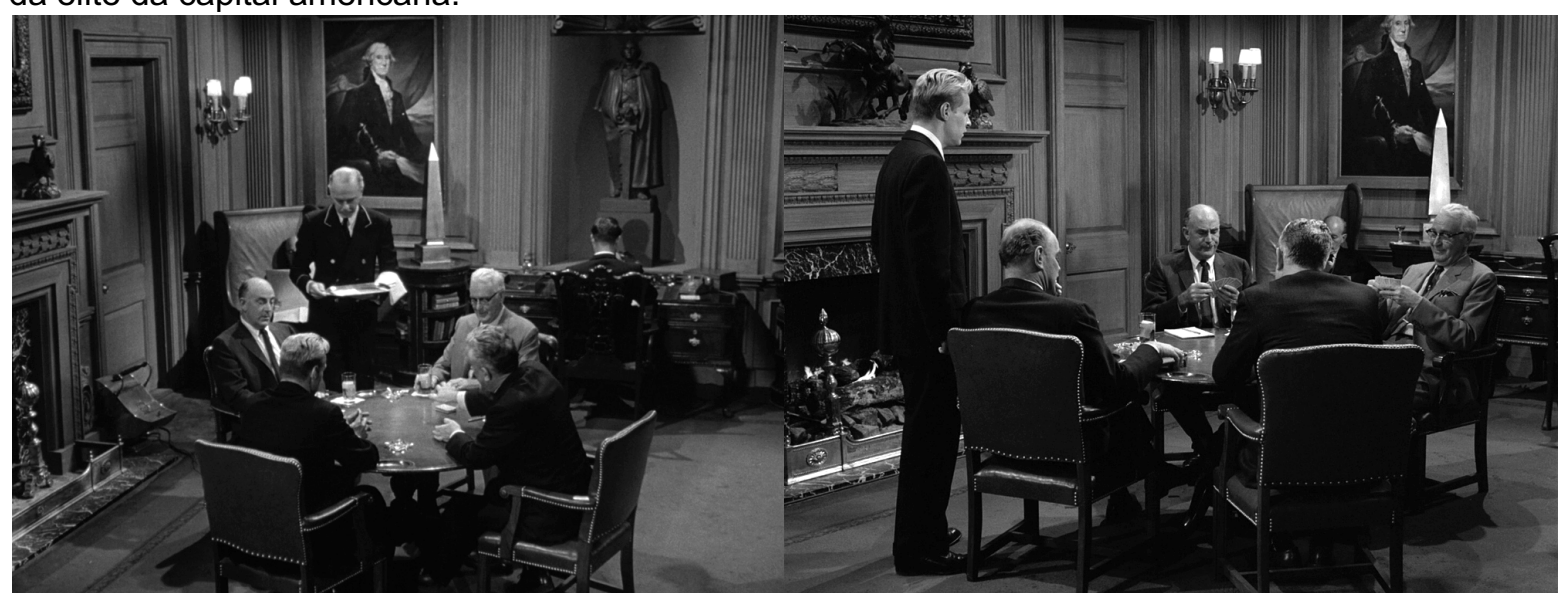

Fonte: elaborado pelo autor (Blu-ray, The Twilight Zone: The Complete Series, CBS, 2017)

Back There expõe a noção de que há um grande esquema na História, um caminho a ser percorrido pela humanidade dentro da lógica do progresso, porém sem ser apologista a ele. Neste caminho, os grandes fatos coletivos não podem ser alterados, a ação individual para transformar o presente de forma profunda é inócua, mas é reconhecido que o presente individual pode ser alterado. Expandindo essa noção para se pensar a concepção de História, pode-se concluir que o que presenciamos nessa viagem no tempo é a proposição de uma visão de História na qual os pequenos detalhes do passado podem ser alterados, por exemplo, por uma pesquisa historiográfica; mas os grandes fatos, os que afetam a maior parte das 
pessoas e estão cristalizados na cultura histórica de dada sociedade, não podem. A narrativa final de Serling na conclusão do episódio é um exemplo que reitera essa concepção, pois a aventura de Peter Corrigan "prova que por um lado que os fios da história são trançados firmemente, e a meada dos eventos não pode ser desfeita, mas, por outro lado, há pequenos fragmentos de tapeçaria que podem ser alterados" 56 ,

Na mesma segunda temporada, quatro episódios após a exibição de Back There, outro episódio de viagem no tempo ao passado seria exibido. Escrito por Rod Serling, The Odyssey of Flight 33, exibiria pela segunda vez na série o avião servindo como máquina do tempo (a primeira foi o episódio The Last Flight, um roteiro de Richard Matheson, ainda na primeira temporada).

\subsection{2- The Odyssey of Flight 33}

O episódio The Odyssey of Flight 33 foi exibido originalmente em 24 de fevereiro de 1961. O $54^{\circ}$ episódio da série e $18^{\circ}$ da segunda temporada, dirigido por Justus Addiss e estrelado por John Anderson, Paul Comi, Sandy Kenyon, Harp McGuire, Beverly Brown e Wayne Heffley, custou USD\$45.536,94. O roteiro final e as filmagens são do mês de outubro de 1960 (GRAMS JUNIOR, 2008, p.370; ZICREE, 2018, p.165).

O voo 33 da Global Airlines, um moderno Boeing 707, saindo de Londres com destino a Nova York, se vê envolto em um forte vento de cauda e perde o contato de rádio com os controladores de voo. Sem que os passageiros e a tripulação possam perceber de imediato, eles foram transportados para Nova York no Período Jurrásico e ao se aproximarem de onde seria a cidade em 1961, observam um dinossauro, para espanto de todos. Realizando um retorno para o local onde sentiram o vento, são novamente impulsionados pelo tempo, indo parar em 1939, chegando a Nova York para observarem, surpresos, os prédios da Feira Mundial de 1939 em Flushing Meadows, próximo ao Aeroporto LaGuardia. Em uma nova tentativa de voltar para sua época, agora quase sem combustível, o capitão e a tripulação se dirigem

\footnotetext{
${ }^{56}$ Tradução nossa de: “Mr. Peter Corrigan, lately returned from a place 'back there', a journey into time with highly questionable results, proving on one hand that the threads of history are woven tightly, and the skein of events cannot be undone, but on the other hand, there are small fragments of tapestry that can be altered."
} 
novamente para o local onde o avião fora lançado pelo tempo, com a esperança de voltarem finalmente para casa.

No livro de Zicree, The Twilight Zone Companion (1992, p.178-179), o irmão mais velho de Rod Serling, Robert J. Serling, famoso escritor de livros que lidavam com a aviação tanto de forma ficcional quanto jornalística/histórica, e que tinha contatos na indústria de aviação, contou que a ideia de Rod para o episódio surgiu durante a visita de Robert a Los Angeles: Rod vira o anúncio enviado para as produtoras de Hollywood pela American Airlines oferecendo uma reprodução da cabine de passageiros do Boeing 707 para aluguel ou compra; ele teria tido a ideia do conceito do episódio enquanto o irmão dirigia.

Rod Serling contou com a consultoria de seu irmão para escrever o roteiro e contar a história de forma mais realista possível, a fim de que os envolvidos com a aviação ou entusiastas notassem a realidade das cenas e, além disso, tudo soasse verdadeiro para o público em geral.

Robert escreveu diálogos e pesquisou os termos e o funcionamento do Boeing 707 para seu irmão, e, ao contrário do que Robert afirmou na entrevista publicada no livro de Zicree (1992, p.179) - que passou as explicações e diálogos somente pelo telefone, pois Rod estava sempre com pressa- , ele enviou uma série de cartas sugerindo diálogos e explicando a rotina na cabine de pilotagem, inclusive desenhando um esquema da posição da tripulação de um Boeing 707 (SERLING, 1960ia, p.1-6; 1960ib, p.1-6). Robert, por exemplo, em carta de 8 de outubro de 1960 afirmaria que:

\begin{abstract}
Aqui está o diálogo adicional que você pediu. Francamente, ele não está 100 por cento correto e não pode estar, pois a situação que você apresenta é tão fantástica que você deu a tripulação um impasse quase impossível. A comunicação Terra-Ar mudou tanto desde 1940 que um Boeing 707 com equipamento de comunicação de 1960 teria um problemão para alcançar uma torre de controle com equipamento de 1940. As frequências, por exemplo, são completamente diferentes [tradução livre] ${ }^{57}$. (Id., 1960ia, p.1)
\end{abstract}

\footnotetext{
57 "Here's the additional dialogue you requested. Frankly, it's not 100 per cent accurate and it can't be, because the situation you present is so fantastic that you've presented the crew with and almost impossible impasse. Air-ground communications have changed so since 1940 that it's likely that a Boeing 707 with 1960 communications equipment would have one helluva time even raising a control tower with 1940 equipment. Frequencies, for example are completely different." - essa carta também foi encontrada por Martin Grams Jr. e citada no seu tópico sobre esse episódio (2008, p.372-374)
} 
Seja como for, os cuidados com a aviação foram insuficientes para parcela do público, dois erros graves de Geografia, além de equívocos de História e Geologia seriam apontados nos dias seguintes à exibição do episódio, mesmo que a parte da aviação tenha sido a mais fidedigna possível e, segundo Robert Serling, elogiada por pilotos (ZICREE, op.cit., p.179).

Um dos erros apontados, inclusive por crianças de onze anos, era o fato de, no período Jurássico - conclusão do público devido à presença do brontossauro -, a llha de Manhattan e os rios da região não existirem ainda, a topografia do terreno seria muito diferente para ser identificada pelo piloto (CORWIN, 1961, p.1-2; HADDAD; KLEIN, 1961, p.1-3; SALTZ, 1961, p.1). Outro erro, também destacado pelo público, ocorreu também na descrição da localização da Feira Mundial de 1939, o piloto afirma aos passageiros que ela estaria no lago Success, quando, na verdade fora realizada em Corona Dumps ou, como foi depois chamado posteriormente, em Flushing Meadows (WALTERS, 1961, p.1). Os apontamentos desse tipo de erro científico demonstram como o público se envolvia com a série e o que eles buscavam quando eram expostos a temas insólitos, principalmente ligados com a ficção científica. O erro de diálogo da localização da Feira Mundial pode ser visto como um equívoco do piloto e não interfere no enredo; já o erro geológico é importante para o desenvolvimento da história e da própria representação da viagem no tempo, pois caso o roteiro fosse fiel ao conhecimento científico sobre a formação da a região de Nova York, a surpresa pela visão do brontossauro pela janela do avião não teria efeito, já que o suspense da aproximação do avião a Nova York é mantido pelo reconhecimento dos marcos geográficos pelos personagens e pelo público. Seja como for, nota-se uma preocupação de parcelas do público com essas questões, principalmente pela associação da série com o gênero ficção científica, o que exigia um cuidado maior com os aspectos científicos a serem extrapolados e não ignorados.

A versão adaptada do episódio para o segundo livro de contos da série More Stories From The Twilight Zone, publicado em 1961, é diretamente baseada no roteiro e foi enviada para a editora antes de o episódio ir ao ar, ainda em outubro de 1960. No conto, foi mantido o nome da companhia aérea do roteiro, Trans-Ocean, porém Serling havia pedido ao editor para mudar para Trans-Globe (no episódio, a empresa foi chamada de Global), pois seu irmão o informara que existia uma empresa real com esse nome (SERLING, 1960f, p.1). Há registro de uma empresa de aviação americana de nome Transocean, que operou de meados dos anos 40 até falir, no início dos anos 
60 (TRANSOCEAN..., s.d, n.p). O conto não foi alterado e até hoje, na versão literária, a companhia aérea é a Trans-Ocean. Além disso, os erros apontados pelo público também se fazem presentes, pois Serling só teria conhecimento deles pela reação do público ao episódio em 1961, e o livro não foi reescrito nas demais edições.

O avião Boeing 707 funciona como máquina do tempo nesse episódio, seguindo o modelo da famosa obra de H.G. Wells A Máquina do Tempo (2010), na qual há a viagem no tempo, mas não no espaço. Ao transpor uma barreira desconhecida de som, o avião começa a ganhar velocidade em referência ao solo e se transporta para o passado; o efeito da viagem é marcado por piscadas de luzes brancas e sons que sinalizavam de forma audiovisual que o deslocamento no tempo foi realizado.

A viagem no tempo ao passado, exposta em The Odyssey of Flight 33, atualiza mitos prévios de navios fantasmas, como o famoso mito do "Holandês Voador" (um navio fantasma, condenado a vagar até o fim dos tempos), para um cenário de ficção científica, onde não existem fantasmas, mas um avião perdido no tempo, tentando desesperadamente retornar a 1961. Essa noção é reforçada pela narração final de Serling, que afirma "Então se em algum momento...em qualquer momento...você ouvir o som de motores a jato voando sobre o céu nublado, [...]...isso pode ser o Global 33 tentando ir para casa... [tradução nossa] ${ }^{58}$. O uso do título "Odisseia" para representar a aventura do avião perdido no tempo remete ao poema grego clássico que apresentava aventuras extraordinárias, este sentido é atribuído ao que observamos a tripulação e os passageiros do avião passarem, perdidos no tempo.

Assim, a viagem no tempo, nesse episódio, serve para realçar o mistério do avião perdido: o não retorno para o presente faz à imaginação do público considerar se eles voltaram pra seu tempo ou ficaram perdidos para sempre ou até acabar o combustível. Na época moderna, um contexto histórico no qual parecia que nada mais era inexplorado e não mapeado na superfície terrestre, um avião a jato perdido no tempo substituiu a embarcação à deriva no mar descobrindo ilhas desconhecidas (perdido no espaço). A escolha das épocas no mesmo espaço geográfico, para onde o avião se desloca sem controle, cria um sentido dentro da história dos EUA e expõe como o passado é retratado.

58 So if some moment...any moment...you hear the sound of jet engines flying atop the overcast, $[. .$.$] ...that would be Global 33$, trying to get home... 
Figura 32 - Avião na capa com engrenagens e tiranossauro: o conto não especifica qual dinossauro foi visto do avião.

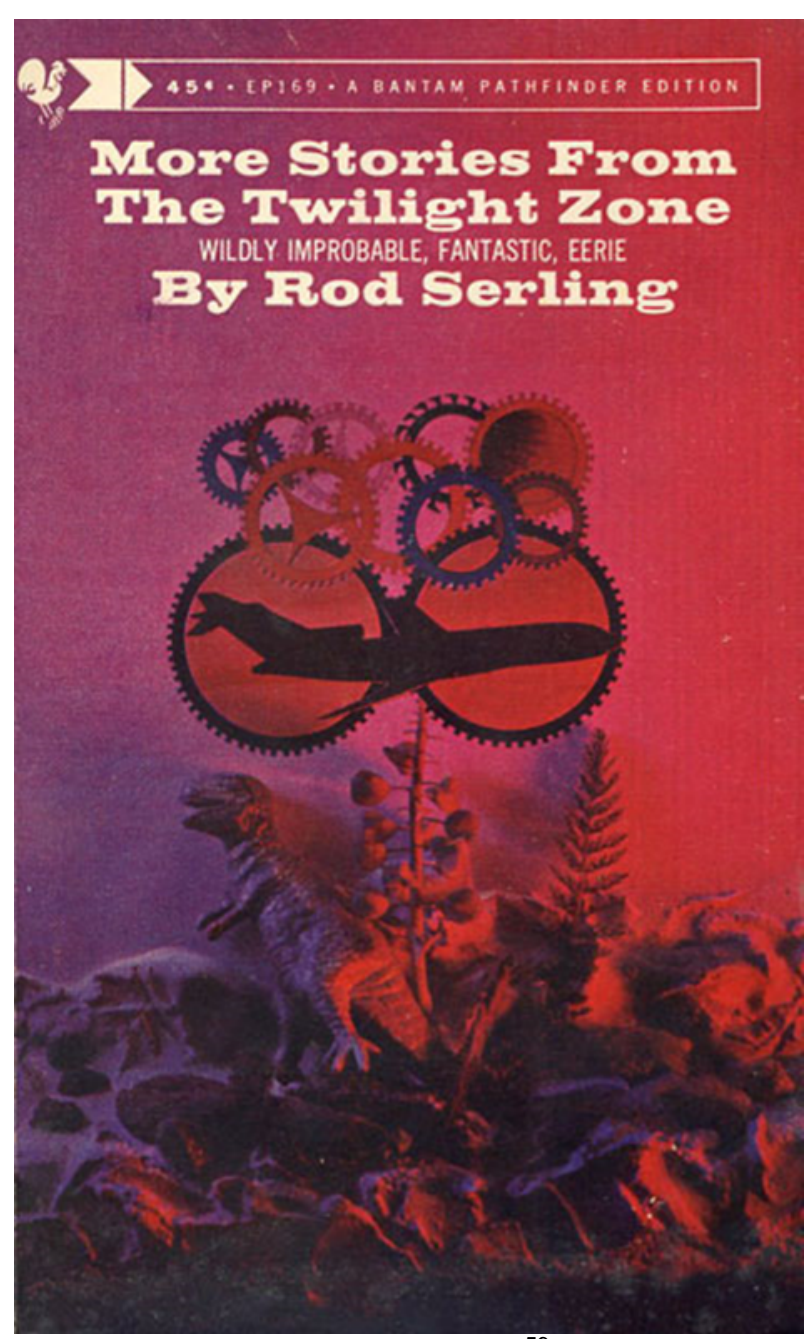

Fonte: Abebooks ${ }^{59}$

Inicialmente, cabe a reflexão sobre o retorno ao período dos dinossauros, um brontossauro pode ser visto pela janela do avião, comendo árvores na ilha de Manhattan, o que localiza o destino do desafortunado avião para o período Jurássico. $\mathrm{Na}$ cultura americana, esse passado distante dos dinossauros substituiu o passado histórico europeu, das ruínas da passagem humana pelo continente e dos processos que levaram ao domínio Europeu sobre o mundo e à expansão dos valores ocidentais, corroborando a noção de Hegel da América como um local sem História e terra do futuro (SCALDAFERRO, p.215), noção compartilhada pelos americanos do século XIX, que viam os EUA como uma "Nação da Natureza" (BOYM, 2001, p.17), contrapondo a História europeia a esta visão com um passado ainda mais distante,

${ }^{59}$ Disponível em: https://pictures.abebooks.com/BOOKIT2/20241778901.jpg. Acesso em: 02/06/2019. 
mais misterioso, portanto mais grandioso e superior ao europeu - um passado natural superior em escala. Como afirma Boym (2001, p.33-34), em uma "Nação da Natureza", o dinossauro seria o unicórnio americano. Assim, a visita aos dinossauros em histórias de viagem no tempo cumpre esse papel de apresentar essa noção de passado antes dos seres humanos em primeira mão e não é algo raro de ser encontrado nas obras de ficção científica da década anterior a Além da Imaginação, como o já destacado influente conto de Ray Bradbury O Som do Trovão (A Sound of Thunder, 1952), e os contos de Lyon Sprague de Camp Arma para Dinossauros ( $A$ Gun for Dinosaur, 1956) e de Arthur C. Clarke A Seta do Tempo (Time’s Arrow, 1950), publicados em revistas circulantes nos países anglófonos do período (TURTLEDOVE;GREENBERG (orgs.), 2016, p.462).

Figura 33 - Visão da janela do Boeing 707. Presente e futuro encontram o passado distante da Terra.

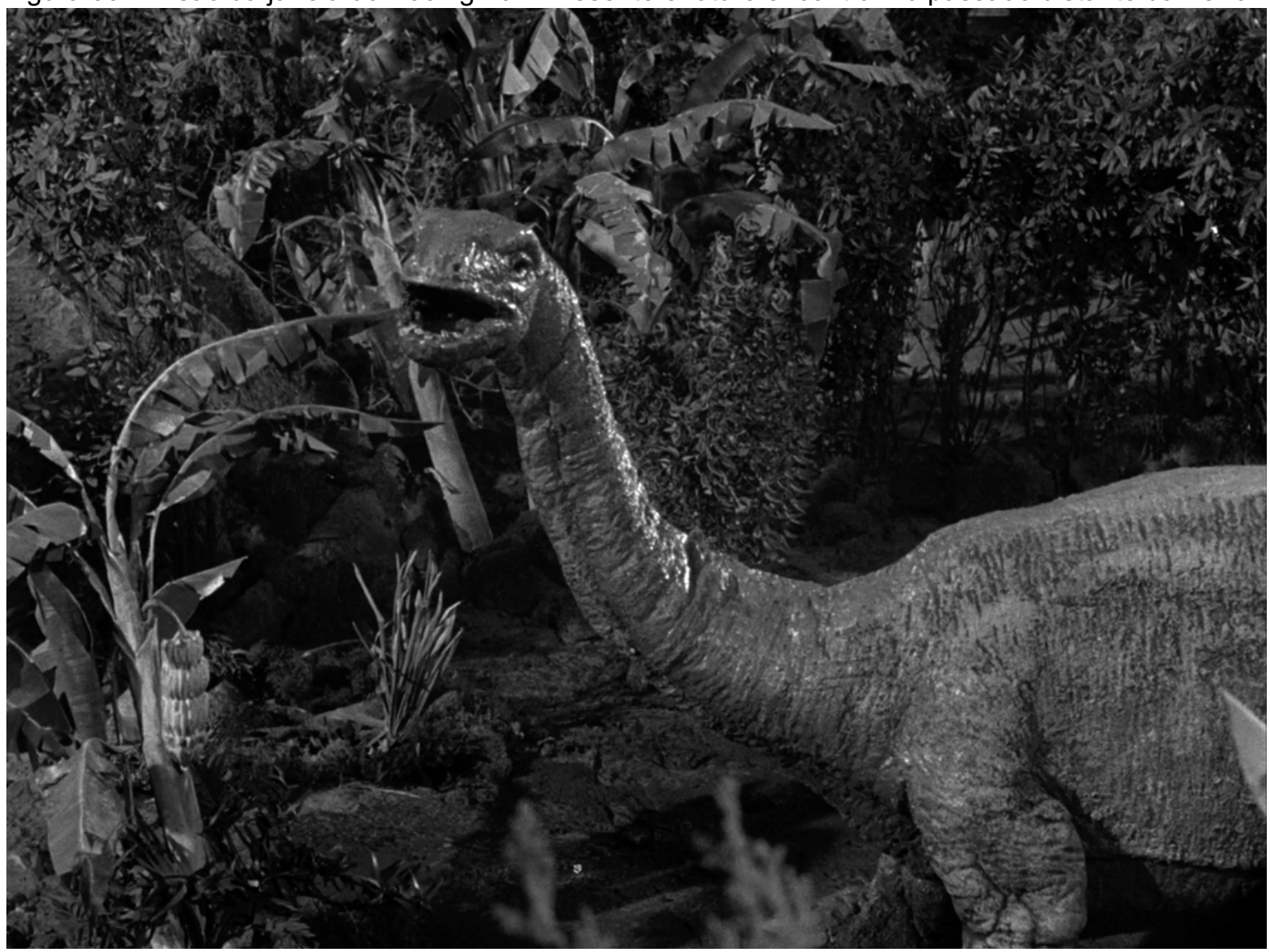

Fonte: elaborado pelo autor (Blu-ray, The Twilight Zone: The Complete Series, CBS, 2017)

A viagem para o período dos dinossauros representa uma escala que alimenta o mito americano dos EUA serem uma terra ahistórica, que cria sua própria História. Portanto, os dois destinos da viagem no tempo, o Jurássico e a Feira Mundial de Nova 
York de 1939, feira que foi inclusive um momento importante para a história da televisão nos EUA, vai do mundo natural antigo para o mundo do progresso tecnológico e contexto de ascensão global dos EUA, ampliado quando relacionamos o presente, com o avião a jato impossibilitado de pousar para reabastecer em 1939 devido à diferença de tecnologia e os avanços nos sistemas de geolocalização disponíveis para o Boeing 707 da aventura de Serling, e reforçado pelo cuidado em retratar o avião, seus instrumentos e o comportamento da tripulação de forma realista.

São articulados três tempos: o passado grandioso e antigo, o da Pré-História; o passado de ascensão e promessa de progresso, o de 1939; e o presente onde o destino se manifestou, em 1961. Entretanto, aí cabe a crítica do episódio ao seu presente, esse suposto controle humano da natureza e seu destino são ilusórios, como pode ser visto pela forma como se dá a viagem no tempo, e o dinossauro surge então para lembrar o possível destino da civilização humana, reforçado no contexto da Guerra Fria: o animal pré-Histórico faz o público recordar da extinção. Isso não é uma inferência exagerada; em carta escrita em 24 de fevereiro de 1961, logo após a exibição do episódio, Rita C. Coleman propôs a Serling uma continuação para o episódio, uma sugestão de enredo para uma parte dois, na qual o avião iria para o futuro e encontraria tudo destruído por uma guerra nuclear e a humanidade dizimada, com os passageiros e tripulação tentando criar uma nova sociedade, o público deveria notar que essa nova sociedade não seria perfeita, mas sim que os seres humanos sempre têm problemas derivados de perspectivas políticas distintas (COLEMAN, 1961, p.1).

Além de representar a falta de controle humano sobre a natureza, a viagem no tempo ao passado foi utilizada por Rod Serling para realizar uma reflexão sobre empatia em momentos de crise. O episódio $A$ Quality of Mercy, utilizou o deslocamento no tempo para passado para mostrar como a falta de senso histórico e a incapacidade de se colocar no lugar dos outros (empatia) pode causar danos nas relações humanas

\subsection{3- A Quality of Mercy}

O episódio A Quality of Mercy foi o $15^{\circ}$ episódio da terceira temporada e $80^{\circ}$ da série, dirigido por Buzz Kulik e estrelado por Dean Stockwell, Albert Salmi, Jerry Fujikawa, Leonard Nimoy, teve custos totais de produção de USD\$ 48.514,18. A 
Quality of Mercy foi filmado entre o final de junho e início de julho de 1961 e exibido em 29 de dezembro de 1961. (GRAMS JUNIOR, 2008, p.462,463; ZICREE, 2018, p.230). O roteiro é de autoria de Rod Serling, baseado numa ideia de Sam Rolfe, famoso roteirista da televisão americana, conhecido pelas séries Paladino do Oeste (Have Gun - Will Travel, 1957-1963) e O Agente da UNCLE (The Man from U.N.C.L.E., 1964-1968). Rofle escreveria o roteiro, mas não conseguiu, e Serling desenvolveu o enredo, inserindo diversos elementos baseados nas suas reflexões e experiências na Segunda Guerra Mundial como soldado no Teatro de Operações do Pacífico (GRAMS JUNIOR, op.cit., p. 464-464).

O tenente Katell, um jovem oficial, chega nas Filipinas para liderar um veterano pelotão de soldados americanos, cansados da guerra, no teatro do Pacífico na Segunda Guerra Mundial. Ávido por mostrar serviço e exercer o comando, o tenente ordena os soldados para atacarem soldados japoneses famintos e doentes que haviam se escondido em uma caverna. Os seus comandados não achavam necessária tal ação e se indispõem com o oficial e, a contragosto, começam os preparativos para atacar os japoneses na caverna, apenas seguindo as ordens devido à hierarquia militar. Ao pegar o binóculo para observar melhor a caverna, Katell o deixa cair no chão e ao pegar o objeto, se transforma em um tenente japonês de nome Yamuri, indo parar no ano de 1942, quando na mesma caverna os soldados americanos famintos e feridos se escondiam. Tendo que seguir ordens de um cruel capitão japonês para atacar os americanos e, assim, exterminá-los, Katell tenta cancelar a ação e aprende sobre a desumanidade da guerra e duvida da obediência cega à cadeia de comando. Retornando instantaneamente a 1945 com uma nova perspectiva sobre a vida humana, vê seus comandados organizando o ataque que fora ordenado por ele anteriormente e aliviado recebe a notícia de que seus superiores cancelaram toda operação, pois uma nova bomba havia sido lançada no Japão e estavam aguardando as reações dos comandantes japoneses,

A viagem ao passado se dá de forma mágica, quando o binóculo que o tenente manuseia para observar o inimigo cai no chão, e segue a forma mais comum encontrada em Além da Imaginação para realizar o transporte do viajante pelo tempo. Ao expor uma forma mágica para representar a viagem - no caso, não há nenhum efeito visual para indicar a viagem -, o episódio evita tanto ter que explicar o deslocamento quanto reforça o aspecto de ação da própria Zona Crepuscular como entidade sobrenatural que intervém nas relações humanas para corrigí-las, no caso, 
utilizando a viagem no tempo para que o tenente Katell aprenda a qualidade da misericórdia, do título do episódio, e volte do passado para o presente, valorizando todos seres humanos e relativizando suas ideias destruidoras, colocando-se no lugar do outro, sejam amigos ou adversários na guerra, ou seja, o passado é um local de aprendizagem para que valores rígidos sejam relativizados por meio de reflexão pela experiência passada em temporalidades distintas.

Entretanto, o tenente, ao retornar ao presente após sua experiência transformadora, não tem tempo de cancelar o ataque que ordenara aos japoneses feridos, famintos e isolados na caverna. Enquanto faz uma profunda reflexão, seu pelotão recebe a notícia da bomba atômica sendo lançada em Hiroshima e de que todas ações militares deveriam ser imediatamente canceladas no aguardo de uma provável rendição japonesa. Katell é provocado pelo sargento que falou para ele não se preocupar, pois haveria outros conflitos nos quais poderia estimular seus ímpetos destrutivos, e ele, agora uma nova pessoa, responde que "Deus nos ajude...Eu espero que não" (SERLING, 1961r2, p.29). No roteiro, enquanto falava isso, ele teria lágrimas nos olhos; no episódio pode-se notar os olhos lacrimejantes, mas nada de muito destaque, o destaque é colocado na sua expressão de choque, reforçando a mudança pela qual o personagem passara. Isso traz consigo uma ironia, ele passara por uma transformação para aprender o absurdo, a inutilidade e a desumanização da guerra, transformação essa reforçada pelo uso da bomba atômica, símbolo de destruição e desumanização, como se esse fato, mais do que representar o fim da guerra para os cansados soldados, marcasse uma maior urgência para que todos no mundo passassem pela mesma transformação do tenente.

Sobre o papel de se colocar no lugar da outra pessoa, o binóculo é utilizado como símbolo dessa transposição reflexiva: é no manuseio do binóculo, instrumento óptico de se observar a distância, que a viagem se realiza. $O$ ato de olhar o mundo pelo olho do outro, mesmo que a princípio exista uma distância, é visto como fundamental para a resolução dos conflitos humanos, uma mensagem que adquiria um peso maior ainda no mundo dividido da Guerra Fria e dos conflitos internos dos EUA, principalmente a questão racial. O episódio expõe a noção de que por mais que existam distâncias entre as pessoas, no caso entre soldados americanos e japoneses nas Filipinas, elas não são instransponíveis, pois somos todos humanos, com as mesmas necessidades básicas. O binóculo quebrado ao chão no retorno ao presente 
do tenente Katell, simboliza que a mensagem fora compreendida e marca o fim da ideia de distanciamento que desumaniza os seres humanos.

Essa reação final, indicando a esperança de que os homens não mais fossem colocados nessas situações, apelava também no contexto do episódio de possível conflito nuclear. $O$ fato da bomba atômica ser citada e a data da aventura ser o dia 6 de agosto de 1945 servem para recordar ao público de como seria uma guerra futura, reforçando a noção de que a Segunda Guerra deveria ser utilizada como reflexão sobre a desumanização de quaisquer guerras. Essa ideia é enfatizada na narração final de Serling, que cita o Mercador de Veneza, de Shakespeare, para posteriormente comentar que essa noção deveria ser aplicada para qualquer nação da face da Terra:

"A qualidade da misericórdia não se impõe,
Cai como a suave chuva do céu
Sobre a terra em baixo. É duplamente abençoada:
Abençoa quem a concede e quem a recebe;" (SHAKESPEARE, 2002, p.65)

A seleção do trecho acima demonstra não só uma erudição de Serling, mas real tentativa didática de elevar a reflexão sobre o presente e influenciar o público, dentro da perspectiva humanista defendida por Rod Serling e que se fazem presentes no próprio conceito da série Além da Imaginação. Assim, esse episódio é um bom exemplo do didatismo e da forma como a série pregava determinados valores, neste caso, utilizando o recurso da viagem no tempo para realçar a ideia de se ver o mundo pelo olhar do outro e, se a empatia não for desenvolvida, pelo menos a clemência e a tentativa de se compreender que as coisas mudam devem ser observadas.

Neste caso, novamente, temos atuando o mesmo símbolo da roda da vida, expresso anteriormente pelo carrossel em Walking Distance: em 1942, os japoneses estavam por cima e queriam matar todos americanos na caverna; já em 1945, os EUA estão por cima e devem aprender a exercitar a misericórdia, expandindo os valores humanos, pois ninguém sabe o futuro. Portanto, a viagem no tempo, já que o tempo é marcação de mudança, é um elemento que reforça a reflexão sobre como as coisas mudam e devemos ter valores humanos pautando sempre nossas relações. Uma mensagem, que Serling reconhece em sua narração, atemporal - e necessária no contexto da série.

Os japoneses, no episódio, são retratados como soldados tão dignos quanto os americanos e, assim como os americanos, seres inseridos num jogo de poder, no qual o oficialato, que não se preocupa com a vida humana, os utilizam como peões 
de um jogo de xadrez. Em um contexto histórico onde o Japão era o principal aliado americano na Ásia, o episódio também servia para humanizar o aliado estratégico, mesmo que essa não fosse a intenção de Serling (que realmente tinha preocupações humanistas), tentando apagar a propaganda racista da Segunda Guerra Mundial esse tema foi explorado com mais detalhes no episódio da quinta temporada The Encounter (1964), de autoria de Martin M. Goldsmith.

Figura 34 - O tenente Katell perde seu ar arrogante ao ser transportado ao passado e transformado em oficial japonês, sendo obrigado a cumprir o mesmo tipo de ordem cruel que exigia de seus comandados no presente.

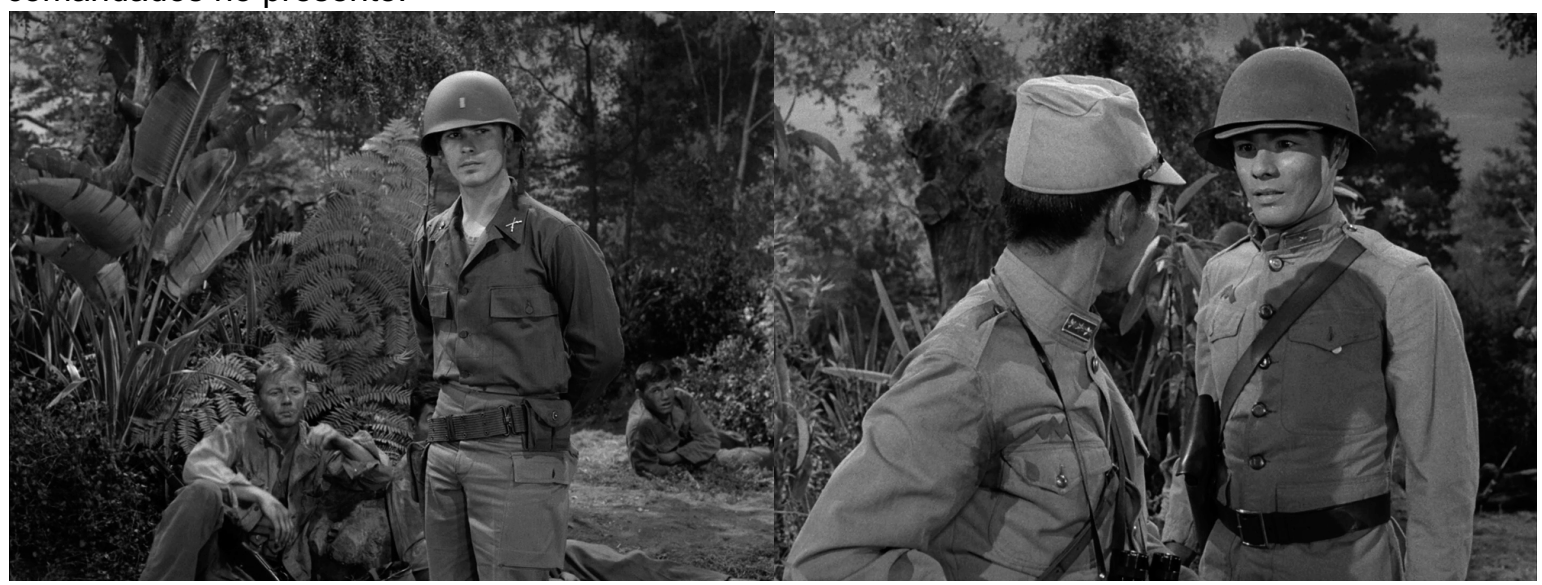

Fonte: elaborado pelo autor (Blu-ray, The Twilight Zone: The Complete Series, CBS, 2017)

Ao contrário de obras que faziam apologia à Segunda Guerra Mundial nas mídias em geral do período, a série Além da Imaginação sempre se apresentou como crítica a quaisquer guerras, principalmente mostrando-as pelo dia a dia e pelas condições dos soldados, retirando o heroísmo do fato de se matar mais ou realizar operações ousadas e colocando-o no ato de se sobreviver mantendo valores humanos básicos, como é o caso da misericórdia nesse episódio.

Essa noção tem total conexão com a biografia de Rod Serling, a sua participação na Segunda Guerra nas Filipinas (local onde se passa o episódio) em combates extremamente violentos, marcou profundamente as suas visões sobre a humanidade e a falta de sentido na guerra. Estas análises críticas sobre a prática social da guerra, principalmente defendendo a tese de que só há perdedores na guerra, estariam presentes em uma série de episódios tanto de sua autoria quanto de outros escritores que retratavam a temática seguindo o mesmo viés e, por isso, faziam-se presentes em Além da Imaginação. Assim, encontramos, por exemplo, os 
episódios The Purple Testament (1960), The Passersby (1961), Still Valley (1961), In Praise of Pip (1963) e The Encounter (1964).

Outro episódio de viagem no tempo mágica, criticaria a televisão do período e a apropriação da História para narrativas vazias e formuláicas, reforçando mitos da História dos EUA. Apelando para o humor, Rod Serling iria satirizar e ironizar o principal gênero de programas televisivos da época, o western. No episódio Showdown with Rance McGrew, encontramos um exame bem humorado de Serling sobre como o gênero era geralmente exibido na televisão.

\subsection{4- Showdown with Rance McGrew}

Em 2 de fevereiro de 1962, após filmagens em meados de outubro de 1961, foi ao ar Showdown with Rance McGrew, o $85^{\circ}$ episódio da série e $20^{\circ}$ da terceira temporada. O programa, escrito por Serling, foi dirigido por Christian Nyby e estrelado por Larry Blyden, Arch Johnson e Robert Cornthwaite, com custos totais de produção de USD\$50.486,33 (GRAMS JUNIOR, 2008, p.476; ZICREE, 1992, p.258).

Rance McGrew é um ator arrogante, que faz sucesso como cowboy heroico de mesmo nome em um programa de televisão, lutando tanto contra bandidos genéricos do velho oeste quanto contra os mais famosos, sempre utilizando dublês em cenas forçadas totalmente clichês. Suas aventuras incomodam os espíritos dos vilões do passado que pedem que o famoso ladrão Jesse James dê uma lição em McGrew. $O$ ator é transportado ao passado para ver como era realmente a vida naquela época e passasse a respeitar a História dos vilões e dos homens que viviam no Velho Oeste. Sendo finalmente desafiado para um duelo por Jesse James, o covarde McGrew acaba reconhecendo suas limitações e retorna ao presente, agindo de forma mais humilde e deixa de ser um herói infalível em aventuras irreais. Para cuidar desse renovado McGrew, Jesse James torna-se seu empresário e consultor.

O roteirista Frederic Louis Fox expôs a Rod Serling a ideia de um vaqueiro contemporâneo sendo transportado ao passado e tendo que viver no período da conquista do Oeste, um conceito originalmente sério transformado em cômico por Serling ao mudar a profissão do vaqueiro para ator e explorar a ideia de como seria se um ator contemporâneo tivesse que viver realmente como o personagem que encenava, nas condições reais de tempo e espaço. Rod Serling afirmava imaginar como o ator John Wayne se comportaria se tivesse que realmente participar das 
guerras que encenava, e explorou essa noção para criar o desastrado Rance McGrew (ZICREE, 1992, p.269). Serling agradeceria à Fox por ter criado o conceito inicial da narrativa e lhe deu crédito e pagamento pela ideia, mesmo que o roteirista tivesse escrito Showdown with Rance McGrew sem ter consciência de que estava emprestando a concepção que ouvira de Fox (GRAMS JUNIOR, 2008, p.478; SERLING, 1961r10, n.p.). Uma versão adaptada do roteiro foi publicada por Serling no livro New Stories from the Twilight Zone, livro composto por seis contos adaptados de roteiros de Serling, escritos pelo próprio, publicado em 1962 no livro New Stories from the Twilight Zone.

Figura 35 - $\mathrm{O}$ ator Rance McGrew chegando para filmar um episódio de sua série de Velho Oeste.

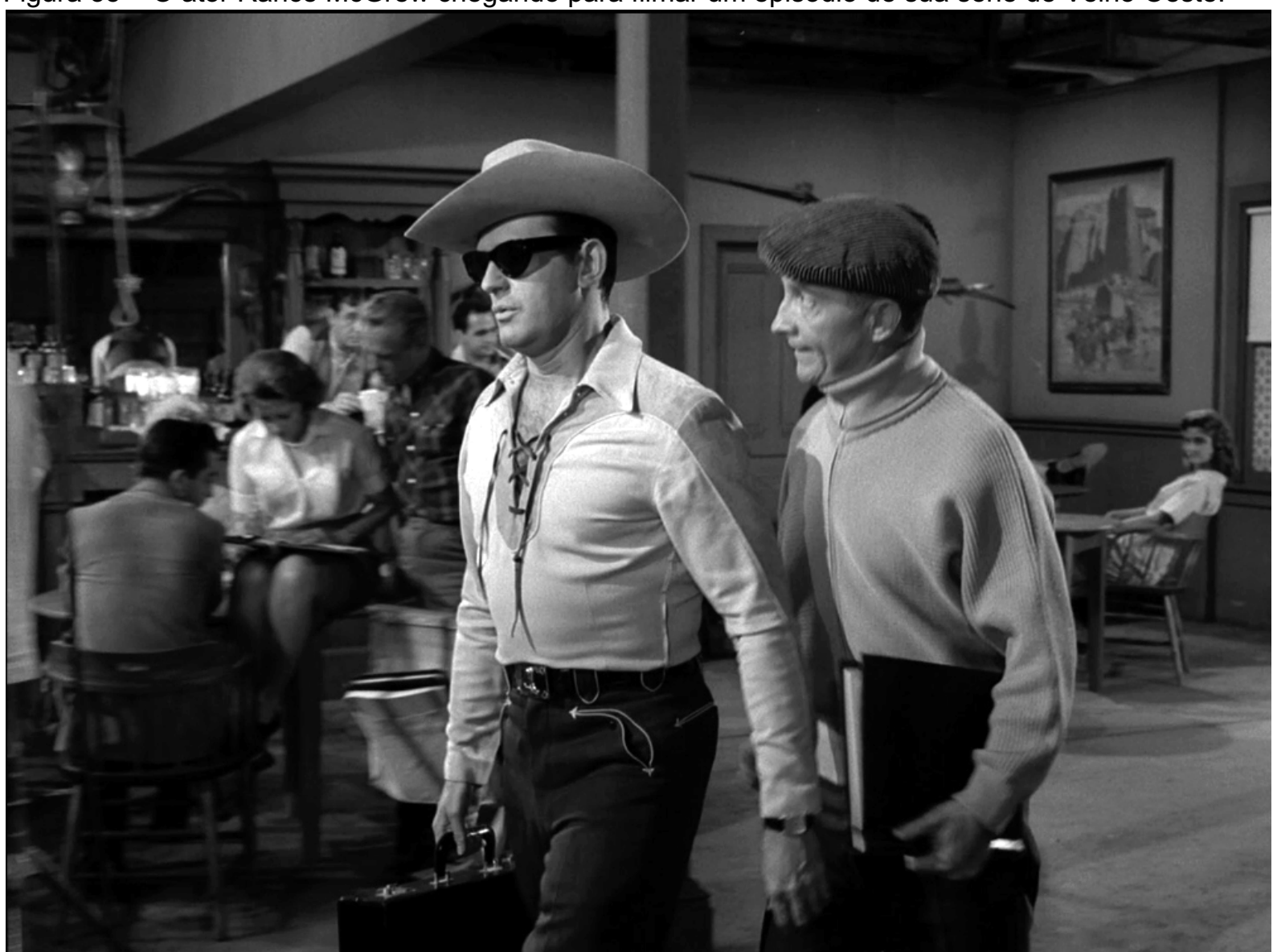

Fonte: elaborado pelo autor (Blu-ray, The Twilight Zone: The Complete Series, CBS, 2017)

Em uma das versões iniciais do roteiro de 20 de setembro de 1961 (SERLING, 1961r10), o bandido que ensinaria a lição para McGrew e se tornaria posteriormente 
seu empresário era Billy the Kid e não Jesse James $^{60}$, esse fato, complementado pela citação de outros bandidos em diferentes versões dos roteiros mostram que não havia uma real preocupação de Serling em retratar os criminosos como entidades individuais, mas apenas fazer alusão a nomes da própria cultura popular sobre o Velho Oeste, expondo uma história na qual tanto faz o bandido, os nomes são intercambiáveis. Os objetivos da narrativa seriam outros e não expor as ações dos malfeitores. Sem especificar seus feitos, a função do bandido é a de revelar a falsidade das ações do herói e não aprofundar questões pessoais ou históricas desses personagens. Isso nos permite compreender com mais profundidade a visão do pesquisador e crítico Marc Scott Zicree (1992, p.269) sobre este episódio. Zicree considera, acertadamente, que no episódio, o Oeste "real" e seus personagens "históricos" são tão falsos quanto o Oeste das séries de televisão que Serling visava criticar. Mesmo tentando problematizar o mito, Serling não conseguiu escapar dele.

Assim como grande parte dos episódios de viagem no tempo escritos por Serling, Showdown with Rance McGrew, também não explica como os fantasmas do passado administram a viagem no tempo. Eles têm o poder de transportar Rance McGrew para o período histórico quando estavam vivos para que ele experimente como era o passado e não a farsa que fazia na televisão. Assim, a viagem no tempo ao passado é utilizada neste episódio como forma de se reafirmar a verdade dos fatos passados, contra mentiras da versão de uma cultura histórica comercial dominante, que mentia para atender aos anseios do público. Assim como toda viagem no tempo deve lidar com a expectativa do público sobre o passado, esse episódio subverte o papel do herói da televisão, mostrando que ele não seria capaz de viver no Velho Oeste "real", em uma crítica da mídia que a própria série Além da Imaginação utilizava para difusão de suas ideias.

As piadas do episódio envolvem a inadequação das noções do presente sobre o passado, a ignorância sobre como eram as condições sociais e a vida dos personagens transformados em mitos pelo presente são expostas para rirmos das desventuras de Rance McGrew. O próprio fato do malfeitor Jesse James virar empresário de McGrew critica, usando o humor, o papel do empresário de atores.

\footnotetext{
${ }^{60}$ Há duas versões do roteiro de número 86, uma com o nome Billy The Kid e outra com Jesse James, este foi o roteiro produzido o que indica que o nome foi alterado entre 20 de setembro de 1961 e os inícios dos ensaios em 16 de outubro de 1961. Na versão publicada em forma de conto em 1962 é Jesse James que entra em contato com o cowboy de televisão.
} 
Esse tipo de ironia e brincadeira com a mídia era característica da obra de Serling e seria explorado de forma bem mais interessante no episódio da quarta temporada The Brad (1963), na qual um fracassado aspirante a roteirista invoca em um ritual de magia o fantasma de William Shakespeare para escrever programas de televisão, um episódio cômico que faz uma ampla crítica a todos aspectos da produção audiovisual do período.

O mundo retratado no episódio é eminentemente masculino, ou seja, os temas de luta e coragem associados ao mito do Oeste são enfatizados. O próprio passado retratado no episódio apresenta homens rústicos, reforçando a visão de que eles sim eram realmente destemidos e brutos, e não seus correspondentes no presente. A atuação de Rance McGrew é a todo momento apresentada como boba e falsa, pois ele não seria tão homem quanto os homens reais do passado, que bebiam álcool e não refrigerante de gengibre, por exemplo. Porém, esse retrato de um passado "macho" serve mais para criticar a falsa representação de homem que a televisão, e por extensão o próprio gênero western em geral, faziam do passado, pois os homens que representavam esses "machos" do passado eram covardes e não detinham as qualidades que emulavam. Obviamente, essa crítica recorre a um imaginário profundo do mito do Oeste na cultura americana, ainda recorrente, visto como representação de um passado comum dos EUA.

O episódio expõe a noção da mitologização da História versus História, sem conseguir fugir do mito, cabe destacar. É citado que os personagens históricos ficaram indignados com a apropriação que uma cultura histórica popular comercial faz do passado e resolvem agir, demonstrando ao presente, no caso o ator, como era o passado, ao transportá-lo para lá. Expondo as diferenças entre o passado vivido e pela visão realizada na televisão do período, os fantasmas do passado procuravam intervir na qualidade do material produzido no presente, preocupados, não só porque são retratados de forma errônea, mas com baixa qualidade e de forma simplória e sem desenvolvimento de personagem - assim, recorrem ao clichê do duelo na frente do bar para assustar o ator.

Esse episódio não seria o único a usar a viagem no tempo para criticar a conquista do Oeste e a visão positiva de uma cultura histórica popular sobre esse período, como veremos adiante em The 7th Is Made Up of Phantoms. Assim, a série de Rod Serling, vista pelo conjunto de episódios que lidam com o tema da fronteira, não necessariamente exibindo a viagem no tempo, criticava a violência e 
desumanização da conquista do Oeste pelos brancos, porém reafirmava a parte da visão do Oeste como local de provações. Assim, a série não duvidava da noção do Oeste como fundamental na História americana e formador do caráter identitário fundamental do americano - exemplificadas na cultura dos EUA por toda uma série de iconografias e representações que influenciaram e foram influenciadas pelas performances da trupe de William Frederick "Buffalo Bill" Cody, e pelo influente historiador Frederick Jackson Turner (WHITE, 1994, p.11). O primeiro realizava shows pelos EUA encenando adaptações livres da História do Oeste, referendadas por seu testemunho de primeira mão e o segundo, autor do respeitado ensaio The Significance of the Frontier in American History, de 1893, que propunha que as instituições americanas, bem como a sua sociedade, se formaram em decorrência da ação de homens comuns na fronteira, ambiente que separava a civilização dos locais hostis e selvagens (JUNQUEIRA, M.A. apud KNOSS, 2004, n.p.) ${ }^{61}$.

Rod Serling falava de dentro de um discurso comum do credo americano e mesmo que criticasse a conquista do Oeste, esses comentários estavam ancorados nos termos dos direitos humanos, como a desaprovação do extermínio dos povos indígenas e o racismo. Entretanto, a ideia de que o americano foi moldado nas adversidades da fronteira está presente na série e não é colocada à prova, este entendimento, por exemplo, reforça a comicidade do ator metido a cowboy, exposto como incapaz de viver na verdadeira fronteira.

Ao criticar diretamente as séries de western do período, por extensão, a nostalgia é atingida. O objetivo do episódio não é lidar diretamente com o tema da nostalgia, utilizando a viagem no tempo como reforço à crítica desse sentimento histórico, como os episódios citados anteriormente; porém, como o apelo e sucesso do western no contexto da exibição da série era pautado pela exposição de um passado idealizado, no qual havia um bem e um mal claramente definidos (até pela cor da roupa), soluções simples (geralmente na base da violência) para os problemas, a exposição de uma terra de liberdade pronta para ser conquistada pelos que tinham os valores certos para enfrentar os dilemas. Ao apresentar qualquer elemento que podia colocar em dúvida parte da representação do Oeste, Serling acaba por minar

${ }^{61}$ Cabe destacar que no contexto da série as ideias de Turner eram criticadas de forma mais contuntende, como o trabalho influente do historiador Richard Clement Wade, publicado em 1959, The Urban Frontier, ou as noções mais complexas da fronteira que surgiam no início dos anos 60 no trabalho do historiador Jack Forbes (LIMERICK In: GROSSMAN, 1994, p.76). 
os ímpetos nostálgicos de parcelas significativas do público televisivo dos anos 50 e início dos 60. Assim, em Showdown with Rance McGrew, quaisquer sentimentos nostálgicos são vistos como falsidades criadas pela cultura popular e reforçados por uma televisão de baixa qualidade.

Figura 36 - Jesse James (com roteiro na mão), agora empresário de McGrew, revisa os episódios para tornar o programa mais realista - para sofrimento de McGrew.

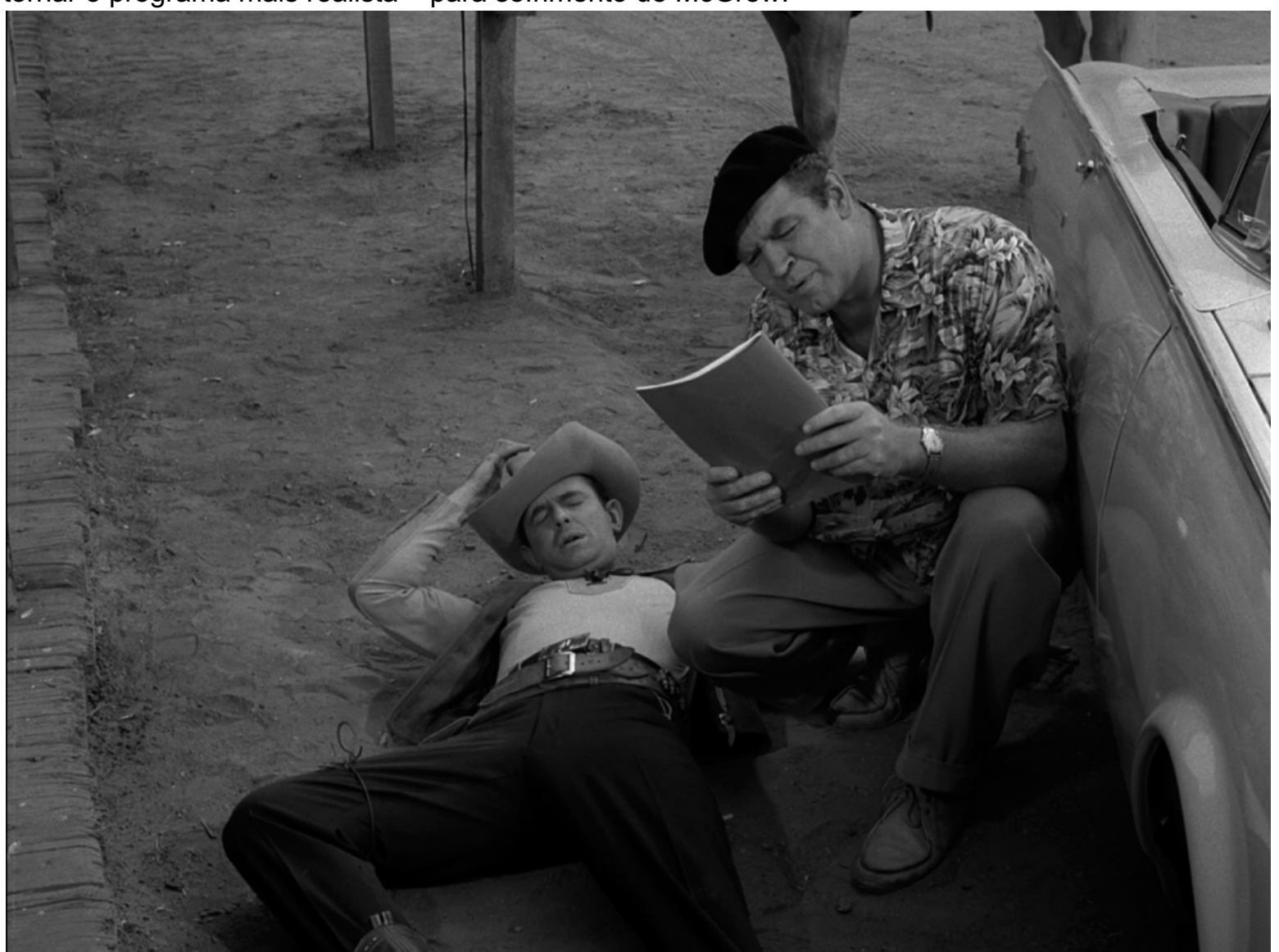

Fonte: elaborado pelo autor (Blu-ray, The Twilight Zone: The Complete Series, CBS, 2017)

Serling percebia que o tratamento desse período em mito simplificado na televisão seria tão danoso à mídia quando à sociedade em geral, pois estaria infantilizando a audiência e deliberadamente mentindo, não propiciando uma reflexão voltada à alteração e ao aperfeiçoamento das instituições do presente, mas sim à busca de respostas simples (bem versus mal, ambos bem definidos e unidimensionais) e até anacrônicas para problemas complexos dos EUA, como os já citados conflitos raciais, reconfiguração das famílias, Guerra Fria, suburbanização, anticomunismo e comunismo.

Cabe destacar, porém, que Rod Serling não menosprezava o gênero western, mas sim sua simplificação na televisão e o não aproveitamento desse gênero nessa 
mídia para fazer grandes reflexões sobre o cotidiano e a natureza humana. Isso pode ser provado na sua malfadada tentativa de criar e escrever uma série de western para a CBS logo após o cancelamento de Além da Imaginação. A série The Loner, que durou apenas uma temporada entre 1965-1966, tinha como proposta inicial apresentar um drama realista sobre o Oeste, com comentários sociais, procurando escapar dos clichês criticados em Showdown with Rance McGrew.

$\mathrm{Na}$ quarta temporada, seria exibido um episódio que ampliaria a ideia de se alterar tragédias do passado expostas no piloto não oficial da série, The Time Element, e em Back There. No Time Last The Past, exploraria a tentativa de se alterar o presente por meio da ação no passado em momentos chave, criando novas possibilidades de futuros, alterando o rumo da História humana que caminharia para um futuro desastroso, na visão do personagem principal.

\subsection{5- No Time Like The Past}

A quarta temporada de Além da Imaginação teve dezoito episódios de uma hora de duração, dois retratariam a viagem no tempo ao passado não nostálgico, como forma de se alterar o presente e trariam discursos semelhantes sobre a capacidade humana de mudar seus rumos por meio da viagem no tempo. Ambos episódios serviriam mais como conscientização do presente, levando o público a refletir o que é necessário para alterar as condições cotidianas a fim de criar um futuro melhor, duvidando de ações individuais como formas de mudar o presente. Essa noção, exposta nos episódios, é condizente com o amplo corpo da série e do trabalho de Rod Serling.

O $10^{\circ}$ episódio exibido nessa temporada (7 de março de 1963 ) e o $112^{\circ}$ que foi ao ar pela série, No Time Like The Past, custou USD\$155.473,57 e foi dirigido por Justus Addiss e estrelado por Dana Andrewsm Marjorie Bennett e Patricia Breslin. Somos apresentados à história de Paul Driscoll, um cientista descontente com o presente e sem quaisquer perspectivas de futuro. Com a ajuda de um amigo, Driscoll opera uma máquina do tempo que o transporta para uma série de contextos históricos que ele deseja alterar: avisar os habitantes de Hiroshima para fugirem antes da bomba atômica cair, matar Hitler na ascensão do nazismo e impedir o afundamento do navio Lusitânia em 1915. Todas ações de Paul são fracassos retumbantes e o pobre cientista desiste de alterar o passado para melhorar o presente e futuro e utiliza a 
máquina do tempo para escapar de sua época, indo para o final do século XIX, mudando para a cidade de Homeville. Lá, começa uma relação com a professora da escola e promete para si não intervir mais no passado. Porém, ao ler num livro que levara consigo que haveria um incêndio na escola, ferindo as crianças, Driscoll tenta impedir e acaba sendo, ele próprio, o causador do incidente. Desapontado, mas com uma nova perspectiva sobre a responsabilidade humana, resolve voltar para seu próprio tempo.

Esse episódio é o primeiro de viagem no tempo da quarta temporada e, como veremos, nota-se a repetição de ideias expostas de forma mais poética e relevante nas temporadas anteriores, o que não desvaloriza o episódio como um documento histórico da própria produção da série e da crítica realizada no contexto da Guerra Fria da negação do presente e desistência do futuro, ou mesmo, a própria adaptação dos indivíduos à condições sociais indesejadas por falta de perspectiva. O comentário dos temas cotidianos do contexto da série se manifesta, nesse programa, na tentativa de Driscoll fugir deles e na lição final aprendida de que deve lutar no presente por um mundo melhor.

Vemos Serling tangenciar o tema da nostalgia, tão caro para o autor. A aventura se passa em grande parte em Homeville, Indiana, uma cidade fictícia similar as exibidas em Walking Distance e A Stop at Willoughby, inclusive com a exposição de vários ambientes em comum, senão os mesmos, reforçados pelas falas de fuga do presente de Driscoll, para uma época mais tranquila. Novamente, de forma didática, Serling expõe os motivos dessa fuga e abadono de um presente sem perspectivas de futuro, marcado por tragédias e desrespeitos a dignidade humana. Reiteradamente são citadas as armas nucleares, as guerras do século $X X$, os massacres a civis pelo mundo e uma escalada do irracionalismo como justificativas de Driscoll para mudar o passado e fugir para 1881.

$\mathrm{Na}$ perspectiva exposta no episódio, Driscoll é um incomodado com as condições humanas de seu contexto histórico. Por exemplo, Serling mostra, no passado, uma versão do século XIX para os discursos que abominava em sua época: vivendo na pensão, Driscoll, sentando à mesa de jantar, ouve os discursos de Hanford, um banqueiro nacionalista belicoso, que defendia que os EUA deveriam exterminar os povos indígenas que atrasavam o desenvolvimento e se impor externamente para formar um império no mundo, "plantando a bandeira americana em todos os lugares". Driscoll se irrita com a fala do banqueiro e, visivelmente 
incomodado, procura desconstruir seu discurso, afirmando que ele defendia guerras e mortes dos outros porque não seria ele que iria morrer e que, no futuro, teriam muitas mortes estúpidas causadas por esse tipo de ideia, mortes que o banqueiro sequer veria, pois seria em um tempo no qual ele já teria morrido de velho. Serling usa o discurso do banqueiro e a resposta de Driscoll para criticar o espírito de americanos, especificamente alinhados a visões nacionalistas da época da Guerra Fria, que defendiam o escalonamento do conflito com a URSS, sem considerar a vida no planeta. Isso fica claro no episódio pela constante citação da bomba atômica e do risco de uma nova guerra mundial como razão para a fuga de Driscoll ao passado. Ao voltar para o passado e ouvir uma versão prévia do mesmo tipo de discurso imperialista corrente na década de 50 e início dos anos 60, Driscoll se irrita e perde a paciência; entretanto, o alvo dessa sequência são as parcelas do público que se alinhavam com a visão do excepcionalismo americano, levando à imposição das vontades dos EUA pelo mundo, noção difundida largamente durante a Guerra Fria.

Figura 37 - Máquina do tempo que leva Driscoll ao passado. Não são dadas muitas explicações de como ela funciona.

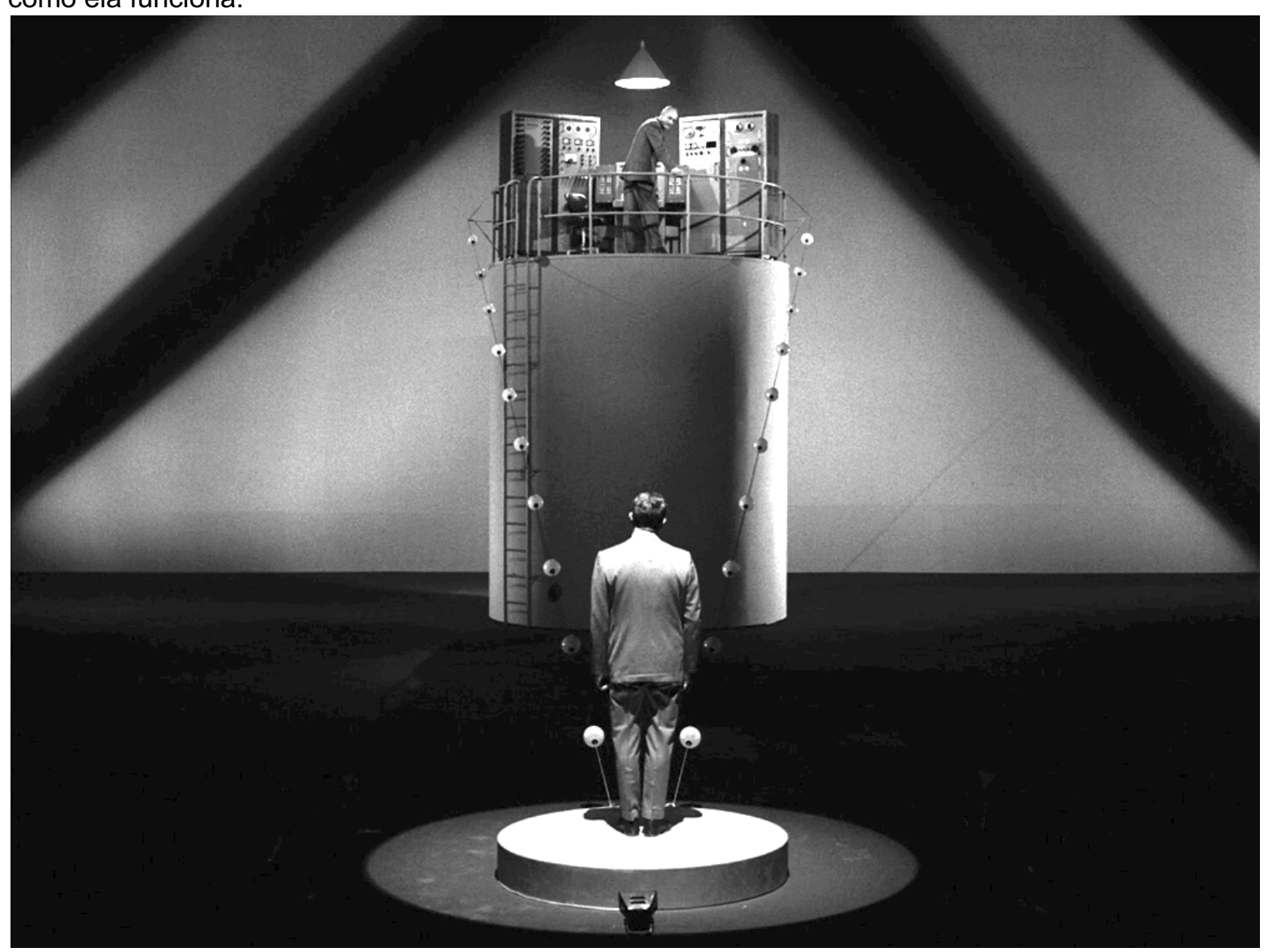

Fonte: elaborado pelo autor (Blu-ray, The Twilight Zone: The Complete Series, CBS, 2017) 
Nas primeiras versões do roteiro, como aquela datada de 20 de julho de 1962 e a sexta, de 24 de julho de 1962 (SERLING, 1962r7), Paul Driscoll iria até o apartamento de seu ex-professor de Física se informar dos seus avanços no desenvolvimento de uma máquina do tempo, em forma de braceletes, e convencê-lo do uso de tal aparelho para escapar do complicado presente para um passado idílico - os braceletes que faziam a viagem no tempo foram abandonados posteriormente para serem substituídos por um equipamento mais imponente e verossímil. Nessas versões, ainda não se encontram as ações de Driscoll para mudar os rumos da História (evacuar Hiroshima, assassinar Hitler, impedir o naufrágio do Lusitânia), há só a tentativa de interferência do ex-professor de Driscoll, que enviou objetos ao passado, como uma caneta para a Liga das Nações nos anos 20, que voltaram quebrados, em clara alusão à impossibilidade de se alterar ao passado apresentando a fórmula que será reafirmada pela posterior ação de Driscoll como causador do incêndio na escola, registrado no livro que lera.

Esse enredo seria posteriormente revisado e enriquecido no decorrer do ano de 1962, inclusive por interferência direta do produtor Hirschman, como a sugestão de que fosse exibido para o público o protagonista sendo informado da necessidade de roupas e dinheiro de 1881 ou o produtor pedindo alteração nos diálogos, pois a escola que seria totalmente queimada no roteiro original não condizia com a escola de tijolos que seria utilizada na filmagem, portanto o incêndio não a destruiria totalmente (HIRSCHMAN, 1962a, p.1-3; 1962b, p.1-2). As crianças, em todas as versões, seriam gravemente queimadas, mas sobreviveriam, sem exibição delas em cena e sem mortes, nos padrões esperados na televisão do período, com autocensura e regras claras do que podia ou não ir ao ar, mais causando desconforto pelo sugerido do que pelo visual.

O episódio chegou a ser refilmado, com grandes alterações e na versão final que foi ao ar, o fato de Driscoll tentar mudar em vão o passado, enfatiza a crítica social. O protagonista tenta evitar fatos que violavam a dignidade e os direitos humanos, o empenho em evacuar Hiroshima antes da bomba atômica corrigiria a morte de inocentes no final da Segunda Guerra Mundial, a morte de Hitler em agosto de 1939 seria uma tentativa de evitar a própria Segunda Guerra, evitando inclusive a destruição de Hiroshima e, recuando a 1915, a pretensão de salvar o transatlântico inglês Lusitânia do torpedo alemão, procurava impedir a entrada dos EUA na Primeira Guerra Mundial, já que a morte de americanos no navio de passageiros britânico, que 
levava armamento escondido para a Europa (PEEK, STEVE, WALSH, 2002, p.259) desencadeou sentimentos antigermânicos nos EUA, principalmente na Costa Leste (SONDHAUS, 2015, p.342) ${ }^{62}$, e foi um evento simbólico nas relações entre EUA e Império Alemão no contexto da guerra.

Assim, ao falhar miseravelmente na tentativa de alterar a História e criar uma nova linha do tempo no qual desastres causados por seres humanos seriam evitados, Driscoll percebe que é impossível alterar o passado e resolve recorrer a fuga nostálgica, causando ele mesmo uma catástrofe que não pôde evitar, pois ela já estava prevista no livro que carregava, ou seja, já estava inserida na História seu retorno ao passado. A lição que o protagonista aprende, expressa em diálogo, é a de que ele deve lutar para mudar o amanhã que ainda não ocorreu, na perspectiva moderna de futuro a ser construído no presente; a tentativa de se alterar o passado ou fugir do presente real é vã - as tragédias causadas pela humanidade não podem ser contidas no passado e tal tentativa seria causadora de mais dor por sua impossibilidade.

A viagem no tempo ao passado em No Time Like The Past, serve para instigar no público a imaginação do "e se...", ao apresentar momentos nos quais o passado poderia ser alterado e novos futuros especulados pela imaginação poderiam se formar. Por frustrar Driscoll, a viagem no tempo aqui se revela como uma forma de trazer o personagem e o público à consciência de que, se procuramos um futuro melhor, o presente é o local que demanda nossa ação e atenção.

Esse aspecto didático do episódio pode ser visto no próprio fato de apontar a tentativa de se evitar/amenizar tragédias humanas causadas por humanos e não eventos naturais catastróficos. A ação humana permeia todos desastres que presenciamos no episódio, não por acaso, dialogando com o conceito moderno de História: o contato com o passado serve para fazer uma reflexão para orientar as ações na construção do futuro. Assim, deve-se aprender e vislumbrar ações danosas

62 O ataque do transatlântico britânico Lusitânia em 1915 por submarinos alemães, que ocasionou a morte de mais de cem americanos entre mais de mil mortos, é visto na cultura histórica popular dos EUA como um dos motivos da entrada americana na Primeira Guerra Mundial, essa visão simplificada - e incorreta - é seguida por Serling nas séries Além da Imaginação e na Galeria do Terror (no episódio Lone Survivor). Para saber mais, ver a obra geral sobre a a Primeira Guerra Mundial do historiador Lawrence Sondhaus. 
humanas para que outras ações que violam a dignidade e os direitos humanos básicos não sejam aceitas no presente e futuro.

Essa ação humana consciente no tempo é reforçada pelo uso da máquina do tempo, o terceiro caso em toda a série, e a primeira com destino exclusivo ao passado. Em oposição aos meios mágicos anteriores de viagem no tempo ao passado, expostos nos episódios da série, o uso da máquina reforça a noção da tentativa de controle da História, domínio e controle humano das temporalidades/mudanças por meio de um instrumento humano construído para tal fim - algo que, no final, é exposto como ilusório e frustrado de forma radical na mensagem global da série, pois não se pode alterar o passado, como tragicamente Driscoll irá aprender.

Figura 38 - O final do século XIX idealizado é o foco principal da nostalgia na década de 50 e início dos anos 60 nos EUA.

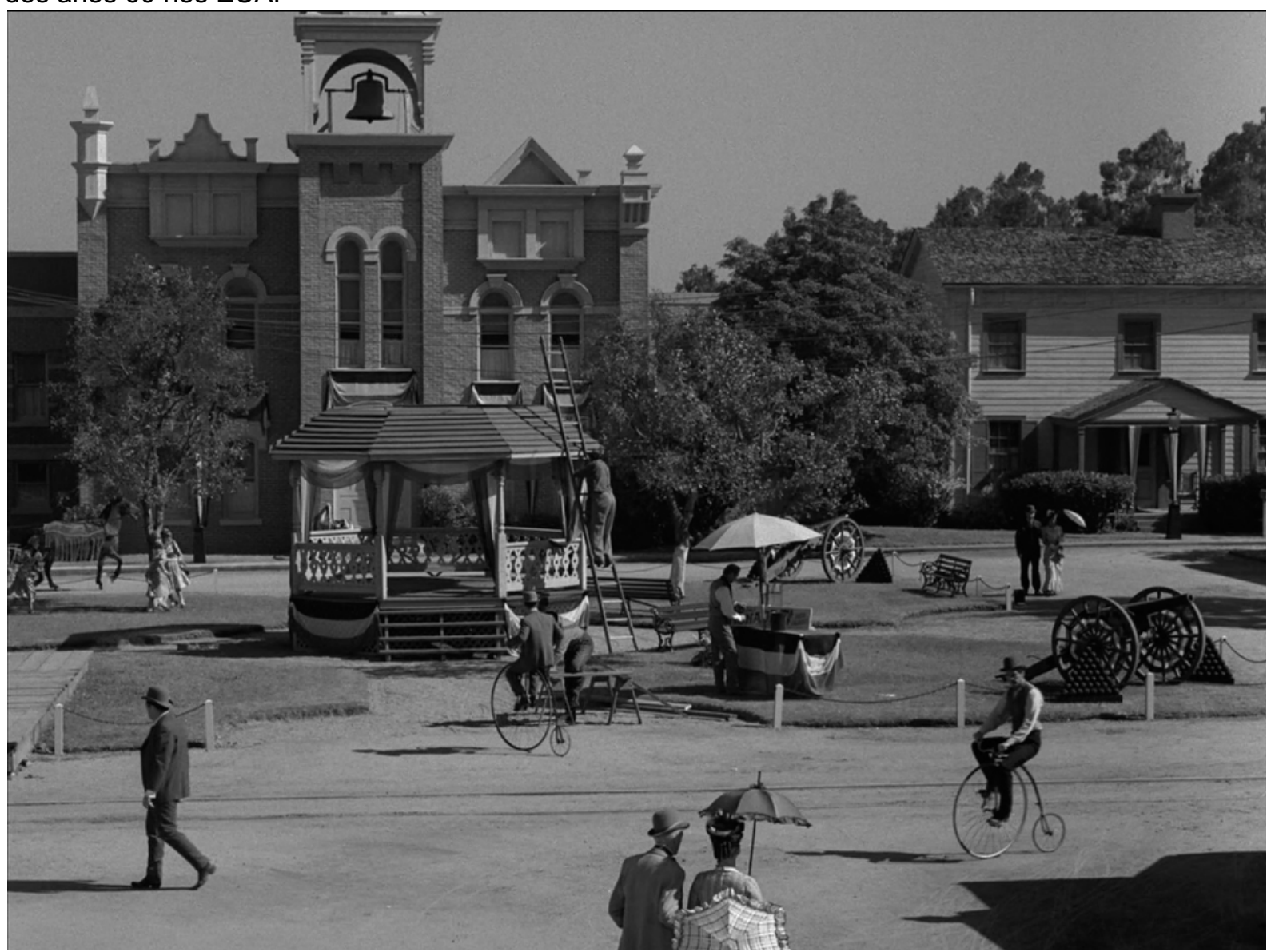

Fonte: elaborado pelo autor (Blu-ray, The Twilight Zone: The Complete Series, CBS, 2017)

Esse episódio é o primeiro que discute de forma clara a criação dos paradoxos e da reação em cadeia imprevisível que uma alteração do passado causaria por toda a História. O paradoxo discutindo, porém, não seguindo no modelo de universo proposto pelo episódio, é o modelo do conto O Som do Trovão de Bradbury. Cabe 
lembrar que a formação dos paradoxos ocasionados pela viagem no tempo era lugar comum nas histórias de viagem no tempo na literatura do período e algo que o público esperaria ser abordado e sua discussão estava ainda mais clara nas primeiras versões do roteiro, representadas no personagem do velho físico (SERLING, 1962r7, p.15), alterado por um amigo de Driscoll na versão final. No modelo de universo escolhido por Serling para este episódio, há a exploração do paradoxo do predestinado, ou seja, ao tentar impedir algo que ocorreu, o personagem se torna a causa do efeito que procurava conter. Mesmo assim, por meio dos diálogos expostos no episódio e nas versões iniciais do roteiro, nota-se que Rod Serling estava ciente dos paradoxos que poderiam ser explorados por esse tipo de aventura, mas deliberadamente não quis aprofundar esse problema, pois procurava atingir outros objetivos ao usar a viagem no tempo e não especular sobre os paradoxos. $O$ caso de amor entre o viajante e a professora e, muito mais, o sentimento de inadequação com o presente de Driscoll são explorados com mais afinco do que a problemática dos paradoxos.

Nesta mesma temporada, outro episódio sobre a viagem ao passado não nostálgico seria exibido. Em Of Late I Think of Cliffordville, o passado individual pode ser alterado e novas linhas do tempo são formadas, em uma história moralista que tocava num tema abordado regularmente por Serling: o mundo empresarial que ascendeu no crescimento econômico dos EUA do segundo pós-guerra.

\subsection{6- Of Late I Think of Cliffordville}

Este episódio foi o $14^{\circ}$ da quarta temporada, $116^{\circ}$ da série, e foi exibido em 11 de abril de 1963. Produzido por Bert Granet, após a saída de Hirschman, dirigido por David Lowell Rich e estrelado por Albert Salmi, Guy Raymond, John Anderson, Julie Newmar e Wright King. Of Late I Think of Cliffordville foi filmado em fevereiro de 1963 e os custos totais de produção foram USD\$ 94.362,00 (GRAMS JUNIOR, 2008, p. 586, 587; ZICREE, 1992, p. 347).

Dono de um império empresarial, William Feathersmith não vê mais sentido em suas conquistas; seu último adversário, o empresário Diedrich, um homem que abrira suas portas para William quando ele se iniciou no mundo dos negócios, foi destruído e levado à falência de forma impiedosa por Feathersmith. Enfadado e embriagado, ao deixar seu escritório, após humilhar o faxineiro que havia crescido na mesma cidade 
onde William Feathersmith havia dado seus primeiros passos rumo a conquistar seu império empresarial, ele entra no elevador e vai parar em um estranho andar, onde uma agente de viagens, uma diaba, faz um acordo para transportá-lo de volta para 1910 na cidade de Cliffordville, cidade onde William tinha começado sua carreira de industrial. Ele queria recomeçar para ter o prazer de conquistar tudo de novo, pois a emoção da conquista não podia mais ser encontrada no presente. Atendendo ao pedido do homem, a diaba o transporta ao passado em Cliffordville, cobrando pela viagem quase todo dinheiro que Feathersmith possuia. Lá, o homem tenta utilizar sua experiência para ganhar dinheiro de forma fácil e estabelecer laços com a família do banqueiro da cidade, cortejando sua filha, que, por sua memória, era uma linda mulher. Feathersmith nota que suas memórias do passado eram, no mínimo, incompletas.

Tentando adquirir terras onde sabia haver petróleo, William é passado para trás pelo banqueiro e por Diedrich, os donos das terras que ele comprara, pois na época não havia tecnologia para extração petrolífera. Além disso, as demais pessoas da cidade não entendem suas orientações para criar novas tecnologias que seriam importantes no futuro, pois Feathersmith sabia quais as tecnologias que dariam dinheiro, mas não sabia, ele próprio, inventá-las e, para piorar, seu corpo, mesmo que externamente fosse jovem, internamente era o de um velho, com todos os problemas de saúde envolvidos, pois como ele não havia especificado que todo o corpo deveria ser feito novo na hora do trato com a diaba, apenas externamente ele era jovem. Ele não tinha sequer força física e vigor para tentar ganhar dinheiro de outra forma. Desesperado, William chama pela diaba e faz um novo acordo para retornar a sua época; porém, para conseguir dinheiro, vende por quase nada as terras onde futuramente seria explorado o petróleo para um jovem e preguiçoso cocheiro, seu futuro faxineiro. Assim, Feathersmith paga o valor pedido pela diaba e retorna ao futuro, porém um futuro alterado pelas ações no passado de William Feathersmith. Agora, no presente, os papéis se invertem, o antigo faxineiro é o dono do império industrial que pertencera a Feathersmith em outra linha do tempo e o antigo milionário é um humilde e simples faxineiro, sofrendo zombarias e humilhações de seu chefe. 
O roteiro de Of Late I Think of Cliffordville foi adaptado por Rod Seling da novelette ${ }^{63}$ Blind Alley, do escritor de ficçao científica Malcom Jameson, publicado originalmente na revista Unknown Worlds em junho de 1943 e, posteriormente, no livro Great Stories of Science Fiction (1951), editado por Murray Leinster. Além disso, o livro de coletâneas organizado por Rod Serling e publicado em 1963, Rod Serling's Triple W: Witches, Warlocks and Werewolves, reproduziria esse conto de Jameson na íntegra (GRAMS JUNIOR, 2008, p. 582; SERLING, 1963, p.36-81).

Figura 39 - William Feathersmith (em pé), mostra para Diedrich seu império empresarial nos EUA. No episódio, Feathersmith representa a pior face do capitalismo do segundo pós-guerra.

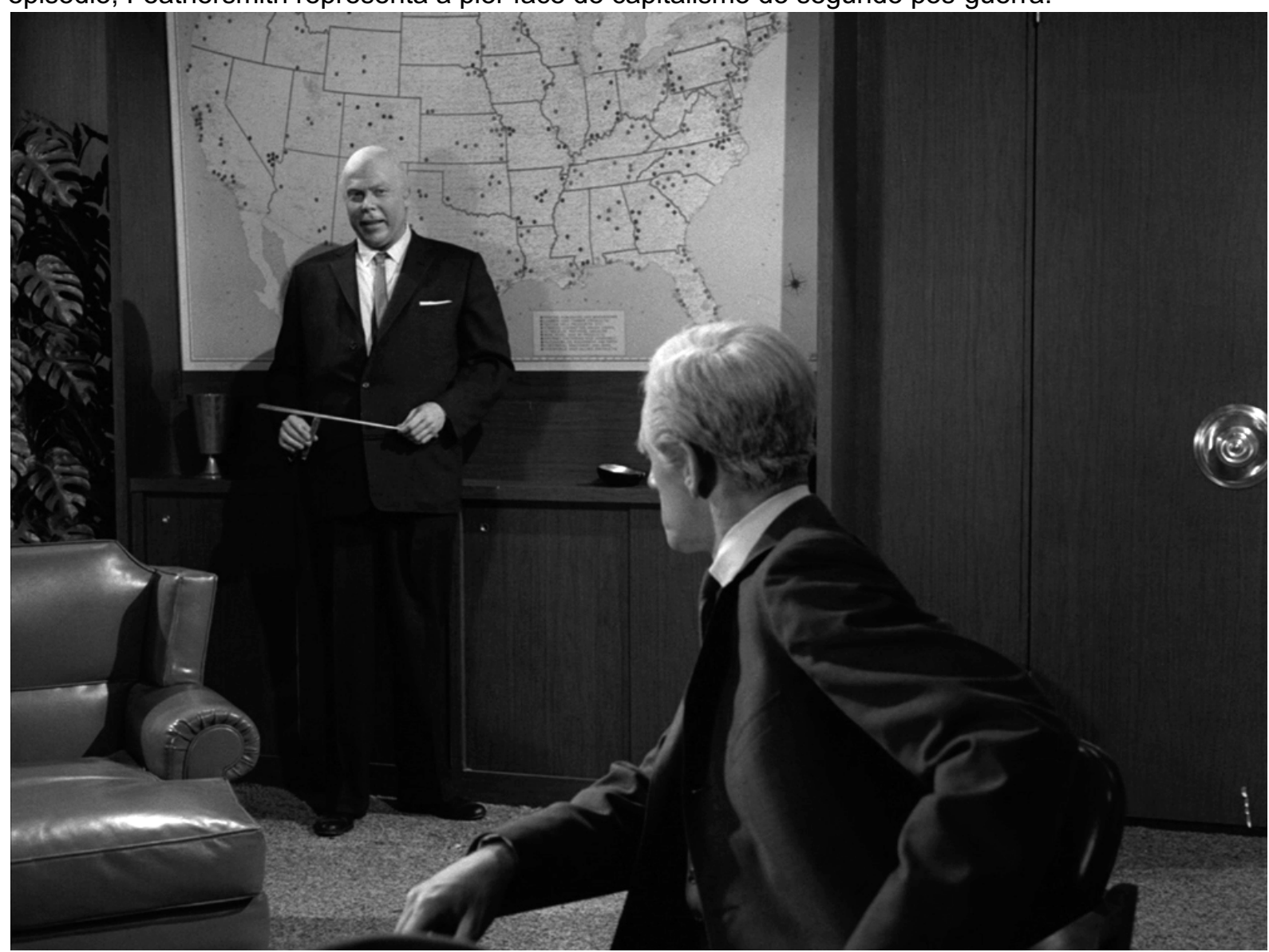

Fonte: elaborado pelo autor (Blu-ray, The Twilight Zone: The Complete Series, CBS, 2017)

A viagem no tempo, nesse episódio, segue o padrão da série de apresentá-la como algo sobrenatural e mágico. Se no episódio anterior, na mesma temporada, havia uma máquina do tempo, neste, a viagem no tempo mágica se dá por meio de ações demoníacas, inclusive a viagem no tempo do protagonista do episódio se dá

63 considerando o número de palavras, uma novelette é uma obra maior que um conto, mas menor que uma novella. 
por ação de uma diaba de sugestivo nome Devlin. Ela abre uma fantástica agência de turismo temporal no prédio de Feathersmith, só acessível a ele; lá, negocia os termos da viagem ao passado, atendendo aos desejos dele de forma literal, obviamente utilizando a esperteza demoníaca, o que não é notado inicialmente pelo personagem, que se coloca de igual para igual com a diaba na negociação dos termos de sua viagem ao passado. Nessa história, o empresário não pode vender sua alma, pois ela já estava marcada como posse do inferno, devido as maldades e os pecados que acumulara por toda vida, principalmente empresarial.

A viagem no tempo é exibida pelo transporte imediato de William para um avião onde é o único passageiro; lá, ele recebe a orientação do piloto de que o avião passou no fuso horário do estado de Indiana, EUA, e que os passageiros deviam arrumar os relógios. Ao mexer no relógio, atrasando-o uma hora, novamente se transporta para o passado, agora em 1910, a caminho de Cliffordville em um trem antigo. Os meios de transporte já explorados na série, como máquinas do tempo, o avião e o trem, são novamente recuperados para representar a viagem no tempo. As primeiras versões do roteiro em janeiro de 1963 apresentavam a viagem se dando inteiramente em trens, uma cena de trem moderno entrando no túnel e saindo dele como um trem antiquado, passando por um túnel escuro, foi a forma imaginada por Serling, inicialmente, para representar a viagem no tempo, que era, de certa forma, mais próxima da versão apresentada por Jameson no conto. A forma incialmente imaginada por Serling para a viagem ao passado neste episódio já havia sido relativamente utilizada em $A$ Stop at Willoughby. Na fonte original literária, o trem que faz a viagem leva horas, parando em cidades no caminho e recuando no tempo.

Reforçando a associação desses meios de transporte com a concepção moderna de tempo, ir do avião ao trem com vagões de madeira é passar para outra temporalidade, ao mesmo tempo em que a alusão à velocidade dos meios de transporte com o tempo é mantida: os transportes que encolhem o espaço, encolhem o tempo e subvertem sua direção.

Assim, temos exposta, nesse episódio, uma das principais formas pelas quais a viagem no tempo é realizada: meios de transporte reais ou fantásticos, associados com movimento e velocidade, remetendo tanto às teorias da Física sobre espaçotempo quanto aos símbolos modernos de progresso - voltar ao passado, passando do avião para o trem, é remeter a uma escala anterior, associada já ao passado. Portanto, mesmo que a senhorita Devlin use meios mágicos para levar 
Feathersmith ao passado, é por meio de símbolos de máquinas do tempo que a série exibe essa passagem.

Ao adaptar uma história publicada 20 anos antes, Serling enfatiza a crítica ao contexto do capitalismo do segundo pós-guerra, realizando alterações significativas no enredo: o conto era uma história que criticava a nostalgia pelo passado de um empreendedor inescrupuloso, mas não inteiramente desprezível, como no episódio da televisão. O Feathersmith de Jameson era um idoso com muitas similaridades aos próprios personagens nostálgicos de Serling, lamentando as mudanças pelas quais seu corpo e os EUA passaram nas quatro primeiras décadas do século $\mathrm{XX}$, além da própria violência da Segunda Guerra Mundial, sentindo profundamente a perda de uma época só existente em sua memória afetiva, ideias de passado compartilhadas por muitos leitores.

Figura 40 - O tema do pacto com o demônio é recorrente em Além da Imaginação, no caso, a viagem no tempo também pode ser acordada com uma diaba.



Fonte: elaborado pelo autor (Blu-ray, The Twilight Zone: The Complete Series, CBS, 2017)

Na obra literária, o protagonista faz um pacto com Satanás, que o leva ao passado, no qual descobre que suas lembranças estavam erradas e o passado era 
muito mais cruel e sem oportunidades. Esta temporalidade é retratada com muito mais ênfase do que no episódio, como um local atrasado e selvagem, e Feathersmith morre no passado, pois não tinha deixado claro para o demônio que gostaria de ter seu corpo e sua condição de saúde restaurados quando fizesse a viagem no tempo; sua péssima sáude, inclusive, era uma das principais motivações para realizar o pacto com o diabo de voltar no tempo. Ironicamente, se tivesse ficado no presente, teria uma sobrevida, pois existia tratamento em sua época, em um texto que reforça a ideia de progresso a todo momento, utilizando Feathersmith como exemplo de como pensamentos nostálgicos, sejam restaurativos ou reflexivos, não devem ser alimentados. Na obra de Jameson, o personagem apresenta lampejos de sabedoria e consegue aprender; já o Feathersmith de Serling é um ser abjeto, arrogante e ignorante. Ampliando a crítica, no enredo de Serling, vemos a Zona Crepuscular punindo exemplarmente o personagem, ao mesmo tempo que deixa uma mensagem que qualquer um do público poderia se tornar um Feathersmith.

Concordando com a crítica de Zicree (1992, p. 348), que afirma que a revelação no episódio de que o corpo de William Feathersmith era velho internamente é desnecessária para o enredo, pois acompanhando suas aventuras no passado, não vemos nada que demonstre que ele não estava bem, muito pelo contrário, ele parece sempre forte, e seu problema, como exposto de forma clara, estaria na sua mente e não em seu corpo: falta de caráter e de humanidade.

Observando o desenvolvimento do roteiro nos meses de janeiro de fevereiro de 1963, nota-se as preocupações de Rod Serling em explicar o que é visto no episódio, como, por exemplo, Feathersmith indo à casa de Dietrich para pedir um emprego, ao perceber que falhara em todas tentativas de ficar rico e devia começar como fizera na linha do tempo antes de voltar ao passado (SERLING, 1963r8, p.48), ou mesmo perceber que seus órgãos ainda eram de velho, mesmo que externamente fosse jovem, pois isso seria informado pelo médico da cidade, que estranhara seus batimentos cardíacos (SERLING, 1963r8, p.50,51). Outros detalhes que foram abandonados nas demais revisões e não chegaram a ir ao ar, como os diálogos que reafirmavam o papel de Feathersmith como um ser desprezível, que não se importava pelos demais humanos, como a presença de falas nas quais ele afirma suas intenções de destruir Dietrich (SERLING, 1963r8, p.16) e a substituição do gênero do demônio. Mais próxima da fonte literária, Feathersmith negociava com um demônio de nome Sam Demon, que cuidava do empreendimento "Desejos, Prognósticos, Viagem no 
Tempo" (SAM DEMON - Wishes, Prognostications - Time Travel), substituído por "Serviço de Viagens da Devlin" (Devlin's Travel Service) (SERLING, 1963r8, p.18), agência de viagens da diaba Devlin na revisão datada de 6 de fevereiro de 1963, uma substituição ao padrão de demônios masculinos presente na série, em um papel de destaque no episódio para Julie Newmar, que encenou uma diaba irônica tanto no trato com Feathersmith quanto na forma de retratar um demônio do mundo dos negócios, uma mulher empresária.

Figura 41 - Feathersmith encontra um passado bem diferente do que se lembrava. Seu retorno a Cliffordville no início do século XX se inicia com quase um atropelamento.

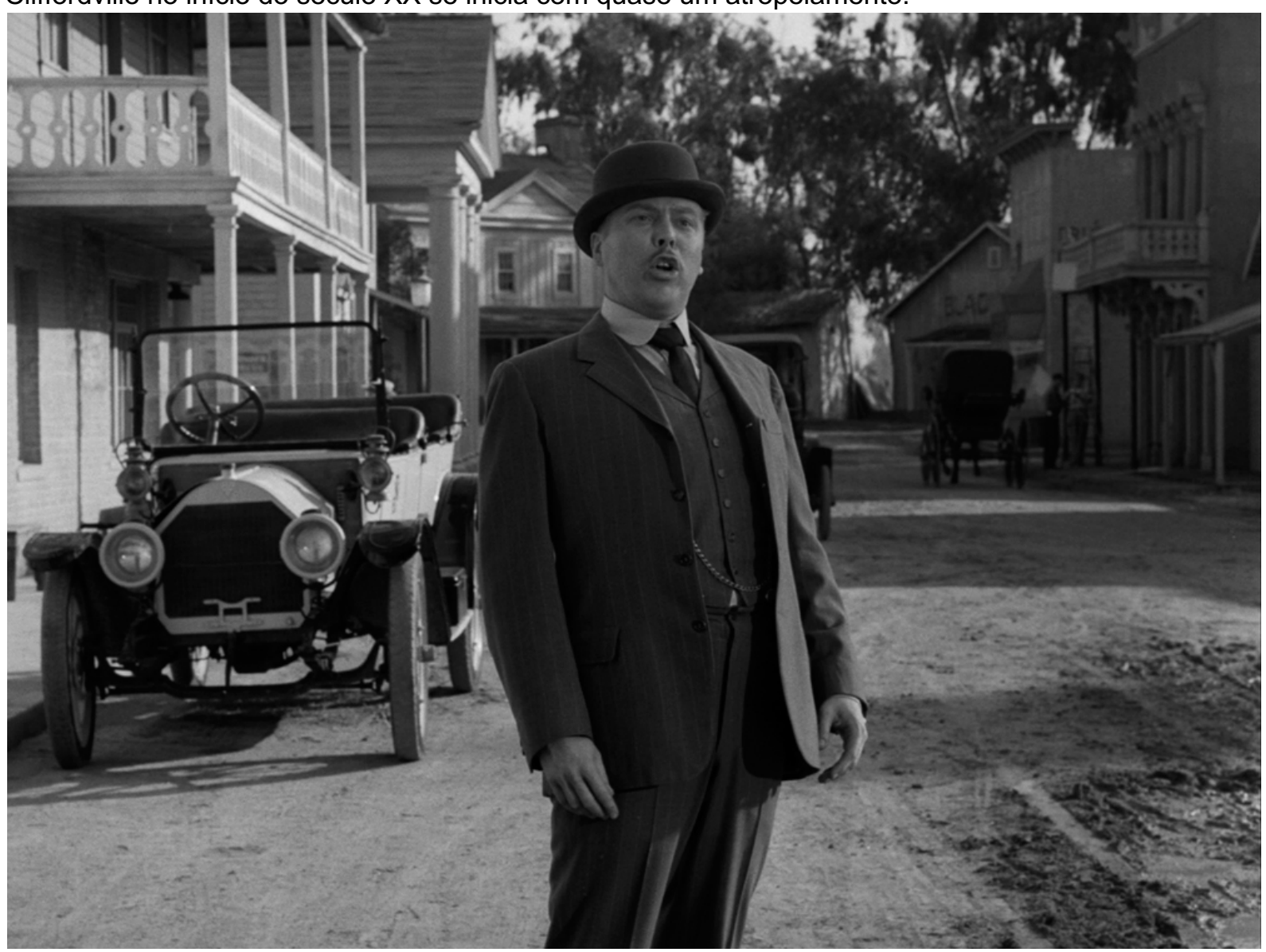

Fonte: elaborado pelo autor (Blu-ray, The Twilight Zone: The Complete Series, CBS, 2017)

O próprio episódio faz alusão a histórias conhecidas na cultura americana de viajantes no tempo: assim que chega ao passado, Feathersmith encontra Hecate dormindo (o servente que trabalharia para ele no futuro) e o acorda chamando-o de forma depreciativa de Rip Van Winkle, o dorminhoco viajante no tempo.

Cabe destacar que este episódio de viagem no tempo ao passado não nostálgico apresenta a alteração da linha do tempo. Os feitos de Feathersmith no passado mudam o presente individual, mas não têm a capacidade de alterar o mundo 
de forma significativa, pois Serling nos propõe a existência de um sistema muito mais amplo: a sociedade capitalista e o progresso se mostram como impossíveis de serem alterados no passado. Os rumos do protagonista mudam, ele acaba perdendo tudo e aprende a ser humilde, agora sofrendo humilhações do patrão insensível e sarcástico.

O tema do pacto com o demônio é parte da cultura ocidental ${ }^{64}$ e foi frequentemente exposto na série Além da Imaginação como forma de apresentar um discurso moralizante de fábula moderna na estrutura da Zona Crepuscular de procurar ensinar e punir personagens que desrespeitavam os direitos humanos e não se preocupavam com seus semelhantes.

O pacto com o demônio serve na série para expor para o público os defeitos de caráter dos personagens - e da própria audiência -, exibindo as consequências nefastas de se alimentar estes defeitos, como se pode observar no primeiro episódio da série a lidar com o tema, Escape Clause (1959), no qual um hipocondríaco egoísta vende sua alma ao diabo em troca de imortalidade. Achando-se mais inteligente que o demônio por pedir para ser imortal, assim nunca teria que entregar sua alma, aplica golpes acidentando-se propositadamente para ganhar dinheiro de seguros e sentir emoções fortes, o homem leva sua amorosa e preocupada esposa à morte. Assumindo a culpa perante a Justiça para receber a pena de morte e assustar os executores, que não poderiam matá-lo, acaba recebendo ironicamente a pena de prisão perpétua, só restando, então, o recurso da "cláusula de escape" do contrato assinado de venda da alma, ou seja, sua morte instantânea com a entrega da alma ao diabo. Essa narrativa expõe uma mensagem de que os problemas e desafios fazem parte da vida e que se deve tomar cuidado com o que se deseja. Parte dessas ideias, normais em acordos desse tipo e em histórias do tipo "três desejos", estão também presentes em Of Late I Think of Cliffordville. William é punido por sua necessidade constante da conquista de poder, dinheiro e prestígio, sempre às custas de outras pessoas cujas vidas ele despreza e arruína com deleite.

Esse episódio não é nostálgico, Feathersmith não parece ser capaz dessa emoção, o passado para ele é lugar de rapina, ambiente onde ele pode adquirir mais rapidamente as emoções de conquista e triunfo que tanto desejava e não sentia mais em 1963, pois já era dono de um enorme complexo industrial. Ele não sente falta das

\footnotetext{
${ }^{64} \mathrm{O}$ estudo comparativo de diversas versões dessa história de Jerusa Pires Ferreira, Fausto no Horizonte (1995), demonstra a amplitude e importância desse tipo de narrativa. No caso de of Late I Think of Cliffordville, a viagem no tempo é acrescentada ao tema tradicional.
} 
experiências do passado: seu lamento por coisas não realizadas está no campo de conquistas que poderia ter alcançado, mas não conseguiu porque estava ou trabalhando, ou não possuia as informações necessárias. Na história de vida de William, seu passado era utilizado para realçar, aos demais, seu caráter único e especial, pois seria um self-made man, um tipo de empreendedor especial que teria erguido um império industrial, começando sem nada, por seu próprio trabalho e força de vontade; assim, não há lugar para saudade do passado em si, mas do que mais poderia ter feito com seu espírito especial. Cabe destacar que, ao lidar com o mito do self-made man, este episódio tocava fundo numa das crenças principais do desenvolvimento capitalista dos EUA e Rod Serling era um crítico contumaz dessa noção.

Figura 42 - No final surpresa do episódio, Feathersmith alterou seu passado e se tornou faxineiro no prédio que na linha do tempo anterior era dono, se tornando uma pessoa humilde.

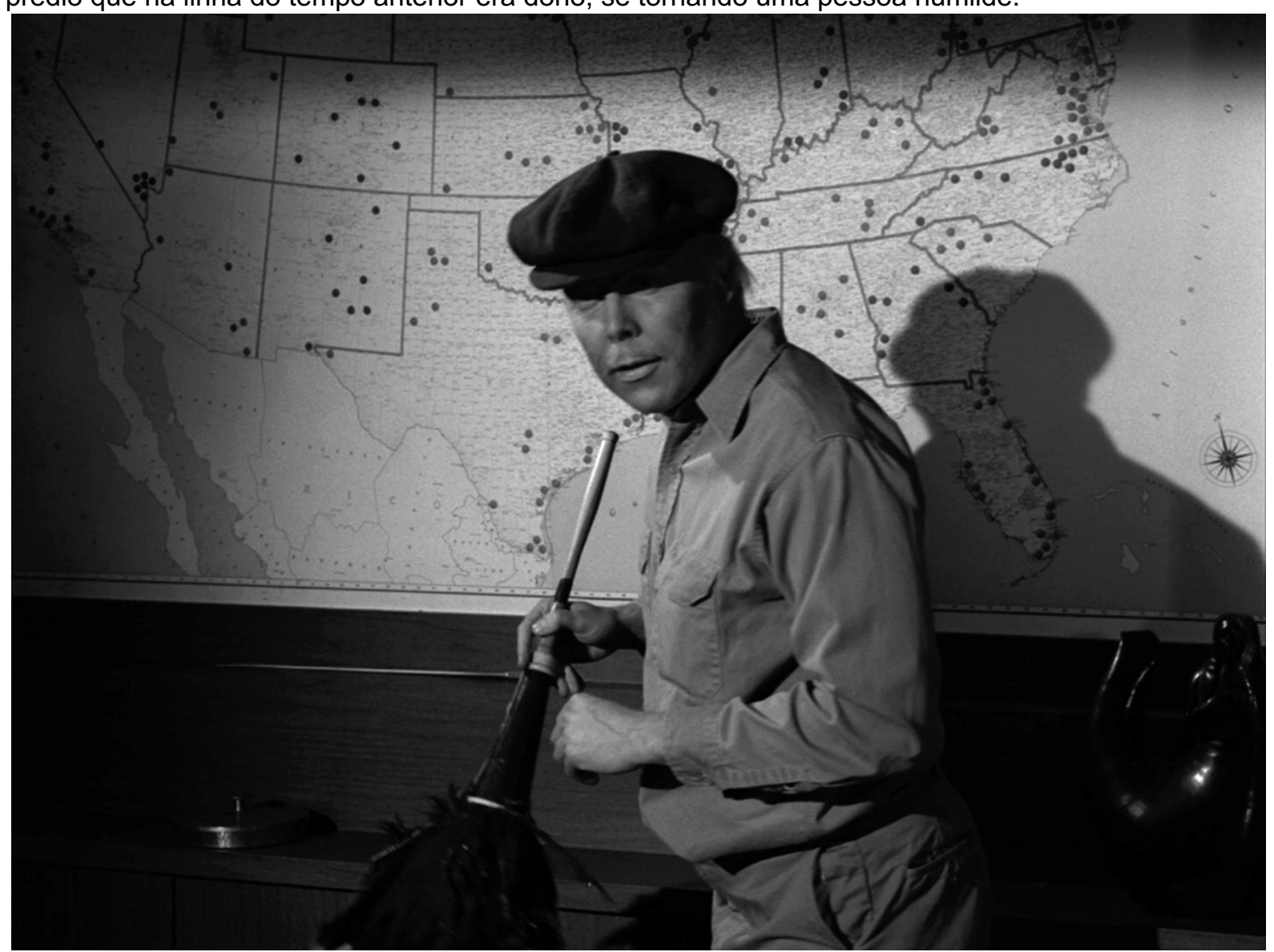

Fonte: elaborado pelo autor (Blu-ray, The Twilight Zone: The Complete Series, CBS, 2017)

Rod Serling, nesse episódio, faz uso da viagem no tempo para desconstruir o mito do self-made man. Ao colocar um exemplar desses heróis americanos para viver no passado, nota-se que a força de vontade não é suficiente, deve-se ter contatos, 
estar no lugar certo na hora certa e o sucesso, ou fracasso, se daria mais por sorte do que por força de vontade ou habilidades superiores. Além disso, o fato de, no final do episódio, os papéis serem trocados na sede da empresa, com Feathersmith no lugar de faxineiro humilde e Hecate na posição de empresário desprezível, expõe uma profunda crítica ao próprio funcionamento do capitalismo americano. No final do episódio, ao expor essa reviravolta irônica, a mensagem deixada é bem clara: não importa o indivíduo, em dadas condições, todos poderiam ocupar o lugar do protagonista dessa fábula; o sistema levaria as pessoas a se comportarem de determinadas formas, e não havia nada em William Feathersmith que o predispusesse a ter o comportamento reprovável que exibia aos demais seres humanos. O sistema moldou-o e o segundo pós-guerra lhe deu espaço para florescer. Portanto, o problema estaria na sociedade americana e em suas propagadas relações econômicas. Somente pela exposição do passado, o mito pode ser descontruído e a viagem no tempo serviria exatamente para revelar a verdade escondida pela cultura e pela memória.

Essa crítica é exposta no episódio como referente apenas ao capitalismo praticado no segundo pós-guerra, com a ascensão de empresários desalmados (não é à toa que ele não tem mais a alma para vender para a senhorita Devlin). Como é deixado claro pelos diálogos e até pela postura de Dietrich, tipos como William Feathersmith não se importavam pelos outros humanos. Esse fato pode ter origem tanto na visão defendida por Serling de um capitalismo humanista - com um estado de bem-estar social operando em paralelo a uma consciência social dos membros da sociedade, ajudando os mais necessitados e vendo-os como iguais -, quanto na experiência da juventude de Serling em Binghamton, uma das "Cidades Triplas", do Square Deal, onde o capitão da indústria George F. Johnson, fabricante de sapatos, que, inspirado por ideais progressistas, implementou políticas de aperfeiçoamento das relações de trabalho e investia nas cidades, em educação e em entretenimento para os empregados e habitantes das "Cidades Triplas". Com certeza, o modelo de empresário ideal para Serling era semelhante a Johnson, humanista e preocupado com o bem-estar da sociedade da qual tirava o seu lucro e sustento.

Haja vista que, como já relatado, Rod Serling não era socialista, e mesmo que, por vezes, Além da Imaginação apresentasse episódios mais planfetários de situações que incomodavam Serling e demais escritores, eles expunham mais uma visão crítica sobre o que notavam como comportamentos anti-humanos enraizados 
ou estimulados na cultura americana do contexto do que uma proposta alinhada diretamente à crítica socialista ou comunista do capitalismo, mesmo que tocasse em pontos em comum, como a questão da exploração do trabalhador ou do sistema mais do que o indivíduo -, como gerador de situações de exploração humana. A mesma crítica que encontramos ao capitalismo em Of Late I Think of Cliffordville já se fazia presente em Patterns (1955) e na própria série era recorrente, como o episódio The Brain Center at Whipple's (1964) na quinta temporada, que juntamente com esse, são os mais claramente críticos ao capitalismo. No caso de The Brain Center at Whipple's, o roteiro de Serling discutia a questão da automação industrial e os conflitos com os trabalhadores.

O passado em Of Late I Think of Cliffordville é relatado como inferior ao presente: a própria associação realizada por William Feathersmith de grandes heróis militares do passado, que tentaram dominar o mundo, como Gengis Khan e Alexandre, o Grande, serve para mostrar o absurdo do personagem e não realçar alguma suposta real grandeza. O episódio deixa claro que, para ele, a História e o passado, servem de incentivo e reafirmam seus ímpetos reprováveis, o que faz todo sentido em um mundo que acabara de passar pela Segunda Guerra Mundial. Uma das primeiras coisas que ele nota, ao chegar em 1910, são as ruas não pavimentadas, vemos uma casa de quarentena por causa do tifo, as pessoas do passado ironizam o desenvolvimento tecnológico que irá surgir no futuro, rindo das propostas de William para gerar dinheiro com seu conhecimento do mundo de 1963. Enfim, a cidade de Cliffordville é uma desagradável cidade pequena, que em nada lembra os relatos idílicos de cidades idealizadas no passado, tão recorrentes na série, inclusive na mesma temporada no episódio No Time Like The Past, em cidade fictícia também localizada no estado do meiooeste americano, Indiana.

Estes fatos indicam que o retorno ao passado para realização do self-made man é o retorno a um mito e cabe ao presente enterrar de vez esse mito, pois esta temporalidade não é inferior à experiência do passado. Assim, a crítica do episódio é a permanência do mito do self-made man na cultura americana dos anos 50 e início dos anos 60, mito este que estava servindo para dar poder para pessoas abjetas e para incentivar a operação de um sistema injusto e cruel. O enredo desse episódio tem um apelo inicial interessante a partir do qual, desde o primeiro momento, antagonizamos Feathersmith, principalmente identificando nele características de pessoas conhecidas da vida cotidiana, porém, o episódio não nos deixa de fora, pois 
em dadas situações distintas na nossa história de vida, em um sistema que corrompe os humanos, poderíamos ocupar o lugar de nosso capataz, mesmo que parcela do público possa entender a troca de lugar entre empregado e patrão como uma justiça poética: o opressor agora é oprimido da mesma forma que oprimia.

$\mathrm{Na}$ quinta temporada, foram exibidos dois episódios de viagem no tempo ao passado não nostálgico, o próximo de nossa investigação, The 7th is Made Up of Phantoms, apresentava uma releitura com viagem no tempo de um dos temas mais famosos na cultura americana, a derrota do General Custer na Batalha de Little Bighorn, explorando a ideia de interferência do presente no passado e, principalmente, como o espírito presente nos EUA no final do século XIX que custou a vida dos povos indígenas, condendando-os ao deslocamento e à morte e, também, encerrou a própria vida de Custer e seus soldados, ainda se fazia presente em meados dos anos 60. A Zona Crepuscular iria intervir para reestabelecer ordem ao mundo, punindo os personagens que veem como positivo esse momento da História dos EUA e fortalecem comportamentos contrários aos direitos humanos no presente.

\subsection{7- The 7th is Made Up of Phantoms}

Na última temporada da série, The 7th is Made Up of Phantoms, dirigido por Alan Crosland Jr. e estrelado por Ron Foster, Randy Boone e Warren Oates, foi o penúltimo episódio de viagem no tempo ao passado a ser exibido. Filmado no mês de junho de 1963 no Albertson's Ranch, parte da Grande Los Angeles, na região da cidade de Thousand Oaks, CA, foi ao ar em 6 de dezembro de 1963, com um custo total de produção de USD\$56.979,67 (GRAMS JUNIOR, 2008, p.636-637). O 10 episódio da quinta temporada, $130^{\circ}$ da série, roteirizado por Rod Serling, utiliza seu conhecimento prévio da época da rádio, onde escrevera um drama histórico sobre o General Custer para o programa Our America (Ibid., p. 638). O conhecimento de Serling sobre esse fato apareceria de forma clara, em detalhes da conversa dos soldados, com diálogos que acabam se tornando pouco críveis dado o domínio das minúcias da expedição de Custer expressos por dois soldados fãs do general.

Três soldados da guarda nacional fazem jogos de guerra na região onde, no século XIX, passara a expedição do General Custer em seu combate com os Lakota Sioux, Cheyenne e Arapaho. Ouvindo barulhos estranhos e encontrando pistas do passado, como se ele acabasse de ter acontecido, os soldados supõem que o tanque 
com o qual se movimentam foi transportado para o passado na véspera do fatídico dia do combate de Custer e a $7^{\text {a }}$ Cavalaria em Little Big Horn, que terminaria com a morte do general e seus comandados. Suspeitando que algo estranho estava se passando, os soldados retornam para seu acampamento, voltando ao presente, e planejam as ações no jogo de guerra, ao mesmo tempo em que arquitetam a busca por pistas da passagem dos índios e da $7^{a}$ Cavalaria. No dia seguinte, novamente, encontram pistas que provavam que eles estavam no passado, inclusive um dos soldados é atingido por uma flecha. Ouvindo os sons da batalha Little Big Horn, o tanque é abandonado e os soldados decidem participar do combate, lutando junto das tropas de Custer. Posteriormente, o tanque é encontrado abandonado por soldados da guarda nacional e, sem pistas dos três soldados, as buscas chegam no memorial da batalha em Little Big Horn. Lá, soldados notam o nome dos três colegas entalhados no monumento em homenagem aos mortos na batalha em 1876.

A história se passa no futuro próximo do público, em 25 de junho de 1964, porém, essa data serve mais para aproximar o público do episódio, tornando-o atual aos seus contemporâneos e localizando a ação no aniversário da Batalha de Little Bighorn. A viagem ao passado ocorre entre 1876 e 1964, uma ponte entre os anos.

A viagem no tempo em The 7th is Made Up of Phantoms, não destoa do conjunto dos episódios da série, ela novamente se dá de forma mágica, no mesmo modelo de Walking Distance, todavia, sem a poesia do episódio de 1959. Os soldados, ao andarem na região do rio Little Bighorn, em Montana, imediatamente, encontramse no passado. É mostrado que, de certa forma não explicada, aquele ponto focal da história americana apresenta um cruzamento de temporalidades distintas, transponíveis sem nenhuma indicação audiovisual especial no episódio: só notamos que eles estão no passado quando os soldados encontram resquícios da presença e da passagem de índios e da $7^{a}$ Cavalaria. A forma pela qual os soldados atuam inicialmente no passado, seguindo os passos da expedição de Custer em Montana, reforça o título do episódio que, traduzido, significa literalmente "A $7^{a}$ é Feita de Fantasmas", o que eles próprios irão se tornar ao tentar intervir no passado: fantasmas da História.

Essa forma de retratar a viagem no tempo, novamente, reforça não o aspecto científico de tal empreitada, o que demandaria por parte de Serling criar algum tipo de explicação inspirada em elementos das ciências e/ou a presença de tecnologias fantásticas. Ao gosto do autor, esse tipo de viagem explora muito mais a noção de 
que qualquer um pode se encontrar no passado de forma inexplicável, um passado na qual contas individuais e coletivas serão cobradas. A viagem no tempo ao passado, nesse episódio, utiliza um fato pretérito de amplo conhecimento do público para forçar uma reflexão sobre o presente, expondo como tal passado ainda não se encontrava superado, seus fantasmas ainda rondavam os EUA dos anos 60 - podendo levar a nação ao desastre.

Figura 43 - Soldados se deparam com o passado, seguindo as pistas dos indígenas e da cavalaria de Custer.

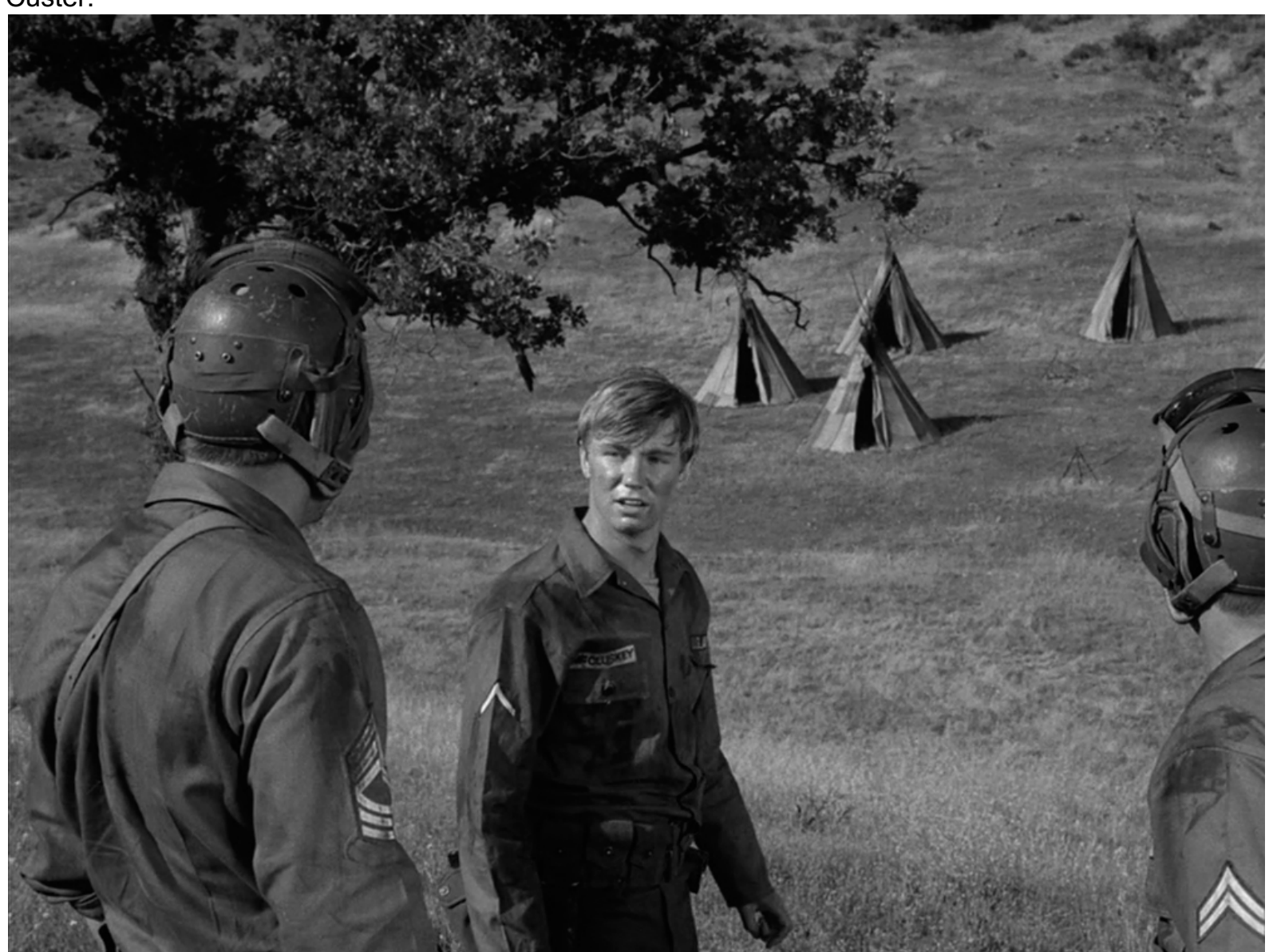

Fonte: elaborado pelo autor (Blu-ray, The Twilight Zone: The Complete Series, CBS, 2017)

O tema do Oeste e da Fronteira, novamente é utilizado. Essa temática é recorrente em diversos episódios de viagem no tempo, tanto ao passado quanto ao futuro, em Além da Imaginação, pois era um tema de interesse de Rod Serling e um gênero de sucesso da televisão do contexto, além de reconhecido no cinema, em obras literárias dirigidas para as mais diversas pessoas, artes plásticas, músicas, etc., mas, principalmente, o Oeste e a Fronteira fazem parte da identidade nacional dos EUA, um lugar especial que foi regularmente retomado no contexto histórico do segundo pós-guerra por expor um ambiente que permitia as mais diversas 
observações sobre o mundo contemporâneo, como os valores de heroísmo e honra, de ética e moral, em um contexto de incertezas internas e com a perspectiva de um conflito nuclear que representasse o fim da experiência dos EUA. Ao lidar com temas tão caros nesse contexto, Serling transmitia sua mensagem humanista de forma reiterada dentro de uma base já compartilhada socialmente na cultura histórica dos EUA.

O comportamento dos três soldados, William Connors, Michael McCluskey e Richard Langsford é exemplo de uma busca por glória à custa de vidas alheias e desprezo pelo coletivo. Os dois primeiros, os que aparentam ser mais escolarizados, conhecem a história do General Custer e demonstram cada vez mais sua admiração pelos feitos do General enquanto chegam perto da batalha final. Já Langsford é retratado como uma pessoa mais simples e humilde, ele supreendentemente não sabe nada de Custer e, por quase todo episódio, tenta remover as ideias de seus colegas de seguir a trilha dos índios e de Custer, lembrando-Ihes tanto que o passado não serviria para nada bom quanto que eles estariam desobedecendo às ordens do jogo de guerra do qual participavam e poderiam sofrer punições. Infelizmente, ele também acaba influenciado por seus dois colegas e se empolga para participar da luta contra os indígenas do lado de Custer. Há um subtexto que pode ser observado: seus dois colegas, representantes de grupos sociais distintos, demovem-no das perspectivas corretas que tinha sobre o que estavam passando, exatamente por ser uma pessoa simples. De forma clara, Serling apresenta a tese de que os grupos sociais de elite estariam causando danos ao espírito dos mais pobres, incentivando comportamentos antissociais que eles não realizariam sem a influencia direta dessa elite, que oferecia glória e benesses por ações controversas. Por não resistir, Langsford acaba sendo punido junto com os outros dois pela Zona Crepuscular, servindo de exemplo para a audiência.

O público é convidado a questionar (sem assistir!) se três soldados modernos indo ao auxílio de Custer na Batalha de Little Bighorn mudariam o destino da batalha, participando dos combates entre a $7^{\text {a }}$ Cavalaria e os Arapaho, Cheyenne e Lakota Sioux. A possibilidade de alteração do passado, já que o presente supostamente mais desenvolvido estava intervindo, é frustrada quando se vê o resultado do conflito. $\mathrm{O}$ final surpresa expõe a ideia de que o presente, se vivido por meio de valores que desprezam grupos e valorizam a morte e a violência, não é superior ao passado, só a tecnologia é superior e ela não serve para alterar a História. 
Figura 44 - A sequência final onde vemos os nomes dos soldados no obelisco do memorial do Little Bighorn Battlefield National Monument (Montana, EUA) revela tanto o destino deles, quanto a incapacidade do trio de alterar a História.

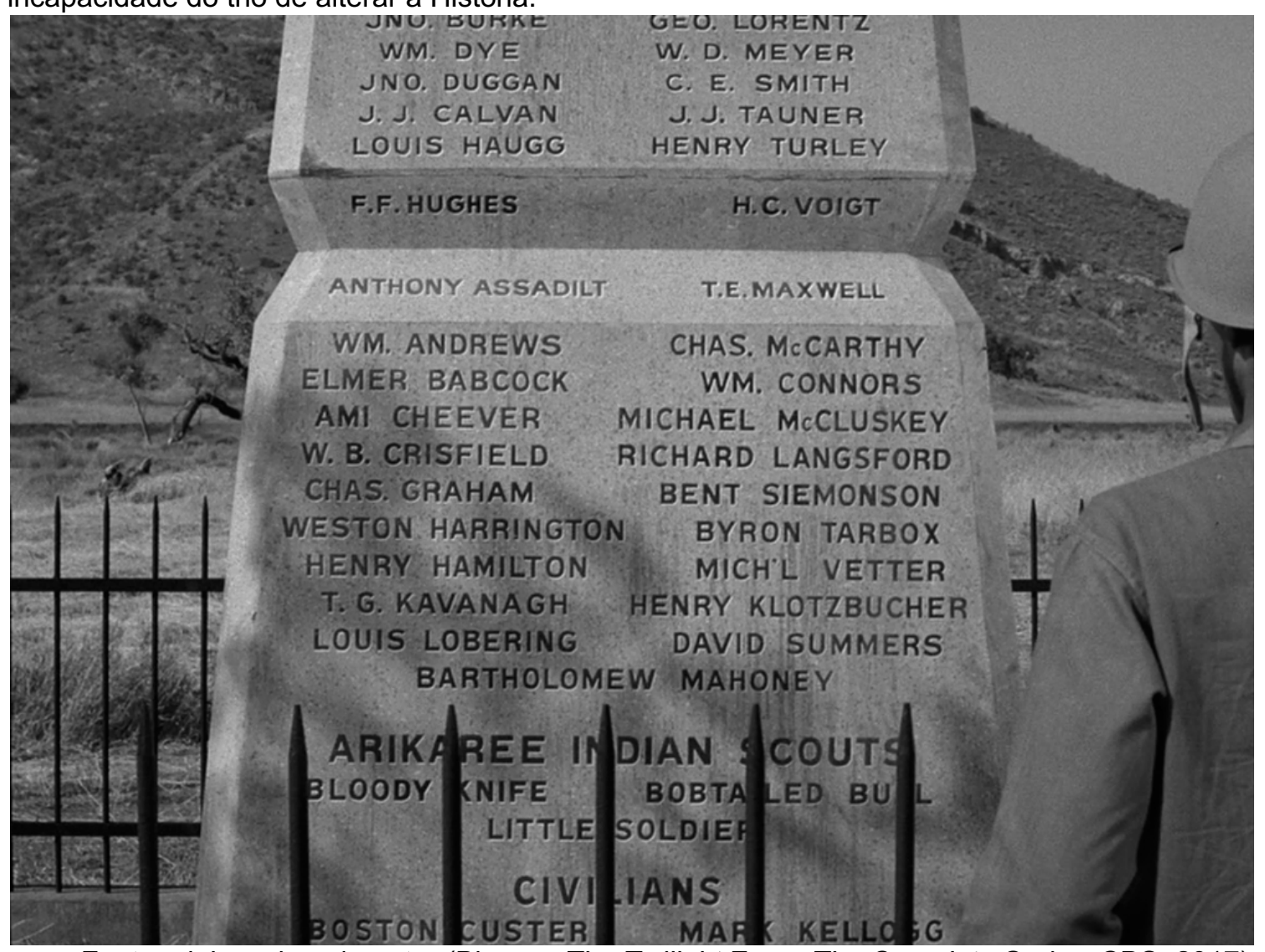

Fonte: elaborado pelo autor (Blu-ray, The Twilight Zone: The Complete Series, CBS, 2017)

Sem contar a exploração literária da história do General George A. Custer, com livros de História, relatos, biografias, poemas, etc., enfatizando as mais diversas visões, suas aventuras já se faziam presentes como um tema importante dos westerns desde o cinema mudo. No ano de 1909, foi exibido On the Little Big Horn/Custer's Last Stand, provavelmente o primeiro filme a retratar a história de Custer, dirigido por Francis Boggs (ROSENBERG, 2004, p.524); para citar mais algumas obras audiovisuais, um filme importante da era do cinema mudo é Custer's Last Fight, de 1912, dirigido por Francis Ford (irmão mais velho do famoso e importante diretor do gênero western John Ford), que também estrelou o filme atuando como Custer. Um indicativo do sucesso desse filme foi sua expansão com cenas adicionais em 1925 (SPENCER, s.d, n.p) e, ao contrário da maior parte dos filmes dessa época sobre Custer, esse não foi perdido. (HUTTON, 2004, p.519). Ainda no ano de 1926, seria lançado Grito da Batalha (The Flaming Frontier), dirigido por Edward Sedgwick, que retratava Custer como o símbolo máximo de heroísmo (Ibid., p. 494). No contexto pré- 
entrada dos EUA na Segunda Guerra Mundial, em 1941, um filme de grande sucesso foi O Intrépido General Custer (They Died with Their Boots On), de Raoul Walsh.

A história de Custer, passando por sua formação até a sua morte, faz parte da própria cultura histórica dos EUA e da identidade nacional, seja por suas representações como herói destemido da civilização, como os filmes citados de 1912 e 1926 o retratam, seja por visões mais críticas, com Custer ou personagens inspirados nele, que já eram propagadas no contexto histórico da produção da série Além da Imaginação.

No segundo pós-guerra, os filmes sobre Custer auxiliaram a mudança na visão do público sobre as Indian Wars $^{65}$ (HUTTON, 2004, p. 507). Houve a tentativa de mostrar o lado dos povos indígenas e esse tema não era considerado controverso, pois seria parte do passado e as tensões raciais polêmicas da época envolviam muito mais brancos e negros do que as relações com os povos indígenas (lbid., p.507). Pode-se notar, então, que as obras que lidavam com a questão indígena, nesse contexto, diziam também sobre questões raciais mais amplas, não restritas a esses povos.

Assim, Custer passou a ser rotineiramente retratado como vilão na cultura popular do período; um exemplo disso é o primeiro filme pós-segunda guerra a lidar com o General, ainda que em um personagem moldado nele, Sangue de Heróis (Fort Apache), de 1948, dirigido por John Ford. Mais caracterizações de Custer, nominais e inspiradas em fatos históricos, podem ser vistas em filmes da época, como Índio Heróico (Sitting Bull), de 1954, dirigido por Sidney Salkow, e o filme da Disney Tonka e o Bravo Comanche (Tonka) de 1958.

Portanto, a crítica exibida no episódio fazia parte do padrão pelo qual os feitos de Custer e a $7^{\text {a }}$ Cavalaria eram retratados no período, principalmente no cinema e na literatura. Assim, Serling, novamente, criticava os westerns que seguiam fórmulas e não faziam revisão ou autocrítica, inserindo elementos fantásticos em um enredo que reforçava a forma crítica de se retratar as Indian Wars e punindo exemplarmente os personagens por terem tentado intervir no passado de forma desumana e buscar algum tipo de glória ao custo de vidas, como era regularmente retratado o General Custer.

${ }^{65}$ Conflitos desde a época colonial entre europeus e seus descendentes contra os povos indígenas, que culminou com extermínio e remanejamento populacional dos povos indígenas. 
Figura 45 - Litografia promocional da cervejaria Anheuser-Busch, de autoria de Otto Becker, vista por anos em bares por todos os EUA (ROBBINS, 2014, p.417). Nela, podemos ver Custer em destaque, apresentado como um grande e corajoso guerreiro, cercado por hordas de índios hostis, uma representação heroica padrão do general como um homem destemido e dos índios como covardes.

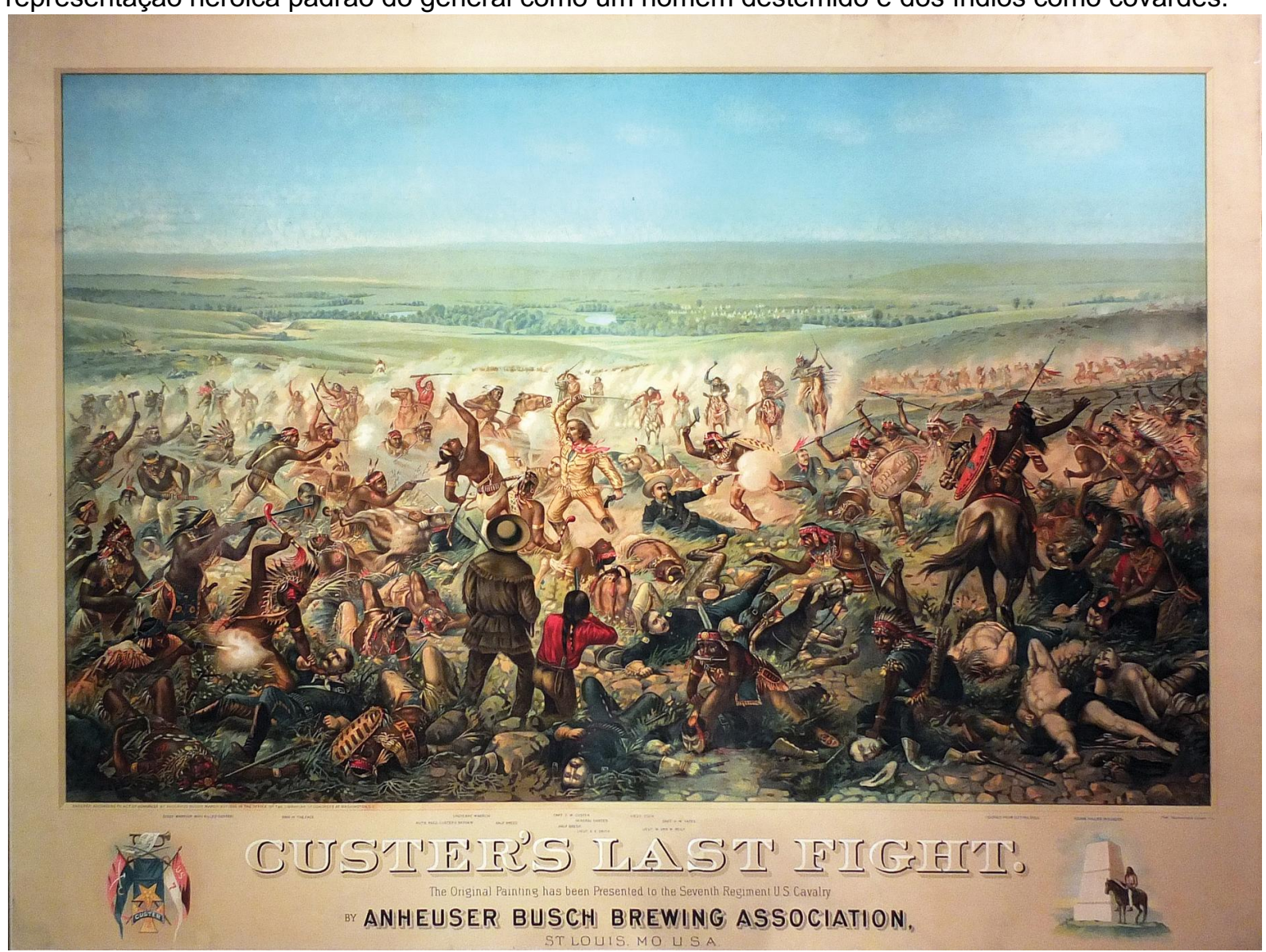

Fonte: Custer Battlefield Museum ${ }^{66}$

Em The 7th is Made Up of Phantoms os três soldados perdem a vida e não alcançam glória nenhuma. Mais do que a alteração de fatos do passado, impossível segundo o conjunto de episódios exibidos na série, a punição com a vida tem cunho moral: no contexto dos anos 60 , não deveria existir mais espaço na sociedade para aquele tipo de comportamento. $\mathrm{O}$ discurso de Serling é claro.

O último episódio de viagem no tempo ao passado não nostálgico em Além da Imaginação foi o episódio Spur of the Moment. Ele apresenta uma visão cética sobre a instituição do casamento e a formação das famílias nucleares, utilizando a viagem no tempo ao passado como forma de expressar uma reflexão sobre as escolhas realizadas na vida.

${ }^{66}$ Disponível em : http://www.custermuseum.org/Custer\%27s\%20Last\%20Fight.htm 


\subsection{8- Spur of the Moment}

Spur of the Moment é o $141^{\circ}$ episódio de Além da Imaginação e o $21^{\circ}$ da quinta temporada, filmado em junho de 1963, foi estrelado por Diana Hyland, Robert Hogan, Roger Davis, Philip Ober, Marsha Hunt e Jack Raine, o roteiro é de Richard Matheson e a direção de Elliot Silverstein. O título original do episódio era Pale Rider, Cavaleira Pálida em tradução livre, alterado a pouco mais de uma semana das filmagens para Spur of the Moment, foi ao ar em 21 de fevereiro de 1964 e teve um custo total de USD\$ 61.452,77 (GRAMS JUNIOR, 2008, p. 671;ZICREE, 1992, p. 378).

A jovem Anne Henderson passeia a cavalo nas propriedades de sua família quando é perseguida por uma cavaleira de trajes pretos, que grita o seu nome enlouquecidamente. Retornando assustada a sua casa, uma mansão, Anne conversa com seu pai e seu pretendente, Robert, um homem simpático e educado, com uma excelente perspectiva de futuro, aprovado por sua família. A história do estranho encontro anterior com a mulher de negro é colocada de lado, quando chega na casa o ex-noivo de Anne, David, um homem impulsivo e emocional, não aceito pelo pai de Anne, que inclusive o expulsa da casa sob a mira de uma arma de fogo. À noite, a festa do noivado de Anne com Robert se realiza e David aparece para conversar com sua amada. Anne, movida por seu coração, decide não se casar com Robert, desejo da família, e sim com David, sua paixão. No futuro, uma amargurada e cínica Anne, casada com David, vive na antiga mansão, agora decadente. Seu marido, um beberrão fútil, perdera toda a forturna de família Henderson e a relação entre os dois é péssima. Anne, com trajes pretos, decide alterar seu passado: toda tarde sai para cavalgar e tenta alertar a si própria para não seguir seu coração de jovem ingênua e se casar com o homem que sua família, e a razão, indicavam como melhor para ela.

O próprio título do episódio denota o principal problema, em tradução livre Spur of the Moment é o "calor do momento", ações tomadas de forma impensadas, que, como vemos no episódio, trazem consigo enormes consequências não intencionais. Os valores dos pais e da tradição parecem ser os corretos, ao invés da paixão e emoções impulsivas.

A viagem no tempo se dá de forma não explicada, a mulher triste, frustrada e irritada do presente, vestida de preto e cavalgando um cavalo da mesma cor de suas roupas faz seu passeio e ao subir um morro, em sua propriedade, instantaneamente, dirige-se ao passado. Anne Henderson viaja de 1964 para 1939, entretanto, mesmo 
que exista uma caracterização da moda do passado, com roupas, indumentárias e carros da década de 30, a questão discutida pelo episódio não é tanto o retrato de um contexto histórico social, mas sim a história individual de Anne e seu círculo íntimo. A forma mágica de viagem no tempo é um mistério para a própria personagem e, caso a sua mãe não se lembrasse do relato dela quando jovem da perseguição de uma mulher estranha no dia da festa de noivado, a história poderia se passar inteiramente na imaginação da moça. Essa interpretação não é de todo despropositada, pois o episódio não fecha totalmente tal possibilidade, porém, visto em conjunto com o trabalho de Matheson, na própria série, e o conjunto com os demais episódios, devemos observar a história como se a viagem no tempo realmente tivesse ocorrido por interferência da Zona Crepuscular.

O episódio apresenta os deslocamentos entre os tempos por meio de efeitos de desfoque da câmera e a inclusão de pequenos brilhos, código de que uma transposição no tempo ao passado estava sendo vista.

Esse episódio, de todos os de viagem no tempo é o único no qual há um viajante do sexo feminino e, dentro dos padrões da época, sua discussão gira em torno de uma lição sobre o matrimônio. Anne Henderson se deixou guiar pelas emoções, não notou a agressividade do seu ex-namorado, que ainda ama. Ele é retratado logo de início como alguém em quem não devemos confiar: agressivo, rude e mal educado; em oposição ao homem com o qual a família queria que ela se casasse: com roupa bem asseada, fala mansa e gravata borboleta, além de ser um profissional dos investimentos, um capitalista capaz de prover a família, mantendo-a como membro da elite econômica dos EUA. Por ter desafiado o futuro que o pai vislumbrava para ela e ter se entregado ao amor, ela abandona o noivo na noite da festa de noivado para ficar com David, algo que nos é claramente mostrado, pelas cenas no presente, ter sido um erro de enormes proporções.

A suspeita inicial induzida pelo episódio na audiência é a de que a mulher de preto estava gritando e perseguindo a jovem para impedir que ela casasse com o homem que sua família desejasse e que seguisse seu coração. Porém, a reviravolta irônica é que, na verdade, ela queria impedir que a jovem usasse seu coração, pois os efeitos futuros de tal decisão irracional seriam nefastos. Essa ideia era expressa por Matheson, que se inspirou nas histórias de viagem no tempo do escritor inglês J.B Priestley para escrever Spur of the Moment (ZICREE, 2018, p.373). O roteirista comentou que gostou do episódio em linhas gerais, sua única crítica foi ao diretor, que 
revelou logo no começo que a mulher de preto é a versão velha da jovem, algo que era só para ser identificado no final e, por todo episódio, deveríamos ver apenas uma figura assustadora em um cavalo, a perseguir a jovem protagonista (GRAMS JUNIOR, 2008, p.673; ZICREE, 2018, p.373).

Figura 46 - A jovem Anne, entre seus dois pretendentes, Robert (a esquerda) e David (a direita). Sua escolha entre razão (Robert) e emoção (David) é o mote do espiódio. A viagem no tempo serve como forma de se avaliar as consequências das nossas ações.

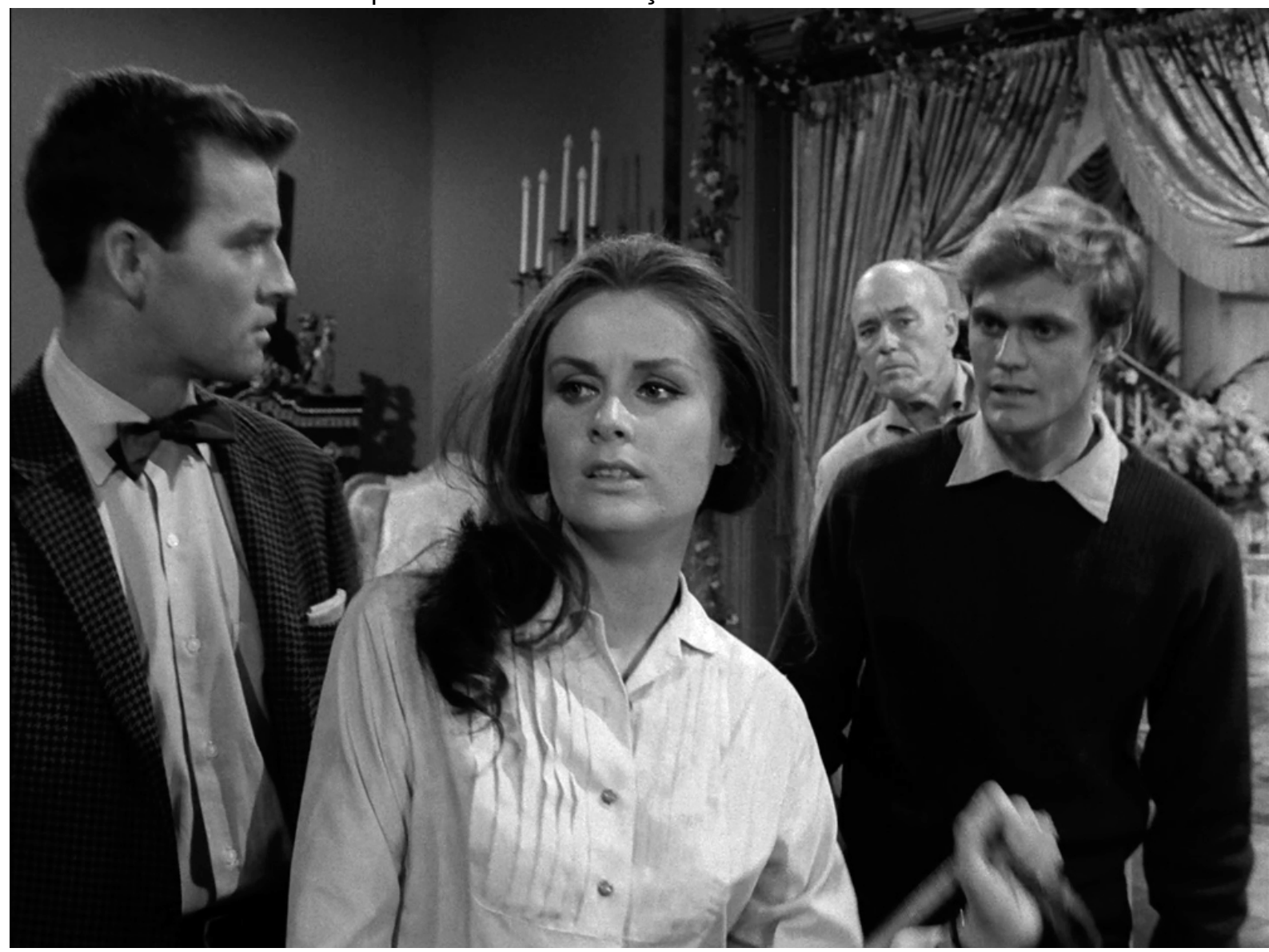

Fonte: elaborado pelo autor (Blu-ray, The Twilight Zone: The Complete Series, CBS, 2017)

Este episódio, mesmo que reforce o papel da família, pois ela quer ter uma família correta corrigindo escolhas passadas e inclusive chegando a culpar seu falecido pai por tê-la mimado, apresenta uma visão um pouco mais ambígua sobre a instituição do casamento. Anne se encontra presa em um casamento fracassado e não vê perspectiva de escapar mais dele com vida; assim, só restaria uma fuga ao passado para mantê-la com alguma esperança de que essa instituição possa de alguma forma, funcionar. Pensando nisso, em um contexto no qual o casamento na sociedade americana era exposto como o destino natural e ideal para as mulheres, temos exposta a visão de que o casamento pode oprimir as mulheres e não há saída 
para essa opressão nas possibilidades futuras, só a suposição de um passado com outro homem, uma outra aposta, seria possível. O casamento destruiu a menina inocente, alegre e cheia de amor, não só emocionalmente, mas também economicamente. Muitas mulheres poderiam se identificar na personagem de Anne e muitos homens se verem como David, um homem fraco, agressivo, covarde e bêbado, além da identificação por parte do público de pessoas da família, amigos, etc. na mesma estrutura de um casamento sem saída.

Figura 47 - A Anne do presente é um ser vampiresco, mais assustando seu eu passado do que a alertando para que não se case com David.

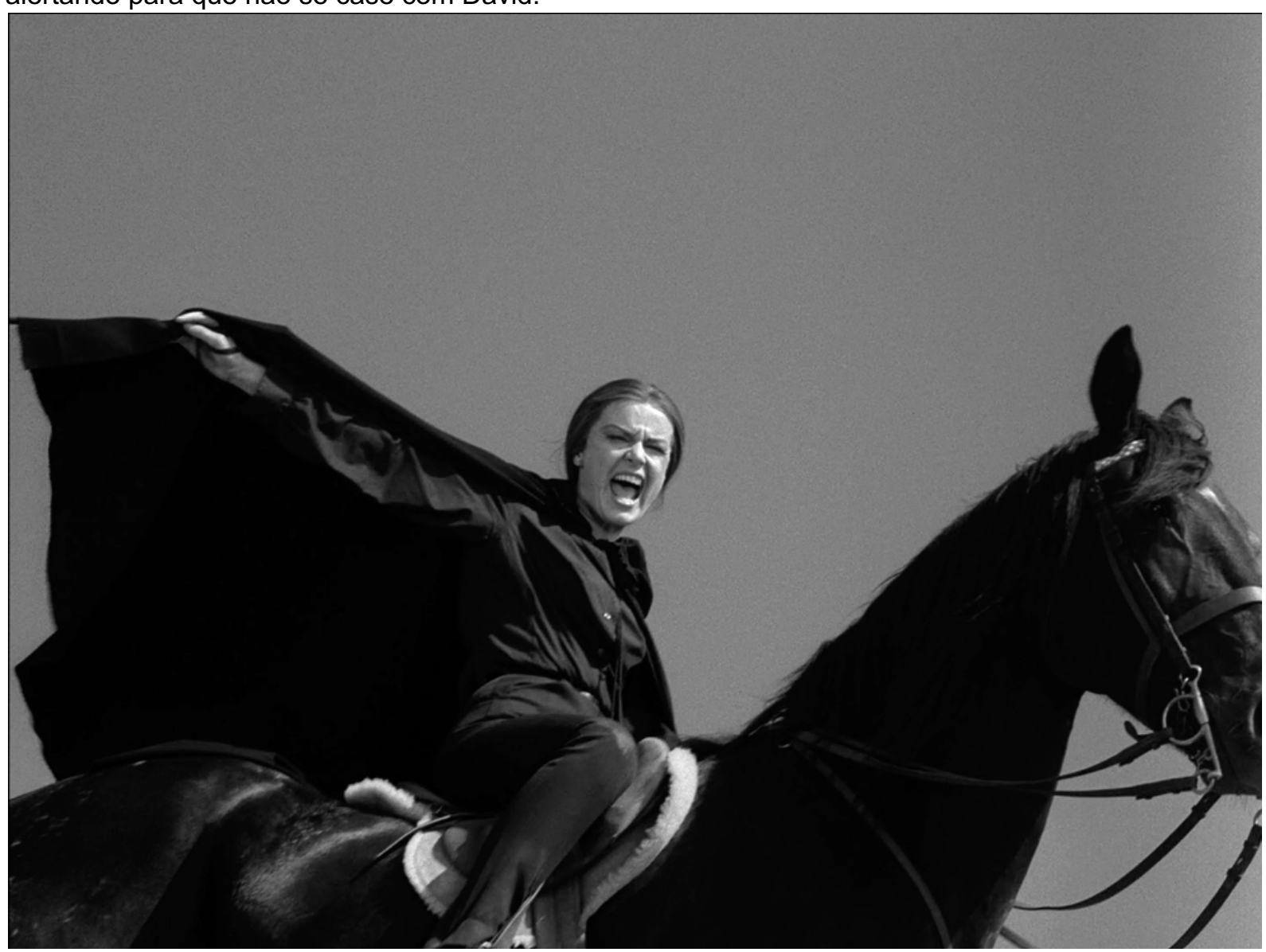

Fonte: elaborado pelo autor (Blu-ray, The Twilight Zone: The Complete Series, CBS, 2017)

A história de Matheson reforça o papel da família e de sua manutenção, utilizando a viagem no tempo para apresentar a impossibilidade da correção dos erros passados e indicar onde estava o problema da personagem principal, irascível e amarga no presente e uma menina apaixonada e inocente no passado, que sofreu muito na vida por ter escolhido um homem retratado como alcoólatra, imprestável, incapaz de prover o sustento da família, ainda por cima, responsável pela falência de toda a família. A viagem no tempo recorrente de Anne ao dia da festa de noivado 
indica a noção do ponto de divergência, o momento passado no qual uma decisão muda todo o resultado de forma radical; a sua falha por não conseguir alterá-lo, mostra que ela deveria buscar a correção dos erros no presente, todavia, por sua relação com a mãe e o marido, e pela sua desistência de mudar seu presente e assumir suas responsabilidades, Anne já se encontra condenada. A idéia do trabalho de Sísifo é exemplificada por suas tentativas fracassadas de alterar o passado, em um episódio que não apresenta qualquer forma de resolução para o conflito principal (PRESNELL; MCGEE, 1998, I.4384).

Ao expor essa história tendo como personagens os membros de uma família com ares aristocráticos do sul dos EUA, há também um subtexto da falência dessa elite, a falência econômica é só um reforço dentro de uma ampla falência moral.

Essa condenação é reforçada pelo jogo de cores do passado e do presente: no passado, a casa é mais clara e cheia de móveis, ela com 18 anos veste-se de branco e anda em um cavalo branco; já no presente ela utiliza uma roupa negra com uma capa negra, que the dá uma aparência de vampiro, agressivamente andando em um cavalo negro. Sua mansão decadente transforma-se em um castelo de conto gótico, todos na casa vivem miseravelmente, envelhecidos e abatidos.

A Zona Crepuscular opera nesse episódio para expor o caso de Anne Henderson e sua malfadada busca de correção do presente por meio da interferência no passado, a fim de puní-la por sua falta de coragem de mudar o presente e o seu comportamento genioso no presente. É pela viagem no tempo que somos levados a refletir sobre quem éramos e quem somos hoje e se gostaríamos de ver no que nos tornamos; a jovem de 18 anos no passado ao ver seu eu futuro, mesmo sem o saber, foge de medo.

Dos episódios de viagem ao passado, esse é o que menos se preocupa com as questões de mudança entre os tempos sociais, focando na experiência individual da passagem do tempo.

\section{6- $O$ que é feito no passado}

A viagem ao passado exposta na série Além da Imaginação demonstra, de forma clara, os usos padrões desse recurso narrativo nas sociedades modernas e expõe as formas pelas quais as articulações entre presente e passado se manifestam na cultura histórica, apresentando-nos como as questões das mudanças são sentidas, 
reproduzidas e respondidas em sociedades orientadas para o progresso, nestas onde as mudanças são percebidas como constantes e radicais e impossíveis de serem controladas; daí, o apelo desse tipo de narrativa, que alimenta uma ideia de controle das mudanças por meio da intervenção em fatos passados, muitas vezes, no final da narrativa, revelando que tal controle é ilusório e que o presente é o tempo da vida, tanto individual quanto social.

Mesmo que não tenha se detido no problema dos paradoxos, quase ausente na série mas constante na produção literária que lidava com a viagem no tempo naquele contexto histórico, as demais questões levantadas pela viagem no tempo foram trabalhadas, o problema do livre arbítrio (pode-se alterar pequenas coisas, mas não os fatos históricos que afetam grandes parcelas da população), a lição reiterada à exaustão de que se deve aprender a viver no presente e se alguma mudança para o futuro é desejável, deve-se procurar meios de intervenção no seu tempo histórico e não fugir para o passado, simbolizado na série pelas tentativas malfadadas de criar um mundo aperfeiçoado por meio de ações no passado.

Há a noção de um grande esquema na História, ancorada na cultura histórica dos EUA, como a presença de personagens históricos marcantes e as formas de se retratar determinados períodos, elementos demonstrados de forma clara nos episódios, onde há uma familiaridade e expectativa por parte do público do que será visto no passado, por exemplo, quando a história se passa no final do século XIX.

Em oposição às histórias nostálgicas, o passado desse tipo de viagem no tempo, tende a ser problematizado, ele não é superior ao presente, nem traz consigo valores intrinsecamente faltantes no presente dos personagens para ser alvo de quaisquer tipos de saudade. Ele é o local onde, por relações de causa e efeito, as condições do presente foram criadas, e, assim, é lá que se procuraria não a explicação das condições presentes para possível alteração, como o conceito moderno de História explora, mas sim a alteração direta do presente pro meio de ações no passado. Portanto, podemos pensar como esse tipo de narrativa compartilha e atua na mesma noção de História oriunda da modernidade, como exposta na obra de Koselleck (2006), mas apelando ao extraordinário para lidar com uma noção idêntica de mudança orientada para o progresso.

Observando os episódios, em Além da Imaginação, de viagem ao passado não nostálgico, são expostos os períodos chave de uma história nacionalista dos EUA, compartilhado por largas parcelas da população como chave identitária, unificadora 
de experiências com o passado e definidora/formadora de uma pátria, como, por exemplo, o mito do Oeste, o assassinato de Lincoln e a Segunda Guerra Mundial. Isso reforça, mesmo que tenham sido abordados de forma crítica na série, esses contextos como locais comuns dos povos que compõem os EUA, dentro da perspectiva da História tradicional, focando nos grandes fatos da nação e os grandes personagens larger than life, extraordinários, do país. Assim, temos expostos diálogos com os contextos históricos que eram vistos como primordiais para a construção do presente dos EUA em finais dos anos 50 e início dos anos 60, e a intervenção nesses outros tempos, nos expõe aos problemas que eram notados por Serling e os demais escritores na sociedade de sua época, e, novamente, o público que de forma majoritária assistia à série em sua exibição original, crianças, mulheres e pessoas com nível superior de ensino formal, compartilhavam das mesmas preocupações e percebiam os mesmos dilemas, cabe dizer que nem sempre concordando com a conclusão da série para resolução dos problemas.

Os principais impasses expostos eram: a perspectiva de um escalonamento das relações internacionais entre os blocos de poder e uma nova guerra mundial, com armas atômicas, simbolizando o fim da humanidade e do que era visto como prosperidade da sociedade americana do segundo pós-guerra; a ascensão de capitalistas desumanos, administradores de grandes corporações, que faziam uso do mito do self-made man ancorado na cultura americana para justificar suas buscas desenfreadas por lucro sem respeito a valores mínimos de dignidade humana; o descompasso entre a tecnologia e o desenvolvimento de valores éticos e morais ancorados nos direitos humanos; a percepção de que noções de passado e seus personagens idealizados, servindo de modelo para ações do presente, prejudicava o verdadeiro progresso, novamente ancorado no aperfeiçoamento dos valores humanos; as instituições sociais idealizadas no período não funcionariam exatamente como o propagado.

Assim, Além da Imaginação utilizou de forma recorrente a viagem no tempo ao passado, tanto nostálgico quanto não nostálgico, para provocar uma reflexão sobre as condições presentes, por meio da comparação e crítica das diferentes temporalidades, fornecendo um diagnóstico das adversidades do seu tempo, que, como atestado pela importância da série na história da televisão, eram compartilhados por grandes parcelas da população e muitos dos quais ainda estão presentes em histórias de viagem no tempo ao passado produzidas atualmente. Sempre recordando 
que, com o já exposto anteriormente, a história de viagem ao passado é um recurso narrativo muito mais difundido do que a viagem no tempo rumo ao futuro, e como veremos em Além da Imaginaçao, uma série na qual diversos episódios se passam no futuro, o futuro das personagens será na maioria dos casos o presente da audiência do programa de televisão.

\section{7- Uma imagem do futuro}

A viagem no tempo na série Além da Imaginação também teve como destino o futuro, com os mais distintos efeitos, no modelo de recompensas e punições da proposta da Zona Crepuscular, esta, agora, encarnada em diversos episódios como o próprio futuro, destino da viagem de pessoas oriundas do passado e futuro da audiência da série. Pode parecer confuso, mas nessa série temos pessoas do século XIX visitando o futuro dos anos 1960, astronauta da década de 1980 retornando para a Terra dos anos de 2020 e até bandidos dos anos 1960 acordando na década de 2060.

Cabe recordar a informação de Clute sobre a viagem no tempo ao futuro estar presente em um número menor de obras e a depender do futuro exposto, alguns temas se desenvolvem com maior recorrência; por exemplo, mesmo Clute afirmando que são raras as histórias de viagem no tempo que se passam no futuro médio, local onde o presente está resolvido (CLUTE, 1995, p.645), os episódios de viagem no tempo de Além da Imaginação que mostram o futuro do público mostram o futuro médio, exatamente para enfatizar os desdobramentos do presente. Além disso, cabe recordar que muitas vezes, o autor de uma história não precisa recorrer à viagem no tempo para expor uma relação entre presente e futuro, personagens do futuro podem cumprir esse papel. Geralmente, a viagem no tempo ao futuro é invocada como forma de se enfatizar o choque entre presente e seus desdobramentos, intencionais ou não. Assim, em Além da Imaginação, uma série que explorou histórias se passando no futuro de forma recorrente, a viagem no tempo expôs mais a questão de desdobramentos positivos, ou pelo menos não negativos, de fatos presentes, muitas vezes corrigindo o passado.

A viagem no tempo com destino ao futuro do protagonista esteve presente em seis episódios e, em cinco destes, o futuro de destino dos viajantes era superior ao presente de onde saíram. Já nos episódios que se passam no futuro do público da 
série sem a viagem no tempo, muitos dos quais já são nosso passado, esta temporalidade é problemática, alvo de governos totalitários, sociedades disfuncionais e conflituosas, mundos destruídos, dilemas com a tecnologia. Portanto, Além da Imaginação, em seu conjunto, não rejeitava a noção de um futuro distópico, destruído por um conflito nuclear ou envolto em problemas semelhantes aos enfrentados pelo contexto de produção da série, mas pela viagem no tempo, mostrou-se uma outra relação com essa temporalidade, um futuro aperfeiçoado.

A Zona Crepuscular, nas histórias de viagem no tempo, expôs o futuro como a sua própria manifestação, não o local onde ela apenas operaria gerando algo insólito. Esse futuro permite uma análise sobre a mudança e apresenta tempos e espaços que podem não ser perfeitos, mas resolveram uma série de problemas do tempo original do viajante, reforçando uma perspectiva de progresso. Portanto, há no recurso da viagem no tempo um elemento unificador dessa temática no contexto histórico da série, o dilema nostalgia versus progresso (duas formas de se relacionar com o tempo oriundas dos modelos modernos) pendia para uma visão de progresso.

De forma recorrente, como veremos, estes viajantes para o futuro não se deslocavam para um tempo desconhecido do público; em apenas dois episódios o futuro estaria localizado no devir da audiência, mas temos nos quatro demais a presença de entes passados no presente imediato ou no futuro próximo do público da série, ou seja, pessoas das décadas anteriores aos anos 50 e 60 se deparando com o mundo americano do contexto da exibição original de Além da imaginação.

As histórias de viagem no tempo ao futuro são o reflexo de uma das formas de se relacionar com as temporalidades no contexto do segundo pós-guerra, com a exploração dessa viagem para se fazer um discurso sobre o presente e a mudança, levando o público a se colocar no lugar de um viajante que tanto pode ver quanto de seu presente já tinha ocorrido (ou não), até imaginar um futuro onde determinados comportamentos negativos já tinham sido abandonados e vistos como bárbaros.

Outro ponto de destaque é que a viagem no tempo ao futuro foi utilizada também em um episódio como forma de se explorar o humor: a comicidade nasce da comparação entre o passado e o presente, o choque do viajante em ver o quanto o mundo havia mudado gera o humor do episódio. Inclusive, como veremos, é no episódio intencionalmente de humor com viagem no tempo que foi realizada a experiência mais radical de linguagem da série Além da Imaginação. 
Os seis episódios que lidam com a viagem no tempo ao futuro estão espalhados pela série, ausentes na quarta temporada. Na primeira temporada, há dois episódios, ambos com personagens do passado se deslocando ao presente em The Last Flight (1960) e Execution (1960); na segunda temporada, um dos episódios explora esse mesmo viés, A Hundred Yards over the Rim (1961), e o outro faz referência à forma de viagem no tempo da famosa história do folclore americano em seu título e enredo The Rip Van Winkle Caper (1961); na terceira temporada, Once Upon a Time (1961), um dos raros episódios cômicos da série, explora a ideia de um homem do século XIX indo parar nos anos 60; e na última temporada, The Long Morrow (1964) exibe uma história de um futuro próximo ao público com a locomoção para um futuro mais distante (médio).

\subsection{1- The Last Flight}

Em 5 de fevereiro de 1960, na primeira temporada de Além da Imaginação, foi ao ar The Last Flight, o $18^{\circ}$ episódio exibido na série. O episódio, filmado em meados de julho de 1959, foi dirigido por William Claxton e teve elenco estrelado por Kenneth Haigh, Simon Scott e Alexander Scourby. Este é o primeiro episódio de Richard Matheson como roteirista, porém, anteriormente, duas histórias suas já haviam sido adaptadas em roteiros feitos por Rod Serling, And When the Sky Was Opened e Third from the Sun, respectivamente os episódios onze e quatorze da série. Os custos totais de produção foram de USD\$ 44.868,76 (GRAMS JUNIOR, 2008, p.239; ZICREE, 2018, p.52, 1992, p.58).

Na Primeira Guerra Mundial, o piloto William Terrance Decker, da Royal Flying Corps (a antiga força aérea do exército britânico), enquanto fazia uma missão no interior da França, pilota o avião e passa por uma nuvem. Ao deixar a nuvem, Decker se dirige a uma base militar, pousando sua aeronave. Enquanto taxeia pela pista, ele fica surpreso com os novos modelos de avião e pela tecnologia avançada que observa, bem distintas do seu pequeno biplano. Ele supõe que os EUA estavam muito mais avançados que a Inglaterra, isso explicaria o que vira. Após parar seu avião, Decker é escoltado por soldados ao chefe da base militar, o Major-General George Harper. Na sala do oficial, Decker informa a homens incrédulos que para ele o dia era 5 de março de 1917 e não 5 de março de 1959, como os americanos afirmavam. Decker contou que ele e seu amigo Mackaye participavam de um combate aéreo 
contra pilotos alemães que estavam em superioridade numérica e seu amigo provavelmente teria morrido, pois Decker fugira sem tentar ajudá-lo, indo em direção a uma grande nuvem. Os oficiais, imaginando que estavam presenciando uma brincadeira bem-feita, pressionam Decker, pois Mackaye, não havia morrido, e, em 1959, era um importante oficial britânico, herói da Segunda Guerra Mundial. Mackaye ainda por cima visitaria a base militar mais tarde, no mesmo dia.

Sem sucesso em convencer os oficiais americanos, Decker acaba percebendo que ele deveria voltar para salvar seu amigo, pois sua presença em 1959, vendo a importância histórica de seu amigo, seria um sinal de que deveria ter coragem e retornar para salvá-lo, salvando muitas vidas no processo. O piloto da Primeira Guerra escapa da base, pega seu avião e retorna para a mesma nuvem, voltando para 1917, salvando Mackaye e sacrificando sua vida. Em 1959, o herói Mackaye chega para inspencionar a base militar e conta para os americanos como fora salvo em 1917 por seu amigo Decker; surpreso, vê objetos do seu amigo e ouve dos americanos uma citação de seu antigo apelido, algo que só alguém de 1917 poderia saber.

O título original para o episódio proposto por Matheson era apenas Flight (Voo, em tradução livre), com a intenção do autor de expressar tanto o movimento do avião quanto a mudança que ocorre com o protagonista; porém, ele reconhecia que o título que acabou sendo adotado após a filmagem, The Last Flight (O Último Voo, em tradução livre), mantinha parcialmente o sentido duplo intencionado pelo escritor, de certa forma focando mais o problema principal do protagonista, pois seria a última vez que Decker se comportaria de forma covarde (ZICREE, 1992, p.60). Ainda sobre Matheson, o pesquisador Zicree identifica, corretamente, uma das principais características dos roteiros de Matheson na série: o enredo se desenvolve de uma forma que prende a atenção do público, o qual deseja mais saber o que irá ocorrer na história, do que se identificar com o personagem (Ibid., p. 59). A busca pela identificação entre público e personagens comuns era uma característica mais da obra de Rod Serling do que de Matheson.

A surpresa de Decker ao se deparar com o aeroporto de 1959, sua fala de que não imaginava que os americanos estavam tão avançados devido à presença de aviões a jato e o tamanho do complexo, já indicam a oposição entre os tempos dentro da perspectiva do progresso. A audiência sabe, antes do personagem, o que se passou e reconhece esse avanço, mas posteriormente receberá a informação de que 
para esse avanço todo ter ocorrido, pessoas corajosas e sacrifícios foram necessários no passado.

Em 1948, foi transmitida na rádio uma história chamada One for the Book parcialmente semelhante a The Last Flight, no programa de antologias Quiet, Please, de autoria de Wyllis Cooper; entretanto, essa história não foi copiada, tampouco inspirou Matheson (GRAMS JUNIOR, 2008, p. 241), haja visto que no enredo de One for the Book, a viagem se dá entre um militar do futuro que, no teste de um foguete, vai para o passado. A produtora de Rod Serling tentou adquirir os direitos dessa história e contatar Wyllis Cooper para evitar acusações de plágio.

Este episódio é o primeiro em toda a série onde há a presença de um tipo de máquina do tempo: o avião. Mesmo que a forma da viagem no tempo esteja no campo da fantasia, pois ao passar por uma certa nuvem, uma fenda no tempo leva o piloto de 1917 a 1960, transportando-se no tempo e não no espaço, no modelo wellsiano. Conforme Serling informou em carta de 18 de março de 1960 a uma criança que não entendeu como o avião pode se transportar de 1916 (sic) para uma base militar em 1959, "esta é uma das ideias de transferência temporal onde uma pessoa vai para frente ou de volta no tempo de forma inexplicável67" (DIAMOND, [março, 1960?], p.23 , tradução livre). Não há nenhum efeito visual que denote uma viagem no tempo, mas a música indica que algo estranho está se passando, uma trilha composta por Bernard Herrmann.

O uso do avião ou outras formas de transporte associados na modernidade com velocidade e tempo, como o trem, seria frequente na série exatamente como símbolo de conquista do espaço e do tempo. Os meios de transportes modernos continuam a popular as histórias de viagem no tempo como mecanismos que permitem a viagem para outras temporalidades. Essa associação está implícita e é aceita como verossímil em sociedades nas quais tais formas de transporte se manifestam como redutoras de tempo e espaço, bem como onde o símbolo do Tempo incorporou o sentido de movimento, aceleração e velocidade.

A viagem ao futuro do piloto Decker mostra que o presente do público foi criado por meio de sacrifícios e ações realizadas no passado; para Decker, a viagem serviu para alterar seu pensamento egoísta e perceber que suas ações tiveram

${ }^{67}$ No orginal "[...], this is one of those time transference ideias where a person goes either ahead or back in time for an unexplained reason." 
consequências positivas no futuro: sua morte ao salvar sem amigo em 1917, futuramente um herói, permitiu a sobrevivência de muitas pessoas. Os aspectos positivos de seu sacrifício se manifestaram tanto na Segunda Guerra Mundial, uma guerra próxima do público e vista como justa, quanto na Guerra Fria, onde o aeroporto francês, uma base americana no exterior, faz parte do Strategic Air Command (Comando Aéreo Estratégico), comando da aeronáutica dos EUA "formado especificamente para projetar o poder americano no exterior, a fim de garantir a deterrance 68 , e lançar um ataque retaliatório poderoso, com armas atômicas, se viesse uma guerra" (MEILINGER, 2012, p.xiv). A base americana em território francês, com herói aviador britânico, tem como pano de fundo também a formação e atuação da OTAN (Organização do Tratado do Atlântico Norte), formada em 1949, que garantia uma rede de cooperação militar entre os países alinhados aos EUA contra possíveis e supostas ações da URSS e seus aliados. O deslocamento para o futuro une os três grandes conflitos internacionais do século $X X$, propondo que guerras sempre irão ocorrer, mas são as ações dos indivíduos que importam, principalmente os valores éticos e morais. Com auto sacrifício/coragem, pode-se salvar vidas e vencer conflitos, uma clara mensagem para os contemporâneos da série.

No episódio, mesmo que flerte com a noção de livre arbítrio (ele podia se salvar ou salvar o amigo), o universo é determinista: o homem viaja para um futuro no qual ele se sacrificou, não havia outra opção exposta para ele realizar no passado, cabendo somente a temporalidade de destino, a Zona Crepuscular, fazê-lo reconhecer e aceitar seu sacrifício como importante para construção do presente/futuro aperfeiçoado. A Zona Crepuscular também tem o papel de torná-lo um ser humano completo, ao se tornar corajoso e tentar salvar seu amigo, Decker cumpre sua função no mundo, essa lição vem de sua viagem no tempo e, assim, ele pode se sacrificar pelo amigo e/ou pela humanidade. Ele ocupa o lugar simbólico de mártir, transmitindo sua lição para o público, como um tipo fantástico de hagiografia.

Como dado interessante sobre o envolvimento do público pela série e a própria noção de que algo sobrenatural poderia estar intervindo na ordem das temporalidades, em 11 de abril de 1961, mais de um ano após a exibição do episódio The Last Flight, o doutor Alan Gessner, um psicólogo diretor do Polk County Mental

68 Teoria tornada central na Guerra Fria, de dissuasão do ataque inimigo por meio da capacidade retaliatória capaz de minar os objetivos da guerra e trazer altos custos para o atacante, no caso, com o uso de armas nucleares devastadoras. 
Health Center (WHITE, 2012, n.p.), escreveu para Rod Seling. O doutor Gessner estaria escrevendo um roteiro e pesquisava sobre relatos oficiais governamentais de fatos sobrenaturais e gostaria de saber se a história do avião exibida na série era baseada em algum relato real, pois tinha ouvido falar de uma história similar ocorrida verdadeiramente na França durante a Segunda Guerra Mundial (GESSNER, 11 abr 1961, p.1). Rod Serling responderia que o roteiro era de Matheson e assumiria que também ouvira falar de diversos casos de objetos que haviam se transportado entre os tempos, mas nada ainda havia sido documentado como verdadeiro (SERLING, 1961f, p.1). Essa ideia de objetos se transportando de forma inexplicável pelas temporalidades, teve uma interessante análise no conto já citado de Jack Finney, I'm Scared (1951), com certeza uma obra conhecida por Rod Serling. Finney relacionava tal fenômeno com a tentativa de parcelas cada vez maiores da população em tentar escapar do presente para outras épocas.

Figura 48 - Contraposição entre o moderno e o antigo, estabelece a relação entre os tempos e indica ao público que ocorreu um deslocamento pelo tempo. O poder dos EUA também está representado na contraposição entre EUA (presente, a esquerda) e Inglaterra (passado, a direita).

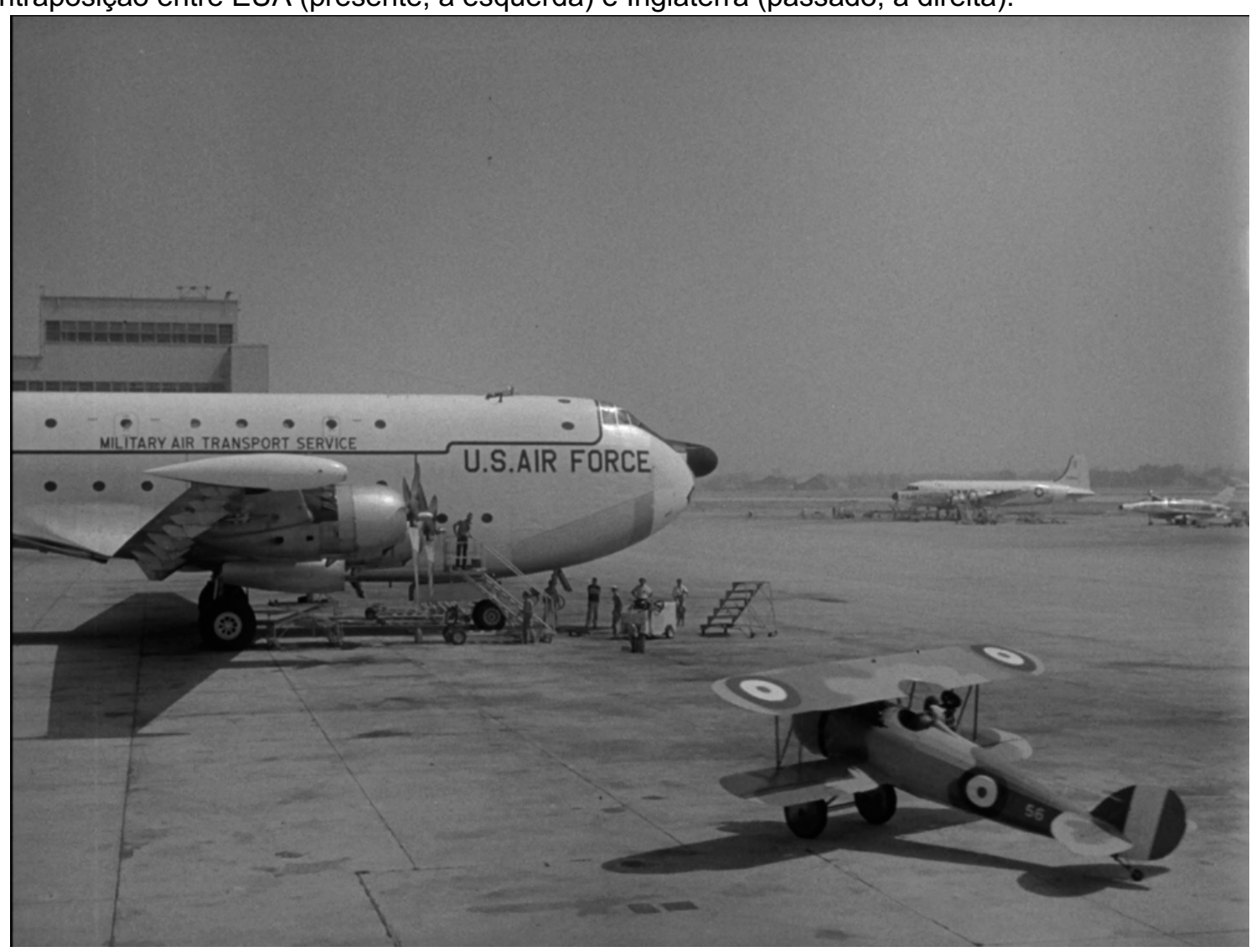

Fonte: elaborado pelo autor (Blu-ray, The Twilight Zone: The Complete Series, CBS, 2017) 
A presença desse tipo de história, que até hoje costuma povoar os noticiários, atraindo a curiosidade, serve como manifestação das vontade de se controlar não só o tempo, mas de dar sentido para a vida em tempos notados como fragmentados e sem magia, como, por exemplo, a história divulgada mundialmente em 2008 (que costuma ressurgir de tempos em tempos na mídia), do relógio de metal identificado como sendo originário da Suiça, encontrado nas escavações da tumba de Si Qing, da dinastia Ming (MISTÉRIO..., s.d.). O fato do objeto misterioso fora do tempo ser um relógio deixa ainda mais clara a relação entre o achado e a viagem no tempo, haja visto o próprio símbolo reificador de tempo ter sido transportado ao passado, dando vazão à crença de que, de alguma forma, a viagem no tempo será desenvolvida no futuro ou já existe em segredo. Essas histórias reforçam a ideia de progresso e alimentam as mais diversas hipóteses oriundas das histórias insólitas, que criaram um repertório social amplo capaz de dar conta de fornecer uma explicação para fatos estranhos que se apropriam livremente de conceitos das ciências.

\subsection{2- Execution}

Indo ao ar em 1 de abril de 1960, Execution foi o $26^{\circ}$ episódio exibido na série, na primeira temporada. Escrito por Rod Serling, baseado em uma história de George Clayton Johnson, foi dirigido por David Orrick McDearmon. Nesse episódio, temos a primeira participação do ator Albert Salmi (GRAMS JUNIOR, 2008, p. 271-272; ZICREE, 2018, p.101; 1992, p.109;). Este ator era um rosto comum nos principais programas de televisão do período e iria aparecer mais duas vezes na série, nos episódios envolvendo viagem no tempo ao passado discutidos anteriormente: $A$ Quality of Mercy, no qual encenou o sargento Causarano, e Feathersmith, em Of Late I Think of Cliffordville (em Execution, ele é Joe Caswell). As filmagens do episódio ocorreram em finais do mês de fevereiro de 1960 e o episódio custou USD\$53.149,32 (GRAMS JUNIOR, op.cit., p.271).

Em 1880, o assassino Joe Caswell está para ser executado na forca. Assim que a corda aperta, ele desaparece e ressurge dentro de uma máquina, em um apartamento de Nova York em 1960. O cientista Manion estava testando um modelo de máquina do tempo capaz de transportar aleatoriamente alguém do passado. Ao analisar Caswell, Manion percebe que há algo errado com ele; o homem do passado é rude, apresenta sinais de ser violento e, ainda por cima, tem uma marca como se 
algo Ihe tivesse apertado o pescoço. Ao comentar com Caswell que ele iria devolvêlo a sua época, tal homem ataca o cientista e o mata. Fugindo do apartamento, o homem do passado circula pela cidade grande, sendo afetado negativamente pelo som, pela aglomeração de pessoas e por tecnologias diversas que não entende, como carros e televisão. Desesperado, retorna ao apartamento e percebe que havia realmente matado o cientista no seu ataque, mas ele não está só: Paul Johnson, um ladrão que havia planejado furtar o cofre de Manion, está lá; os dois homems entram em luta corporal e Caswell é morto por Johnson. O bandido assassino de 1960, tentando abrir o cofre, acaba acionando por acidente a máquina do tempo e é transportado para 1880, ocupando o lugar de Caswell na forca, para surpresa das pessoas presentes no evento, que viram um corpo sumir e outro aparecer no lugar para ser morto.

Como citado anteriormente, o roteiro escrito por Serling foi adaptado de história adquirida de George Clayton Johnson; este escritor teve tanto histórias adaptadas para a série por outros roteiristas quanto fez seus próprios roteiros, como o famoso episódio Kick the Can (1962), refilmado por Steven Spielberg no filme No Limite da Realidade (Twilight Zone: The Movie, 1983). O conto, não lançado durante o período de exibição da série, somente foi publicado em 1977 no livro Scripts and Stories Written for The Twilight Zone.

Rod Serling reescreveu muito do material no conto de Johnson, na obra literária o vilão se chama Jason Black e há a presença de dois cientistas, o Dr. Miles e seu assistente Nolam. Temos também uma explicação do funcionamento da máquina do tempo: por ser um modelo experimental, os cientistas só conseguem definir a data $\mathrm{e}$ a máquina pega alguém do passado e o leva para o presente, futuro do viajante. A ideia original dos cientistas era pegar personagens históricos para que a História se tornasse um "livro aberto" (JOHNSON, 1996, I.285). Black consegue escapar do laboratório dos cientistas e corre solto pela cidade, sentindo-se chocado com o que presencia: carros, luzes, televisores, etc. Após se encontrar com uma garota, ser atropelado sem gravidade e ter pego uma pistola e balas da vitrine de uma loja de material esportivo, acaba tentando atacar os cientistas e é baleado e morto pela polícia. Ao morrer, seu corpo se transporta automaticamente para o passado, onde ocupa o lugar de enforcado antes de desaparecer. Há a discussão, por meio de um personagem feminino, de que talvez houvesse algum tipo de salvação ou segunda chance para o homem, ele é mais um ser do passado que vivera num mundo violento 
e perdido do que puramente mal, algo que foi retirado da adaptação de Serling. Para o pesquisador Zicree, o roteiro foi uma adaptação pobre do conto (ZICREE, 2018, p.102; 1992, p.110), porém, as alterações inserem o enredo do episódio no corpo mais amplo dos episódios de viagem no tempo, fornecendo um fundo moral e uma reflexão sobre o presente.

No relatório da autocensura da CBS datado de 29 de janeiro de 1960, havia algumas solicitações de mudanças a serem realizadas no episódio, como retirar referências a Deus em falas do cientista, que nenhuma marca aparecesse na jukebox, no bar e no televisor, que fossem tomado os cuidados esperados na época sobre a exibição de violência e, em uma cena na qual Caswell cuspiria, que fosse filmada de forma a evitar repugnância por parte do público (GOTSCHALL, 1960, p.1-2). A maior parte das alterações seriam seguidas pela produção, menos onde o vilão chamaria a Bíblia de "este livro", mas Serling teria conseguido manter a fala (GRAMS JUNIOR, 2008, p.283).

Esse é o primeiro episódio que utiliza o tema do western para apresentar a contraposição entre os tempos, o que demonstra a força da cultura histórica e desse passado percebido como fundamental para formação da identidade nacional americana, porém não idealizada por Serling. Numa perspectiva de progresso, o passado vindo para o futuro se mostra inadequado, ele é violento e irracional, e, se condições semelhantes pudessem ainda se fazer presentes, elas deveriam ser eliminadas. Vemos nesse episódio o esboço crítico que acompanhou Serling por toda sua carreira ao lidar com o gênero western. A viagem no tempo, aqui, fortalece e clarifica a crítica.

Na ironia exibida no final surpresa, o bandido do futuro de Caswell, Johnson ${ }^{69}$, acaba indo para o passado para ocupar o lugar na forca do cowboy assassino, este morto por Paul Johnson em 1960 com a corda da cortina do laboratório de Manion. A fala final de Serling que afirma que a "justiça pode levar anos e a punição não está sujeita a um calendário" (SERLING,1959r5, p.28) completa a mensagem da história na qual a ordem é restaurada por meio da viagem no tempo. Entretanto, deve-se atentar para a conclusão exposta pelo episódio de que alguns comportamentos

\footnotetext{
${ }^{69}$ Sabemos o nome do bandido de 1960 ao ler o roteiro, no episódio em nenhum momento ele tem seu nome revelado. Para facilitar o entendimento de qual bandido estamos falando, utilizei o nome dado por Serling ao malfeitor de 1960.
} 
antissociais danosos se fazem presentes em todas as épocas e devem desaparecer, essa ideia foi inserida por Serling e está ausente no conto de George Clayton Johnson.

A própria ideia exposta no episódio do transporte de "um primitivo do século XIX" para a "selva do século XX", como dito pelo desafortunado inventor da máquina do tempo, expõe de forma irônica um dos problemas discutidos no episódio: o homem do passado não consegue se adaptar ao mundo do presente, pois traz consigo experiências cotidianas que não se ajustam à experiência da vida nas "selvas" das cidades. Mesmo que em linhas gerais, o progresso seja claro, como a presença do telefone, dos automóveis e das luzes, a ironia faz a crítica do presente, ao expor as dificuldades que o ente passado tem no futuro, dificuldades que não são percebidas, ou são naturalizadas pela audiência da série em seu cotidiano, como a questão da poluição sonora e visual. A ênfase em elementos como esses, reforça a criticidade do presente, mesmo que, como dito, esta temporalidade seja apresentada como mais desenvolvida tecnologicamente, mas não ética ou moralmente, algo que ainda estaria em construção - demandando a atenção da Zona Crepuscular. Assim, não há uma visão de que no passado se encontram valores perdidos a serem reconstruídos no presente, noção exposta, por exemplo, nos roteiros de Serling de viagem a um passado nostálgico - cada destino da viagem indica uma forma de se lidar com as expectativas de mudanças no presente.

A vilania de Caswell é a todo momento reiterada, mesmo que Serling insira um comentário social quando o cowboy assassino discute com Manion, de certa forma justificando o seu comportamento violento porque ele vinha de uma experiência de vida baseada na violência e na sobrevivência do mais forte - isso, por algum tempo, aproxima o cowboy do público e mostra uma reflexão sobre o que tornaria uma pessoa má às vistas da sociedade -, mas em linhas gerais Caswell é exposto como um vilão psicótico. Para não deixar dúvidas, o reforço visual já o insere em uma tradição representativa não subvertida: suas vestes são escuras, símbolo do cowboy mau no código dos westerns populares, e no decorrer da história, ao tentar sair sem sucesso de uma cabine telefônica, ele ainda por cima ganha um ferimento no rosto ao quebrar o vidro, um corte característico de cicatriz de vilão ou anti-herói, indo de debaixo do olho para cima, deixando o globo ocular intacto, semelhante à cicatriz do vilão Scar do desenho Rei Leão (The Lion King, 1994).

A Zona Crepuscular é o futuro do viajante involuntário, ela dá a segunda chance para o malfeitor Joe Caswell, uma chance de recomeçar em outro tempo e espaço, 
construindo uma nova história para si, mas sua maldade e a violência brutal não permitem que ele possa ter uma nova vida. A série Além da Imaginação, em diversos episódios, expôs uma visão contrária à pena de morte, punição prevista em lei em muitos estados americanos durante a exibição da série (e até hoje) e, a princípio, a Zona Crepuscular, por meio da viagem no tempo, interveio para retirar do Estado tal prerrogativa, tomando para si, como sempre fazia, o papel de tentar transformar e julgar os personagens. No caso de Caswell, sua maldade era tão grande que para proteção da sociedade, ele precisou ser retirado totalmente do convívio com as demais pessoas, ou seja, não aproveitou sua segunda chance: o seu comportamento antissocial e violento ao extremo é, em última instância, responsável por sua própria morte. Caswell acaba sendo punido por suas ações no mundo da Zona Crepuscular. Já Johnson também sofre a punição por ser a versão no presente de Caswell.

Figura 49 - Caswell assustado pelos estímulos visuais e auditivos. O "primitivo" na "selva" da cidade grande moderna.

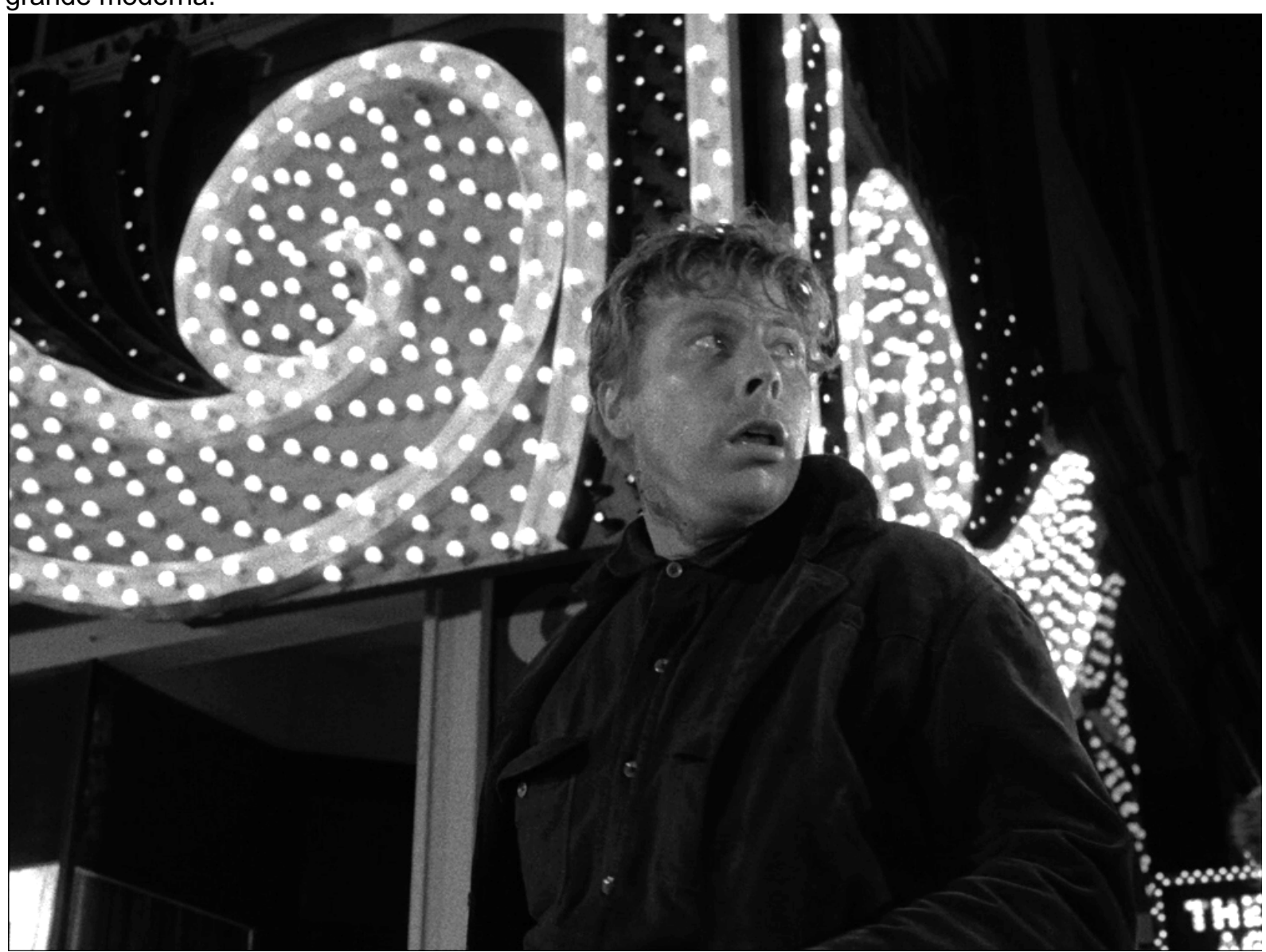

Fonte: elaborado pelo autor (Blu-ray, The Twilight Zone: The Complete Series, CBS, 2017)

Há uma perspectiva de futuro exposta: por remover as pessoas violentas e danosas para a sociedades, como os dois bandidos que agiam a sangue frio, 0 
episódio propõe que não há lugar no futuro humano/americano para esse tipo de pessoa/comportamento. No contexto histórico dos EUA, marcado por conflitos internos e externos, a série se posicionava contra a violência e irracionalidade ao utilizar a Zona Crepuscular como forma de evitar os danos causados por essas pessoas para a coletividade, o que, cabe destacar, cria um discurso aberto o suficiente para ser dirigido a pessoas que viessem a causar alguma disrupção no status quo, mas isso não era uma intenção de Serling, haja vista a sua biografia.

Nesse episódio, há a presença de uma máquina do tempo, que parece um tipo de box poligonal; no roteiro, ela era descrita como uma batisfera (SERLING, 1959r5, p.7), uma esfera oca para mergulho. Seu funcionamento e quais os princípios físicos que estão por trás de sua operação não são explicados, mas a presença da máquina do tempo capaz de teleportar pessoas do passado, aleatoriamente, para o seu presente indica a tentativa do cientista George Manion de controlar a História e, no modelo comum nas histórias de ficção científica do período, ser punido com a vida por sua tentativa de brincar de Deus, no caso, mexer no fluxo do tempo. A incapacidade de Manion de saber realmente quem estava trazendo do passado demonstra um certo desleixo com as consequências de sua invenção e mesmo sua abordagem do problema ao perceber que havia uma aura de maldade no homem que trouxera do passado é displicente: logo após notar que há algo errado com Joe Caswell devido à marca de corda no pescoço, ele já avisa que irá devolvê-lo ao passado. Isto expõe uma posição elitista, como se o bandido fosse aceitar sua ordem apenas por ele ser mais inteligente ou mesmo ser um homem da ciência, frente a, como denominara anteriormente o homem do passado, um primitivo.

Há neste episódio uma brincadeira com a tradição audiovisual que remete a famosa anedota, reproduzida até hoje, das exibições do filme L'Arrivée d'un train en gare de La Ciotat (1896), na qual o público, que nunca tinha visto um filme, ao ver o trem chegando na estação, teria corrido de medo, escondendo-se aterrorizado para trás das cadeiras ${ }^{70}$. No episódio, traduzindo o evento para o mundo da televisão, Caswell, em uma versão 1960 do saloon clichê do western, vê na televisão um cowboy de filme desafiar o inimigo para um duelo, ao qual Caswell responde prontamente,

70 Sobre o mito que cerca a História da exibição desse filme, ver: LOIPERDINGER, Martin. "LUMIÈRE'S 'ARRIVAL OF THE TRAIN': Cinema's Founding Myth." The Moving Image: The Journal of the Association of Moving Image Archivists, vol. 4, no. 1, 2004, p. 89-118. 
sacando a arma ao mesmo tempo que o cowboy da televisão e disparando um tiro certeiro, que destrói o aparelho. Caswell, surpreso e com medo, foge assustado tanto com o que acabara de fazer, quanto com os gritos do barista chamando a polícia.

No contexto histórico, a forma pela qual a cidade de Nova York é retratada, inclusive pela fotografia do episódio, dá lhe um aspecto caótico, uma representação a qual se opunha o imaginário dos subúrbios para a classe média. Assim, as imagens rápidas das luzes, carros passando e aglomerações humanas, com o som característico, eram símbolos recorrentes das grandes cidades das quais camadas cada vez maiores das populações fugiam. O incômodo de Caswell reverberava nas expectativas de parcelas da audiência da série e dos planejadores urbanos modernos.

O próximo episódio a lidar com a viagem ao futuro, também escrito por Serling para a segunda temporada, retornaria à temática do western, agora na luta pela sobrevivência de uma família em um ambiente hostil e inóspito, transformado no futuro pelos seus sacrifícios no passado.

\subsection{3- A Hundred Yards Over the Rim}

O episódio foi o $59^{\circ}$ exibido na série e o $23^{\circ}$ da segunda temporada, indo ao ar em 7 de abril de 1961. Roteirizado por Rod Serling e dirigido por Buzz Kulik, A Hundred Yards Over the Rim foi filmado no início de março de 1961 no deserto na região de Lone Pine, Califórnia, estrelado por Cliff Robertson, John Astin, Evans Evans, Ed Platt. Os custos totais de produção foram de USD\$ 58.879,17 (GRAMS JUNIOR, 2008, p.389; ZICREE, 1992, p.195; Id., 2018, p.182).

Chris Horn é o patriarca que leva sua família e um grupo de colonos pelo deserto rumo à Califórnia em 1847, enfrentando diversas privações no caminho, como falta de água, comida, calor extremo e ataques de indígenas, além disso, o próprio filho de Horn está doente, com poucas esperanças de sobrevivência naquele ambiente inóspito. O grupo começa a duvidar da liderança de Horn e cogita abandonar a busca por novas terras e voltar para Ohio. Para sobrevivência de todos, Chris Horn pega seu rifle e parte em uma última busca por água e caça, subindo um morro. Do outro lado do morro, vê uma estrada asfaltada e postes; andando na estrada, é quase atropelado por um caminhão e, ao cair, seu rifle dispara acidentalmente e fere superficialmente seu braço. Vendo um restaurante e posto de gasolina, ele se dirige à construção para procurar ajuda; sem o saber, ele tinha ido parar em 1961. No 
restaurante, ele conhece Joe e Mary, os proprietários do posto e restaurante que o ajudam no que podem; Mary cuida de seu braço e lhe dá penicilina, explicando como tomar o remédio e sua função de impedir infecções bacterianas e Horn recebe a informação de onde havia água natural e animais silvestres na região. Um médico é chamado para Horn e acredita que o homem de roupas e armas antiquadas estava sofrendo de algum tipo de problema mental, mas havia algo de estranho, pois a restauração de seus dentes era de um tipo que não era mais realizado há muito tempo. Como o caso parecia ser mais sério do que pensavam à primeira vista, eles decidem ligar para a polícia. Enquanto isso, Horn descobre um livro no restaurante e ao lê-lo, recebe a informação de que seu filho se tornou um um médico importante na História dos EUA. Tendo certeza de que sua viagem no tempo deveria ter ocorrido por alguma razão maior, ele, então, decide fugir do lugar e voltar a sua época, levando consigo a penicilina. Na fuga, agora com a polícia atrás, ele deixa sua arma cair no deserto, mas consegue escapar em direção ao morro, retornando para 1847. Agora em seu tempo, Horn instruiu seu grupo sobre onde achar água e caça e ensina como o remédio deve ser administrado a seu filho doente, sua empolgação reacende a esperança de todos os colonos. Em 1961, Joe recupera a arma de Horn do deserto, pois era uma antiguidade possivelmente valiosa, mas a arma estava envelhecida e quase se desfaz totalmente: algo muito estranho havia se passado naquele dia.

A ideia original de Serling era a história se passar no interior do estado do Arizona, como pode ser visto em roteiro datado de 30 de janeiro de 1961 (SERLING, 1961r1; GRAMS JUNIOR, 2008, p.340), posteriormente alterado para a Califórnia, mais próximo do destino dos colonos em sua travessia pelo Oeste.

A viagem ao futuro de Chris Horn se dá por forma mágica, no modelo de Walking Distance: caminhando no deserto, automaticamente, ele se transporta de 1847 para 1961 e seu retorno à sua época também se dá da mesma forma. A fotografia de Clemens no episódio faz o papel de indicar o deslocamento no tempo; Horn anda na vastidão natural desértica de 1847 e o vemos já 1961, atravessando um deserto marcado por torres de energia, em direção às obras da civilização (fim da fronteira), como se estivesse se deslocando por um planeta alienígena, impressão realçada pela música.

O presente em 1961 é o do progresso, não só tecnológico; a tecnologia é o primeiro aspecto que o episódio chama atenção para reflexão do público. Mas também se nota o progresso social: os índios da região vivem na comunidade, há uma 
sociedade organizada e desenvolvida no lugar; a violência que marcava a conquista do oeste em 1847 encontra-se encerrada. O futuro não tinha mais os valores negativos do século XIX. O fato da arma de Chris Horn se transformar em antiga e desfazer no presente, quando ele volta a sua época, reforça a mensagem de que o passado de violência não teria mais espaço no presente de 1961, uma ideia semelhante a Execution (1961), mas muito mais positiva sobre o presente.

Figura 50 - Chris Horn guia sua família e um grupo de colonos pelo deserto rumo a Califórnia.

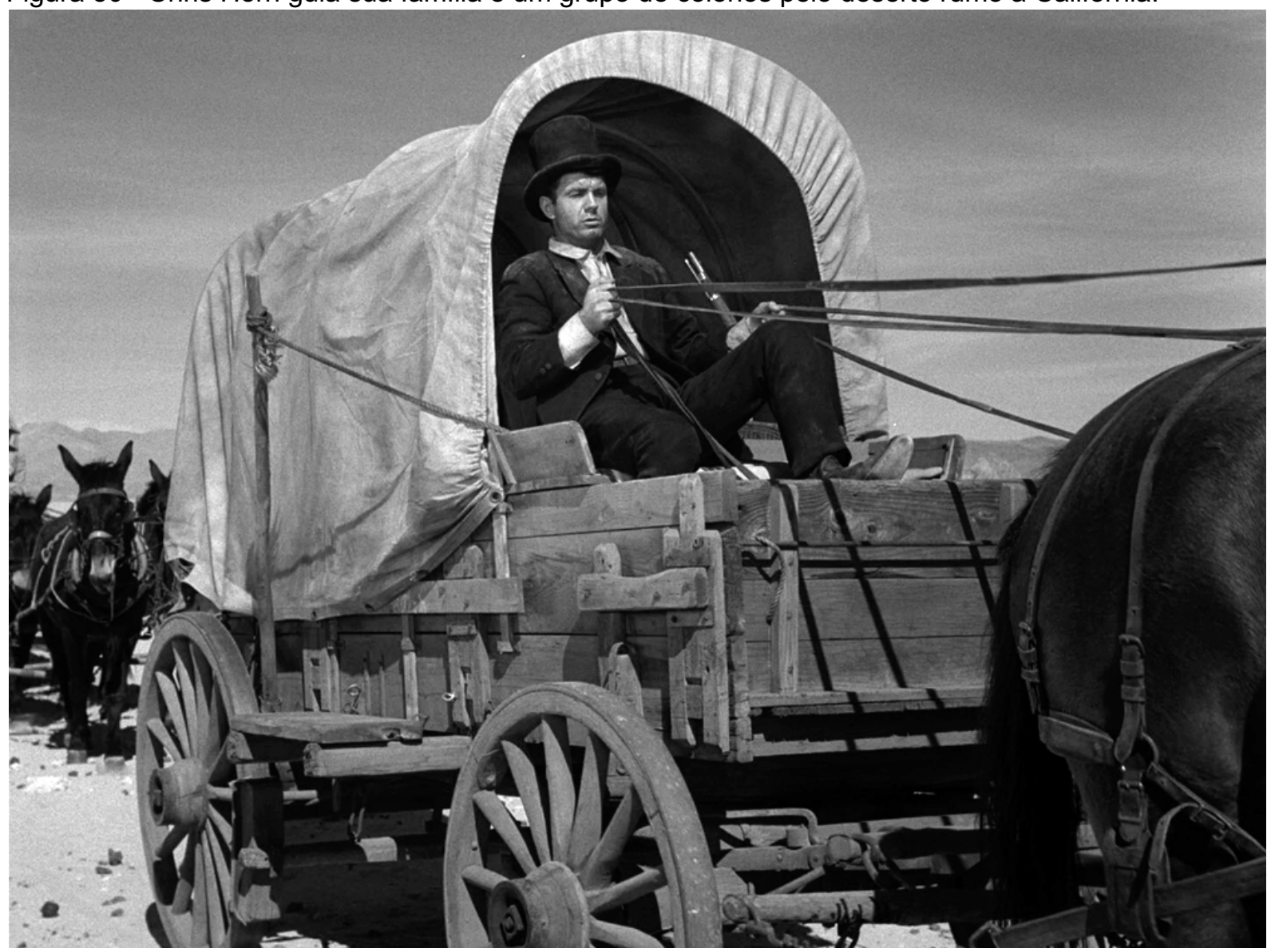

Fonte: elaborado pelo autor (Blu-ray, The Twilight Zone: The Complete Series, CBS, 2017)

Esse episódio utiliza a viagem no tempo ao futuro como forma de refletir sobre a formação dos EUA, dentro da perspectiva da formação do povo americano proposta por Jackson Turner. O episódio, sem se basear em primeira mão na obra do historiador, bebe da cultura histórica iniciada por ele e que acabou retroalimentada e referendada por sua tese de formação dos EUA. A Hundred Yards Over the Rim representa as ideias de Turner de forma audiovisual: "A fronteira é a mais rápida e mais efetiva forma de americanização. Aí, wilderness - a natureza inóspita e remota - domina o colono" (TURNER, 2004, p.25) e "[...] notamos que a froneira promoveu a 
formação da nacionalidade complexa do povo americano" (Ibid., p.41). É exatamente ao processo de americanização que assistimos, encenado em uma história insólita sobre viagem no tempo, apropriando-se da cultura histórica tradicional, que via os EUA como uma sociedade que floresceu de um início primitivo e se via representada nesta cultura histórica, como igualitária e democrática (WHITE, 1994, p.13). No ambiente da fronteira, uma "metáfora para promessa, progresso e engenhosidade" (WORVEL apud LIMERICK, 1994, p.68), é enfatizada a mensagem do episódio, ancorada nesses pilares.

Ainda expondo a cultura histórica do período, o retrato dos colonos vítimas dos ataques indígenas, da natureza e da doença faz parte da forma de retratar a própria história da conquista do Oeste, a vitimização dos colonos brancos como forma não só de justificar os massacres - seriam apenas retaliação - (WHITE, 1994, p.27), mas ampliar o heroísmo das ações e a herança na forma tanto material, com o espaço conquistado a duras penas, quanto espiritual, deixada para as próximas gerações.

Figura 51 - Contraposição entre passado (esquerda) e presente (direita). A viagem no tempo ao futuro de Chris Horn o leva a presenciar os efeitos dos sacrifícios das pessoas do passado. $O$ desenvolvimento, simbolizado pelo restaurante e posto de gasolina a beira de estrada onde antes era um ambiente inóspito, surpreende o homem do século XIX.

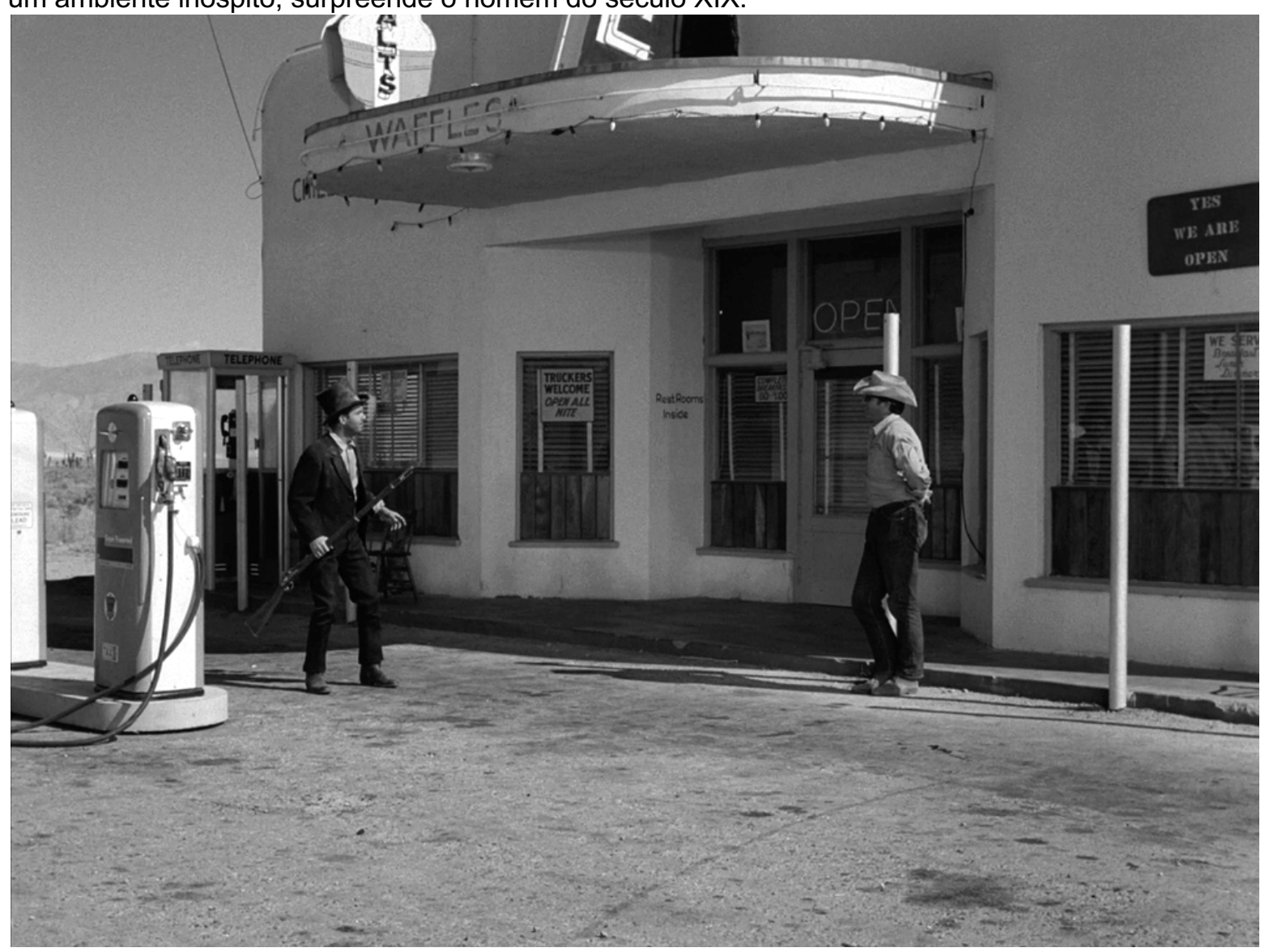

Fonte: elaborado pelo autor (Blu-ray, The Twilight Zone: The Complete Series, CBS, 2017) 
O fato de roupas, artefatos, veículos e animais serem fiéis a expectativa do público - o próprio ator Cliff Robertson afirmava que pesquisou as roupas que os colonos utilizaram na travessia no deserto em meados do século XIX (ZICREE, 2018, p.183), além do repertório já adquirido pelo contato com o gênero western -, reforça a verossimilhança do episódio e adentra à representação do passado pertencente à cultura histórica. A oposição entre esses elementos e os do presente do público da série, como os postes de energia, os carros e o restaurante, faz parte do jogo entre passado, presente e futuro que a audiência é convidada a realizar.

Em A Hundred Yards Over the Rim, é estabelecida exatamente a relação entre esse passado e um futuro médio, no qual o processo histórico já se encontra completo. Esse futuro reconhece a importância do passado e o ajuda, pois o passado de superação é onde foram forjados os valores e as próprias vantagens do presente: o fato do menino que iria morrer sem o antibiótico ter sido importante para 0 desenvolvimento da medicina exemplifica de forma clara essa ideia.

Figura 52 - O cowboy do Velho Oeste é substituído pelo empreendedor.

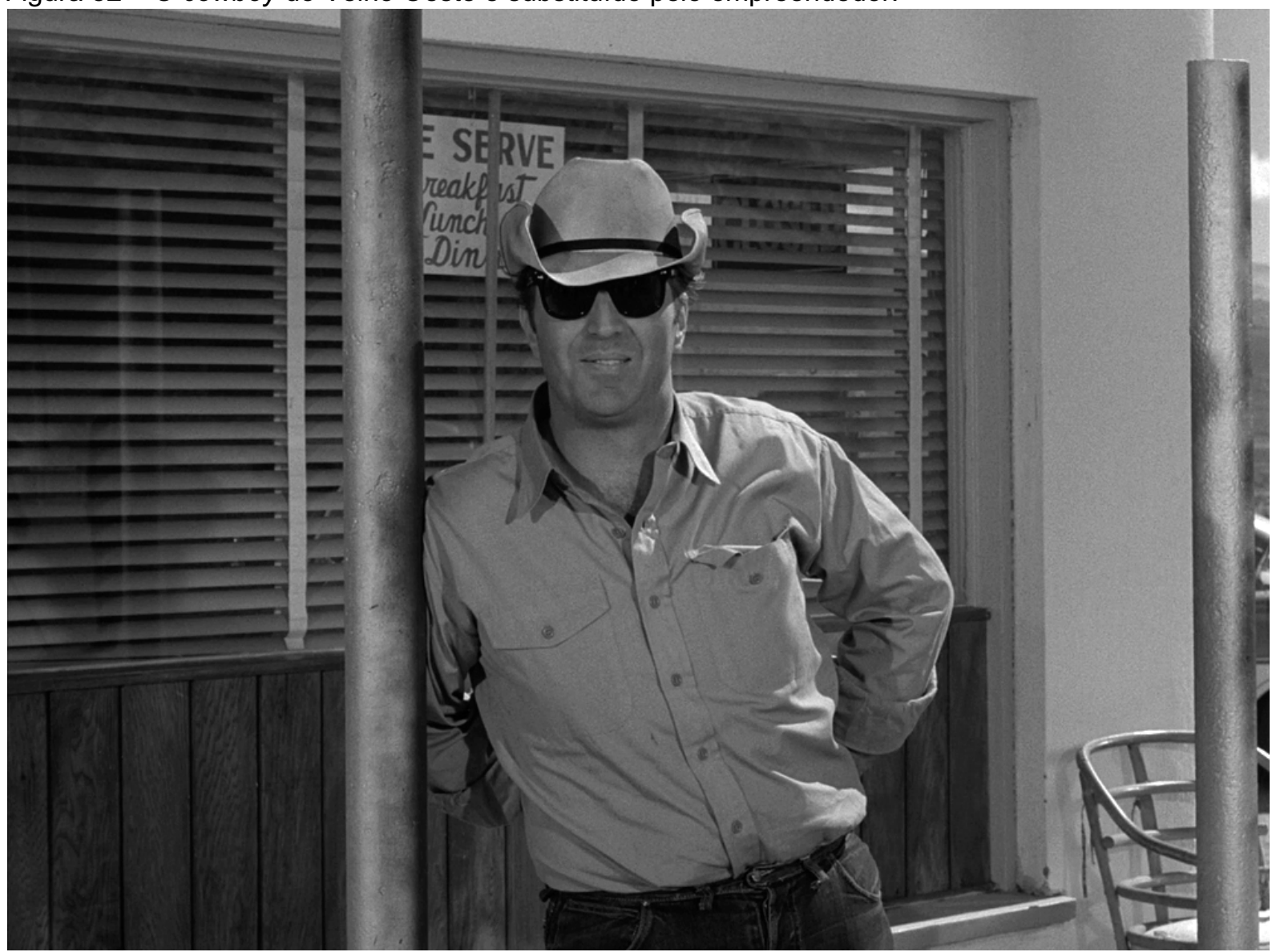

Fonte: elaborado pelo autor (Blu-ray, The Twilight Zone: The Complete Series, CBS, 2017) 
Cabe destacar que quando Turner publicou seu artigo mais famoso, The Significance of the Frontier in American History, sua crença e a de muitos de sua época era também de conclusão do período histórico que descrevera, isso em 1893, pois o conflito com o wilderness já estaria encerrado. Outro indicativo de como a percepção das mudanças pode se manifestar no trabalho historiográfico moderno, por exemplo, trabalhos orientados com a perspectiva de o fim do Oeste, o fim do Ocidente e o fim da própria História. O episódio de forma clara mostra para o seu público que o tempo do protagonista já era passado e superado. O episódio brinca com a ordem da relação causa-efeito, é o futuro que cria o passado. Vemos literalmente o futuro iluminando o passado.

Não era também estranho ao público da época o papel primordial do patriarca da família como herói. Chris Horn representa o que é esperado de um pai no contexto da série: o auto-sacrifício por sua família. Este papel do pai não será contestado neste episódio e em grande parte da série, mas podemos encontrar episódios que problematizavam o ideal de família propagado no período, que se valia da televisão como forma de difundir os papeis sociais de cada membro familiar de forma idealizada; geralmente a série criticava esses ideais, como em Living Doll (1963).

Este episódio não apresenta a reviravolta irônica surpresa no final e a Zona Crepuscular opera para recompensar o esforço, sacrifício e resiliência dos colonos: levando o líder do grupo ao futuro e dando-lhe a chance de salvar o seu filho e o seu desanimado grupo. A própria narrativa faz uso de temas semelhantes à história bíblica de Moisés, demonstrando a formação do americano padrão idealizado: Chris Horn guia pelo deserto o povo escolhido para formar o futuro de estradas, telefones, automóveis e remédios, por meio da ação da Zona Crepuscular.

A resiliência de Horn para salvar sua família e realizar o sonho americano no Oeste serve, no episódio, para inserir a história na tradição das aventuras de colonos no Oeste, que povoam a cultura popular americana desde o próprio século XIX, apresentando, em um contexto familiar ao público, o elemento da misteriosa viagem no tempo e a influência do presente/futuro no passado. A viagem no tempo ajuda o sonho americano a se realizar, colocando lado a lado dois contextos que estariam se encerrando: a conquista do Oeste terminando com a chegada dos colonos na Califórnia e o sucesso dos descendentes deles e o período do segundo pós-guerra, no contexto histórico da série, marcado pelos prognósticos negativos do próprio fim da civilização, numa guerra mundial ou na própria falência das instituições 
americanas. Já que, segundo o mito do Oeste, a própria democracia americana é derivada das formas de organização desenvolvidas pelos colonos na conquista da fronteira, a democracia só sobreviveria por constante manutenção e reafirmação dos valores positivos associados aos colonos e exprimidos pelos personagens no episódio.

Os diversos episódios em Além da Imaginação que lidam com o gênero western e, nesse universo, inserem a viagem no tempo vão além de introduzir em um gênero cultural globalizado importante a temática ancorada no insólito presente na série, dando vazão a um gosto pessoal de Serling, ou fato baseado meramente no sucesso do western na televisão do período. O historiador americano James R. Grossman, ao falar da permanência das histórias do velho oeste na cultura daquele país, pode nos fornecer uma importante pista, ele afirma:

"[...] Os americanos continuam a contar variantes dessas histórias [narrativas da fronteira] porque elas são tanto do futuro dos EUA quanto de seu passado. O legado das histórias promovidas no ensaio de Turner e no palco de Cody [Buffalo Bill] não apenas falam de quem nós éramos (e somos), mas como nós nos tornamos assim, e quem entre nós pode ser incluído no 'nós". ${ }^{71}$ (GROSSMAN (org.), 1994, p.4, tradução nossa)

O episódio expõe exatamente de forma didática essa relação entre os tempos, quem os americanos eram e quem são hoje, de forma intimamente ligada pela viagem no tempo. Pode ser inserido no "nós" quem ajuda o próximo, mantendo valores básicos civilizacionais vivos, como a caridade e a empatia. Com a força dessa mensagem presente no episódio, há a proposição de uma visão positiva não só sobre o passado - que, como já vimos, era comum na viagem no tempo ao passado na série - , mas também sobre o presente e as perspectivas de futuro.

Na sequência, o próximo episódio na ordem original de exibição também iria mostrar uma viagem a um futuro avançado, agora superando o presente do público. A forma utilizada de viagem está inferida no próprio título do episódio, The Rip Van Winkle Caper.

\footnotetext{
${ }^{71}$ No original: [...] Americans continue to tell variants of these stories because they are as much about the American future as the American past. The legacy of these histories enacted in Turner's essay and on Cody's stage tell us not only who we were (and are) but how we got to be that way, and who among us gets to be included in the "we".
} 


\subsection{4- The Rip Van Winkle Caper}

Filmado logo em seguida a A Hundred Yards Over the Rim, no mês de março de 1961, The Rip Van Winkle Caper utilizou a mesma locação na região de Lone Pine, Califórnia, com o propósito de economizar dinheiro. O $24^{\circ}$ episódio da segunda temporada, $060^{\circ}$ na série, foi exibido duas semanas depois que $A$ Hundred Yards Over the Rim, em 21 de abril de 1961 - na sexta-feira 14 de abril, foi exibida uma repetição do episódio The Mighty Casey (1960) (THOMPSON, 2015, p.5957) -. Esse episódio apresentava uma viagem no tempo, mostrando um futuro mais avançado do que o do público da série, futuro este que, quando exibido, é fundamental para o final irônico com reviravolta, característico do programa. Novamente, um roteiro de Rod Serling, The Rip Van Winkle Caper foi dirigido por Justus Addiss e estrelado por Oscar Beregi, Lew Gallo, John Mitchum, Simon Oakland, Shirley O'Hara e Wallace Rooney. Os custos totais da produção foram de USD\$55.016,62. (GRAMS JUNIOR, 2008, p. 391,392; ZICREE, 1992, p.197; ZICREE, 2018, p.184). O roteiro foi adaptado em conto escrito por Serling em 1962 no livro New Stories from the Twilight Zone, da Bantam Books.

Os ladrões DeCruz, Brooks e Erbie, liderados pelo cientista ladrão Farwell roubam um trem com ouro com destino ao Fort Knox. Para escapar da polícia após o ousado feito, seguem o plano de Farwell de se esconderem todos em uma caverna camuflada e entrarem em animação suspensa em cápsulas que utilizavam um gás criado para Farwell para esse fim. Eles dormiriam por cerca de cem anos, quando poderiam sair do sono para gastar o ouro, sem correr o risco de serem presos. Acordando no futuro, sem saber com certeza quantos anos haviam dormido, três dos ladrões despertam e descobrem que Erbie havia morrido, uma pedra havia quebrado sua cápsula, o ar entrou e apenas seu esqueleto repousava na cápsula. Tentando decidir o que fazer, os três entram em conflito e DeCruz, querendo fugir, pega o veículo que eles haviam escondido na caverna com parte do ouro e atropela e mata Brooks, destruindo o caminhão e perdendo todo o ouro que estava nele no processo. Só restam a DeCruz e Farwell andarem a pé pelo deserto rumo a alguma cidade, e caminhando por muito tempo por uma estrada vazia, começam a cogitar que talvez uma guerra nuclear tenha ocorrido; porém, quando um avião cruza os céus, é gerada a esperança de que andavam rumo à civilização. Em uma das pausas para descansar, Farwell perde seu cantil com água e passa a sucumbir à sede; DeCruz notando a 
oportunidade de negócio, começa a trocar goles de água pelas barras de ouro que Farwell levava em sua mochila. No dia seguinte, os homens ainda andavam pelo deserto quando DeCruz decide aumentar o preço da água, exigindo duas barras por gole e Farwell, indignado, o ataca, matando o ladrão. Sozinho e com todo ouro que conseguia carregar, Farwell continua sua caminhada pelo deserto, até que, sem água e com queimaduras do sol em sua pele, começa a perecer de sede e cansaço extremos. Quase morto, vê um carro diferente vindo em sua direção: um casal que voltava de um piquenique para o carro e tenta ajudá-lo, mas ele estava fraco e desidradado demais e acaba morrendo carregando o ouro. Surpreso, o casal comenta a estranha oferta que o fraco homem fizera: ele havia oferecido todo o ouro se the salvassem. Isso era algo muito esquisito para eles, pois todos sabiam que o ouro não tinha nenhum valor, pois há muito tempo atrás os seres humanos haviam aprendido a manufaturá-lo.

O título do episódio remete diretamente ao conto de Washington Irving, Rip Van Winkle (1819), invertendo a caracterização simpática do personagem título ao não apresentar personagens agradáveis, salvo Farwell, que pode ser visto com uma certa simpatia pelo viés trágico de seu destino e sua interação com DeCruz. Assim como o Rip Van Winkle dormia no período colonial das treze colônias que viriam a formar os EUA e acordava em uma nação já independente, com uma nova formação social e novo sistema politico, os três bandidos dormem no presente e acordam num futuro mudado, onde o que era valorizado por eles e por seu contexto histórico nada mais significa. Esta é uma clara mensagem ao contexto americano de início dos anos 60 de que aquela sociedade não iria durar para sempre. Portanto, o título remete tanto à relação temporal do conto de Irving - entre passado e presente/futuro e a reflexão do tempo histórico (mudanças) -, quanto da própria forma de viagem no tempo em si.

A viagem se dá por meio de animação suspensa, o primeiro caso dessa popular forma de viagem no tempo exibida na série (um outro episódio na última temporada, The Long Morrow, também exploraria a mesma ideia como forma de viagem no tempo para o futuro) e, ao contrário do conto de Irving, os bandidos não mostram sinais de envelhecimento, pois o sistema que utilizaram para dormir e acordar no futuro interrompia o funcionamento dos órgãos. Esse episódio traz semelhanças com o enredo do episódio da primeira temporada I Shot an Arrow into the Air (1960), no qual um grupo de astronautas se acidenta, pensam estar um outro planeta e disputam os parcos recursos e o astronauta vitorioso na luta pela sobrevivência, por enganar e até 
matar seus colegas, descobre no final que o foguete voltara à Terra e eles se encontravam próximos à civilização. O conflito em I Shot an Arrow into the Air foi importante por também representar uma das influências para o filme Planeta dos Macacos de 1968 (Planet of the Apes), obra cujos primeiros roteiros foram de autoria de Rod Serling. The Rip Van Winkle Caper também pode ser visto como contendo elementos presentes nesse filme, como a animação suspensa, a morte de um dos ladrões na cabine e os valores que veem do presente não significarem mais nada em uma sociedade futura distinta.

A representação audiovisual da viagem no tempo, nesse episódio, se dá pela fumaça do gás que preserva o corpo vivo e inalterado por cem anos e o movimento da câmera se dirigindo da caverna onde os quatro bandidos dormem para o céu, momento acompanhado por uma música que fortalece que estamos presenciando algo fantástico.

Este elemento de mostrar um futuro médio, no qual o presente do público, seus valores e desejos se encontram superados e até são alvos de chacota é um dos atrativos da viagem no tempo ao futuro e, ao contrário de uma obra que se passa no futuro com pessoas dessa temporalidade, o choque entre modos distintos de ver o mundo pode ser explorado de forma mais clara, aproximando a crítica ao presente e tornando-a mais visível.

Assim como no episódio anterior, somos expostos ao final da narrativa a um futuro positivo; nesse, os valores materialistas destrutivos do presente foram superados e são motivo de troça pelos entes futuros. O ouro, já chamado de vil metal, não detém qualquer valor especial, após o ser humano aprender a manufaturá-lo e as suspeitas dos bandidos de que talvez houvesse ocorrido uma $3^{a}$ Guerra Mundial, nuclear, não se concretizam. Esta era uma preocupação geral e constante no contexto da Guerra Fria do início dos anos 60, marcado por testes cada vez mais poderosos de armas nucleares, aumento da retórica belicista, disputas territoriais por áreas da influência entre as potências e incentivo do governo americano para as famílias construírem abrigos nucleares, um ambiente propício para o prognóstico de um futuro conflito atômico de ordem mundial.

Todas expectativas negativas do presente sobre o futuro se mostrariam incorretas nesse episódio, reafirmando o que vemos no conjunto de episódios da série: nos que exibem o futuro em si, ele é problemático, mas na viagem no tempo, o 
futuro é apresentado sob olhares positivos ou com versões novas dos antigos problemas.

Figura 53 - Ladrões em animação suspensa em seus caixões de vidro, esperando para acordarem no futuro onde serão ricos.

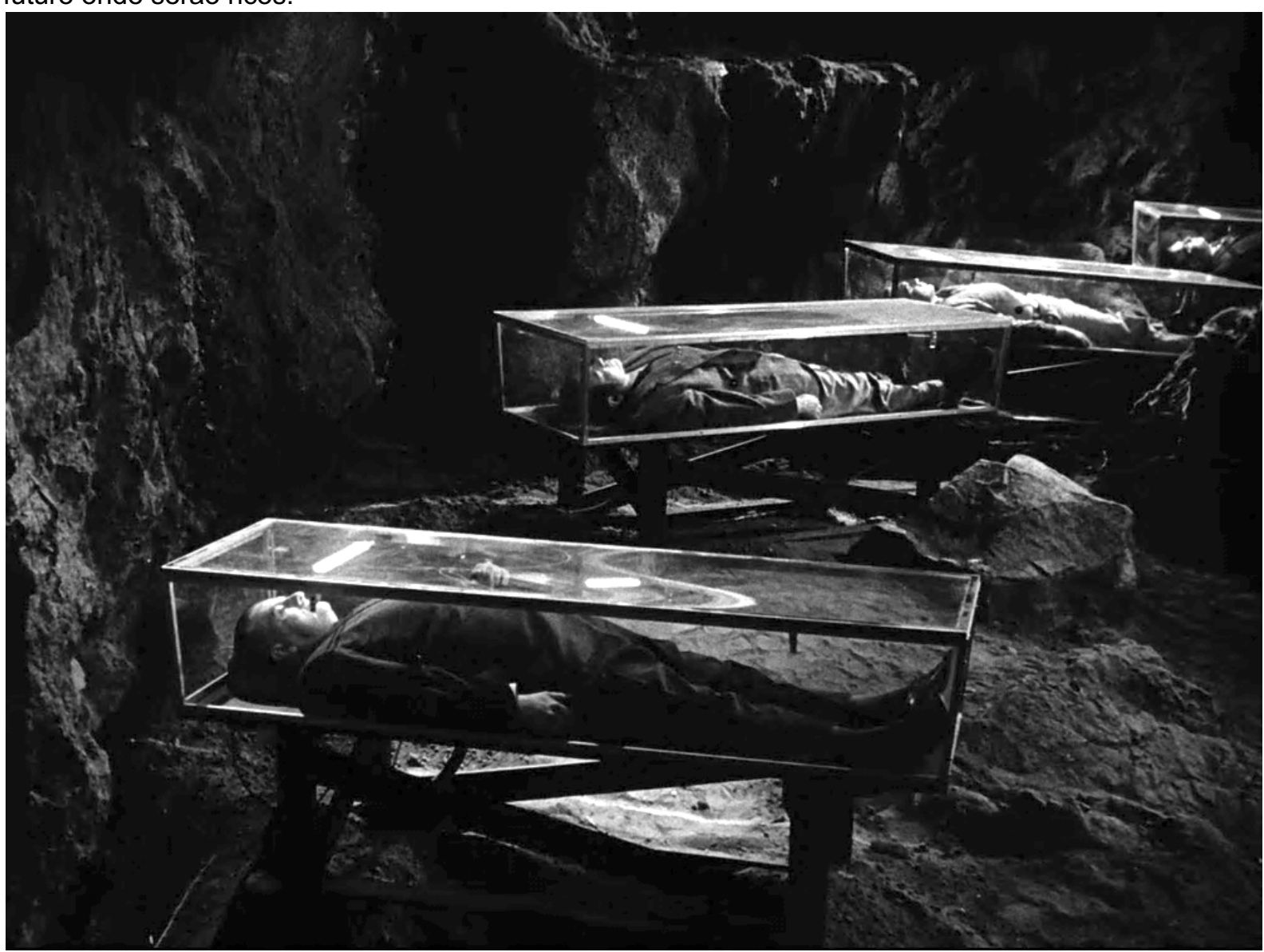

Fonte: elaborado pelo autor (Blu-ray, The Twilight Zone: The Complete Series, CBS, 2017)

O episódio brinca com essas expectativas negativas e utiliza os bandidos para representarem pessoas que passariam por cima de todos para adquirir bens materiais, no caso o ouro. Simbolizando o acesso aos bens materiais e à riqueza, o ouro era roubado do trem que ia para Fort Knox, cidade onde se localiza o famoso United States Bullion Depository, construção onde se encontra uma grande quantidade da reserva de ouro dos EUA que, na época, era o padrão que dava suporte para o dólar. O dólar, no contexto histórico, era a moeda central do sistema econômico global (MAIA, Geraldo; MARIANO, Jefferson e OLIVEIRA, Giuliano C., 2008, p.206). Não causa surpresa ver o bandido DeCruz se comportar como um capitalista ao vender o pouco que restava de sua água ao malfadado bandido Farwell, seguindo a lei da oferta e da procura, cobrando cada gole de água em barras de ouro, expondo no filme as últimas consequências, amorais, do sistema econômico vigente. Farwell é o cientista 
criador do esquema do roubo com gás do sono e animação suspensa, ele próprio é a representação do uso da ciência e tecnologia pela sociedade contemporânea da série, utilizada para o mal, haja visto o assalto e o medo dele de que tenha havido uma guerra nuclear nos cem anos que dormiram, um contraste com a informação de que no futuro aprenderam a manufaturar ouro. O próprio Farwell parece estar mais interessado com o mundo futuro do que com o próprio ouro, elemento reforçado de forma textual por Serling no conto (SERLING, s.d. c3); sua participação no crime tem mais o aspecto de curiosidade científica, testar se o plano funcionaria, do que uma intenção exposta em ficar rico. Assim, mais do que apenas criticar a busca por riquezas desenfreadas, o episódio expunha uma visão sobre o funcionamento do sistema econômico americano do Segundo pós-guerra, representado pela divisão e organização do trabalho dos supercriminosos, propondo sua possível superação no futuro.

Figura 54 - Casal do futuro que encontra um moribundo Farwell na beira da estrada, surpresos pela oferta de Farwell em dar ouro em troca de ajuda.

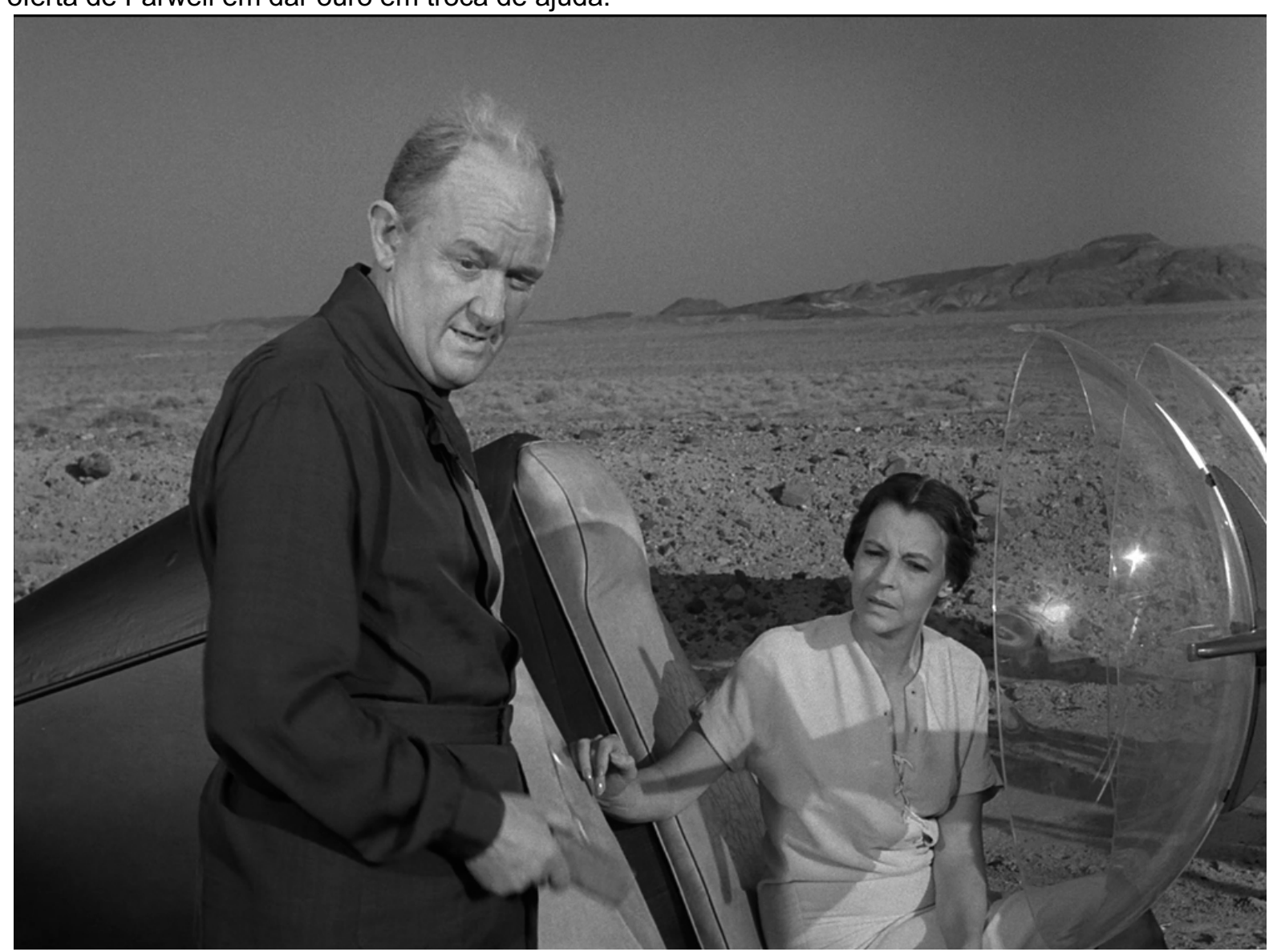

Fonte: elaborado pelo autor (Blu-ray, The Twilight Zone: The Complete Series, CBS, 2017)

Cada um dos malfeitores era especializado em uma área que foi mobilizada para realização do crime, sob supervisão e organização principal de Farwell, doutor 
em química e física e descrito por Serling, no conto, como um homem com aparência de um professor universitário (SERLING, s.d. c3, p.2) ${ }^{72}$. Erbe era especialista em engenharia mecânica, Brooks especialista em armas e DeCruz especialista em demolição. Ao contrário do roteiro e da versão filmada, o conto descreve o esforço, o ensaio e o desenvolvimento das habilidades que os ladrões de alto nível realizaram para consumar o crime e como o crime foi efetuado, inclusive faz alusão a mortos e feridos que não são citados no roteiro e na versão filmada. O grupo formou um tipo de divisão do trabalho, organizado/idealizado por Farwell para roubar o ouro do trem, a qual expõe a posterior crítica que o episódio faz sobre o presente.

É exibida uma implicação explícita entre avanço moral e avanço tecnológico, condizente com as expectativas pertencentes ao mito do progresso: ao desenvolver uma forma de todos terem acesso às riquezas, máquina que cria ouro infinito, acabouse a disputa entre humanos e quaisquer formas de conflito, elemento reforçado pela morte dos ladrões, condicionados ao modo de vida do presente moderno (e nosso) de disputa por bens materiais para consumo e como forma de ascensão social. Não foram filosofias que alteraram o ser humano, mas sim o desenvolvimento da tecnologia. Assim, a tecnologia e a ciência alteraram a sociedade futura, tornando-a mais pacífica e humanística, como podemos ver no diálogo e nas expressões físicas do casal que encontra o moribundo Farwell e pela própria exibição de parte dessa tecnologia fantástica, no modelo de carro futurístico (construído para o filme de 1956, Planeta Proibido, [Forbidden Planet]). Não há no futuro espaço para seres criados voltados para valores destruidores, e a Zona Crepuscular irá testá-los se eles teriam ou não condição de se adaptarem à nova condição humana, e eles falham por desvios de caráter: são egoístas, mesquinhos, desonestos e cobiçam uma vida de prazeres adquiridos por meio de dano, fraude e roubo.

O conto explora o que se deu após o casal ter deixado Farwell morto no deserto e ter comentado que iria ligar para a polícia. Em uma sequência que enfatizava a mensagem de Rod Serling (já que o conto não se fechava com a narração do escritor), quinze minutos depois do casal partir, a polícia chegou de helicóptero e constatou a morte do cientista, sem ser capaz de identificá-lo. Nas semanas seguintes, os demais corpos seriam encontrados e também categorizados como indigentes, o ouro ficou 72 O conto adaptado do roteiro foi publicado em 1962 no livro New Stories from the Twilight
Zone de Rod Serling. 
largado no deserto e no carro destruído ${ }^{73}$. Reforçando a crítica, caso alguém ainda pudesse ter quaisquer duvidas, Serling concluiria o conto afirmando que:

[...] Logo ele [ouro] se tornaria parte da paisagem. Alguns itens amarelos bobos se juntavam a sálvia, erva-sal, sagina, e o imortal cacto. Como os senhores Farwell, Erbe, Brooks e DeCruz, ele não tinha valor. Nenhum valor afinal (SERLING, s.d. c3, p.26, tradução nossa) $)^{74}$.

Once Upon a Time, o penúltimo episódio exibido na série é o mais ousado em termos de linguagem audiovisual na forma de representar a viagem no tempo. Nesse episódio, as temporalidades apresentam mais semelhanças do que diferenças.

\subsection{5- Once Upon a Time}

Once Upon a Time foi exibido na terceira temporada da série no dia 15 de dezembro de 1961. O episódio, filmado no início do mês de setembro do mesmo ano, foi o $13^{\circ}$ da temporada e $078^{\circ}$ do total de episódios de Além da Imaginação. O roteiro original de Richard Matheson, estrelado por Buster Keaton, George E. Stone, Jesse White, Milton Parsons e Stanley Adams, foi dirigido por Norman Z. McLeod, com custos totais de produção de USD\$ 67.250,76 (GRAMS JUNIOR, 2008, p.455; ZICREE, 1992, p.259; ZICREE, 2018, p.249).

O diretor Norman Z. McLeod foi contratado pelo produtor Buck Houghton (ZICREE, 1992, p.260). O veterano diretor estreou sua carreira na época do cinema mudo e é famoso por obras de comédia; apenas para citar algumas obras e atores que foram dirigidos por ele encontramos: Os Quatro Batutas (Monkey Business, 1931) e os Gênios da Pelota (Horse Feathers, 1932) com os irmãos Marx; A Caminho do Rio (Road to Rio, 1947), com Bing Crosby e Bob Hope: ambos atores trabalharam com McLeod em diversos filmes em sua longa carreira. Mesmo tendo trabalhado com grandes nomes da comédia no cinema, McLeod ainda não havia trabalhado previamente com Buster Keaton. Isso demonstrava o cuidado da produção em, ao lidar com o passado, trazer efetivamente quem conhecia o gênero comédia pastelão, gênero primordial em Once Upon a Time.

\footnotetext{
${ }^{73}$ Assim como no roteiro, DeCruz tenta fugir com um carro que falha e cai num abismo e não com o caminhão, veículos invertidos na versão filmada.

${ }^{74}[. .$.$] It soon became imbedded in the landscape. Some dull-yellow items that joined the sage,$ saltbrush, pearlweed, and the imperishable cacti. Like Messrs. Farwell, Erbe, Brooks and DeCruz, it had no value. No value at all.
} 
O nome de maior destaque do episódio é o do renomado ator da era do cinema mudo Buster Keaton. $O$ ator, após uma série de problemas de adaptação para o cinema falado e envolto em problemas pessoais, havia encontrado na nova mídia, a televisão da década de 50 , um renascimento de sua carreira, seja na exibição de seus antigos filmes para uma nova geração e para adultos nostálgicos, seja em novos programas televisivos. Assim, sua presença em um episódio que envolve a viagem no tempo e ironiza a nostalgia reforça a relação presente, passado e futuro que o episódio transmite.

O faxineiro Woodrow Muligan é um homem descontente com sua época e cidade; ele vive em 1890 em Harmony, Nova York. O preço da comida, o barulho e os anúncios publicitários com garotas menos vestidas que o geral o incomodam profundamente. Ao chegar em seu trabalho, descobre que seu chefe, o cientista Gilbert, inventara uma máquina do tempo: um capacete que permitia viajar no tempo, mas o viajante só poderia ficar por trinta minutos no tempo de destino; após esse tempo, o capacete e quem quer que o estivesse vestindo, retornaria automaticamente para 1890. Gilbert sai para comemorar sua invenção e deixa o capacete na oficina, o curioso Mulligan mexe no capacete e o aciona sem querer enquanto imagina como seria viver em uma época sem os problemas que o irritam no mundo. Viajando para 1962, Mulligan se vê em um mundo muito pior para ele: a comida é mais cara ainda, o barulho dos carros e caminhões é absurdo em comparação com o trânsito de 1890 e os anúncios publicitários mostram garotas muito mais ousadas. $O$ capacete quebra e Mulligan, desesperado, tenta procurar ajuda para consertá-lo; em sua busca, conhece Rollo, um cientista que o encaminha para uma assistência técnica. Ele também é um descontente com sua época e sonha poder voltar para o passado de onde Mulligan era originário, em sua ideia, um período mais tranquilo. Após o capacete ser consertado, e alguns problemas com a polícia local, Rollo se apodera do capacete e Mulligan corre e se segura em Rollo, no último momento, sendo transportado juntamente com ele para 1890. Feliz agora em viver em sua época, Mulligan vê que Rollo, que agora trabalhava ajudando Gilbert, está cada vez mais descontente em viver no seu passado, pois faltam equipamentos e conforto. Ajudando Rollo e a si mesmo, livrando-se de um homem reclamão, Mulligan coloca o capacete em Rollo e o devolve a 1962.

Woodrow Mulligan é um personagem padrão de Keaton, com as peculiaridades de seus personagens, visualmente reconhecíveis pelo seu chapéu (chapéu pork pie) 
e seu olhar inocente. Como destaca o historiador Geoffrey Nowell-Smith (1997, p.81), os personagens de Keaton geralmente são sonhadores, ingenuamente lançados em situações impossíveis ou ridículas, que passam por uma série de obstáculos para realizar seus desejos e terminam a história mais sábios, porém mantendo sua inocência. Richard Matheson criou o personagem exatamente para Buster Keaton, sem alterar as características pelas quais o ator era reconhecido.

O título do episódio pode ser traduzido como "Era uma vez", frase inicial consagrada nos contos de fadas, um título que remete também a um passado distante, nos contos de fadas, um passado genérico não definido. Na forma de um conto de fadas moderno, por meio da comédia advinda das situações enfrentadas por Keaton em 1890 e em 1962, temos um conto de fadas do século XX ensinando a aceitação da sua própria época/presente. A própria série Além da Imaginação tem esse sentido de conto de fadas para um público moderno; esta noção, inclusive, pode ajudar a entender o sucesso da série com as crianças e o aspecto moralizante da Zona Crepuscular.

Assim, em Once Upon a Time, a Zona Crepuscular opera para ensinar ao público que todas as épocas têm seus problemas e não se deve querer escapar de seu tempo com a pretensão de melhorias significativas da vida, apresentando uma visão cética sobre passado, presente e o próprio futuro. Por exemplo, Mulligan, andando pela rua em 1890, reclama dos preços que considera altos da comida, da poluição sonora, da decadência moral, do trânsito das carruagens, mas ao chegar em 1962, presencia algo infinitamente pior, preços muito mais altos, muito mais barulho, anúncios de propaganda que considera obscenos e caos nas ruas. Enquanto, no passado, Mulligan é quase atropelado por cavalos, em seu futuro, enfrenta veículos automotores. O que, inicialmente, aparece como uma crítica ao progresso, no final, revela-se como ensinamento de aceitação do seu presente: o curioso cientista de 1962 que volta com Mulligan para 1890, crítico de seu tempo, inicialmente envolto por nostalgia por um passado idealizado, não consegue sobreviver em 1890, pois Ihe falta a tecnologia para trabalhar e o mínimo de amenidades modernas para sobrevivência. Mulligan aprende essa lição, simbolizada pelo fato dele colocar o capacete na cabeça de Rollo e fazer o insatisfeito homem retornar para sua própria época.

A viagem no tempo se dá por uma tecnologia maravilhosa, um capacete que transporta quem o coloca e o que é tocado por ele para qualquer ano anotado em um disco com datas contadas de dez em dez. Pode-se, assim, visitar qualquer ano por 30 
minutos, devendo o viajante estar com o capacete quando o tempo se esgotar para retornar para seu próprio presente. Essa ideia dos 30 minutos para visitar outro tempo, faz uma alusão à própria mídia audiovisual, no caso, à própria televisão, por meio dela e seus programas. Lembrando que Além da Imaginação, na terceira temporada, ocupava o espaço de 30 minutos na televisão. A chamada "janela para o mundo" não é apenas uma janela espacial, mas também temporal. Como vimos, a maior parte dos episódios de viagem no tempo exibidos no conjunto da série não apresentava máquinas do tempo e a presença da máquina, quando invocada como nesse episódio, reforça tanto o humano tentando controlar o tempo (vida), quanto a própria noção de tecnologia, em uma perspectiva de progresso e desenvolvimento que instiga a imaginação do público e propõe uma perspectiva de futuro, pois tal tecnologia não se encontra no presente da audiência - nem no nosso.

Figura 55 - Mulligan com o capacete que o transporta ao futuro. Nessa comédia a máquina do tempo também está dentro de um quadro cômico.

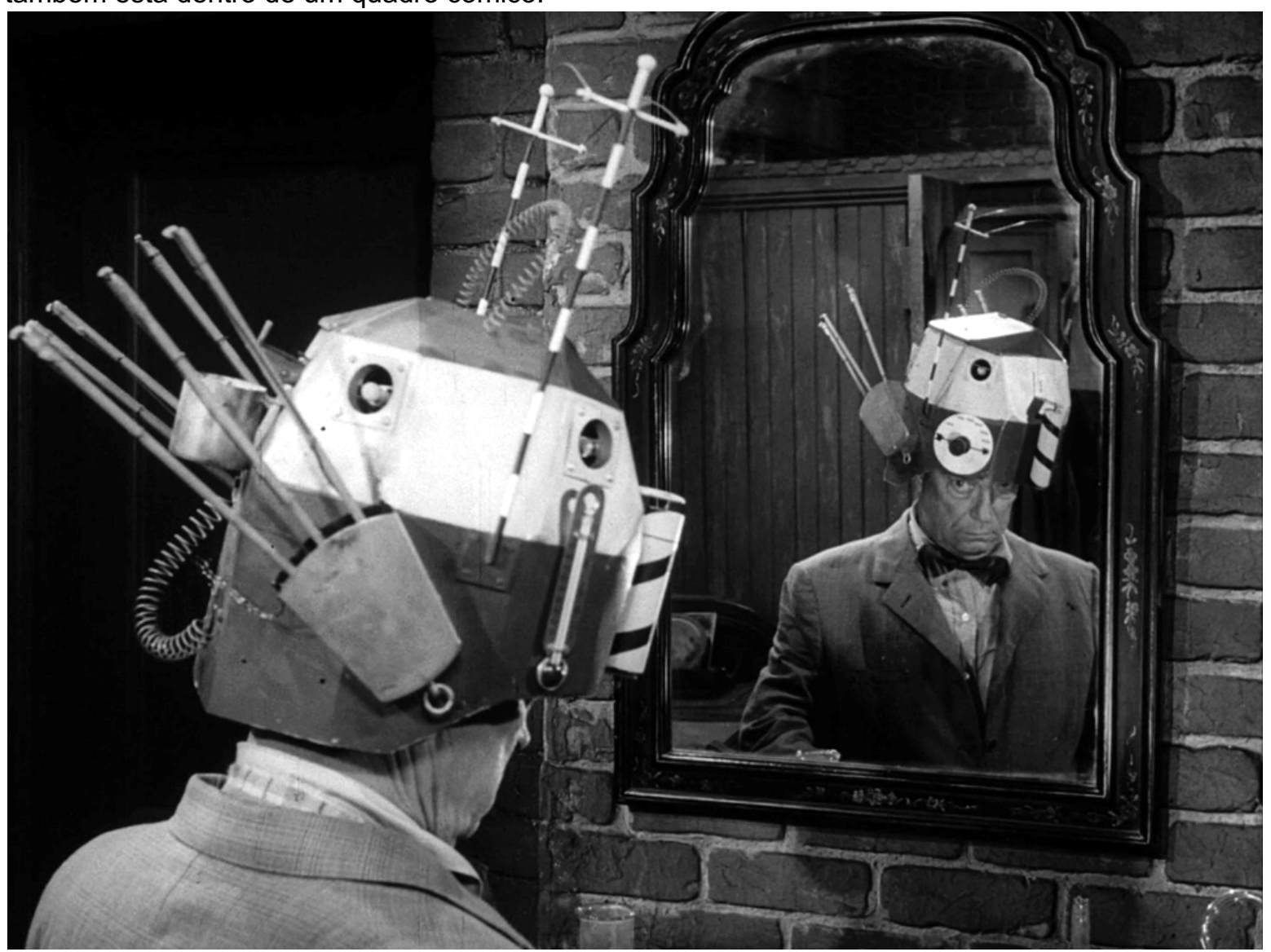

Fonte: elaborado pelo autor (Blu-ray, The Twilight Zone: The Complete Series, CBS, 2017)

Ao mostrar que sempre percebemos e nos sentimos incomodados por coisas negativas em nossa época, mas que, ao ter um olhar histórico - no episódio, 
experimentar outras épocas pelo recurso da viagem no tempo-, o episódio acaba por reforçar a ideia de que se deve aceitar o presente, pois devemos relativizar nossas críticas, o passado e o futuro trazem também situações que nos desagradariam profundamente. Em Once Upon a Time, isso se dá de forma cômica, o que enfatiza e torna a mensagem simpática. Essa mensagem não foge do padrão do uso da viagem no tempo em Além da Imaginação e demonstra uma visão sobre o mundo geralmente proposta por esse tipo de narrativa.

Todas sequências que se passam em 1890 são exibidas como filme mudo, uma proposta interessante de marcar as diferentes épocas. Ao colocar filme mudo na televisão, nota-se a percepção de que o cinema e a televisão não deveriam ser vistos como "universos separados[...], mas pertencentes e unidos como parte de um único processo de evolução [tradução nossa]", como expõe Paolo Cherchi Usai (apud NOWELL-SMITH (org.), 1997, p.6) ao explicar como a lanterna mágica, o cinema e a televisão se desenvolveram no tempo e no espaço. Assim, a sequência em filme mudo é a forma escolhida para retratar o passado da mídia audiovisual, contrapondo-a ao presente, chamando atenção do público para as mudanças da linguagem audiovisual que ocorreram com o passar do tempo. A repetição de cenas que se passam em 1962 semelhantes ao já visto nas cenas do passado, em filme mudo em 1890, agora utilizando a forma padrão da série em retratá-las, fornece uma noção de História de que em todos os tempos, sempre há problemas e insatisfação com o presente. Entretanto, cabe destacar que a experiência do público do cinema mudo era bem distinta da que temos ao nos depararmos no episódio, por exemplo, muitos filmes mudos eram realizados utilizando técnicas de coloração e outros elementos da exibição, que foram perdidos ou são impossíveis de serem reconstruídos. Temos então no episódio uma alusão ao cinema mudo e às obras desse período que haviam sobrevivido.

Assim, a escolha do cinema mudo para representar o passado, emulando sua estética, mas incorporando enquadramentos e movimentos de câmera padrões de televisão e do próprio conjunto da série ${ }^{75}$, enfatiza a noção expressa por Aumont e

\footnotetext{
75 Segundo o pesquisador Martin Grams Jr (2008, p.458) a ideia de transformar a sequência em 1890 em mudo teria surgido na equipe de produção após Serling e Houghton assistirem a versão bruta do episódio. Na edição para emular o cinema mudo pré-1926, antes da padronização da velocidade, foram retirados frames do filme e inserido temas de músicas tradicionais no piano.
} 
Marie (2001, p.202) de que o cinema mudo "é antes de tudo, uma época do cinema" mais do que meras escolhas estéticas, estas escolhas que não se encerram com o da época do cinema mudo na década de 30. Como época, ela marca a distinção dos tempos, sinalizando de forma clara a distinção entre 1890 e os anos 1960. Curiosamente, vemos um filme mudo para retratar um período anterior ao próprio cinema, se considerarmos o ano de 1895 como marco da emergência desta forma de expressão artística, o que demonstra que estamos vendo mais uma representação do espírito de uma época do que datas específicas.

A distinção do mudo e falado é utilizada como contraposição entre as temporalidades, tanto o cinema mudo quanto a presença do grande ator Buster Keaton são símbolos do passado audiovisual. O próprio ator, homenageado em Once Upon a Time, entrou no jogo entre as temporalidades realizado pelo episódio como um resquício de outra época, levada aos anos 1960 por meio da tecnologia, mas que tem o passado como seu ambiente original, como podemos notar na conclusão do episódio.

Figura 56 - Nos anos 60, Mulligan (a direita) é ajudado por Rollo (a esquerda), outro descontente com seu presente que aprenderá a viver em sua própria época.

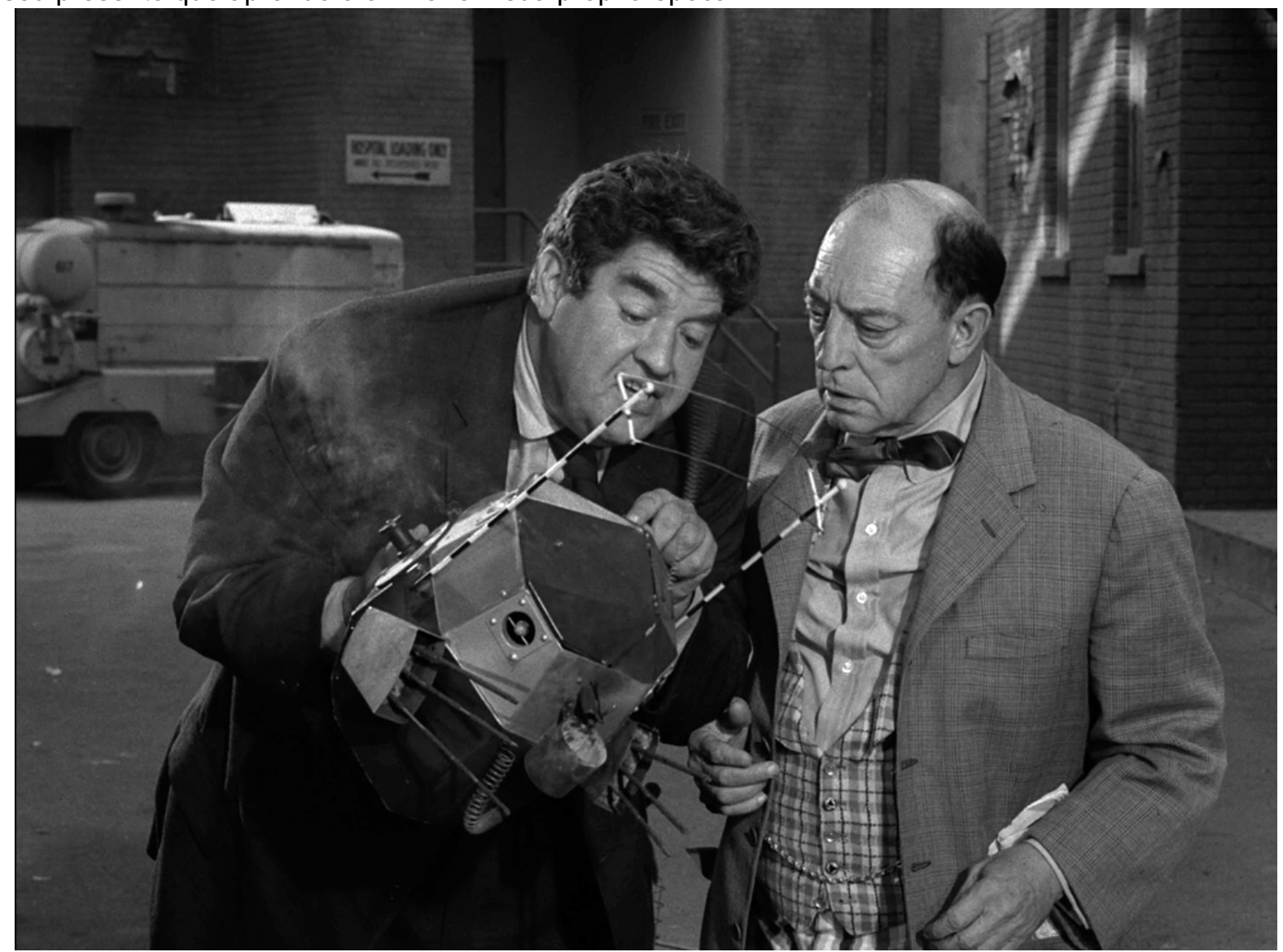

Fonte: elaborado pelo autor (Blu-ray, The Twilight Zone: The Complete Series, CBS, 2017)t 
Este episódio de viagem no tempo segue o padrão da série ao expor a nostalgia pelo viés da nostalgia reflexiva, no qual os tempos e seus personagens - algo marcado neste episódio de forma clara pela presença de Buster Keaton como protagonista - são utilizados para que se faça uma reflexão crítica sobre as mudanças e a saudade por um passado idealizado. Entretanto, a mensagem é distinta dos episódios dessa temática escritos por Rod Serling, que ao expor um passado nostálgico, indicava perspectivas de alteração do presente para construção de um futuro inédito, com a saudade servindo de trampolim para a criação do novo. O roteiro de Matheson propõe que sempre estamos insatisfeitos com nosso presente e a reflexão sobre os ímpetos nostálgicos das sociedades contemporâneas deveriam ser relativizados, pois sempre partem de equívocos nas expectativas das épocas: ambos estão errados, o ente passado imaginando que o futuro será melhor e o ente futuro imainando que o passado era melhor.

Essa visão cínica no contexto histórico da série criticava de forma contundente qualquer ideologia do progresso, qualquer visão conservadora ou propostas de aperfeiçoamento das sociedades e indivíduos, pois tudo é sempre problemático. Uma mensagem proposta em um contexto de grandes transformações e com o prognóstico de um futuro de destruição total da civilização. Por meio do humor, Once Upon a Time mostra que todos os tempos têm seus aspectos positivos e negativos e não existe a relação de superioridade, desenvolvimento ou evolução entre quaisquer temporalidades. Não existe perfeição no passado, no presente ou no futuro e a comédia nos mostra isso de forma clara.

Portanto, na experiência mais ousada com a linguagem audiovisual para representar temporalidades distintas, a mensagem da narrativa reforça a visão de que o presente das pessoas é o local onde elas estão melhor adaptadas, como Serling fala na narração final: "ele [Mulligan] aprendeu - definitivamente da maneira mais difícil- que há muita sabedoria em uma terceira frase antiga, que é a seguinte: 'Fique no seu próprio quintal'. Para a qual pode ser adicionado, 'e, se possível, ajude os outros a ficarem nos deles' [tradução nossa]"76. Essa conclusão pode ser interpretada como convite ao conformismo social mais amplo, étnico-racial, econômico, político, por exemplo. E não seria um absurdo afirmar que este episódio propõe um total

\footnotetext{
76 "he has learned-definitely the hard way-that there's much wisdom in a third old phrase, which goes as follows: 'Stay in your own backyard.' To which it might be added, 'and, if possible, assist others to stay in theirs'"
} 
conformismo e imobilismo por meio da comparação entre as épocas distintas do desenvolvimento dos EUA, conformismo que podia acalmar os medos dos problemas reais enfrentados no presente.

O último episódio de viagem no tempo ao futuro, The Long Morrow, faz parte das inúmeras histórias de amor contadas no século $X X$ que utilizam a viagem no tempo para reafirmar laços sentimentais entre um casal de amantes, separados pelo tempo, tão bem exemplificados em obras como Em Algum Lugar do Passado (Bid Time Return ${ }^{77}$, 1975), de Richard Matheson. Ao contrário de obras mais ousadas, a viagem no tempo em The Long Morrow seguiria o modelo do dorminhoco, o segundo caso na série Além da Imaginaçao.

\subsection{6- The Long Morrow}

The Long Morrow, o $135^{\circ}$ episódio exibido em Além da Imaginação, o $13^{\circ}$ exibido na quinta temporada, foi ao ar em 10 de janeiro de 1964. Dirigido por Robert Florey, com roteiro de Rod Serling, tinha como protagonistas os atores Robert Lansing e Mariette Hartley. Filmado em meados de setembro de 1963, ao custo total de produção de USD\$ 49.776,09 (GRAMS JUNIOR, 2008, p.653; ZICREE, 2018, p.402).

Nos anos 1980, Douglas Stansfield é um astronauta escolhido para uma missão pioneira: pesquisar um planeta fora do nosso sistema solar, uma viagem que levaria quarenta anos para ser completada. Quando retornasse à Terra, Stansfield teria mais de 70 anos, mas fisicamente ainda estaria na faixa dos 30 anos, pois seria colocado em animação suspensa, dormindo por quase toda a viagem. No meio tempo entre a sua escolha e a partida para o espaço, o astronauta conhece Sandra Horn, uma funcionária da agência espacial, e os dois se envolvem romanticamente, mesmo sabendo do que o futuro reservava a ambos: eles seriam separados para sempre no momento que Douglas entrasse no foguete. Após Douglas Stansfield partir, sem que ele soubesse, Sandra pediu para ser colocada em animação suspensa, devendo ser revivida quando Douglas retornasse de sua missão, ela dorme esperando seu amado. No espaço, nos primeiros meses da viagem, Stansfield acorda da animação suspensa para checagem geral da nave e comunicação de rotina e resolve quebrar a máquina

\footnotetext{
77 O livro foi adaptado para o cinema em 1980 com o título em inglês Somewhere in Time, nome pelo qual o livro passou a ser publicado posteriormente, capitalizando o enorme sucesso do filme.
} 
de animação suspensa, decidindo ficar acordado e envelhecer naturalmente, por toda a viagem, pois queria encontrar o amor de sua vida e ter a mesma idade que ela. $A$ missão é concluída e 40 anos depois, Douglas Stansfield retorna para a Terra e, ao conversar com o chefe da agência, descobre que Sandra tinha se mantido dormindo jovem por todo esse tempo por ele. O casal se encontra nos mesmos corredores onde se conheceram 40 anos antes e um velho Stansfield e uma jovem Horn se emocionam; porém, o velho astronauta pede que ela o deixe e encontre um novo homem e seja feliz, pois ela ainda é jovem e tem toda a vida pela frente. A contragosto, a moça aceita a orientação de Douglas. Além desse fato triste, toda a missão havia sido marcada por desencontros: ele não encontrara vida no planeta distante e logo em seguida a sua partida, novos motores para viagem espacial foram desenvolvidos e os dados que ele trouxe de volta para a Terra já eram conhecidos.

Figura 57 - Primeiro encontro de Doulgas e Sandra. O cenário frio da agência espacial nos insere em um mundo da razão, onde as emoções não têm lugar.

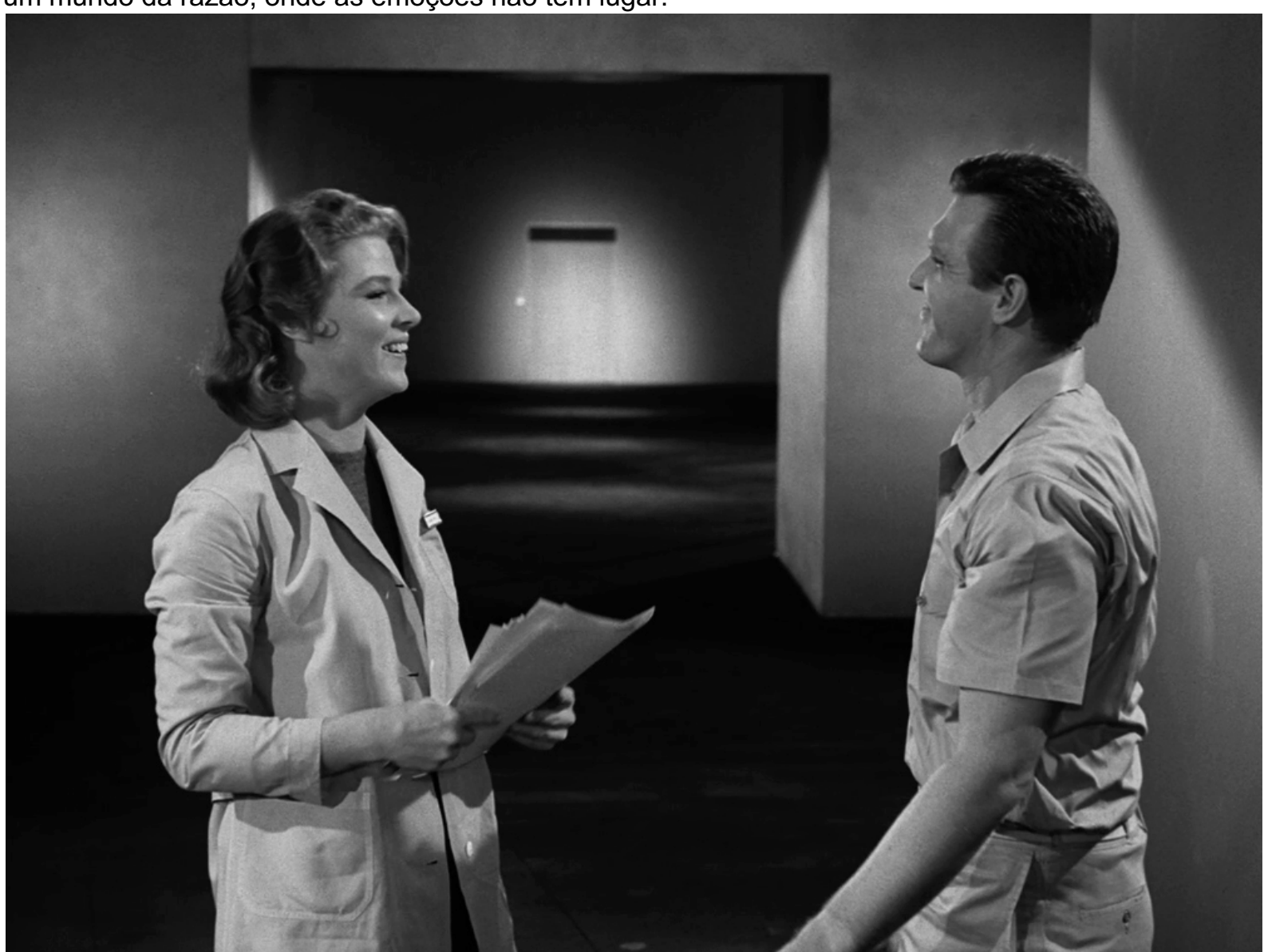

Fonte: elaborado pelo autor (Blu-ray, The Twilight Zone: The Complete Series, CBS, 2017)

Nas primeiras versões do roteiro para Além da Imaginação, como a de 27 de agosto de 1963 (SERLING, 1963r12), a viagem espacial, ida e volta, se daria em 35 
ano; havia também uma sequência abandonada nas revisões posteriores do roteiro, na qual Douglas Stansfield acordava do sono, mandava uma mensagem para a Terra e quebrava a cápsula. Essas cenas dariam detalhes sobre como ele sobreviveu por tanto tempo: alimentando-se da comida reservada para alguma emergência, caso a cápsula tivesse algum problema. Essa sequência estragava o final surpresa, no qual o desencontro do casal é o elemento irônico que leva o público a refletir sobre os personagens e sentir simpatia pelos dois na malfadada narrativa, que revela um forte conceito de amor propagado pelo mundo via Europa.

Esse episódio é uma versão inspirada (acrescentando o tema da viagem espacial e da viagem no tempo) no pequeno conto natalino do prolífico contista $\mathrm{O}$. Henry (pseudônimo de William Sydney Porter), O Presente dos Magos (The Gift of the Magi), publicado em jornal em Nova York em 1905 e posteriormente, 1906, na coletânea de contos do mesmo autor, The Four Million (BILAL, 2012, p.686). O Presente dos Magos é uma poética história de um casal pobre que se ama e tenta se presentear no Natal, sacrificando o que mais gostavam um pelo outro, sem saber do desencontro que isso Ihes traria. A moça, orgulhosa de seu lindo cabelo, vende seu cabelo em troca de dinheiro para comprar uma corrente de relógio para seu esposo, para facilitar o uso do relógio herança de família que o homem adorava. Na hora de revelar ao marido que havia cortado o cabelo e com medo que ele não a achasse mais bonita, descobre que ele the comprou de Natal pentes luxuosos para os seus prezados cabelos. O preço que pagara pelos pentes foi o relógio que ele tanto gostava. Ambos os presentes, mais que meros presentes, representavam o amor sacrificial (Ibid., p.687), o desencontro dos presentes envoltos em auto sacrifício do casal reforça o amor incondicional. A ideia de amor exposta nesse conto pode ser traçada até Shakespeare e sua peça Romeu e Julieta, de finais do século XVI. Rod Serling já havia adaptado em 1948 o conto O Presente dos Magos para a rádio em Ohio, inclusive dando voz ao protagonista, e escrito, em 1961, um roteiro para televisão da mesma história por encomenda da Igreja Presbiteriana Unida nos Estados Unidos da América (GRAMS JUNIOR, 2008, p.655).

$\mathrm{Na}$ versão de Serling, o próprio tempo é sacrificado pelo amor, Douglas Stansfield sacrifica sua juventude ao ficar fora da cápsula e envelhecer naturalmente, pensando que sua amada estaria velha quando retornasse à Terra 40 anos depois e Sandra Horn sacrificou sua vida, esperando em animação suspensa, o retorno do amado, em um amor, que ao contrário do conto de O. Henry, existe mas não traz a 
união do casal, pois Douglas estava velho demais e desejava que sua amada pudesse aproveitar a vida, vivendo em 2027 como jovem. Em uma conclusão triste evidenciando a ideia de que "não há amor maior que o sacrifício por outra pessoa"78.

A viagem no tempo se dá por animação suspensa, denominada exatamente por essa expressão consagrada da ficção científica, o segundo caso na série do modelo visto em The Rip Van Winkle Caper, o estilo "dorminhoco" de se viajar para o futuro. A cápsula onde o astronauta dorme, como o próprio Serling fala na narração da abertura do episódio, remete a um caixão. A técnica utilizada de animação suspensa é um tipo de congelamento com preservação do corpo, que não envelhece. Vemos a cápsula com a disposição do corpo do astronauta como o de um cadáver, e as marcas de congelamento, com a formação de gelo, dão a impressão de uma pessoa morta dentro de um bloco de gelo. Lembrando da associação regular do gelo e frio com a falta de emoções (haja vista o termo coração gelado para denominar alguém incapaz de demonstrar sentimentos), a cápsula seria o local que acabaria com as emoções, no caso, o amor do astronauta, pois o tempo nessa história é a distância do desejo em um mundo de obrigações, trabalhos e desencontros. Em tal mundo, mesmo que se resista, como o astronauta fez ao não se submeter ao congelamento, ficando acordado quase todos os 40 anos da viagem, o efeito desejado não irá ser alcançado.

O papel da Zona Crepuscular em The Long Morrow, como Serling fala também na narração inicial, é o de ser o próprio espaço percorrido pelo foguete, a viagem em si. A Zona Crepuscular não recompensa o personagem principal nem a moça por seu amor, ela ensina, de forma poética, pela tragédia a importância do autossacrifício, ao mesmo tempo em que mostra a futilidade de toda empreitada realizada, criticando o progresso. É a oposição entre trabalho, dever, heroísmo, pioneirismo versus amor que a Zona Crepuscular vai expor a fim de levar à reflexão da audiência, pois o mundo moderno valorizaria muito mais o trabalho e o dever do que o amor. $O$ astronauta podia decidir não embarcar na aventura de 40 anos que iria separá-lo do amor de sua vida, mas estava fascinado em ser um pioneiro na viagem fora do sistema solar, e

\footnotetext{
78 Ideia expressa pelo historiador da televisão Jim Benson em comentário disponível como extra do episódio The Long Morrow na coletânea The Twilight Zone: The Complete Series, CBS, 2016. Blu-ray.
} 
mesmo sabendo que Sandra, se sobrevivesse, estaria com quase 70 anos quando ele retornasse ainda jovem, assume a empreitada e acaba servindo de exemplo.

Figura 58 - Douglas congelado em animação suspensa. A cápsula e o tipo de deslocamento no tempo são semelhantes ao episódio The Rip Van Winkle Caper, porém o aspecto fúnebre da animação suspensa é mais explorado em The Long Morrow.

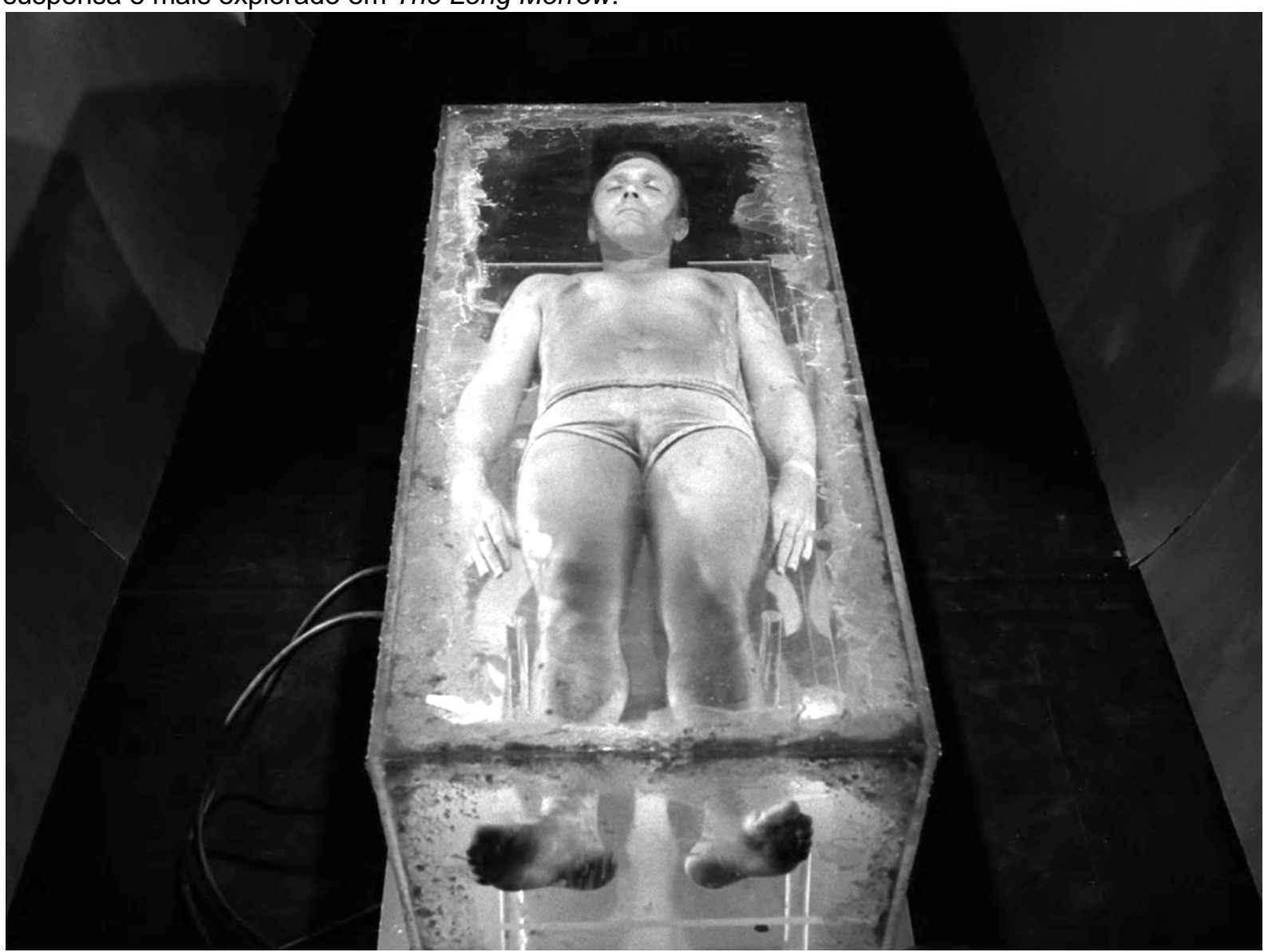

Fonte: elaborado pelo autor (Blu-ray, The Twilight Zone: The Complete Series, CBS, 2017)

Como dado curioso, não é citado no enredo a questão do fenômeno da dilatação do tempo na viagem espacial. É apenas dito que a nave viajaria muito mais rápido que a luz, mas o tempo passaria de forma igual na nave e na Terra. O mesmo conceito da viagem no tempo, por animação suspensa em alta velocidade, pode ser encontrado no roteiro de Serling para o Planeta dos Macacos (SERLING, 1964r9), que ele começaria a trabalhar em 1964. Na adaptação de Rod Serling para o livro homônimo de Pierre Boulle, um grupo de astronautas em animação suspensa dorme por milhares de anos e acorda em um planeta similar à Terra, onde os símios ocupam o lugar antes dos humanos, vivendo em cidades, dirigindo carros, etc.; no final, é descoberto que o planeta era a Terra no futuro e o astronauta sobrevivente é executado pelos símios, nas ruínas da Estátua da Liberdade. No livro de Boulle, lido 
por Serling, apenas em 1964, para desenvolvimento da adaptação para o cinema, é descrito o fenômeno da dilatação do tempo de forma didática (BOULLE, 2015, p.18).

Assim, enquanto pode-se especular que Serling não estivesse a par de todo o conceito da dilatação do tempo em 1963, quando escreveu The Long Morrow, o mesmo não pode ser dito de seu roteiro para o filme Planeta dos Macacos (Planet of the Apes, 1968); Serling deixou os astronautas dormirem como Rip Van Winkle por dois mil anos, com o tempo ocorrendo de forma igual na nave espacial e na Terra, ignorando as próprias informações científicas inseridas pelo francês Pierre Boulle em sua obra. Rip Van Winkle, inclusive é citado textualmente pelos astronautas no roteiro de Serling (SERLING, 1964r9, p.141). Tal exemplo demonstra a própria dificuldade em expor conceitos de difícil entendimento da Física, em obras da cultura de massa e, mais ainda, a importância do enredo se sobrepondo às teorias científicas, em uma obra de ficção científica ou obra que dialoga com elementos desse gênero: em The Long Morrow, caso fosse considerada a dilatação do tempo na viagem de Stansfield, seu envelhecimento e o da Sandra Horn seriam extremamente desproporcionais e uma outra história teria que ser escrita, com maior dificuldade para o escritor em manter o suspense e o final surpresa; porém, em Planeta dos Macacos, Serling deve ter preferido ficar no terreno conhecido do tema do dorminhoco que acorda em outra época, tema explorado duas vezes por ele em Além da Imaginação e parte do folclore americano ${ }^{79}$.

O fato de lançar a história, como tendo início nos anos de 1987 e 1988 serve para explicar o desenvolvimento do voo interestelar e a invenção das formas de animação suspensa, com a ideia de um futuro de progresso tecnológico e científico. Uma interpretação de um crítico de jornal, pós exibição do episódio em 1964, citada por Grams Jr. (2008, p.656), comentava que o episódio criticava a velocidade do progresso da exploração espacial e, mais ainda, o progresso da tecnologia e ciência em detrimento do humano. Esse exemplo nos permite pensar como a série toca os elementos vistos como problemáticos do mundo por parcelas das sociedades de forma ampla, geral e de forma facilmente compreensível, o que nos permite inserir os dilemas atuais no esquema crítico proposto por Serling, atualizando de forma fácil a mensagem da série. Isso explicaria o apelo de muitos episódios até os dias de hoje -

\footnotetext{
${ }^{79}$ Com a mudança de roteirista para Michael Wilson, o filme O Planeta dos Macacos (Planet of the Apes, 1968) incorporou a dilatação do tempo como explicação para a viagem no tempo ao futuro vista na obra.
} 
como seu uso nos sistemas de ensinos anglófonos, sua exibição constante na televisão e as tentativas de reimaginar os episódios, seja em filmes de diversas épocas ou mesmo remakes e novas encarnações da série.

Assim, a história é uma viagem no tempo do futuro próximo para o futuro médio, o futuro próximo servindo de extrapolação para verossimilhança da narrativa, localizando os artefatos necessários para a viagem espacial e no tempo; e o futuro médio, expondo a ideia de um progresso cada vez maior, e uma marcha do tempo que torna todos, os humanos e as tecnologias, obsoletos. O próprio pioneirismo de Douglas foi em vão, pois enquanto ele se deslocava 20 anos para chegar no planeta fora do Sistema Solar, os humanos desenvolveram outras formas de viagem e teriam chegado lá e voltado à Terra ainda antes dele. Quando ele retorna 40 anos depois de ter saído, todas informações sobre o planeta já eram conhecidas, sua viagem fora em vão - seu heroísmo está mais em ter se auto sacrificado por amor, durante a viagem espacial, do que a viagem em si.

No contexto histórico da série, Rod Serling demonstra que o progresso é desumanizador e acaba afastando as pessoas. Não se pode confiar nos avanços tecnológicos e deve-se refletir sobre as grandes mudanças às quais todos estão expostos, tanto individuais, como a velhice, quanto sociais: a viagem de 40 anos não significou qualquer avanço para o conhecimento espacial humano. Inclusive, em diálogo no roteiro revisado de 5 de setembro de 1963, o General Walters, no século $\mathrm{XXI}$, ao ser surpreendido com o retorno do foguete de 1987, chega a afirmar que "Eles saem em uma missão e já se tornam obsoletos quase no momento que saem de vista", e continua; "[...][astronautas] trazem de volta descobertas que nós já descobrimos, fazem observações as quais nós já observamos ${ }^{80 " ~(S E R L I N G, ~ 1963 r 12, ~ t r a d u c ̧ a ̃ o ~}$ nossa).

Neste episódio, o futuro, tanto 1987 quanto 2027, é exposto como mais avançado tecnologicamente que o presente e a crítica ao progresso é oposta a uma perspectiva mais ampla que serve para reforçar a própria noção de progresso. No futuro mais avançado de 2027 , temos a impressão de que os problemas sociais do presente foram resolvidos, tanto os de 1987 quanto os de 1964. A humanidade sobreviveu à Guerra Fria de alguma forma, os prognósticos de destruição nuclear não

\footnotetext{
${ }^{80}$ No original: "They go off on a mission that becomes obsolete almost the moment they're out of sight. [...], bringing back discoveries we've already discovered, making observations we've already observed".
} 
se concretizaram e o ser humano cada vez mais conquista o espaço, como a própria viagem de Douglas Stansfield comprova por sua inutilidade. Os roteiros de Serling com viagem no tempo ao futuro exprimem uma confiança em que os problemas do presente estariam superados em algum tempo futuro.

O recurso narrativo da viagem no tempo ao futuro, em Além da Imaginação, se contrapunha a impulsos nostálgicos, escapistas e de falta de perspectivas, elementos presentes em outras produções culturais televisivas de sucesso no período, como os westerns, as comédias e os detetives. O tema da viagem ao futuro faz parte do conjunto regular e constante por Rod Serling, e demais roteiristas, de criar histórias nas quais essa forma de deslocamento era apresentada como instrumento de ponderação sobre as mudanças individuais e sociais, encaminhando a discussão para reforçar os valores humanísticos propagados em Além da Imaginação. Uma clara proposta de que se estes valores humanísticos ainda estavam ausentes no cotidiano, por meio da reflexão sobre o passado, presente e futuro, eles teriam maior chance de se concretizarem por todo o globo no devir - uma esperança ainda compartilhada em nossa época. 
"We're not doomed. In the grand scheme of things, we're just tiny specks that will one day be forgotten. So it doesn't matter what we did in the past, or how we'll be remembered. The only thing that matters is right now. This moment. This one spectacular moment we are sharing together." ${ }^{181}$

(BoJack Horseman)

"What do you see (What do you see)

When you dream about the future

Do you see me?

What do you see (What do you see)

When you dream about your heart?

What do you see (What do you see)

When you dream about the future?

Dream about the future" 82

(The Apples in Stereo)

\section{7- O Grande Esquema das Coisas}

A possibilidade de se viajar no tempo e presenciar outros tempos e espaços, corrigir erros, vivenciar outras sociedades e descobrir, enfim, qual é o destino humano e qual é a parte que nos cabe no grande esquema da vida e do universo são ideias fascinantes. O desenvolvimento de narrativas que abriram a possibilidade de imaginarmos tudo isso, como vimos, é parte do próprio desenvolvimento do Tempo como símbolo para atender e dar sentido às mudanças que ocorrem nas mais diversas sociedades modernas. A viagem no tempo é, assim, uma forma de se relacionar com a mudança e as permanências, bem como com os ímpetos ahistóricos; ela atualmente se faz presente em quaisquer manifestações artísticas e parecem fazer sentido - e é algo até esperado - por largas parcelas da população mundial, haja vista as sempre recorrentes matérias jornalísticas divulgadas, em escala global, por grandes

\footnotetext{
${ }^{81}$ Fala do personagem fictício BoJack Horseman (Will Arnett) na série de televisão homônima, episódio "That's Too Much, Man!" (2016). Tradução nossa: "Nós não estamos condenados. No grande plano das coisas, nós somos apenas pequenas partículas que um dia serão esquecidas. Então não importa o que fizemos no passado, ou como seremos lembrados. A única coisa que importa é o agora. Este momento. Este momento espetacular que compartilhamos juntos."

82 Trecho da música Dream About The Future (2010), da banda The Apples in Stereo. "O que você vê (O que você vê)/ Quando sonha com o futuro?/ Você me vê?/ O que você vê (O que você vê)/ Quando sonha sobre seu coração?/ O que você vê (O que você vê)/ Quando sonha sobre o futuro?/ Sonha sobre o futuro" [tradução nossa].
} 
conglomerados de comunicação a cada vez que algo semelhante a uma viagem no tempo ficcional passa a ser vislumbrado pela prática científica, principalmente ao passado.

Presenciamos o nascimento e as funções sociais da viagem no tempo, sua íntima ligação com a ideia de um tempo histórico e ideia de História oriundos dos séculos XVIII e XIX europeus, noções expandidas juntamente com os interesses comerciais e geopolíticos das potências europeias por todo o globo, criando uma linguagem comum e forma compartilhada por largas parcelas da humanidade de perceber e viver o tempo. Em um mundo cada vez mais "acelerado", onde as mudanças são cada vez mais rápidas e incontroláveis e os prognósticos de futuro, tanto expostos pela ficção científica quanto por economistas e demais cientistas sociais, parecem nascer já ultrapassadas, a viagem no tempo continua mantendo sua relevância, pois ela sempre popõe alguma forma de exposição e reflexão sobre as mudanças.

Os problemas ocasionados nas narrativas que mostram alguma forma de viagem no tempo estimulam a imaginação sobre o passado e o futuro e acabam trazendo novas percepções sobre o próprio presente, que é o tempo de referência utilizado para a percepção das mudanças. O sucesso estrondoso do filme da Disney Vingadores: Ultimato (Avengers: Endgame, 2019) é um exemplo excelente da pertinência das funções sociais da viagem no tempo. O blockbuster, para marcar o fim de um enorme universo fílmico iniciado na primeira década do século XXI, utlizou a viagem no tempo como forma de unir uma grande parte dos vinte e um filmes anteriores, com total autoconsciência da tradição cinematográfica e uso das fórmulas dos filmes mais famosos de viagem no tempo.

Portanto, as histórias de viagem no tempo são uma das manifestações de como as mais diversas sociedades lidam e percebem as mudanças, permitindo-nos observar de forma clara o grau de consciência e aceitação dessas mudanças, expondo medos, alegrias, perspectivas e especulações de como as distintas temporalidades se articulam e criam sentidos tanto de apologia ao presente quanto críticas ao mundo como experiência, e abre novas perspectivas no devir, tanto dentro de algum modelo mais amplo utópico ou distópico quanto de pequenas experiências de cunho individual. Faz parte da temática propor alguma forma de visão final que enfatiza um universo fatalista ou que permite o livre-arbítrio, confirmando ou 
subvertendo as mais diversas percepções de um sentido da vida que possa ser imaginado por alguém que entra em contato com uma narrativa de viagem no tempo.

Com respeito ao destino, a viagem no tempo ao passado geralmente apresenta a possibilidade de retorno a essa temporalidade como um local de fuga do presente, tanto pelo viés da nostalgia quanto pela procura ou encontro das causas do presente de origem do viajante. Essas histórias englobam problemas e perigos da viagem, habitualmente não intencionais e que podem ou não envolver a formação de paradoxos, os quais acabam sendo enfrentados pelos personagens. A presença da cultura histórica de dada sociedade é marcante nesse tipo de viagem e revela os períodos mais comuns de destino da viagem, que podem ser os marcos da história tradicional ou nacional, refletidos em contextos de traumas sociais, grandes dilemas nacionais e local de saudade, fornecendo tanto ao viajante quanto ao público, uma visão em primeira mão das representações do passado expostos pela historiografia, tanto para enfatizá-las quanto para criticá-las, até mesmo fazendo uso da ironia no retrato de determinados contextos históricos. Além disso, é comum encontrarmos nesse tipo de história alguma forma de preservação do passado que não permite alterações das relações causa e efeito, ou quando elas ocorrem e são mantidas até o final, muitas vezes são no nível que afetam poucos personagens, sem grandes alterações sociais. A viagem no tempo ao passado é mais comum que a viagem no tempo ao futuro, o que pode ser explicado parcialmente pelo desenvolvimento dessas narrativas, pois a viagem ao passado apresentaria o problema dos paradoxos que seriam mais interessantes e desafiadores para muitos escritores, mas, ainda mais significativo, ela é uma apropriação cultural livre das amarras da ciência e da cultura histórica de dada sociedade e contexto. A força de imaginar um novo presente por meio de alterações não no presente, mas no que se acreditam serem as causas do presente é algo irresistível para sociedades orientadas pelo progresso, nas quais aprender a lidar com muitas mudanças rápidas faz parte de sua própria sobrevivência. A viagem ao passado pode discutir os ímpetos nostálgicos e ahistóricos das sociedades, reforçando ou negando esses ímpetos.

Já a viagem no tempo ao futuro, ao ser uma aceleração da experiência humana com o tempo, comumente expõe um tempo no qual o presente do viajante já se encontra realizado, ou seja, as propostas de sociedades em voga no presente, os dilemas sociais, as instituições, etc., se manifestam de forma plena ou já estão superadas. A depender do autor, a viagem no tempo ao futuro pode explorar tanto 
esse aspecto de presente realizado quanto a própria mortalidade do viajante, ou mesmo o fim da História. Essas narrativas se encontram em menor quantidade se comparadas à viagem no tempo ao passado, pois muitas das temáticas exploradas nesse tipo de história já são expostas, sem a necessidade de uma viagem no tempo e sem o autor precisar explicar ou criar mais elementos. As histórias podem se passar inteiramente com personagens do próprio futuro para que as relações entre presente e futuro sejam estabelecidas, portanto a viagem no tempo ao futuro aproxima o público e os problemas dos próprios protagonistas, enfatizando a relação entre as temporalidades que determinado autor procura expor.

Mesmo que seja verdade que um autor possa contar determinada história acontecendo inteiramente no passado (o que é feito até hoje) e, como vimos, isso era comum até o desenvolvimento de obras litertárias que irão começar a explorar as possibilidades do futuro, a viagem ao passado, ao se relacionar com a prática social da História, tende a enfatizar determinados elementos, como a questão da nostalgia e a possibilidade de alteração do presente, propondo uma orientação para o futuro, como presenciamos nos documentos investigados.

No caso do contexto histórico pesquisado, nota-se a viagem no tempo sendo um ambiente de reforço, crítica e comentário sobre a cultura histórica tradicional ou hegemônica e identidade nacional, ligada aos grandes períodos compartilhados por largas parcelas da população dos EUA e que acabam sendo reinterpretados pelas mais diversas culturas globais, haja vista a exportação massiva dos produtos culturais americanos. A crítica ao presente fazia uso dos mitos nacionais americanos, tanto os reforçando quanto os criticando duramente na viagem no tempo ao passado e criando uma perspectiva de futuro progressista, dentro do mito do progresso e dos ideais humanísticos.

A importante série televisivia de antologias Além da Imaginação, capitaneada por Rod Serling, como documento histórico do contexto, expôs os usos mais constantes da viagem no tempo a fim de ponderar sobre como as mudanças estavam sendo vividas pela sociedade americana (indo além dos próprios EUA) no contexto de exibição inicial do programa. Além disso, como pudemos perceber, Além da Imaginação lidou com e expõs reflexões críticas sobre os mitos nacionais dos EUA, como o excepcionalismo americano, a conquista do Oeste e a ascensão do self-made man, dentre outros, utilizando a viagem no tempo para problematizar e propor novas interpretações no contexto tanto de ascensão dos EUA como portência mundial na 
Guerra Fria quanto das enormes mudanças que varreram os EUA no segundo pósguerra, ambos processos intimamente conectados.

Parte do sucesso posterior de Além da Imaginacao está na forma pela qual a série lidou, de forma reiterada e constante, com os temas caros à formação da identidade dos EUA como nação, tornando a série também parte marcante da cultura dos EUA e um símbolo de sua televisão, superando as barreiras que poderiam limitar o programa a ser lembrado apenas como exemplo restrito ao insólito. Isso se deu pois, o programa, em muitos episódios, aprofundou-se na análise da sociedade e cultura dos EUA, aí inclusas as interpretações sobre o seu passado, as relações no presente e as perspectivas de futuro. No caso, os episódios de viagem no tempo demonstram isso de forma clara e fazem parte desse processo.

Mesmo que a série não tenha lidado com a questão dos paradoxos gerados pela viagem no tempo, o que vimos em seu contexto histórico (e além) ser algo que tem um apelo para os criadores desse tipo de narrativa, as demais funções sociais da viagem no tempo se fazem presentes, especificamente a ideia de que vivemos no presente e quaisquer perspectivas de mudanças devem ser realizadas nesta temporalidade e que, caso certas condições da tradição humanística sejam implementadas por indivíduos e sociedades, o futuro seria cada vez mais aperfeiçoado.

Ao expor as relações modernas com o símbolo Tempo, o tema da viagem no tempo, evidenciado de forma clara em Além da Imaginação, encontrou-se de forma singular com a ideia de Rod Serling de marcar suas histórias pela ação da Zona Crepuscular, um espaçotempo agente das histórias do programa, responsável por julgar, punir, purificar e recompensar indivíduos e sociedades, utilizando como norte valores e princípios vistos por Serling (e não só ele) como capazes de melhorar a vida de todos seres humanos, como o respeito aos direitos humanos. Nos episódios da viagem no tempo, a própria Zona Crespuscular passa a ser o Tempo.

A criação do programa de televisão Além da Imaginaçao faz parte do próprio desenvolvimento desta mídia. Ela mesma parte de um amplo processo de novas relações entre espaço e tempo e das formas como os gêneros fantásticos passaram, no contexto do segundo pós-guerra, a fornecer interpretações para o mundo que estava sendo vivido pelas sociedades, especificamente a americana, como se pode ver pela ascensão da ficção científica, com o contexto da Guerra Fria e as suas armas nucleares e os medos tanto do fim das civilizações por guerras, mas também pela 
desintegração das instrituições sociais. Soma-se a esses fatos o crescimento da geração nascida no segundo pós-guerra, que passou a compreender melhor e utilizar os elementos fantásticos para dar sentido e se relacionar com a realidade, o que pode ser constatado pelo sucesso posterior à exibição original que a Além da Imaginação experimentou, logo após ser vendido no sistema de syndication, expandindo o acesso à série, permitindo a exibição em horários e dias distintos, em diversas emissoras pelos EUA e no resto do mundo.

Desse modo, Além da Imaginação é um documento das próprias relações de produção televisiva dos EUA nos anos 50 e meados dos anos 60: desde o problema da autocensura da mídia, a enorme influência dos patrocinadores, o uso de temas insólitos como subterfúgio, desenvolvimento tecnológico, acordos e legislação envoltos na produção de programas, o acesso à programação, a forma como empresas se organizaram para produzir material para televisão e o papel do Estado. Mesmo que Rod Serling possuísse afinidade com o insólito, seu investimento para criar e produzir Além da Imaginação teve grande parcela de percepção de como ele poderia se manter relevante na própria televisão, uma mídia que ele percebia ter um enorme potencial artístico, mas estava sendo abandonada pelos grandes roteiristas por pressões comerciais pausterizadoras.

A figura de Rod Serling também é importante. O criador e produtor de Além da Imaginação era um nome reconhecido nos dramas da época, roteirista de rádio, televisão e cinema, reputado como um dos grandes roteiristas dos EUA quando decidiu criar Além da Imaginação, no final da década de 50 . Seu nome tanto trazia prestígio ao fantástico na televisão, quanto parecia demonstrar uma rejeição a televisão vista como séria. Uma ideia de que ele estaria se reinventando não era completamente verdadeira, pois os temas humanos de que ele gostava não deixaram de existir e se manifestaram com muito mais força e longevidade por meio do uso do sobrenatural, da ficção científica e da fantasia. Um humanista ativo até sua morte nos anos 70, participante ativo dos debates que varriam os EUA, tanto por meio de suas obras quanto por entrevistas, artigos de jornal, palestras e cartas. Cabem destaques as suas críticas à baixa qualidade da programação televisiva, à influência e ao controle dos patrocinadores na programação, aos extremismos políticos, aos preconceitos, ao incentivo à ignorância e cerceamento às liberdades, principalmente à liberdade de expressão. Serling também era um defensor das minorias e fazia o máximo para 
colocar no papel de protagonistas, em suas obras, as etnias e grupos que via sendo excluídos.

A série Além da Imaginação, em seu conjunto, expressava em grande parte as convicções de Serling, mesmo em roteiros não assinados por ele, sobre a vida e as perspectivas de futuro, tanto dos EUA quanto da humanidade. A ideia de uma Zona Crepuscular que funciona como um tipo de purgatório e juiz da humanidade, reestabelecendo o equilíbrio social, recompensando pessoas desprezadas pela sociedade, punindo malfeitores, dando segundas chances a pessoas que se desviaram, geralmente de forma irônica e com alguma reviravolta para surpreender o público, dava ênfase à crítica social e ecoava a filosofia humanística de Rod Serling.

A influência e a relevância de Além da Imaginação na história da televisão mundial demonstram o amplo alcance e, mais ainda, a concordância com muitos dos projetos de Serling, confirmando a importância dos gêneros insólitos como criações humanas fundamentais para as sociedades contemporâneas, na condição de elemento mediador e influenciador das experiências com a realidade em um mundo ainda orientado pelas expectativas e pelas tentativas de controle das mudanças incognoscíveis, cada vez mais rápidas.

Assim, Além da Imaginação nos fornece um amplo aspecto das mudanças, permanências, prognósticos de futuro e interpretações do passado no contexto do segundo pós-guerra dos EUA, especificamente finais dos anos 50 e meados dos anos 60 , utilizando a viagem no tempo de forma clara para representar o espírito da época e participar do debate público, reforçando e criticando diversas posturas individuais e coletivas frente aos possíveis rumos da sociedade americana e da humanidade.

No grande esquema das coisas, a viagem no tempo surge, então, como uma forma que temos para imaginar uma existência diferente em algum país estrangeiro do passado ou do futuro, recuperando o que perdemos sem nunca possuir, dando vazão às pressões cotidianas de um mundo regido pelo Tempo, fazendo-nos entrar em contato com o que fomos e com quem podemos nos tornar, para, afinal, permitir a observação do presente de forma mais profunda e complexa. 


\section{REFERÊNCIAS BIBLIOGRÁFICAS}

\section{Audiovisual}

A Hundred Yards Over the Rim. Direção: Buzz Kulik. Intérpretes: Cliff Robertson, John Astin, Evans Evans, Ed Platt. Roteiro: Rod Serling. Los Angeles: CBS, 1961. The Twilight Zone: The Complete Series, 2016. Blu-ray.

A Quality of Mercy. Direção: Buzz Kulik. Intérpretes: Dean Stockwell, Albert Salmi, Jerry Fujikawa e Leonard Nimoy. Roteiro: Rod Serling. Los Angeles: CBS, 1961. The Twilight Zone: The Complete Series, 2016. Blu-ray.

A Stop at Willoughby. Direção: Robert Parrish. Intérpretes: James Daly, Patricia Donahue e Howard Smith. Roteiro: Rod Serling. Los Angeles: CBS, 1960. The Twilight Zone: The Complete Series, 2016. Blu-ray.

Back There. Direção: Direção: David Orrick. Intérpretes: Russsell Johnson, Carol Eve Rossen, John Lasell, Lew Brown, Bartlett Robinson e Paul Hartman. Roteiro: Rod Serling. Los Angeles: CBS, 1961. The Twilight Zone: The Complete Series, 2016. Bluray.

Execution. Direção: David Orrick McDearmon. Intérpretes: Albert Salmi e Russell Johnson. Roteiro: Rod Serling. Los Angeles: CBS, 1960. The Twilight Zone: The Complete Series, 2016. Blu-ray.

No Time Like The Past. Direção: Justus Addiss. Intérpretes: Dana Andrewsm Marjorie Bennett e Patricia Breslin. Roteiro: Rod Serling. Los Angeles: CBS, 1963. The Twilight Zone: The Complete Series, 2016. Blu-ray.

Of Late I Think of Cliffordville. Direção: David Lowell Rich. Intérpretes: Albert Salmi, Guy Raymond, John Anderson, Julie Newmar e Wright King. Roteiro: Rod Serling. Los Angeles: CBS, 1963. The Twilight Zone: The Complete Series, 2016. Blu-ray.

Once Upon a Time. Direção: Norman Z. McLeod. Intérpretes: Buster Keaton, George E. Stone, Jesse White, Milton Parsons e Stanley Adams. Roteiro: Richard Matheson. Los Angeles: CBS, 1961. The Twilight Zone: The Complete Series, 2016. Blu-ray. Showdown with Rance McGrew . Direção: Christian Nyby. Intérpretes: Larry Blyden, Arch Johnson e Robert Cornthwaite. Roteiro: Rod Serling. Los Angeles: CBS, 1962. The Twilight Zone: The Complete Series, 2016. Blu-ray. 
Spur of the Moment. Direção: Elliot Silverstein. Intérpretes: Diana Hyland, Robert Hogan, Roger Davis, Philip Ober, Marsha Hunt e Jack Raine. Roteiro: Richard Matheson. Los Angeles: CBS, 1964. The Twilight Zone: The Complete Series, 2016. Blu-ray.

Static. Direção: Buzz Kulik. Intérpretes: Dean Jagger e Carmen Mathews. Roteiro: Charles Beaumont. Los Angeles: CBS, 1961. The Twilight Zone: The Complete Series, 2016. Blu-ray.

The 7th is Made Up of Phantoms. Direção: Alan Crosland Jr. Intérpretes: Ron Foster, Randy Boone e Warren Oates. Roteiro: Rod Serling. Los Angeles: CBS, 1963. The Twilight Zone: The Complete Series, 2016. Blu-ray.

The Incredible World of Horace Ford. Direção: Abner Biberman. Intérpretes: Par Hingle, Nan Martin e Ruth White. Roteiro: Reginald Rose. Los Angeles: CBS, 1963. The Twilight Zone: The Complete Series, 2016. Blu-ray.

The Last Flight. Direção: William Claxton. Intérpretes: Kenneth Haigh, Simon Scott e Alexander Scourby. Roteiro: Richard Matheson. Los Angeles: CBS, 1959. Blu-ray.

The Long Morrow. Direção: Robert Florey. Intérpretes: Robert Lansing e Mariette Hartley. Roteiro: Rod Serling. Los Angeles: CBS, 19. The Twilight Zone: The Complete Series, 2016. Blu-ray.

The Mike Wallace Interview, 1959. New York: ABC. The Twilight Zone: The Complete Series, 2016. Blu-ray.

The Odyssey of Flight 33. Direção: Justus Addiss. Intérpretes: John Anderson, Paul Comi, Sandy Kenyon, Harp McGuire, Beverly Brown e Wayne Heffley. Roteiro: Rod Serling. Los Angeles: CBS, 1961. The Twilight Zone: The Complete Series, 2016. Bluray.

The Rip Van Winkle Caper. Direção: Justus Addiss. Intérpretes: Oscar Beregi, Lew Gallo, John Mitchum, Simon Oakland, Shirley O'Hara e Wallace Rooney. Roteiro: Rod Serling. Los Angeles: CBS, 1961. The Twilight Zone: The Complete Series, 2016. Bluray.

The Time Element. Direção: Allen Reisner. Intérpretes: William Bendix, Martin Balsam, Darryl Hickman e Carol Kearney. Roteiro: Rod Serling. Los Angeles: CBS, 1958. The Twilight Zone: The Complete Series, 2016.Blu-ray.

The Trouble With Templeton. Direção: Buzz Kulik. Intérpretes: Brian Aherne e Pippa Scott. Roteiro: E. Jack Neuman. Los Angeles: CBS, 1960. The Twilight Zone: The Complete Series, 2016. Blu-ray. 
Walking Distance. Direção: Robert Stevens. Intérpretes: Gig Young, Frank Overton, Irene Tedrow e Michael Montgomery. Roteiro: Rod Serling. Los Angeles: CBS, 1959 The Twilight Zone: The Complete Series, 2016. Blu-ray.

\section{Cartas}

ALSUP, Bill, [Correspondência]. Destinatário: Rod Serling. [Hollywood?], [1961?]. Wisconsin: Wisconsin Historical Society (Rod Serling Papers, 1943-1971). Caixa 10, 2017.

AMMERMAN, Dan S., [Correspondência]. Destinatário: Rod Serling. New York, 2 jun 1961. Wisconsin: Wisconsin Historical Society (Rod Serling Papers, 1943-1971). Caixa 17, 2017.

ANTONOFF, Jeff Antonoff; FREEMARK, Michael, [Correspondência]. Destinatário: Rod Serling. New York, 3 jan 1961. Wisconsin: Wisconsin Historical Society (Rod Serling Papers, 1943-1971). Caixa 10, 2017.

ARCHER, Dirce, [Correspondência]. Destinatário: Rod Serling. Culver City, 29 jan 1960a. Wisconsin: Wisconsin Historical Society (Rod Serling Papers, 1943-1971). Caixa 10, 2017.

.. [Correspondência]. Destinatário: Rod Serling. Culver City, 10 fev 1960b. Wisconsin: Wisconsin Historical Society (Rod Serling Papers, 1943-1971). Caixa 10, 2017.

.. [Correspondência]. Destinatário: Rod Serling. Culver City, 30 jun 1960c. Wisconsin: Wisconsin Historical Society (Rod Serling Papers, 1943-1971). Caixa 12, 2017.

.. [Correspondência]. Destinatário: Rod Serling. Culver City, 18 jul 1960d. Wisconsin: Wisconsin Historical Society (Rod Serling Papers, 1943-1971). Caixa 13, 2017.

BEAUMONT, Charles, [Correspondência]. Destinatário: Rod Serling. [Hollywood?], 3 dez 1960. Wisconsin: Wisconsin Historical Society (Rod Serling Papers, 1943-1971). Caixa 15, 2017.

DEAR Rod Serling, [Correspondência]. Destinatário: Rod Serling. Beverly Hills, 24 fev 1960. Wisconsin: Wisconsin Historical Society (Rod Serling Papers, 1943-1971). Caixa 11, 2017.

COLEMAN, Rita C., [Correspondência]. Destinatário: Rod Serling. Hollywood, 24 fev 1961. Wisconsin: Wisconsin Historical Society (Rod Serling Papers, 1943-1971). Caixa 16, 2017. 
CORWIN, Philip, [Correspondência]. Destinatário: Rod Serling. [Hollywood?], 25 fev 1961. Wisconsin: Wisconsin Historical Society (Rod Serling Papers, 1943-1971). Caixa 16, 2017

CRAWFORD, J.H., [Correspondência]. Destinatário: Rod Serling. Los Angeles, 3 mai 1961a. Wisconsin: Wisconsin Historical Society (Rod Serling Papers, 1943-1971). Caixa 17, 2017.

. [Correspondência]. Destinatário: Rod Serling. Los Angeles, 3 jun 1961b. Wisconsin: Wisconsin Historical Society (Rod Serling Papers, 1943-1971). Caixa 17, 2017.

CONNOR, Edward, [Correspondência]. Destinatário: Rod Serling. New York, 28 fev 1961. Wisconsin: Wisconsin Historical Society (Rod Serling Papers, 1943-1971). Caixa 16, 2017.

DIAMOND, Norman, [Correspondência]. Destinatário: Rod Serling. [Pacific Palisades?], [março, 1960?]. Wisconsin: Wisconsin Historical Society (Rod Serling Papers, 1943-1971). Caixa 11, 2017.

EXCERPTS from Catholic Booklet on the Right Wing, New York: The New York Times, 2 abr 1962. Wisconsin: Wisconsin Historical Society (Rod Serling Papers, 1943-1971). Caixa 19, 2017.

FABER, George, [Correspondência]. Destinatário: Rod Serling. Pacific Palisades, 22 dez 1965. Wisconsin: Wisconsin Historical Society (Rod Serling Papers, 1943-1971). Caixa 4, 2017.

GALVIN, Fred, [Correspondência]. Destinatário: Rod Serling. [Pacific Palisades?], 27 out 1959. Wisconsin: Wisconsin Historical Society (Rod Serling Papers, 1943-1971). Caixa 9, 2017.

. [Correspondência]. Destinatário: Rod Serling. Pacific Palisades, 4 jul 1960. Wisconsin: Wisconsin Historical Society (Rod Serling Papers, 1943-1971). Caixa 12, 2017.

GESSNER, Alan, [Correspondência]. Destinatário: Rod Serling. Pacific Palisades, 11 abr 1961. Wisconsin: Wisconsin Historical Society (Rod Serling Papers, 1943-1971). Caixa 17, 2017.

GOTSCHALL, Donald L., [Relatório da Edição]. Destinatário: A.E. Houghton- Cayuga Productions, 29 jan 1960. Wisconsin: Wisconsin Historical Society (Rod Serling Papers, 1943-1971). Caixa 10, 2017.

GOOCH, Mary Shomette, [Correspondência]. Destinatário: Rod Serling. [Hollywood?], 5 nov 1959. Wisconsin: Wisconsin Historical Society (Rod Serling Papers, 1943-1971).

Caixa 10, 2017. 
HADDAD, Michael; KLEIN, Douglas, [Correspondência]. Destinatário: Rod Serling. New York, 28 fev 1961. Wisconsin: Wisconsin Historical Society (Rod Serling Papers, 1943-1971). Caixa 16, 2017.

HICKEY, James, [Correspondência]. Destinatário: Rod Serling. Interlaken, 13 abr 1961. Wisconsin: Wisconsin Historical Society (Rod Serling Papers, 1943-1971). Caixa 12, 2017.

HIRSCHMAN, Herbert, [Correspondência]. Destinatário: Rod Serling. Interlaken, 27 jul 1962a. Wisconsin: Wisconsin Historical Society (Rod Serling Papers, 1943-1971). Caixa 19, 2017.

. [Correspondência]. Destinatário: Rod Serling. Interlaken, 1 ago 1962a. Wisconsin: Wisconsin Historical Society (Rod Serling Papers, 1943-1971). Caixa 19, 2017.

HOUGHTON, Buck, [Correspondência]. Destinatário: Rod Serling. Pacific Palisades, 15 nov 1961. Wisconsin: Wisconsin Historical Society (Rod Serling Papers, 19431971). Caixa 18, 2017.

KEMP, Earl, [Correspondência]. Destinatário: Rod Serling. [Pacific Palisades?], 5 mar 1960. Wisconsin: Wisconsin Historical Society (Rod Serling Papers, 1943-1971). Caixa 11, 2017.

JAECKEL, Howard, [Correspondência]. Destinatário: Rod Serling. [Pacific Palisades?], 10 fev 1961. Wisconsin: Wisconsin Historical Society (Rod Serling Papers, 1943-1971). Caixa 16, 2017.

FLOR, Jo Ellen, [Correspondência]. Destinatário: Rod Serling. [Pacific Palisades?], 15 ago 1961. Wisconsin: Wisconsin Historical Society (Rod Serling Papers, 1943-1971). Caixa 18, 2017.

KAPLAN, Sam, [Correspondência]. Destinatário: Allan Amenta. Quacker Hill, 7 abr 1961. Wisconsin: Wisconsin Historical Society (Rod Serling Papers, 1943-1971). Caixa 17, 2017.

. [Correspondência]. Destinatário: Rod Serling. Interlaken, 1 jul 1964. Wisconsin: Wisconsin Historical Society (Rod Serling Papers, 1943-1971). Caixa 4, 2017.

LADD, Bill, [Correspondência] Destinatário: Rod Serling. [Pacific Palisades?], 29 abr 1963. Wisconsin: Wisconsin Historical Society (Rod Serling Papers, 1943-1971). Caixa 1, 2017.

LEE, Bonnie. [Correspondência] Destinatário: Rod Serling. [Pacific Palisades?], 9 jul 1960. Wisconsin: Wisconsin Historical Society (Rod Serling Papers, 1943-1971). Caixa 13, 2017. 
MORRIS, Frank. [Comunicação interna]. Destinatário: Bill Self, cc.: Serling e Houghton, 16 abr 1959. Wisconsin: Wisconsin Historical Society (Rod Serling Papers, 1943-1971). Caixa 5, 2017.

OLMSTED, Connie, [Relatório]. Destinatário: Rod Serling, [1959?]. Wisconsin: Wisconsin Historical Society (Rod Serling Papers, 1943-1971). Caixa 9, 2017. [Correspondência]. Destinatário: Dave Acker. Wheeling, 22 fev 1961. Wisconsin: Wisconsin Historical Society (Rod Serling Papers, 1943-1971). Caixa 16, 2017.

PATTERSON, John M. [Correspondência]. Destinatário: Rod Serling. [Pacific Palisades?], 3 ago 1960. Wisconsin: Wisconsin Historical Society (Rod Serling Papers, 1943-1971). Caixa 13, 2017.

ROGERS, Henry C., [Correspondência]. Destinatário: Betty O'Hara. Los Angeles, 28 mai 1963. Wisconsin: Wisconsin Historical Society (Rod Serling Papers, 1943-1971). Caixa 4, 2017.

REYNOLDS, John T., [Correspondência]. Destinatário: Rod Serling. Pacific Palisades, 1 abr 1964. Wisconsin: Wisconsin Historical Society (Rod Serling Papers, 1943-1971). Caixa 4, 2017.

ROD SERLING FAN MAIL [Relatório]. [1960?]. Wisconsin: Wisconsin Historical Society (Rod Serling Papers, 1943-1971). Caixa 4, 2017.

SAK, Norman. [Correspondência]. Destinatário: Rod Serling. [Pacific Palisades?], [1960?]. Wisconsin: Wisconsin Historical Society (Rod Serling Papers, 1943-1971). Caixa 4, 2017.

SALTZ, Diane, [Correspondência]. Destinatário: Rod Serling. [Pacific Palisades?], 24 fev 1961. Wisconsin: Wisconsin Historical Society (Rod Serling Papers, 1943-1971). Caixa 16, 2017.

SERLING, Robert, [Correspondência]. Destinatário: Rod Serling. [Pacific Palisades?], 8 out 1960ia. Wisconsin: Wisconsin Historical Society (Rod Serling Papers, 19431971). Caixa 14, 2017.

. [Correspondência]. Destinatário: Rod Serling. [Pacific Palisades?], $23 \mathrm{dez}$ 1960ib. Wisconsin: Wisconsin Historical Society (Rod Serling Papers, 1943-1971). Caixa 14, 2017.

SERLING, Rod. [Correspondência]. Destinatário: Michael Yazzolino. Whittier, 4 mar 1960a. Wisconsin: Wisconsin Historical Society (Rod Serling Papers, 1943-1971). Caixa 10, 2017.

. [Correspondência]. Destinatário: Don Lee. Chicago, 7 mar 1960b. Wisconsin: Wisconsin Historical Society (Rod Serling Papers, 1943-1971). Caixa 10, 2017. 
SERLING, Rod. [Correspondência]. Destinatário: Earl Kemp. Chicago, 18 mar 1960c. Wisconsin: Wisconsin Historical Society (Rod Serling Papers, 1943-1971). Caixa 10, 2017.

. [Correspondência]. Destinatário: Meade Freerson III. Philadelphia, 23 mai 1960d. Wisconsin: Wisconsin Historical Society (Rod Serling Papers, 1943-1971). Caixa 12, 2017.

. [Correspondência]. Destinatário: Vilius Brazenas. Stamford, 4 out 1960e. Wisconsin: Wisconsin Historical Society (Rod Serling Papers, 1943-1971). Caixa 14, 2017.

. [Correspondência]. Destinatário: Richard E. Roberts. New York, 11 out $1960 f$. Wisconsin: Wisconsin Historical Society (Rod Serling Papers, 1943-1971). Caixa 14, 2017.

. [Correspondência]. Destinatário: Ray Bradbury. Los Angeles, 5 dez 1960g. Wisconsin: Wisconsin Historical Society (Rod Serling Papers, 1943-1971). Caixa 15, 2017.

. [Correspondência]. Destinatário: Charles Beaumont. North Hollywood, 5 dez 1960h. Wisconsin: Wisconsin Historical Society (Rod Serling Papers, 1943-1971). Caixa 15, 2017.

. [Correspondência]. Destinatário: Sra. Robert Kasanda. Hillside, 13 dez 1960i. Wisconsin: Wisconsin Historical Society (Rod Serling Papers, 1943-1971). Caixa 15, 2017.

. [Correspondência]. Destinatário: Scott W. Ryall. Bakersfield, 6 jan 1961a. Wisconsin: Wisconsin Historical Society (Rod Serling Papers, 1943-1971). Caixa 15, 2017.

. [Correspondência]. Destinatário: Greville Bathe. St. Augustine, 9 jan 1961b. Wisconsin: Wisconsin Historical Society (Rod Serling Papers, 1943-1971). Caixa 15, 2017.

. [Correspondência]. Destinatário: Thomas Broddle. Winchester, 11 jan 1961c. Wisconsin: Wisconsin Historical Society (Rod Serling Papers, 1943-1971). Caixa 16, 2017.

. [Correspondência]. Destinatários: Jeff Antonoff e Michael Freemark;. Philadelphia, 22 fev 1961d. Wisconsin: Wisconsin Historical Society (Rod Serling Papers, 1943-1971). Caixa 16, 2017.

. [Correspondência]. Destinatário: Howard Jaeckel. New York, 3 mar 1961e. Wisconsin: Wisconsin Historical Society (Rod Serling Papers, 1943-1971). Caixa 16, 2017.

[Correspondência]. Destinatário: Alan Gessner. Bartow, 20 abr $1961 \mathrm{f}$. Wisconsin: Wisconsin Historical Society (Rod Serling Papers, 1943-1971). Caixa 17, 2017.

. [Correspondência]. Destinatário: Hunter Brown. Los Angeles, 26 mai 1961g. Wisconsin: Wisconsin Historical Society (Rod Serling Papers, 1943-1971). Caixa 17, 2017.

. [Correspondência]. Destinatário: Bill Ladd, Louisville, 23 mai $1963 a$. Wisconsin: Wisconsin Historical Society (Rod Serling Papers, 1943-1971). Caixa 1, 2017.

. [Correspondência]. Destinatário: Gordon L. Swirsky, Pittsfield, 23 mai 1963b. Wisconsin: Wisconsin Historical Society (Rod Serling Papers, 1943-1971). Caixa 1, 2017. 
SERLING, Rod. [Correspondência]. Destinatário: Art Hostetler, Warren, 9 jul 1963c. Wisconsin: Wisconsin Historical Society (Rod Serling Papers, 1943-1971). Caixa 1, 2017.

. [Correspondência Produção]. Destinatário: Ralph Nelson e Willard Block, 9 set 1963d. Wisconsin: Wisconsin Historical Society (Rod Serling Papers, 1943-1971). Caixa 27, 2017.

. [Correspondência]. Destinatário: Marianne Minasian, Monterey Park, 25 mar 1964. Wisconsin: Wisconsin Historical Society (Rod Serling Papers, 1943-1971). Caixa 1, 2017.

. [Correspondência]. Destinatário: Laurel Smith, Stockton, 3 abr 1968. Wisconsin: Wisconsin Historical Society (Rod Serling Papers, 1943-1971). Caixa 4, 2017.

. [Correspondência]. Destinatário: William F. Bauernfeind, Whitewater, 22 jan 1970. Wisconsin: Wisconsin Historical Society (Rod Serling Papers, 1943-1971). Caixa 4, 2017.

SANTANELLO, Kenneth, [Correspondência]. Destinatário: Rod Serling. Pawtucket, 31 dez 1959. Wisconsin: Wisconsin Historical Society (Rod Serling Papers, 1943-1971). Caixa 10, 2017.

SMITH, Laurel. [Correspondência]. Destinatário: Rod Serling. [Pacific Palisades?], 30 dez 1967. Wisconsin: Wisconsin Historical Society (Rod Serling Papers, 1943-1971). Caixa 4, 2017.

UNGAR, Florence, [Correspondência]. Destinatário: Rod Serling., 28 jun 1961. Wisconsin: Wisconsin Historical Society (Rod Serling Papers, 1943-1971). Caixa 17, 2017.

KASANDA, Robert Sra., [Correspondência]. Destinatário: Rod Serling. [Pacific Palisades?], 19 nov 1960. Wisconsin: Wisconsin Historical Society (Rod Serling Papers, 1943-1971). Caixa 14, 2017.

HENDERSON, Joyce, [Correspondência]. Destinatário: Rod Serling. Hollywood, 3 nov 1961. Wisconsin: Wisconsin Historical Society (Rod Serling Papers, 1943-1971). Caixa 18, 2017.

HANSEN, Bill, [Correspondência]. Destinatário: Rod Serling. Hollywood, 24 dez 1960. Wisconsin: Wisconsin Historical Society (Rod Serling Papers, 1943-1971). Caixa 15, 2017.

SMYTH, Joseph, [Correspondência]. Destinatário: Columbia Broadcasting System, 1 out 1961. Wisconsin: Wisconsin Historical Society (Rod Serling Papers, 1943-1971). Caixa 18, 2017.

WALTERS, E. Nancy, [Correspondência]. Destinatário: Rod Serling. New York, 24 fev 1961. Wisconsin: Wisconsin Historical Society (Rod Serling Papers, 1943-1971). Caixa 16, 2017. 
WILKINS, Paul, [Correspondência]. Destinatário: Rod Serling. Culver City, 20 jun 1960a. Wisconsin: Wisconsin Historical Society (Rod Serling Papers, 1943-1971). Caixa 13, 2017.

. [Correspondência]. Destinatário: Rod Serling. Culver City, 28 jun 1960b. Wisconsin: Wisconsin Historical Society (Rod Serling Papers, 1943-1971). Caixa 13, 2017.

Roteiros

MATHESON, Richard. Once Upon a Time. Wisconsin: Wisconsin Historical Society (Rod Serling Papers, 1943-1971). Caixa 66, 2017.

NEUMAN, E. Jack. The Trouble with Templeton, 1960. Los Angeles: UCLA Library Special Collections - Charles E. Young Research Library (Buzz Kulik Papers, 19421994). Caixa 42, 2019.

SERLING, Rod, A Hundred Yards over the Rim, 1961r1. Wisconsin: Wisconsin Historical Society (Rod Serling Papers, 1943-1971). Caixa 65, 2017.

A Quality of Mercy, 1961r2. Wisconsin: Wisconsin Historical Society (Rod Serling Papers, 1943-1971). Caixa 66, 2017.

. A Stop at Willoughby, 1960r3. Wisconsin: Wisconsin Historical Society (Rod

Serling Papers, 1943-1971). Caixa 64, 2017.

. Back There, 1960r4. Wisconsin: Wisconsin Historical Society (Rod Serling Papers, 1943-1971). Caixa 65, 2017.

. Execution, 1959r5. Wisconsin: Wisconsin Historical Society (Rod Serling

Papers, 1943-1971). Caixa 64, 2017.

I Shot An Arrow Into The Air, 1958r6. Wisconsin: Wisconsin Historical Society

(Rod Serling Papers, 1943-1971). Caixas 63-64, 2017.

. No Time Like the Past, 1962r7. Wisconsin: Wisconsin Historical Society (Rod

Serling Papers, 1943-1971). Caixa 68, 2017.

. Of Late I Think of Cliffordville, 1963r8. Wisconsin: Wisconsin Historical

$\overline{\text { Society }}$ (Rod Serling Papers, 1943-1971). Caixa 68, 2017.

. Planet of the Apes: Second Draft, 1964r9. Wisconsin: Wisconsin Historical

Society (Rod Serling Papers, 1943-1971). Caixa 43, 2017.

. Showdown with Rance McGrew, 1961r10. Wisconsin: Wisconsin Historical

Society (Rod Serling Papers, 1943-1971). Caixa 66, 2017.

. The 7th Is Made Up of Phantoms, 1963r11. Wisconsin: Wisconsin Historical

Society (Rod Serling Papers, 1943-1971). Caixa 70, 2017.

. The Long Morrow, 1963r12. Wisconsin: Wisconsin Historical Society (Rod

Serling Papers, 1943-1971). Caixa 70, 2017.

. The Odyssey of Flight 33, 1960r13. Wisconsin: Wisconsin Historical Society

(Rod Serling Papers, 1943-1971). Caixa 65, 2017.

. The Rip Van Winkle Caper, 1961r14. Wisconsin: Wisconsin Historical Society

(Rod Serling Papers, 1943-1971). Caixa 65, 2017.

. Walking Distance, 1959r15. Wisconsin: Wisconsin Historical Society (Rod

Serling Papers, 1943-1971). Caixa 63, 2017.

. Where Is Everybody?, 1959r16. Wisconsin: Wisconsin Historical Society (Rod

Serling Papers, 1943-1971). Caixa 62, 2017. 
Contos

George Clayton Johnson. Scripts and Stories Written for The Twilight Zone. San Diego: Valcour and Krieger, 1977. Kindle.

SERLING, Rod. A Stop at Willoughby, s.d. c2 Wisconsin: Wisconsin Historical Society (Rod Serling Papers, 1943-1971). Caixa 40, 2017.

. More Stories from the Twilight Zone. [S.I.]: Rod Serling Books, 2013. Kindle. . New Stories From the Twilight Zone. [S.I.]: Rod Serling Books, 2013. Kindle. (org.). Rod Serling's Triple W: Witches, Warlocks and Werewolves. New York:

Bantam Books, 1963.

. Showdown with Rance McGrew, s.d. Wisconsin: Wisconsin Historical Society (Rod Serling Papers, 1943-1971). Caixa 40, 2017.

. Stories from the Twilight Zone. [S.I.]: Rod Serling Books, 2013. Kindle.

. The Odyssey of Flight 33. Wisconsin: Wisconsin Historical Society (Rod

Serling Papers, 1943-1971). Caixa 40, 2017.

. The Rip Van Winkle Caper, s.d. Wisconsin: Wisconsin Historical Society (Rod

Serling Papers, 1943-1971). Caixa 40, 2017.

. Walking Distance, s.d. c1 Wisconsin: Wisconsin Historical Society (Rod

Serling Papers, 1943-1971). Caixa 40, 2017.

\section{Livros}

ADAMI, Saulo. Homem Não Entende Nada: Arquivos Secretos do Planeta dos Macacos. São José dos Pinhais: Editora Estronho, 2015.

ADAMS, Douglas. Guia definitivo do mochileiro das galáxias. São Paulo: Arqueiro: 2015.

ALKON, Paul K. Origins of Futuristic Fiction. Athens: University of Georgia Press, 2010.

ASIMOV, Isaac et al. Travels Through Time. Milwaukee: Raintree Publishers Inc., 1981.

AUMONT, Jacques; MARIE, Michel. Dicionário teórico e crítico de cinema. Campinas: Papirus, 2003.

AURTHUR; SERLING; T UNICK; et al., The Relation of the Writer to Television. Santa

Barbara: Center for the Study of Democratic Institutions, 1960.

BARRON, Neil. Anatomy of Wonder: A Critical Guide to Science Fiction. 5th ed. Westport: Libraries Unlimited, 2004.

BASSIOR, Jean-Noel. Space Patrol: Missions of Daring in the Name of Early Television. Jefferson: McFarland \& Company, 2012. Kindle. 
BAYLEY, Edwin R. Joe McCarthy and the Press. Madison: University of Wisconsin Press, 1981.

BEKAR, Clifford T.; CARLAW, Kenneth I., LIPSEY, Richard G. Economic Transformations: General Purpose Technologies and Long-Term Economic Growth, New York: Oxford University Press, 2005.

BENJAMIN, Walter. Sobre o conceito de história. In: Magia e Técnica, arte e política: ensaios sobre literatura e história da cultura. $3^{\mathrm{a} e d . ~ S a ̃ o ~ P a u l o: ~ B r a s i l i e n s e, ~} 1985$. p.222-233.

BINGEN, Steven; SYLVESTER, Stephen X.; TROYAN, Michael. MGM: Hollywood's Greatest Backlot. Solana Beach: Santa Monica Press, 2011.

BLOCH, Marc. Apologia da história ou o ofício do historiador. Rio de Janeiro: Jorge Zahar Editor, 2002.

BLUM, John Morton, Years of Discord: American Politics and Society, 1961-1974; New York: W.W. Norton \& Company Ltd., 1991.

BOOKER, M. Keith. Historical Dicionary of Science Fiction in Literature. Lanham: Rowman \& Littlefield Publishers, 2015.

BOULLE, Pierre. O Planeta dos Macacos. São Paulo: Aleph, 2015.

BOYM, Svetlana. The Future of Nostalgia. New York: Basic Books, 2002.

BOYM, Svetlana. The Future of Nostalgia. New York: Basic Books, 2001.

BRAUDEL, Fernand. A longa duração. In: História e Ciências Sociais. Lisboa: Editorial Presença, 1986, p. 7-39.

BRINKLEY, Alan. The Unfinished Nation: A Concise History of the American People, 8th. ed.. New York: McGraw-Hill Education, 2016.

BUZZARD, Karen. Tracking the Audience: The Ratings Industry from Analog to Digital. New York: Routledge, 2012.

CAMUS, Albert. O Mito de Sísifo - Ensaio sobre o absurdo. Rio de Janeiro: Editora Record, 2008.

CAHN, Victor. Walking Distance: Remembering Classic Episodes from Classic Television. Eugene: Resource Publications, 2014.

CAPUZZO, Heitor. O Cinema Além da Imaginação. Vitória: Fundação Ceciliano Abel de Almeida, 1990.

CASTILHO, M. L. C. de Fábulas e Lendas Japonesas. Círculo do Livro, São Paulo, 1987. 
CHARTIER, Roger. A história ou a leitura do tempo. Belo Horizonte: Autêntica Editora, 2015.

CHERMAN, Alexandre; VIEIRA, Fernando. O tempo que o tempo tem: por que o ano tem 12 meses e outras curiosidades sobre o calendário. Rio de Janeiro: Jorge Zahar Ed., 2008.

CHRISTOPHER, John. Chung-Li - A Agonia do Verde. Mundos da Ficção Científica 19. Rio de Janeiro: Francisco Alves, 1980.

CLAEYS, Gregory. Utopia: a História de uma Ideia. São Paulo; Edições SESC SP, 2013.

CLUTE, John. In: MACEY, Samuel L. (org.). Encyclopedia of Time. London: Routledge, 1994, p.643

COUCH, N.C. Christopher, IN: GIBBONS, Christina T; VARNUM, Robin (orgs.) The Language of Comics: Word and Image. Jackson: University Press of Mississippi, 2007. CROWTHER, Peter (org.). Tales in Time. Clarkston: White Wolf Publishing, 1997.

DIXON, Wheeler W. The Space Opera and Early Science Fiction Television. In: TELOTTE, J.P. (org.). The Essential Science Fiction Television Reader. Lexington: University Press of Kentucky, 2008. p. 93-110.

DOHERTY, Thomas, Cold War, Cool Medium: Television, McCarthyism, and American Culture. New York: Columbia University Press, 2003.

EDGERTON, Gary R. The Columbia History of American Television. New York: Columbia University Press, 2007.

EDWARDS, M.; STABLEFORD B. In: CLUTE, John; NICHOLLS, Peter (orgs.). The Encyclopedia of Science Fiction, London: Orbit Books, 1995, p.1227

EFFINGHAM, Nikk. Contemporary Philosophy. In: JONES, Matthew; ORMROD, Joan (orgs.). Time Travel in popular Media: Essays on Film, Television, Literature and Video Games. Jefferson: McFarland \& Company, 2015. p. 20-34.

ELIADE, Mircea. O Mito do Eterno Retorno. Lisboa: edições 70, 1981.

ELIAS, Nobert. Sobre o tempo. Rio de Janeiro: Jorge Zahar Ed., 1998.

FARLEY, Ralph Milne. The Omnibus of Time. Los Angeles: Fantasy Publishing Company, 1950.

FELDMAN, Leslie Dale. Spaceships and Politics: The Political Theory of Rod Serling. Lanham: Lexington Books, 2010. Kindle.

FERREIRA, Jerusa Pires. Fausto no horizonte; razões míticas, texto oral, edições populares. São Paulo, Hucitec, 1995. 
GLEICK, James. Time Travel: A History. New York: Pantheon Books, 2016.

GOLDFIELD, Edwin D., Statistical Abstract of the United States: 1960. Washington, DC: Bureau of the Census, U.S. Department of Commerce, 1960.

. Statistical Abstract of the United States: 1961. Washington, DC: Bureau of the

Census, U.S. Department of Commerce, 1961.

GRAMS JUNIOR, Martin, WILKSTROM, Patrik. The Alfred Hitchcock Presents Companion. Churchville: OTR Publishing, 2001.

GRAMS JUNIOR, Martin. The Twilight Zone: Unlocking the Door to a Television Classic. Churchville: OTR Publishing, 2008.

HAINING, Peter (org.). Timescapes: Stories of Time Travel. London: Seventh Zenith Ltd, 1997.

HARTOG, François. Os antigos, o passado e o presente. Brasília: Editora UnB, 2003. . Evidência da História: o que os historiadores veem. Belo Horizonte: Autêntica Editora, 2011.

- Regimes de Historiciade: presentismo e experiências do tempo. Belo Horizonte: Autêntica Editora, 2013.

. Regimes de historicidade: presentismo e experiências do tempo. Belo Horizonte: Autêntica, 2014.

HAWKING, Stephen W. e MLODINOW, Leonard. O Grande Projeto. Rio de Janeiro: Nova Fronteira, 2011.

HAWKING, Stephen W., THORNE, Kip S. e outros. O futuro do espaço-tempo. São Paulo: Companhia das Letras, 2005.

HEATH, R.; SLUSSER, G. Arrows and Riddles of Time: Scientific Models of Time Travel. In: LEIBY, D.; SLUSSER, G.; WESTFAHL, G. (orgs.). World Enough and Time: Explorations of Time in Science Fiction and Fantasy. Westport: Greenwood Press, 2002. p.11-24.

HERMAN, Arthur. A ideia de decadência na história ocidental. Rio de Janeiro: Record, 1999.

HILMES, Michele. Only Connect: A Cultural History of Broadcasting in the United States. 4th ed. Boston: Wadsworth, 2014.

HUNT, Lester H. And Now, Rod Serling, Creator of The Twilight Zone: The Author as Auteur. In: CARROLL, Noël Carroll; HUNT, Lester H.(orgs.). Philosophy in the Twilight Zone. Oxford: Wiley-Blackwell, 2009, p. 5-25. 
HUTTON, Paul A. "Correct in Every Detail": General Custer in Hollywood. In: HUTTON, Paul A. (org.) The Custer Reader. Norman: University of Oklahoma Press, 2004. p. 487-524.

IRVING, Washington. A Lenda do Cavaleiro sem Cabeça e Rip Van Winkle. São Paulo: Editora lluminuras Ltda., 2003.

JAMESON, Fredric. Archaeologies of the Future: The Desire Called Utopia and Other Science Fictions. New York: Verso, 2005.

JOHNSON, Catherine. Negotiating value and quality in television historiography. In: WHEATLEY, Helen (org.) Re-viewing Television History: Critical Issues in Television Historiography. London: I.B. Tauris, 2007. p. 55-66.

JOHNSON, Rian. Introduction. In: VANDERMMER, ANN; VANDERMMER, Jeff (orgs.). The Time Traveler's Almanac: A Time Travel Anthology. London: Head of Zeus, 2013.

JONES, Matthew; ORMROD, Joan (orgs.). Time Travel in popular Media: Essays on Film, Television, Literature and Video Games. Jefferson: McFarland \& Company, 2015.

KING, Stephen. Dança Macabra: o terror no cinema e na literatura dissecado pelo mestre do gênero. Rio de Janeiro: Objetiva, 2013.

KOSELLECK, Reinhart. Futuro Passado - Contribuição à Semântica dos Tempos Históricos. Rio de Janeiro: Contraponto, 2006.

.[et. al.] O Conceito de História. Belo Horizonte: Autêntica Editora, 2013.

KRUSE, Kevin M. e SUGRUE, Thomas J (org.), The New Suburban History. Chicago: The University of Chicago Press, 2006.

LEIBY, David A. The Tooth That Gnaws: Reflections on Time Travel In: SLUSSER, George E.; RABKIN, Eric S. Intersections: Fantasy and Science Fiction. Carbondale: Southern Illinois University Press, 1987.

LEITCH, Thomas, POAGUE, Leland Poague (orgs.). A Companion to Alfred Hitchcock. Oxford: Wiley-Blackwell, 2011.

LESSER, Jeffrey. A Discontented Diaspora: Japanese Brazilians and the Meanings of Ethnic Militancy, 1960-1980. Durham: Duke University Press, 2007.

LIMERICK, Patricia N. The Adventures of The Frontier In The Twentieth Century. In: GROSSMAN, James R. (org.) The Frontier in American Culture. Los Angeles: University of California Press, 1994. p.67-102. 
LIPSITZ, George. Time Passages - Collective Memory and American Popular Culture. Minneapolis: University Of Minnesota Press, 2001.

MARGLIN, Stephen A. In: MARGLIN, Stephen A.; SCHOR, Juliet B. The Golden Age of Capitalism: Reinterpreting the Postwar Experience. New York: Oxford University Press, 2000.

MARQUES, José. Roteiro da primeira viagem de Vasco da Gama à Índia (Álvaro Velho): Leitura Crítica, notas e estudo Introdutório. Porto: Faculdade de Letras da Universidade do Porto, 1999.

MARTIN, Kathleen. O livro dos símbolos. Reflexões sobre imagens arquetípicas. Köln: Taschen, 2012.

MAY, Elaine Tyler, Homeward Bound: American Families in the Cold War Era. New York: Basic Books, 1999.

MCGEE, Marty; PRESNELL, Don. A Critical History of Television's The Twilight Zone, 1959-1964. Jefferson: McFarland \& Company, 1998.

MCGIM, LISA, In: MULLOY, D.J. The World of the John Birch Society: Conspiracy, Conservatism, and the Cold War. Vanderbilt University Press, 2014.

MCGIRR, Lisa. The War on Alcohol: Prohibition and the Rise of the American State. New York: W. W. Norton \& Company, 2016.

MCNEIL, Alex. Total Television: The Comprehensive Guide to Programming from 1948 to the Present. 4th ed. New York: Penguin Books, 1996.

MEILINGER, Phillip S., Bomber: The Formation and Early Years of Strategic Air Command. Maxwell Air Force Base: Air University Press, 2012.

MELBYE, David. Irony in The Twilight Zone: How the Series Critiqued Postwar American Culture. Lanham: Rowman \& Littlefield Publishers, 2016. Kindle.

MILLER, Cynthia; VAN RIPER, A. Bowdoin. 1950s "Rocketman" TV Series and Their Fans: Cadets, Rangers, and Junior Space Men. New York: Palgrave Macmillan, 2012. Kindle.

MULLOY, D.J. The World of the John Birch Society: Conspiracy, Conservatism, and the Cold War. Nashville: Vanderbilt University Press, 2014.

MYERS, Robert E. (org.) The Intersection of Science Fiction and Philosophy. Westport: Greenwood Press, 1983.

NAHIN, Paul J. Time Machines: Time Travel in Physics, Metaphysics, and Science Fiction. 2nd ed. New York: Springer-Verlag New York, Inc., 1999. 
NEUFELD, Michael J. (org.). Spacefarers: Images of Astronauts and Cosmonauts in the Heroic Era of Spaceflight. Washington, DC: Smithsonian Institution Scholarly Press, 2013.

NIETZSCHE, Friedrich. Além do Bem e do Mal: Prelúdio de uma filosofia do futuro. Curitiba: Hemus, 2001.

NOVELLO, Mario. Máquina do tempo: um olhar científico. Rio de Janeiro: Zahar, 2005. NOVOTNY, Lawrence. Reflections of a Nation's Angst; or, How I Learned to Stop Worrying and Love The Twilight Zone. In: AUSTIN, Allan W.; WRIGHT, David (orgs.), Space and Time Essays on Visions of History in Science Fiction and Fantasy Television, Jefferson: McFarland \& Company, 2010. p.9-28

NOWELL-SMITH, Geoffrey, The Oxford History of World Cinema. Oxford Press, 1997. PEEKE, Mitch; JONES, Steven; WALSH-JOHNSON, Kevin. The Lusitania Story. Barnsley: Pen \& Sword Books, 2002.

PETERSON, Merrill D., Lincoln in American Memory. New York: Oxford University Press, 1994.

PROSSER, Harold Lee. Running from the Hunter: The Life and Works of Charles Beaumont. Rockville: Wildside Press, 2010.

PUDDINGTON, Arch, Broadcasting Freedom: The Cold War Triumph of Radio Free Europe and Radio Liberty. Lexington: University Press of Kentucky, 2000.

REYNOLDS, Kenneth. The Twilight Zone: Rod Serling's Wondrous Land. Bloomington: iUniverse, 2014.

ROBBINS, James S. The Real Custer. Washington, DC: Regnery Publishing, 2014.

ROBERTS, Adam. The History of Science Fiction. New York: Palgrave Macmillan, 2005.

ROMAN, James. From Daytime to Primetime: The History of American Television Programs. Westport: Greenwood, 2005.

ROSE, Kenneth D., One Nation Underground: The Fallout Shelter in American Culture. New York: NYU Press, 2001.

ROSENBERG, Bruce A. Custer: The Legend of the martyred hero in America. In: HUTTON, Paul A. (org.) The Custer Reader. Norman: University of Oklahoma Press, 2004. p. 525-545.

ROST, Antoine. Doze lições sobre a história. Belo Horizonte: Autêntica, 2015. ROWLAND, Ian. The Full Facts Book of Cold Reading. $6^{\text {th }}$ edition. [S.I.]: Ian Rowland Limited, 2014. 
RUBIN, Steven Jay. The Twilight Zone Encyclopedia. Chicago: Chicago Review Press, 2018.

SANDER, Gordon F. Serling: The Rise and Twilight of Tv's Last Angry Man. New York: Cornell University Press, 2011.

SCHNEIDER, Susan (org.). Science Fiction and Philosophy: From Time Travel to Superintelligence. 2nd ed. Oxford: Wiley-Blackwell, 2016.

SCONCE, Jeffrey. Haunted Media: Electronic Presence from Telegraphy to Television. Durham: Duke University Press, 2000.

SEABOOK, Jack. Stealing Trough Time: on the Writings of Jack Finney. Jefferson: McFarland \& Company, 2006.

SERLING, Anne. As I Knew Him: My Dad, Rod Serling. New York: Citadel Press, 2013. SHAKESPEARE, William. O Mercador de Veneza. Água-forte: Almada, 2002. Ebook SILVA, Renán. Lugar de Dúvidas: Sobre a prática da análise histórica: breviário de inseguranças. Belo Horizonte: Autêntica Editora, 2015.

SILVERBERG, Robert (org.). Trips in Time: Nine Stories of Science Fiction. New York: Dutton Juvenile, 1977.

SLIDE, Anthony. Magnificent Obsession: The Outrageous History of Film Buffs, Collectors, Scholars, and Fanatics. Jackson: University Press of Mississippi, 2018. [digital].

SONDHAUS, Lawrence. A Primeira Guerra Mundial. São Paulo: Editora Contexto, 2015.

Spacefarers: Images of Astronauts and Cosmonauts in the Heroic Era of Spaceflight. STABLEFORD, Brian. Historical Dictionary of Science Fiction Literature. Lanham: The Scarecrow Press, Inc., 2004.

STANYARD, Stewart T. Dimensions Behind The Twilight Zone: A Backstage Tribute to Television's Groundbreaking Series. Toronto: ECW Press, 2007.

STERN, Philip Van Doren. Travelers in Time. Garden City: Doubleday \& Company, Inc., 1947.

TAIRA, Ricardo. Rosa da Liberdade: A história de Rosa Miyake e do programa de TV Imagens do Japão. São Paulo: Contexto, 2018.

TELOTTE, J.P. (org.). The Essential Science Fiction Television Reader. Lexington: University Press of Kentucky, 2008.

TERRACE, Vincent. Encyclopedia of Television Shows, 1925 through 2010. Jefferson: McFarland \& Company, 2011. 
TERRACE, Vincent. Television Series of the 1950s: Essential Facts and Quirky Details. Lanham: Rowman \& Littlefield Publishers, 2016 THOMPSON, Dave. The Twilight Zone FAQ: All That's Left to Know About the Fifth Dimension and Beyond. Milwaukee: Applause Theatre \& Cinema Books, 2015.

TURNER, Frederick Jackson. O Significado da Fronteira na História Americana. In: KNAUSS, Paulo (org.). Oeste Americano: Quatro Ensaios de história dos Estados Unidos da América de Frederick Jackson Turner. Niterói: EdUFF, 2004. p. 23-54.

VANDERMMER, ANN; VANDERMMER, Jeff (orgs.). The Time Traveler's Almanac: A Time Travel Anthology. London: Head of Zeus, 2013.

WEITEKAMP, Margaret A. Setting the Scene for Human Spaceflights: Men Into Space and The Man and the Challenge. In: NEUFELD, Michael J. (org.). Spacefarers: Images of Astronauts and Cosmonauts in the Heroic Era of Spaceflight. Washington, DC: Smithsonian Institution Scholarly Press, 2013. p. 9-33.

WELLS, H.G. A Máquina do Tempo. Rio de Janeiro: Objetiva, 2010.

WESTFAHL, G. Introduction: The Quarries of Time. In: LEIBY, D.; SLUSSER, G.; WESTFAHL, G. (orgs.). World Enough and Time: Explorations of Time in Science Fiction and Fantasy. Westport: Greenwood Press, 2002. p.1-7.

WHITE, R. Frederick Jackson Turner and Buffalo Bill. In: GROSSMAN, James R. (org.) The Frontier in American Culture. Los Angeles: University of California Press, 1994. p.7-64.

WHITTY, Stephen. The Alfred Hitchcock Encyclopedia. Lanham: Rowman \& Littlefield, 2016.

WINTHROP, Jordan. The Americans. Boston: McDougal Littell, 1996.

WITTENBERG, D. Time Travel: The Popular Philosophy of Narrative. New York: Fordham University Press, 2013.

WOMACK, John. Into the Sun: Air Force Memories, 1957-1976, The Rise to Power. Hickory: Soliloquy Press, 2011.

ZAHAVI, Gerald. Workers, Managers, and Welfare Capitalism: The Shoemakers and Tanners of Endicott Johnson, 1890-1950. Chicago: University of Illinois Press, 1988. Disponível em: < https://www.albany.edu/faculty/gz580/ejhistory/ej_book.html>. Acesso em: 20/08/2018.

ZICREE, Marc Scott. The Twilight Zone Companion. 2nd Edition. Hollywood: SilmanJames Press, 1992. 
ZICREE, Marc Scott. The Twilight Zone Companion. 3rd Edition. Hollywood: SilmanJames Press, 2018.

\section{Artigos, Teses e Periódicos}

ALMEIDA Junior, Licinio Nascimento. Conjecturas para uma Retórica do Design Gráfico. Tese de Doutorado. Programa de Pós-Graduação em Design. Departamento de Artes \& Design da PUC-Rio. 2009.

BATES, Cary. Die Now, Live Later!. In: Action Comics. New York: National Periodical Publications, Inc. no. 463, Sep. 1976. Disponível em: < https://readcomiconline.to/Comic/Action-Comics-1938/Issue-

463?id=25695\&quality=lq\#1>. Acesso em: 02/03/2019.

BAXTER, Stephen. The Technology of Omniscience: Past Viewers in Science Fiction. Foundation: The International Review of Science Fiction. London: Science Fiction Foundation. Volume 29, 80, Autumm 2000. p.97-107.

BÍBLIA Online - Disponível em: <https://www.bibliaonline.com.br> Acesso em: 15/01/2018.

BILAL, Hafiz Ahmad. Discourse analysis of The Gift of the Magi. (Smith's Discourse Modes). Academic Research International,.Vol. 2, No. 1, Jan 2012.

CARVALHO, Eugênio Rezende. Norbert Elias Frente aos Desafios de Superação da Aporia entre Tempo Físico e Tempo Social. Anais do $6^{\circ}$. Seminário Brasileiro de História da Historiografia -O giro-linguísticoe a historiografia: balanço e perspectivas. Ouro Preto: EdUFOP, 2012.

. A Concepção Holística e Processual de Tempo de Norbert Elias. In: Anais

Eletrônicos do $14^{\circ}$ Seminário Nacional de História da Ciência e da Tecnologia - $14^{\circ}$ SNHCT. Belo Horizonte, Campus Pampulha da Universidade Federal de Minas Gerais, 2014.

CHADWICK, Bruce. Anything Does Go in "Anything Goes," a Spectacular Musical about the 1930s. The History News Network (HNN). Disponível em: < https://historynewsnetwork.org/article/138257>. Acesso em: 06/06/2019.

CONLON, Christopher. The Creators of Twilight Zone, Logan's Run, and Dozens More Fantasy Classics Remember the West Coast Writers' Group. The Rod Serling Memorial Foundation, 1999. Disponível em: < https://www.rodserling.com/csorcerers.htm>. Acesso em: 15/01/2018. 
DERRY, Stephen. The Time Machine and Wells's Social Trajectory. Foundation: The Review of Science Fiction. Liverpool: Science Fiction Foundation. 65, Autumm, 1995. p.16-24.

DIAS JR., J. A. O Caminho para Além da Imaginação. Significação: Revista de Cultura Audiovisual, v. 46, n. 51, 31 jan. 2019.

EUA, NSC 68: United States Objectives and Programs for National Security, 1950. Naval War College Review, Vol. XXVII (May-June, 1975). p. 51-108. Disponível em: <https://www.mtholyoke.edu/acad/intrel/nsc-68/nsc68-1.htm>. Acesso em: 05/08/2018.

EUA, Servicemen's Readjustment Act of 1944, Public Law 346, 78th Cong., 2d sess. (June 22, 1944), Disponível em: $<$ http://www.ourdocuments.gov/doc.php?flash=true\&doc=76>. Acesso em: 23/03/2018.

FEDERAL COMMUNICATIONS COMMISSION. Consumer Guide: Obscene, Indecent and Profane Broadcasts. Consumer and Governmental Affairs Bureau, 2016. Disponível em: $<$ https://www.fcc.gov/sites/default/files/obscene_indecent_and_profane_broadcasts.p df>. Acesso em: 02/03/2018.

FRASER, C.G. IVAN TORS, PRODUCER; DEVELOPED 'FLIPPER' AND OTHER TV SERIES. New York Times, June 7, 1983. Disponível em: <http://www.nytimes.com/1983/06/07/obituaries/ivan-tors-producer-developed-flipperand-other-tv-series.html>. Acesso em: 05/01/2018.

HAMILTON, Edmond. The True History of Superman and Batman. In: World's Finest Comics. New York: National Comics Publications, Inc. no. 81, Mar-abr, 1956. Disponível em: < https://readcomiconline.to/Comic/World-s-Finest-Comics/lssue81 ? id=48005\#1>. Acesso em: 02/03/2019.

HAWKING, S. W. Chronology protection conjecture. Phys. Rev. 15;46(2), 5 Jul 1992, p.603-611.

HUNTINGTON, John. The Time Machine and Wells's Social Trajectory. Foundation: The Review of Science Fiction. Liverpool: Science Fiction Foundation. 65, Autumm, 1995. p.6-15. 
KIESEWETTER, John. 'The Twilight Zone' had roots in Cincinnati. Cincinnati Enquirer, online. 27 mai 2014. Disponível em: < https://www.cincinnati.com/story/news/history/2014/05/27/rod-serling-twilight-zonewkrc-tv/9624063/>. Acesso em: 20/01/2018.

KMET, Michael. Script Clearance and Research: Unacknowledged Creative Labor in the Film and Television Industry. Mediascape Blog. 28 Ago 2012. Disponível em: $<$ http://www.tft.ucla.edu/mediascape/blog/script-clearance-and-researchunacknowledged-creative-labor-in-the-film-and-television-industry/>. Acesso em: 20/01/2018.

LANGFORD, David; STEVENS, Geoffrey. Lights Out. SFE - The Encyclopedia of Science Fiction. Dispoível em: <http://www.sf-encyclopedia.com/entry/lights_out>, 2017. Acesso em: 14/04/2018.

LEBOW, Richard Ned; STEIN, Janice Gross. "Deterrence and the Cold War." Political Science Quarterly, vol. 110, no. 2, 1995, p. 157-181. Disponível em: $<w w w . j s t o r . o r g / s t a b l e / 2152358>$ Acesso em: 13/07/2018.

LOIPERDINGER, Martin. "LUMIĖRE'S 'ARRIVAL OF THE TRAIN': Cinema's Founding Myth." The Moving Image: The Journal of the Association of Moving Image Archivists, vol. 4, no. 1, 2004, pp. 89-118.

MAIA, Geraldo; MARIANO, Jefferson e OLIVEIRA, Giuliano C. O sistema de Bretton Woods e a dinâmica do sistema monetário internacional contemporâneo. Pesquisa \& Debate (Online), v. 34, p. 195-219, 2008.

MARTIN, Emmie. Here's how much it costs to produce one episode of 'Game of Thrones'. Consumer News and Business Channel. Disponível em: $<$ https://www.cnbc.com/2019/04/12/how-much-it-costs-to-produce-an-episode-ofgame-of-thrones.html . Acesso em: 01/05/2019.

MISTÉRIO ainda sem respostas. O relógio encontrado em tumba da dinastia Ming, de 400 anos - Entenda. History Channel. Disponível em: $<$ https://seuhistory.com/noticias/misterio-ainda-sem-respostas-o-relogio-encontradoem-tumba-da-dinastia-ming-de-400-anos-0> Acesso em: 01/06/2018.

OLIVEIRA, G. C.; MAIA, G.; MARIANO, J. O sistema de Bretton Woods e a Dinâmica do Sistema Monetário Internacional Contemporâneo. Pesquisa \& Debate, SP, volume 19, número 2 (34) p. 195-219, 2008

PENAFRIA, Manuela. Análise de Filmes - conceitos e metodologia(s). Trabalho apresentado no VI Congresso SOPCOM, Lisboa, Portugal, 2009. 
RENAUX. Sigrid. Os mundos fantásticos de Rip Van Winkle. Araraquara: Itinerários, 19: $91-1$ 14, 2002.

RUSSELL, W.M.S. Time Before and After The Time Machine. Foundation: The Review of Science Fiction. Liverpool: Science Fiction Foundation. 65, Autumm, 1995. p.24-40. SCALDAFERRO, Maikon Chaider Silva. Hegel e o fim da História. Fortaleza: Polymatheia, vol. V, n 8, 2009, p. 211-230.

SERLING, Rod. The Journal of the Screen Producers Guild, Beverly Hills: Screen Producers Guild, set. 1959.

SFE - The Encyclopedia of Science Fiction. Dispoível em: <http://www.sfencyclopedia.com/>.

SRIMAD Bhāgavatam. (Bhāgavata Purāṇa). Canto 9: Liberation [S.I.: s.n., s.d]. Disponível em: < https://www.vedabase.com/en/sb/9/3>..Acesso em: 15/03/2017.

SOUZA, José Inacio de Melo. A TV Tupi no acervo do Arquivo Histórico de São Paulo: novas fontes. Informativo Arquivo Histórico de São Paulo: Informativo n.28- jan, 2011 Disponível em: <http://www.arquiamigos.org.br/info/info28/img/TVTupiteleteatros.pdf> Acesso em: 08/01/2018.

SPENCER, Henry McDonald. In the Twilight Zone. The Lotus Magazine, Vol. 9, No. 7, apr., 1918. p. 353-359. Disponível em: < http://www.jstor.org/stable/20544048>. Acesso em: 15/04/2017.

SPENCER, Richard V. Custer's Last Fight. s.d. In: American Film Institute, s.d. Disponível em: <https://catalog.afi.com/Catalog/moviedetails/154>. Acesso em: 20/11/2018.

STEVENS, Geoffrey. Out There. SFE - The Encyclopedia of Science Fiction. Dispoível em: <http://www.sf-encyclopedia.com/entry/out_there>, 2017. Acesso em: 14/04/2018.

THE LINCOLN symbol, New York: The New York Times, 1955, p.14. Disponivel em: <https://www.nytimes.com/1955/02/12/archives/the-lincoln-symbol.html>. Acesso em: 18/07/2017.

TIBBETTS, John C. "The Watchers: "Tales of Tomorrow" on Television." Journal of the Fantastic in the Arts 19, no.3, 74, 2008, p.379-98. Disponível em: <http://www.jstor.org/stable/24352383> Acesso em: 04/07/2018..

TRANSOCEAN Air Lines 1946 - 1960. S.d, s.p. Disponível em: <http://www.taloa.org/> Acesso em: 03/10/2018. 
TWILIGHT. In: Online Etymology Dictionary. [S.I.: s.n.]. Disponível em: <https://www.etymonline.com/word/twilight>. Acesso em: 14/01/2018.

VADICO, Luiz. O $13^{\circ}$ macaco ou a estrategia social de evasão do tempo: um panorama sobre o tema da viagem no tempo, baseado em filmes de produção Hollywoodiana. 2000. 175 p. Dissertação (mestrado) - Universidade Estadual de Campinas, Instituto de Artes, Campinas, SP. Disponível em: <http://www.repositorio.unicamp.br/handle/REPOSIP/284641>. Acesso em: 27 jul. 2018.

VON MARTIUS, Karl Friedrich; RODRIGUES, José Honório. Como se deve escrever a História do Brasil. Revista de História de América. No. 42 (Dec., 1956), p. 433-458. WESTCOTT, Kathryn. HG Wells or Enrique Gaspar: Whose time machine was first? BBC News, 9 abr 2011. Disponível em: <https://www.bbc.com/news/world-europe12900390 >. Acesso em: 15/04/2017.

WHITE, Gary. Pioneering Psychologist Alan Gessner Dies at Age 86, 2012. Disponível em: < https://www.theledger.com/article/LK/20120725/News/608086716/LL/>. Acesso em: 12/09/2018.

ZICREE, Marc. Rod Serling and Ray Bradbury - The Untold Story, 2014. Disponível em: <https://www.youtube.com/watch?v=8bhvb8Tmi38>. Acesso em: 15/08/2017. 